Anna Christina Miana

\title{
ADENSAMENTO E FORMA URBANA: INSERÇÃO DE PARÂMETROS AMBIENTAIS NO PROCESSO DE PROJETO
}

Tese de Doutorado apresentada à Faculdade de Arquitetura e Urbanismo da Universidade de São Paulo para a obtenção do título de Doutor em Arquitetura e Urbanismo

Área de concentração: Tecnologia da Arquitetura

Orientadora: Prof. Dra. Marcia Peinado Alucci

Co-orientadora: Prof. Dra. J oana Carla Soares Gonçalves

São Paulo

2010 
AUTORIZO A REPRODUÇÃO E DIVULGAÇÃO TOTAL OU PARCIAL DESTE TRABALHO, POR QUALQUER MEIO CONVENCIONAL OU ELETRÔNICO, PARA FINS DE ESTUDO E PESQUISA, DESDE QUE CITADA A FONTE.

E-MAIL: annamiana@uol.com.br

Miana, Anna Christina

M618a Adensamento e forma urbana : inserção de parâmetros

ambientais no processo de projeto / Anna Christina Miana. --São

Paulo, 2010.

393 p. : il.

Tese (Doutorado - Área de Concentração: Tecnologia da Arquitetura)

FAUUSP.

Orientadora: Marcia Peinado Alucci

Co - Orientadora: Joana Carla Soares Gonçalves

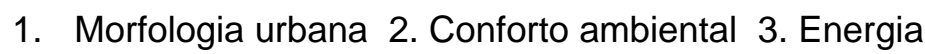
4. Sustentabilidade I.Título

CDU 711.41 
Dedico este trabalho aos meus queridos pais e ao meu marido com meu amor e a minha eterna gratidão. É deles também o mérito desta minha conquista. 


\section{Agradecimentos}

A Deus, pela oportunidade de enfrentar mais um desafio e por não permitir que eu estivesse sozinha nesta jornada. As pessoas que de alguma forma me ajudaram são aqui mencionadas com toda minha gratidão.

O meu profundo agradecimento as minhas queridas orientadoras e amigas Márcia Alucci e Joana Gonçalves pela confiança depositada, pelas orientações que me guiaram durante toda pesquisa e por aceitarem junto comigo o desafio pela busca de como contribuir para a produção de espaços urbanos mais sustentáveis. Obrigada Marcia, pela honra de sua orientação ao longo desses anos e por me ensinar o que vai além da teoria. Obrigada Jo por me introduzir ao tema da pesquisa, por todo o incentivo e por fazer mais que 0 possível para me ajudar a crescer profissionalmente.

Em especial, meu profundo agradecimento à minha família. Meu marido, José Henrique e meus pais, José Carlos e Maria Cecília, pelo amor tão essencial para o meu desempenho. Também, pela preocupação com todas as etapas e todas as dificuldades vividas nesse meu processo de amadurecimento profissional. Pelo interesse demonstrado para com o tema de pesquisa e pela intensa dedicação e participação em tudo que foi possível. Aos meus irmãos Thereza Rachel e Carlos Eduardo, e meus cunhados Marcelo, Carolina e Ana Paula, pelo amor e apoio incondicional.

Meu carinho e agradecimento aos pesquisadores do LABAUT - Laboratório de Conforto Ambiental e Eficiência Energética da Faculdade de Arquitetura e Urbanismo da Universidade de São Paulo, pelo contínuo aprendizado nestes oito anos de convivência. Em especial aos professores Anésia Frota, Fernando Cremonesi, Roberta Kronka e Denise Duarte pela disponibilidade em transmitir o conhecimento e a experiência adquirida. Aos colegas, hoje grandes amigos, Rafael Brandão, Alessandra Prata Shimomura, Leonardo Monteiro e Norberto Moura, pelas discussões e fundamental ajuda durante esta pesquisa, e por compartilharam comigo tantos momentos de incertezas e também de conquistas. $E$ as companheiras Bruna Luz, Luciana Ferreira, Erica Mitie, Paula Shinzato, Monica Marcondes, Rita Buoro, Andrea Vosgueritchian e Carolina Leite e companheiros José Ovídio, Rodrigo Cavalcanti e Alex Uzueli, pela amizade e pelo aprendizado durante o desenvolvimento de trabalhos conjuntos. Sem vocês, com certeza, tudo seria mais difícil. 
A todos os pesquisadores que participaram junto ao LABAUT FAUUSP do exercício de projeto apresentado no Urban Age, pelas horas de trabalho em grupo, em busca de parâmetros, métodos e soluções fundamentais para a realização desta pesquisa.

A supervisora desse trabalho no exterior, Ester Higueras, a quem agradeço pela receptividade e atenção dispensada no estágio realizado no exterior, pela credibilidade que depositou no meu potencial de pesquisadora, e pela fundamental contribuição para o desenvolvimento deste trabalho.

Ainda no que diz respeito aos trabalhos dessa investigação no exterior, meus sinceros agradecimentos a todos que me receberam para entrevista, por acreditarem no tema da pesquisa e por colaborarem para o sucesso desses estudos. Os nomes desses profissionais e as respectivas empresas às quais esses representam estão presentes na lista. Em Madrid, à Andres Ortega, da E.T.S.A da Politécnica de Madrid e do Andrés Perea Ortega Arquitecto; Ana Iglesia, da Empresa Municipal de la vivienda, Prefeitura de Madrid; Michael Moradiellos, do Ecossistema Urbano e Juan Arana, do Equipo Bloque arquitectos. Em Barcelona à Cyntia Echave Martinez, da Agencia de Ecología Urbana de Barcelona (BCN). Em Londres à John Worthington e Steven Smith, do DEGW architects and consultants; Raul Moura e Sandro Tubertini, do BDSP Partnership Consulting Engineers, Alessandra da Fieno Cobian, Kohn Pedersen Fox Associates (KPF); Guy Battle, do Battle McCarthy Consulting Engineers and Landscape Architects e Peter Sharratt, do WSP. À Sue Riddlestone, BioRegional, pelo envio de material para pesquisa via email.

Com respeito às entrevistas realizadas no Brasil, vale destacar a grande contribuição de Pedro Sales, da Secretaria Municipal de Planejamento da Cidade de São Paulo (SEMPLA), de Regina Meyer, da FAUUSP e de Candido Malta, do escritório de Planejamento, Urbanismo e Arquitetura URBE. Obrigada por seus depoimentos experientes na área da pesquisa, também por sua atenção e conversas que estimularam muitas reflexões sobre o tema.

Novamente agradeço aos Professores Pedro Sales e Norberto Moura pelas críticas e orientações que auxiliaram o prosseguimento e finalização desse trabalho, na ocasião do exame de qualificação.

Sou ainda profundamente grata à Liza Andrade, pelo exemplo de profissional e por me ajudar sempre, desde a época de graduação. 
Por me introduzir na Área do Conforto Ambiental e me orientar sempre que solicitada, Eleonora Sad de Assis.

Às amigas e também colegas de profissão Cintia Mara Figueiredo e Maria Tereza Diniz, por estarem sempre presentes. Obrigada pelas palavras de força e incentivo nos momentos que mais precisei.

As colegas e amigas da Anab Regina Nogueira e Silvia Manfredi pela confiança e pelos momentos que trabalhamos juntas.

Durante as etapas de trabalho no exterior, gostaria de agradecer Tereza Bruzzi, Andrea Vosgueritchian e aos amigos da USP do programa Santander Banespa pelo apoio, companhia e pelos bons momentos.

Aos meus padrinhos, Eduardo e Anna Lucia, por me acolherem com tanto carinho e por serem muitas vezes meu suporte aqui em São Paulo.

À minha avó Elza, aos meus tios e primos que de longe acompanham os meus passos e torcem por mim.

As secretárias da Pós Graduação, em especial a Regina, Isa, Ivani e Maria Inês e as secretárias do Departamento de Tecnologias, Silvana e Viviane, pela dedicação e atenção com que me auxiliaram ao longo do percurso.

Aos bibliotecários da FAU e da FAU Maranhão, em especial a Regina, Maria José, Estelita e Paola pela ajuda e simpatia sempre.

Novamente, agradeço aos amigos Leo, Ale, Rafa, Eriquinha e Lu, pelo o carinho e dedicação durante a revisão do texto da tese e pela ajuda e todo apoio, principalmente, nessa fase final.

Ao Conselho Nacional de Desenvolvimento Científico e Tecnológico (CNPq), por ter financiado esta pesquisa e a Pró-reitoria da Pós-Graduação da Universidade de São Paulo (PRPG/USP) e ao Santander Banespa pelo auxílio para realização das atividades dessa pesquisa no exterior.

Por fim, com carinho especial, agradeço ao meu filho Tiago, meu grande companheiro na difícil fase de conclusão da Tese. Novamente agradeço a ele, meus afilhados, Mariana e Pedro e meus sobrinhos, por ser uma fonte de inspiração para a construção de cidades melhores e mais sustentáveis. 
Àqueles que acreditaram em mim e na pesquisa e que de alguma maneira contribuíram para sua realização, MUITO OBRI GADA! 
A presente pesquisa parte do problema que o crescimento e o adensamento urbano são inevitáveis e que vêm causando diversos danos ao meio natural e à qualidade ambiental das cidades. Diante disso, visando minimizar os impactos gerados pelo processo de urbanização, com base na idéia de que o adensamento urbano pode ser positivo para a construção de cidades mais sustentáveis, o trabalho parte da necessidade da inserção da camada meio ambiente no processo de projeto urbano. Além disso, todas as outras camadas (usos, estoque construído, redes de infraestrutura, etc) também devem ser analisadas sob o enfoque ambiental. Para isso, o trabalho apresenta como objetivo geral a elaboração de um método para inserção de fatores ambientais relacionados ao adensamento e a forma urbana no processo de projeto. Esta pesquisa foi desenvolvida em três distintos momentos: um primeiro de fundamentação teórica e construção de conceitos; um segundo momento de análise e avaliação de projetos urbanos contemporâneos sob os aspectos da sustentabilidade ambiental e; um terceiro momento de síntese e proposição da incorporação de parte da camada meio ambiente no processo de projeto urbano. Durante o desenvolvimento da pesquisa, verificou-se que, de fato, os projetos que apresentaram uma preocupação explícita com as questões ambientais, por parte dos projetistas, obtiveram melhores resultados, na avaliação com relação à sustentabilidade urbana, como, por exemplo, os ecobairros presentes na Europa. Além disso, foi concluído que não existem soluções únicas, cada sitio e cada projeto necessita de medidas específicas relacionadas às suas características próprias. Da mesma maneira que não existe um método de projeto universal, já que esse é definido diante dos problemas e potencialidades apresentados. Porém são necessárias a definição e adoção de parâmetros e regras que orientem o processo de projeto que visa à sustentabilidade ambiental, atendimento às exigências humanas e produzindo espaços urbanos de qualidade com o mínimo impacto ao meio natural.

Palavras-chave: morfologia urbana, conforto ambiental, energia, sustentabilidade. 
This research is based on the assumption that urban growth and densification are inevitable and have been causing damage to the natural environment and the environmental quality of cities. With the objective of minimize the impacts caused by the urbanization processes and assuming that urban densification can be positive to the achievement of more sustainable cities, the research introduces the environmental layer in the process of developing urban projects. Furthermore, all the other fundamental layers (use, building stock, infrastructure, etc) should also be accessed through the environmental perspective. In order to do that, the general objective of this work is the definition of a method for the insertion of environmental factors related to the densification and urban form in the design process of the built environment. This research was carried out in three phases: the first one is about the formulation of the theoretical background including the definition of key concepts; a second phase of analysis of contemporary urban projects approaching environmental and sustainable aspects and; the third phase of synthesis and proposition to include a key part of the environmental layer in the design process of the built environment. During the development of the research, it was verified that the case study projects which express a clear concern with environmental issues from the designer's perspective got better overall results in the assessment of urban sustainability, such as the eco-neighborhoods in Europe. Besides, it was concluded that there are no unique solutions, each place and project needs specific measures related to its own features. In the same token, there is not one unique method or universal project, once this is defined by the local problems, challenges and potentialities. However, it is necessary the definition and adoption of design rules which can direct the design process towards environmental sustainability, people's expectations and urban spaces with quality and the reduced environmental impact.

Key-words: urban form, environmental comfort, energy, sustainability 
Figura 1: Consumo energético desagregado setor residencial ..............................................................32

Figura 2: Consumo energético desagregado setor residencial ........................................................ 33

Figura 3: Área com potencial de adensamento, Região da Luz, São Paulo............................................ 37

Figura 4: Área com potencial de adensamento, Barra Funda, São Paulo ........................................... 37

Figura 5: Esquema ilustrativo das camadas do projeto urbano com os enfoques que estas devem ser

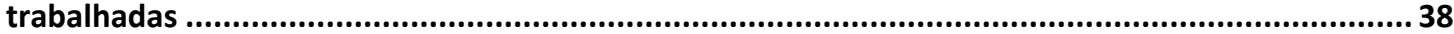

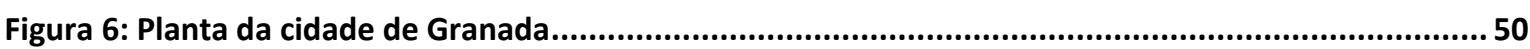

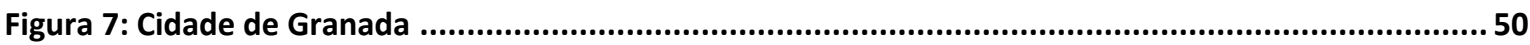

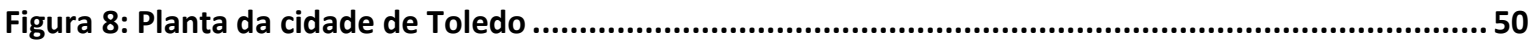

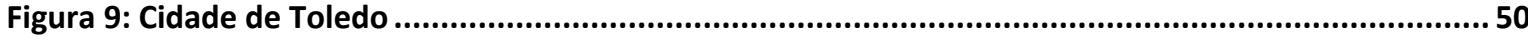

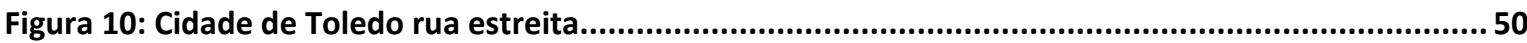

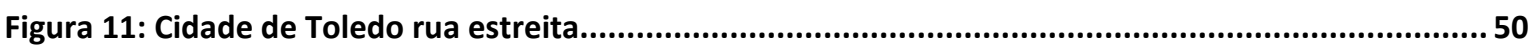

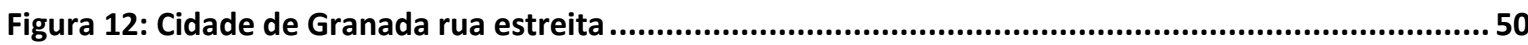

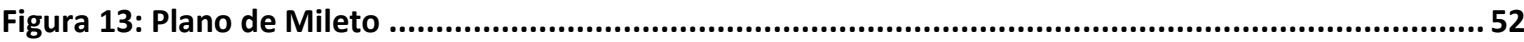

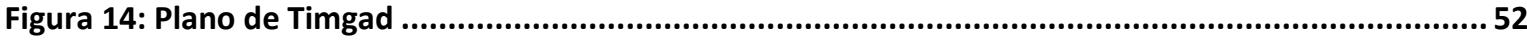

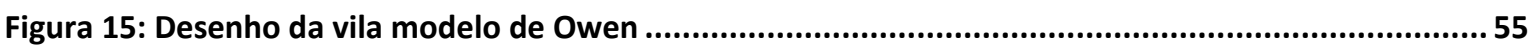

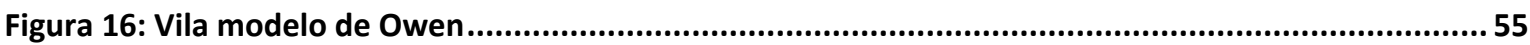

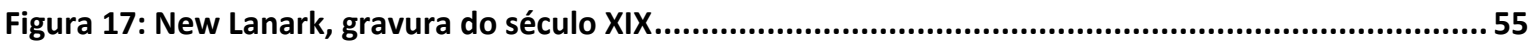

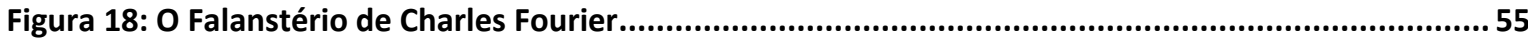

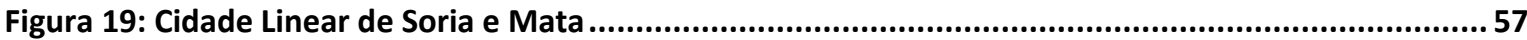

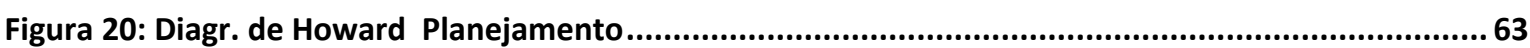

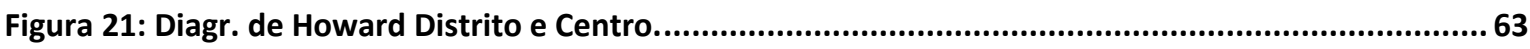

Figura 22: Diagr. de Howard Constelação de Cidades ........................................................................63

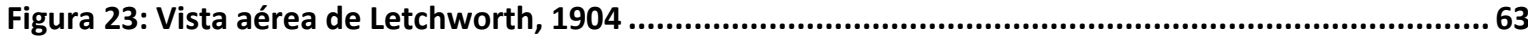

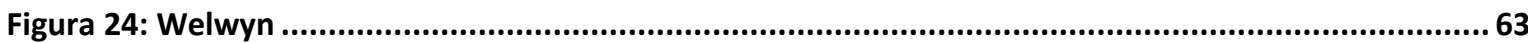

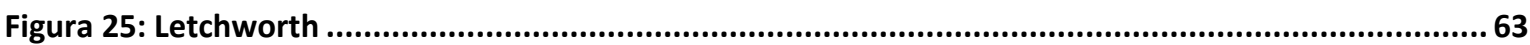

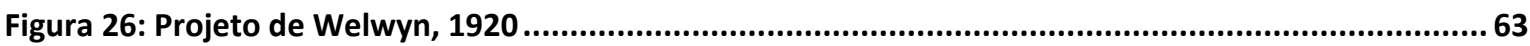

Figura 27: Imagem proposta Broad Acre City de Frank Lloyd Wright .............................................66

Figura 28: Imagem proposta Broad Acre City de Frank Lloyd Wright .................................................66

Figura 29: Cidade Industrial de Tony Garnier (1904) - Planta parcial do bairro residencial.......................68

Figura 30: Cidade Industrial de Tony Garnier (1904) - habitações unifamiliares ...................................68

Figura 31: Siedlung Westhausen de Ernst May - Planta .....................................................................69 
Figura 32: Planta da divisão do bosque para o jardim privado. - Figura 33: corte - Figura 34: imagem das fachadas.

Figura 35: Desenho de Le Corbusier para as Cidades-Torres - Planta ................................................. 76

Figura 36: Desenho de Le Corbusier para as Cidades-Torres - Perspectiva ............................................ 76

Figura 37: La Ville Radieuse: planta de implantação com as faixas de zoneamento. ............................... 76

Figura 38: Imagens Cidade Contemporânea de 3 milhões de habitantes ........................................... 76

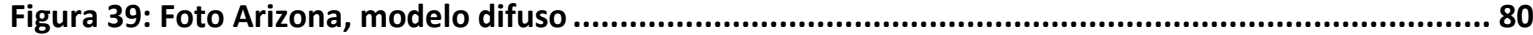

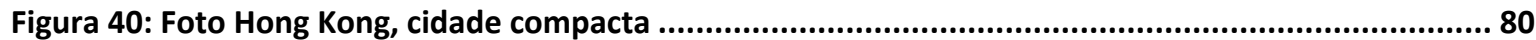

Figura 41: Bloco perímetro da quadra Barcelona ...................................................................... 84

Figura 42: Bloco perímetro da quadra Barcelona .................................................................... 84

Figura 43: Edifício Lâmina - Ministério da Educação, Rio de Janeiro, 1940 - Fachada Norte......................85

Figura 44: Edifício Lâmina - Banco Sul- Americano (atual Banco Itaú), São Paulo, 1965............................ 85

Figura 45: Edifício Torre - New York .............................................................................................8 85

Figura 46: Edifício Torre - Montagem com vários edifícios altos ...................................................... 85

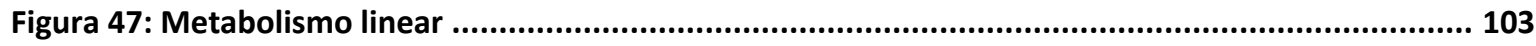

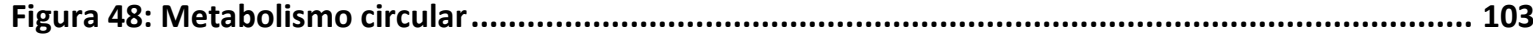

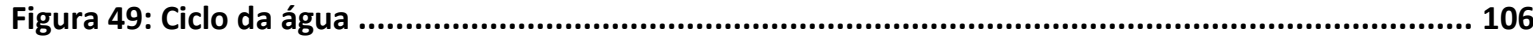

Figura 50: Impactos no ciclo da água após a construção em áreas urbanas .......................................... 106

Figura 51: Diferença no amortecimento do hidrograma de enchente em função da modificação no

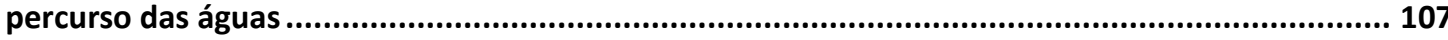

Figura 52: Gráfico de vazão x tempo, ilustrando o impacto da retificação dos rios no hidrograma de cheia. 107

Figura 53: Ciclo energético modelo atual............................................................................ 108

Figura 54: Ciclo energético modelo proposto para futuro .......................................................... 108

Figura 55: Estudo densidade populacional $x$ ocupação do solo urbano................................................ 111

Figura 56: Estudo de Rogers sobre a relação entre densidade e forma urbana ................................... 119

Figura 57: Estudo de Vargas sobre a relação entre densidade e forma urbana ..................................... 119

Figura 58: Imagem aérea projeto Expo Sevilha ............................................................................ 171

Figura 59: Imagem aérea da área da Expo Sevilha ................................................................. 171

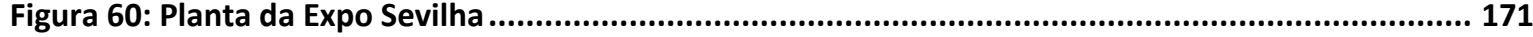

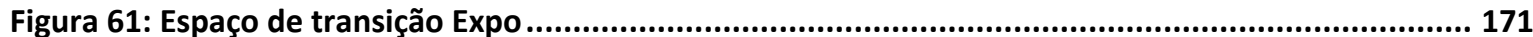

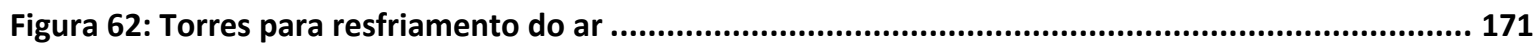

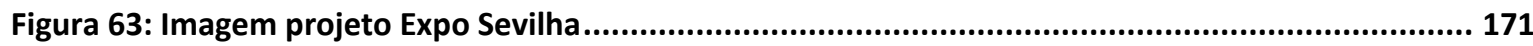

Figura 64: Área antes da intervenção urbana, Lisboa ...................................................................... 177

Figura 65: Área após a intervenção urbana, Lisboa ................................................................... 177 
Figura 66: Imagem da área da Expo Lisboa, atualmente ........................................................... 177

Figura 67: Imagem da área da Expo Lisboa, atualmente ......................................................... 177

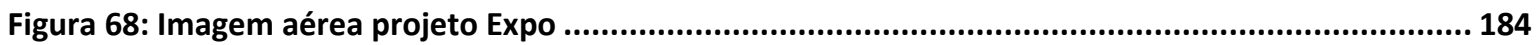

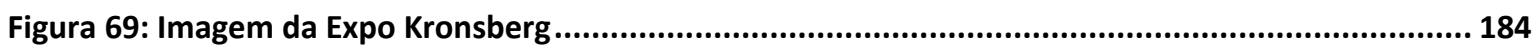

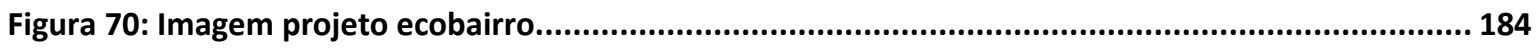

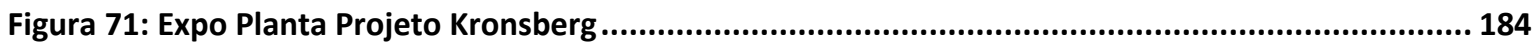

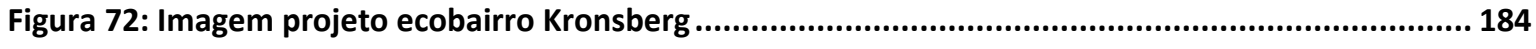

Figura 73: Imagem projeto ecobairro Kronsberg ..................................................................... 184

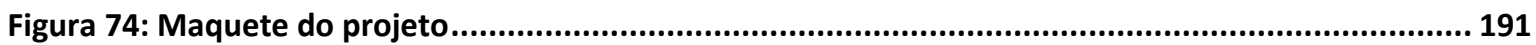

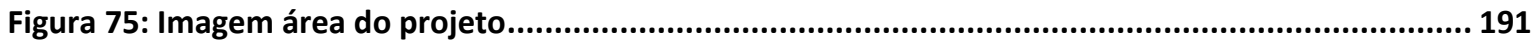

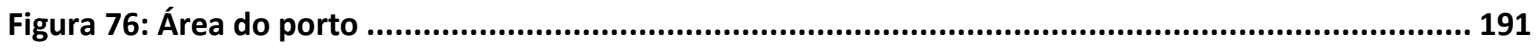

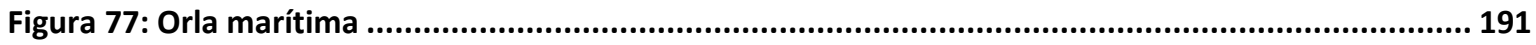

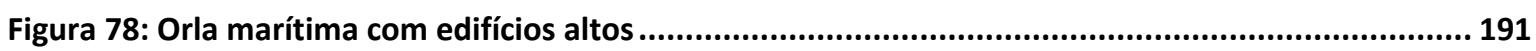

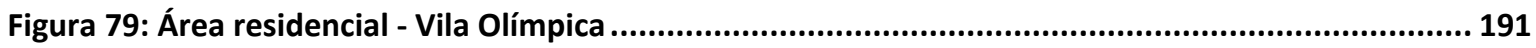

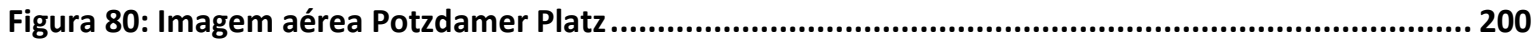

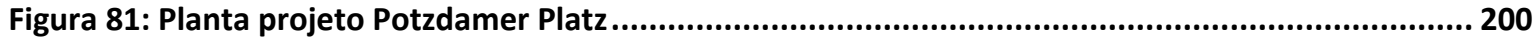

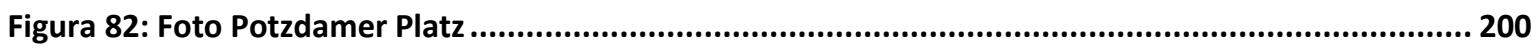

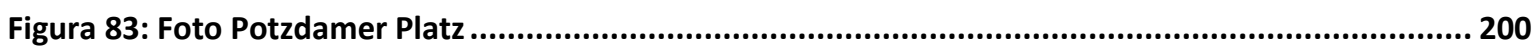

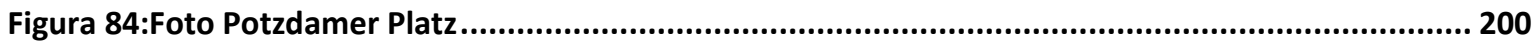

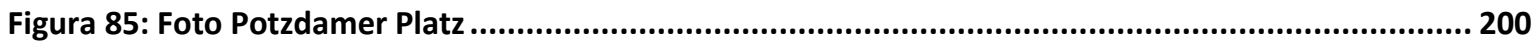

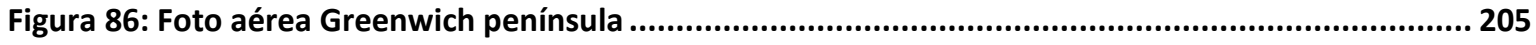

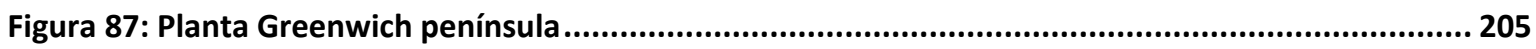

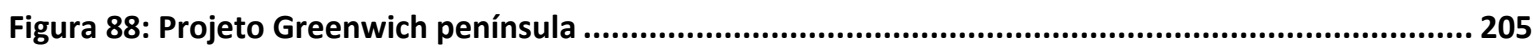

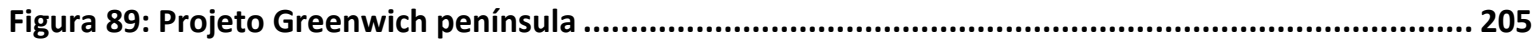

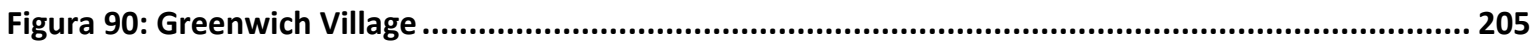

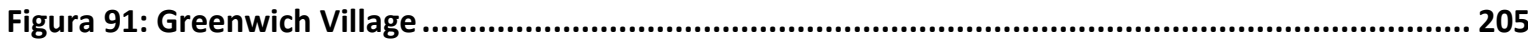

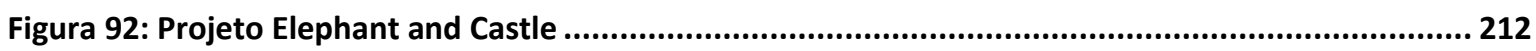

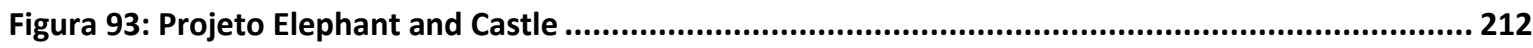

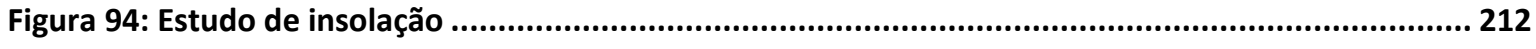

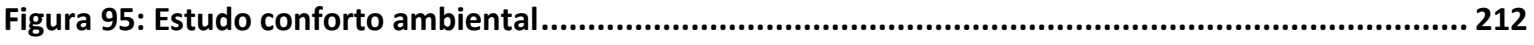

Figura 96: Foto do bairro Elephant \& Castle.............................................................................. 212

Figura 97: Foto do bairro Elephant \& Castle............................................................................... 212

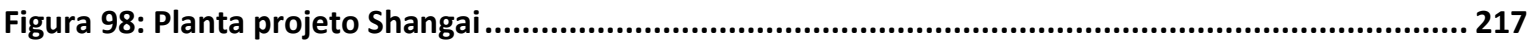

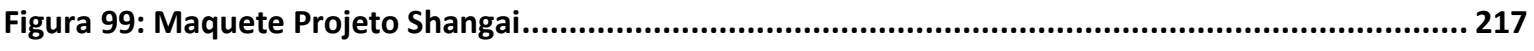

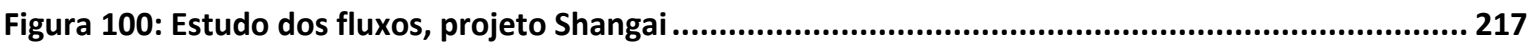

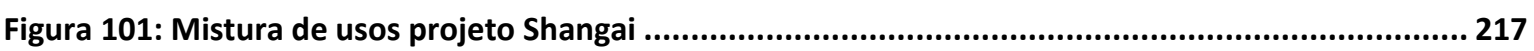

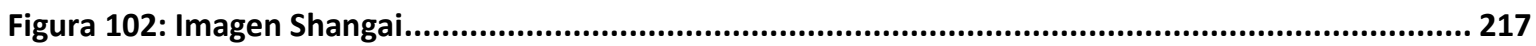




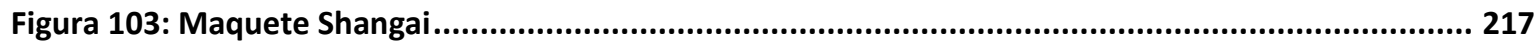

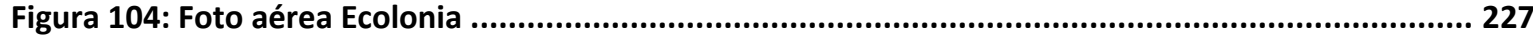

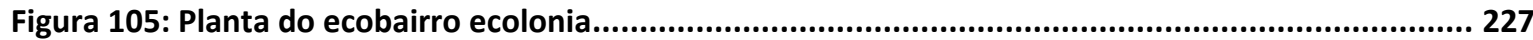

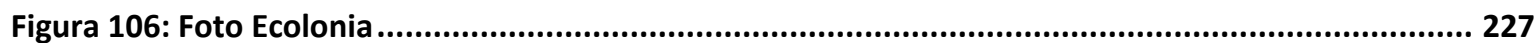

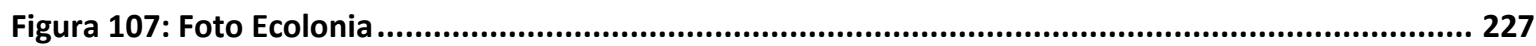

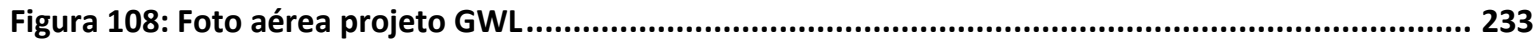

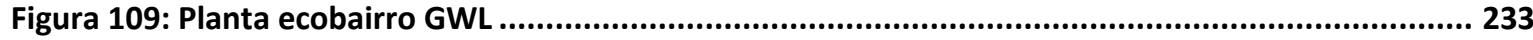

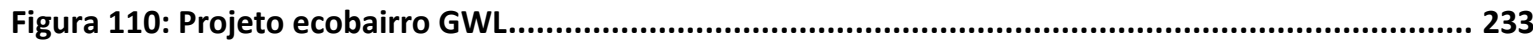

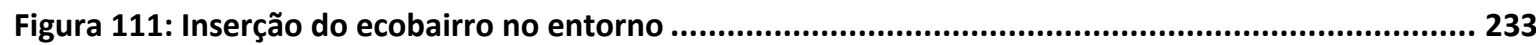

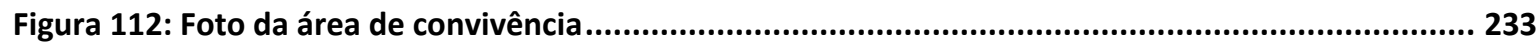

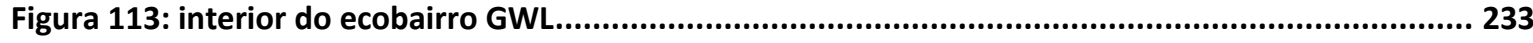

Figura 114: Imagem aérea Ecobairro Viikki.................................................................................................. 240

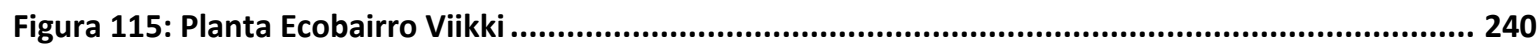

Figura 116: Foto a área do projeto ecobairro Viikki ........................................................................... 240

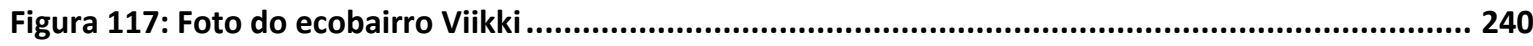

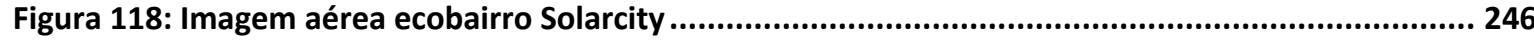

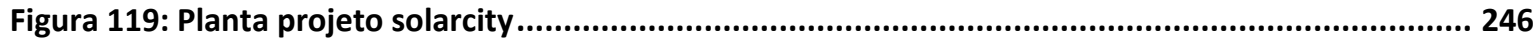

Figura 120: Estudo de insolação dos edifícios do ecobairro solarcity .................................................. 246

Figura 121: Estudo de insolação dos edifícios do ecobairro solarcity ........................................................ 246

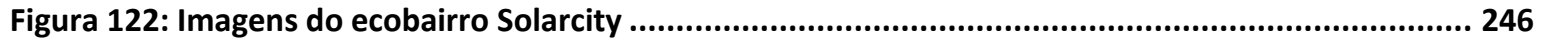

Figura 123: Esquema comparando Bedzed a um modelo de bairro convencional .................................. 249

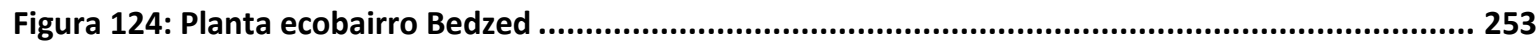

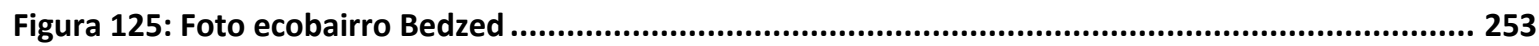

Figura 126: Estudo de insolação para definir forma e distâncias entre edificações ................................. 253

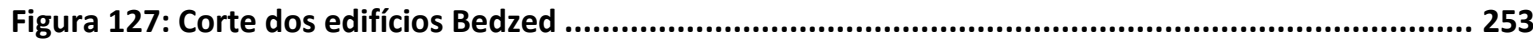

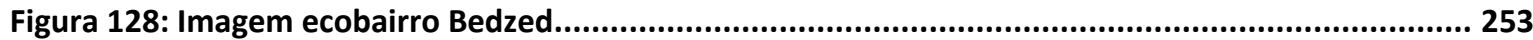

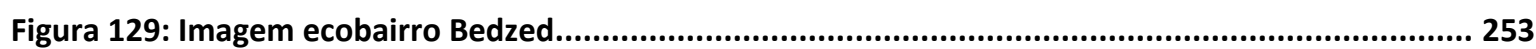

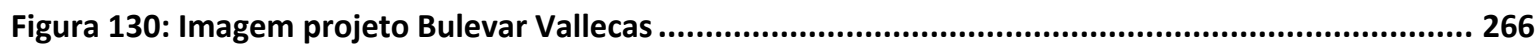

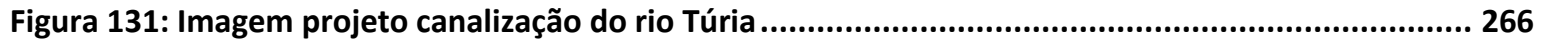

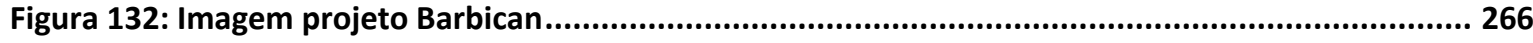

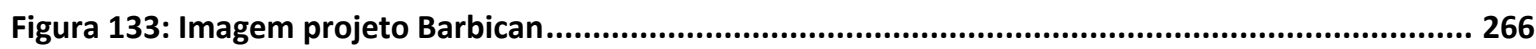

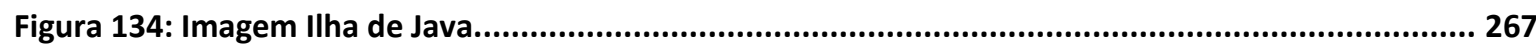

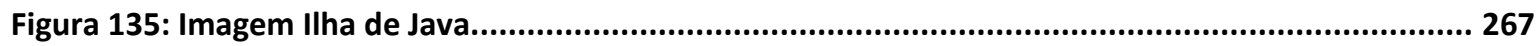

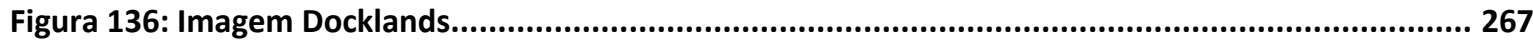

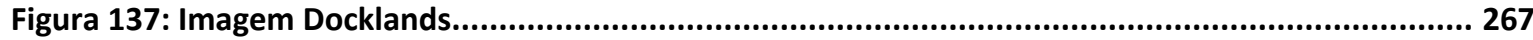


Figura 138: Imagem CETHS 267

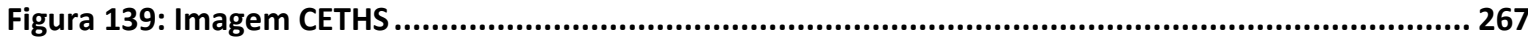

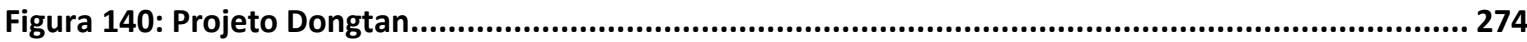

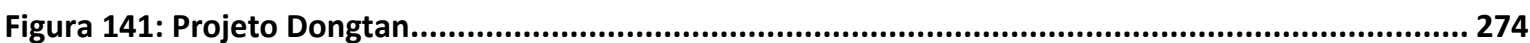

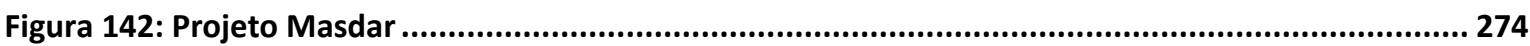

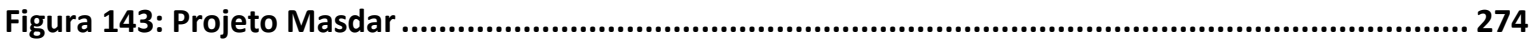

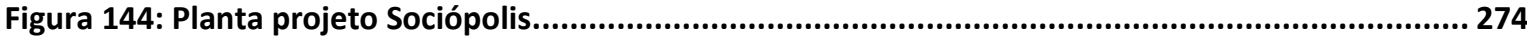

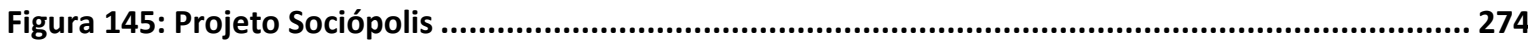

Figura 146: Mapa da área de interesse PRIH do Bairro da Luz , São Paulo.......................................... 292

Figura 147: Foto da área de interesse PRIH do Bairro da Luz , São Paulo.......................................... 292

Figura 148: Mapas Densidades de ocupação para São Paulo - Densidade construtiva por distrito de São

Paulo e Densidade Populacional por distrito de São Paulo.......................................................... 293

Figura 149: Mapa de uso do solo da área de estudo PRIH no bairro da Luz, São Paulo........................... 295

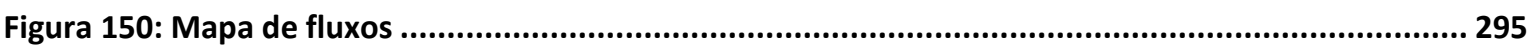

Figura 151: Mapa de gabarito dos edifícios da área de estudo, PRIH do bairro da Luz, São Paulo........... 297

Figura 152: Mapa de cheios e vazios da área de estudo, PRIH do bairro da Luz, São Paulo..................... 297

Figura 153 - Avaliação bioclimática da cidade de São Paulo pelos métodos de Mahoney e Givoni......... 299

Figura 154 - Avaliação bioclimática da cidade de São Paulo pelos métodos de Mahoney e Givoni......... 299

Figura 155: Diagnóstico Climático da cidade de São Paulo, baseado em dados de temperatura e umidade

do ar plotados sobre a carta psicrométrica, com a delimitação das zonas bioclimáticas. ............... 300

Figura 156: Frequência de ocorrência da iluminância no plano horizontal para São Paulo ..................... 302

Figura 157: Análise das obstruções máximas que permitissem uma hora de sol nas fachadas Norte, Nordeste, Leste e Sudeste 307

Figura 158: Ângulos de obstrução (máximo) para cada orientação para latitude $24^{\circ}$ 309

Figura 159: Aplicação e verificação dos ângulos de obstrução da quadra adotada para estudo, visando a

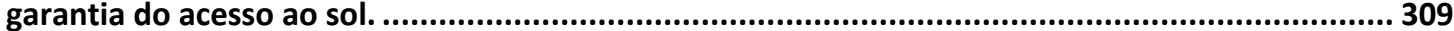

Figura 160: Estudo de sombra as 10hs no solstício de inverno - Cenário 01 quadras perimetrais........... 310

Figura 161: Estudo de sombra as 10hs no solstício de verão - Cenário 01 quadras perimetrais.............. 310

Figura 162: Estudo da qualidade do ar quadras perimetrais, nível térreo. ........................................ 311

Figura 163: Estudo da qualidade do ar quadras abertas, nível térreo. ................................................ 311

Figura 164: Variáveis e estudos técnicos para avaliação do conforto térmico nos espaços abertos ........ 313

Figura 165: Desempenho do conforto térmico nos espaços abertos - Cenário 01 quadras perimetrais... 313

Figura 166: Desempenho do conforto térmico nos espaços abertos - Cenário 02 quadras abertas. ........ 313

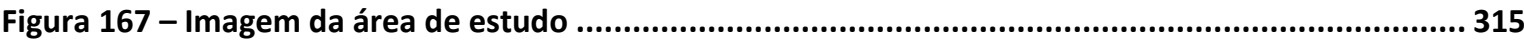

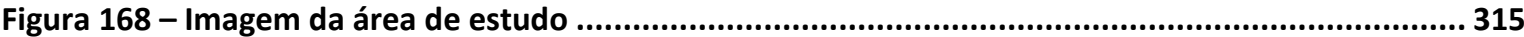

Figura 169: Ábaco para a determinação da distância mínima entre edificações..................................... 332

Figura 170: Modelo de envelope com recuos progressivos.......................................................... 332 
Figura 171: Cálculo do ângulo de obstrução 332

Figura 172: Carta Solar - Latitude 24오 Sul.

Figura 173: Gráfico Auxiliar. 333

Figura 174: Quadrante solar universal. 334

Figura 175: Relógio de sol montado com as lâminas do livro do Rivero. 334

Figura 176: Maquete do Heliodon de régua.

Figura 177: Maquete do Heliodon com um arco 335

Figura 178: Avaliação do índice de permeabilidade do solo .

Figura 179: Esquema da estrutura do método de inserção de parâmetros ambientais no processo de projeto 349

Figura 180: Classificação climática Anstrahler. 392

Figura 181: Classificação climática Koppen Geiger 392 


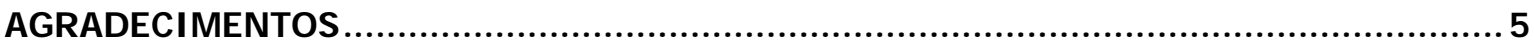

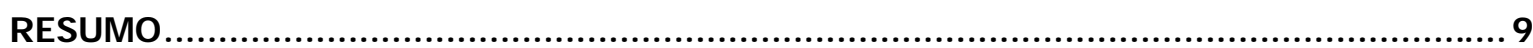

ABSTRACT

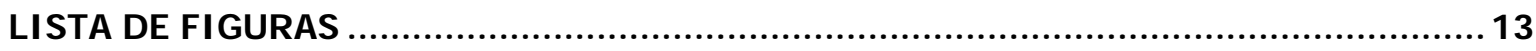

SUMÁRI O.......................................................................................................................... 19

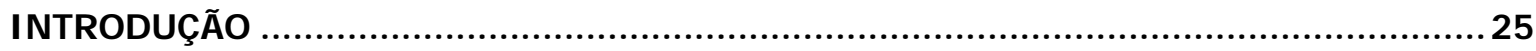

1. A QUESTÃO AMBI ENTAL NAS REFERÊNCI AS HI STÓRI CAS DO PROJ ETO URBANO ... 47

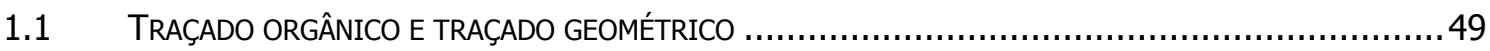

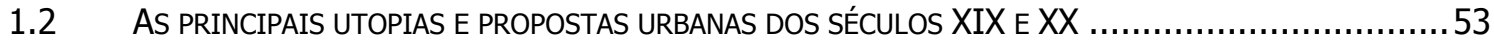

1.2.1 New Lanark e Falanstério - Robert Owen e Charles Fourier ................................54

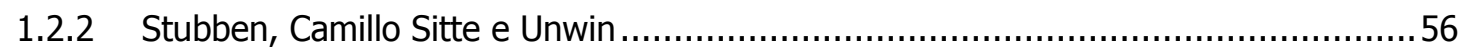

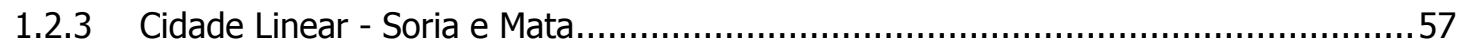

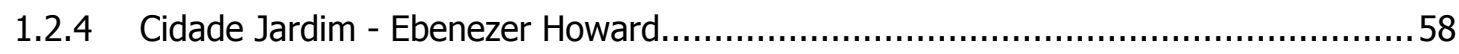

1.2.5 Plano de extensão de Barcelona - Ildefonso Cerdá ............................................64

1.2.6 Cidades Modernistas - F. L. W., Tony Garnier, Walter Groupis e Le Corbusier ..........65

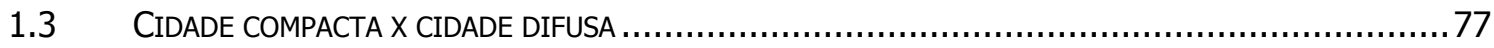

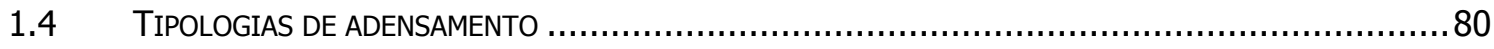

CAPÍTULO 2 - ÁREAS URBANAS E QUALIDADE AMBI ENTAL: CONCEITOS E DEFI NI ÇÕES

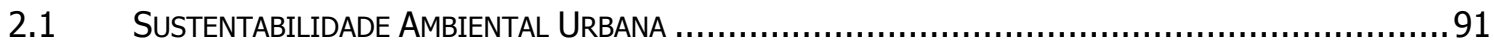

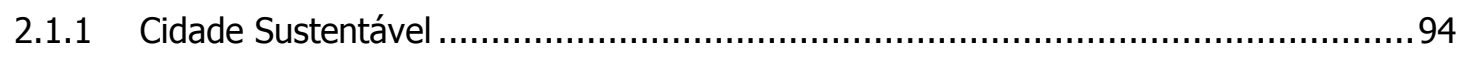

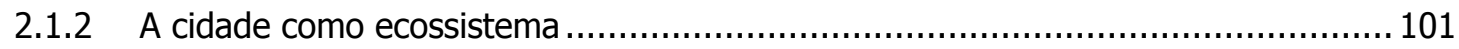

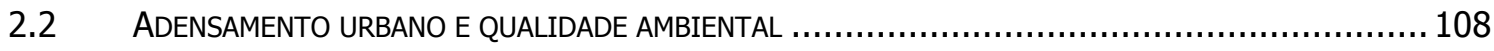

2.2.1 Aspectos favoráveis e desfavoráveis do adensamento urbano............................109 
2.2.2 Estudos sobre a densidade urbana e os aspectos ambientais 115

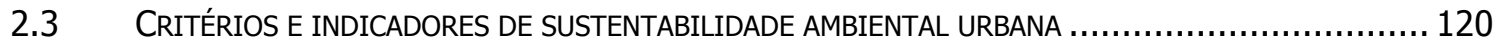

2.3.1 Requisitos, critérios e indicadores existentes.............................................. 125

2.3.2 Indicadores para a avaliação dos projetos contemporâneos ............................... 141

\section{CAPÍtULO 3 - ASPECTOS DA SUSTENTABILIDADE URBANA NOS PROJETOS CONTEMPORÂNEOS 155}

3.1 PROJETOS DE EXPOSIÇÕES INTERNACIONAIS E EVENTOS ESPORTIVOS.................................. 165

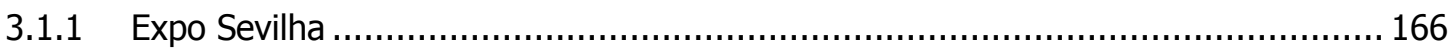

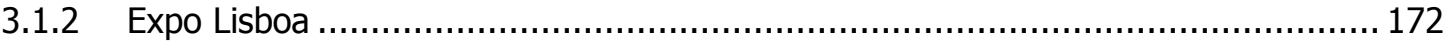

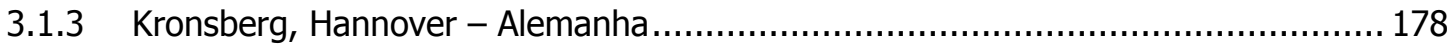

3.1.4 Vila olímpica em Barcelona ....................................................................... 185

3.1.5 Quadros projetos de exposições internacionais e eventos esportivos ................... 192

P.2 Projetos de ReCUPeração de BairRos Degradado.................................................. 194

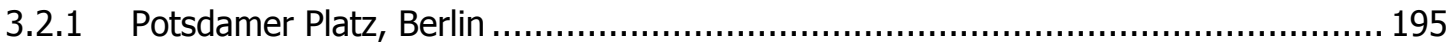

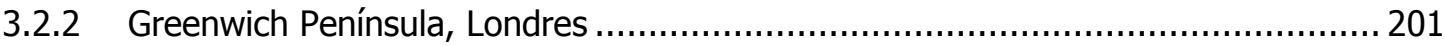

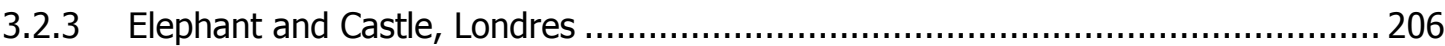

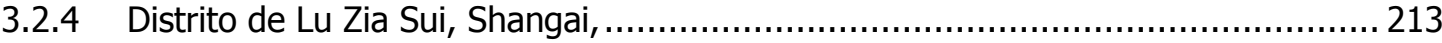

3.2.5 Quadro de avaliação qualitativa dos projetos de bairros degradados .................... 218

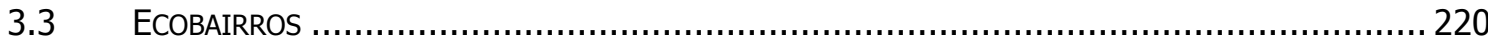

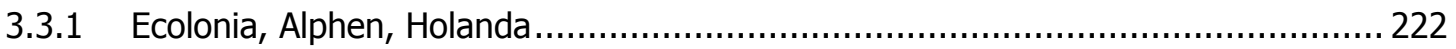

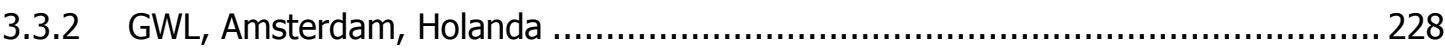

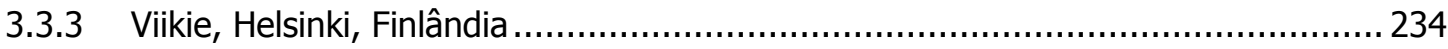

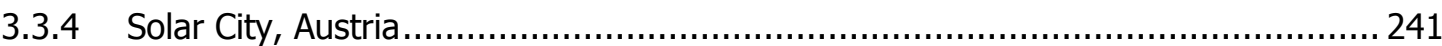


3.3.5 Bedzed, Londres, Reino Unido 247

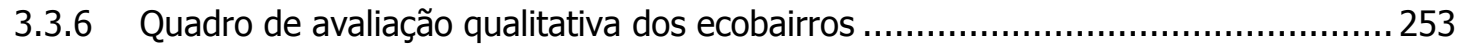

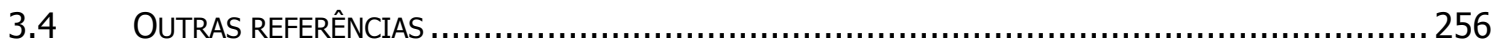

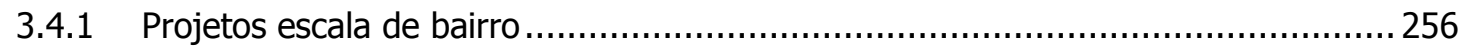

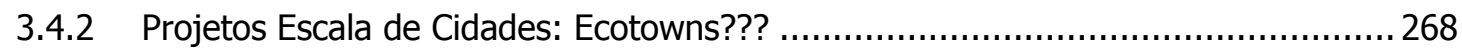

CAPÍTULO 4 - PROPOSTA DE INSERÇÃO DE PARÂMETROS AMBIENTAIS NO PROCESSO

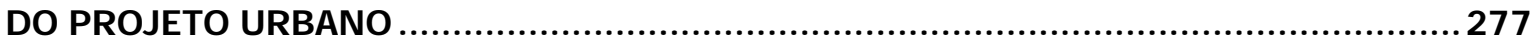

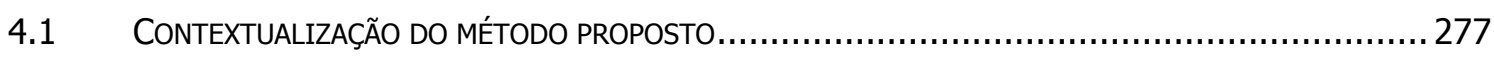

4.1.1 Metodologia Dimensões morfológicas do Processo de Urbanização...................... 279

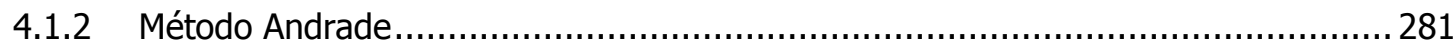

4.1.3 Método Higueras: Urbanismo bioclimático........................................... 283

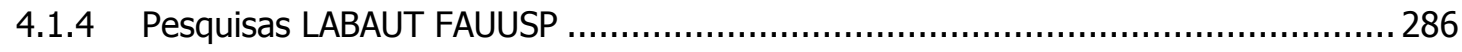

4.2 ESTUdO DE CASO: EXERCÍCIOS DE PROJETO LABAUT FAUUSP ................................. 291

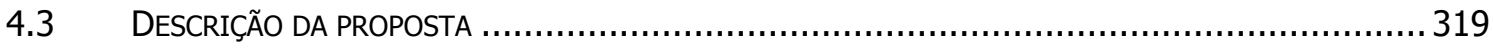

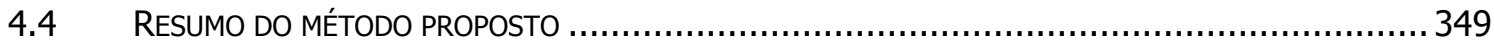

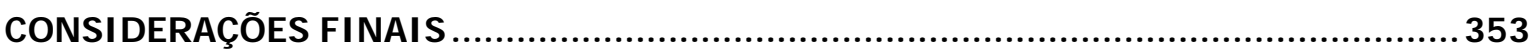

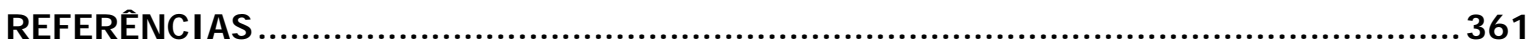

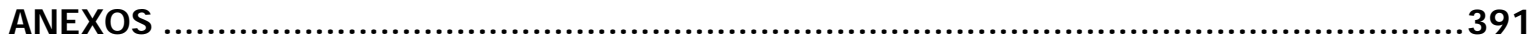


"Todos nós sabemos que há algo errado com nossas cidades, e que esse algo pode piorar se não aspirarmos a um modelo diferente de cidade no futuro. Se as formigas podem solucionar questões como tamanho, caráter e função correta de suas cidades, devemos ser capazes de fazer o mesmo com as nossas." (ROGERS, 2001, p.vii). 
24 


\section{INTRODUÇÃO}

\section{Colocação e Justificativa do Problema}

A presente pesquisa parte do problema que o crescimento e o adensamento urbano são inevitáveis e que vêm causando diversos danos ao meio natural e à qualidade ambiental das cidades.

Porém, deve-se destacar que a urbanização não é um mal em si, o problema é como construir e adensar as cidades. O homem sempre busca alterar o meio ambiente em função das suas necessidades socialmente definidas, e essas alterações mal conduzidas são a causa de muitos problemas no meio urbano (DUARTE, 2000).

Diante disso, visando minimizar os impactos gerados pelo processo de urbanização, com base na idéia de que o adensamento urbano pode ser positivo para a construção de cidades mais sustentáveis, o trabalho parte da necessidade da inserção do layer $^{1}$ meio ambiente no processo de projeto urbano, ou seja, além das outras "camadas do projeto" como usos, estoque construído e redes de infra-estrutura, as variáreis ligadas ao meio natural (relevo, vegetação, água, energia e clima) devem ser incorporadas ao projeto. Além disso, as outras camadas também devem ser analisadas sob o enfoque ambiental. ${ }^{2}$

No início da revolução industrial, a população mundial era de um bilhão de habitantes. Até 1930, atingiu-se dois bilhões, e atualmente este número gira em torno de 6,0 bilhões. Estima-se que até 2025 a população mundial será em torno de 8,5 bilhões, e em 205010 bilhões de habitantes (ROGERS, 2001).

Junto com este crescimento populacional, a porcentagem de habitantes que vivem nas cidades e nas zonas rurais também vem modificando. Em 1900 apenas $10 \%$ da população mundial vivia em cidades, e 90\% vivia no campo. Em 2000, esse número aumentou para 50\%. Segundo previsões do World Bank Group (2002), em 2050 a população mundial será de 10 bilhões de habitantes e $75 \%$ desse total viverá em centros urbanos.

\footnotetext{
${ }^{1}$ Expressão usada no meio, que pode ser traduzida como camada.

${ }^{2}$ Um esquema ilustrando esta idéia das camadas e enfoques do projeto urbano é apresentado no próximo item desta introdução.
} 
A Tabela 01 apresenta alguns dados do crescimento da população mundial e da porcentagem de população urbana, com sua distribuição pelos continentes. Pode ser verificado como esta distribuição populacional é desigual. Por exemplo, a Ásia tem mais da metade da população do planeta, e sua população urbana em 2000 era de apenas $37,7 \%$. Os dados mostram que a Ásia e a África são os dois continentes que ainda apresentam uma população rural maior que uma população urbana. Porém, é previsto que até 2025 a população urbana nestes continentes ultrapasse os 50\%, como já aconteceu nos demais continentes desde 1975. Europa, América do Norte, Oceania e América Latina apresentavam em 2000 uma população urbana de 75,1\%, 77,4\%, 70,2\% e $76,6 \%$, respectivamente, sendo previsto para 2025 um crescimento significativo destas taxas.

Tabela 1: Dados de população e de população urbana ${ }^{3}$

Fonte: ABIKO,2006 - notas de aula

\begin{tabular}{llll}
\hline \multirow{2}{*}{ ANO } & POPULAÇÃO (X1000) / POPULAÇÃO URBANA (\%) \\
& $\mathbf{1 9 7 5}$ & $\mathbf{2 0 0 0}$ & $\mathbf{2 0 2 5}$ \\
\hline \multirow{2}{*}{ MUNDO } & 4076985 & 6158051 & 8294341 \\
& 37.7 & 47.5 & 61.0 \\
\hline \multirow{2}{*}{ ÁFRICA } & 413988 & 831596 & 1495772 \\
& 25.1 & 37.3 & 53.8 \\
\hline \multirow{2}{*}{ ÁSIA } & 2405987 & 3735846 & 4959987 \\
\multirow{2}{*}{ EUROPA } & 24.6 & 37.7 & 54.8 \\
\hline \multirow{2}{*}{ AMÉRICA DO NORTE } & 676389 & 729803 & 718203 \\
\multirow{2}{*}{ OCEANIA } & 67.1 & 75.1 & 83.2 \\
& 239289 & 306280 & 369566 \\
\multirow{2}{*}{ AMÉRICA DO SUL } & 21.8 & 77.4 & 84.8 \\
\hline \multirow{2}{*}{ BRASIL } & 71.8 & 30651 & 41027 \\
& 319893 & 70.2 & 74.9 \\
\hline
\end{tabular}

Com relação ao Brasil, o país apresentava uma população urbana de mais de $80 \%$, sendo previsto para 2025 que este número chegue a quase $90 \%$. Pode-se dizer que a região metropolitana de São Paulo é a grande contribuidora deste número, já que a sua população praticamente dobrou nos últimos 45 anos (GONÇALVES, 2007).

\footnotetext{
${ }^{3}$ Notas de aula, disciplina PCC5100, oferecida pelo departamento de engenharia de construção civil da Escola Politécnica da USP, pelo professor Alex Abiko, realizada no dia 05 de abril de 2006.
} 
Dados apresentados na exposição Global Cities - realizada na Tate Modern, em Londres, de 20 de junho a 27 de agosto de 2007, mostram que, atualmente, existem mais de vinte megacidades com mais de dez milhões de habitantes, além de aproximadamente 450 regiões metropolitanas com mais de um milhão de habitantes. Somadas, essas áreas representam mais de um bilhão de habitantes sobre uma porção relativamente pequena da superfície do planeta.

O problema é que o crescimento e adensamento dessas cidades, normalmente, resultam em impactos sobre o clima, os ecossistemas e a qualidade de vida no ambiente urbano. As cidades são vistas como uma das principais responsáveis por grande parte do impacto ambiental gerado no mundo.

A ação humana, por meio do processo de urbanização, atinge o clima em todas as escalas, com resultados quase sempre negativos.

A capacidade das cidades de alterar o clima local foi primeiramente identificada por Luke Howard em 1833 em seus estudos para a cidade de Londres (OKE, 1982). No decorrer dos anos, diversos estudos comprovaram estas alterações e identificaram um fenômeno que ficou conhecido como "ilha de calor", definido por um aumento da temperatura à medida que se deixa a área rural adjacente à cidade e se caminha em direção ao centro adensado. Estudos climatológicos da década de 70 estabeleceram correlações entre este aumento de temperatura e a população da cidade (OKE, 1973).

Além do aumento da temperatura, a urbanização diminui a umidade, modifica a direção dos ventos, aumenta o índice de pluviosidade e altera a composição química da atmosfera. Com isto, é previsto, que o clima pode se tornar mais rigoroso, prejudicando o conforto térmico dos habitantes das cidades, além de ocasionar diversas catástrofes ambientais, como o surgimento de tempestades, ressacas, tufões, e outros problemas decorrentes também destas mudanças climáticas.

O aumento do índice pluviométrico ocasiona uma alteração do nível do mar, que vem subindo algo em torno de 1,5 a 2,0 milímetros por ano. Este problema se agrava com o derretimento das calotas polares, intensificando o aumento do nível do mar, podendo chegar até meio metro antes do fim do século (ROGERS, 2001, p.4).

A elevação do nível do mar pode levar ao desaparecimento de diversas ilhas e pedaços de terra, além de destruir a vida de imensas populações ao longo da costa. 
Além do impacto causado ao clima, o desenvolvimento das cidades vem acompanhado de diversos outros problemas ambientais, decorrentes em maior ou menor grau do crescimento urbano e do aumento da população mundial.

O mais evidente é a transformação do solo natural em solo urbano. Isto pode causar uma degradação e contaminação dos solos, sobretudo em zonas industriais. De acordo com os dados ambientais das Nações Unidas de 1993 e 1994, 17\% dos solos em todo o mundo foram atingidos desde 1945.

Essa transformação do solo também prejudica o ciclo natural da água, que é interrompido pela sua impermeabilização, aumentando o escoamento e a velocidade da água superficial. Além disto, pode ocasionar a poluição e o assoreamento dos rios e lagos, causados pelo transporte de detritos lançados nas ruas ${ }^{4}$.

Isso implica, entre outros problemas, na redução da disponibilidade de água, que se agrava com o aumento da demanda causado pelo processo de urbanização e adensamento urbano.

Segundo Andrade (2006), a devastação ambiental ocorrida ao longo do século passado, bem como a contaminação e o uso indiscriminado desse recurso natural, provocaram a redução considerável dos mananciais.

O recurso água é difícil de esgotar, porém o acesso a água potável é dramático em muitas ocasiões. A escassez de água potável é um dos mais graves indicadores dos impactos da atividade humana sobre os recursos naturais. A demanda mundial por água duplica a cada 20 anos, e é maior do que o crescimento da oferta de água potável. Além disso, as cidades têm que buscar seus recursos hídricos em locais cada vez mais distantes. Atualmente, um terço da população mundial sofre com a carência de água e dois terços da população terão dificuldades em obter água no ano 2025 (PNUMA apud ANDRADE, 2005).

Além da poluição dos solos e da água, talvez a mais sentida pela população seja a poluição do ar, que entre outras conseqüências, afeta diretamente a saúde pública.

\footnotetext{
${ }^{4}$ O ciclo ecológico urbano da água será explicado no capítulo 2 da Tese.
} 
A qualidade do ar significa a capacidade do meio ambiente em receber e diluir poluentes emitidos para atmosfera. É possível afirmar que em áreas urbanas há um maior risco de contaminação do ar decorrente do aumento de fontes poluidoras, indústrias e veículos, assim como uma maior dificuldade à dispersão de poluentes.

Dados mostram que, atualmente, dois trilhões de metros cúbicos de vapores de fumaça são emitidos por ano pelos veículos e, provavelmente, o número de automóveis irá dobrar até o ano de 2030, aumentando este número (MEGALE, 2002, p.35).

Os transportes nas cidades são responsáveis por mais de $50 \%$ das emissões contaminantes, e em muitas cidades este valor é superado, como em Barcelona, 60\%, Paris, $70 \%$ e na Cidade do México, considerada a maior e a mais poluída cidade do mundo, 80\%. Nesta última, circulam mais de quatro milhões de automóveis. Dados mostram que a poluição dessa cidade é seis vezes mais tóxica do que os índices aceitáveis pela Organização Mundial de saúde, sendo que quantidade de ozônio excede o nível de alerta mais de 300 dias do ano (SERVANT, 2001, p.35).

A situação na cidade é ainda agravada pela redução e má distribuição da área verde. $A$ vegetação reduz a poluição do ar por meio da retenção e filtragem de partículas de poeira nas superfícies das folhas e das trocas gasosas, liberando o oxigênio e absorvendo o dióxido de carbono, dióxido de nitrogênio e dióxido de enxofre.

Em muitos países, a contaminação do ar também está diretamente relacionada ao consumo de energia elétrica, através de matrizes poluidoras de geração de energia. Sobre isso, verificou-se que nos últimos 20 anos o consumo mundial de energia aumentou em cerca de $50 \%$, de uma forma geral, sendo que parte significativa dessa energia é gerada a partir de combustíveis fósseis, cuja queima produz gases geradores do chamado efeito estufa, principalmente $\mathrm{O}_{\mathrm{CO}_{2}}$ (IEA, 2002). ${ }^{5}$ As emissões deste gás na atmosfera são responsáveis por um aumento considerável da temperatura no planeta e conseqüentemente, por uma elevação das áreas desérticas e do nível dos oceanos, entre outros impactos ambientais. Além disso, a qualidade do ar também pode prejudicar a vida

\footnotetext{
${ }^{5}$ Durante a Conferência de Kyoto, em dezembro de 1997, foi aprovado um protocolo destinado a limitar as emissões de seis gases $\left(\mathrm{CO}_{2}, \mathrm{CH}_{4}, \mathrm{~N}_{2} \mathrm{O}, \mathrm{HFC}_{\mathrm{S}}, \mathrm{PFC}_{\mathrm{S}}\right.$ e $\left.\mathrm{SF}_{6}\right)$ que são os principais causadores do efeito estufa. $\mathrm{A}$ União Européia, por exemplo, se comprometeu a reduzir em $8 \%$ as emissões desses até 2010, dividindo proporcionalmente essa responsabilidade centre os 15 países que a integram. Atualmente quase todos os países não cumpriram a meta ou nem sequer assinaram esse protocolo (HIGUERAS, 2009).
} 
animal e vegetal e provocar precipitação ácida na atmosfera, dependendo do seu grau de poluição.

De acordo com Rogers (1997), atualmente, as cidades consomem três quartos de toda a energia do mundo e causam pelo menos a mesma parcela da poluição global. Ele ainda completa:

As cidades são o centro da produção e do consumo de grande parte dos bens industriais e acabaram se transformando em parasitas da paisagem, em enormes organismos drenando o mundo para seu sustento e energia: inexoráveis consumidores e causadores de poluição. (ROGERS, 1997, p.27).

No Brasil, embora o consumo de energia não resulte necessariamente na emissão de $\mathrm{CO}_{2}$, devido à composição da matriz energética, ele não está desvinculado da questão ambiental. Pelo contrário, a grande participação das hidroelétricas torna o impacto social e ambiental das represas e reservatórios uma importante preocupação. ${ }^{6}$ Somado a isso, as previsões para países em desenvolvimento demonstram que esses sofrem algumas restrições de abastecimento energético que estão ocultas pelas desigualdades sociais, ou seja, se toda a massa empobrecida desses países utilizasse o mínimo de energia elétrica necessário para ter uma vida digna, a energia elétrica gerada nos mesmos não seria suficiente (MEADOWS et. al., 2004).

Vale destacar a desigualdade com que estes recursos são consumidos. O hemisfério norte representa $20 \%$ da população mais rica do mundo é a que consome aproximadamente $80 \%$ dos recursos naturais disponíveis de todo o planeta, produzindo uma contaminação global equivalente (PNUD, 1998).

Essa desigualdade de consumo de recursos e poluição entre os países, pode ser observada nas tabelas. A Tabela 2 apresenta dados sobre as matrizes geradoras de energia em sete países, o quanto cada um destes países emite de CO2. E a Tabela 3 apresenta uma comparação da emissão de CO2 por continente.

\footnotetext{
${ }^{6}$ Bermann, Celio. Notas de aula, disciplina POE - Políticas Energéticas Ensino e Pesquisa na área de Energia. Curso de Especialização em Conforto Ambiental e Conservação de Energia, CECACE, FAUUSP. Realizado em fevereiro de 2001.
} 
Tabela 2: Dados matriz energética

Fonte: Dados - elaborada por BRANDAO, 2009

\begin{tabular}{|c|c|c|c|c|c|c|c|}
\hline Matriz & $\begin{array}{l}\text { Gás }-39,3 \% \\
\text { Carvăo-33,4\% } \\
\text { Nuclear-20,6\% } \\
\text { Renovável }-3,8 \% \\
\text { Outros }-2,9 \%\end{array}$ & $\begin{array}{l}\text { Carvāo- } 76,7 \% \\
\text { Gás-14,2\% } \\
\text { Hidro-6,8\% } \\
\text { Petroleo-1,3\% } \\
\text { Outros-1,0\% }\end{array}$ & $\begin{array}{l}\text { Nuclear-78\% } \\
\text { Hidro- } 11 \% \\
\text { Fóssil-10\% } \\
\text { Sol.Nento-0,2\% } \\
\text { Outros-0,6\% }\end{array}$ & $\begin{array}{l}\text { Fóssil-64\% } \\
\text { Nuclear-23\% } \\
\text { Hidro- } 12 \% \\
\text { Geotérm. }-0,3 \% \\
\text { Outros }-2,4 \%\end{array}$ & $\begin{array}{l}\text { Carvāo-49,0\% } \\
\text { Gás-20,0\% } \\
\text { Nuclear-19,4\% } \\
\text { Hidro-7,0\% } \\
\text { Petróleo-1,6\% } \\
\text { Outros-3,1\% }\end{array}$ & $\begin{array}{l}\text { Hidro- } 75,8 \% \\
\text { Gás }-8,5 \% \\
\text { Carvăo-3,8\% } \\
\text { Nuclear-3,0\% } \\
\text { Import- }-8,9 \%\end{array}$ & $\begin{array}{l}\text { Hidro }-63,9 \% \\
\text { Gas-16,19\% } \\
\text { Geotérm. }-6,4 \% \\
\text { Carväo- } 9,7 \% \\
\text { Vento- } 1,1 \% \\
\text { Outros- } 2,7 \%\end{array}$ \\
\hline $\begin{array}{l}\mathrm{CO}_{21} \\
\mathrm{kWh}\end{array}$ & 0,46 & 1,051 & 0,056 & 0,44 & 0,608 & 0,029 & 0,1 \\
\hline Fonte & $\begin{array}{l}\text { Electricity } \\
\text { info.org (2006) }\end{array}$ & $\begin{array}{l}\text { Australian Instiof } \\
\text { Energy (2006) } \\
\text { Uranium Info.Center } \\
\text { (2006) }\end{array}$ & $\begin{array}{l}\text { IEA (2004) } \\
\text { Bustamante } \\
\text { (2006) }\end{array}$ & $\begin{array}{l}\text { IEA (2004) } \\
\text { US-EPA (2006) }\end{array}$ & IEA (2006) & $\begin{array}{l}\text { BEN 2007 } \\
\text { Ministério da } \\
\text { Gièncise } \\
\text { Tecnologia }\end{array}$ & $\begin{array}{l}\text { Mihraratne, } \\
\text { Vale \& Vale } \\
2005\end{array}$ \\
\hline
\end{tabular}

Tabela 3: Dados Emissão de $\mathrm{CO}_{2}$ por pessoas/ ano

Fonte: elaborada por BRANDAO, 2009

\begin{tabular}{l|c|c}
\hline Regifäo & $\begin{array}{c}\text { Populagão } \\
(\mathrm{m} \text { ilhöes) }\end{array}$ & $\begin{array}{c}\mathrm{CO} 2 \\
\text { (ton/pessoa/ano) }\end{array}$ \\
\hline Ásia & 3.222 & 2,3 \\
África & 710 & 0,9 \\
America Latina e Caribe & 484 & 2,3 \\
Europa Ocidental & 384 & 9,0 \\
Europa Central e Oriental & 343 & 7,7 \\
Oriente Médio e Ásia & 307 & 4,0 \\
Central & & 19,0 \\
América do Norte & 299 &
\end{tabular}

Previsões apontam que a emissão de $\mathrm{CO} 2$ devido ao uso das edificações pode chegar a $30 \%$ do total em 2030 (LEVINE et. al., 2007). Atualmente, as edificações são responsáveis por $8 \%$ da emissão de $\mathrm{CO} 2$ em termos de energia primária, somada a 13\% em usos indiretos. Uma distribuição regional mostra que a maioria dessas emissões ocorre em países desenvolvidos, sendo a América do Norte a que mais emite

Com relação ao consumo mundial de energia elétrica, aproximadamente $33 \%$ desse é usado pelos edifícios (IEA, 2009). Sendo que a energia consumida nos setores residenciais e comerciais é de $23 \%$ do consumo mundial. A energia utilizada varia consideravelmente dependendo da região e dos pais em decorrência da geografia, localização e clima. Vale destacar que existe uma diferença na natureza da demanda de 
energia e no desempenho de edifícios entre os países pertencentes ao OECD (Organization for Economic Co-operation and Development) e os não pertencentes (maioria dos países em desenvolvimento) (LEVINE M. et al, 2007). Nos países pertencentes ao OECD, maioria localizada em regiões frias, o consumo de energia com calefação representa $60 \%$, seguida de aquecimento de água com $18 \%$ (WBSD, 2007). Já os países não pertencentes ao OECD não necessitam tanto de aquecimento artificial, sendo a iluminação e os equipamentos de ar condicionado os grandes consumidores no setor comercial e os sistemas de refrigeração e aquecimento de água, no setor residencial.

Segundo Goldemberg (2001), no Brasil o parque edificado é responsável por $46 \%$ do consumo energético nacional, sendo que o setor residencial $(22,6 \%)$ e comercial $(14,2 \%)$ são os principais responsáveis pelos altos índices de crescimento do consumo.

De acordo com Almeida et al (2001) no setor residencial os sistemas refrigeração são responsáveis por $34 \%$ do consumo de energia elétrica da edificação, os sistemas de iluminação $12 \%$ e de aquecimento de água $21 \%$. No setor comercial os sistemas de condicionamento artificial são responsáveis por $36 \%$ e os sistemas de iluminação $52 \%$.

Os gráficos apresentados nas Figuras 1 e 2 mostram essa diferença entre o Brasil, EUA e Reino Unido com relação ao consumo energético desagregado por setor.

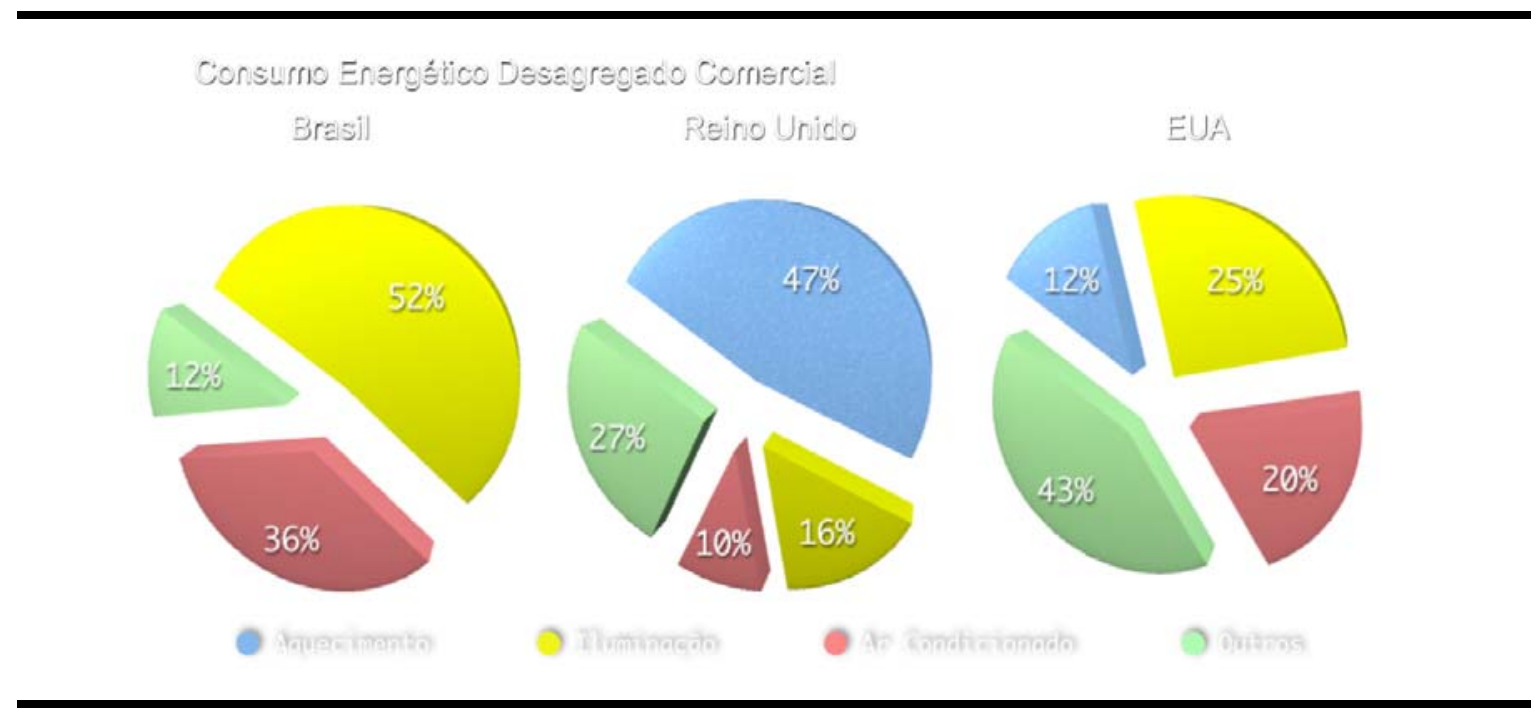

Figura 1: Consumo energético desagregado setor residencial

Fonte: ALMEIDA et al (2001) (Dados Brasil); e GREEN building bible (2006) (Dados Reino Unido) UNITED STATES (2008) (Dados EUA) elaborado por BRANDÃO 
Consurno Energético Desegregeco Resiliencie.

Brasil

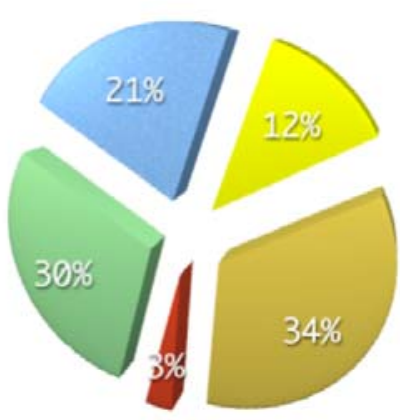

Reino Unicio

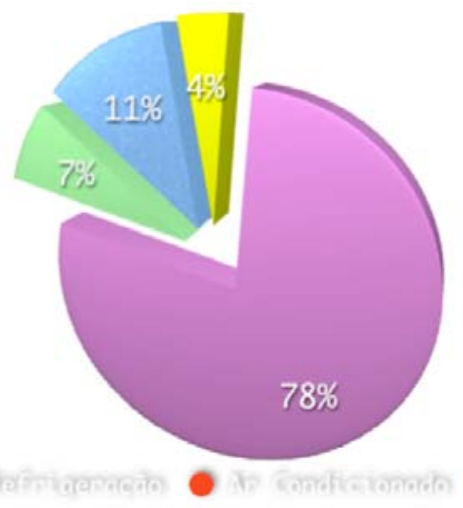

EUA

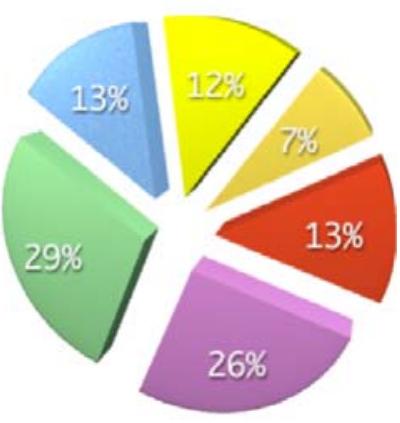

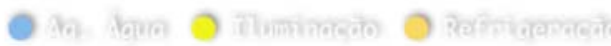

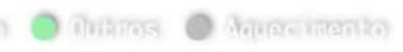

Figura 2: Consumo energético desagregado setor residencial

Fonte: ALMEIDA et al (2001) (Dados Brasil); e GREEN building bible (2006) (Dados Reino Unido) UNITED STATES (2008) (Dados EUA) elaborado por BRANDÃO

Apesar disso, McKinsey (2009) identificou através de estudos realizados em 36 países que o setor das edificações é o que tem o maior potencial para redução de parcela significativa do consumo de energia elétrica, e conseqüentemente, da emissão de $\mathrm{CO}_{2}$ em todos os países e em todos os níveis de custos (LEVINE et al., 2007).

Observa-se que os sistemas que mais consomem energia elétrica estão também relacionados ao acesso aos recursos naturais. Não basta projetar o edifício corretamente e com as mais avançadas tecnologias, se não está garantido que esse terá acesso ao sol, à luz natural e ao vento.

Por outro lado, em países quentes a necessidade pode ser outra. Brandão (2004) demonstrou, por exemplo, que a obstrução e sombreamentos provocados por edifícios urbanos resultam em alterações significativas no seu consumo energético. A tecnologia atual permite adequar ambientes confinados a qualquer condição desejada, através de sistemas artificiais de iluminação e climatização. Isso, porém, demanda gastos energéticos, determinados pela incapacidade da edificação de atingir estas condições de maneira natural.

Sendo assim, os projetos das edificações devem ser adequados ao clima e ao contexto local, da mesma forma que devem ser analisados os impactos ambientais dessas sobre as construções vizinhas e os espaços externos localizados no entorno imediato. 
O impacto ambiental, positivo ou negativo, que qualquer construção vai causar ao meio urbano inclui, em resumo: a ventilação ao redor das edificações e a dispersão de poluentes, que está relacionada ao conforto do pedestre e a qualidade do ar; a ventilação natural das edificações, o acesso ao sol e a disponibilidade de luz natural, que está relacionada ao conforto térmico e luminoso e a demanda de energia elétrica; a acumulação de calor pela radiação e atividades dentro dos edifícios, que estão relacionadas ao desempenho térmico das edificações, conforto dos pedestres; e a propagação de ruído urbano.

Vale destacar também os parâmetros projetuais do ambiente construído e as tipologias edificatórias, que são relacionados com as condições microclimáticas locais (e basicamente ao desempenho ambiental das edificações e dos espaços externos): a forma das edificações ou tipologia, a orientação e altura das edificações, a área construída, a distância entre as edificações, a forma, dimensionamento e orientação dos espaços externos, os materiais aplicados nas superfícies, a inserção de vegetação e água e suas relações com a forma construída.

Com base nestas considerações, um dos principais desafios correntes para o projeto urbano na tentativa de contribuir para a eficiência energética das edificações e uma cidade mais sustentável é demonstrar as possibilidades de introduzir alta densidade em áreas construídas dentro dos limites da infra-estrutura local e da qualidade ambiental, buscando os benefícios sociais e econômicos. A questão da densidade e da forma urbana vem acompanhada de uma série de possibilidades projetuais, determinadas pelas particularidades do ambiente e do contexto urbano. Em áreas consolidadas, por exemplo, as metas para adensamento populacional são determinadas pela infra-estrutura local, além da ligação desenvolvida entre o ambiente construído, a capacidade da infraestrutura e o potencial de desempenho e sustentabilidade ambiental.

Oportunidades de melhoria da qualidade ambiental nas cidades também surgem em vazios urbanos e áreas da periferia, onde pode ser desenvolvida uma nova morfologia configurativa, com o suporte de novas tecnologias, além de alcançar altos níveis de sustentabilidade ambiental urbana. Nestes casos, a meta de densidade é determinada e limitada pelos requisitos e critérios relacionados às questões de qualidade ambiental, como acesso ao sol, qualidade do ar, conforto do pedestre, desempenho energético das edificações e potencial de geração de energia na área das edificações. 
Meyer aponta o pensamento e a ação urbanística num momento atual de descrédito, que alimenta o desafio do projeto urbano a criar novas estratégias de ação e novos modelos de reflexão. Segundo Meyer, o dilema está entre promover a continuidade ou estimular a ruptura do pensamento e da prática oriundas dos princípios modernistas no nosso país, do qual somos herdeiros em linha direta. Ela ainda afirma:

"A meta não é apenas construir uma pauta de questões capazes de conduzir o projeto urbano cujo ponto de partida não é mais circunscrever áreas, criar perímetros de ação baseados em tipologias ou morfologias que apontam homogeneidade ou continuidade urbana. Mas, sobretudo, criar novos parâmetros para um trabalho de projeto urbano." (MEYER, 2004, p.)

Algumas questões contemporâneas relacionadas ao projeto urbano no momento atual, lançadas durante a exposição Global Cities, realizada na Tate Modern, em Londres, de 20 de junho a 27 de agosto de 2007, são consideradas e servem de inspiração para esta pesquisa (GONÇALVES, 2007, p.19).

"Que cidades queremos construir?

"A forma urbana das nossas cidades afeta o futuro do planeta e a sua sustentabilidade?

Como as cidades poderão acomodar bilhões de pessoas com qualidade e dignidade?

É possível que a qualidade de vida nas cidades seja melhorada e os seus impactos ambientais reduzidos por meio de estratégias de projeto, envolvendo aspectos da arquitetura, projeto urbano e planejamento?"

Neste contexto, pode-se afirmar que os assentamentos urbanos adequados ao meio ambiente, reduzem o consumo de água, de energia e a contaminação, proporcionam um melhor microclima local e um bem estar para a população, decorrente de uma melhora na qualidade de vida. Atualmente existem alguns exemplos, que serão apresentados no capítulo 03 dessa Tese, de ecocidades, ecobairros e urbanizações ambientais, que comprovam isso (HIGUERAS, 2007, p.17). ${ }^{7}$

\footnotetext{
7 Alguns destes exemplos podem ser encontrados no capítulo 03 da Tese e nas referências: Ruano (2000), Gauzin-Müller (2001), Rogers (2001), Beatley (1999) e EMVS (2005).
} 
Segundo Andrade (2007, p.x) "os procedimentos de projeto necessitam incluir a dimensão ecológica8 baseados em valores da relação entre o homem e a natureza que considerem a espécie humana como parte dos ecossistemas naturais."

Enfim, esta pesquisa parte da premissa que o adensamento urbano pode ser positivo, desde que a sustentabilidade ambiental seja um princípio orientador do processo de produção do espaço urbano.

Através de uma análise destes projetos esta pesquisa tem como premissa, demonstrar que o projeto urbano baseado em critérios de sustentabilidade, pode gerar cidades com qualidade ambiental, resultando menos impacto ao meio natural. Além disso, estes projetos podem apresentar grande coesão conceitual, servindo como novo paradigma para as intervenções urbanas contemporâneas.

\section{Objeto da Pesquisa}

O objeto da pesquisa é o processo de projeto urbano visando o adensamento com qualidade ambiental com ênfase nas exigências humanas, nos requisitos, critérios e soluções.

A definição de qualidade ambiental está baseada principalmente em: consumo eficiente de recursos (água e energia); ambientes urbanos menos poluídos; conforto ambiental satisfatório em edifícios e espaços urbanos; transporte eficiente para pessoas e produtos em termos de consumo de energia, impacto ambiental e mobilidade, e presença de nichos ecológicos.

A partir do objeto teórico da pesquisa, ou seja, do estudo do processo de projeto urbano, visando ao adensamento com qualidade ambiental, foi introduzido um objeto concreto, que são áreas com potencial de adensamento, ou seja, áreas urbanas com infraestrutura instalada e baixa densidade construtiva, como por exemplo, a área da luz, em São Paulo (Figura 3) ou os vazios urbanos presentes na região da Barra Funda, também em São Paulo (Figura 4).

\footnotetext{
${ }^{8}$ Será explicado no capitulo 02 da tese.
} 


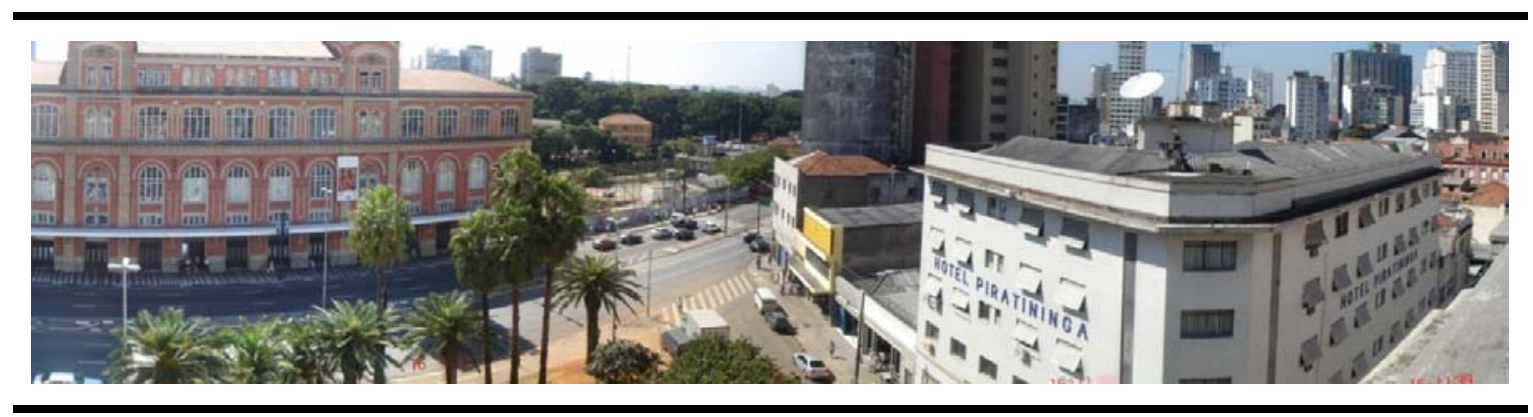

Figura 3: Área com potencial de adensamento, Região da Luz, São Paulo

Fonte: Renata Sandoli, cedida para autora

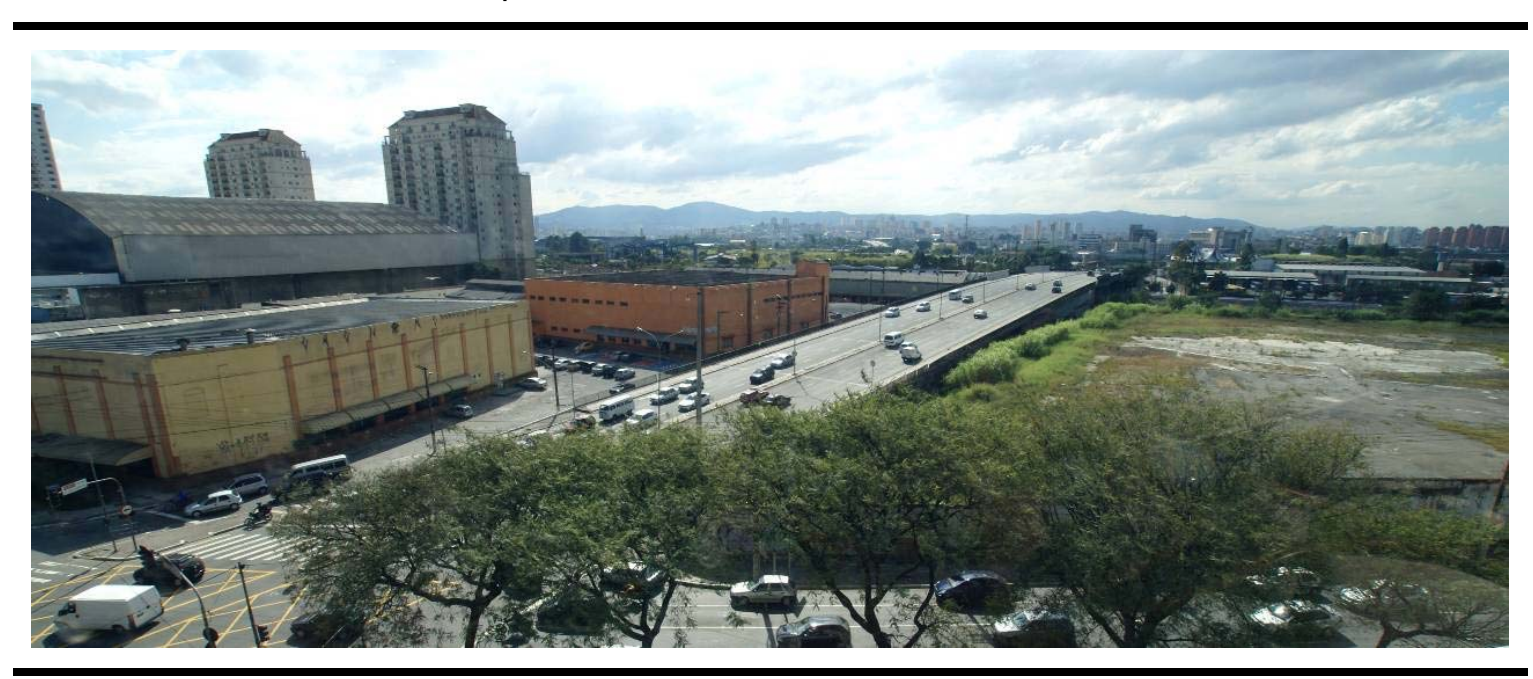

Figura 4: Área com potencial de adensamento, Barra Funda, São Paulo

Fonte: Renata Sandoli, cedida para autora

Hipótese e Objetivos da Pesquisa

Essa pesquisa tem por hipótese, que o adensamento urbano e a qualidade ambiental são compatíveis desde que as questões ambientais sejam consideradas no processo de projeto. Ou seja, é possível adensar áreas urbanas garantindo o acesso ao sol, a disponibilidade da luz natural, a qualidade do ar, o conforto acústico, a eficiência energética das edificações, a ventilação urbana, a coleta e reuso de água da chuva, etc.

Para comprovar esta hipótese a pesquisa parte da premissa que para o adensamento urbano causar menos impactos ao meio natural ou até mesmo impactos positivos, e ainda gerar cidades com mais qualidade ambiental, os projetos urbanos devem incluir a camada meio ambiente no processo de projeto, que no escopo desta pesquisa inclui: solo, água, energia, vegetação e clima. Além disso, todas as demais camadas do projeto e suas interrelações devem ser analisadas também sob o enfoque ambiental. 
A Figura 03 apresenta um esquema desta idéia, do que seria o projeto urbano no momento atual com suas camadas (usos, estoque construído, redes e meio ambiente) e os enfoques com que cada uma destas camadas deve ser analisada (ambiental, econômico, social, estético e cultural). Como já foi dito a camada meio ambiente é formada pelas seguintes variáveis ambientais: relevo, vegetação, água, energia e clima.

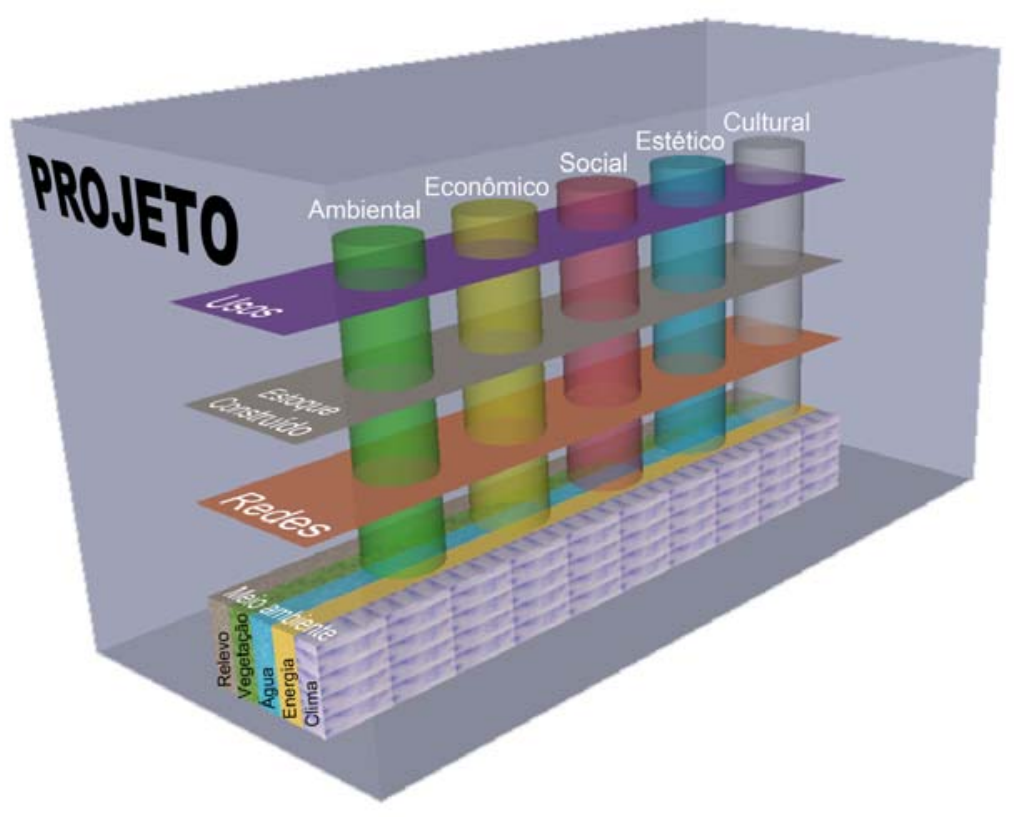

Figura 5: Esquema ilustrativo das camadas do projeto urbano com os enfoques que estas devem ser trabalhadas

Fonte: elaborado pela autora

Diante disto, o objetivo geral deste trabalho é a elaboração de um método para inserção de parâmetros ambientais relacionados ao adensamento e a forma urbana ${ }^{9}$ no processo de projeto.

${ }^{9}$ A forma urbana é uma composição de três subformas: a forma do reparcelamento do solo, a forma do traçado viário e; a forma do estoque construído. Lamas (2004) faz uma reflexão sobre a forma urbana enquanto objeto do urbanismo, ou melhor, enquanto corpo da materialização da cidade capaz de determinar a vida humana em comunidade. Segundo a autora: "A forma física do espaço é uma realidade para a qual contribui um conjunto de fatores socioeconômicos, políticos e culturais. Sem dúvida que a economia, ou as condições socioeconômicas de produção do espaço, se refletem profundamente na sua forma. Mas a forma urbana é também, ou deverá ser, o resultado da produção voluntária do espaço. As formas não têm apenas a ver com concepções estéticas, ideológicas, culturais ou arquitetônicas, mas encontram-se indissociavelmente 
Para alcançar o objetivo geral foram estabelecidos os seguintes objetivos específicos:

1- Definição do conceito de cidade sustentável com base nos princípios da sustentabilidade e nos ciclos ecológicos urbanos;

2- Definição do conceito de qualidade ambiental;

3- Seleção de requisitos, critérios e indicadores de qualidade ambiental relacionados ao adensamento e a forma urbana;

4- Compreensão da camada meio ambiente de maneira ampla e identificação das variáveis ambientais que são afetadas pelo adensamento e forma urbana e que devem ser inseridas no processo de projeto;

5- Resgate de teorias e soluções projetuais adequadas do ponto de vista da sustentabilidade ambiental, nas referências históricas do desenho urbano;

6- Avaliação da sustentabilidade ambiental de projetos urbanos contemporâneos identificando soluções de sucesso e deficiências na inserção de princípios básicos do urbanismo comprometido com o meio natural;

7- Realização do exercício de projeto urbano para o bairro da Luz em São Paulo, junto com o grupo de pesquisa do LABAUT FAUUSP, no qual a autora está inserida. ${ }^{10}$

\section{Metodologia de Pesquisa}

Esta pesquisa foi realizada em três distintos momentos: um primeiro de fundamentação teórica e construção de conceitos, um segundo momento de análise e avaliação e um terceiro momento de síntese e proposição.

No primeiro momento, de fundamentação teórica e construção de conceitos, foi realizada uma ampla revisão bibliográfica, tanto dos aspectos históricos quanto de conceitos de definições relacionados ao tema da pesquisa.

Primeiramente foi realizado um estudo histórico dos projetos e utopias urbanas, que influenciaram e ainda influenciam o desenvolvimento das cidades, buscando identificar os

ligadas a comportamentos, à apropriação e utilização do espaço, e à vida comunitária dos cidadãos. "(LAMAS, 2004).

${ }^{10}$ LABAUT FAU USP - Laboratório de Conforto Ambiental e Eficiência Energética da Faculdade de Arquitetura e Urbanismo da Universidade de São Paulo. 
aspectos relacionados à sustentabilidade ambiental considerados em cada proposta urbana.

Depois foi abordando vários aspectos relacionados à sustentabilidade e a qualidade ambiental de forma a compreender a camada meio ambiente que deve ser considerado dentro do processo de projeto.

Para isso, são definidos conceitos importantes para a compreensão do trabalho, entre eles a caracterização de cidade sustentável, qualidade ambiental, os ciclos ecológicos urbanos e os principais indicadores e critérios de sustentabilidade urbana.

O segundo momento da pesquisa consiste no estudo de intervenções urbanas recentes de referência internacional. Para conhecimento dos projetos contemporâneos foram realizados estudos nas referências bibliográficas mais recentes, além de entrevistas com arquitetos, engenheiros e profissionais da área e visitas técnicas no Brasil e no exterior. Com base nos conceitos apresentados na segunda fase da pesquisa e na seleção de indicadores, alguns projetos urbanos foram avaliados qualitativamente com relação à sua sustentabilidade ambiental.

No terceiro momento da pesquisa foi proposta a incorporação de parte da camada do meio ambiente no processo de projeto urbano. Ou seja, diante das variáveis relacionadas à sustentabilidade ambiental urbana abordadas nas duas primeiras fases da pesquisa, são definidos exigências, requisitos e critérios relacionados diretamente ao adensamento populacional e a forma urbana e proposto um método de como inseri-los no projeto.

Para isto foi realizada uma análise dos projetos pilotos elaborados pelo grupo de pesquisadores do LABAUT FAUUSP, grupo este no qual a autora está inserida. Esses exercícios de projeto foram: o primeiro, "Sustainable urban spaces: a case study in São Paulo, Brazil", realizado durante os anos de 2005 e 2006, em parceria com o Profs. Dr. Koen Steemers da University of Cambridge e a Profa. Dra. Susannah Hagan da University of East London; o segundo, "Desenho Urbano para o Desempenho Ambiental com 
Benefícios Sócio-Econômicos", foi desenvolvido em 2008, com a cooperação internacional London School of Economics, Urban Age. ${ }^{11}$

Além disto, foram realizados estudos das ferramentas computacionais, para simulações e avaliações de aspectos específicos do projeto.

\section{Estrutura da Tese}

A tese foi estruturada em três partes: uma primeira parte de construção de conceitos, uma segunda parte de análise e avaliação e uma terceira de síntese e proposição.

Esta tese apresenta cinco capítulos. A primeira parte está dividida nos capítulo 01 e 02, a segunda nos capítulos 03 e a terceira parte está inserida no capítulo 04.

O capítulo 01 da tese consiste em um estudo histórico das principais propostas urbanísticas desde a revolução industrial até a arquitetura moderna. O objetivo é resgatar as principais utopias urbanas que tiveram relevância e influenciaram o processo de constituição das cidades atuais, identificando as conseqüências da aplicação destas, principalmente sob ponto de vista da sustentabilidade ambiental.

Neste mesmo capítulo é apresentada uma breve discussão de modelos de ocupação compacto e modelos difusos e, por fim, as tipologias de adensamento urbano.

No capítulo 02 da tese são apresentados conceitos relevantes e pertinentes à discussão do tema de maneira contextualizada. São caracterizados alguns termos como cidade sustentável e qualidade ambiental, necessários para o entendimento da metodologia proposta e para a incorporação do tema nas discussões de projeto urbano.

Neste capítulo são descritos o funcionamento dos ciclos ecológicos urbanos, ciclo da água e da energia, buscando entender como estes recursos devem ser considerados no processo de projeto urbano para a produção de cidades mais sustentáveis.

Ainda no capítulo 02 é apresentada uma síntese relacionado o adensamento urbano à qualidade ambiental, ou seja, quais são as variáveis ambientais que são afetadas direta ou indiretamente pelo adensamento urbano.

\footnotetext{
${ }^{11}$ Este projeto foi apresentado na Conferência Internacional Urban Age - São Paulo, em dezembro de 2008, e pode ser encontrado no site da mesma.
} 
Por fim, é apresenta uma revisão da literatura nacional e internacional sobre os indicadores de sustentabilidade mais usados, desde o surgimento das agendas 21 até o desenvolvimento dos sistemas de certificação.

Com o objetivo de identificar soluções arquitetônicas de sucesso e realizar uma revisão crítica, apontando para as falhas na inserção de princípios da sustentabilidade ambiental de alguns projetos recentes que são considerados paradigmáticos, no capítulo 03 são apresentadas intervenções urbanas contemporâneas de referência internacional e uma avaliação qualitativa destes, com base na revisão e seleção de indicadores de sustentabilidade urbana estabelecidos por Rueda ${ }^{12}$.

Além dos aspectos ambientais, são verificados os resultados econômicos e sociais das intervenções urbana, abordando questões como, por exemplo, a diversidade de usos e rendas, mobilidade e eficiência do sistema de transporte, proximidade e socialização do espaço público, entre outros.

Durante a conferência internacional Urban Age, realizada em São Paulo, em 2008, foi levanta uma questão sobre a necessidade de rigor nas decisões de projeto.

Com relação à macro dimensão ecológica, é possível dizer que, muitas questões relacionadas à sustentabilidade são subjetivas. Porém, quando é abordada a dimensão bioclimática, é possível definir regras, estabelecer indicadores e parâmetros, que orientem o processo de projeto, para que este alcance o objetivo de reduzir os impactos ambientais gerados pelo adensamento urbano, construindo espaços de qualidade.

Diante disto, o capítulo 04 da tese apresenta uma proposta de método de inserção de parte da camada meio ambiente no processo de projeto urbano.

Por fim, são apresentas as conclusões do trabalho com base no estudo histórico, na fundamentação teórica sobre o tema, na análise das experiências de projetos urbanos contemporâneos e na aplicação prática.

Ainda nas considerações finais, é apresentado um resumo do método proposto e as possibilidades de futuras pesquisas e trabalhos práticos relacionados ao tema da tese.

\footnotetext{
12 RUEDA, Salvador. Plan especial de indicadores de Sostenibilidad de la Actividad Urbanística de Sevilla. Barcelona, 2006. Disponível em <http://www.bcnecologia.net> Acesso em mar. de 2008.
} 
É importante destacar que esta tese tem como objetivo construir um referencial e sua qualidade está na abrangência. Sendo assim, ela apresenta um caráter informativo e amplo, sem perder a perspectiva critica e propositiva. 
"Cada uma dessas cidades é um sonho lógico: a cidade não é tão má quanto seu inferno, nem vai ser tão boa quanto à utopia. Até aqui tudo bem. Cada ciência trabalha com conceitos ideais, como o zero e o infinito do matemático, como as direções norte, sul, leste e oeste do geógrafo, e não podem viver sem esses conceitos. É verdade, o avanço do matemático para o infinito nunca atinge $o$ seu alvo, nem as explorações do geógrafo, nem a pesquisa do astrônomo. Contudo, sem essas direções intangíveis, esses pontos cardeais, quem poderia se movimentar, sem acabar caindo em um buraco? Assim, antes que nos percamos, ou na escuridão do inferno paleotécnico, ou diante da Eutopia Neotécnica da cidade do futuro, esses extremos nos permitem medir e criticar a cidade do presente, e promover sua melhoria, sua renovação essencial." (GEDDES, 1994, p.79). 


\section{A QUESTÃO AMBIENTAL NAS REFERÊNCIAS HISTÓRICAS DO}

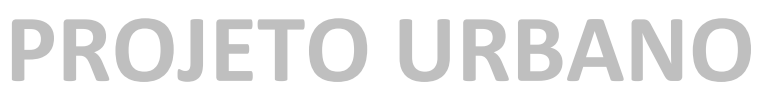

Apresenta um histórico da abordagem do desenho urbano focando na inclusão das questões ambientais desde a revolução industrial até a arquitetura moderna. Neste resgate histórico são analisadas as principais utopias e propostas urbanas do fim do século XIX e século XX que tiveram relevância e influenciaram o processo de constituição das cidades atuais.

É fundamental aprender com a história da arquitetura e do urbanismo. Um olhar para a história pode ser útil e indicar paradigmas a serem aprimorados para atender às necessidades presentes e futuras. Com isto, são identificadas as boas soluções arquitetônicas do ponto de vista da sustentabilidade urbana.

Segundo Sandoli (2008) o estudo das cidades idealizadas mostra aspectos de contraposição à realidade existente, formando um embasamento teórico. Enquanto que o estudo das cidades existentes ou planos implementados mostra as conseqüências de algumas decisões projetuais e a relação entre os aspectos físicos e outras questões como o clima, a sociedade, a economia, a tecnologia e etc.

Sobre a construção das cidades Le Corbusier define:

"(...) a estrutura das cidades nos revela duas espécies de acontecimentos: o ajuntamento progressivo, aleatório, com seu fenômeno de estratificação lenta, de formação escalonada e depois sua força de atração adquirida, crescente, força centrífuga, sedução violenta, investida, balbúrdia. Foi assim Roma, como é Paris, Londres, ou Berlim. Ou então: a construção da cidade, nascida de um programa, de uma vontade, de uma ciência adquirida; é assim Pequim ou são as cidades fortes do Renascimento, ou são as cidades colonizadoras dos romanos erigidas no âmago dos países bárbaros." (CORBUSIER, 1992, p.83)

Desde o renascimento até o modernismo, diversas utopias foram elaboradas e muitas cidades idealizadas. O século XX foi um período de grandes transformações e incertezas, 
uma época propicia para o aparecimento de novas teorias urbanas, uma vez que, a industrialização promovia o deslocamento das pessoas do campo para as cidades, acelerando o crescimento dessas (PESSOA, 2006).

O crescimento acelerado das cidades vinha acompanhado de problemas ambientais e sociais. Segundo Gonçalves (2003), o debate sobre as direções que deveriam tomar o crescimento das cidades tratava das condições de degradação social e ambiental do meio urbano, que dominavam as primeiras cidades industriais do mundo. Em Paris, por exemplo, as populações urbanas, reunidas pelo propósito de expandir as atividades econômicas, viviam um processo de crescimento demográfico contínuo, sem o acompanhamento compatível de uma infraestrutura urbana, incluindo projetos residenciais e de espaços públicos. Além dos registros da exploração econômica do trabalho humano, as classes mais pobres encontravam-se submetidas a cidades marcadas por uma péssima qualidade do ar, falta de áreas verdes, falta de saneamento público, e unidades habitacionais insalubres.

Outros acontecimentos também foram importantes na formação das cidades, como as guerras e os avanços tecnológicos. As guerras permitiram que certas idéias se fortificassem e desta maneira atuassem como catalisadores no processo de transformação das cidades. Já os avanços tecnológicos geraram, muitas vezes, a necessidade de rever os conceitos das cidades como, por exemplo, o surgimento e uso dos automóveis.

Abordando estas questões refletidas no desenho da cidade e nas principais utopias e propostas urbanísticas o capítulo abrange três diferentes períodos da história.

O primeiro aborda o desenho urbano nas cidades históricas, desde a antiguidade até a Idade média. O segundo abrange o período após a revolução industrial, abordando sobre os principais utopistas e suas propostas de cidade, destacando o modelo de Cidade Jardim de Howard. O último consiste no período do movimento moderno, na qual são analisadas as idéias de Le Corbusier para a construção da cidade contemporânea 


\subsection{Traçado orgânico e traçado geométrico}

$\mathrm{Na}$ passagem da Antiguidade para a Idade Média, as cidades se transformaram profundamente. Na Antiguidade, a cidade desempenhava três funções principais, a militar, a função administrativa e política e a função econômica.

Já na metade da Idade Média, as cidades sofreram muitas transformações com o desenvolvimento do feudalismo, perdendo temporariamente as suas antigas funções.

Até este período é possível analisar os dois traçados urbanos reguladores da maior parte das cidades, o traçado orgânico e o traçado geométrico.

Higueras (2007) define o traçado orgânico como aquele que apresenta similaridades com a natureza, onde encontra-se uma hierarquia de estruturas, simetrias axiais e a forma circular ou oval como elementos dominantes da composição.

Como exemplos de cidades orgânicas, destacam-se os primeiros assentamentos humanos (Avebury, Ggantija, Stonehenge, etc.), as cidades suméria (Ur, Korsabad, etc.), as cidades da idade do bronze (Hattusa, Micenas, Knosos, etc.) e as cidades medievais árabes, cristianas ou hispanomuçulmanas (Madrid, Toledo, Granada, Berna, Burgos, etc.).

De um modo resumido e sintético, o desenho do conjunto nas cidades orgânicas históricas foi determinado pelo relevo, ou seja, pelas ladeiras montanhosas ou em cima delas. Sua estrutura urbana aparecem hierarquizadas, dispõem de poucos espaços públicos (com exceção dos centros religiosos e políticos) e de pouca vegetação.

$\mathrm{Na}$ Espanha, existem numerosas cidades cujo centro histórico corresponde a uma configuração de cidade orgânica, caracterizadas por sua ruas sinuosas e estreitas; ruasescadas transversais; quadras trapezoidais e de grandes dimensões; lotes com pouca frente de fachada e muito profundos; alta densidade urbana com edifícios altos e poucos espaços livres e zonas verdes. 

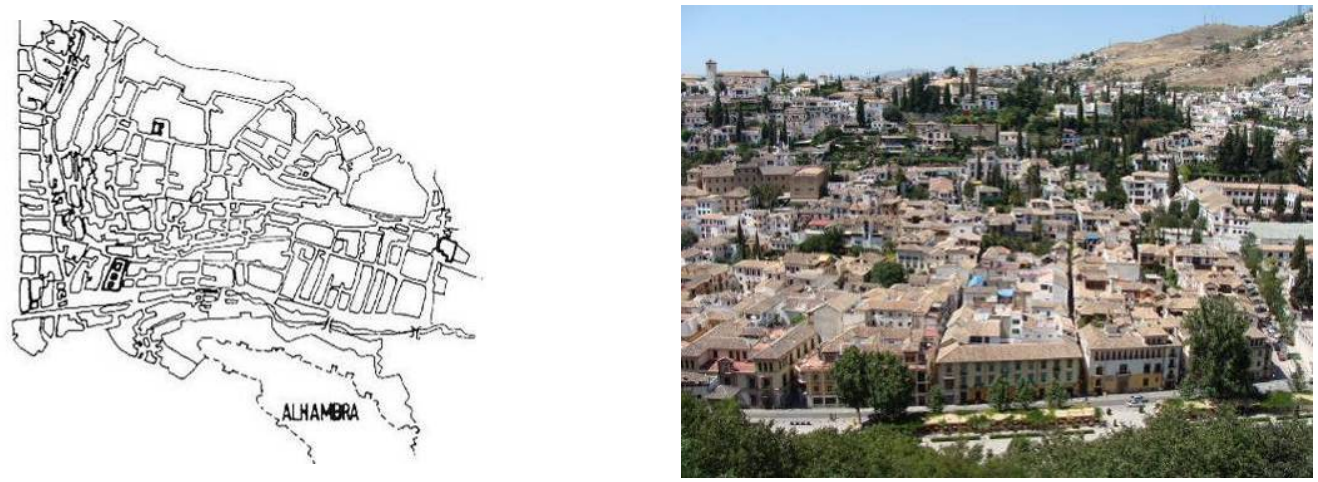

Figura 6: Planta da cidade de Granada

Fonte: HIGUERAS, 2007
Figura 7: Cidade de Granada

Fonte: foto da autora

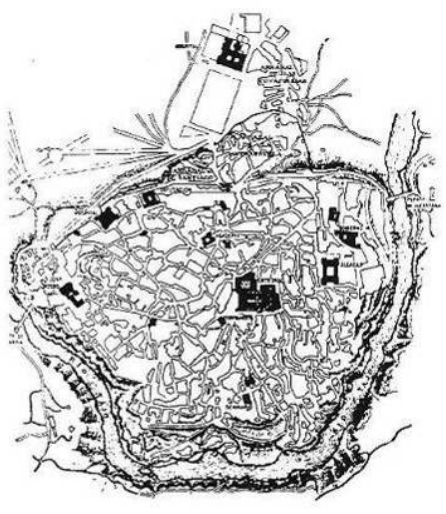

Figura 8: Planta da cidade de Toledo

Fonte: HIGUERAS, 2007

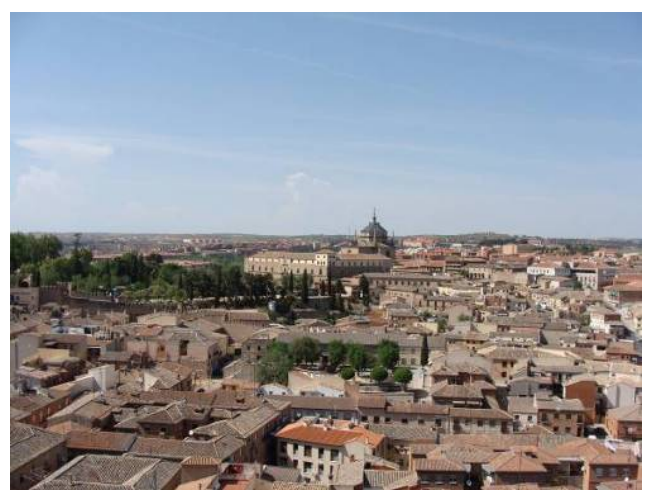

Figura 9: Cidade de Toledo

Fonte: foto da autora
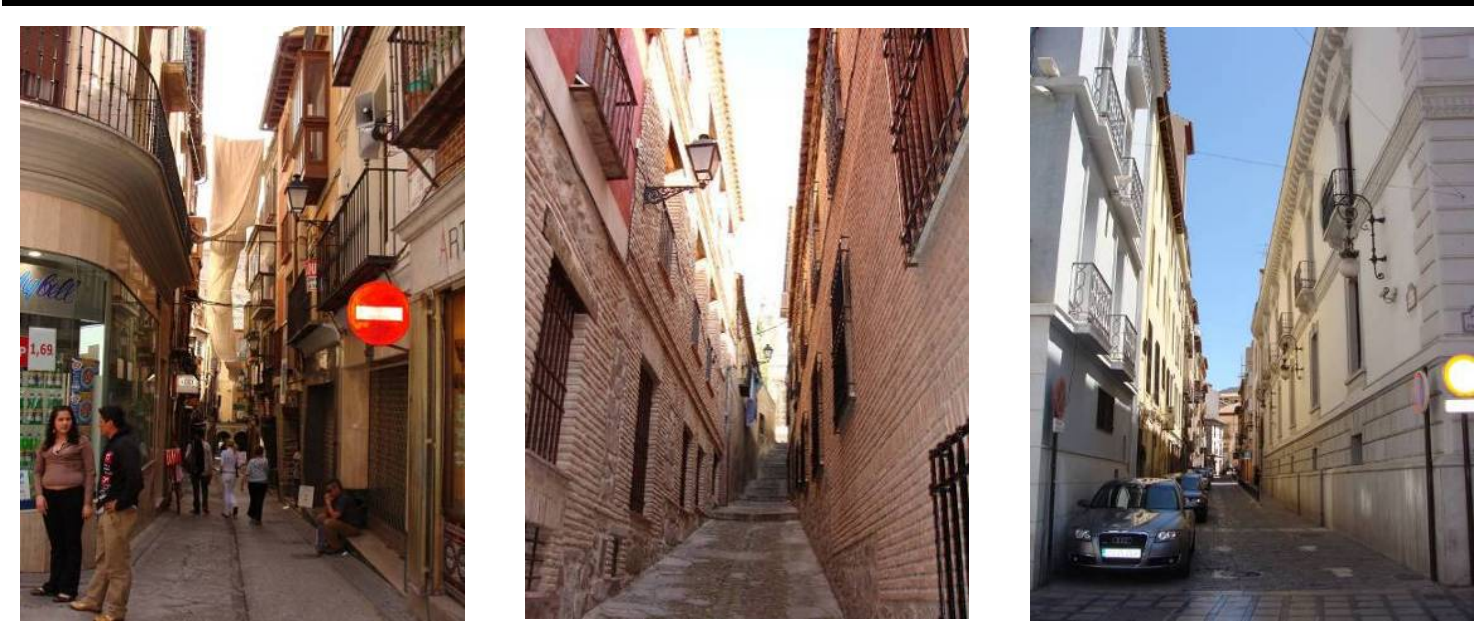

Figura 10: Cidade cle Toledo rua estreita

de Figura 11: Cidade Toledo rua estreita

Fonte: foto da autora
Fonte: foto da autora de Figura 12: Cidade de Granada rua estreita

Fonte: foto da autora 
Com relação ao desenho da casa, os tipos e modelos são os mais diversificados, com as fachadas de orientações variadas, condicionada pelas ruas, e que por sua vez eram adaptadas ao relevo. Apresentavam um alto grau de obstrução, decorrente das estreitas ruas e do progressivo aumento das alturas das edificações.

Já o traçado geométrico, é caracterizado principalmente por uma geometria retilínea, desvinculada a qualquer traçado natural do entorno, que conforma as vias hierarquizadas com as quadras e lotes de forma geométrica, quadradas, retangulares, semicirculares, etc. .

O desenho do conjunto da cidade geométrica se caracteriza pela implantação em terrenos planos, ignorando qualquer tipo de acidente no relevo. Na sua maioria, a estrutura urbana viária encontra-se hierarquizada com um viário principal de maior seção e outras ruas secundárias locais. São importantes os espaços públicos, sendo freqüente a existência de praças configuradas na mesma estrutura principal do assentamento. Também é comum, apresentar outros espaços públicos de menor importância, subordinados ao espaço central.

Com freqüência, a malha se orienta segundo os quatro eixos cardiais, norte-sul, leste e oeste, porém esta disposição pode ser favorável para algumas latitudes e para outras não. Em climas frios essa é mais convenientes que para os quentes, já que as fachadas sul e norte recebem uma radiação solar excessiva, sendo necessário adotar elementos de sombreamento, para controle do ganho de calor.

Higueras (2007) afirma que o fator determinante nas cidades antigas era a simbologia místico-religiosa do movimento do sol. De qualquer forma, é necessário ressaltar a oportunidade de não se repetir o layout interno da casa, já que cada orientação gera condições distintas de insolação e ventilação. Porém, na maioria dos casos, isto não aconteceu.

Os primeiros exemplos de cidade geométrica são encontrados nas cidades egípcias, que abrigavam os trabalhados da construção das pirâmides.

As cidades gregas, como Delfos, Mileto, Rodas, Pérgamo, Olinto e Priene são as mais significativas, e que se tornaram referência para as novas cidades colonizadas pelos gregos. 
Pode-se dizer que, entre estas, Mileto se tornou o paradigma da cidade geométrica, cujo traçado ficou conhecido como traçado hipodâmico. Nesta cidade, a quadrícula sobre um terreno triangular orienta a trama nordeste - sudoeste, com dois portões naturais e um teatro formado pelo desnível da ladeira. As quadras possuem as dimensões de $30 \times 53 \mathrm{~m}$, com uma proporção de 4/7, com um total de 400 unidades para 10.000 habitantes. A importância do espaço público se concentrava na ágora, descoberta e limitada pelos pórticos. A partir do traçado hipodâmico foram projetadas outras cidades, com malha ortogonal com eixos norte-sul e leste- oeste, formando as quadras.

Segundo Higueras (2007), a cidade de Atenas combina uma estrutura do tecido residencial dominante na cidade orgânica com a disposição dos templos a partir de um conceito de perspectiva complexo e inovador. A estrutura viária é composta de ruas largas e pavimentadas, sendo as principais de 9,0 metros e as secundárias de 3,5 metros. As habitações dispunham de uma cisterna abaixo do pátio, que recolhia a água da chuva dos telhados.

As cidades romanas, também partem de uma malha reticular para configurar espacialmente a sua estrutura urbana.

Contrastando com as estruturas orgânicas das cidades medievais, no mesmo período os espanhóis reurbanizaram o continente americano, com base no desenho geométrico, justificando pela simplicidade do traçado e a facilidade de divisão. Santiago do Chile, Buenos Aires e Filadélfia são alguns exemplos.

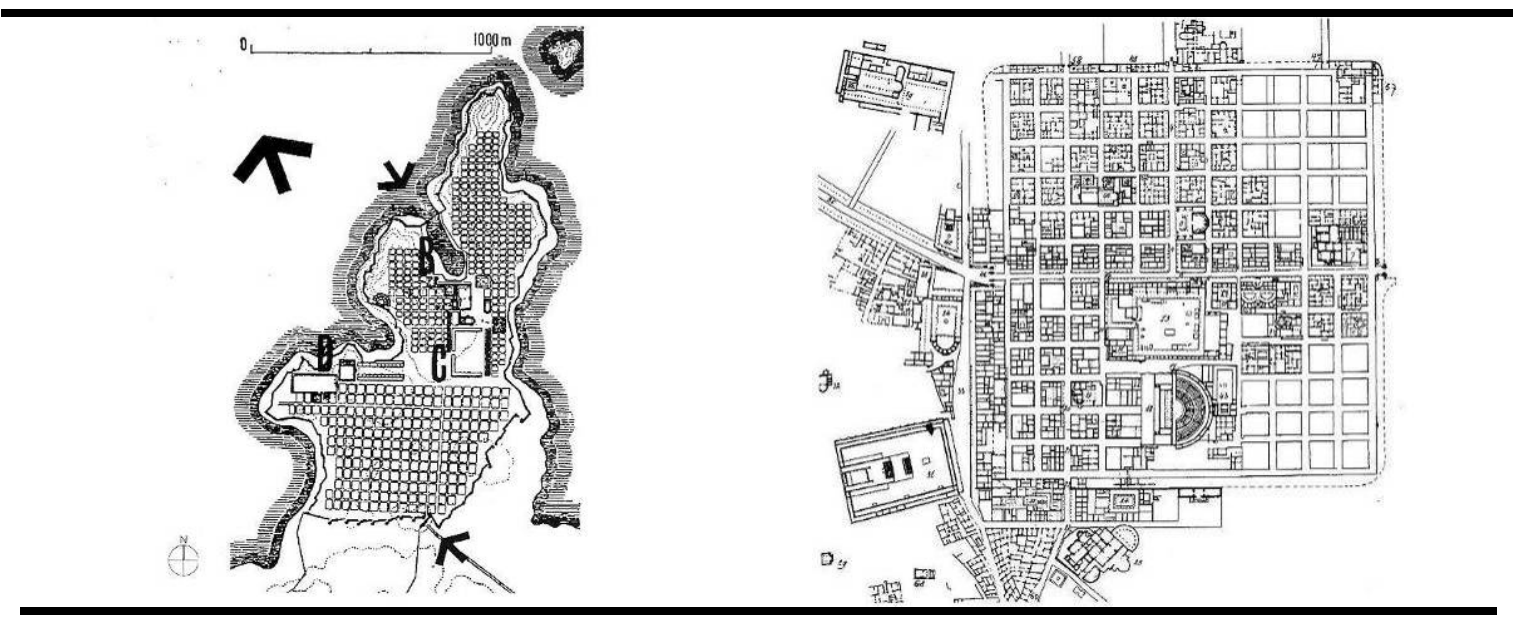

Figura 13: Plano de Mileto

Fonte: HIGUERAS, 2007
Figura 14: Plano de Timgad

Fonte: HIGUERAS, 2007 


\subsection{As principais utopias e propostas urbanas dos séculos XIX e XX}

A revolução industrial é determinante segundo numerosos autores, já que as mudanças tecnológicas, socioeconômicas e ambientais são de escala que merecem um estudo diferenciado, posto que, a partir de então a cidade sofreu profundas transformações.

Nos séculos XVIII e XIX, as condições ambientais das cidades começaram a se deteriorar, decorrentes do aumento da população urbana. O quadro de poluição, densidade excessiva e desigualdade social geraram diversas reações. Mumford (1998, p. 513) afirma que: "talvez a maior contribuição dada pela cidade industrial tenha sido a reação que produziu contra os seus próprios maiores descaminhos; e, para começar, a arte do saneamento ou da higiene pública."

Toda vez que uma cidade atinge um determinado nível de desenvolvimento e crescimento da malha urbana e da população, a questão da falta de qualidade ambiental é necessariamente levantada, em muitos casos em decorrência do surgimento e proliferação de doenças contagiosas, conhecidas como "pestes urbanas".

Segundo Silva (2005), os estudos recentes sobre a constituição do urbanismo como disciplina técnica e profissional no Brasil tem-se direcionado a este período da história, anterior à consolidação do Movimento Modernista, nos quais o foco passou a ser a atuação de profissionais ligados a um ideário higienista e sanitarista.

"Esses estudos se apóiam numa literatura que trata o advento da saúde pública moderna como uma face do processo de consolidação do modo de vida burguês e da nova estrutura econômica inaugurada pela Revolução industrial ao longo do século XIX. O urbanismo apóia-se nessas práticas que visam ao saneamento das cidades." (SILVA, 2005, p.70)

É importante observar a atuação de médicos na ordenação do espaço urbano durante esse período da história. A concepção de doença baseada na teoria dos Miasmas, ${ }^{13}$ motivava os médicos a considerar os efeitos ambientais sobre a saúde dos indivíduos. Porém, com o advento da medicina microbiana no século XIX, os médicos

\footnotetext{
13 emanações provenientes de matérias pútridas ou de moléstias contagiosas e transmitidas através do ar, considerados os agentes causadores de maior parte das doenças
} 
progressivamente se voltariam ao tratamento direto dos indivíduos, fazendo das preocupações ambientais anteriormente tratadas, uma questão auxiliar. (SILVA, 2005)

Desde então, a preocupação com o espaço urbano acabou sendo absorvida pelos urbanistas.

Sendo assim, é neste período de consolidação da indústria, de expansão territorial, aumento da população urbana e inicio dos primeiros movimentos rumo à globalização que as utopias urbanas se destacam. Estas utopias influenciaram muitas das soluções de desenho urbano e até os dias de hoje são tidas como referência.

\subsubsection{New Lanark e Falanstério - Robert Owen e Charles Fourier}

Na fase pré-urbanista do século XIX, empresários filantrópicos, preocupados com a qualidade de vida de seus empregados, deram início a empreendimentos habitacionais em harmonia com a paisagem, como a vila modelo de New Lanark de Robert Owen (1817) e o palácio social de Fourier (1822).

Robert Owen e Charles Fourier foram os primeiros utópicos que tentaram materializar uma comunidade em equilíbrio com a natureza, segundo uma postura paternalista e ideal, que proporcionava trabalho, residência, lazer e serviço a seus trabalhadores. Ambos demonstraram grande inquietação com o tratamento dispensado à natureza. "Para eles 0 progresso só poderia se alcançado pela educação e respeito às leis naturais que prendem o homem à terra e fazem dele seu eteno devedor." (FARIAS FILHO, 1996, p.251).

O esforço de Owen resultou em um projeto de base iluminista, um sociedade urbana vivendo em condições digna educada para dominar a máquina e explorar as possibilidades de revolução industrial (FARIAS FILHO, 1996).

Sendo assim Owen imagina um estabelecimento ideal urbano higiênico, ordenado e criador (FARIAS FILHO, 1996). New Lanark apresentava uma nova forma de organização social, de relação de trabalho e de ocupação espacial. O projeto foi idealizado como uma vila modelo semi-rural para 1200 habitantes, com o objetivo de estabelecer um sentido de comunidade auto-suficiente por meio da proximidade com a indústria e o campo, acreditando ter um efeito saudável sobre os trabalhadores o que, conseqüentemente, retornaria em benefícios para a indústria (ANDRADE, 2005). 
O esquema estava longe das circunstâncias reais, e por esta razão, não teve o êxito esperado, com exceção das experiências nos Estados Unidos, onde os resultados foram melhores (HIGUERAS, 2007).

Fourier propôs o falanstério, um edifício onde seriam realizadas todas as funções da cidade. Sandoli (2008, p.21) descreve:

"Era como uma cidade em miniatura, sem ruas externas, com população aproximada de 2.000 pessoas, de todas as raças, classes, sexos e idades. Houve várias tentativas de se implantar um falanstério na Bélgica, Estados Unidos e Brasil, mas todas essas comunidades, sustentadas por uma indústria, dissolveram-se em poucos anos."

Os ideais de Owen e Fourierm de algum modo influenciaram outros utopistas no início deste século, inclusive Ebenezer Howard, idealizados da cidade jardim.

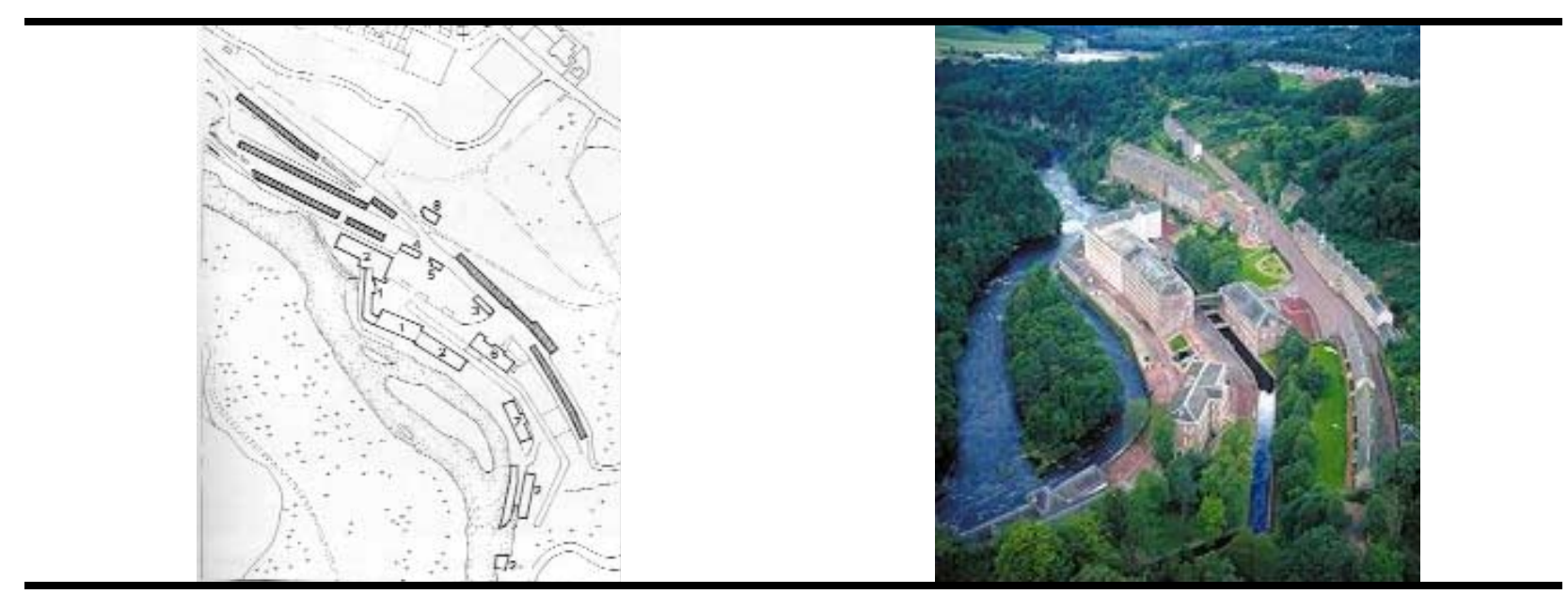

Figura 15: Desenho da vila modelo de Owen

Fonte: Disponível em <www.newlanark.org > apud ANDRADE, 2005

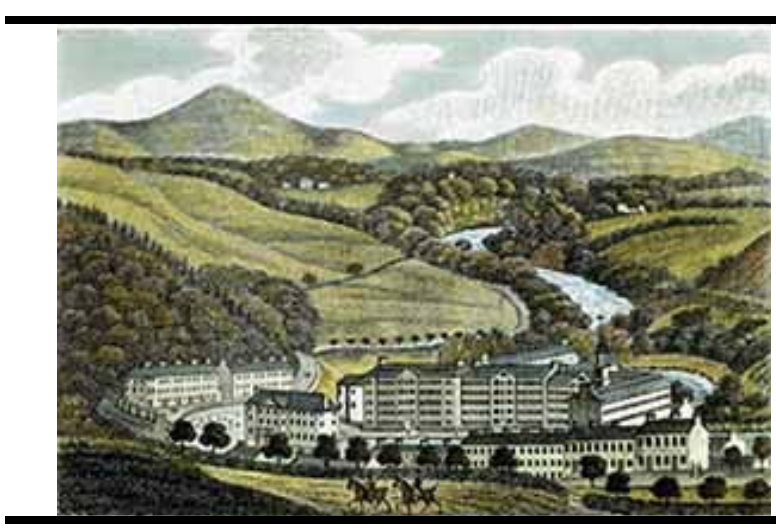

Figura 17: New Lanark, gravura do século XIX

Fonte: ANDRADE, 2008.
Figura 16: Vila modelo de Owen

Fonte: Disponível em <www.newlanark.org > apud ANDRADE, 2005

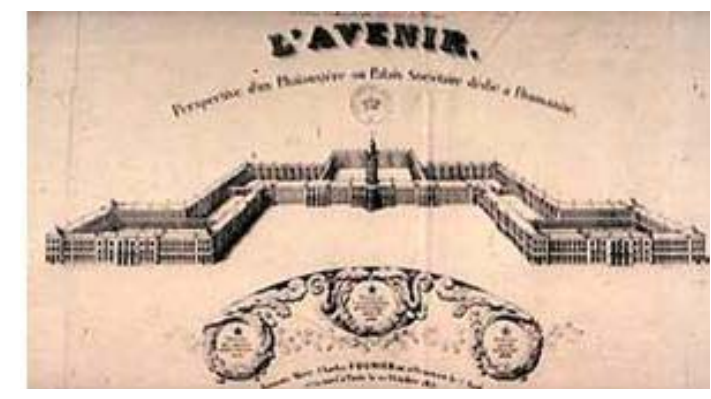

Figura 18: O Falanstério de Charles Fourier Fonte: Vigiar e punir. Michel Foucault; Petrópolis, Editora Vozes, 1987 apud SANDOLI, 2008. 


\subsubsection{Stubben, Camillo Sitte e Unwin}

Alguns anos mais tarde, são escritos e publicados alguns importantes trabalhos sobre estética e desenho urbano como a enciclopédia Der Statebau, Handbuch der Architektur, de Joseph Stubben, A Arte de construir as cidades, de Camillo Sitte, ou A Prática do Planejamento Urbano, de Unwin, tratados que tiveram enormes repercussões e influência. Stubben foi o teórico e prático mais prestigiado na Alemanha de 1880 , até a Primeira Guerra. Sua obra teve sucesso também em outros países. Segundo Lamas (2004), Stubben abordava a estética e a técnica de construção de edifícios e da cidade, em função do plano e da integração do urbanismo e a arquitetura.

Em sua obra, Stubben estuda uma seleção de exemplos característicos da urbanística oitocentista, como modelos repetíveis e cuja aplicação permitia resolver os problemas identificados na cidade. Preocupa-se em isolar os problemas e resolvê-los através de modelos, sendo que para cada problema, um modelo espacial-físico, integrado na organização geral da cidade (LAMAS, 2004).

Camillo Sitte introduz uma orientação diversa, baseada nos princípios compositivos e arquitetônicos medievais. Critica a rigidez dos traçados repetitivos dos planos de extensão alemães, determinados por questões como o tráfego e as infraestruturas, menos preocupados com os resultados paisagísticos, ambientais e morfológicos (LAMAS, 2004).

Sitte recusa a tradição haussmanniana, de alinhamento retilíneo, propondo seqüências construídas de modo orgânico, assimétrico e variado. Relega para segundo plano questões como zoneamento, as infra-estruturas, densidades, índices urbanísticos ou o funcionamento da cidade (LAMAS, 2004).

Sitte domina a pequena escala e por isso, destaca-se a sua importância para intervenções pontuais nos tecidos urbanos (LAMAS, 2004).

As obras de Sitte influenciaram fortemente os urbanistas por toda Europa, até o próprio Le Corbusier. Porém, o movimento moderno assimilou mais os seus aspectos de revivalismo medieval do que o seu conteúdo essencial.

Em 1909 o Parlamento Inglês aprova a primeira lei sobre Planejamento urbanístico e é publicada a obra de Unwin, que tem como objetivo melhorar e estimular a aplicação da lei do urbanismo, face ao empobrecimento estético e qualitativo das cidades e à sua 
uniformização. Também é seu objetivo a elaboração de métodos de projetar a cidade e seus bairros (LAMAS, 2004).

Sua obra adquiriu grande repercussão e ainda nos dias de hoje readquire atualidade, como se tivesse sido escrito por alguém protagonista da polêmica dos últimos vinte anos sobre o desenho e a forma da cidade (LAMAS, 2004).

Unwin revela influência de Sitte, depois segue uma discussão sobre o formalismo regular dos traçados clássicos e o irregular, característica dos espaços medievais, evidenciando as vantagens e desvantagens de cada um (LAMAS, 2004).

Segundo Lamas (2004), o discurso de Unwin é preciso e sistemático, e procura o equilíbrio entre as necessidades funcionais e os objetivos estéticos na cidade.

\subsubsection{Cidade Linear - Soria e Mata}

Em 1882, Soria e Mata propõem que as cidades deveriam ser construídas ao longo de uma artéria principal de comunicação, intitulada "cidade linear". Esse modelo de ocupação poderia expandir-se indefinidamente ou ramificar-se como uma árvore. As áreas residenciais e os edifícios administrativos são implantados ao longo do eixo principal, não havendo um centro de cidade (PESSOA, 2006).

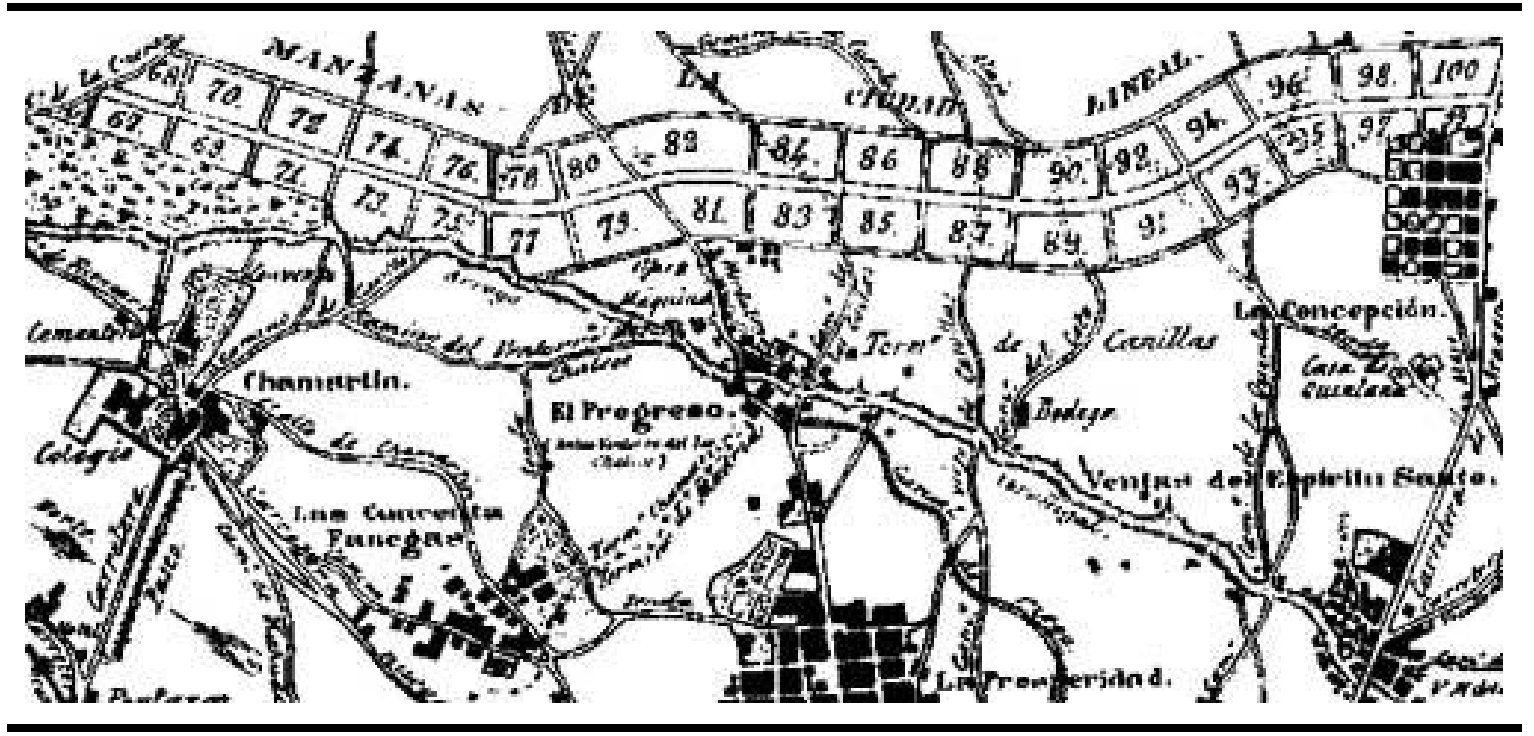

Figura 19: Cidade Linear de Soria e Mata

Fonte: Disponível em <www.arch.umd.edu > apud SANDOLI, 2008 


\subsubsection{Cidade Jardim - Ebenezer Howard}

O modelo de Cidade Jardim, considerado até hoje como referência, presentes em numerosos planos e projetos foi desenvolvido por Ebenezer Howard, em 1898. Entre os arquitetos que trabalharam com a cidade jardim, Howard foi o que mais se destacou por ser o precursor e por propor um modelo teórico mas com argumentos precisos que permitiram colocá-lo em prática.

Na sua visão, as cidades pós-revolução industrial estavam se transformando em lugares inadequados de viver, principalmente em decorrência das suas condições insalubres. Para Howard somente vivendo perto do campo as pessoas poderiam ter boa saúde e boa qualidade de vida (PESSOA, 2006). Howard (1996) afirma: "... cidade e campo devem estar casados, e dessa feliz união nascerá uma nova esperança, uma nova vida, uma nova civilização".

A industrialização e o transporte propiciaram o aparecimento de aglomerações urbanas, sem controle espacial, social ou sanitário. Em resposta a elas, a cidade jardim propunha estruturas residenciais autônomas, relacionadas ao campo e com um equilíbrio entre zonas residenciais, industriais e equipamentos urbanos. Um novo modelo de ocupação urbana, combinando a diversidade, oportunidades, entretenimentos e socialização, existentes na cidade e espaços verdes, tranqüilidade, ar puro e etc., presentes no campo, ou seja, as vantagens da cidade com os benefícios da vida no campo.

O modelo da cidade jardim caracterizava-se pelo desenho informal de ruas e vias de acesso as edificações, com a inserção de jardins e campos verdes ao redor dos edifícios de diferentes tamanhos e funções, na busca de espaços públicos com qualidade ambiental (GONÇALVES, 2003).

O modelo ideal era composto de 30.000 habitantes, colocados em 400 hectares de área urbana, cercada por 2.020 hectares de terreno agrícola, chamado de cinturão verde, onde residiriam mais 2.000 habitantes. O cinturão verde era pensado com a dupla função, de abastecer a população urbana, ao mesmo tempo em que representava uma barreira física à descentralização urbana, para manter a eficiência da infraestrutura física e econômica da cidade (GONÇALVES, 2003).

A cidade jardim segue uma forma circular, dividida em seis setores radiais separados por boulevares que começavam em parque central. O sistema de transporte era composto por 
um espaço para a ferrovia contornando o perímetro da cidade e avenidas concêntricas ao parque eram destinadas aos automóveis.

Assim como as cidades industriais, a da cidade jardim previa a mistura de usos e funções, o que é importante para a otimização da infraestrutura, assim como para a vivacidade da área urbana. Para isso, foi proposta uma ocupação de tamanho e densidade limitados, à distância que as pessoas podem andar, baseados em uma avaliação empírica e em parâmetros arquitetônicos da época.

Segundo Gonçalves (2003), a cidade jardim trazia conceitos de contenção da descentralização urbana, mesmo prevendo campos verdes e grandes avenidas dentro dos limites da cidade. Sendo assim quando uma cidade atingia a sua capacidade de suporte criavam-se outras novas em torno da cidade central de 58.000 habitantes, que funcionaria como um núcleo cultural, formando uma constelação de cidades interligadas por meio de ferrovias e rodovias. Com isso, o equilíbrio entre o urbano e uma natureza domesticada era mantido.

De maneira resumida, o complexo era formado por seis núcleos de cidades jardins com 32.000 habitantes e uma cidade central de 58.000, todas envolvidas por cinturões verdes, interligavam-se, totalizando 250.000 habitantes, cobrindo 66.000 acres dos quais apenas 8.000 seriam de área construída (HOWARD, 1996).

Segundo Geddes (1994), Howard não apenas planejou diagramaticamente uma cidade jardim ideal, mas também indicou como deveria ser providenciada sua construção, como seriam supridos os seus serviços, como seria financiada e administrada.

As Figuras 20 a 22 apresentam os Diagramas de Howard da cidade jardim, sendo: a Figura 20 o diagrama de planejamento; a Figura 21 o diagrama da cidade dividida em 6 setores e a Figura 22 o diagrama da constelação de cidades.

A teoria de cidade jardim foi colocada em prática por Raymond Unwin e Barry Parker, em Letchworth, em 1904 (Figura 23, Figura 24); Unwin em Hampstead, em 1909 e por Howard e Unwin em Welwyn, em 1919 (Figura 25, Figura 26).

Com relação à Letchworth e Hampstead, devido à localização fora de Londres, desde a sua concepção foi subúrbio jardim. Porém, tratou-se de configurar uma comunidade ideal, incluindo normas para a integração social de seus residentes. 
Letchwork e Hampstead consistem num assentamento onde os usuários moram perto do trabalho, com indústria e agricultura apoiando-se mutuamente, apesar das áreas de lavoura terem sido planejadas em menor quantidade do que desejava Howard.

A proposta apresenta uma densidade máxima de 20 habitações/ ha, rodeada de muita vegetação. As ruas estão orientadas seguindo, geralmente, as curvas de nível, predominando o traçado noroeste-sudeste, distanciando as fachadas a $16,50 \mathrm{~m}$. Com isto as fachadas apresentam, em geral, boas condições de insolação (HIGUERAS, 2007).

No caso de Letchwork, Andrade (2005, p34) descreve:

"O desenho, proposto pelos arquitetos Unwin e Parker, segue o pensamento de Camillo Sitte, que propunha o traçado orgânico próprio à escala humana, com referência às cidades medievais, que eram mais próximas ao campo. Sendo assim Letchwork apresenta (...) traçado simples, claro e informal, com um centro urbano elevado composto de árvores de porte e edifícios municipais, próximo à estação. Essa cidade foi dividida em regiões de 5.000 habitantes com suas próprias infra-estruturas. As habitações para as diversas classes sociais formam blocos isolados entre si, recuados do alinhamento do terreno, com jardins fronteiriços. As ruas têm acesso secundário com "cul de sac" e passeios gramados, arbustos e árvores, que dão continuidade ao verde dos espaços públicos. Além dessas feições, a cidade foi pensada como auto-suficiente em termos de indústria e terras agrícolas, diferente da idéia de subúrbio."

Letchworth e Hampstead destacam-se pelas tipologias variadas e um alto valor compositivo. Panerai, Castex e Depaule (apud HIGUERAS, 2007, p.42) comentam: "Hampstead manifesta-se como um catálogo de soluções a dois problemas: a circulação e a unidade de vizinhança, cuja resposta formal é o agrupamento."

Welwyn, projetada em 1919 por Howard como teórico e Unwin como desenhista, foi a experiência que mais se aproxima da idéia original de cidade jardim, servindo como exemplo para 25 novas cidades ao redor de Londres.

Em Welwyn se tentou enfatizar a idéia de urbano um pouco perdida em Letchworth, estruturando a cidade com um grande boulevar central de $60 \mathrm{~m}$ de largura. $\mathrm{O}$ condicionante de implantação foi o traçado das ruas que, em geral, seguiam os caminhos pré-existentes. A presença do trem foi significativa para a implantação, porém, segundo 
Higueras (2007), logo se transformou em um subúrbio satélite com poucos habitantes e escassa atividade produtiva. A idéia de criar uma cidade auto-suficiente nunca se realizou. Uma das características mais positivas da proposta foi o cuidado com a preservação das condições ambientais, projetando amplos espaços verdes para recreação, principalmente na periferia da cidade central, ao longo dos limites dos cinturões agrícolas (HIGUERAS, 2007).

A influência do postulado da cidade jardim aparece em várias cidades européias, entre elas: Amsterdam (arquitetos H P. Berlage e Michel de Klerk), Viena (arquitetos Peter Beherens, HGessner e Karl Ehn) e nas cidades inglesas construídas após a segunda guerra mundial e nas cidades americanas, a partir da década de trinta (PESSOA, 2006).

O plano de Amsterdam Sul, de H. P. Berlage, em 1914 propõem um bairro jardim, no qual as zonas verdes são o eixo central dos elementos que estruturam toda a ordenação, com edifícios de baixa densidade e um sistema viário curvilíneo e hierarquizado. No plano são propostas edificações de três tipologias diferentes. Uma tipologia de residência unifamiliar, de baixa densidade, em 20ha de superfície, uma segunda de habitações conjugadas, de densidade média, em 70ha e outra também plurifamiliar de alta densidade, sobre 190ha de solo.

Esta diversidade tipológica é uma característica bastante significativa, já que esta é indispensável para conseguir complexidade, diversidade e variedade social e de paisagem urbana.

Segundo Higueras (2007), além desta, outros aspectos positivos do projeto são as corretas condições de insolação nas fachadas principais e o equilíbrio entre zonas verdes e espaços edificados.

Após a primeira guerra mundial, o movimento de cidades-jardim se tornou um movimento de planejamento de novas cidades para a reconstrução na Inglaterra. Entretanto, somente após a segunda guerra, aprova-se um programa com grandes similaridades ao planejamento de Howard, o "New Towns Act", de 1946, programa esse que foi desenvolvido para abrigar 60.000 habitantes ao redor de Londres (ANDRADE, 2005).

Posteriormente, nos EUA, foram produzidos exemplos representativos baseados nos princípios de Howard. Porém, segundo Andrade (2005, p.36): "as primeiras vozes do planejamento não foram de industriais preocupados com os trabalhadores $e \quad 0$ 
desenvolvimento socioeconômico, mas de profissionais de arquitetura da paisagem que davam ênfase ao desenho físico e aos aspectos da vida em comunidade como Olmsted, Vaux e Cleveland."

A existência de um vasto território propiciou a adoção das cidades jardim como laboratório para construir a cidade ideal na natureza. Uma idéia que foi incentivada pela política tributária de empréstimos hipotecários, que acabou consolidando o modelo de ocupação dispersa (HIGUERAS, 2007).

Atualmente, o modelo de cidade jardim segue vivo e muito representativo, no momento em que o contato do homem com a natureza está dentro das aspirações de uma grande parte da população, e também nas propostas que consideram o equilíbrio, a sustentabilidade e a adequação ao meio ambiente. Esse conceito de cidade pode ser encontrado nos empreendimentos com preocupações ecológicas, como os ecobairros ${ }^{14}$.

Por fim, Andrade (2008, p.6) destaca os princípios em comum do desenvolvimento sustentável e da cidade Jardim:

"(...) alguns princípios de desenvolvimento urbano sustentável podem ser identificados no modelo de Cidade-Jardim tais como: tamanho controlado com acessibilidade aos espaços verdes e aos pedestres, transporte público adequado, uso misto (de-zoneamento), reaproveitamento de resíduos sólidos em terras agrícolas e centros comerciais com economia local. Porém, outros princípios precisam ser reformulados ou completados.

Uma das grandes críticas ao modelo de Cidade-Jardim sob o ponto de vista da sustentabiliade é o efeito da suburbanização que este causou, ou seja, a expansão urbana com baixas densidades que ocupam terras agricultáveis. Este efeito é melhor percebido nos EUA, e hoje no Brasil é representado pela expansão de condomínios irregulares sem infra-estrutura econômica e preocupações ecológicas.

Apesar desse efeito, deve-se considerar que o caminho para o desenvolvimento urbano sustentável é justamente tentar completar as partes ausentes nos ideais de Howard, um utopista do século XX, que acreditava na possibilidade de planejamento de comunidades balanceadas com mistura de classes sociais, desenvolvimento

\footnotetext{
${ }^{14} \mathrm{O}$ conceito e projeto de ecobairros serão apresentados no capítulo 03 da Tese.
} 
econômico, sistema de cooperativismo e bem estar social atrelado ao desenho da paisagem."
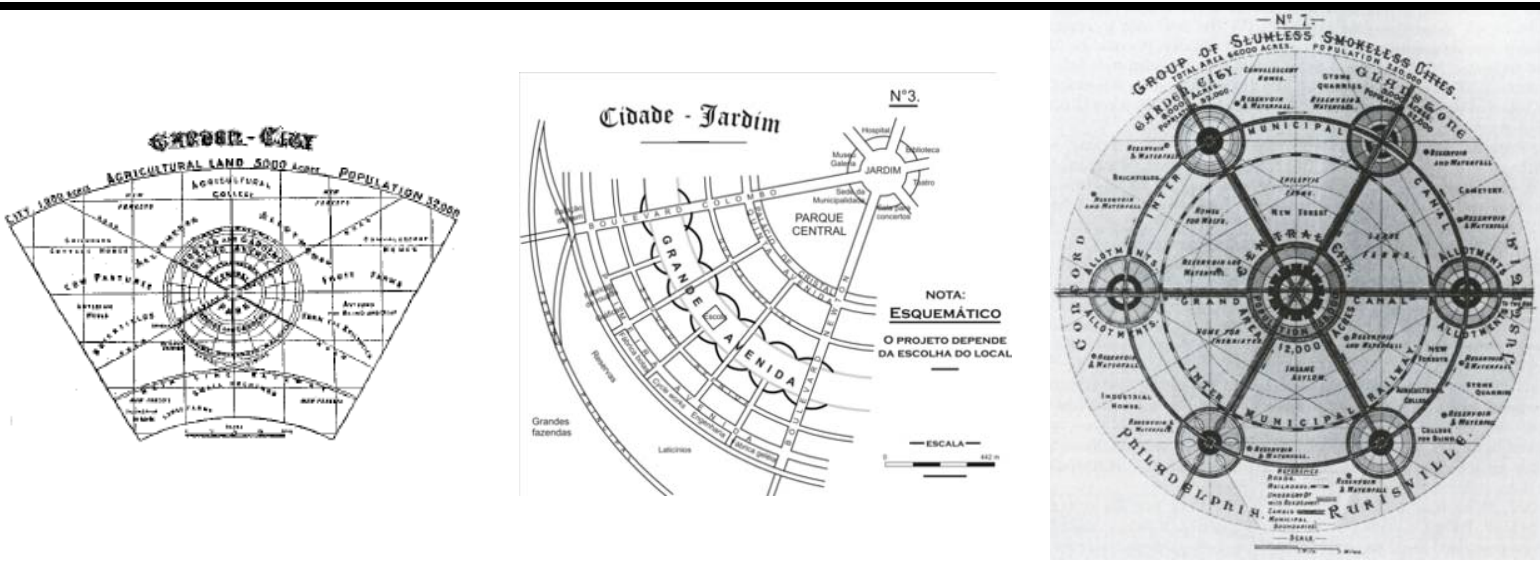

Figura 20: Diagr. de Howard Planejamento

Figura 21: Diagr. de Howard Distrito e Centro.

Figura 22: Diagr. de Howard

Fonte: HOWARD, 1996

Fonte: HOWARD, 1996 Constelação de Cidades

Fonte: HOWARD, $1996^{15}$
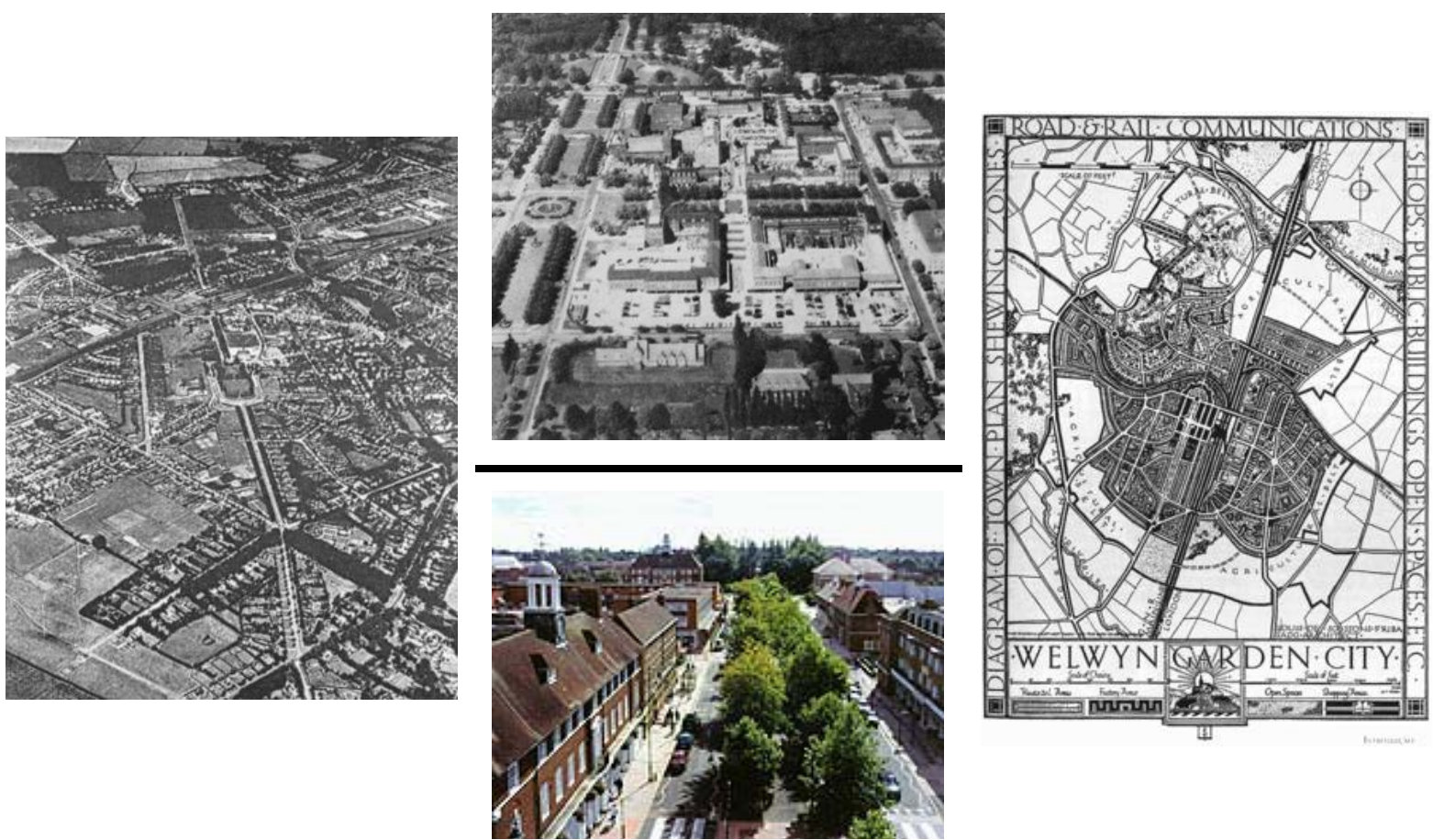

Figura 23: Vista aérea de Figura 24: Welwyn Letchworth, 1904

Figura 25: Letchworth

Figura 26: Projeto de Welwyn, 1920

Fonte: Disponível em: <http://urbanidades.arq.br/bancodeimagens/displayimage.php?pos>

${ }^{15}$ Disponível em: <http://urbanidades.arq.br/bancodeimagens/displayimage.php?pos> Acesso em: jan 2009. 


\subsubsection{Plano de extensão de Barcelona - Ildefonso Cerdá}

Ildefonso Cerdá (1859-64) propôs para expansão de Barcelona um plano que consistia na ocupação do perímetro de quadras de $113 \mathrm{~m} \times 113 \mathrm{~m}$ e vias de $20 \mathrm{~m}$ de largura, de tal maneira que cada conjunto de nove quadras e vias correspondentes se inscrevem dentro de um quadrado de $400 m$ de lado. Segundo Figueroa $(2006$, p.3) (...) "a quadricula estende-se até os núcleos urbanos vizinhos e envolve a cidade medieval. Apesar de aparentar a imposição de uma nova ordem, indiferente ao contexto, o ajuste das bordas é feito com extrema habilidade tendo como suporte avenidas diagonais que surgem a partir de conexões pré-existentes."

Na concepção original as edificações perimetrais ocupavam dois ou no máximo três dos lados, não ultrapassando mais do que dois terços da superfície do quarteirão. Os espaços internos se abririam para a cidade constituindo valiosos espaços de lazer, onde o perímetro da quadra deixa de ser o limite do espaço público. Algumas quadras eram cortadas na diagonal por grandes avenidas, dando destaque aos edifícios de esquina. " $O$ corte diagonal nas arestas da quadra transforma o simples cruzamento de vias em lugar, gera também desta forma maior amplitude visual dos edifícios de esquina." (FIGUEROA, 2006, p.3).

Do desejo original de Cerdá permaneceu apenas o traçado viário, as quadras foram maciçamente ocupadas no perímetro junto ao alinhamento da calçada retomando um caráter que a reaproximou da quadra tradicional. Para se ter uma idéia, originalmente as quadras foram concebidas com $67.000 \mathrm{~m}^{3}$ de área construída, atualmente após 150 anos de adensamento progressivo temos em média $295.000 \mathrm{~m}^{3}$ de área construída por quadra (FIGUEROA, 2006).

Ressalta-se que Cerdá pretendia resolver as disfunções e desafios que a sociedade da metade do século XIX tinha e que em síntese se centravam na higiene e salubridade, na mobilidade, onde cada modo de transporte tinha sua rede específica, a integração de rendas no mesmo edifício e o equilíbrio entre o construído e o verde que não é mais que o equilíbrio entre funcionamento urbano e descompensação urbana. 


\section{Corbusier}

A arquitetura moderna brasileira é fruto de um processo histórico complexo. A extensão territorial do país e a sua diversidade cultural fizeram com que a eclosão da arquitetura moderna brasileira não ocorresse a partir de um único centro de irradiação, mas que tivesse diversos eventos fundamentais que dinamizaram o seu desenvolvimento.

É possível dizer que o movimento moderno teve um saldo positivo em relação à postura adotada pelos arquitetos e urbanistas, frente às questões ambientais. Foram bastante consideráveis as soluções que surgiram no desenho urbano e nas formas arquitetônicas. Estes mestres, não deixaram para a arquitetura atual um conjunto de obras e de regras a serem seguidas, mas deixaram muitos modelos experimentais com os quais se pode aprender.

Numa época em que nem existia o termo Desenvolvimento Sustentável, alguns exemplos da arquitetura moderna brasileira souberam dar respostas mais condizentes com seu significado que muitas obras atuais, sendo pertinente recuperar certos princípios e exemplos desse momento da arquitetura e do urbanismo (MOURA, 2007).

\section{Broad Acre City - Frank Lloyd Wright}

Em 1935, Frank Lloyd Wright publica a sua proposta, Broad Acre City, novamente união entre campo e cidade, na qual esses não se distinguem, tampouco o centro de cidade. Propunha-se uma cidade predominantemente horizontal e bucólica, onde as pessoas viveriam em residências cercadas por jardins.

Wright acusa a cidade industrial de alienar o indivíduo no artifício, sendo que só o contato com a natureza poderia devolver o homem a si mesmo e permitir um harmonioso desenvolvimento da pessoa como totalidade. Neste modelo, a natureza volta a ser o meio contínuo no qual todas as funções urbanas estão dispersas e isoladas sob a forma de unidades reduzidas (FARIAS, FILHO, 1996).

Cada família sem filhos possuiria no mínimo um acre de terra para morar, e à medida que a família crescesse, a sua cota aumentaria até cinco acres (ANDRADE, 2008).

Hassenplug (2007 apud Sandoli, 2008):

"Sendo rural e urbana ao mesmo tempo, ela combina e integra aspectos tradicionais e modernos desde o primeiro momento. Os colonizadores, seguindo o ideal do 'homem 
comum', criaram o que eu chamo de 'paisagem republicana', uma paisagem que não é rural nem urbana, mas ambas simultaneamente - uma paisagem híbrida de proveniência americana. A versão radical da Broad-Acre-City de Frank Lloyd Wright é um exemplo perfeito de uma paisagem republicana americana. Ela apresenta uma paisagem rural-urbana ortogonalmente estruturada - um espaço sem nenhum centro".

Nesses aspectos, são claras as influências da cidade jardim de Ebenezer Howard, porém, Wright propõe um descentralismo mais radical do que Howard. Ele justificou seus ideais a favor da descentralização urbana, a partir do uso do automóvel e da expansão da eletricidade, antecipando o fato de que juntos, esses dois fenômenos do mundo moderno permitiriam que as cidades crescessem indefinidamente na direção horizontal (GONÇALVES, 2003).

As teorias de Wright nunca se concretizaram na forma em que ele as havia proposto, porém ao ver o espraiamento dos imensos subúrbios das cidades americanas há de lembrar dessas idéias de Wright. "Lá, nos espaços dos subúrbios, protegidos pelos princípios da ética protestante, ainda persiste algo caro à alma americana: o antigo sonho de liberdade e comunhão com a natureza." (FARIAS FILHO, 1996, p.253).
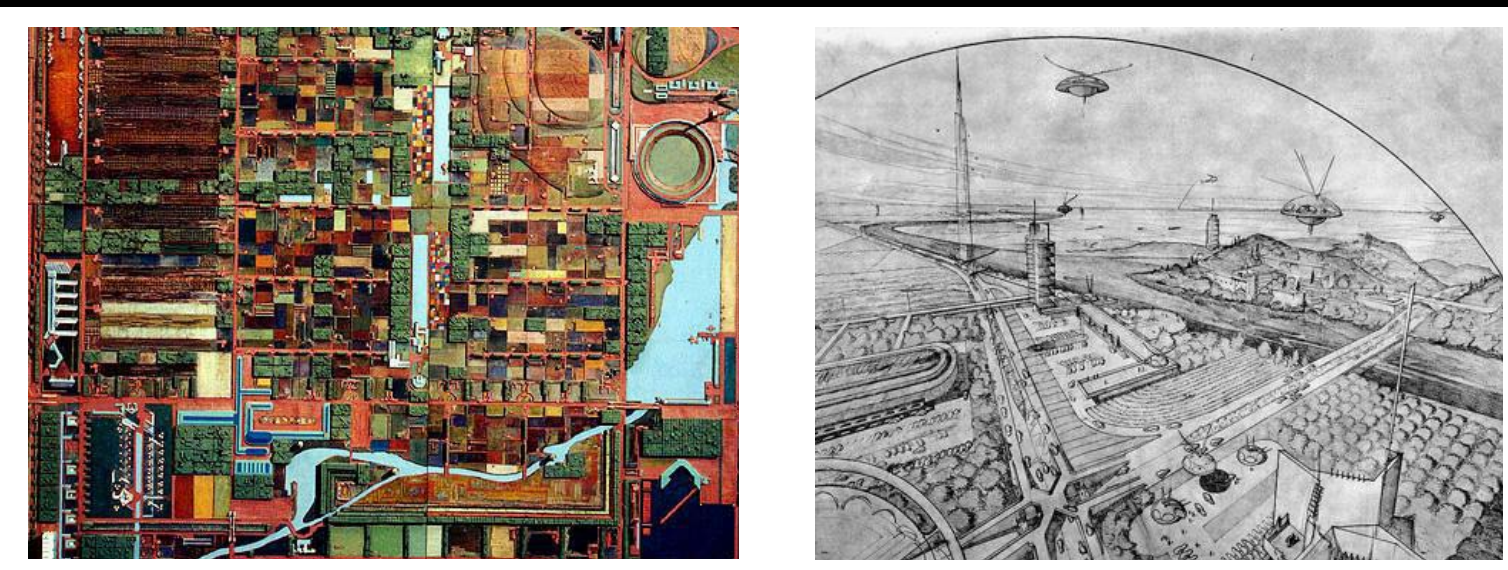

Figura 27: I magem proposta Broad Acre City de Frank Lloyd Wright

Figura 28: I magem proposta Broad Acre

Fonte: FISHMAN, Robert. Urban Utopias in the Twentieth Century apud Sandoli, 2008. City de Frank Lloyd Wright

Fonte: FISHMAN, Robert. Urban Utopias in the Twentieth Century apud Sandoli, 2008. 


\section{Cidade Industrial - Tony Garnier}

Tony Garnier é autor da Cidade Industrial, modelo apresentado na França em 1904. Este modelo apresenta algumas inovações, apesar se ter sido desenvolvido a partir de habitações unifamiliares, em unidades isoladas, como as habitações das cidades-jardins inglesas. Silva (2006, p.29) destaca tais inovações como:

"a disposição ordenada dos volumes construídos totalmente independentes uns dos outros, a uma distancia equilibrada e constante, entre si e em relação ao alinhamento das vias; volumes implantados em quadras de formato retangular-alongado, que evidenciam a preocupação com soluções unitárias, porém de grande sentido plástico em seu conjunto; a homogeneidade da volumetria geral, composta de edificações de mesma tipologia e gabarito de um ou dois pavimentos; a ausência de cercas e muros divisórios entre os lotes, transformando o espaço não construído em áreas públicas abertas ao livre transito dos pedestres; a utilização de árvores nos espaços livres, dando idéia de jardim ou parque público."

Para Tony Garnier, uma cidade industrial ideal deveria possuir cerca de 35.000 habitantes, estar implantada em um terreno em parte montanhoso, em parte plano, ser atravessada por um rio; ser construída com materiais pertencentes à região escolhida e utilizar a força hidráulica como geradora de energia. O solo da cidade deveria ser um grande parque e permitir a travessia em todos os sentidos.

Tony Garnier descrever as disposições dos elementos principais no terreno, os regulamentos em relação a essas disposições e ressalta que todos esses devem ser construídos de modo a tornar possível uma extensão da cidade.

Le Corbusier (2004) destaca que o projeto da cidade industrial propõem pela primeira vez, um solo de cidade transformado em domínio publico e prestando-se a instalação de dispositivos comunitários úteis a todos os habitantes. Por outro lado, Le Corbusier (2004) critica a baixa densidade do modelo.

As Figuras 29 e 30 apresentam a planta e imagem do bairro residencial da cidade industrial proposta por Tony Garnier, nas quais é possível observar a forte presença de vegetação, a pureza do volumes e o espaço dedicado ao pedestre. 


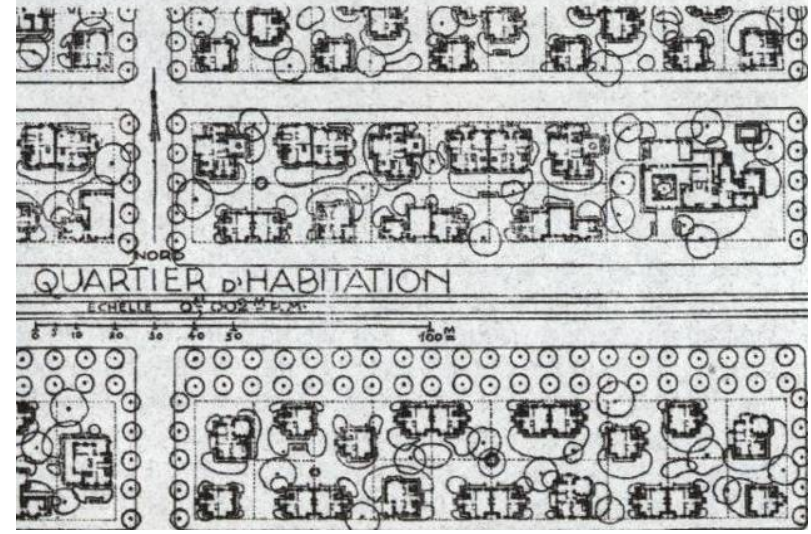

Figura 29: Cidade I ndustrial de Tony Garnier (1904) - Planta parcial do bairro residencial

Fonte: LAMAS, 2004

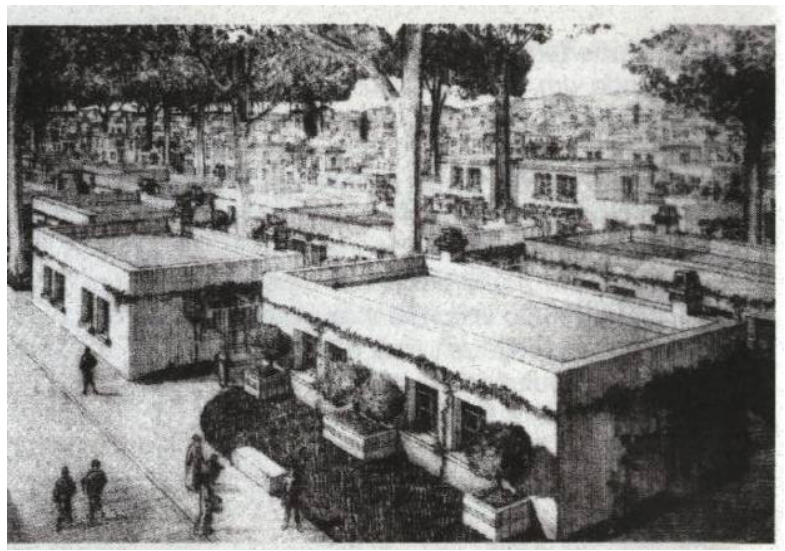

Figura 30: Cidade Industrial de Tony Garnier (1904) - habitações unifamiliares Fonte: LAMAS, 2004

\section{A Cidade Funcional - Walter Groupis}

Destaca-se que foram os arquitetos do movimento moderno os primeiros que mostraram uma preocupação por conseguir que as habitações fossem ensolaradas, e que as edificações fossem desenhadas segundo os critérios de sol e vento. A precária situação que se encontravam as cidades, altamente adensadas, provocavam sérias doenças e epidemias, conhecidas como pestes urbanas. Diante desta situação, surgiu uma reflexão teórica e prática acerca da necessidade de que as habitações tinham de receber sol e vento, e deste modo melhorar as condições higiênicas e sanitárias (HIGUERAS, 2007).

Entre as idéias teóricas e as construções mais ou menos experimentais, destaca-se o projeto de Siedlung Dammerstock, elaborado por Walter Gropius, em 1927, que resume a teoria do bairro funcional. Esta teoria pode ser sintetizada em quatro critérios básicos: clara distinção entre o traçado viário e a trama dos edifícios, dispostos perpendicular as ruas; colocação dos blocos de casas em linha sobre uma área verde, apresentando uma distância entre si calculada com relação a sua altura e orientação segundo os critérios de insolação direcionados, preferencialmente, norte-sul; concentração de serviços coletivos nas margens do tecido residencial e; concepção do sistema construtivo em série.

Sobre os critérios de insolação, Gropius analisou a razão entre a altura edificada e o espaço perdido pela sombra, constatando que, com mais de cinco pavimentos, o espaço 
perdido pela sombra é maior que o que se reduz do solo pela ocupação do edifício, se considerar que as habitações do primeiro pavimento recebem sol.

Para a definição das distâncias mínimas entre as fachadas, Gropius estabeleceu a seguinte regra: "igual a uma vez e meia a altura do mesmos, preferivelmente no caso de uma orientação norte-sul e duas vezes e meia se tratando de uma orientação lesteoeste". (HIGUERAS, 2007).

Vale destacar que apesar dessa preocupação com o sol e o vento, os bairros funcionalistas se projetavam com uma absoluta ausência de referência da natureza e do entorno.

Outro aspecto importante refere-se inversão de papéis, ou seja, até agora a unidade de habitação era conseqüência da forma do edifício, que era resultante da forma do lote, que era resultante da sua localização na quadra. Agora para o urbanismo moderno a célula de habitação é o elemento base da formação da cidade (FIGUEROA, 2006).
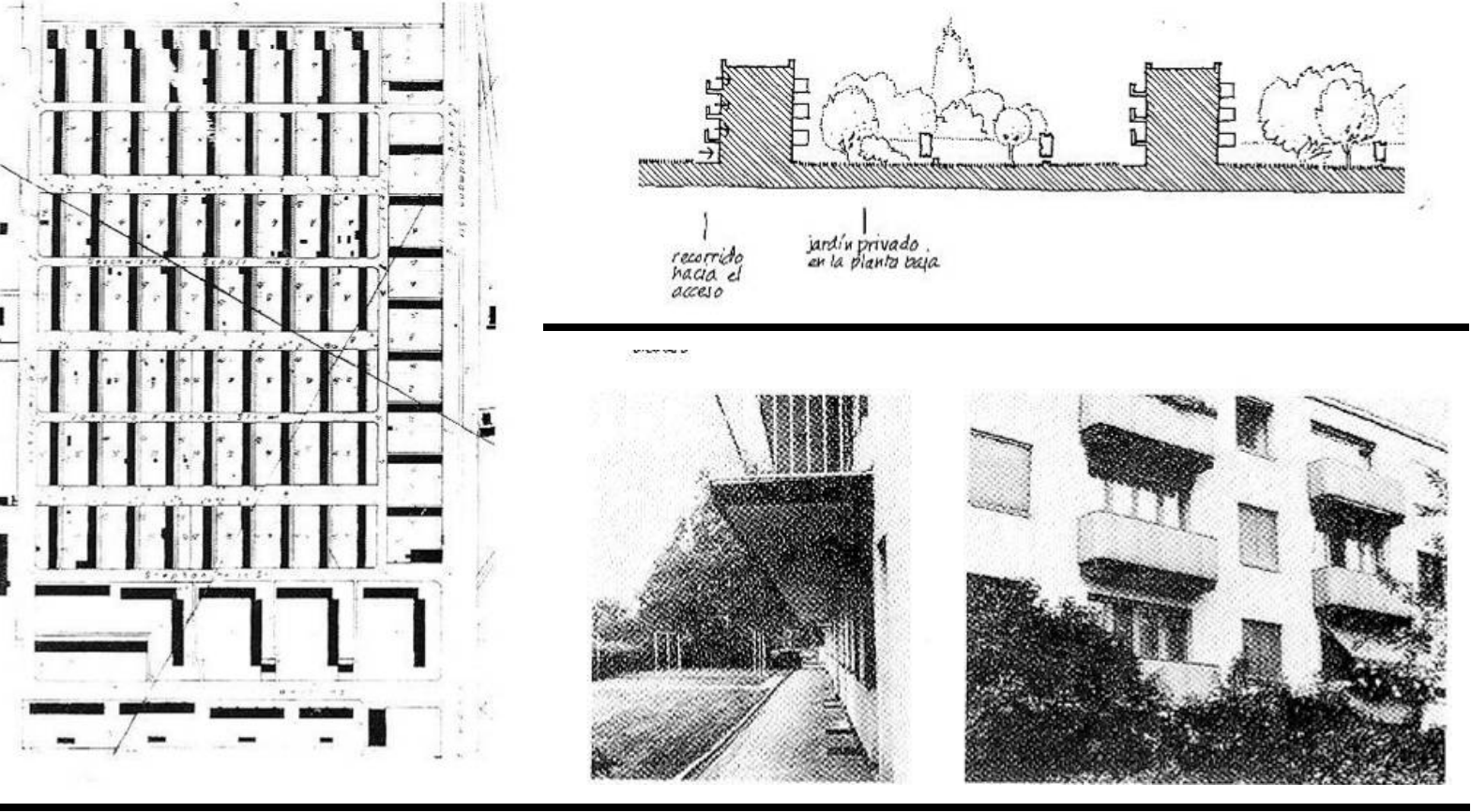

Figura 31: Siedlung Westhausen de Ernst May - Planta

Fonte: HIGUERAS, 2007.

Figura 32: Planta da divisão do bosque para o jardim privado. - Figura 33: corte - Figura 34: imagem das fachadas

Fonte: HIGUERAS, 2007. 


\section{Propostas urbanísticas de Le Corbusier}

Muitos utopistas influenciaram o trabalho de Le Corbusier. A influência de Camillo Sitte, por exemplo, pode ser verificada nos traçados sinuosos e pitorescos dos caminhos de pedestres de seus planos urbanísticos, ou, no movimento progressivo, cuidadosamente estudado, uma espécie de versão arquitetônica das seqüências espaciais de pequena escala, orgânicas e variadas.

Já a cidade-jardim de Howard esta presente em vários estudos urbanos, mesmo criticando o modelo espalhado e antieconômico da cidade-jardim inglesa. Além dessas, Silva (2006) destaca mais duas, Tony Garnier através da cidade funcional e Auguste Perret, e por meio do uso do concreto armado, permitindo a verticalização, respectivamente.

Em 1920, Auguste Perret idealiza as Cidades-Torres, que consistem em aglomerações compostas de grandes arranha-céus de planta cruciforme, implantados ordenadamente a grande distância uns dos outros. Em 1920, Le Corbusier apresenta croquis esboçando as idéias de Perret para as cidades torres.

Silva (2006) as Cidades-Torres eram dotadas de edifícios altos e idênticos, de 220 metros de altura (60 andares) e de 150 a 200 metros de base, afastados entre si 250 a 300 metros, dispostos em terrenos livres contínuos tratados como parques. Estes eram cortados por grandes vias de trafego mecanizados, o qual se organizaria conforme as características e velocidades especificas. Dessa maneira, a intensa verticalização proporcionaria densidades cinco a dez vezes superiores as verificadas nas aglomerações urbanas tradicionais, deixando parte significativa do solo livre de construções.

Le Corbusier (2002, p.33) descreve o projeto:

"Partindo do acontecimento construtivo capital que é o arranha-céu americano, bastaria reunir em alguns raros pontos essa forte densidade de população e de elevar lá, em 60 andares, construções imensas. 0 cimento armado e o aço permitem essas audácias e sobretudo se prestam a um certo desenvo/vimento das fachadas graças ao qual todas as janelas se voltarão de cheio para o céu; assim, doravante, os pátios serão suprimidos. A partir do décimo - quarto andar, é a calma absoluta, é o ar puro. Nessas torres que abrigarão o trabalho até então asfixiado em bairros compactos $e$ em ruas congestionadas, todos os serviços, de acordo com a feliz experiência 
americana, serão reunidos, proporcionado a eficácia, a economia de tempo e de esforços e com isso uma calma indispensável. Essas torres, elevadas a grande distancia umas das outras, dão em altura o que até então se estendia em superfície; deixam vastos espaços que empurram para longe delas as ruas cheias de ruído e de uma circulação mais rápida. Ao pé das torres se desenrolam os parques; o verde se estende por toda a cidade. As torres se alinham em avenidas imponentes; é verdadeiramente a arquitetura digna deste tempo."

Além destas referências, toda a fundamentação básica do Urbanismo Moderno presente na obra de Le Corbusier encontram-se sintetizadas na intitulada Carta de Atenas.

A Carta de Atenas, escrita por Le Corbusier, é a versão pessoal das conclusões do IV CIAM (Congressos Internacionais de Arquitetura Moderna), realizado em 1933 sob o tema A cidade Funcional. Este documento foi escrito de próprio punho e publicada em 1941, oito anos após a realização do Congresso que reuniu um grupo analisando a planta de 33 cidades de quatro continentes.

A Carta de Atenas se tornou um referencial, por reunir os preceitos do urbanismo racional e funcionalista pregado pelos arquitetos modernistas, ao qual Le Corbusier adicionou contornos e ênfase de caráter pessoal.

Sua proposta, cristalizada na Carta de Atenas em 1943, propõe uma organização urbana totalmente funcional, com separação rígida de atividades e um resultado formal consistente com edificações afastadas umas das outras para proporcionar ventilação e insolação adequadas e entremeadas por espaços verdes totalmente livres da circulação de automóveis (LE CORBUSIER, 1997).

Para Le Corbusier (1987), o fim dos congestionamentos nos centros urbanos seria possível com o aumento da densidade urbana, diminuindo assim, as distâncias a serem percorridas. Tal medida deveria ser acompanhada de um aumento de áreas verdes dentro da cidade, combinada com a implantação de edifícios comerciais altos e blocos residenciais mais baixos e compactos.

Le Corbusier recorre à filosofia básica da cidade funcional, formulando seus cincos pontos: pilotis; terraza-jardim; planta livre; abertura horizontal e fachada livre. Destaca-se que nenhum desses cinco pontos pode ser adotado de maneira generalizada, sem considerar as características do clima local, do entorno construído e da tipologia edificadora. 
Ao contrário de Howard, o desenho urbano de Le Corbusier, caracterizava-se por uma presença marcante das formas geometrias pura, introduzindo a ordem do racionalismo cartesiano, tanto no que se refere ao desenho dos espaços abertos, como na volumetria dos edifícios (GONÇALVES, 2003).

Segundo Gonçalves (2003), as propostas de Le Corbusier para as novas bases do planejamento urbano tiveram um forte caráter internacional, referindo-se à reformulação de diferentes cidades do mundo. Seus estudos para a cidade contemporânea passaram por um processo evolutivo, resultando em três modelos distintos e complementares: a cidade contemporânea, em 1922, a cidade radial em 1935 e a cidade regional, em 1939.

A cidade contemporânea, dimensionada para abrigar três milhões de habitantes, era formada por três partes principais. Um distrito de serviços e negócios com edifícios de até sessenta andares, contornados por uma faixa de blocos residências, também de edifícios altos, de aproximadamente doze andares. Limitando o espaço de influência dos edifícios, era previsto um cinturão verde não construído, guardado para expansões futuras. Finalmente, uma última zona, caracterizada como o subúrbio urbano, com indústrias e mais residências, como as cidades jardins do século 19, implantados ao longo de todo o perímetro da cidade, junto à faixa de proteção (GONÇALVES, 2003).

Segundo Silva (2006) o núcleo central do modelo urbanístico ocupava uma área de aproximadamente 2.560 hectares, na forma de um retângulo orientado segundo os pontos cardeais, sendo a maior dimensão leste-oeste. Seu sistema viário, totalmente hierarquizado, era implantado de acordo com a mesma orientação, sendo que as duas vias principais de circulação eram coincidentes com os eixos longitudinal e transversal desse retângulo sendo que, no cruzamento desses se localizava a estação de trens, metros e ônibus.

Nesse núcleo central vinte e quatro edifícios de planta cruciforme de 150 x 150m e altura de $200 \mathrm{~m}$, eram dispostos em quatro linhas paralelas de seis edifícios, que definia uma espécie de praça central totalmente arborizada. Mais a oeste desta praça, localiza-se um grande jardim inglês junto ao "core", área de possível expansão. O core era envolvido por uma área de habitação coletiva de edifícios de doze pavimentos, tipo lâmina e o tipo bloco fechado, que abrigavam ao todo 600 mil habitantes. Ao todo a densidades desse 
núcleo era de 3.000 hab/ha, sendo 300 hab/h nos edifícios tipo lâmina e 305 hab/h nos edifícios tipo bloco fechado (SILVA, 2006).

Este núcleo urbano central era envolvido por uma faixa livre de ocupação, constituída de bosques, que ao redor desta, implantavam-se os loteamentos do tipo cidade-jardim, que concentrava a maior parte da população urbana, com 2.400.000 habitantes (SILVA, 2006). Com relação à proposta Silva critica:

"Assim, a Cidade Contemporânea, propriamente dita abrigava de fato, uma população de 600.000 pessoas, 20\% apenas dos 3 milhões de habitantes que se propunha a alojar, os quais, em sua maioria absoluta, moravam em bairros concebidos nos moldes da cidade -jardim tradicional. Dada a profunda irracionalidade deste modelo disperso de urbanismo, de características suburbanas, ao qual o mestre não cansava de criticar em seus textos, a solução de sua Cidade Contemporânea de três milhões de habitantes não deixa de ser contraditória e, porque não dizer decepcionante...Como explicar que, ao mesmo tempo em que prega obstinadamente um novo conceito de cidades, baseado na concentração $e$ na verticalização, por todas as vantagens que apresentaria em relação às formas urbanísticas correntes, o seu próprio modelo teórico tenha $80 \%$ da população alojada em condições opostas?"(SILVA, 2006, p.151).

Em 1930, Le Corbusier propõe a Cité Radieuse, cidade radiosa, uma cidade densa resolvida com edifícios tipo torre para uso residencial e comercial. A proposta de ville Raudiense consiste em uma estrutura reticular de grandes dimensões com amplos espaços livres e verdes, que paradoxalmente aportam poucas vantagens reais aos residentes, já que com freqüência aparece vazia de conteúdo, sendo tratados como espaços residuais (HIGUERAS et al, 2008).

Segundo Silva (2006), a Cité Radieuse também era organizada em moldes racionais, com as respectivas funções implantadas em zonas específicas, posicionadas segundo as melhores condições de acesso, sendo servidas por um sistema de circulação traçado para a movimentação de veículos, em consonância com outros meios de transporte urbano (metrô, ferrovias), independente das vias de pedestre. Como resultado dessa distribuição de usos e atividades completamente segregadas sobre o território urbano, apresentando- 
se uma grande desigualdade e uma dificuldade de resolver a vida social dos cidadãos (HIGUERAS et al, 2008).

A Ville Raudieuse apresenta uma concepção mais evoluída, abandonando a forma concêntrica e adotando sistemas de faixas paralelas para as diferentes funções urbanas. A cidade radiosa organizava-se a partir de quatro grandes faixas paralelas, correspondentes aos setores comercial, residencial, manufatura e industrial. Além das quatro faixas, a proposta ainda apresentava entre essas, bandas complementares: uma de hotéis e embaixadas; uma verde de proteção e uma de armazéns gerais (SILVA, 2006).

Nesta proposta, a área residencial era composta de blocos de habitação coletiva erguidos sob pilotis e ocupava a posição intermediária da cidade, ficando eqüidistante dos dois principais setores de trabalho. Com isto, Le Corbusier resolvia três premissas, que ainda hoje são consideradas importantes para a sustentabilidade ambiental das cidades: aumentava a densidade demográfica, liberava o solo urbano para a vegetação e reduzia os deslocamentos.

Nessa proposta a zona verde encontra-se dentro da cidade, tratados como um grande parque público e não mais formando um cinturão, como nos modelos de cidade jardim. Le Corbusier afirmava que, desta forma, o verde seria mais aproveitado pela comunidade.

Outro aspecto que diferencia a proposta da cidade radiosa é que o conjunto não era mais implantado com base nos pontos cardeais. Preocupados com as condições de insolação na fachada norte, Le Corbusier rotacionou o eixo longitudinal da cidade em relação à direção norte-sul, garantindo um mínimo de radiação solar em todas as fachadas (SILVA, 2006).

Em um terceiro momento de seus estudos, no final da década de 1930, Le Corbusier propõe a cidade linear Industrial. Essa proposta é resultado do reconhecimento da ligação entre a indústria na cidade com o sistema de transporte, que não parecia resolvido de maneira satisfatória na segunda proposta. Sendo assim, na cidade linear Industrial as atividades industriais são alinhadas junto a rotas apropriadas de transporte.

Desde 0 início as propostas de Le Corbusier foram intensamente criticadas, principalmente pela minimização da diversidade da forma arquitetônica e pela segregação entre os usos no espaço urbano. 
Le Corbusier justificava o radicalismo de suas idéias com a afirmação de que, a vida moderna propiciada pela era das máquinas, demandaria regras de um planejamento urbano diferenciado do herdado ao longo da história das cidades.

Apesar das propostas de Howard e as de Le Corbusier partirem de visões distintas de cidade, uma organicista e outra mecanicista, elas apresentavam vários pontos em comum, que originaram críticas semelhantes. Jacobs (1973) afirma que, apesar da resistência aos movimentos de cidades- jardins em relação à nova cidade moderna, a Ville Radieuse de Le Cobusier deriva exatamente do esquema conceitual proposto por Howard no início do século, tentando adaptá-lo a grandes aglomerações de população.

Outra crítica colocada por vários autores, diz respeito ao autoritarismo, derivado de ambas as posturas que, muitas vezes, focavam excessivamente na questão dos transportes e higiene e centravam no arquiteto e urbanista ou engenheiro, o papel de médico ou salvador da área urbana sobre a qual ele intervia (GUNN \& CORREIA, 2001).

Além disso, como o movimento moderno é marcado pelo emprego de uma nova linguagem arquitetônica, construtiva e compositiva, em muitos casos foi copiada somente a forma, deixando de lado a base intelectual que a impulsionava. Como resultado, são geradas soluções de baixa qualidade presentes em várias cidades do mundo.

Le Corbusier e os arquitetos do chamado movimento moderno, impuseram uma nova ordem mundial ao planejamento de cidades reais, dominando o campo do urbanismo até a década de 1960, com paradigmas que foram bem assimilados em cidades como Brasília (FARIAS FILHO, 1996). Com sucessivas adaptações, estes paradigmas orientaram a maior parte da produção urbana e arquitetônica no pós-guerra europeu, expandindo sua influência ainda para alguns casos específicos nas Américas (MENNEH, 1997).

Os princípios da cidade modernista podem ser verificados no projeto de Brasília, de Lucio Costa. Entre eles podemos citar: um traçado racional e geométrico, a cidade desenvolvida para o automóvel, segregação de atividades, presença de edifícios verticais, liberando o solo urbano para a vegetação e áreas livres, etc.

Enfim, Farias Filho (1996, p.254) resumi as principais intenções das cidades modernas e algumas conseqüências da sua forma:

"Nascidas da pranchetas, em nome da operacionalidade e do conforto, da qualidade de vida e dos espaços urbanos, as cidades modernistas conquistaram um sem número de melhorias urbanas, sem alcançarem, contudo, o tão esperado convívio com a 
natureza. Antes disso, foram palcos de efeitos subjacentes à sua própria forma: ampliação da segregação social e espacial motivada por espaços vazios, sem sentido, sem vida."

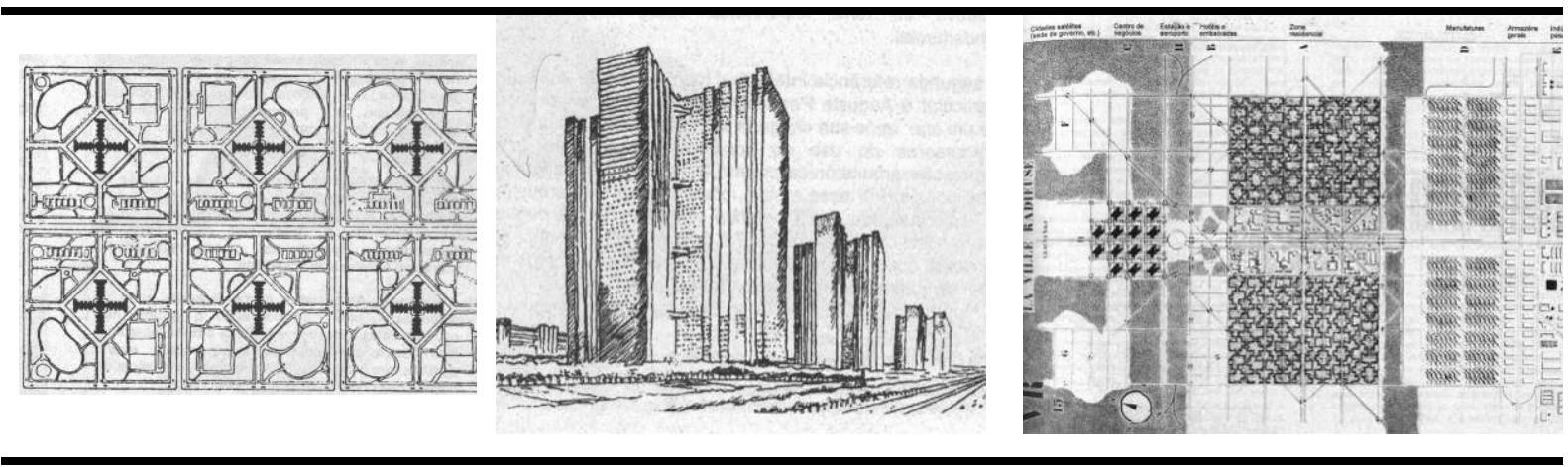

Figura 35: Desenho de Figura 36: Desenho de Le Le Corbusier para as Corbusier para as CidadesCidades-Torres - Planta Torres - Perspectiva

Figura 37: La Ville Radieuse: planta de implantação com as faixas de zoneamento.

Fonte: Towards a New Fonte: Towards a New Fonte: Le Corbusies, 1964, apud architecture .apud Silva, architecture apud Silva, 2006 SILVA, 2006 2006

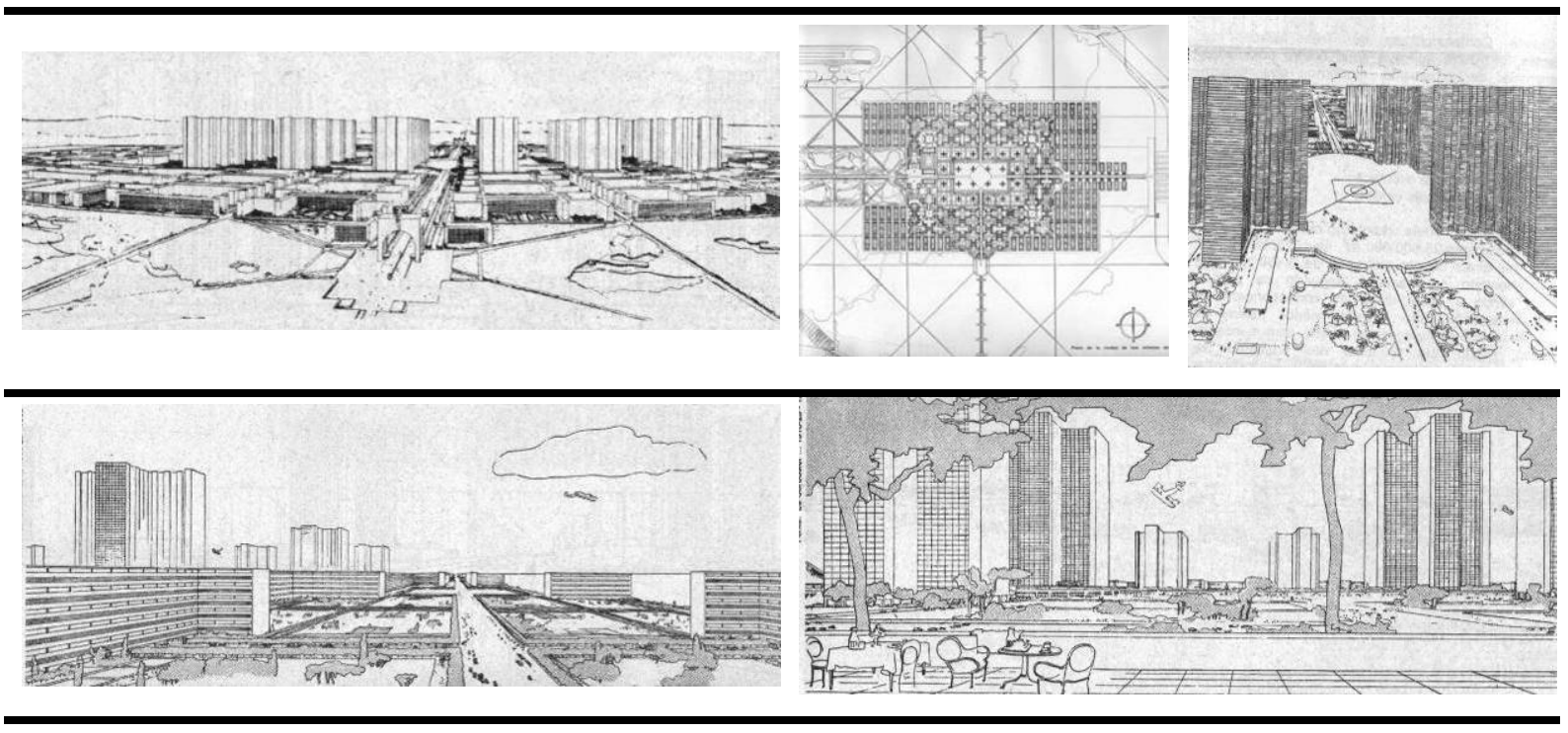

Figura 38: I magens Cidade Contemporânea de 3 milhões de habitantes

Fonte: Le Corbusies, 1956, apud SILVA, 2006 


\subsection{Cidade compacta $\mathrm{x}$ cidade difusa}

O carro ofereceu ao homem da cidade, a possibilidade da moradia distante dos centros urbanos de convívio e trabalho. Isso resultou em modelos de ocupação urbana dispersos, com graves conseqüências para o meio natural e com mudanças nem sempre positivas na qualidade de vida da população.

De uma forma geral, as utopias urbanas aqui apresentas, discutem essa questão de densidades controladas, como as cidades jardim, tentando abrigar uma grande população em um espaço reduzido, como as proposta das cidades modernas verticais. Enfim, o desfio sempre foi resolver os problemas decorrentes da concentração humana em espaços relativamente pequenos.

Porém, apesar dessa preocupação, muitas delas acabaram gerando cidades dispersas. As cidades jardim, por exemplo, em muitos casos, se transformou em subúrbio jardim e as cidades funcionalistas, já estavam comprometidas desde a sua concepção, com base no uso do automóvel e na segregação dos usos, ou sejas, a atividades de morar separada das atividades de trabalho e lazer, aumentando a necessidade de deslocamentos diários. Alguns desses modelos caracterizam-se pela expansão horizontal dos subúrbios, viabilizada principalmente pelo baixo custo do combustível e pela infra-estrutura crescente de rodovias, saneamento básico e energia

Enquanto Le Corbusier projetava a cidade para receber os automóveis, desenhando avenidas expressas e suspensas, sem preocupações com as conseqüências ambientais decorrentes desse meio de transporte urbano, propostas mais recentes para as cidades compactas têm como objetivo minimizar o uso do automóvel dentro do perímetro urbano (GONÇALVES, 2003).

Atualmente um modelo mais compacto é defendido por vários urbanistas, que acreditam que este é o caminho para a sustentabilidade ambiental das cidades.

O capítulo 02 da Tese apresenta uma discussão apontando os aspectos favoráveis e desfavoráveis da alta densidade urbana. Como a compacidade está diretamente relacionada à densidade urbana, os aspectos abordados se estendem a discussão sobre modelos de ocupação compacto versus modelo de ocupação difuso. Sendo assim, esta parte da pesquisa consiste em destacar a existência da discussão sobre estes dois 
modelos de ocupação, sob o enfoque ambiental, dividindo os urbanistas e arquitetos a favor e contra a compacidade urbana.

Higueras et al. (2008) destaca autores defensores da cidade compacta como: Jacobs (1961), Nwman e Keworthy (1989), Elkin et al. (1991), Sherlok (1991), Enwicht (1992), McLaren (1002), Owens e Rickaby (1992) e a diretoria da União Européia. Segundo esses autores, as principais vantagens da cidade compacta consiste: no menor consumo de solo urbano; na grande versatilidade de morfologias urbanas possíveis, a existência de transporte público que oferece mobilidade para toda a população, a redução dos tráfegos de veículo privado, a existência de áreas multifuncionais as quais é possível chegar andando; a sociabilidade e os intercâmbios pessoais e a segurança da população. A forma de cidade compacta é considerada bastante sustentável frente a outras opções.

A compacidade tem a ver com a forma e com suas funções. Para Rogers (2001) a cidade compacta é sustentável e promove a eqüidade, abrigando atividades diversas e que, ao mesmo tempo, se sobrepõem.

A proximidade de usos e funções na cidade compacta permite que o transporte público tenha a massa crítica para manter-se e oferecer um serviço regular, cômodo e próximo, e que a mobilidade em bicicleta e os deslocamentos a pé sejam possíveis. Na cidade compacta, a maioria dos cidadãos tem acesso a cidade e podem disfrutá-la sem depender de ninguém. Os idosos, crianças e as pessoas sem habilitação são cerca de $70 \%$ dos cidadãos que não tem acesso a cidade quando habitam em urbanizações dispersas (RUEDA, 2006).

O número de contatos em potencial por unidade de energia e tempo consumido em transporte é muito maior na cidade compacta que na cidade difusa. A mesma proporção, as emissões contaminantes para cada contacto são muito menores na cidade compacta que na dispersa (RUEDA, 2006).

Peter Calthrope (HIGUERAS et al, 2008) demonstrou empiricamente que ao aumentar a densidade se reduz os deslocamentos, ou seja, a menor densidade urbana, mais consumo de energia per capita. Os resultados teóricos comparativos de distribuição de uma determinada população em vários modelos de formas de cidades (compacto, radial, linear, disperso em núcleos) mostram que a opção da cidade compacta era a mais eficiente energeticamente, e em segundo lugar a distribuição da população em cidades 
médias dispersa. Os demais modelos não eram eficientes desde o ponto de vista do consumo energético. Nas cidades jardim satélites eram gerados numerosos deslocamentos entre elas que poderia ser resolvido por um sistema de transporte público. Os modelos lineares não resolveriam seu deslocamento de maneira eficaz, fora do eixo principal. E no caso de assentamentos radiais o resultado era negativo, já que nas vias principais geravam mais congestão.

Naes (1996) realizando estudos experimentais em Oslo, concluiu que a forma da cidade contemporânea pode estar diretamente relacionada como o consumo energético e de aí que resultam umas formas mais sustentáveis que outras comparativamente.

Enfim, quanto mais descentralizada for uma cidade, e maior as extensões de sua mancha urbana, mais custosa e menos eficiente se tornam a instalação e a operação de infraestrutura, incluindo todos os serviços (GONÇALVES, 2003).

Além disso, a separação entre as pessoas com rendas diferentes na cidade compacta é menor que na difusa. Por outro lado, a mescla de rendas que se dá em boa parte do tecido construído gera, entre outros elementos, uma maior coesão social. As urbanizações da cidade dispersa são ocupadas segundo a renda, o que provoca uma segregação social que aumenta com o uso quase exclusivo do espaço público pelos residentes da urbanização.

As soluções formais adotadas na cidade compacta, tanto no espaço público como na edificação, permitem estabelecer uma separação entre o que é cidade e o que é campo. Porém uma grande desvantagem do modelo compacto é a falta de espaço físico, principalmente para a criação de áreas verdes e livres para lazer.

Higueras et al. (2008) destaca autores contra a cidade compacta Breheny (1992), Knights (1996), Van dek Valk e Faludi (1992), Green (1996). Segundo esses autores a cidade compacta pode apresentar as seguintes desvantagens: congestão, o conceito de cidade verde está em contradição com o de cidade compacta, já que nessas as zonas verdes são escassas e em muitos casos residuais ou quase impossível de incrementar; se produz inevitavelmente segregação da população devido a carência de solo urbano; o aproveitamento de energias passivas é mais factível em habitações isoladas ou germinadas.

A conclusão é que a forma de cidade compacta necessita ser revista de acordo com os tempos atuais, não só considerando a cidade propriamente dita, mas também seu 
território e área de influência, adotando para a escala o modelo adequado com base nas suas particularidades e recursos.

A adequada forma da cidade, nas escalas territorial e urbana, deve ser específica para cada cidade, de acordo com suas características próprias (ambientais, climáticas, sociais, econômicas, etc) tratando sempre de garantir a redução dos impactos ao meio ambiente (HIGUERAS, et. al., 2008). Autores com Frey (1999) e Naes (1996) propõem como ideal uma mescla entre formas compactas e difusas segundo a escala urbana, ou seja, dispor de estruturas formais compactas na escala urbana local, organizadas mediante estruturas de formas difusa (estrela, radiais, retículas) na escala regional ou metropolitanas unidas por meios de transporte eficiente e não contaminante. Esta solução permite uma boa acessibilidade equilibrada com amplos espaços abertos entre as diferentes cidades compactas e, por outro lado um adequado controle sobre o uso e eficiência do transporte, preservando as zonas verdes de interesse.
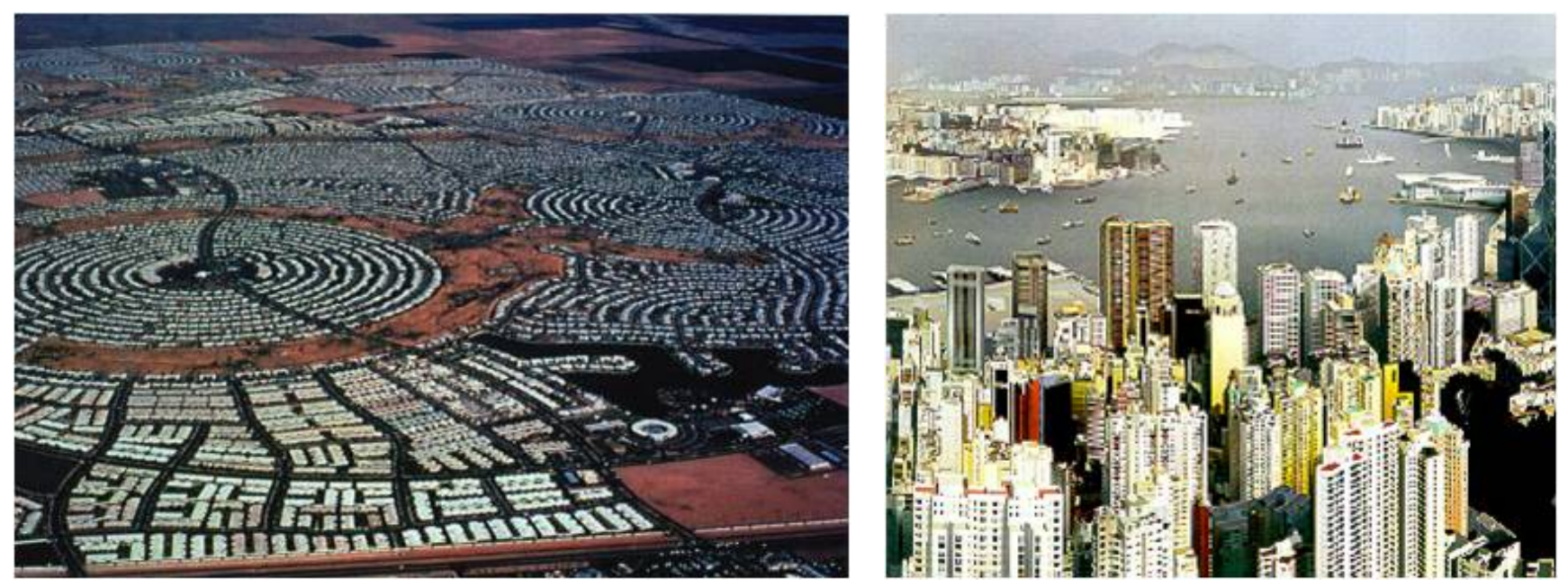

Figura 39: Foto Arizona, modelo difuso

Fonte: ROGERS, 1999

Figura 40: Foto Hong Kong, cidade compacta

Fonte: GONÇALVES, 2003

\subsection{Tipologias de adensamento}

Nesse trabalho serão apresentadas três tipologias de adensamento para a composição da morfologia urbana: o edifício lâmina, característico da arquitetura moderna brasileira, o bloco perimetral, morfologia de quadra presente em várias cidades européias e; o edifício torre, ícone da arquitetura contemporânea, presente em todas as megacidades. 
Nenhuma tipologia arquitetônica é por si só melhor que as outras, cada uma apresenta vantagens e desvantagens particulares dependendo do clima e da função. Destaca-se ainda que a diversidade edificatória é um atributo de sustentabilidade, implicando uma variedade de formas arquitetônicas que ajuda a estruturar o espaço, uma variedade de tipologias habitacionais, uma variedade de pessoas e, uma melhor adequação das condições locais (HIGUERAS, 2009).

A tipologia perimetral foi idealizada por Ildefonso Cerdá (1859-64), no plano de extensão para Barcelona, que consistia na ocupação do perímetro de quadras de $113 \mathrm{~m}$ x $113 \mathrm{~m}$. Na concepção original as edificações perimetrais ocupavam dois ou no máximo três dos lados, não ultrapassando mais do que dois terços da superfície do quarteirão. Os espaços internos se abririam para a cidade constituindo valiosos espaços de lazer, onde o perímetro da quadra deixa de ser o limite do espaço público. Algumas quadras eram cortadas na diagonal por grandes avenidas, dando destaque aos edifícios de esquina.

As propostas iniciais de Cerdá, ensanches, foram sofrendo alterações aumentando a área construída por quadra de $67.000 \mathrm{~m}^{3}$ para uma média de $295.000 \mathrm{~m}^{3}$.

Duas cidades européias desenvolveram experiências extremamente significativas desta tipologia: Amsterdã e Viena. Em Amsterdã destaca-se o uso dos edifícios perimetrais como instrumentos de ordenação perante uma nova hierarquia de vias e espaços urbanos através de construção diferenciada das esquinas, e pela evolução do miolo da quadra a partir da redução dos jardins privados e inserção de ruas e pátios internos destinados ao uso semipúblico. No caso de Viena destacam-se os pórticos resultantes que definiam com clareza os acessos ao interior da quadra, e a resolução das habitações coletivas em edifícios mais estreitos, favorecendo a ventilação e insolação dessas unidades e, o tratamento das fachadas internas das quadras (FIGUEROA, 2006).

A partir dos anos oitenta outras cidades européias como Berlin e Barcelona, envolvidas em programas de transformações urbanas, adotam as estratégias de remodelação e reconstituição perimetral de quadras parcialmente consolidadas. Segundo Figueroa (2006), a quadra recupera a ocupação perimetral, o desenho da rua tradicional e o valor como referência urbana da esquina. Pequenos fracionamentos do perímetro possibilitam o acesso ao centro da quadra que volta a assumir o papel de espaço coletivo.

Em resumo, conclui-se que o perímetro é uma solução tipológica de adensamento urbano presente em várias cidades européias, e que apresenta, em geral, as seguintes 
vantagens: ruas com uma melhor proporção para garantir insolação e ventilação sempre que estejam bem orientados; reforça a relação do edifício com as atividades do espaço público da calçada; interior da quadra livre para criação de espaços coletivos, públicos ou semipúblicos mais protegidos do ruído urbano e demais problemas das ruas e calçadas, e para a implantação de vegetação, melhorando o microclima urbano e aumentando a área permeável.

Além disso, estudos mostram matematicamente que o perímetro é a solução tipológica mais eficiente com relação ao consumo de solo (MARTIN, 1975).

Com relação aos aspectos desfavoráveis dessa tipologia Higueras (2009, p.73) aponta: congestão em determinadas ruas, quando associada à alta densidade; dificuldades de dispersão de poluentes, criação de canais de vento. Além disso, se a retícula não está bem orientada, as edificações ficam comprometidas termicamente e, consequentemente, energeticamente.

Duas outras tipologias de adensamento são os edifícios lâminas e os torres, ambas tipologias de edifícios altos, uma com base retangular e outra quadrada, respectivamente.

O edifício lâmina teve sua concepção idealizada durante a arquitetura moderna, se tornado sintese dos princípios dessa época. A escolha pela forma laminar pelos urbanistas modernos se deve: pela ausência de hierarquia entre as partes, pela capacidade de crescimento ilimitado, pela equivalência de condições para os distintos elementos e, pela relação de proximidade entre o espaço interior e o espaço exterior (FIGUEROA, 2006).

Para Le Corbusier essa tipologia oferece a conquista do espaço público contínuo a partir da implantação do edifício sobre pilotis. Além disso, a possibilidade da implantação dessa tipologia edificatória não está mais vinculada ao sistema viário, mas sim a melhor orientação solar e a incorporação em pavimentos elevados de funções urbanas tradicionalmente vinculadas à cota do térreo (FIGUEROA, 2006).

A tipologia de edifícios torre, conhecida hoje como international style, estilo internacional, está presente na maioria das grandes cidades, em todo o mundo. ${ }^{16}$

${ }^{16}$ Com relação ao tema edifícios altos, destacam-se as pesquisas de Gonçalves (2004) Umakoshi (2008). Ambas as pesquisas apresentam os impactos positivos e negativos da 
Com relação à implantação de edifícios altos, Gonçalves (2004) comenta que devido a diferença de altura entre o edifício e o entorno urbano dois impactos ocorrem inicialmente: o de marcar geograficamente uma localidade da cidade e o de provocar alterações no microclima urbano, em decorrência dos efeitos combinados entre a altura e a forma do edifício, e a morfologia do entorno. Os efeitos sobre o microclima urbano podem ser positivos, ou negativos, dependendo das condições climáticas locais e das características físicas finais da morfologia urbana, resultantes da inserção do edifício.

Segundo Gonçalves (2004) a maior vantagem do edifício alto é a capacidade de adensamento populacional e a proximidade entre diferentes usos e atividades, atuando, inclusive, sobre a eficiência energética urbana com a otimização do transporte público. Por outro lado, essa capacidade de acúmulo de densidade populacional é também entendida como uma desvantagem e ameaça para a qualidade da vida urbana.

Pela sua natureza e tamanho, os edifícios altos representam um desafio de projeto e podem afetar negativamente a qualidade ambiental do espaço público, com a criação de grandes barreiras, extensas áreas de sombreamento e turbulências de vento indesejáveis. Além disso, tipologia arquitetônica do edifício alto tipo torre é de difícil integração urbana e social, afastando seus residentes das atividades no nível da rua.

Assim, a própria forma do edifício alto pode ser classificada como uma desvantagem na morfologia urbana. Por essa razão, o modo como essa tipologia se conecta ao solo e se relaciona com os pavimentos mais próximos à rua é um aspecto fundamental para a conformação dos espaços abertos de domínio público (GONÇALVES, 2004).

Ainda assim, a verticalização oferece vantagens indiscutíveis, como a imagem trazida pela arquitetura da verticalidade e a maior presença de espaços abertos nos lotes urbanos que poderão ser inseridas ao espaço de domínio público. O uso público do nível térreo em edifícios altos (presente nas teorias e nos modelos de cidades de torres de Le Corbusier) tem sido revivido com sucesso em projetos europeus que enfatizam o transporte público em detrimento da circulação do automóvel.

verticalização, e apontam os principais aspectos da sustentabilidade ambiental a serem considerados no projeto e inserção destes edifícios na cidade. As pesquisas apresentam também uma avaliação de vários projetos de edifícios altos em distintas partes do mundo. 
Essas duas tipologias, normalmente, são inserida em quadras abertas. Segundo Figueroa (2006) a quadra aberta é por essência um elemento híbrido conciliador, que permite a diversidade e a pluralidade da arquitetura contemporânea. Ela recuperar o valor da rua e da esquina da cidade tradicional, assim como entende as qualidades da autonomia dos edifícios modernos. A relação entre os distintos edifícios e a rua se dá por alinhamentos parciais, o que possibilita aberturas visuais e o acesso mais generoso do sol (FIGUEROA, 2006).

Além disso, se bem desenhada a quadra aberta possibilita implantar as habitações nas melhores orientações. Higueras (2009) destaca mais duas vantagens: possibilidade de grande quantidade de zonas verdes próximas as habitações e consumo eficiente do solo por habitação.

Com relação aos aspectos desfavoráveis da tipologia de bloco aberto Higueras (2009, p.73) aponta: a monotonia, a uniformidade, o mau desenho dos blocos que não consideram a trajetória do sol para tratamento das fachadas e; zonas de sol e sombra muito diferenciadas, as quais se devem designar usos adequados.
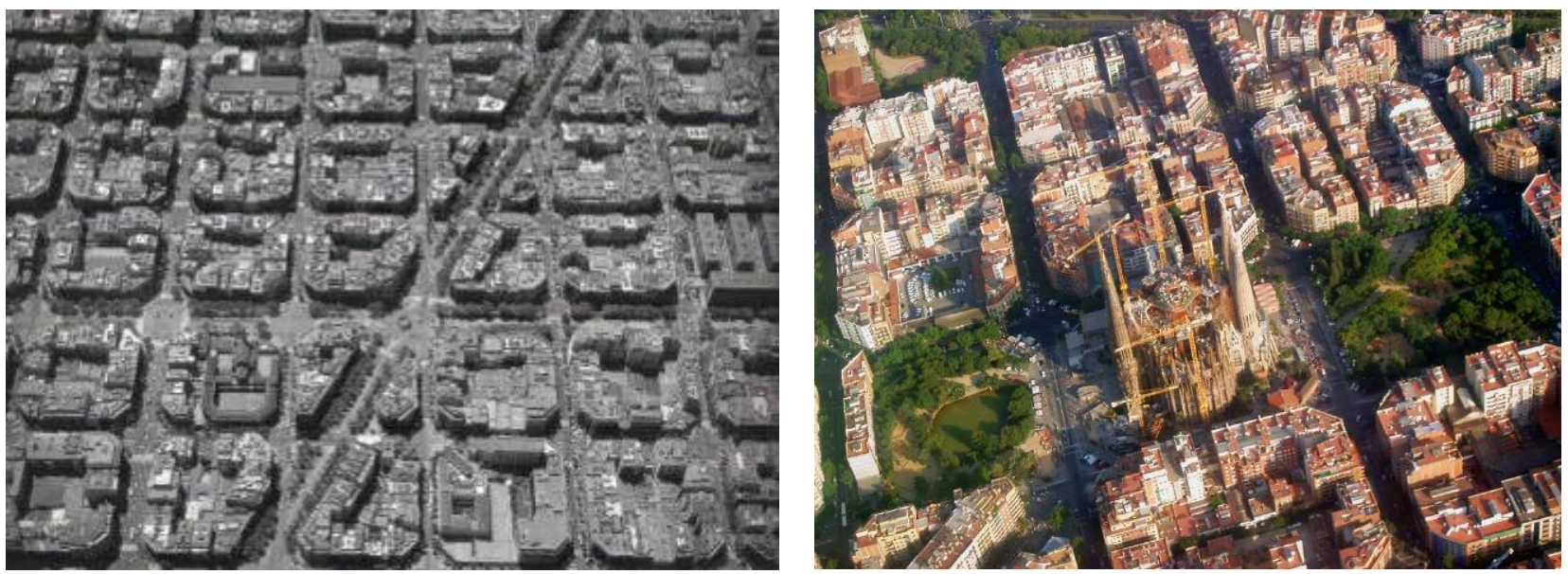

Figura 41: Bloco perímetro da quadra Figura 42: Bloco perímetro da quadra Barcelona Barcelona

Fonte: UMAKOSHI, 2008. 

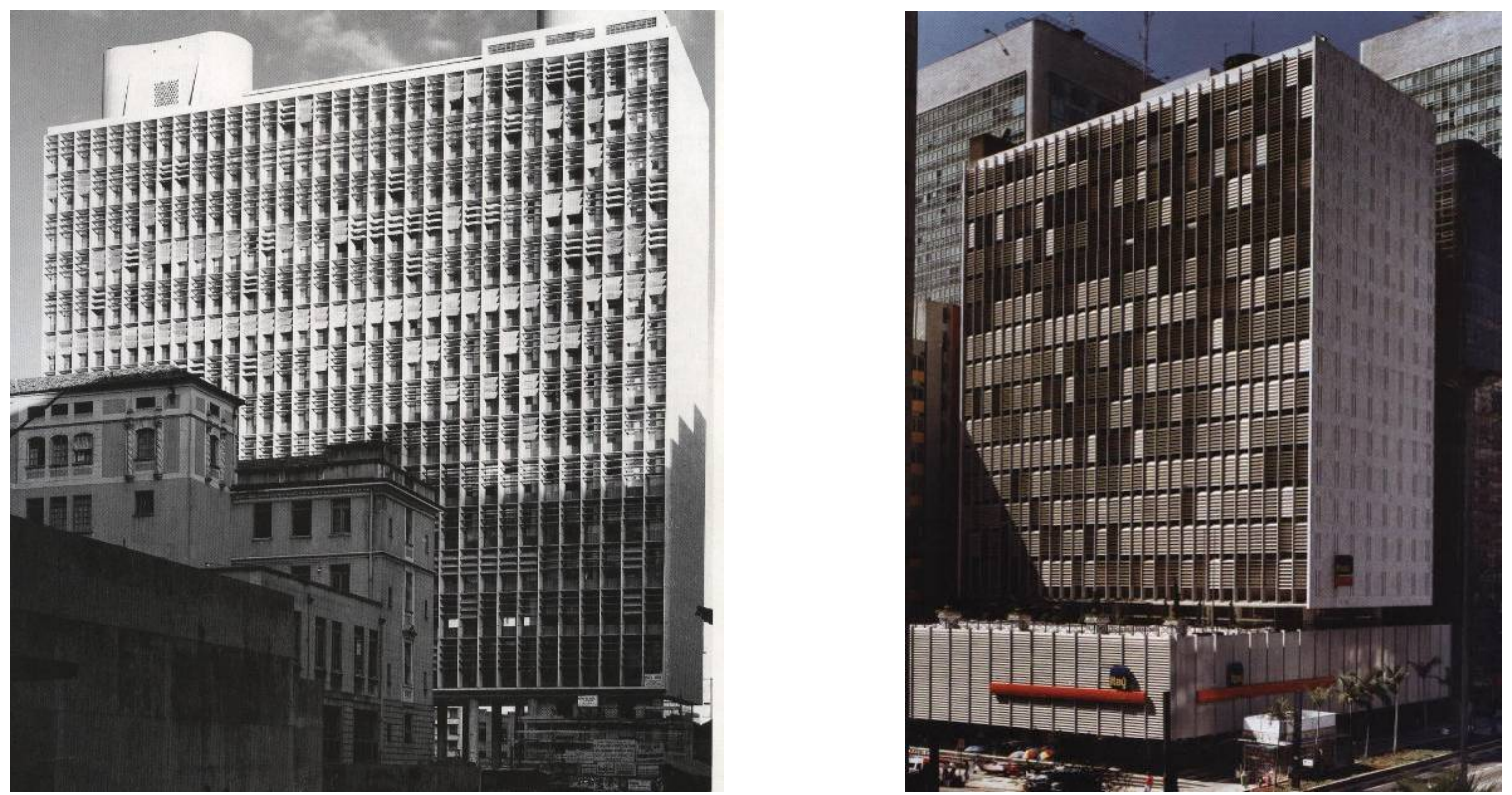

Figura 43: Edifício Lâmina - Ministério da Figura 44: Edifício Lâmina - Banco SulEducação, Rio de Janeiro, 1940 - Fachada Americano (atual Banco Itaú), São Paulo, Norte 1965.

Fonte: Goodwin, 1943

Fonte: BRUAND, 1981
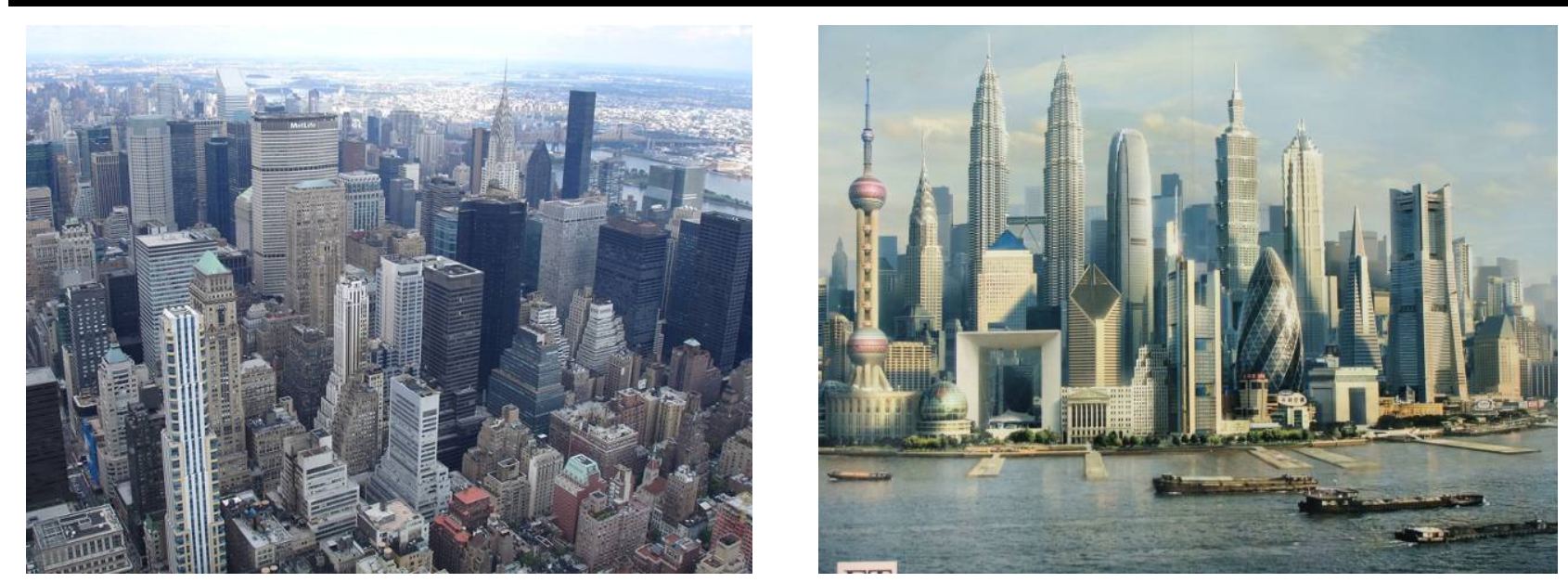

Figura 45: Edifício Torre - New York Fonte: UMAKOSHI, 2008.

Figura 46: Edifício Torre - Montagem com vários edifícios altos

Fonte:Foto da autora 
" $A$ cidade é o produto mais complexo da mente humana, não apenas por envolver um enorme aparato de conhecimento $e$ técnica, mas por ser obra coletiva que se transforma no tempo e no espaço, resultando em uma criatura que mesmo servindo ao criador não se subjuga a ele, tal como um enigma que reatualizase constantemente. Por ser um desafio permanente, a cidade vira um fetiche para a humanidade, motivando a imaginação, provocando encantamento e medo, até porque a cada salto de desenvolvimento, o homem se afasta mais e mais de sua ligação visceral com a terra, perturbando todo seu sistema de crenças e valores." (FARIAS FILHO, 1996). 


\section{CAPÍTULO 2 - ÁREAS URBANAS E QUALIDADE AMBIENTAL: CONCEITOS

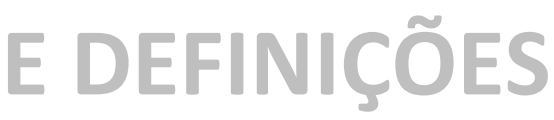

A preocupação com a escassez de recursos naturais tem dado uma nova dimensão à questão ambiental, que ganhou destaque mundial após a proclamação do ano do Meio Ambiente pelas Nações Unidas, em 1970, somada a convocação das conferências mundiais sobre o tema.

Nesta época existiam duas posições polarizadoras da problemática ambiental, uma defendida pelo Clube de Roma e outra expressa na declaração da Conferência de Estocolmo (MOREIRA, 1997).

Em 1968 é criado o Clube de Roma por cientistas de vários países, na tentativa da proposição de soluções para os complexos problemas decorrentes das crescentes pressões demográficas, que já exerciam sobre o equilíbrio do ecossistema do planeta, atingindo, principalmente, os recursos não renováveis. O informe, "Limites do crescimento" mostrava que se o crescimento demográfico e econômico continuasse, em longo prazo iria ocorrer uma degradação ambiental ainda maior, ocasionando escassez de recursos, poluição, fome, doenças, culminando em um alto índice de mortalidade. Segundo Meadows (1971), era necessário adotar uma política mundial de controle do crescimento econômico e populacional a qual foi denominada política do "crescimento zero", que propunha sua paralisação imediata, e que por este radicalismo foi bastante contestada.

Em contraponto foi estabelecido na Conferência de Estocolmo, em 1972, propõem um controle gradual dos crescimentos econômicos e populacional, ou seja, uma correção dos danos ambientais causados pelo desenvolvimento econômico e a estabilização, em médio prazo, da população mundial (VIOLA, 1991). Foi, então, estabelecida a obrigação de proteger e melhorar o meio ambiente para as gerações presentes e futuras, assim como 0 
reconhecimento da responsabilidade dos estados por danos ao meio ambiente fora de suas fronteiras.

Surge, então, o conceito de desenvolvimento sustentável, chamando atenção para o impacto das atividades humanas sobre o meio ambiente, enfocando o desenvolvimento econômico e social e o crescimento da preocupação global em relação às limitações ambientais (NSSD, 2003).

Passados 20 anos, no final dos anos 80, havia três posições polarizadoras da problemática ambiental. Uma, do Earth First que propunha uma drástica redução populacional e desocupação humana de vários ecossistemas. Outra, do partido Verde Alemão, que propunha nova ética ecológica e não crescimento do produto mundial bruto, por meio da redistribuição do poder e da realocação de recursos produtivos. E uma terceira, expressa no relatório "Nosso Futuro Comum"17 da Comissão de Bruntland, que defendia a sustentabilidade ambiental e social, o planejamento familiar, e o repasse de recursos de sistemas produtivos predatórios para sistemas produtivos sustentáveis. Essa ultima abordagem reconhece o vínculo entre o ambiente, ações, ambições e necessidades humanas, que torna o ambiente inseparável do desenvolvimento e em especial do desenvolvimento sustentável. (VIOLA, 1991, p.6)

Segundo Moreira (1997) essas abordagens da problemática ambiental apresentam enfoque diferente, ora a paralisação do crescimento econômico, ora a correção de danos materiais, ora a desocupação humana de alguns ecossistemas, ora a redistribuição de poder e de recursos produtivos, ora a sustentabilidade ambiental e social. Porém apesar dessas diferenças, estas posições apresentam em comum o mesmo conceito de ambiente, ou seja, as relações dos homens com a natureza para preservação dos recursos naturais.

Assim, Moreira (1997) delimita o conceito de ambiente como: "as relações dos homens com a natureza para preservar os recursos naturais em processos de desenvolvimento sustentável". Segundo ele o ambiente construído pode ser entendido como: "o resultado da profunda transformação do ambiente para adequá-lo às necessidades da aglomeração, e para transformá-lo em habitat da população e das atividades humanas aglomeradas." (MOREIRA, 1997).

\footnotetext{
${ }^{17}$ BRUNDTLAND, 1987.
} 
Com base nestas definições e na visão de biólogos, paisagistas e urbanistas, Moreira (2009) conceitua o ambiente urbano como:

"As relações dos homens com o espaço construído e a natureza, em aglomerações de população e de atividades humanas, constituídas por fluxos de energia e de informação para nutrição e biodiversidade; pela percepção visual e atribuição de significado às conformações e configurações da aglomeração; e pela apropriação e fruição (utilização e ocupação) do espaço construído e dos recursos naturais." (MOREIRA, 2009, p.4).

E completa:

"Este conceito de ambiente possibilita abordar qualquer localização do espaço urbanizado e construído como lugar de intercâmbio de energia das atividades humanas com a natureza para satisfação das necessidades biológicas dos organismos, como lugar susceptível de percepção visual e atribuição de significado, e como lugar de interação das atividades humanas com o espaço construído e com os recursos naturais." (MOREIRA, 2009, p.4).

Esse conceito possibilita entender a definição de impacto ambiental, segundo Branco (1984 apud MOREIRA, 1997) como: "...uma poderosa influência exercida sobre o meio ambiente, provocando o desequilíbrio do ecossistema natural", ou seja, "qualquer alteração produzida pelos homens e suas atividades, nas relações constitutivas do ambiente, que excedam a capacidade de absorção desse ambiente."

Moreira (1997) define estas relações, tornando possível compreender a questão da sustentabilidade no contexto urbano. Antes disto é interessante resgatar a origem do termo "Sustentabilidade", ou melhor, "Desenvolvimento Sustentável", já que o termo vem sendo aplicado aleatoriamente nos mais diversos seguimentos da sociedade, não só nas instituições de pesquisa, órgãos governamentais e organizações não governamentais. Esta proliferação da utilização do termo, sem um consenso e respaldo científico, acaba fazendo com que o termo se generalize e, em alguns casos, se banalize. (SILVA, 2000; ULTRAMARI, 2000; KRONKA, 2003).

\subsection{Sustentabilidade Ambiental Urbana}

Em 1987, a World Commission on Environment and Development, define o termo desenvolvimento sustentável como: "Desenvolvimento econômico e social que atenda 
as necessidades da geração atual sem comprometer a habilidade das gerações futuras atenderem as suas próprias necessidades." (WCED, 1987, BRUNDTLAND, 2001). ${ }^{18}$

Segundo Higueras (2009) o termo apresenta a vantagem de estabelecer um consenso de partida para todos, porém essa se converte em desvantagem, já que são muitas as vias de atingir o desenvolvimento sustentável entre os grupos sociais, políticos, etc.

O desenvolvimento sustentável abrange as três dimensões: ambiental, social e econômica. A dimensão ambiental requer o equilíbrio entre proteção do ambiente físico e seus recursos, e o uso destes de forma a permitir que o planeta continue a suportar uma qualidade de vida considerada aceitável. A dimensão social objetiva o desenvolvimento de mais sociedades justas, que proporcionem oportunidades de desenvolvimento humano e um nível aceitável de qualidade de vida. E por fim, a dimensão econômica requer um sistema econômico que facilite o acesso a recursos e oportunidades e o aumento de prosperidade para todos, dentro dos limites do que é ecologicamente possível, sem ferir os direitos humanos básicos (SILVA, 2003, p.2.).

Naredo (1996) e Rueda (2006) comentam que o desenvolvimento sustentável é um paradoxo, uma vez que são vocábulos contraditórios, pois a palavra sustentabilidade está ligada a idéia de reduzir a pressão sobre os sistemas de suporte e o desenvolvimento implica o contrário.

Acselrad (2001) afirma que desde a publicação do Relatório Brundtland, diversas matrizes discursivas têm sido associadas à noção de sustentabilidade, destacando: a da eficiência, da equidade, da escala, da ética e a da auto-suficiência. As matrizes da eficiência e da escala estão associadas a uma racionalidade econômica, buscando otimizar ou conter os processos e a pressão que eles exercem sobre os recursos naturais e assim, viabilizar a continuidade dos mesmos e da sociedade. As matrizes da equidade e da ética tratam de uma mudança de paradigma, pois se interessam por uma justiça inviável no sistema

\footnotetext{
${ }^{18}$ Versão original: "Sustainable development is development that meets the needs of the present without compromising the ability of future generations to meet their own needs. It contains within it two key concepts: the concept of needs, in particular the essential needs of the world's poor, to which overriding priority should be given; and the idea of limitations imposed by the state of technology and social organization on the environment's ability to meet present and future needs." (BRUNDTLAND, 1987)
} 
capitalista. E por fim a da auto-suficiência prega a desvinculação das economias nacionais e sociedades tradicionais dos fluxos do mercado mundial.

Dentre as variadas definições do termo Higueras (2009) destaca a proposta pelo ICLEI (Consejo Internacional para Iniciativas Ambientales Locales) por seu conceito globalizador do meio, no qual abrange questões do sistema natural, do sistema construído e os sociais, relacionando ao potencial de desenvolver-se em base a capacidade de carga do meio:

"A sustentabilidade supõe a melhora no nível de vida conforme a capacidade de carga do meio ambiente natural e urbano. A sustentabilidade implica que 0 consumo de recursos não supere a capacidade da natureza para recolocá-los. Aborda a manutenção da biodiversidade, a saúde e a qualidade de vida no futuro. A sustentabilidade é um equilíbrio dinâmico e um caminho no qual as metas se articulam a médio e longo prazo, em base aos condicionantes intrínsecos de cada localidade." (ICLE, 1994, tradução nossa)

Embora pareça que há um consenso nos meios científicos e políticos, o desenvolvimento sustentável ainda é um conceito amplo e de difícil aplicabilidade de maneira direta. Costa (2000) afirma que o consenso gerado em torno do termo, na verdade, se deve mais pelo resultado de sua generalidade e imprecisão do que pela sua consistência.

A imprecisão do conceito de sustentabilidade sugere que não há ainda hegemonia estabelecida entre os diferentes discursos. Ao contrário dos conceitos analíticos voltados para a explicação real, a noção de sustentabilidade está submetida às lógicas das práticas.

A sustentabilidade ainda é vista como "um princípio em evolução, um conceito infinito, que poucos sabem o que é (...) a sustentabilidade é uma noção a que se pode recorrer para tornar objetivas diferentes representações e idéias." (ACSELRAD, 2001, p.29).

A maior dificuldade do tema da Sustentabilidade consiste justamente em abordar um tema que ainda não possui um respaldo científico, ou seja, "a sua noção está mais relacionada a uma tendência, a um processo norteador de reflexões e ações determinadas por opções humanas em face ao seu relacionamento com o meio envoltório em circunstâncias específicas" (SILVA, 2000, p.09). 
Segundo Acselrad (2001) para se afirmar que algo é sustentável é preciso recorrer a uma comparação de atributos entre dois momentos situados no tempo: entre passado e presente, entre presente e futuro. São sustentáveis as práticas que se pretendam compatíveis com a qualidade futura postulada como desejável, sendo que esta prelação entre presente conhecível e futuro desejável, coloca a noção de sustentabilidade no campo do que alguns chamam de "causalidade teológica19"(ACSELRAD, 2001, p.29).

Apesar de sua amplitude e generalidade, aplicando este conceito no contexto urbano, é possível definir os princípios fundamentais para tornar as cidades mais sustentáveis, permitindo que a sustentabilidade seja avaliada e medida, através de instrumentos como os indicadores e índices.

Maria Berrini retoma o conceito de Brundtland ${ }^{20}$ para transferido ao desenvolvimento urbano:

"Uma cidade que consome recursos não renováveis, que gera resíduos e emissões, que compromete a qualidade social e estética, será insustentável quando superar a capacidade de carga do ambiente. Por capacidade de carga se entende como a capacidade de reação frente a essas pressões mediante os processos de autodepuração, absorção e reciclagem de resíduos, recuperando os recursos $e$ mantendo intactos os não renováveis." (BETINI, 1998, p.183, tradução nossa).

\subsubsection{Cidade Sustentável}

Segundo Fariña (EMVS, 2006) para melhorar a sustentabilidade se pode:

"en primer lugar mejorar los processos para conseguir los mismos resultados com menos consumo de energia, de suelo, de producción de desechos o de contaminación...el segundo aspecto es um problema de justicia social...para conseguir que el aumento de eficiência no implique um mayor consumo de los que más consumen, sino que se traduzca em uma mejora de los países em vias de desarrollo,

\footnotetext{
${ }^{19}$ Segundo Costa (1994 apud ACSELRAD, 2001, p.30) causalidade teológica, "que tem, como causa suficiente de um comportamento, um acontecimento que contém em sua descrição a exigência de que um outro acontecimento, chamando seu fim, aconteça. Ou seja, a causa é definida pelo fim; a ordem de sequencia dos acontecimentos está embutida na condição antecedente definida como causa."

${ }^{20}$ BRUNTLAND, 2001.
} 
(...)o de las capas sociales más desfavorecidas. Pero todavia existe um tercer aspecto, que es el social(... ) ya que se precisa un cambio em los hábitos de consumo y de los valores prioritários de la sociedade actual."

Já são diversas referências que destacam os princípios que devem ser base do desenvolvimento sustentável das cidades. Higueras (2009) comenta que desde a publicação do "Libro verde sobre Medio ambiente Urbano", em 1990, vem sendo realizado esforços para identificar problemas comuns nas áreas urbanas e os aspectos de intervenção prioritários. Os fundamentos de um desenvolvimento sustentável estão ligados aos seguintes temas chaves do urbanismo (HIGUERAS et. al., 2009, p.16 e HIGUERAS, 2009, p.46):

- Estudo adequado da densidade urbana e das conseqüências geradas tanto pela alta densidade, quanto pelas extremamente baixas. A densidade estabelece uma relação entre o número de pessoas por superfície ocupada, tendo conseqüências direta sobre: a ocupação do solo; o uso do transporte público eficaz; a congestão urbana; a complexidade; no consumo de energia per capita, etc; ${ }^{21}$

- $\quad$ Diversidade de tipologias edificatórias, que implica: na variedade de formas arquitetônicas; na variedade de habitações; na variedade de pessoas segundo sai renda e; melhor adequação das condições locais; ${ }^{22}$

- $\quad$ Propostas de usos mistos, evitando zonas monofuncionais; ${ }^{23}$

\footnotetext{
${ }^{21}$ As vantagens e os problemas das altas e das baixas densidades são discutidos no item 2.2 desta Tese. 22 Sobre a diversidade Jacobs (2000, p.245, 246, 253) coloca: "Muito embora as combinações intrincadas de construções, usos e panoramas sejam necessárias para os distritos bem-sucedidos, será que a diversidade traz consigo, igualmente, as desvantagens de má aparência, dos usos antagônicos e do congestionamento que Ihes são normalmente atribuídas pela doutrina e pela literatura do planejmaneto urbano? Essas supostas desvantagens baseiam-se na imagem dos distritos malsucedidos, que não têm muita, mas pouca diversidade. Elas evocam a imagem de áreas residenciais monótonas, dilapidadas, pontilhadas com umas poucas empresas miseráveis, de-pauperadas. (...) A diversidade urbana emergente, do tipo que é catalisada pela associação de usos principais combinados, ruas frequentes, mistura de prédios de várias épocas e custos e forte concentração de usuários, não acarreta as desvantagens da diversidade comumente presumida pela pseudociência do urbanismo. Como harmonizar visualmente a diversidade urbana, como respeitar sua liberdade ao mostrar visualmente que se trata de uma forma de ordem, é o problema estético fundamental das cidades."

23 Segundo Gonçalves (2004) a implementação do uso misto em edifícios ou mesmo em quadras urbanas, é dificultada por aspectos econômicos e culturais. No caso do edifício, um programa de uso misto incorre na previsão de vias separadas de circulação vertical, por motivos culturais e de segurança, o que pode
} 
- Favorecer a coesão social através da diversidade sócio-econômica da população, facilitada pela oferta de diferentes tipos de habitações;

- Sistema de zonas verdes e espaços livres estruturantes da vida urbana, adequados em quantidade e qualidade aos requisitos sociais e ambientais de cada área, considerando a habitabilidade dos espaços livres, a continuidade dos espaços verdes e a biodiversidade;

- Otimização das redes de abastecimento de infra-estruturas urbanas quantificadas e localizadas seguindo critérios de eficiência;

- $\quad$ Equipamentos integrados com a rede de espaços livres e zonas verdes;

- Gestão sustentável do tráfego urbano, com diversidade de medidas: zonas de uso preferencial para pedestres e ciclistas, rede de transporte público eficiente e diversificado, etc.;

- $\quad$ Redução e reutilização de resíduos sólidos urbanos em todas as escalas (resíduo doméstico a de demolições); ${ }^{24}$

- Valorização ambiental do solo circundante, como controle da expansão urbana, como redutor da pegada ecológica e como espaço de conexão da cidade com seu exterior.

Segundo Rueda (EMVS, 2006), um dos grandes objetivos atuais é o desenvolvimento de modelos urbanos mais sustentáveis, e para isso o primeiro requisito é reduzir a atual pressão que exercem os sistemas urbanos sobre os sistemas naturais de suporte. $\mathrm{O}$ autor

comprometer os padrões de eficiência econômica dos empreendimentos. Para o edifício contribuir com a vitalidade urbana no nível das ruas e calçadas, seus usos e serviços devem estar conectados com edificações vizinhas, ao invés de conter uma vasta diversidade de serviços e funções internamente.

DEGW (1998) é ressaltado que em edifícios que ocupam uma quadra, por exemplo, é fundamental a incorporação do uso misto, com o intuito de promover fluxos contínuos de pessoas, no entorno urbano. Diferentemente, para uma série de edifícios próximos, na mesma quadra urbana ou em quadras vizinhas, o uso misto pode estar distribuido entre os vários edifícios, cada um servindo a um propósito. Ou seja, as considerações de mistura de uso, são uma função do tamanho dos edifícios e das características de localização.

24 No Japão o lixo da cidade de Tóquio chega a um valor estimado de 20 milhões de toneladas por ano (ROGERS, 2001, px). Em São Paulo esse número é, aproximadamente, 5,5 milhões, sendo que, a produção de resíduos sólidos cresceu três vezes mais que a população em dez anos (DUARTE, Alessandro, SALLUM, Erika apud GONÇALVES, 2004). Daí a urgente necessidade de aplicar a política 3R's com relação aos resíduos sólidos. 
comenta que esse é o caminho para aumentar nossa capacidade de antecipação hoje reduzida pelo aumento crescente das conseqüências que gera o processo em direção à insustentabilidade. Assim como a pressão dos sistemas de suporte por exploração, o impacto por contaminação do ar, da água e do solo também depende da organização das cidades.

Reduzir a pressão sobre os sistemas de suporte e o aumento da complexidade urbana são partes da mesma equação E/H proposta por Rueda (EMVS, 2006), onde E é a energia, expressão do consumo dos recursos que necessita o sistema para manter a complexidade H. O consumo dos recursos, a E, está relacionado entre outros fatores, aos modelos de ocupação do território, de urbanismo, de mobilidade, de tipologias arquitetônicas e de metabolismo urbano, e dos estilos de vida que são reflexos dos modelos anteriores (EMVS, 2006, p.18).

Sendo assim, a equação E/H é a expressão da eficiência urbana, que se converte na função guia da sustentabilidade, em vista que, sua evolução no tempo coloca em manifesto dois aspectos ligados a mesma: o consumo de recursos, com a simplificação dos ecossistemas de suporte e a organização urbana (EMVS, 2006, p.17).

Segundo Rueda (EMVS, 2006), o novo paradigma de cidade sustentável se baseia nos quatro eixos fundamentais: a compacidade, a complexidade, a eficiência e a estabilidade social.

A compacidade é aquilo que manifesta a qualidade de compacto, representa uma massa muito unida, um agregado dos elementos constituintes dos quais estão pouco ou nada separados um dos outros. No âmbito urbano, a compacidade expressa a idéia de proximidade dos componentes que formam a cidade, ou seja, a reunião em um espaço mais limitado dos usos e das funções urbanas. Desta forma, a compacidade facilita o contato, o intercâmbio e a comunicação que são a essência da cidade (EMVS, 2006).

A complexidade na cidade está ligada a diversidade de usos e funções urbanas, a qual permite um acesso à cidade sem restrições. O aumento da complexidade em um espaço limitado supõe um aumento de trajetórias de relação entre os diversos portadores de informação, que permite o aumento de sinergias de todo o tipo.

A eficiência consiste em conseguir a máxima eficiência do uso dos recursos e a mínima perturbação dos ecossistemas urbanos. 
A estabilidade social se refere ao aumento da diversidade e da integração, gerando a coesão social. Sobre a coesão social necessária para a vida urbana nos bairros Hernández (1997) comenta: "al hablar de Barrio nos referimos a territorio, a proximidad del espacio de actuación de los individuos, a la posibilidad de generar acciones con el morar, a que nuestra acción tiene que estar referida a un espacio concreto accesible y reconocible." (apud HIGUERAS, 2009, p. 27).

Cada um destes conceitos incorpora um importante número de variáveis que estão associadas à idéia principal. Cabe ressaltar que os quatro conceitos principais, se encontram interrelacionados e como conseqüência também estão suas variáveis.

Com base nestes quatro eixos Rueda (2006) aponta os aspectos que os novos projetos urbanos mais sustentáveis devem abranger:

"Construir entornos urbanos com uma densidade edificatória e compacidade urbana ótima, que garanta o equilíbrio entre o espaço construído e o espaço livre. Este aspecto relaciona um determinado nível de ocupação do solo e a distribuição do trecho edificado dentro do âmbito de estudo, tendo em conta, as alturas máximas e a proporção das larguras das ruas. Também está relacionado ao grau de compacidade para organizar as redes de mobilidade e as funções derivadas do modelo.

Máximo aproveitamento do potencial de mistura de usos que permita uma elevada diversidade urbana. Esta diversidade se relaciona com o tipo de pessoas jurídicas, a superfície que se destina e a distribuição destas dentro do âmbito.

Máxima eficiência no uso dos recursos locais com a finalidade de reduzir o mínimo os impactos sobre os ciclos de matéria, e os fluxos de energia que regulam a biosfera. Neste sentido, é necessário tratar os edifícios como parte da oferta local de energia através de sua capacidade nas coberturas, a gestão do ciclo local da água e a gestão dos resíduos.

A criação de entornos que propiciem a coesão social dos futuros habitantes. Isto implica em uma distribuição de usos do solo que permita uma mescla de rendas e por sua vez, uma conformação edificatória mais flexível a medida dos requerimentos espaciais dos diversos grupos sociais: planos de habitação social, estratégias de transporte e acessibilidade, serviços sociais e desenho da rede de equipamentos e espaços públicos." (RUEDA, 2006, p.6, tradução nossa). 
Dauncey e Peck (2002) estabeleceram os princípios de sustentabilidade associados à morfologia urbana que podem orientar o projeto de cidades sustentáveis, trazendo benefícios no seu desenvolvimento econômico social e, principalmente, ambiental. São eles: proteção ecológica (biodiversidade), adensamento urbano, revitalização urbana, implantação de centros de bairro e desenvolvimento da economia local, implementação de transporte sustentável e moradias economicamente viáveis, comunidades com sentido de vizinhança, tratamento de esgoto alternativo, drenagem natural, gestão integrada da água, energias alternativas e, finalmente, as políticas baseadas nos 3R's (reduzir, reusar $e$ reciclar).

Andrade (2005) traduziu estes princípios em técnicas e estratégias, estabelecendo um método para o desenho urbano objetivando proporcionar assentamentos humanos economicamente viáveis e em equilíbrio com a natureza. ${ }^{25}$

Rogers (2001) define como deve ser uma cidade sustentável, abordando além dos limites da sustentabilidade ambiental:

"Uma cidade justa, onde justiça, alimentação, abrigo, educação, saúde e esperança sejam distribuídos de forma justa e onde todas as pessoas participem da administração;

Uma cidade bonita, onde arte, arquitetura e paisagem incendeiem a imaginação $e$ toquem o espírito;

Uma cidade criativa, onde uma visão aberta e a experimentação mobilize todo o seu potencial de recursos humanos e permitam uma rápida resposta à mudança;

Uma cidade ecológica, que minimize seu impacto ecológico, onde a paisagem e a área construída estejam equilibradas e onde os edifícios e a infra-estrutura sejam seguros e eficientes em termos de recursos;

Uma cidade fácil, onde o âmbito público encoraje a comunidade à mobilidade, e onde a informação seja trocada tanto pessoalmente quanto eletronicamente;

Uma cidade compacta e policêntrica, que proteja a área rural, concentre e integre comunidades nos bairros e maximize a proximidade;

\footnotetext{
${ }^{25}$ Será descrito no capítulo 04 da Tese.
} 
Uma cidade diversificada, onde uma ampla gama de atividades diferentes gere vitalidade, inspiração e acalentem uma vida pública essencial."

Enfim, com enfoque na esfera ambiental abordada nesta pesquisa, conclui-se que a cidade sustentável deve atender a demanda de adensamento urbano, gerando espaços com qualidade ambiental, causando o menor impacto possível ao meio natural, ou que implica um controle da pegada ecológica ${ }^{26}$, um fechamento dos ciclos de matéria e energia e a adaptação dos assentamentos urbanos ao clima e ao meio ambiente no qual estão inseridos.

Aplicando o conceito sustentável ao edifício, Gonçalves, Duarte e Kronka Mulfarth (2007) comentam que em lugar do termo "edifício sustentável", é mais correto dizer "edifício mais sustentável", no sentido de ser mais sustentável do que o convencional, mais sustentável do que habitualmente se faz, já que sustentabilidade é um processo. A expressão "edifício sustentável" pode passar uma idéia de auto-suficiência, que não é estritamente verdadeira. Do ponto de vista da sustentabilidade ambiental, a meta é a eficiência no uso dos recursos naturais como água, energia e matéria-prima, e não, necessariamente, a autonomia, principalmente quando se tratam de áreas urbanizadas.

Com relação à conceituação de qualidade ambiental, os autores se dividem em dois grupos: aqueles que definem a qualidade ambiental atrelada a aspectos socioeconômicos, tal como segurança pública, transporte, educação, etc; e os autores que tratam a qualidade ambiental preocupando-se mais com as condições do ambiente natural modificado, ou seja, com o meio físico propriamente dito (BUCCHERI FILHO, 2006).

De acordo com esta ultima corrente, dentro da esfera sustentabilidade a qualidade ambiental está associada, principalmente: ao consumo eficiente de recursos naturais, água, energia e matéria; à ambientes urbanos menos poluídos; à conforto ambiental dos seres humanos em edifícios e espaços externos; ao transporte eficiente para pessoas e produtos em termos de consumo de energia, impacto ambiental e mobilidade; ao controle dos resíduos e; à presença de nichos ecológicos.

\footnotetext{
${ }^{26}$ Este conceito será definido no item 2.3.1 da Tese.
} 


\subsubsection{A cidade como ecossistema}

Rogers (2001) afirma que não haverá cidade sustentável, do ponto de vista ambiental, até que a ecologia urbana seja também fator presente no projeto urbano.

O princípio fundamental da ecologia é baseado na interação e na interdependência, ou seja, um sistema ecológico é um complexo de fatores e condicionantes interrelacionados. Sendo assim, para sua compreensão não é suficiente analisar os componentes separadamente, e sim, é necessário analisar também as suas relações (ODUM, 1963; HUGGETT, 1983, apud BETTINI, 1998, p189).

Pena-Vega (2003) diz que um ecossistema é um princípio dinâmico, um grande ciclo que engloba o conjunto da biosfera e no qual todas as unidades de interação são interconectadas em uma vasta e intrincada rede de relações. Andrade (2005) comenta que o ecossistema é uma totalidade complexa auto-organizada e auto-organizante.

Com base nessas características, muitos autores, principalmente ecólogos e geógrafos, consideram os sistemas urbanos um ecossistema, ou melhor, estes devem ter um planejamento ecossistêmico, o que implica em uma concepção global e não somente uma análise particularizada das partes que o integram.

A idéia de considerar a cidade como um sistema vivo não é nova, já que Geddes (1915) e Mumford (1960) no princípio e meados do século passado, respectivamente, já abordavam sobre o ecossistema da cidade. E em 1973 a UNESCO lançou um projeto de estudo, referindo o tema da cidade como um ecossistema artificial, tornando essa idéia reconhecida internacionalmente. ${ }^{27}$

Marcus e Detwyler (1972) dividem a cidade em dois componentes, o homem urbano e o meio ambiente urbano, e concluem que, de fato, o entendimento da dinâmica das interações entre estes dois elementos é facilitada se a cidade é reconhecida como um ecossistema, "o ecossistema urbano", com necessidades biológicas, essenciais à sobrevivência da população, e requisitos culturais, necessários ao funcionamento e crescimento da cidade. Para os autores, as necessidades biológicas são: ar; água; espaço; energia (alimento e calor); abrigo; e disposição de resíduos. $E$ as necessidades culturais são: organização política; sistema econômico (trabalho, capital, materiais e poder);

\footnotetext{
27 UNESCO. Programa Man and Biosphere. 1973.
} 
tecnologia; transporte e comunicação; educação e informação; atividades sociais e intelectuais; e segurança (NUCCI, 2008).

Andrade compartilha desta idéia apontando a necessidade de um uma nova ciência guiada por uma visão sistêmica da estrutura da cidade e interdependência essencial de todos os fenômenos físicos, biológicos, culturais e sociais que ali ocorrem (ANDRADE, 2005).

Pena-Veja (2003) considera os ecossistemas como sistemas abertos, o que significa que os sistemas vivos mantêm uma troca contínua de energia, matéria e informação com o seu meio. Os seres vivos, por exemplo, necessitam degradar energia e materiais para se manterem vivos, e a única maneira de obter esta energia é através do sol, que transformada pela fotossíntese é utilizada por outros seres vivos na cadeia alimentícia. Destaca-se que mesmo existindo uma fonte externa, os ecossistemas naturais funcionam em ciclo, desde que não existam fatores externos que os sobrecarreguem.

Observa-se que diferente dos ecossistemas naturais a cidade atual possui um sistema linear e não tem uma fonte de energia inesgotável como o sol, que garante indefinidamente o seu funcionamento.

O ecossistema urbano está relacionado aos grandes percursos horizontais dos recursos de água e energia, capazes de explorar outros ecossistemas e provocar desequilíbrios territoriais (HIGERAS, 2009).

Para a maior sustentabilidade das cidades os atuais processos lineares de produção, causadores de poluição, e de consumo devem ser substituídos por aqueles que objetivem um sistema circular de uso e reuso. Estes processos aumentam a eficiência global do núcleo urbano e reduzem o impacto no meio ambiente. Girardet (1999) argumenta que "a solução está na busca de um metabolismo circular nas cidades, onde o consumo é reduzido pela implementação de eficiência e onde a reutilização de recursos é maximizada." Para isso é preciso reciclar materiais, reduzir a geração de resíduos sólidos, conservar os recursos naturais não-renováveis e investir no consumo dos renováveis (ROGERS, 2001). 


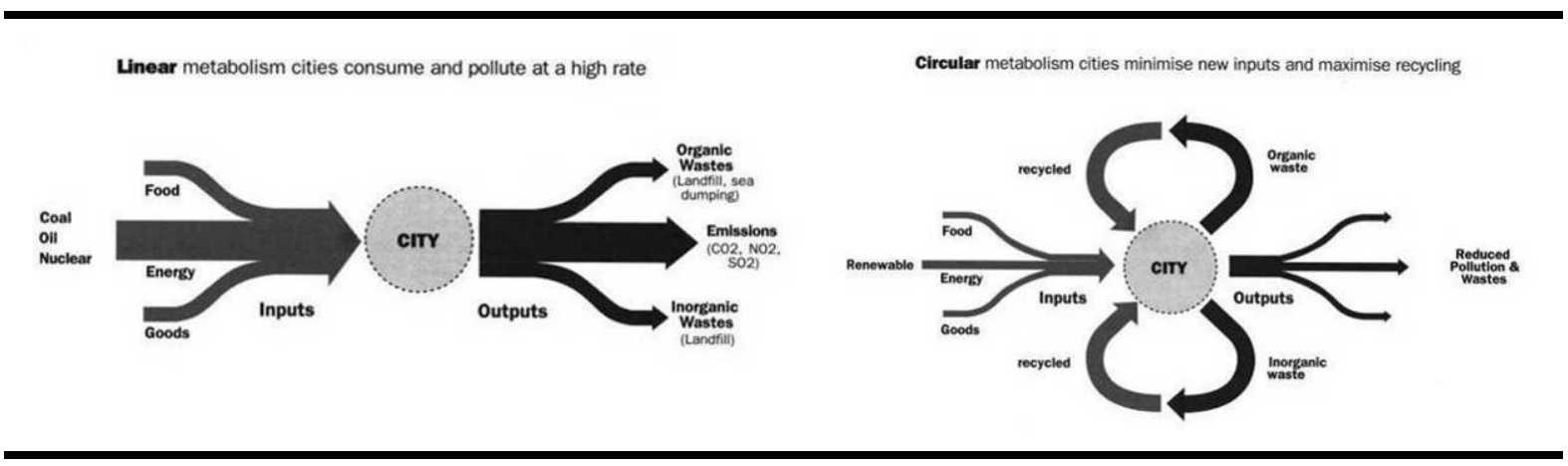

Figura 47: Metabolismo linear

Fonte: ROGERS, 2001
Figura 48: Metabolismo circular

Fonte: ROGERS, 2001

Dentro desta teoria Andrade resume:

"as cidades devem ser consideradas como ecossistemas complexos, com uma densa rede de processos metabólicos e intercâmbio de matéria, energia e informação: uma forma de organização não-linear que integra os componentes de um sistema sob diversos caminhos. São sistemas abertos e altamente dependentes de outros ecossistemas do seu entorno, com os quais interagem por meio de fluxos e trocas." (ANDRADE, 2005, p.58).

A idéia de analisar a cidade como um ecossistema, além do interesse científico, é útil para definir soluções de menor escala próprios do funcionamento interno da cidade.

Além disso, esta consideração é essencial para o desenvolvimento de indicadores ambientais para a cidade, já que são as próprias descrições do ecossistema urbano as primeiras a passar de uma visão antropocêntrica e compartimentada do monitoramento ambiental urbano, para uma concepção sistêmica. Ribeiro e Mello completam:

"O conceito de ecossistema, aplicado aos assentamentos humanos, permite visualizar com clareza os principais fluxos energéticos, de alimentos, de materiais, de informação e de pessoas que se destinam aos assentamentos humanos e que dele se originam". (RIBEIRO \& MELLO, 1996, p. 65).

Segundo Rueda (2008), a única via para reduzir as incertezas atuais passa, necessariamente, por reduzir as perturbações que os homens infligem aos ecossistemas, independente da escala. Para isto é importante vincular o regime metabólico a entropia gerada e ao consumo de recursos. 
Sendo assim, vale abordar sobre os principais ciclos ${ }^{28}$ urbanos, do ar, da água, da matéria e da energia, e quais os aspectos que devem ser considerados para que estes se fechem e contribuam para a sustentabilidade da cidade.

Com relação ao ciclo atmosférico os objetivos principais são: diminuir a sua contaminação e o efeito da ilha de calor. Para alcançar o primeiro objetivo é necessário: a adoção de transporte público e privado não contaminante; o uso de fontes de energias renováveis; a busca pela eficiência energética do modelo urbano e das edificações e; o controle de emissões industriais. Com relação ao efeito da ilha de calor, vale adotar as seguintes medidas: aumento e controle da distribuição de zonas verdes em áreas centrais; uso de cores claras em pavimentos e fachadas e; redução da emissão de calor pelos equipamentos (HIGUERAS, 2009).

Como já foi comentado na introdução da Tese, é importante destacar que a qualidade do ar está ligada diretamente à saúde da população. Dados apresentados na Folha de São Paulo em abril de 2010 mostram que a qualidade do ar na Região da Grande São Paulo só foi considerada boa em 17 dos 90 dias medidos pela Cetesb. Nos demais dias a qualidade do ar oscilou entre má, inadequada ou regular, colocando em risco a saúde da população, principalmente crianças e idosos, podendo causar tosse seca, ardência nos olhos, cansaço e falta de ar (FOLHA DE SÃO PAULO, 2010).

O ozônio é um gás tóxico que se forma principalmente a partir da queima de combustíveis, que composto com nitrogênio e oxigênio lançados pelos automóveis, ajudam a formar o gás após reagirem com a luz do sol (FOLHA DE SÃO PAULO, 2010).

Rueda (2008) apresenta um esquema comparando a contaminação do ar gerada pelo modelo disperso e por um modelo compacto, embasado nos princípios de sustentabilidade com relação à eficiência no consumo dos recursos. O modelo disperso se assemelha aos modelos de cidades atuais, enquanto que o modelo para um futuro mais sustentável adota as medidas citadas acima, reduzindo assim a contaminação atmosférica.

\footnotetext{
${ }^{28}$ Segundo Capra (2002) ciclo é a continuidade dos fluxos de matéria e energia do ambiente que alimentam os organismos vivos e conseqüentemente produzem resíduos continuadamente. Os resíduos de uma espécie são os alimentos de outra.
} 
Com relação ao recurso natural água, segundo Andrade (2005) a sua escassez é uma das graves conseqüências dos impactos da atividade humana sobre os recursos naturais. A devastação ambiental, a contaminação e o uso indiscriminado desse recurso natural provocaram a redução considerável dos mananciais.

Isto agrava ainda mais o acesso a água potável que já é preocupante, visto que, a maior parte da água doce, que representa $0,01 \%$ da água do planeta, está em forma de gelo ou em circulação (chuva, evaporação e deslocamento de vapor), e o restante está distribuído de maneira não uniforme.

Os sistemas tradicionais de drenagem interrompem o ciclo natural da água na sua circulação contínua: a chuva, a infiltração do solo até o lençol freático, a evaporação e o deslocamento de vapor.

Somado a isso, o processo de urbanização pode causar grandes alterações no ciclo hidrológico como: o aumento da precipitação; a diminuição da evapotranspiração, o aumento do escoamento superficial, a redução da infiltração da água, a alteração no nível do lençol freático, a maior erosão do solo, o aumento de enchentes e à poluição de águas superficiais e subterrâneas (VALASKI, 2008). Tudo isto em decorrência principalmente da impermeabilização do solo e da canalização dos leitos dos rios.

Deve-se aqui abordar o grave problema das inundações presentes em parte das cidades brasileiras, que vem se agravando não só decorrente do processo de urbanização, mas também pelas mudanças climáticas, que vêm ocasionando verdadeiras tragédias ambientais, e que de certa forma é conseqüência direta das ações humanas. Para se ter idéia dos prejuízos econômicos causados por uma enchente a EMPLASA fez uma estimativa de cálculo supondo que a produção diária de São Paulo fosse da ordem de U\$ 225 milhões ano, em virtude dos alagamentos ocorridos pela maior enchente do ano de 1991, a cidade deixou de produzir U\$ 68 milhões, ou seja, 30\% (MATTES, 2001). Isso somado aos problemas sociais, que normalmente são irreparáveis.

Brito (1925) comenta: "O problema das inundações é um problema estabelecido pelos caprichos da atividade do homem." (FERREIRA, 2007, p.32).

As calhas fluviais originais, submetidas a cheias sazonais, desempenhavam um papel vital no escoamento e acomodação das águas. Reduzir as dimensões das planícies de 
inundação, mediante sua substituição por canais artificiais, significou contribuir para essa problemática. (MATTES, 2001).

Atualmente as medidas de controle sustentáveis buscam administrar o escoamento na fonte através da recuperação da capacidade de infiltração ou da detenção do escoamento adicional gerado pelas superfícies urbanas. O princípio fundamental desse controle é o de que qualquer novo empreendimento deve manter as condições naturais pré-existentes de vazão (TUCCI, 2007 apud FERREIRA, 2007). ${ }^{29}$

Rueda (2008) apresenta um esquema comparando a gestão da água no modelo atual e no modelo mais sustentável.

Em resumo, os requisitos com relação ao ciclo da água para projetos urbanos mais sustentáveis são: limitar a impermeabilização das superfícies para reduzir o escoamento superficial e os riscos de inundações; proteger o lençol freático, coleta e reuso da água da chuva para diferentes usos, através das coberturas e da criação de bacias de captação integradas às áreas verdes; tratamento e reuso das águas residuais para uso apropriado; e reduzir o consumo de água potável (HIGUERAS, 2009 e GAUZIN-MÜLLER, 2002).
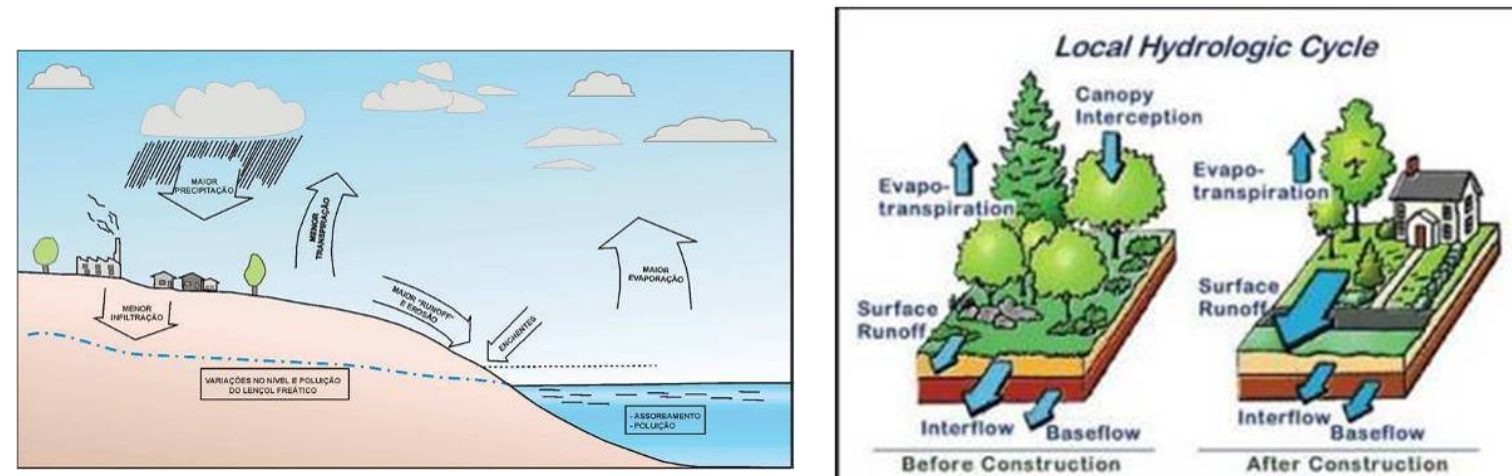

Figura 49: Ciclo da água

Fonte: VALASKI, 2008

Figura 50: I mpactos no ciclo da água após a construção em áreas urbanas

Fonte: Maryland Department of Enviroment Stomwater Manual, apud ANDRADE, 2005.

\footnotetext{
${ }^{29}$ Ferreira (2007) apresenta algumas medidas de controle de escoamento, aumentando a capacidade de infiltração e/ou armazenamento para reter parte das águas pluviais.
} 


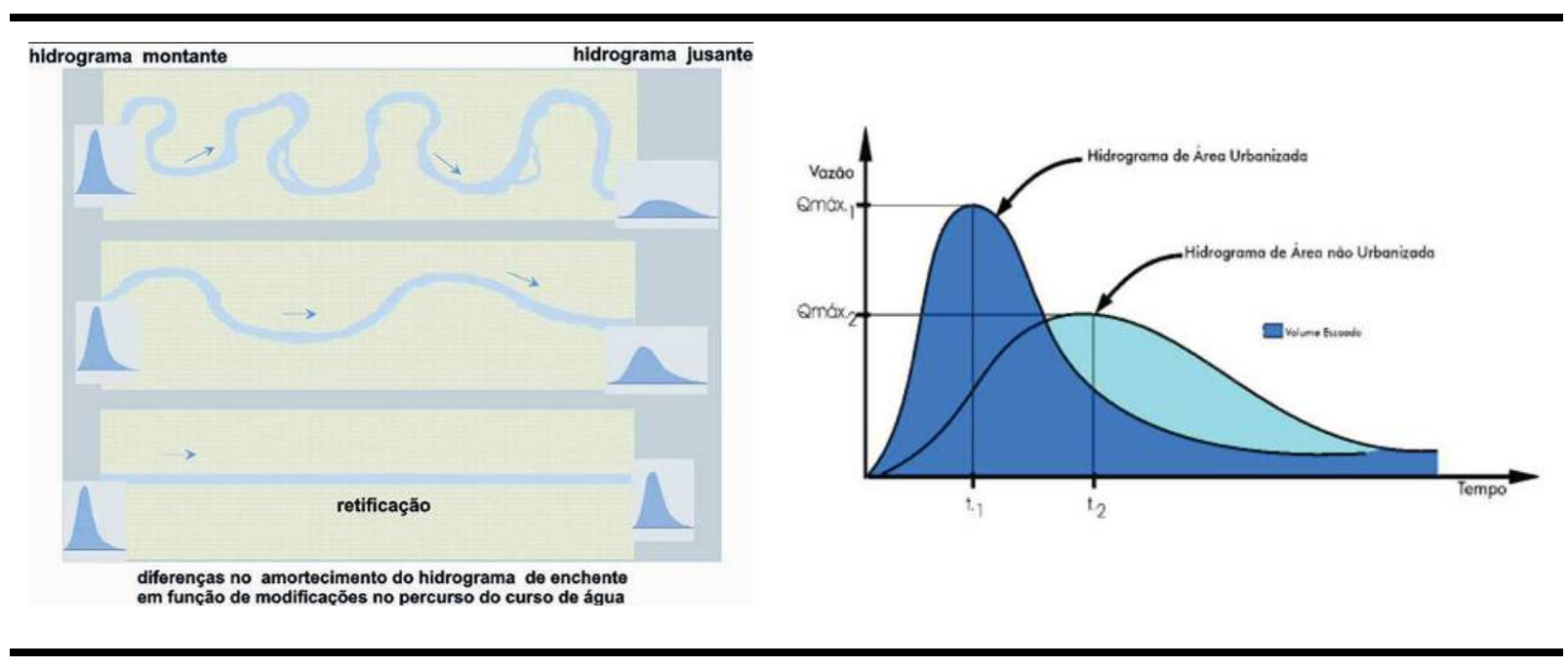

Figura 51: Diferença no amortecimento do Figura 52: Gráfico de vazão $x$ tempo, hidrograma de enchente em função da ilustrando o impacto da retificação dos rios modificação no percurso das águas

Fonte: NETTO, 2004 apud FERREIRA, 2007 no hidrograma de cheia.

Fonte: NETTO, 2004 apud FERREIRA, 2007

No ciclo da matéria orgânica e de resíduos o objetivo é adotar a política 3R's, reduzir, reusar e reciclar. "A necessidade de se reciclar o lixo urbano é crescente, de modo que as tecnologias utilizadas, ainda que onerosas, atenuam um dos mais graves problemas que caracterizam a urbosfera moderna." (LAGO, 1986 apud FREITAS, 2005, p.135).

Destaca-se que o lixo orgânico pode ser utilizado para geração de energia, através do gás metano, que pode ser vendido e utilizado em fábricas. A queima em incineradores, em lugar de produzir fumaça e poluição do ar, pode gerar vapor d'água e energia elétrica (FREITAS, 2005).

Com relação ao ciclo energético os objetivos principais são: a redução da necessidade de demanda energética, ou seja, tanto o modelo urbano quanto as edificações devem ser menos dependentes da energia para cumprir suas necessidades; e o uso de energias renováveis e não contaminantes, como a energia solar, eólica, hidráulica, biomassa, geotérmica e outras que se encontra em fase de pesquisa, como o hidrogênio.

A Figura 53 apresenta um esquema comparando um modelo energético atual e outro modelo mais sustentável do ponto de vista do consumo de energia e da contaminação gerada pelas fontes energéticas (RUEDA, 2008). 


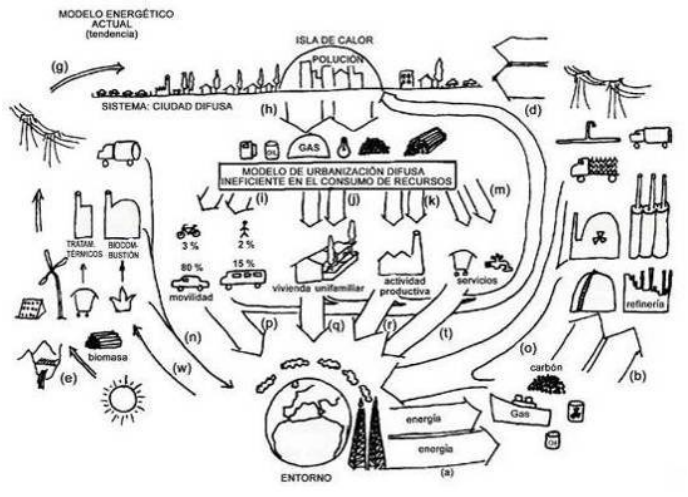

Figura 53: Ciclo energético modelo atual Fonte: RUEDA, 1999

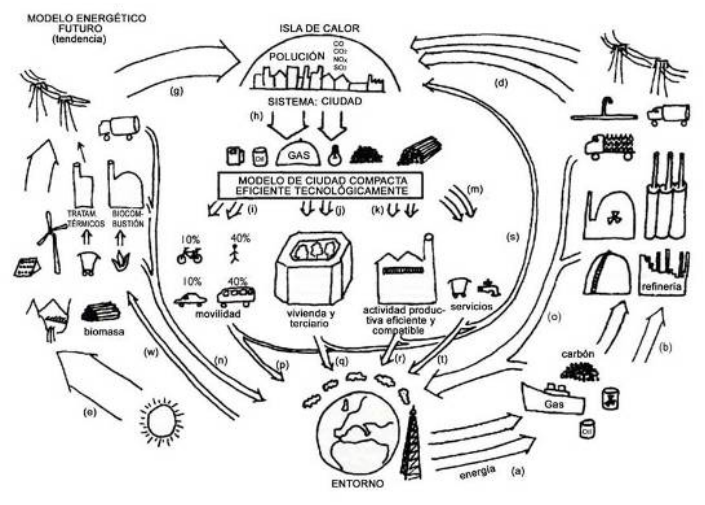

Figura 54: Ciclo energético modelo proposto para futuro

Fonte: RUEDA, 1999

\subsection{Adensamento urbano e qualidade ambiental}

A densidade é um dos indicadores e parâmetros de desenho urbano a ser utilizado no processo de projeto, planejamento e gestão dos assentamentos urbanos. Acioly define:

"Ela representa o número total da população de uma área urbana específica, expressa em habitantes por unidade de terra ou solo urbano, ou o total de habitações de uma determinada área urbana, expressa em habitações por unidade de terra. Geralmente utiliza-se hectare como unidade de referência quando se trabalha com áreas urbanas." (ACIOLY, 1998, p.16).

Habitantes por hectare ou habitações por hectare são valores utilizados para indicar qualidades específicas e o potencial de desenvolvimento de um local em relação à densidade, que pode ser líquida ou bruta. A densidade líquida expressa o número total de pessoas residindo em uma zona urbana dividida pela área estritamente residencial, enquanto que e a densidade bruta divide por toda a área do assentamento, incluindo ruas, espaços públicos e outros usos (ACIOLY, 1998).

"As densidades urbanas afetam diretamente os processos de desenvolvimento urbano, tanto ao nível da cidade, quanto do bairro, exercendo um impacto significativo na saúde, meio ambiente, na produtividade das cidades e no processo de desenvolvimento humano como um todo". (ACIOLY, 1998, p.10). 


\subsubsection{Aspectos favoráveis e desfavoráveis do adensamento urbano}

A densidade é um fator chave da sustentabilidade, que ligada ao modelo de ocupação e organização da cidade tem conseqüências diretas sobre: o uso eficiente do transporte público e da infra-estrutura em geral; a congestão e a complexidade urbana; a ocupação do solo; o consumo de recursos naturais, água e energia, a geração de resíduos sólidos; a contaminação da água, do ar e do solo; a porcentagem de área permeável; ao clima urbano, a permeabilidade ao vento; o ruído urbano; o acesso ao sol e a disponibilidade de luz natural.

McHarg (2000) revelou que doenças físicas (do coração, tuberculose, diabetes, sífilis, cirroses, disenterias) e doenças sociais (homicídio, suicídio, uso de drogas, alcoolismo, roubo, violação, assalto, delinqüência juvenil, mortalidade infantil) apresentam em grande concentração nas áreas mais adensadas da cidade. Sobre esse problema Acioly (1998) comenta que altas densidades podem resultar em situações de risco à saúde pública, embora seja difícil separar o que é causado pela densidade e o que é causado pela pobreza associado a esta.

As pessoas que moram em ambientes densamente ocupados estão expostas a transmissão de doenças por estarem sujeitas, entre outros aspectos, a condições de habitação subnormal em áreas ausentes de um mínimo de infra-estrutura básica. A falta de ventilação, de insolação e luz natural, somada a presença de resíduos sólidos nos espaços de convivência, juntamente com a má qualidade da habitação, e à falta de conhecimentos básicos de higiene, são alguns dos fatores que aumentam a susceptibilidade às doenças, e que podem ser agravos na medida em que se aumenta a densidade (ACIOLY, 1998).

Somado a isso, assentamentos humanos de alta densidade podem sobrecarregar e mesmo causar uma saturação do solo urbano, aumentando a pressão de demanda sobre este, produzindo um meio ambiente inadequado ao desenvolvimento urbano. A alta densidade urbana significa um risco maior de degradação ambiental, principalmente pelo aumento da poluição e geração de resíduos sólidos.

Apesar disso, Freitas (2005) em um estudo avaliando a qualidade ambiental em diferentes bairros em Recife, constatou a não associação entre adensamento e degradação ambiental, já este problema foi encontrado tanto em localidades com altas, quanto com baixas densidades. 
O adensamento construtivo também afeta o clima urbano ${ }^{30}$, podendo esta interferência ser positiva ou negativa dependendo, entre outros fatores, do clima da região. Altas densidades, por exemplo, podem gerar sombreamento das edificações no meio urbano, que em climas quentes pode ser positivo. Por outro lado, a elevação da temperatura do ar afetando as trocas por condução e convecção entre os edifícios e o meio externo é um problema em locais de clima quente.

Em geral, altas densidades contribuem para o aumento da temperatura do ar e a diminuição da umidade relativa do ar decorrente, principalmente, da substituição da cobertura vegetal pelos volumes edificados e pelas vias de circulação, interferindo no albedo (refletância) das superfícies urbanas e no processo de evaporação. ${ }^{31}$

As elevadas temperaturas das superfícies pavimentadas provocam um aumento da temperatura do ar e de outras superfícies do entorno, que se agravam quando a forma urbana não favorece a dissipação do calor através das trocas térmicas por ondas longas com o fundo de céu e por meio da ventilação natural.

O adensamento construtivo interfere na permeabilidade ao vento, modificando sua velocidade e direção, o que pode, entre outras conseqüências, dificultar a dispersão de poluentes.

Essas alterações no microclima urbano afetam o conforto térmico nos espaços externos, o consumo de energia elétrica das edificações e podem causar ou intensificar o fenômeno ilha de calor. ${ }^{32}$

\footnotetext{
${ }^{30}$ Os climas urbanos são modificações locais das condições atmosféricas. A sua formação depende tanto do clima regional, no qual a localidade está situada, quanto dos aspectos naturais e das características da urbanização. (FREITAS, 2005, p.83).

31 Pomerantz et al (2000 apud BRANDÃO, 2009) realizaram um estudo substituindo os materiais urbanos, principalmente pisos e pavimentos, visando minimizar o aquecimento dos recintos urbanos e verificaram que o aumento do albedo dos materiais de revestimento urbano em 0,1 ocasionam reduções na temperatura superficial de até $4^{\circ} \mathrm{C}$. Em outro estudo (TAHA, CHANG \&AKIBARI, 2000), foi proposta a alteração da refletância das superfícies e o aumento da superfície vegetada em três cidades americanas, constatando reduções em até dois graus na temperatura do ar, além dos benefícios na qualidade do ar e na redução da concentração de ozônio.

${ }^{32}$ O fenômeno denominado ilha de calor está explicado na introdução da Tese.
} 
A congestão e o ruído urbano são também problemas em altas densidades, causada pelo excesso de pessoas e veículos e pela ausência de espaço suficiente. Além da saturação do espaço, altas densidades implicam em sobrecarga nas infra-estruturas, sistemas de drenagem, de abastecimento d'água e esgoto sanitário. Isso pode causar, por exemplo, um problema comum nas grandes cidades que são as enchentes, geradas pelas águas pluviais que não conseguem ser totalmente evacuadas através dos sistemas de drenagem saturados, assim com não são absorvidas naturalmente, devido ao aumento da impermeabilização do solo urbano (ACIOLY, 1998 p.31).

Em ambientes densos há poucos espaços para áreas livres e zonas verdes, em contraponto com baixas densidades que possibilitam a construção de parques, jardins e demais ambientes bucólicos. Apesar disso, especialistas em habitação têm assumido que quanto maior a densidade, melhor será a utilização e otimização do solo urbano, enquanto que os assentamentos de baixa densidade consomem enormes glebas de terra para um número relativamente pequeno de habitantes.

Para ilustrar o potencial de otimização do solo das altas densidades, foi realizado um estudo simplificado relacionando densidade populacional e ocupação de solo urbano. 0 estudo mostra que caso a densidade da cidade de São Paulo fosse 90hab/ha, seria necessário a área de uma circunferência com um raio de $26 \mathrm{~km}$ para acomodar toda sua população. Esta opção se assemelha à realidade atual, como mostra a Figura 55. Aumentando a densidade populacional para 250hab/ha, o raio da circunferência da área necessária para abrigar a mesma população seria $15 \mathrm{~km}$ e, se a densidade fosse $1000 \mathrm{hab} / \mathrm{ha}$, o raio da circunferência seria $8 \mathrm{~km}$.

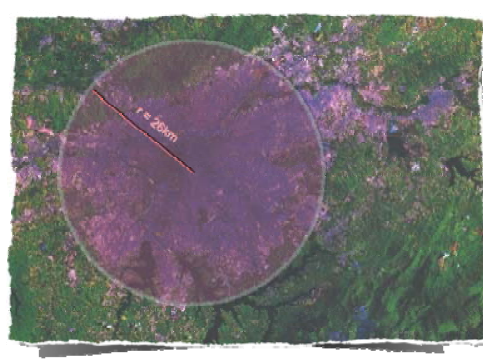

Densidade 90 hab/ha

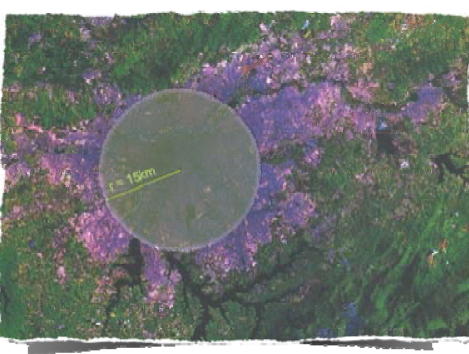

Densidacle $=250 \mathrm{hmb} / \mathrm{ha}$

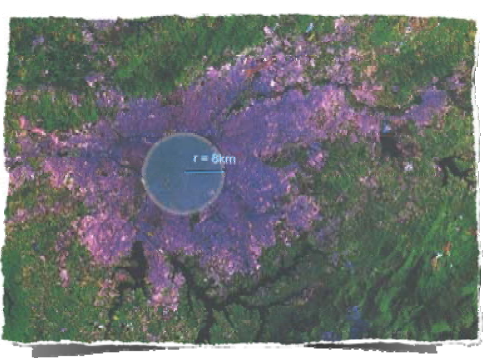

Densidade $=1000 \mathrm{hab} / \mathrm{ha}$

Figura 55: Estudo densidade populacional $x$ ocupação do solo urbano 
As cidades que atualmente incentivam, em seus planos de crescimento, políticas de aumento da densidade urbana justificam-se pela eficiência na provisão e manutenção das infra-estruturas e serviços urbanos e pela dinâmica econômica criada pelas relações de proximidade entre empresas. A alta densidade tende a facilitar a oferta e distribuição eficiente de infra-estrutura, enquanto que baixas densidades significam longas redes de infra-estrutura, em potencial estado de ociosidade para poucos consumidores e, portanto, altos custos de investimentos per capita tanto para instalação quanto na operação (ACIOLY, 1998, p.33). ${ }^{33}$

Em conseqüência dos altos custos e da precariedade dos sistemas de transporte público, em baixas densidades há um incentivo maior ao uso do veículo privado, provocando uma maior dispersão das atividades e um acesso discriminado para a população de maior poder aquisitivo. Isso também gera a necessidade do uso de automóveis para a realização das atividades diárias, podendo causar um tráfego nos centros urbanos, principalmente em horários de pico.

O conceito de intensificação de atividades e geração de receitas é acompanhado das considerações para com a densidade. De acordo com isso, as medidas de planejamento com relação à distribuição das funções urbanas na malha edificada da cidade, têm um papel estratégico na garantia da dinâmica dos fluxos no espaço público. Segundo Jacobs (2000, p.221):

"O distrito precisa ter uma concentração suficientemente alta de pessoas, sejam quais forem seus propósitos. Isso inclui pessoas cujo propósito é morar lá. Durante séculos, provavelmente todos aqueles que pensaram a respeito das cidades perceberam que parece haver relação entre a concentração de pessoas e as especialidades que elas conseguem manter."

\footnotetext{
${ }^{33}$ Os custos de infra-estrutura normalmente são altos e divididos pelo número de habitantes. Um estudo relacionando densidade demográfica e custo com a instalação e manutenção da infra-estrutura (pavimentação, esgoto, água, gás, drenagem e eletricidade) verificou-se que entre 200 e $450 h a b / h a$. Abaixo desses valores a instalação e manutenção da infra-estrutura tornam-se muito onerosa, e acima de 450hab/ha pode-se dizer que não se gasta muito menos com a infra-estrutura mesmo aumentando a densidade (MASCARÓ, 1979 apud NUCCI, 2008).
} 
O aumento da complexidade através das possibilidades da diversidade de usos no espaço da cidade e facilidade de acessos, constitui também parte do argumento pelas vantagens econômicas e sociais da alta densidade urbana. O escritório inglês de projeto e consultoria DEGW (1998), caracteriza uso misto de um edifício ou uma área da cidade, mediante a taxa mínima de $50 \%$ de um determinado uso, liberando os outros $50 \%$ para outros usos. No entanto, os mesmos autores dessa definição reconhecem que a busca da diversidade urbana não exige rigorosamente uma divisão de usos nessas proporções, mas a mistura é indispensável (GONÇALVES, 2004).

Gonçalves (2004) destaca que no caso de um bairro predominantemente residencial, ou um distrito primordialmente financeiro, por exemplo, esses usos podem tomar até $80 \%$ da área, deixando o restante para a inserção de usos complementares, como comércio ou lazer. Essas combinações já garantiriam a vitalidade urbana e o dobro do aproveitamento da infra-estrutura urbana e do próprio edifício, passando das tradicionais oito horas, para dezesseis horas.

Sobre esta questão, Jacobs (2000, p.221) comenta:

"Todos sabem que uma quantidade imensa de pessoas concentra-se nos centros das cidades e que, se não houvesse tal concentração, não haveria centro urbano que se prezasse - certamente não com a diversidade típica de centros. Porém, essa relação entre concentração populacional e diversidade de usos quase não é levada em conta quando se refere aos bairros cujo uso principal é o residencial. (...) Sem o auxílio da concentração de pessoas que aí moram, só podem existir pouca infra-estrutura ou pouca diversidade de usos nos lugares habitados e onde elas são mais necessárias."

Outro aspecto favorável das altas densidades urbanas está ligada ao consumo de recursos naturais, água e energia. Percebe-se que altas densidades são menores consumos energéticos, ou melhor, são mais eficientes já que altas densidades tendem a ter modelos de ocupação mais compactos, que como comentado, reduzem a necessidade de deslocamentos (ver Tabela 4).

A Tabela 5 apresenta uma síntese dos principais aspectos favoráveis e desfavoráveis da baixa e alta densidade, adaptado do quadro apresentado por Acioly (1998). 
Tabela 4 - Densidade demográfica e deslocamentos cotidianos em 12 cidades

Fonte: PINI, 2004 apud FREITAS, 2005, p. 139

\begin{tabular}{|c|c|c|c|c|}
\hline \multicolumn{5}{|c|}{ Densidade demográfica (hab/ ha) e deslocamentos cotidianos (\% ) } \\
\hline cidade & densidade & $\begin{array}{l}\text { Automóveis } \\
\text { particulares }\end{array}$ & $\begin{array}{l}\text { Transporte } \\
\text { público }\end{array}$ & $\begin{array}{l}\text { A pé ou de } \\
\text { bicicleta }\end{array}$ \\
\hline Phoenix & 13 & 93 & 3 & 3 \\
\hline Perth & 15 & 84 & 12 & 4 \\
\hline Washington & 21 & 81 & 14 & 5 \\
\hline Sydney & 25 & 65 & 30 & 5 \\
\hline Toronto & 59 & 63 & 31 & 6 \\
\hline Hamburgo & 66 & 44 & 41 & 15 \\
\hline Amsterdam & 74 & 58 & 14 & 28 \\
\hline Estocolmo & 85 & 34 & 46 & 20 \\
\hline Munique & 91 & 38 & 42 & 20 \\
\hline Viena & 111 & 40 & 45 & 15 \\
\hline Tokio & 171 & 16 & 59 & 25 \\
\hline Hong Kong & 403 & 3 & 62 & 35 \\
\hline
\end{tabular}

Tabela 5 - Quadro síntese das vantagens e problemas do adensamento urbano

Fonte: ACIOLY, 1998 adaptado

\begin{tabular}{|c|c|c|}
\hline Densidade & Aspectos Favoráveis & Aspectos Desfavoráveis \\
\hline \multirow{8}{*}{$\begin{array}{l}\text { Alta } \\
\text { densidade }\end{array}$} & eficiência na oferta de infra-estrutura & sobrecarga nas infra-estruturas \\
\hline & uso eficiente do solo & poluição \\
\hline & vitalidade urbana & $\begin{array}{l}\text { maiores riscos de degradação } \\
\text { ambiental }\end{array}$ \\
\hline & geração de receitas & $\begin{array}{l}\text { congestionamentos e saturação do } \\
\text { espaço. }\end{array}$ \\
\hline & maior controle social & menos áreas livres \\
\hline & $\begin{array}{l}\text { facilidade de acessos aos } \\
\text { consumidores }\end{array}$ & ruído urbano \\
\hline & maior acessibilidade ao emprego & alteração no clima urbano \\
\hline & economias de escala & criminalidade \\
\hline \multirow{5}{*}{$\begin{array}{l}\text { Baixa } \\
\text { densidade }\end{array}$} & menos poluição & $\begin{array}{l}\text { precária acessibilidade aos } \\
\text { serviços }\end{array}$ \\
\hline & mais silêncio e tranquilidade & $\begin{array}{l}\text { pouca interação e controle } \\
\text { social }\end{array}$ \\
\hline & $\begin{array}{l}\text { possibilidades de saneamento de } \\
\text { custo }\end{array}$ & $\begin{array}{ll}\text { baixo altos custos para oferta e } \\
\text { manutenção dos serviços; }\end{array}$ \\
\hline & & $\begin{array}{l}\text { altos custos e precariedade } \\
\text { do transporte pública }\end{array}$ \\
\hline & & $\begin{array}{l}\text { excesso de consumo de terra } \\
\text { urbana e infra-estrutura } \\
\text { aumento do consumo de } \\
\text { energia }\end{array}$ \\
\hline
\end{tabular}




\subsubsection{Estudos sobre a densidade urbana e os aspectos ambientais}

Por apresentar diversas vantagens, mas também gerar ou acentuar alguns problemas, a densidade urbana é ainda uma questão muito polêmica. Urbanistas e demais profissionais da área se dividem em grupos a favor e contra o adensamento das cidades, e com base nas suas conseqüências alguns autores tentam limitar este crescimento.

Macedo (1987), por exemplo, relaciona o adensamento construído e demográfico ao congestionamento das ruas, a escassez real de espaços livres para lazer e a obsolescência da infra-estrutura, entre outros fatores, e que "(...) deve ser recomposta a altos custos, destruição de tecidos e modos de vida urbanos significativos e a destruição ou emparedamento de situações de relevo importantes na caracterização da paisagem da cidade."

Lynch (1980) relaciona densidade à produção de ruído urbano, à disponibilidade de áreas de lazer e ao espaço necessário para estacionamentos. Segundo o autor, a medida que se aumentam as construções, muitas áreas livres cedem espaço para vias de trânsito intenso e para estacionamentos de veículos. Com este enfoque, Lynch realiza estudos para padrões americanos, considerando a densidade de 30 famílias por hectare ou 105 hab/ha já problemática, atingindo a completa congestão em 450 famílias por hectare (apud FREITAS, 2005).

MASCARÓ (1979) defende uma densidade mais elevada, com base nos custos com a instalação e manutenção da infra-estrutura (pavimentação, esgoto, água, gás, drenagem e eletricidade). Em um estudo relacionando densidade demográfica e custo com de urbanização, o autor verificou que essa relação se encontra ideal entre 200 e 450hab/ha. Abaixo desses valores a instalação e manutenção da infra-estrutura tornam-se muito onerosa, e acima de 450hab/ha pode-se dizer que não se gasta muito menos com a infraestrutura mesmo aumentando a densidade (apud NUCCI, 2008)

Para a Associação Norte-Americana de Saúde Pública o padrão recomendável se encontra na faixa recomendada por Mascaró (1979), no valor de 312,5hab/ha (NUCCI, 2008).

Segundo Campos Filho (1972) "(...) não é nenhum absurdo a proposta de desenvolverem-se 'cenários' de diferentes formas urbanas, alternativas e estilos de vida relacionados com densidades em torno de 400 a 500hab/ha". Em entrevista com o urbanista, Campos Filho defende a possibilidade de 2400 hab/ha em centros consolidados, como o caso do bairro da Luz em São Paulo, com base na capacidade 
instalada do sistema de transporte público existente. Campos Filho ainda acredita que este número poderá aumentar no futuro. ${ }^{34}$

Rogers e Rueda compartilham dessa idéia de adensar áreas urbanas já consolidadas, acreditando que a solução para a sustentabilidade das cidades está em modelos de ocupação densos e compactos. Apesar disso, para Rueda (2006) a densidade mínima é 45 habitações/ha e a recomendável, para a Espanha, varia em torno de 60 habitações/ha. Esse valor não é tão alto se comparado com a proposta de adensamento de Campos Filho, porém está adequada a realidade espanhola, atendendo a demanda e aos princípios da sustentabilidade relacionados à compacidade. Também para Espanha, com os mesmos objetivos, a Prefeitura de Madrid recomenda um valor de densidade aproximado ao de Rueda para Sevilha, de 60 a 70 habitações/ha. ${ }^{35}$

Com base no mesmo enfoque, ou seja, atender a demanda existente, visando uma maior sustentabilidade das cidades, esta pesquisa parte da idéias de que a densidade ótima é a maior que se consegue, sem perder a qualidade ambiental e sem causar um transtorno na infra-estrutura existente.

"Para Lynch não existe a densidade ideal, e sim, para cada parâmetro de análise existe uma densidade máxima. E afirma: "o planejador não está comprometido com nenhum número exato, mas sim o suficientemente familiarizado com as implicações das densidades para poder aconselhar uma decisão inteligente para uma situação dada, ou para evitar um tipo de edificações ou de atividades inapropriadas para uma densidade prefixada por outras considerações. "( $(\mathrm{YNCH}, 1980$ p.38).

Para Mascaró:

"a densidade urbana é um tema que permanece altamente polêmico. Talvez pela imagem de alto padrão de vida, que alguns casos transmitem ao observador, formouse a idéia de que alta qualidade de vida só consegue com densidade populacional baixa. Dispor de sol, ventilação privacidade etc, só seria possível em baixas densidades. Porém, os melhores estudos mostram que as densidades baixas não são

\footnotetext{
${ }^{34}$ Informação verbal extraída das entrevistas com o arquiteto e urbanista Candido Malta Campo Filho, para esta pesquisa, em março de 2008, e para a realização do exercício de projeto desenvolvido pelo LABAUT FAU USP para o Urban Age, em junho de 2008.

${ }^{35}$ Área de Gobierno de Urbanismo e Vivienda Del Ayuntamiento de Madrid. Buenas Prácticas en arquitectura y urbanismo para Madrid: criterios bioclimáticos y de eficiencia energética. Madrid, 2009.
} 
boas nem más por si só. $O$ inconveniente é haver densidades inadequadas aos tipos de edificações implantadas." (MASCARÓ, 2003, apud FREITAS, 2005, p.123)

É importante ressaltar que a densidade por si só não é um indicador de qualidade ambiental urbana, já que com uma mesma densidade é possível compor diferentes formas urbanas, com diferentes configurações de espaços abertos, condições microclimáticas e distribuições de usos, que interferem diversamente na qualidade de vida.

Rogers realizou um estudo com três composições diferentes (edifícios torres, edifícios baixos e horizontais e edifícios de altura mediana), ilustrando como diferentes formas arquitetônicas podem construir com a mesma densidade, no caso 75 habitações por hectare, apresentando diferentes resultados em relação aos espaços públicos e privados. $^{36}$

A primeira composição arquitetônica é formada por edifícios altos, implantados em espaços abertos, cobrindo pequena parcela da quadra. Não existe jardim privado e nenhuma relação direta do edifício com as ruas ao redor. A segunda apresenta um layout típico de Londres, com habitações baixas e horizontais, de 2 a 3 pavimentos, com presença de jardins frontais privados. Nesse caso os espaços públicos e livres são definidos pela continuação da rua, que tem seu potencial reduzido devido à grande parcela de solo construído. E a terceira composição é constituída de edifícios de diferentes alturas e configurações, implantados ao redor de um espaço aberto, que contém serviços e facilidades para a comunidade, jardins privados e semi-públicos. Atividades comerciais e de serviços públicos são distribuídas no pavimento térreo, visando à vitalidade urbana (DETR, 1999).

De maneira similar, Vargas (2003) desenvolve um estudo apresentando como pode ser distribuída uma densidade máxima hipotética, de 260 economias por hectare, ou seja, pessoas que habitam e que trabalham por unidade de solo urbano. Em um quarteirão vazio em uma cidade abstrata, sem nenhuma ocupação adjacente ou contexto préexistente é proposto: 16 edifícios de 4 pavimentos com quatro habitações/escritórios por

36 DETR - Department of the Environment, Transport and the Regions of London. Towards an Urban Renaissance. Final Report of the Urban Task Force, chaired by Lord Rogers of Riverside. London: E. and FN SPON, 1999. 
pavimento, baseado no padrão europeu de edifícios relativamente baixos colados uns aos outros, formando um quarteirão compacto, homogêneo e com seu miolo totalmente livre, bem iluminado e ventilado; ou 8 edifícios de 8 pavimentos com quatro habitações por pavimento, conformando um arranjo de viés modernista; ou ainda, 4 edifícios de 16 pavimentos com quatro habitações /escritórios por pavimento, com grandes afastamentos e baixa ocupação do solo.

Outros estudos realizados na Universidade de Cambridge na Inglaterra, mostraram como a densidade da Ilha de Manhattan de 32.022 pessoas $/ \mathrm{km}^{2}$, no ano de 2000, caberia redistribuída em blocos de no máximo sete pavimentos, ocupando os perímetros das quadras, como em Barcelona (GONÇALVES, 2004.).

Vale destacar que Barcelona é a mais compacta da Europa, com uma densidade de 33.666 pessoas $/ \mathrm{Km}^{2}, 400$ unidades habitacionais por hectare, distribuída em edifícios variando entre 4 e 6 pavimentos, estruturados ao redor do perímetro de quadras, configurando pátios internos de uso semi-público. ${ }^{37}$

Com isso, vale destacar que, a opção pelo edifício alto não está obrigatoriamente relacionada a altas densidades urbanas sim pelos demais benefícios que pode trazer a cidade (GONÇALVES, 2004).

\footnotetext{
37 Informação extraída do site http://www.demographia.com, da empresa norte-americana Wendell Cox Consultancy, disponível em: março de 2000.
} 


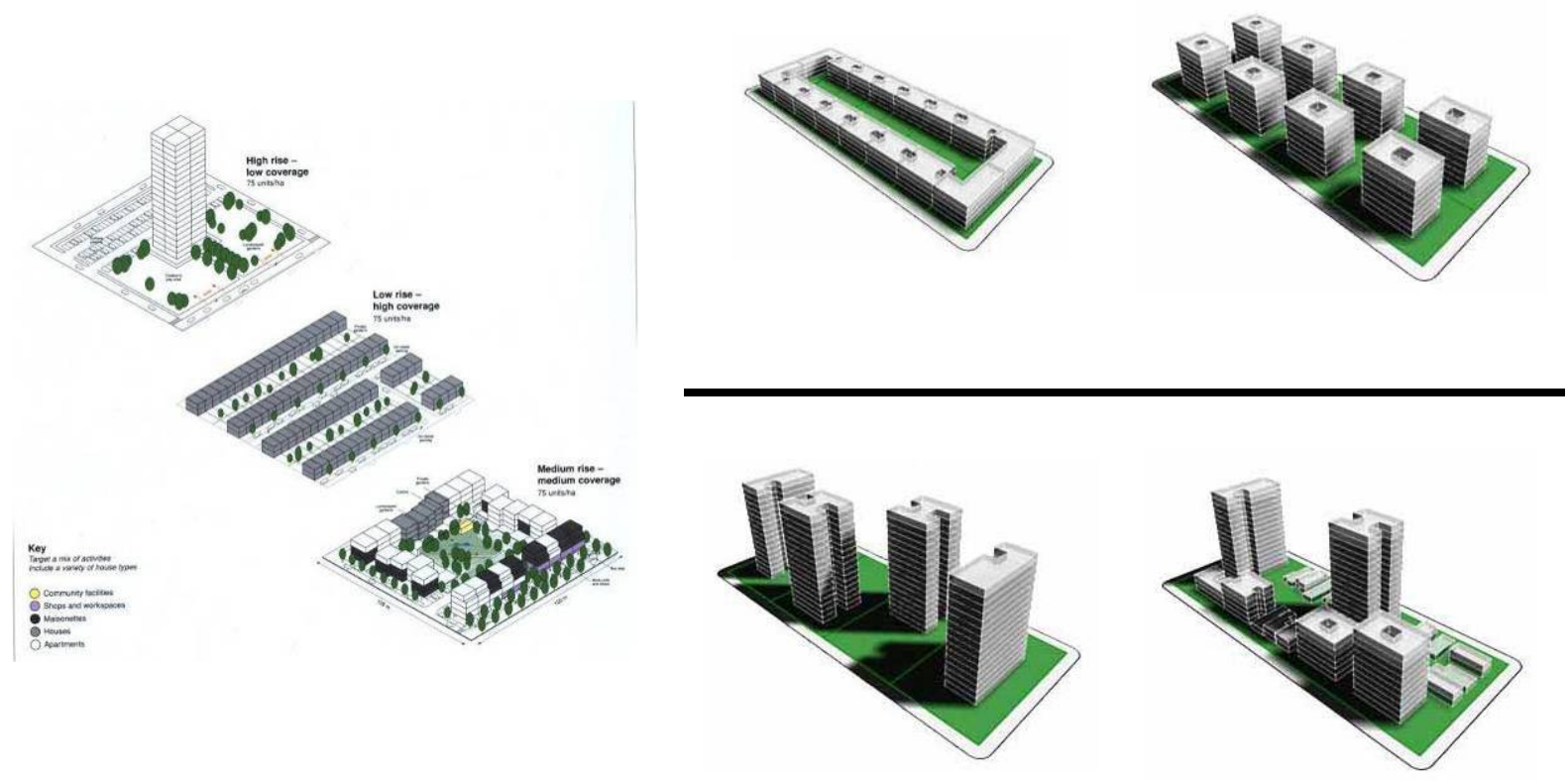

Figura 56: Estudo de Rogers sobre a relação entre densidade e forma urbana

Figura 57: Estudo de Vargas sobre a relação entre densidade e forma urbana

Fonte: Vargas, 2003

Fonte: DETR, 1999

Acioly (1998) elenca alguns fatores que influenciam a densidade urbana: "layout do assentamento e equilíbrio entre o público e o privado; tipologia habitacional; dimensão e formas das edificações; legislação de planejamento; dimensão do lote; Standards das ruas, infra-estrutura e transporte; tamanho da família e; disponibilidade de solo urbano." (ACIOLY, 1998, p.23).

Freitas (2005) completa, destacando alguns parâmetros urbanísticos que agem diretamente sobre a densidade, tais como: coeficiente de utilização, taxa de ocupação, afastamento entre as edificações e percentual de solo natural em cada lote. Estes determinam os limites de adensamento de uma determinada área, podendo ou não contribuir para aspectos relacionados à qualidade ambiental.

Apesar desta pesquisa não abordar os instrumentos de planejamento urbano que viabilizam o adensamento garantindo a qualidade ambiental, sabe-se que essas discussões vão muito além do projeto. Cabe destacar uma colocação de Acioly:

"A densidade urbana está em discussão e forçando os governos locais a reverem suas regulamentações e zoneamento, a fim de permitir que ocorram densificação de uso e 
de população, incorporação de novas áreas intra urbanas, urbanização, regulação $e$ densificação de assentamentos informais, renovação urbana e qualificação do espaço existente e fomento à diversificação das atividades e uso da ocupação urbana. Isso provoca a reorganização do espaço construído da cidade e sua readequação às novas necessidades que tendem a fomentar um modelo de cidade compacta em constante processo de renovação e contínua adaptação do espaço construído existente. Isso implica flexibilização dos instrumentos de gestão e política urbana e implantação de um processo de planejamentos dinâmico e alerta." (ACIOLY, 1998, p.41)

Por fim, diante dessas colocações, surgem algumas questões que ainda estão em aberto e devem ser refletidas: Existe um limite de adensamento? Qual é o limite? Em função de que? Como adensar as áreas urbanas de forma aceitável ambiental, econômica e socialmente? Quais são os critérios a serem considerados em decisões de projeto e de planejamento?

\subsection{Critérios e indicadores de sustentabilidade ambiental urbana}

As questões ambientais ganharam mais espaço dentro das políticas de desenvolvimento, em 1992, durante a Conferência das Nações Unidas no Rio de Janeiro. Nesta conferência, a mudança climática foi reconhecida como uma realidade demonstrada cientificamente, e a partir daí começaram a aparecer algumas soluções para esse problema. Ficou então definido que as estratégias de desenvolvimento sustentável deveriam integrar os aspectos ambientais em planos e políticas de desenvolvimento.

Durante evento foram, então, assinados os seguintes acordos: a Agenda 21; a Carta da Terra; os Convênios sobre a Mudança Climática; convênios sobre a Diversidade Biológica e a Declaração dos Princípios relativos aos bosques. A Tabela 6apresenta um resumo dos grandes acordos mundiais sobre meio ambiente.

Tabela 6: Acordos mundiais sobre meio ambiente.

Fontes - Edwards, 1999, p.XIII.

ACORDOS MUNDIAIS SOBRE MEIO AMBIENTE

1972 Conferencia de Estocolmo sobre meio ambiente humano (Reino Unido)

1979 Convenção de Genebra sobre a contaminação do ar (ONU)

1980 Estratégia Mundial sobre conservação (IUCN) 


\section{ACORDOS MUNDIAIS SOBRE MEIO AMBIENTE}

1983 Protocolo de Helsinki sobre qualidade do ar

1983 Comissão Mundial sobre meio ambiente e sustentabilidade(ONU)

1987 Protocolo de Montreal sobre a camada de ozônio (ONU)

1987 Nosso Futuro Comum (ONU)

1990 Livro verde sobre o meio ambiente (UE)

1992 Conferência das Nações Unidas no Rio de Janeiro (ONU)

1996 Conferencia habitat (ONU)

1996 Conferencia de Kyoto sobre aquecimento global (ONU)

2000 Conferencia de Haya sobre mudanças climáticas

A Agenda 21 consiste em um plano de ação global que estabelece uma visão em longo prazo para equilibrar necessidades econômicas e sociais com os recursos naturais do planeta. A Agenda 21 local define desde os critérios de sustentabilidade, a filosofia, estratégia e programas operativos que serão desenvolvidos nos próximos anos em uma localidade, para melhorar a qualidade de vida da população.

As Agendas 21 são instrumentos para conseguir um desenvolvimento sustentável local, um processo contínuo que parte da cidadania. Durante a Conferência das Nações Unidas no Rio de Janeiro, 178 governos assinaram suas Agendas 21.

A Agenda 21 foi o acordo de maior incentivo para o desenvolvimento de indicadores ambientais. A partir de 1992, visando atender aos capítulos da Agenda que abordam a relação entre meio ambiente e desenvolvimento sustentável (capítulo 8 e capítulo 40), a comissão para o desenvolvimento sustentável das Nações Unidas vem direcionado o movimento para a construção de indicadores de sustentabilidade.

Os indicadores de sustentabilidade surgiram primeiro na esfera das nações, em resposta a Agenda 21. Em 1996, esta comissão publicou um conjunto de 134 indicadores e em 2000, este conjunto foi reduzido para 57.

O termo indicador vem do verbo em latim indicare, que significa divulgar ou apontar, anunciar ou tornar evidente publicamente, ou estimar ou por um preço sobre. Os indicadores são sinais de fatos ou sistemas complexos, são informações que apontam as características dos sistemas ou que destacam o que está acontecendo. Os indicadores são ferramentas constituídas por uma ou mais variáveis usadas para simplificar a informação 
sobre fenômenos complexos, de forma a facilitar a comunicação e a possível quantificação dos fenômenos (VOSGUERTCHIAN, 2006, p.160).

Um indicador é um parâmetro ou valor derivado de parâmetros que fornece informações sobre um determinado fenômeno (OECD, 1993.). Segundo Silva:

"um indicador possui significado sintético e é desenvolvido para um determinado objetivo específico. Essas duas características fazem com que seu significado transcenda as propriedades diretamente associadas ao valor do parâmetro e apontam as principais virtudes do uso de indicadores, que são: reduzir o número de medidas e parâmetros necessários para descrever determinada situação (...) e, simplificar o processo de informações através do qual os resultados dessas medidas chegam ao usuário final." (SILVA, 2007, p.48)

Um indicador pode ser uma variável qualitativa, um ranking variável ou uma variável quantitativa. Os indicadores quantitativos são os mais difundidos, porém os indicadores qualitativos são importantes, principalmente se a informação não é quantificável, ou quando a informação quantitativa não estiver disponível.

Problemas complexos do desenvolvimento sustentável requerem alternativas integradas dos indicadores, ou uma agregação dos mesmos. Há alguns indicadores agregados que fazem os enclaves entre as distintas entradas do desenvolvimento sustentável explicito e foram desenvolvidos para essa finalidade, podendo ser considerados índices de desenvolvimento sustentável (HARDI; BARG, 1997, apud ANDRADE, 2007).

Os indicadores são utilizados para: reduzir o número de medidas e parâmetros necessários para descrever uma determinada situação, e simplificar o processo de informação através do qual os resultados destas medidas chegam ao usuário final (SILVA, 2003).

Segundo Bettini, os indicadores são modelos que nos permitem monitorar e comunicar informações sobre os progressos ou as tendências, transformado estas em dados objetivos. Em uma publicação, a World Resources Institute define: "os indicadores representam um modelo empírico da realidade, não a realidade em si mesma". A publicação ainda sugere algumas características que fazem dos indicadores eficazes para orientar as políticas públicas são elas (BETTINI, 1998, p192, tradução nossa):

- $\quad$ utilidade para o usuário; 
- $\quad$ relevante para as políticas, ou seja, devem ajustar-se a interpretar o estado do ambiente, as pressões da atividade humana em relação com os objetivos de políticas e programas nacionais e locais;

- $\quad$ elevada capacidade de síntese, os indicadores devem ser capazes de sintetizar em um valor numérico uma grande quantidade de informação.

Mueller completa que um bom indicador deve conter os seguintes atributos: simplificação, quantificação, comunicação, validade e pertinência (MUELLER et al. (1997), apud SATTLER, 2007).

Além disso, os indicadores devem contemplar recortes em séries temporais e espaciais. Por esta razão, Sattler (2007) destaca que os indicadores de sustentabilidade não são instrumentos universais, aplicáveis a qualquer realidade, porém é possível reconhecer elementos de generalidade, que permitem que os mesmos indicadores possam ser aplicados em situações diferenciadas.

O processo de elaboração ou seleção de indicadores requer a modelização dos fenômenos que se desejam observar e, a simplificação do problema que se pretende monitorar em um número limitado de variáveis que seja possível medir e agregar. Este processo está ligado a uma base conceitual definida e à finalidade a que se propõem.

Diante disto, fica claro que os indicadores de sustentabilidade são um mecanismo efetivo para o projeto e construção de cidades mais sustentáveis. Porém é difícil e complexo selecionar um conjunto de indicadores capazes de representar a interdependência entre sistema urbano e recursos naturais globais e concluir daí a sua sustentabilidade.

Destaca-se que por si só os indicadores não são capazes de promover melhorias. Metas são também necessárias, para embasar os indicadores e permitir a avaliação do progresso. Os indicadores podem auxiliar no desenvolvimento de diretrizes para projetos de intervenções urbanas e edificações, sendo ferramentas importantes de tomada de decisão no que tange às conquistas e aos desafios da organização em alcançar suas metas.

Para completar o entendimento dessas ferramentas de projeto e de avaliação é necessário definir os conceitos de índice, e parâmetro.

Índice é entendido como o resultado da combinação de um conjunto de parâmetros associados uns aos outros por meio de uma relação pré-estabelecida que dá origem a um novo e único valor. Nesta associação são atribuídos valores relativos a cada parâmetro 
que compõe o índice, e a relação pode ser estabelecida por meio de estatística, formulação analítica ou cálculo de razão matemática.

Conforme ressaltado pela OECD, quando um parâmetro é entendido como indicador seu valor transcende o número ou a característica e, si, adquirindo outro significado. Marzall estabelece uma relação entre indicador e parâmetro:

"o indicador como um instrumento que evidencia mudanças que ocorrem em um dado sistema, em função da ação humana; padrão como o ideal a ser alcançado, no caso, a sustentabilidade, e os parâmetros ou descritores como aqueles aspectos da realidade que são determinantes para que o padrão seja atingido, devendo ser, portanto, monitorados. Para estes, então, deverão ser encontrados indicadores." (MARZALL, 1999, apud, SATTLER, 2007).

Sattler (2007) destaca a importância da existência de parâmetros, abordando que não há como fazer diagnósticos, definir prioridades de atuação, elaborar programas e projetos, avaliar o desempenho de atividade, direcionar investimentos, sem uma referência de parâmetros a orientar as praticas que visam a construção de uma cidade mais sustentável.

Segundo Bettini (1998), a diferença dos indicadores ambientais tradicionais para os indicadores de sustentabilidade, é que os indicadores de sustentabilidade tentam refletir as relações do sistema urbano com os sistemas naturais a nível local ou global.

Tomando a definição de Holmberg, indicadores de sustentabilidade (ambiental) são medidas que relacionam a distância entre o estado atual (do ambiente) e o seu estado sustentável. Para se falar em indicadores de sustentabilidade, este patamar sustentável deve, portanto, ser conhecido ou razoavelmente estimado (HOLMBERG et al., 1991).

Sendo assim, fica claro que o desafio é relacionar medidas de desempenho a indicadores mais amplos de progresso em direção à sustentabilidade. Para isto é necessário a obtenção de dados para gerar indicadores de desempenho em relação a metas de sustentabilidade, ainda que persistam as dificuldades de acesso a dados necessários à formulação e manutenção dos indicadores. 
Para medir a sustentabilidade ambiental de uma cidade é necessário relacionar a demanda de recursos necessários para satisfazer as necessidades de seus habitantes com a capacidade de deixar o capital natural para satisfazer tal demanda no futuro.

Pode-se dizer que a seleção de indicadores capazes de expressar esta relação é bastante complexa, porém importantes progressos vêm sendo realizados na tentativa de desenvolver modelos conceituais para classificar os indicadores de sustentabilidade urbana.

\subsubsection{Requisitos, critérios e indicadores existentes}

Dentre os indicadores ambientais e os de sustentabilidade urbana existentes, destacam-se os mais utilizados e os que mais se enquadram na proposta de avaliação dos projetos contemporâneos, apresentada no capítulo 03, assim como no método de inserção de parâmetros ambientais no processo de projeto, apresentado no capítulo 04 da Tese.

\section{Indicadores da UNCHS (Nações Unidas e Banco Mundial)}

Em nível internacional a iniciativa de maior contribuição foi o programa de indicadores desenvolvido pelas Nações Unidas e o Banco Mundial visando a Conferência das Nações Unidas para Assentamentos Urbanos (habitat II). O programa foi adotado pelos países membros da seção preparatória da conferência em abril de 1994. Especialista das Nações Unidas e do Banco Mundial elaboraram uma lista de indicadores chave para o monitoramento das cidades.

O objetivo destes indicadores era melhorar as políticas de intervenção das agencias de desenvolvimento multilateral e as ações dos governos nacionais.

Operativamente o programa se baseia nos aspectos focados pelo Comitê Nacional instituído para a preparação do Habitat II, os governos nacionais e as autoridades locais.

A utilização dos indicadores está prioritariamente encaminhada a guiar os informes nacionais sobre as diferentes ações, com os seguintes objetivos: acompanhar a evolução sobre a influência das urbanizações no impacto ambiental; identificar os problemas e prioridades atuais e futuras; desenvolver estratégias e planos de ação e; conhecer a capacidade das instituições locais nas prioridades e opções de construção.

Foram selecionados vinte e sete indicadores urbanos que se articularam em cinco módulos: sócio-econômico, infra-estrutura, transporte, gestão urbana e governo local. 
Outra iniciativa que merece destaque foi a lista de indicadores ambientais desenvolvida pela Agencia Européia de Meio Ambiente. A Task Force da Agencia Européia de Meio Ambiente, encarregada de preparar o primeiro informe paneuropeu (Europe's Environment: The Dobris Assessment) sobre o estado do meio ambiente, seleciona um conjunto indicadores que possibilitasse a comparação entre cidades de diferentes países europeus.

A análise do meio ambiente urbano se baseia em 55 indicadores agrupados em três categorias: estruturais urbanas (densidade, tipo de uso do solo e mobilidade), o uso dos recursos (energia e materiais) e a qualidade do meio ambiente urbano (qualidade do ar, ruídos, segurança, áreas verdes e qualidade das habitações).

Porém, devido à falta de acesso e organização de informações, somente 20 dos 55 indicadores selecionados puderam ser adotados, prejudicando parte dos objetivos dos autores do trabalho de tentar examinar as relações entre as características estruturais urbanas, o uso dos recursos (energia e materiais) e a qualidade do meio ambiente urbano.

O modelo conceitual proposto pela OCDE para o desenvolvimento de indicadores ambientais constitui a base de referência de muitos programas elaborados para desenvolver indicadores urbanos. Este modelo propõe um sistema de classificação de informação capaz de descrever as interações entre sistema humano e sistema ambiental. As informações classificadas segundo o modelo pressão-estado-resposta (PSR) respondem as seguintes questões (BETTINI, 1998):

"Qual é estado do meio ambiente e dos recursos naturais?

Quais são as pressões das atividades humanas?

Quais são as respostas da sociedade as mudanças ambientais?" (BETTINI, 1998, p203, tradução nossa)

A OCDE introduz uma seleção significativa e organizada de indicadores ambientais. 0 modelo se estrutura através de uma série de áreas problema que identificam conflitos ambientais de relevância. Foram identificadas treze áreas, nas quais se tratam temas de qualidade ambiental e outras que se concentram na qualidade dos recursos. As áreas são: mudança climática, destruição da camada de ozônio, acidificação, contaminação tóxica, 
meio ambiente urbano, biodiversidade, diversidade de ecossistemas, resíduos, recursos hídricos, recursos florestais, recursos marítimos, erosão e indicadores gerais.

Entre os objetivos da OCDE é promover o desenvolvimento sustentável mediante a redução da contaminação e a gestão coerente dos recursos naturais, o que implica a integração da política ambiental na economia setorial, assim como a cooperação internacional.

A Comissão de Desenvolvimento Sustentável (CSS) e as Nações Unidas (UNSTAT) utilizam uma aproximação similar para classificar os indicadores de sustentabilidade em uma matriz que inclui variáveis de pressão, estado, resposta, e os temas da Agenda 21. Através destes indicadores, é possível identificar e orientar as atividades que interferem no meio ambiente e são fundamentais do ponto de vista da sustentabilidade.

Outra aproximação foi proposta pelo Ministério do Meio Ambiente holandês que caracteriza uma série de determinantes do desenvolvimento sustentável, aos quais é possível agregar as variáveis ambientais e construir índices de sustentabilidade. Estes elementos determinantes são classificados em três dimensões políticas: ambiental, econômica e social (ADRIAANSE, 1994, apud BETTINI, 1998).

Para cada dimensão é possível caracterizar temas específicos sobre estes, estabelecer níveis de sustentabilidade e metas para diversos atores sociais e econômicos. A filosofia de fundo de esta aproximação é que, devido a classificação das informações por problemas, se consegue caracterizar relações entre as diferentes fontes de pressão e as respostas específicas necessárias para enfrentar tais problemas.

Em 1996, o Ministério do meio Ambiente da Espanha também publicou uma série de monografias dedicadas ao estudo e definição dos indicadores ambientais, propondo uma relação de indicadores classificados por áreas ambientais que são: atmosfera, resíduos, meio urbano, recursos naturais (biodiversidade, bosques, costas, meio marítimo, solo, água). ${ }^{38}$

\footnotetext{
${ }^{38}$ Ministério de medio ambiente. Dirección general de calidad y evaluación ambiental. Sistema Español de Indicadores Ambientales: área de medio ambiente. Madrid, 2000.
} 


\section{Iniciativas de Sustentabilidade de Seattle}

Saindo do âmbito de indicadores de nação, para o âmbito local, o programa Sustainable Seattle merece destaque. A iniciativa nasceu em 1991 e foi realizada por um grupo de voluntários que promovia a idéia de desenvolver uma lista de indicadores de sustentabilidade para a cidade.

Foi então desenvolvida uma preliminar lista de 100 indicadores para monitorar a sustentabilidade do município, que submetida a um processo de seleção realizado por um painel cívico formado por 150 participantes que representavam diversos setores da comunidade urbana, foi reduzida para 40 indicadores.

A intenção dos autores não era criar uma lista exaustiva de indicadores, que abrangesse todas as dimensões da sustentabilidade urbana. Cada indicador proposto mede uma destas dimensões, e o conjunto formam uma base para uma discussão sobre quais os elementos constituem uma cidade sustentável.

É importante destacar que apesar da dimensão local da iniciativa, a seleção dos indicadores de Seattle foi cuidadosa em considerar a conservação do capital de recursos naturais globais.

Outra iniciativa no âmbito local são os indicadores de sustentabilidade do Fórum Cívico de Barcelona. A lista de indicadores de sustentabilidade do Fórum Cívico de Barcelona foram premiados internacionalmente no Concurso de Buenas Prácticas patrocinado por Dubai em 1998, A experiência do Fórum Cívico para Barcelona nasceu de cidadãos sensibilizados com o meio ambiente e de ONGs. Foram propostos 65 indicadores de sustentabilidade, agrupados em 10 metas para melhorar a sustentabilidade de Barcelona. Cada meta tem um objetivo muito concreto que estão relacionados com a estrutura urbana, a formação do território, a economia, as características sociais, as emissões de resíduos sólidos, líquidos e ao ar, a salubridade das habitações, o emprego, a biodiversidade, o uso eficiente dos recursos naturais, a saúde das pessoas, a regulação climática, a educação, o 
fomento da vida de bairro, a ótima distribuição de trabalho social e o tempo livre e a igualdade das formas de vida. ${ }^{39}$ :

\section{Tabela 7: I ndicadores de sustentabilidade do Fórum Cívico de Barcelona}

Fonte: HIGUERAS, 2008.

\section{I ndicadores de sustentabilidade do Fórum Cívico de Barcelona}

1 - os recursos devem ser utilizados de maneira eficaz sem superar o ritmo de renovação dos recursos renováveis, substituindo progressivamente os não renováveis;

2 - o funcionamento da cidade não deve colocar em perigo a saúde das pessoas, nem superar a capacidade de carga do meio natural;

3- a biodiversidade deve ser valorizada e protegida;

4 - Incentiva-se o estabelecimento de uma aliança global com as outras cidades e povos, para preservar os sistemas naturais comuns da terra como a regulação climática e a camada de ozônio, e para eliminar a pobreza.

5 - todos devem ter acesso aos bens e serviços básicos de habitação, saúde, educação e segurança;

6 - A cidade deve preservar a mescla de funções incentivando a proximidade e a vida de bairro para que o acesso aos serviços urbanos não se faça a custas do meio ambiente;

7 - o trabalho social e o tempo livre devem distribuir-se equitativamente entre todas as pessoas, homens e mulheres;

8 - a igualdade das formas de vida dos cidadões deve incrementar;

9 - todos devem ter acesso a um trabalho remunerado, com um salário digno e uma contratação estável;

10 - a economia deve ser diversificada e a dependência do exterior deve reduzir. Sempre que sejam possíveis as necessidades devem satisfazer-se preferencialmente com recursos locais.

\section{Pegada Ecológica}

Para passar dos indicadores que descrevem o estado do meio ambiente urbano para os indicadores capazes de interpretar a direção das tendências em ação, é necessário compreender o conceito de saúde ambiental da cidade.

As definições de saúde ambiental proposta por Opschoor e Costanza (1994) se ajustam a intenção de articular o conceito de sustentabilidade ambiental em variáveis ambientais mensuráveis. Segundo Opschoor e Costanza o conceito de saúde ambiental do sistema é

39 Indicadores de sustentabilidade. Fórum Cívico para uma Barcelona Sustentável. Disponível em: http://habitat.aq.upm.es - tradução nossa. 
a habilidade dos sistemas por si mesmos (residência, capacidade de recuperação) para manter sua própria estrutura e função no tempo frente a fatores externos.

Devido à dificuldade de definir o estado de saúde de um sistema, é possível tentar medir seu inverso, ou seja, o estresse máximo que pode ser absorvido pelo sistema.

O conceito de pegada ecológica (ecological footprint) foi desenvolvido pelos pesquisadores canadenses William Rees e Mathis Wackernagel, em 1996, com o objetivo de visualizar as conseqüências diretas do desenvolvimento urbano sobre o planeta, ou seja, quantificar o impacto ambiental das cidades.

A pegada ecológica compreende a superfície ecológica produtiva requerida para sustentar uma cidade, ou a área no planeta necessária para suprir o seu consumo de recursos e produtos, considerando a produção de alimentos, a extração de matéria-prima e a capacidade do meio natural de absorver os resíduos gerados por esse consumo, em particular as emissões de $\mathrm{CO}_{2}$.

Devido ao metabolismo linear da cidade, esta requer, para seu funcionamento, tanto o consumo de ateria e energia como uma superfície para eliminar seus resíduos sólidos líquidos e gasosos (ROGERS, 2001).

Segundo Higueras (2007), este conceito teve uma grande importância para vislumbrar o verdadeiro entendimento da sustentabilidade, na medida que abordava as repercussões da urbanização sobre a capacidade finita do planeta Terra. Ao tratar de um território finito e limitado, o planejamento do desenvolvimento sustentável passa por conceitos como igualdade e equilíbrio entre os países.

William Rees e Mathis Wackernagel (1995) mediram a pegada ecológica per capita dos países industrializados, e compararam a disponibilidade global de áreas produtivas per capita com a apropriação per capita por parte dos habitantes das áreas urbanizadas destes países, desde 1900 até os dias de hoje. Eles concluíram que esta superfície aumentou de 1 a 4-6 hectares, enquanto que a superfícies produtiva disponível a nível mundial diminuiu de 5 a 1,7 hectares per capta (BETTINI, 1998).

Estimativas indicam que em 2050 a população poderá alcançar 10.000 milhões de habitantes, com uma pegada ecológica podendo ser no máximo de 1,2 hectares por habitante (HIGUERAS, 2007). 
A Tabela 8 apresenta a pegada ecológica de diferentes países, mostrando a desigualdade entre estes.

Tabela 8: Pegada Ecológica

Fonte: HIGUERAS, 2007, p68

MAIORES PEGADAS ECOLÓGICAS

\begin{tabular}{lc}
\hline Estados Unidos & $9,6 \mathrm{ha}$ \\
Emirados & $8,97 \mathrm{ha}$ \\
Canadá & $8,56 \mathrm{ha}$ \\
Noruega & $8,17 \mathrm{ha}$ \\
Nova Zelândia & $8,13 \mathrm{ha}$ \\
Suécia & $7,95 \mathrm{ha}$ \\
Espanha & $4,20 \mathrm{ha}$ \\
Chile & $3,90 \mathrm{ha}$ \\
México & $2,50 \mathrm{ha}$ \\
China & $1,40 \mathrm{ha}$ \\
\hline & MENORES PEGADAS ECOLÓGICAS \\
\hline MOZAMBIQQUE & $0,56 \mathrm{ha}$ \\
NEPAL & $0,57 \mathrm{ha}$ \\
HAITI & $0,62 \mathrm{ha}$ \\
REPÚBLICA CONGO & $0,62 \mathrm{ha}$ \\
\hline
\end{tabular}

A principal utilidade do conceito de pegada ecológica é poder estabelecer uma comparação entre o desenvolvimento possível e as capacidades do planeta, com a finalidade de corrigir as tendências desfavoráveis. É aplicável também para estabelecer um controle eficaz dos países desenvolvidos com relação aos hábitos de consumo e os resíduos, e ainda, para evitar que os países em desenvolvimento sigam a mesma tendência que os já desenvolvidos (HIGUERAS, 2007).

Para medir a pegada ecológica de uma cidade é preciso identificar a demanda de sol e de recursos que resultam de cada tipo de consumo e, converter esta demanda em superfície produtiva.

Rees e Wackernagel (1995) propuseram cinco categorias principais de consumo (alimentação, moradia, transporte, consumos e serviços) e cinco categorias de uso do solo (área degradada, área cultivada, área de pastos, bosque produtivo e área energética). Os resultados se sintetizam em uma matriz, que permite converter um determinado recursos per capita em superfície produtiva para sustentar tal uso 
Higueras (2007) recomenda a incorporação dos cálculos das pegadas ecológicas nas Agendas locais ou em planejamentos urbanos, com os seguintes objetivos: controlar a localização da população; conter a erosão do solo com vegetação, cultivos etc., para que possam continuar sendo produtivos e; otimizar a eliminação de resíduos sólidos, líquido e gasosos derivados do funcionamento da cidade, fechando o metabolismo urbano com o reuso ou reciclagem dos resíduos.

\section{Indicadores do ecossistema urbano}

Baseado no conceito de ecossistema urbano, na publicação La città sostenible, Alberti propôs um modelo conceitual para desenvolver indicadores de sustentabilidade para as cidades. Para analisar as interações entre os sistemas urbanos e o meio ambiente foi destacada a necessidade de relacionar qualidade ambiental na cidade (qualidade do ar, ruído, tráfego, etc.), o funcionamento ambiental (consumo energético, usos de materiais, usos de água, resíduos sólidos, etc.), e a estrutura urbana (densidade, concentração de atividades, etc.) (ALBERTI et al, 1994, capitulo VI, apud BETTINI, 1998, p.206).

O modelo proposto é composto de três dimensões, que são: a estrutura urbana; os fluxos urbanos; a qualidade urbana. A estrutura urbana pode ser avaliada segundo o perfil da comunidade (população, atividade e ambiente construído), as dimensões espaciais (concentração, expansão e uso do solo) e as relações espaciais (distribuição funcional e mobilidade). Os fluxos de recursos (energia, água e materiais) e os fluxos de informação são examinados em conjunto com os elementos de infra-estrutura e tecnologia. A qualidade urbana engloba várias dimensões. O modelo indica cinco categorias: $a$ qualidade física, química e biológica do ambiente; a diversidade; acessibilidade; igualdade e eficiência e; a capacidade de aprendizagem da comunidade.

\section{Indicadores de Sustentabilidade Ambiental da atividade urbana de Sevilha}

A Agência de Ecologia Urbana de Barcelona (BCN), direcionada por Salvador Rueda, vem trabalhando com modelos de cidades e com conceitos para avaliá-las e torná-las mais sustentáveis. Com base nestes conceitos de compacidade, complexidade, eficiência e estabilidade, a BCN em parceria com a prefeitura de Sevilha desenvolveu um plano especial de indicadores de sustentabilidade ambiental, que consiste em um instrumento prévio da formulação do planejamento urbano, marcado pelo plano diretor da cidade (RUEDA, 1999 e RUEDA, 2000). 
A Agência de Ecologia Urbana de Barcelona vêm contribuindo muito para o desenvolvimento de pesquisas e projetos na área, tendo como um dos seus principais objetivos a formulação de instrumentos que permitam repensar as cidades e seu entorno em relação com a sustentabilidade, incluindo a ecologia urbana como disciplina de analise e planejamento urbano (BCN, 2008).

Nesse plano é estabelecido um conjunto de indicadores que condicionam o processo de planejamento urbano seguindo um modelo de cidade compacta em sua organização, eficiente nos fluxos metabólicos e com coesão social.

Os indicadores e condicionantes apresentados por Rueda têm como objetivo manter uma coerência entre todos os componentes que interferem no ecossistema urbano com o meio que o serve de suporte.

Todos os indicadores vêm acompanhados de um resumo metodológico de cálculo e/ou analise gráfica e um valor de referência, baseado no modelo de cidade sustentável estabelecido pela própria agencia.

No âmbito da estrutura física o Plano especial recomenda uma densidade construída e um grau de compacidade suficiente para gerar uma proximidade de usos e funções e configurar um espaço público promotor da idéia de cidade.

Com relação ao espaço público o Plano especial proíbe a construção de condomínios fechados, recomenda $25 \%$ da superfície do sistema viário destinados ao transporte motorizado, e as paradas de transporte público devem distanciar $300 \mathrm{~m}$ de qualquer ponto da trama urbana.

Com relação às áreas verdes, o plano recomenda a articulação uma rede de espaços verdes acessíveis aos habitantes, apontando a importância da porcentagem de área verde, assim como a forma com que esta está distribuída.

Já os fluxos metabólicos devem integrar-se desde a concepção e do projeto tanto no edifício quanto na organização do território. O objetivo principal para a água e energia é conseguir a auto-suficiência ou ao menos aproximar-se dela. No caso dos fluxos materiais, recomenda-se potencializar a hierarquia na gestão dos resíduos denominados 3R (reduzir, reciclar e reutilizar), seja no desenvolvimento da edificação, do urbanismo, da infra-estrutura, como no funcionamento da cidade ou na demolição após a vida útil. 
O modelo de indicadores proposto por Rueda (2006) é baseado no urbanismo de três níveis, ou seja, três planos em horizontal (altura, superfície e subsolo) religados em vertical. O objetivo é redistribuir as funções próprias do sistema, concentradas na superfície, de maneira que o subsolo e a altura assumam parte destas funções. Desta maneira, uma grande parte do espaço em superfícies é liberada, favorecendo o uso para o desenvolvimento das relações entre os cidadãos.

A Tabela 9 apresenta as inter-relações que se estabelece entre os distintos eixos do modelo de sustentabilidade, aplicado ao urbanismo dos três níveis.

Tabela 9: Urbanismo em três níveis com base nos princípios de compacidade, eficiência e complexidade.

Fonte: RUEDA, 2006.

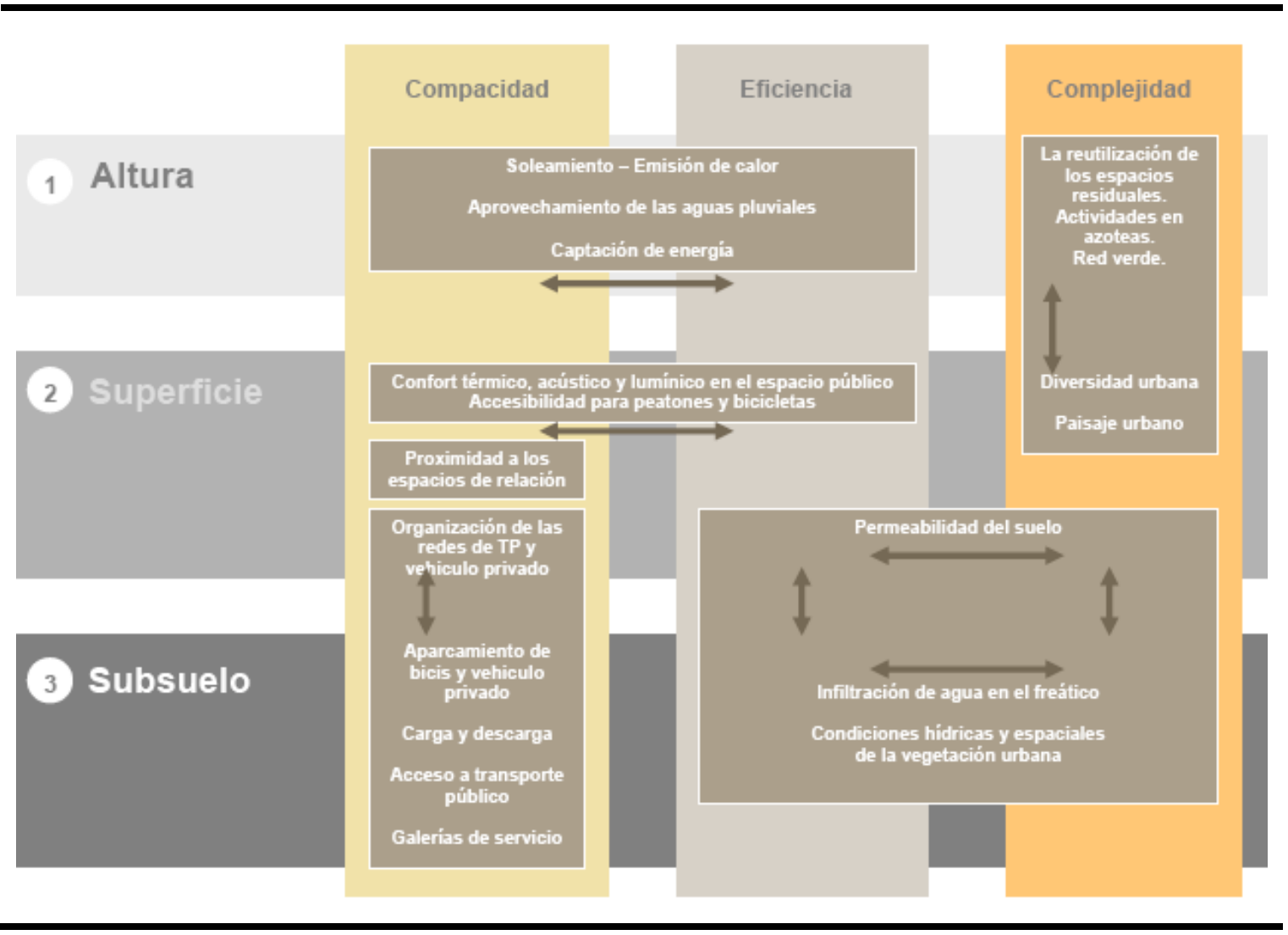

Os indicadores foram desenvolvidos com base nos conceitos de compacidade, complexidade, eficiência e estabilidade, sendo que cada um destes conceitos incorpora um número de variáveis que estão associadas à idéia principal e que em muitas vezes eles estão relacionados entre si. Os indicadores foram separados em sete grupos, de acordo com o tema específico ao qual estão relacionados, totalizando em 44 indicadores e 
condicionantes: morfologia urbana, espaço público e mobilidade; organização urbana; metabolismo urbano; aumento da biodiversidade; coesão social e eficiência do sistema (RUEDA, 2006).

A Tabela 10 apresenta a Estrutura do Plano de Indicadores de sustentabilidade ambiental urbana de Sevilha, com os sete grupos de indicadores.

Tabela 10:Estrutura do Plano de Indicadores de sustentabilidade ambiental urbana de Sevilha

Fonte: RUEDA, 2006, tradução nossa

\section{I NDI CADORES RELACI ONADOS COM A MORFOLOGI A URBANA}

1.1. Densidade construída

1.2. Compacidade absoluta

1.3. Compacidade corrigida

\section{I NI CADORES RELACI ONADOS COM O ESPAÇO PÚBLI CO E COM A MOBI LI DADE}

2.1. Viário público para o tráfego de automóveis e o transporte público de superfície

2.2. Viário público para pedestre e outros usos do espaço público

2.3. Continuidade da rua corredor

2.4. Proibição de condomínios fechados

2.5. Adoção de arvores segundo a proteção vertical de sombra do solo

2.6. Potencial de conforto térmica nos espaços urbanos

2.7. Disposição de luminárias sem causar ofuscamento

2.8. Desenho de introdução das TIC (Tecnologia da Informação e Comunicação) na paradas de ônibus

2.9. Acessibilidade das paradas da rede de transporte público de superfície

2.10. Acessibilidade da rede de bicicletas

2.11. Acessibilidade das plataformas logísticas subterrâneas

2.12. Reserva de espaços de estacionamento: veículos privado

2.13. Galerias de serviços

2.14. Reserva de espaços de estacionamento: bicicletas

2.15. Acessibilidade dos cidadãos com mobilidade reduzida 


\section{INDICADORES RELACIONADOS COM A ORGANIZAÇÃO URBANA: A} COMPLEXI DADE

3.1. A complexidade urbana - $\mathrm{H}$

3.2. Distribuição entre atividade e residência

3.3. Superfície mínima entre os locais

3.4. A proporção de atividade de proximidade

3.5. Diversidade de atividades: índice de especialização

3.6.A proporção de atividades densas em conhecimento: Atividades @

\section{INDI CADORES RELACI ONADOS COM O METABOLI SMO URBANO}

4.1. Auto-geração energética das habitações

4.2. Auto-suficiência hídrica da demanda urbana

4.3. Minimização dos sistemas de coleta nos espaços público. Resíduos sólidos urbanos

4.4. Minimização e recuperação dos resíduos gerados da construção e demolição

4.5. Uso de materiais reutilizados, reciclados e renováveis

4.6. Reserva de espaço para os processos de autocompostagem

4.7. Reserva de espaços para a instalação de pontos limpos

4.8. Nível sonoro

\section{INDI CADORES RELACI ONADOS COM AO AUMENTO DA BI ODI VERSI DADE}

5.1. Acesso dos cidadãos aos espaços verdes

5.2. Compensação da impermeabilização: Índice de permeabilidade

5.3. Adoção de árvores nos espaços públicos

5.4. Corredores verdes

5.5. Uma segunda capa de biodiversidade na altura: coberturas verdes

5.6. Uma segunda capa de biodiversidade na altura: verde nas fachadas

5.7. Reserva de espaço livre nos interiores das quadras

5.8. Compacidade corrigida ponderada 
5.9. Requerimentos de espaços livres

\section{I NDI CADORES RELACI ONADOS COM A COESÃO SOCI AL}

6.1. Acesso a equipamentos e serviços básicos

6.2. Mescla de rendas nas edificações residenciais: habitação de proteção pública

\section{FUNÇÃO GUI A DA SUSTENTABI LI DADE}

7.1. Eficiência do Sistema Urbano

Sistemas de Certificação

Como pode ser visto, na esfera urbana já existe uma série de indicadores ambientais e de sustentabilidade, porém, ainda não há um sistema que certifique ou avalie o projeto urbano com relação a sua sustentabilidade, ou melhor, os que existem ainda estão em fase de experimentação. Como, exemplo, destaca-se o Leed Neighborhood, desenvolvido pela instituição US Green Building Council (USGBD) ${ }^{40}$ e o $\mathrm{HQE}^{2} \mathrm{R}^{41}$, desenvolvido pelo CSTB, financiado pela Comissão Européia, através do programa Energy, Environment and Sustainable Development (City of tomorrow), que estão sendo adotado por algumas instituições e pelo grandes escritórios de Londres como um guia ou uma referência.

Em compensação no âmbito da edificação existem conceituados sistemas de certificação, que avaliam o grau de sustentabilidade de um projeto de acordo com determinados critérios de desempenho, que podem englobar desde consumo de energia até tópicos como, por exemplo, o impacto ambiental gerado por tintas (GONCALVES, 2006).

Pode-se dizer que o primeiro indício da necessidade de se avaliar o desempenho ambiental de edifícios veio da constatação que, mesmo os países que acreditavam dominar os conceitos de projeto ecológico, não possuíam meios para verificar quão mais sustentáveis eram de fato os seus edifícios (SILVA, 2007).

Somado a isto, o interesse pela avaliação ambiental de edifícios veio com o consenso entre pesquisadores e agencias governamentais quanto à classificação de desempenho

${ }^{40}$ LEED FOR NEIGHBORHOOD DEVELOPMENT. Disponível em <http://www.usgbc.org> Acesso em jul. de 2008.

${ }^{41} \mathrm{HQE}^{2} \mathrm{R}$. Sustainable renovation of buildings for sustainable neighbourhoods. Disponível em <http://hqe2r.cstb.fr> Acesso em jan. de 2010. 
atrelada aos sistemas de certificação ser um dos métodos para elevar o nível de desempenho ambiental do estoque construído e das novas edificações (SILVA, 2007).

No nível de edifícios e do ambiente construído, o desenvolvimento de indicadores de sustentabilidade apresenta os seguintes objetivos: prover avaliações detalhadas para o diagnóstico de eventuais necessidades de intervenção no estoque construído, estabelecer metas de desempenho; medir o desempenho de edifícios e projetos para que estes atendam a exigências mínimas; auxiliar a avaliar estratégias para melhorar a qualidade de vida; utilizar como diretrizes e ferramentas para melhorar as práticas correntes e a qualidade da construção e encorajar a demanda do mercado por níveis superiores de desempenho ambiental.

Além destes objetivos, os sistemas de certificação também podem ser utilizados para fins de marketing e de comunicação com as partes interessadas. O grande problema é que, em muitos casos, este se torna o principal interesse para a obtenção de selos ambientais. Mesmo assim, ainda deve-se considerar a importância do uso destes sistemas.

Segundo Gonçalves (2006), os sistemas de certificação introduzem mudanças metodológicas e práticas, integrando as várias disciplinas interdependentes que estão envolvidas na concepção e na operação dos edifícios.

Atualmente os sistemas de certificação mais utilizados são: BREAM Certification System (Building Research Establishment Environmental Assessment Method) ${ }^{42}$, LEED (Leadership in Energy and Environmental Design) ${ }^{43}$ e o HQE Certification System ${ }^{44}$

Todos esses avaliam os projetos por um sistema de pontuação com formato checklist, para a obtenção de selos. Os sistemas têm caráter voluntário e atuam como instrumentos de valorização no mercado.

Segundo Umakoshi (2008) o sistema BREEAM é um método de avaliação de edifícios criado pelo Reino Unido em 1990, que se tornou base para o desenvolvimento de muitos sistemas posteriores. Este sistema teve como base a avaliação do desempenho de

\footnotetext{
${ }^{42}$ Disponível em: < http://www.bre.co.uk/> Acesso em: out. 2008.

${ }^{43}$ Disponível em: <http://www.usgbc.org/DisplayPage.aspx?CategoryID=19> Acesso em: out. 2008.

${ }^{44}$ Disponível em: < http://www.assohqe.org/> Acesso em: out. 2008.
} 
edifícios nas seguintes áreas: gerenciamento; uso de energia relacionado à emissão de $\mathrm{CO}_{2}$; saúde e bem estar; poluição da água e do ar; transporte eficiente com relação ao consumo de energia; uso do solo; ecologia; materiais; consumo e eficiência no uso do recurso natural água.

O LEED foi um programa criado em 1994 pelo US Green Building Council (USGBC), instituição esta financiada pelo National Institute of Standads and Technology (NIST), com o intuito de desenvolver um sistema de avaliação e classificação do desempenho ambiental de edifícios, de forma a estimular e acelerar o alcance de metas ambientais ou mesmo superá-las. Inspirado no sistema inglês BREEAM, o LEED foi inicialmente aplicado em edifícios comerciais a partir de quatro pavimentos (SILVIA, 2008). Enquanto o sistema LEED vem sendo aplicado fora dos Estados Unidos, a adoção do sistema de avaliação BREEAM para empreendimentos fora do Reino Unido é proibida.

A estrutura do programa é baseada em especificações de desempenho e tem como referência normas e recomendações de órgãos renomados como ASHRAE, a ASTM, a EPA e o DOE (SILVA apud VOSGUERICHIAN, 2007). As áreas avaliadas são: sítios sustentáveis, eficiência do uso da água, energia e atmosfera, energia renovável, materiais e recursos, qualidade ambiental interna, inovação e processo de projeto.

O HQE Certification System foi criado na França em 2002 sob responsabilidade do CSTB (Centre Scientifique et Tecnhi du Batiment) e busca avaliar o desempenho ambiental dos edifícios comerciais e assegurar a qualidade ambiental desde o projeto até a execução. Essa certificação também foi inicialmente pensada para avaliar edifícios comerciais. Os aspectos avaliados são: relação do edifício com o seu entorno; escolha integrada dos produtos, sistemas e processos construtivos; canteiro de obras com baixo impacto ambiental; gestão de energia, de água, de resíduos; conforto térmico, acústico, visual e olfativo; qualidade sanitária dos ambientes, do ar e da água (UMAKOSHI, 2008).

Umakoshi (2008) destaca que esses sistemas de avaliação não representam uma metodologia ou procedimento de projeto para um melhor desempenho ambiental, mas sim, uma ferramenta de avaliação. Além disso, apesar da contribuição do tipo checklist fazer parte desse mercado há décadas, todos os sistemas ainda apresentam algumas deficiências, principalmente, com relação aos aspectos de conforto ambiental e aos impactos gerados pela inserção do edifício no contexto urbano, mesmo sendo considerados por todos com diferentes pesos. 
Silva (2003) apresenta os principais outros sistemas para a avaliação ambiental de edifícios, abordando outros além dos três aqui comentados. ${ }^{45}$ Segundo a autora o sistema canadense BECAP (Building Environmental Performance Assessment Criteria) é o primeiro orientado a pesquisas metodológica, o GBG (Green Building Challenge), é o sucessor do BECAP e utilizado no estudo exploratório e o sistema japonês CASBEE (Comprehensive Assessment System for Building Environmental Efficiency) é o método que introduziu alguns conceitos inovadores à avaliação de edifícios. Silva (2003) compara cinco dos sistemas de avaliação existentes, BREAM, BECAP, LEED, GBtool e o CASBEE, analisando o que eles avaliam, como e qual a pontuação que deve ser atingida, apresentando um quadro síntese deste estudo. ${ }^{46}$

Gonçalves (2006) aborda outro ponto a ser ressaltado, a importância em restringir a aplicação de qualquer sistema de avaliação de desempenho ambiental que não tenha sido adaptado para um determinado contexto em termos de critérios e pesos. Apesar de que estes sistemas estão em constante evolução e muitas instituições de pesquisa vêm tentando adequar estes a outras realidades. No Brasil, por exemplo, grupos de pesquisadores vêm trabalhando para adaptar o Leed e o GBtool para a realidade brasileira.

Outro aspecto a ser considerado é com relação à avaliação da sustentabilidade somente por meio dos sistemas de certificação. Sobre isso Gonçalves comenta:

"Especialmente quanto aos indicadores, fica a questão sobre a capacidade de os checklists definirem sustentabilidade. $A$ esse respeito, pode-se dizer que, enquanto o desempenho ambiental da construção pode ser medido pelos sistemas de avaliação, a síntese que deve ser realizada pela concepção para a arquitetura sustentável não tem como ser integralmente contemplada por esses mesmos métodos." (GONCALVES, 2006)

\footnotetext{
${ }^{45}$ Quadro resumo dos principais sistemas para a avaliação ambiental de edifícios (SILVIA, 2003, p. 35).

SILVA, Vanessa Gomes da. Avaliação da sustentabilidade de edifícios de escritórios brasileiros: diretrizes e base metodológica. Tese (Doutorado em Engenharia Civil). São Paulo: POLI/USP, 2003.

${ }^{46}$ Quadro comparativo dos principais sistemas para a avaliação ambiental de edifícios (SILVIA, 2003, p. 63).
} 


\subsubsection{Indicadores para a avaliação dos projetos contemporâneos}

É importante observar que as questões ambientais ganharam mais espaço dentro das políticas de desenvolvimento, o que gerou uma demanda por indicadores que possibilitassem analisar a situação atual das cidades, fazer diagnósticos e elaborar diretrizes para projetos de intervenções urbanas, visando à construção de uma cidade mais sustentável.

Está claro que os indicadores de sustentabilidade são um mecanismo efetivo para o projeto e construção de cidades mais sustentáveis. Não há como fazer diagnósticos, definir prioridades de atuação, elaborar programas e projetos, avaliar o desempenho de atividade e direcionar investimentos, sem uma referência de parâmetros a orientar as praticas que visam construir cidades com menos impacto ambiental e mais qualidade de vida para seus habitantes.

Porém, desenvolver ou selecionar um conjunto de indicadores capazes de representar a interdependência entre sistema urbano e recursos naturais globais, e concluir daí a sua sustentabilidade, é um desafio bastante complexo. O objetivo é desenvolver instrumentos informativos e medidas que reflitam os princípios da sustentabilidade e que sejam capazes de apontar as tendências e guiar as tomadas de decisões.

A seleção de indicadores deve estar ligada a uma base conceitual definida e à finalidade a que se propõem. Para isto é necessário responder as seguintes perguntas:

Quais são os objetivos dos indicadores que se pretende selecionar?

Que dados são necessários para desenvolver estes indicadores?

Que nível de agregação espacial e temporal se deseja?

Deve-se ressaltar que os indicadores devem propiciar a simplificação de um conjunto de informações, ser pertinentes e de fácil compreensão.

Diante disso e com base, principalmente, nos Indicadores de Sevilha (RUEDA, 2006) foram estabelecidas cinco categorias, cada uma com três indicadores que têm relação direta com o desenho urbano, para a análise qualitativa dos projetos contemporâneos sob o enfoque da sustentabilidade ambiental urbana. 
As classificações temáticas analisadas nos projetos são: Compacidade; Mobilidade, Espaço Público e Área Verde; Eficiência no uso dos recursos naturais, água e energia; Diversidade Urbana e Expressão Arquitetônica.

Esses temas abordam além dos aspectos ambientais, os resultados econômicos e sociais da intervenção urbana abordando questões como, por exemplo, a diversidade de tipologias e usos, mobilidade, eficiência do sistema de transporte, proximidade e socialização do espaço público.

São apresentados as classificações temáticas, seus objetivos e seus indicadores. 0 objetivo de cada classificação temática e seus indicadores de sustentabilidade apresenta as diretrizes desenvolvidas para a concepção de um urbanismo sustentável, ou seja, comprometido com o meio ambiente e com a finalidade de atender as metas da sociedade atual.

As análises dos projetos urbanos são baseadas nos seguintes temas:

\section{Categoria 01 - Indicadores relacionados com a Compacidade}

Objetivo: Ordenar a expansão e a remodelação urbana. Garantir uma densidade suficiente para atender à demanda atual, estabelecendo um mínimo de compacidade, ou seja, reunir em um espaço limitado certo número de pessoas, usos e funções urbanas, potencializando a probabilidade de contato, de intercâmbio e de comunicação.

Prevenir a proliferação da cidade difusa e sua dispersão no território urbano.

Potenciar os deslocamentos a pé, de bicicleta e em transporte público, reduzindo a necessidade do uso de automóveis.

\section{I ndicadores:}

- $\quad$ Densidade edificada: número de habitações por hectare, ou seja:

Densidade edificada $=$ número de habitações/ superfície total $(\mathrm{Ha}$.)

\section{- Compacidade absoluta:}

Este indicador relaciona diretamente o volume edificado com o território, tendo em conta somente a intensidade edificada. O indicador representa a altura média da edificação de uma determinada área.

Compacidade absoluta $=$ volume edificado $\left(\mathrm{m}^{3}\right) /$ unidade de superfície urbana $\left(\mathrm{m}^{2}\right)$

- Proximidade de usos e funções urbanas: 
Esta categoria avalia o projeto tanto com relação à morfologia urbana, quanto com relação à proximidade de usos e funções urbanas, para que desta forma seja possível atingir o modelo compacto sustentável.

\section{Relevância dos indicadores ${ }^{47}$ :}

Sabe-se que a população mundial está aumentando, assim como a porcentagem de habitantes que vivem nas cidades. Diante disto, é necessário propor para os novos projetos urbanos densidades que atendam a demanda atual e às previsões de crescimento populacional.

A sustentabilidade da cidade está diretamente relacionada à sua forma de ocupação. Modelos mais compactos reduzem a ocupação do solo urbano e o consumo de recursos naturais.

A compacidade no âmbito urbano expressa a idéia de proximidade dos componentes que conformam a cidade, ou seja, a reunião em um espaço limitado de usos e funções urbanas.

A cidade compacta busca a eficiência no uso dos recursos naturais, sendo o principal deles e não renovável, o solo. Como estratégia de eficiência e minimização do uso do solo é necessário abandonar o conceito de zonificação funcionalista, incentivando o uso misto, permitindo aumentar a complexidade e ao mesmo tempo liberar o espaço natural da pressão que gera o modelo de cidade difusa.

A compacidade é um eixo da sustentabilidade urbana que incide na forma física da cidade, na sua funcionalidade, na organização das redes de mobilidade e de espaços livres. O modelo compacto diminui os deslocamentos e como conseqüência disto, reduz o consumo de recursos naturais e o tempo destinado a esta função.

O modelo compacto de ocupação territorial é o tópico da sustentabilidade que mais tem conseqüências diretas sobre os outros eixos: a eficiência, a complexidade e a estabilidade.

\section{Categoria 02 - I ndicadores relacionados com a Mobilidade}

\footnotetext{
${ }^{47}$ A importância do adensamento urbano e do modelo compacto de cidade é uma das questões discutidas na Tese.
} 
Objetivo: Está servido de um sistema eficiente de transporte público, de preferência segregado, para que desta maneira o adensamento e o projeto de novas edificações urbanas não tenham um impacto negativo sobre a mobilidade urbana.

Favorecer a acessibilidade espacial ao transporte público.

Promover o modo de transporte mais sustentável, como o deslocamento por bicicleta ou a pé, através da construção de ciclovias e caminhos para o pedestre interligados ao transporte público e as áreas destinadas a estacionamento de veículos. Habilitar espaços destinados ao estacionamento de bicicletas.

Inibir o uso do automóvel, reduzindo o número de vagas de estacionamento e restringindo o acesso em certas áreas do projeto, como por exemplo, no interior das quadras ou próximo aos espaços públicos.

\section{Indicadores:}

\section{- Acesso ao transporte público:}

Acesso a pé e em veículos de duas rodas a rede de transporte público, a uma distancia inferior de 300m desde qualquer ponto da cidade. Ou seja, se considera uma rede de transporte público acessível quando os deslocamentos a pé até a parada mais próxima não superem a cinco minutos.

O transporte público deve estar conectado aos principais pontos de atração da cidade e articulado a outros nós de intercâmbio modal.

- Incentivo ao transporte sustentável (a pé e de bicicleta):

Construção de ciclovias e caminhos para o pedestre interligados ao transporte público, as áreas destinadas a estacionamento de automóveis e aos principais pontos do projeto urbano.

A bicicleta se converte em um verdadeiro modo de transporte se conta com uma rede própria interconectada em todo o território e segregada de outros modos de transporte de superfícies, se conta com estacionamentos seguros e se condicionam diversas unidades de transporte público para transportar bicicletas e superar os impedimentos de uso que impõem inclinações superiores a $4 \%$.

\section{- Inibir o uso de automóveis:}


Incentivo a redução do uso do automóvel, através da redução e especificação do espaço destinado ao estacionamento, da restrição o acesso em certas vias no interior das quadras ou próximo aos espaços públicos ou de outras medidas alternativas com a mesma finalidade.

Rueda (2006), por exemplo, recomenda a estrutura do viário em superquadras, em espanhol "supermanzanas", no qual os veículos a passeio só podem circular nas vias periféricas, e as vias interiores são restritas para os veículos dos residentes, de emergência e de serviço.

\section{Relevância dos indicadores:}

A sustentabilidade ambiental de um projeto urbano está diretamente relacionada à disponibilidade e eficiência do transporte público. O projeto apoiado pelo de transporte público promove uma melhoria na qualidade de vida de seus cidadãos, que poderão se deslocar com maior facilidade e economia.

Caso o projeto seja implantado em uma área desprovida de transporte público, seus residentes terão que utilizar o veículo privado como meio de locomoção. Isto implica um aumento do número de automóveis na cidade, junto com todos os seus impactos, como por exemplo, o aumento da poluição, do consumo de energia, do ruído urbano, e perda da qualidade dos espaços públicos.

\section{Categoria 03 - I ndicadores relacionados com o Espaço Público e Área Verde}

Objetivo: Conceber o espaço público como eixo da cidade, liberando este de sua função a serviço dos automóveis para convertê-lo em espaço de convivência, de intercâmbio, de lazer e outros múltiplos usos.

Fortalecer o papel do pedestre em favor de uma nova cultura de mobilidade sustentável que permita contribuir para a vitalidade sócio-econômica nas ruas e demais espaços livres e reconstruir a proximidade como valor urbano.

Aumentar a autonomia dos grupos sociais sem acesso ao veículo privado.

Garantir horas de insolação através das características do entorno e de sombras a partir da presença de árvores ou elementos arquitetônicos para um maior conforto dos usuários nos espaços públicos.

Promover as áreas verdes, garantindo o acesso dos cidadãos ao desfrute da natureza, minimizando o impacto sobre a biodiversidade.

Criar uma rede de espaços verdes, livres e gratuitos para todos os cidadãos, vinculada aos valores de recursos naturais, ecológicos e paisagísticos da cidade. 


\section{I ndicadores:}

- Relação da Porcentagem da superfície de viário público destinado ao transporte motorizado e destinado ao espaço livre: Porcentagem de viário público para o tráfico de automóveis de passeio e de transporte público de superfície ( $\mathrm{Vtm})$, em comparação com a porcentagem de viário público destinado aos espaços livres.

Llardent (1982 apud NUCCI, 2008) define o sistema de espaços livres como sendo o conjunto de espaços urbanos ao ar livre, destinados ao pedestre para descanso, passeio, prática esportiva e outras atividades de lazer.

Vtm $=\Sigma$ sup. viario transporte motorizado $\left(\mathrm{m}^{2}\right) /$ superficie total de viario $\left(\mathrm{m}^{2}\right)$

$V p p=\Sigma$ sup. viaria peatonal y otros usos $\left(\mathrm{m}^{2}\right) /$ superficie total de viario $\left(\mathrm{m}^{2}\right)$

\section{- Qualidade e Habitabilidade dos espaços públicos (conforto térmico e acústico):}

Este indicador serve para identificar a porcentagem de tempo de uso útil do espaço público em que uma pessoa se encontra em condições críticas tolerantes ou de conforto térmico em função das características dos materiais, da configuração espacial e das condições do microclima.

Porém, para avaliar o conforto térmico dos pedestres nos espaços externos seria necessário pelo menos um estudo de sombras e da ventilação natural e para isto necessitariam informações detalhadas sobre o projeto, seu entorno e o clima da região.

Como o objetivo deste estudo é uma avaliação ampla e qualitativa dos projetos urbanos observou-se algumas características desses que favorecem ou prejudicam o conforto térmico e acústico dos espaços livres como, por exemplo: presença de árvores ou elementos arquitetônicos que proporcionem sombra nos espaços livres, presença de vegetação, distância de avenidas e vias carregada de tráfego motorizado ou outra fonte de ruído e poluição, etc.

Além disso, observou-se o potencial do desenho urbano com relação ao acesso ao sol e a luz e à permeabilidade ao vento, visando o conforto térmico e a dispersão de poluente.

Outro fator de qualidade do espaço livre é a sua acessibilidade. Os espaços livres localizados em ruas e avenidas com trânsito intenso têm o seu acesso dificultado, e, sendo assim, a simples presença do espaço livre não garante a sua utilização. 
- Quantidade e acesso dos cidadãos às áreas verdes:

Llardent (1982 apud NUCCI, 2008) define área verde como qualquer espaço livre em que predominem as áreas plantadas com vegetação. Michel Saillard (1982 apud NUCCI, 2008) diz que espaço verde é o espaço público ou privado que oferece com toda a segurança aos usuários ótimas condições, tanto no que se refere a prática de esportes ou jogos como a passeios, momentos de descontração e repouso, e onde o elemento fundamental de composição é a vegetação.

Llardent (1982 apud NUCCI, 2008) afirma que é difícil fixar índices de vegetação ideal em $\mathrm{m}^{2} /$ habitante, e que isso seria pouco aproveitável, pois poderia ser útil para certo tipo de cidade, e para outro não. Mesmo assim ele e outros autores propõem alguns índices por habitante.

Porém para esta avaliação será observado à proporção de área verde com relação a toda a área do projeto e a sua distribuição.

A proximidade da população aos espaços verdes é um parâmetro que avalia sua qualidade, já que esta depende de que a população possa desfrutar cotidianamente ou com regularidade destes espaços. O objetivo é que todo cidadão disponha de acesso a uma zona verde a uma distância que possa ser percorrida em menos de cinco minutos a pé.

\section{Relevância dos indicadores:}

Limitação da superfície de viário público destinado ao transporte motorizado, com o objetivo de reduzir a hegemonia do automóvel, favorecendo o transporte público e os outros modos de transporte a curta distância. Desta maneira, reduz o consumo de energia e melhoram-se as condições ambientais relacionadas aos espaços públicos, como ruído e a contaminação do ar.

Rueda (2006) recomenda um máximo de $25 \%$ da superfície de viário público destinados ao transporte motorizado e o restante, um mínimo de 75\% para o pedestre e outros usos do espaço público.

Se o planejamento da cidade propõe o adensamento e o modelo de forma urbana mais compacta, a população vai poder se deslocar a pé e de bicicleta, necessitando de espaço próprio para esta atividade. Além disto, a população residente não vai perder tanto tempo com o deslocamento, tendo mais tempo para o lazer e com isso é necessário a criação de espaços para que essa população ocupe seu tempo livre de forma saudável. 
Para que estes espaços livres sejam habitáveis eles devem ser projetados de maneira a propiciar o conforto térmico e acústico do pedestre.

Para a melhoria da habitabilidade destes espaços, a presença de vegetação tem um papel muito importante. As áreas verdes podem contribuir para a melhoria do microclima e da qualidade do ar no seu entorno, garantindo um pouco mais de qualidade ambiental na cidade

Em climas quentes, a presença de vegetação na cidade contribui para a melhoria do clima urbano em geral, aumentando a umidade do ar e reduzindo a temperatura do ar, por meio da evapotranspiração. Somado a isso, a vegetação reduz o stress térmico e minimiza os efeitos da ilha de calor.

No verão vegetação através das árvores, também pode propiciar sombra em áreas livres e nas fachadas das edificações, e no inverno por meio da formação de uma barreira, pode proteger os pedestres dos ventos frios.

Com relação à qualidade do ar, a vegetação reduz a poluição por meio da retenção de partículas de poeira na superfície da folha e das trocas gasosa, liberando o oxigênio e absorvendo o dióxido de carbono, dióxido de nitrogênio e dióxido de enxofre.

Outros benefícios das áreas verdes são o aumento das áreas permeáveis da cidade, favorecendo a absorção da água da chuva e o aumento da diversidade biológica nas áreas urbanas

Além dos impactos ambientais positivos gerados pelos espaços verdes, podem-se apontar também diversos benefícios sociais tais como a estética urbana e efeitos psicológicos nos seus habitantes.

Estudos na área de psicologia ambiental demonstraram que a presença de vegetação na cidade afeta as reações emocionais das pessoas; elas ficam mais amigáveis, mais cooperativas, menos deprimidas. A vegetação também influencia a qualidade de vida urbana, sugerindo um ambiente melhor, mais seguro e mais limpo para se viver.

Os espaços livres proporcionam áreas de lazer isoladas do stress da vida urbana. O lazer é importante para o bem-estar e prevenção de doenças. Essas atividades iniciam um processo de liberação de endorfinas que irão atuar em todos os sistemas humanos. Além dos benefícios físicos o lazer apresenta grande valor simbólico (BURJATO, 2004, p.10). 
Promover a prática de atividades de lazer está previsto na legislação brasileira como direito social e pode representar economia para os cofres públicos, além de ampliar a qualidade de vida dos cidadãos (BURJATO, 2004, p10).

Comunidades que conseguem oferecer boas condições de utilização do tempo livre se beneficiam com maior número de indivíduos saudáveis e produtivos, e conseqüente ampliação do desenvolvimento social.

Em resumo, a vegetação ajuda a minimizar os efeitos antropológicos gerados pelo desenvolvimento das áreas urbanas.

\section{Categoria 04 - Indicadores relacionados com a Eficiência no uso dos Recursos Naturais água e energia}

Objetivo: Reduzir a dependência energética dos edifícios através da minimização da necessidade de consumo e do uso de energias renováveis (captadores térmicos e fotovoltaicos).

Estabelecer estratégias distintas segundo as tipologias edificatórias.

Otimizar a demanda de água doméstica, pública e comercial a partir da aplicação de medidas de economia.

Aproveitamento das águas não potáveis procedente do âmbito urbano em seus três níveis: atmosfera, superfícies e subsolo. Isto implica no aproveitamento das águas pluviais, residuais, subterrâneas e outras possíveis fontes vinculadas ao entorno urbano.

\section{Indicadores:}

\section{- $\quad$ Eficiência energética:}

Este indicador serve para identificar a adoção de estratégias arquitetônicas para o melhor desempenho térmico e luminoso das edificações com o objetivo de reduzir o seu consumo de energia elétrica, através da minimização do uso de equipamentos de calefação e ar condicionado e iluminação artificial.

Através do desenho urbano e da arquitetura, o objetivo é reduzir o consumo de energia em comparação com as referências locais.

- Geração de energia renovável: 
Verifica-se o incentivo a geração e uso de energias renováveis como, por exemplo: a aplicação de painéis fotovoltaicos nas fachadas e coberturas para o aproveitamento da energia solar, o uso de captadores térmicos para aquecimento, também por meio da energia solar, a instalação de turbinas para geração de energia eólica, etc.

\section{- $\quad$ Consumo de água:}

Este indicador serve para identificar a adoção de estratégias para aproveitamento das águas pluviais e reuso das águas residuais e demais fontes vinculadas ao entorno urbano. Além disto, verificar o incentivo à redução do consumo de água.

\section{Relevância dos indicadores:}

A importância destes indicadores está em reduzir o impacto gerado pelo processo de urbanização, no que diz respeito ao aumento da demanda dos recursos naturais, água e energia e, aumento da geração de resíduos sólidos.

Sendo assim, os novos projetos urbanos devem considerar os ciclos ecológicos da água e da energia.

\section{Categoria 05 - Indicadores relacionados com a Diversidade Urbana e Expressão} Arquitetônica:

Objetivo: Favorecer a diversidade de usos, rendas, cultura e étnica.

Favorecer a acessibilidade espacial aos serviços básicos (saúde, educação, emprego, etc.), ou seja, acesso a pé ou em veículos de duas rodas a rede básica de equipamentos e serviços.

Sintetizar arquitetura, tecnologia e natureza visando conseguir um bom desempenho ambiental e uma identidade, uma expressão arquitetônica.

\section{Indicadores:}

\section{- Diversidade de usos:}

Desenhar uma cidade de distancia curta, na qual os serviços básicos sejam acessíveis espacialmente e economicamente a todos os cidadãos, incluindo a população vulnerável por qualquer circunstância.

\section{- Diversidade Social}


$\mathrm{VP}=\Sigma$ habitações protegidas / total habitações construídas

Rueda (2008) recomenda para os novos projetos urbanos uma reserva de $30 \%$ das habitações para baixa renda ${ }^{48}$, assegurando a distribuição equilibrada de este tipo de moradia no conjunto da cidade, e contribui para a coesão social.

\section{- $\quad$ Diversidade edificatória e Expressão arquitetônica:}

Integração entre arquitetura, tecnologia, natureza e diversidade.

\section{Relevância dos indicadores:}

Os serviços urbanos básicos constituem para a cidadania um capital social fixo e valioso, tanto como suporte físico para a prestação de serviços coletivos, como por seu papel estruturante na organização da cidade.

A acessibilidade a esses serviços básicos informa o grau de compactação urbana e de mistura de usos na cidade. Um equilíbrio na distribuição desses serviços reduz a necessidade de deslocamento e incentiva a justiça social na distribuição dos recursos.

Além disso, a diversidade de usos está diretamente ligada à vitalidade da urbana, essencial para a segurança dos cidadãos e para a geração de receitas, entre outros aspectos sócio-econômicos.

Garantir o solo suficiente para habitações de interesse social, denominada em inglês "affordable housing" e, em espanhol "viviendas asequibles" ou protegias, atendendo a necessidade dos coletivos que não dispõem dos recursos econômicos suficiente.

Incentivar novas tipologias de habitação social, assim como diversificar a oferta de moradias, ampliando os tipos e formas, para possibilitar uma gama maior de produtos.

Promover a coesão Social através da mistura de usos e de rendas e da ocupação do espaço público por pessoas sem importar com sua condição social.

Com relação à diversidade de tipologias arquitetônicas Higueras (2009) comenta que esse é um atributo de sustentabilidade na medida em que implica: a variedade de formas

\footnotetext{
48 Habitação de interesse social, denominada em inglês "affordable housing", em espanhol habitação de promoção pública, vivienda de promoción pública ou viviendas asequibles ou protegidas, que são habitações com o preço abaixo do mercado e com condições reguladas de acesso, compra ou aluguel.
} 
arquitetônicas que ajuda a estruturar o espaço, variedade de tipologias habitacionais; variedade de pessoas e; melhor adequação das condições locais.

Os projetos devem ser avaliados tanto pelos aspectos ambientais quanto pela qualidade arquitetônica.

A Tabela 11 apresenta um resumo das categorias e indicadores estabelecidos para avaliação qualitativa dos projetos urbanos contemporâneos.

Tabela 11: Quadro resumo de indicadores de sustentabilidade urbana

\section{Categoria 01 - Indicadores relacionados com a Compacidade}

Densidade edificada

Compacidade absoluta

Proximidade de usos e funções urbanas

\section{Categoria 02 - Indicadores relacionados com a Mobilidade}

Acesso ao transporte público

Incentivo ao transporte sustentável (a pé e de bicicleta)

Inibir o uso de automóveis

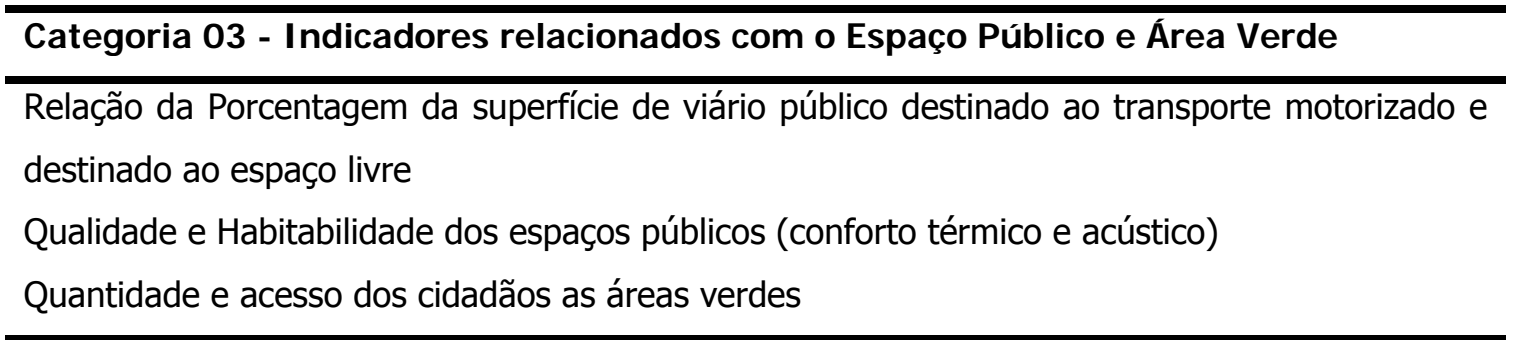

Categoria 04 - Indicadores relacionados com a Eficiência no uso dos Recursos

Naturais, água e energia

Eficiência energética

Geração de energia renovável

Consumo de água

Categoria 05 - Indicadores relacionados com a Diversidade Urbana e Expressão

Arquitetônica:

Diversidade de usos

Diversidade Social

Diversidade edificatória e Expressão arquitetônica 
"O desenvolvimento sustentável também necessita tanto de pragmatismo como de idealismo. É preciso pessoas que possam nos mostrar em que direção nós podemos estar nos dirigindo, aqueles que possam criar experimentos e projetos pilotos, em certos momentos de tamanhos pequenos e em outros, de tamanhos grandes, os quais superarão 0 medo que temos do desconhecido e que nos fará capaz de afrouxar nossos laços de uma era, uma geração e, de fato, com os hábitos trazidos com a revolução industrial como um todo. Projetos $e$ experimentos que nos darão confiança para olhar para frente, para um novo milênio, o qual nós podemos estar certos de que será o milênio da escassez dos recursos naturais. Grande parte do planeta já está poluído e até a metade deste século que se inicia, haverão dez bilhões de habitantes na Terra, habitantes que o planeta terá que sustentar. Isto é apenas concebivel com sucesso se nós utilizarmos tanto nosso olhar visionário como nosso pragmatismo." (Ekins, apud GONÇALVES, 2003) 


\section{CAPITTULO 3 - ASPECTOS DA SUSTENTABILIDADE URBANA NOS

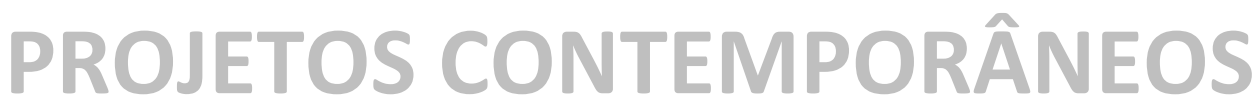

A incorporação dos princípios da sustentabilidade ambiental no projeto urbano pode ser uma solução para minimizar os impactos causados pelo processo de urbanização e aumento da densidade populacional, construindo cidades com qualidade e que viabilizem a existência de sociedades mais sustentáveis

Para isso, a preocupação com o meio ambiente deve ser um princípio norteador do projeto urbano e a dimensão ecológica ${ }^{49}$ deve ser inserida no processo de projeto.

Diante disso, é necessário responder as seguintes perguntas: Quais são os conceitos da sustentabilidade ambiental que devem ser incorporados ao projeto urbano e como isto pode ser feito?

Buscando as respostas a essas questões na aplicação prática, este capítulo apresenta um estudo de projetos urbanos que têm uma abordagem mais recente que clama por preocupações ambientais.

O objetivo principal é apresentar intervenções urbanas mais conscientes com relação ao meio ambiente e que, por essa razão, trouxeram benefícios à cidade e a seus residentes. Para isso, foram selecionados alguns projetos urbanos de diferentes partes do Continente Europeu e da China e avaliados qualitativamente com base em alguns indicadores de sustentabilidade ambiental que tem uma relação direta com a forma urbana. ${ }^{50}$

49 ANDRADE, 2007. Dimensão ecológica - baseadas em valores da relação entre o homem e a natureza que considera a espécie humana como parte dos ecossistemas naturais.

50 Os indicadores adotados se baseiam, principalmente, nos indicadores ambientais urbanos desenvolvidos para Sevilha. Fonte: RUEDA, Salvador. Plan especial de indicadores de Sostenibilidad de la Actividad Urbanística de Sevilla. Barcelona, 2006. Disponível em <http://www.bcnecologia.net> Acesso em mar. de 2008. 
No capítulo anterior foram definidas as variáveis ambientais e esses indicadores, possibilitando elencar os aspectos básicos que devem ser considerados na elaboração de projetos urbanos que visam diminuir o impacto ambiental do processo de urbanização.

Além disso, através das análises qualitativas é possível apontar soluções de sucesso que podem ser consideradas exemplos de aplicação dos princípios da sustentabilidade ambiental no projeto, sendo referências para elaboração futuras intervenções urbanas.

Como resultado deste capítulo pretende-se demonstrar que o projeto urbano baseado nos princípios de sustentabilidade pode gerar cidades de maior qualidade ambiental, minimizando os impactos ao meio natural se comparadas as nossas cidades atuais. ${ }^{51}$

Os projetos dos ecobairros aqui apresentados, por exemplo, comprovam que, de fato, os projetos urbanos adequados ao meio ambiente reduzem o consumo de água, de energia e a contaminação, proporcionando um melhor microclima local e um bem estar para a população, decorrente de uma melhora na qualidade de vida (HIGUERAS, 2007, p.17).

Além disso, esses projetos podem apresentar grande coesão conceitual, servindo como novo paradigma para as intervenções urbanas contemporâneas.

Da mesma maneira que é possível identificar boas soluções projetuais do ponto de vista da sustentabilidade, a avaliação qualitativa dos aspectos relacionados à sustentabilidade ambiental urbana também permite realizar uma visão crítica de alguns projetos que vendem a imagem de sustentáveis, "Green", "ecos", apontando para as deficiências na inserção de requisitos básicos de um desenho urbano comprometido com meio ambiente. $^{52}$

Para este estudo foram analisados alguns projetos urbanos, sendo que treze desses foram avaliados qualitativamente sob os temas apresentados no item 2.3.2 do capítulo anterior, que são: Compacidade; Mobilidade, Espaço Público e Área Verde; Eficiência no uso dos recursos naturais, água e energia e; Diversidade Urbana e Expressão Arquitetônica.

\footnotetext{
${ }^{51}$ Os problemas das nossas cidades atuais são apresentados na introdução da Tese e a caracterização de qualidade ambiental é apresentada no Capítulo 02.

52 Os requisitos básicos de um desenho comprometido com o meio ambiente são apresentados no Capítulo 02 da Tese.
} 
Com enfoque nessas questões foram estudados projetos em duas escalas, da cidade e do bairro. Com relação às intervenções urbanas escala de bairro, foram selecionadas experiências atuais que se destacam por apresentarem estratégias de projeto que visam o menor impacto ao meio natural, trazendo benefícios ao ambiente construído e a seus usuários. Ou seja, projetos que têm algo que se deve aprender com relação à aplicação dos princípios da sustentabilidade ambiental no projeto urbano.

Muitos dos projetos selecionados são apresentados em algumas referências bibliográficas específicas do tema abordado como, por exemplo: Ruano (2000), Gauzin-Müller (2001), Rogers (2001), Beatley (1999) e EMVS (2005).

Além disso, durante o desenvolvimento da pesquisa foram realizadas entrevistas com arquitetos, engenheiros e demais profissionais da área, que forneceram diversas informações sobre os projetos que foram e estão sendo desenvolvidos e destacaram alguns considerados referência internacional e que deviam ser estudados.

O objetivo era selecionar uma amostra significativa e reduzida com relação ao número de projetos, porém, ampla e diversificada com relação aos seguintes aspectos:

- Localização: cidades de economias em desenvolvimento; cidades de referencia em desenho urbano ou que vem adotando medidas em prol de uma sustentabilidade urbana maior;

- Contexto urbano: vazios urbanos incluindo vazios físicos e áreas degradadas com potencial de adensamento; centros urbanos consolidados com a infra-estrutura subutilizada e áreas periféricas ligadas ao centro urbano através de um sistema de transporte público eficiente e diversificado;

- Contexto climático: projetos em diferentes climas com diferentes necessidades;

- Escala urbana: escala de bairro e escala metropolitana e, principalmente, projetos que trouxeram benefícios para um escala maior que a de intervenção;

- Finalidade: projetos que visam atender as exigências humanas do novo século, sendo desenvolvidos com base nos princípios da sustentabilidade ambiental; adensamento de centros urbanos consolidados e com infra-estrutura subutilizada ou projetos de recuperação de áreas degradadas e em desuso, em busca de um maior grau de sustentabilidade urbana; intervenções urbanas que buscam atender a um demanda habitacional, ou projetos que, simplesmente, objetivam promover 
uma experiência e uma discussão de idéias em torno das necessidades urbanas do novo século, ou qual o modelo de ocupação adequado para gerar espaços urbanos de qualidade, com um menor impacto ambiental;

- Caráter: projetos com caráter inovador; experimental; paradigmático; tradicional ou expressivo arquitetonicamente;

- Repercussão: projetos premiados; projetos polêmicos e projetos que de alguma maneira se tornaram exemplos para outras intervenções.

Os projetos escala de bairro foram agrupados de acordo com o "tipo" de intervenção: projetos urbanos desenvolvidos a partir da realização de exposições internacionais e eventos esportivos; projetos de recuperação de áreas degradas e; projetos de novos bairros "mais sustentáveis", conhecidos como "ecobairros".

As exposições internacionais e os eventos esportivos, na maioria das vezes, funcionam como catalisadores para a realização de grandes intervenções urbanas. Em muitos casos, o projeto do evento é o incentivo necessário para a resolução de problemas da cidade com relação, principalmente, à infra-estrutura e às áreas degradadas, resultando na transformação nos locais onde são implantados, com benefício que ultrapassam esses limites.

Com relação aos projetos de recuperação de áreas degradadas, esses representam uma grande oportunidade de melhorar o grau de sustentabilidade das cidades. Muitas cidades do mundo que se desenvolveram com a industrialização, como, por exemplo, São Paulo, Buenos Aires, Londres e Rotterdam sofreram um processo de diminuição da função industrial nos últimos 30 anos, deixando grandes áreas ociosas ou subutilizadas e degradadas ambientalmente. Diante disso, a implantação de projetos nesses "vazios urbanos $^{\prime \prime 53}$ são importantes para melhorar a dinâmica da cidade, atender a uma demanda de adensamento e transformar essas áreas urbanas já consolidadas, trazendo, na maioria das vezes, benefícios sociais, econômicos e ambientais para toda a cidade.

Já os ecobairros destacam-se por apresentar de maneira clara o comprometimento com o meio natural, através da incorporação dos princípios da ecologia urbana ao projeto. Os

\footnotetext{
${ }^{53}$ Conceito de vazio urbano será explicado no ítem 3.2 deste capítulo.
} 
ecobairros são assentamentos urbanos relativamente recentes, nos quais o cuidado com a conservação e integração com o meio ambiente são temas estruturantes.

Vale destacar que é na escala do bairro ou aglomerado onde são desenvolvidas as relações da forma urbana e os elementos estruturadores do espaço, com sua respectiva resposta ambiental, por meio do conhecimento do local (ANDRADE, 2005, p.188).

Através de uma intervenção pontual, todos esses projetos trouxeram, de alguma maneira benefícios para a cidade e seus residentes, uns mais outros menos. Além disso, eles apresentam estratégias de projeto que podem ser reaplicadas em outros casos, desde que seja considerado o contexto local.

Um dos grandes problemas dos projetos desvinculado do seu contexto local é a não adequação ao clima, ou seja, projetos considerados referência muitas vezes são implantados em diversas cidades do mundo independente da diversidade das condições locais. Isso normalmente gera problemas de desconforto ao homem e o consumo excessivo de recursos.

Existem quatro grandes zonas climáticas no mundo, de acordo com a classificação de A.N.STRAHLER (clima frio, clima temperado, clima quente úmido e clima quente seco). Ou de uma forma mais específica, cinco tipos de clima (clima tropical, clima árido, clima temperado ou clima temperado quente, clima continental ou clima continental frio e clima glacial), que se dividem em 11 subtipos, de acordo com a classificação climática de Köppen-Geiger. ${ }^{54}$ Isso sem contar que em uma mesma cidade existem diferentes microclimas.

Diante dessa diversidade fica claro a necessidade do conhecimento do contexto climático tanto para desenvolvimento de projetos, quanto para sua avaliação. O conhecimento do clima local e a correta avaliação de um diagnóstico climático permitem definir as estratégias projetuais básicas para o bom desempenho das edificações e do conjunto urbano.

\footnotetext{
${ }^{54}$ No anexo é apresentada essas duas classificações dos climas do mundo, Classificação de A.N.STRAHLER e Classificação Climática de Köppen-Geiger, com os mapas especificando as localidades.
} 
Com exceção do ecobairro Viikki, localizado na Finlândia, a uma latitude de $61^{\circ} 55^{\prime} \mathrm{N}$, os demais projetos foram propostos para cidades situadas nas latitudes entre $30^{\circ} \mathrm{e} 60^{\circ} \mathrm{N}$, zona de clima Temperado, segundo a classificação A.N.STRAHLER. ${ }^{55}$

Em região de clima temperado, tanto o período frio quanto o quente representam uma parte substancial do ano e, por tanto, é necessário estabelecer certo equilíbrio estacional mediante medidas que permitam aproveitar os recursos naturais, sol e vento, em determinada época do ano e em proteger dos mesmos em outra.

Segundo a classificação climática de Köppen-Geiger, a Finlândia apresenta um clima temperado frio (ou continental), com temperatura do ar em torno de $10^{\circ} \mathrm{C}$ no mês mais quente e abaixo de zero no mês mais frio. Nesses locais onde o inverno é muito frio, a implantação das edificações deve privilegiar as áreas ensolaradas e protegidas dos ventos. ${ }^{56}$ Deve-se reduzir ao máximo as trocas entre ambientes externos e internos, já que as perdas de calor por convecção são muito altas devido às baixas temperaturas exteriores. Por isso, as edificações devem ser compactas e apresentar superfícies mínimas de exposição. As vegetações não devem ser implantadas muito perto das edificações para não aumentar a umidade. Apesar das estações de verão e inverno serem bem definidas, o verão é bastante ameno, ao contrário de outros países do continente europeu.

Cidades localizadas na Espanha ou em Portugal, por exemplo, apresentam um verão mais quente, com elevada temperatura do ar e baixa umidade relativa. Esses países apresentam um clima mediterrâneo ou clima temperado úmido com verão seco, segundo Köppen-Geiger. Esse clima apresenta estações de verão e inverno bem definida e uma temperatura média do ar compreendida entre $-3^{\circ} \mathrm{C}$ e $18^{\circ} \mathrm{C}$ no inverno. ${ }^{57}$ Para esse clima recomenda-se insolação e proteção contra os ventos dominantes no inverno e sombreamento e ventilação no verão. As perdas de calor por evaporação também é uma estratégia possível, devido o fator baixo de umidade relativa do ar.

Deve-se destacar que, em Barcelona, esse clima não é tão característico como na cidade de Sevilha, também na Espanha, já que em Barcelona a umidade relativa do ar é mais

\footnotetext{
${ }^{55}$ Ver anexo.

${ }^{56}$ Disponível em: < http://pt.wikipedia.org> Acesso em: agosto de 2009.

57 idem
} 
elevada devido à presença do mar mediterrâneo, girando em torno de $65 \%$ nos meses mais críticos.

Segundo a classificação climática de Köppen-Geiger, Londres e demais cidades do Reino Unido possuem um clima temperado úmido com verão temperado. ${ }^{58}$ De acordo com essa classificação e com o diagnóstico climático ${ }^{59}$, verifica-se que durante o inverno a temperatura do ar é muito baixa, em torno de $5^{\circ} \mathrm{C}$, e a uma umidade relativa é alta, cerca de $80 \%$ no mesmo período, o que implica em uma necessidade de aquecimento. ${ }^{60}$ Nos períodos de verão os riscos de desconforto são trazidos principalmente pelas altas umidades e não pela temperatura do ar que é amena, cerca de $25^{\circ} \mathrm{C}$. Com isso, a estratégia recomendada é a ventilação (GONÇALVES, 2003).

As cidades da Holanda e as cidades do lado oeste da Alemanha apresentam condições climáticas semelhantes às do Reino Unido. Já as cidades do lado leste da Alemanha e as da Áustria apresentam um clima temperado frio com inverno seco e com verão temperado. ${ }^{61}$

A cidade de Shangai, na China, apresenta um clima subtropical úmido, ou seja, uma transição entre o clima tropical de menor latitude e o temperado frio de latitude maior (Cfa e Cfb, segundo classificação de Köppen-Geiger). ${ }^{62}$ As temperaturas no inverno ficam por volta dos $6^{\circ} \mathrm{C}$, com umidade relativa em torno de $65 \%$; já no verão, além das altas temperaturas em torno dos $28^{\circ} \mathrm{C}$, a umidade relativa é alta, em torno de $75 \% .^{63} \mathrm{Com}$ isso, para as edificações o condicionamento ambiental artificial é necessário em grande parte do ano, enquanto estratégias de sombreamento e massa térmica interna continuam

\footnotetext{
58 idem

59 Diagnóstico climático extraído de GONÇALVES, 2003

60 Disponível em: <http://www.weatherbase.com/> e em <http://www.worldclimate.com/> Acesso em agosto de 2009.

${ }^{61}$ Disponível em: < http://pt.wikipedia.org> Acesso em: agosto de 2009.

62 idem

63 Disponível em: <http://www.weatherbase.com/> e em <http://www.worldclimate.com/> Acesso em agosto de 2009.
} 
sendo fundamentais para a redução do ganho de calor. Além disso, o sombreamento é essencial para o conforto do pedestre em espaços externos.

De uma maneira geral, os projetos aqui apresentados tiveram uma preocupação em adotar estratégias de adequação ao clima local, visando principalmente à eficiência energética, já que nos países para onde foram propostas tais intervenções urbanas, a matriz principal geradora de energia está relacionada, entre outros fatores, à emissão de $\mathrm{CO}_{2}$.

A redução do consumo de energia elétrica é um dos principais objetivos em quase todos os projetos e não está ligada somente à eficiência energética das edificações, mas também ao modelo de ocupação urbana, à mobilidade urbana (através de um sistema eficiente de transporte público e do incentivo de outros modos de locomoção) e à geração e uso de energia renovável.

A qualidade e a habitabilidade dos espaços públicos também são preocupações presentes em quase todos os casos e que, de alguma forma, conduzem o projeto urbano.

Com relação aos aspectos sociais e econômicos, os projetos se divergem, visto que alguns desses incentivam a construção de habitações mais acessíveis a classes menos favorecidas e a adoção de usos mistos, enquanto outros, em minoria, apresentam um caráter exclusivista, não considerando a população local ou a diversidade social e econômica.

Diferente dos projetos escala de bairro, os projetos de novas cidades que aqui são apresentados foram selecionados, principalmente, por três motivos: primeiro, por serem projetos recentes e de grande repercussão embasada nas suas preocupações ambientais; segundo, por terem sido desenvolvidos por escritórios de atuação internacional e, terceiro, por verificar que apesar disso, alguns desses projetos não atendem aos requisitos básicos da sustentabilidade ambiental urbana ${ }^{64}$, tornando exemplos questionáveis sob esse ponto de vista.

Nesta pesquisa os projetos de novas cidades são abordados, porém não são avaliados, visto que não se tinha informação suficiente para avaliar todos os aspectos estabelecidos.

\footnotetext{
${ }^{64}$ Os princípios básicos da sustentabilidade ambiental são apresentados no capitulo 02 da Tese.
} 
Além disso, acredita-se que, sob o enfoque da pesquisa, os projetos de menor escala construídos em áreas urbanas já consolidadas ou próximos a elas são melhores exemplos que os projetos de novas cidades, que partem do zero, implantados em áreas verdes, "greenfield", ou no meio do deserto.

A Tabela 12 apresenta a lista dos projetos avaliados, suas localizações e seus status.

Tabela 12: - Lista dos Projetos Urbanos estudados

\begin{tabular}{|c|c|c|c|}
\hline ESCALA DE BAI RRO & PROJ ETO & LOCALIZAÇÃO & STATUS \\
\hline \multirow{4}{*}{$\begin{array}{c}\text { EXPOSI ÇÕES } \\
\text { I NTERNACIONAIS E } \\
\text { EVENTOS } \\
\text { ESPORTIVOS }\end{array}$} & Expo Sevilha & Sevilha, Espanha & construído \\
\hline & Expo Lisboa & Lisboa, Portugal & construído \\
\hline & Kronsberg & Hannover, Alemanha & construído \\
\hline & Vila Olímpica Barcelona & Barcelona, Espanha & construído \\
\hline \multirow{4}{*}{$\begin{array}{c}\text { RECUPERAÇÃO DE } \\
\text { BAI RROS } \\
\text { DEGRADADOS }\end{array}$} & Potsdamer Platz & Berlin, Alemanha & construído \\
\hline & Greenwich & Londres, Reino Unido & construído \\
\hline & Elephant and Castle & Londres, Reino Unido & projeto \\
\hline & Lu Zia Sui & Shangai, China & projeto \\
\hline \multirow{5}{*}{ ECOBAI RROS } & Ecolonia & Alphen, Holanda & construído \\
\hline & $G W L$ & Amsterdam, Holanda & construído \\
\hline & Viikie & Helsinki, Finlândia, & construído \\
\hline & Bedzed & Londres, Reino Unido & construído \\
\hline & Solar City & Linz, Austria & construído \\
\hline
\end{tabular}

As avaliações foram realizadas com base nas informações de acesso público, em relatórios de projeto e entrevistas com os projetistas. Por essa razão, alguns indicadores que necessitavam de informações e estudos mais específicos não foram considerados.

Vale registrar a dificuldade de obter informações sobre alguns projetos, principalmente dados técnicos. De uma maneira geral, os projetos são descritos de forma ampla e superficial e pouco se fala dos critérios ambientais adotados na fase de desenvolvimento do projeto, mesmo quando esses existem. Isso pode ser explicado pelo fato dos projetos quando finalizados serem bastante recentes, assim como o desenvolvimento das 
pesquisas nesta área. Por mais que existam exemplos de projetos urbanos comprometidos com o meio natural e o conforto ambiental do usuário no decorrer da história, a inserção da camada ambiental no processo de projeto ainda é muito recente.

Além disso, percebe-se a necessidade de filtrar a veracidade das informações disponíveis, já que muitas destas são apresentadas apenas como marketing para a valorização projeto.

A Tabela 13 apresenta a legenda dos quadros-resumo das avaliações qualitativas dos projetos urbanos.

Tabela 13: Legenda da avaliação qualitativa dos projetos urbanos

Indicadores relacionados com a Compacidade

$\mathbf{X}$ não apresenta nenhum indicador de modelo compacto

apresenta um indicador que propicia o modelo compacto

apresenta dois indicadores propicia o modelo compacto

apresenta três indicadores propicia o modelo compacto

Indicadores relacionados com a Mobilidade / Espaço Público e Área Verde / Eficiência / Diversidade Urbana

$\mathbf{X}$ não atende a nenhum indicador / requisito

atende a um indicador / requisito

atende a dois indicadores / requisitos

atende aos três indicadores / requisitos 


\subsection{Projetos de Exposições Internacionais e Eventos Esportivos}

As exposições internacionais foram um acontecimento típico do século XIX e das primeiras décadas do século XX e sempre tiveram um importante papel no desenvolvimento das cidades.

Desenvolvidas na França a partir de 1798, as exposições nacionais e internacionais inscreveram ao longo da história da arquitetura e do urbanismo uma série de estereótipos arquitetônicos, como o pavilhão de cristal de John Baxton, construído para a exposição de Londres de 1851. No início, essas exposições tinham como principal função exibir novas tecnologias e descobertas. Atualmente, com o desenvolvimento dos meios de comunicação, os países perderam a necessidade de um espaço físico para apresentar seus avanços tecnológicos. Sendo assim, foi necessário rever o conceito das exposições, tornando-as muito mais interessantes pela sua organização do que pelo objeto de exposição.

Fuão (1992) comenta:

"Afora os objetivos em si mesmos, as exposições universais sempre foram um meio de conseguir outros fins. Sob o pretexto de "expor", ocuparam terrenos, abriram-se avenidas, expandiram e transformaram a cidade. Empreendimentos estes que possivelmente, em situações normais, seriam totalmente impraticáveis, tais como foram as intervenções de Haussmann em Paris para a exposição universal de 1885, promovida por Napoleão III."

Assim como as exposições internacionais, as realizações de eventos esportivos, na maioria das vezes, vieram acompanhadas de um plano urbanístico fundamental para o seu sucesso e para uma posterior transformação na parte da cidade onde esses são implantados.

Tanto as exposições quanto os eventos esportivos podem ser propostos de duas maneiras com relação à cidade. Segundo Sales (1999, p78), a primeira consiste em situar no âmbito metropolitano ou Municipal as instalações necessárias a partir de critérios econômicos, tanto para construção dos equipamentos como das infra-estruturas. Ou realizar obras monumentais, que se destacam na paisagem urbana, deixando a cidade com seus problemas. Exemplos desse tipo de proposta são os projetos Olímpicos da Cidade do México, Mônaco e Montreal e a Expo de Sevilha, que realizou obras 
monumentais no setor periférico da cidade e o projeto para Los Angeles, que dispersou as instalações olímpicas em toda região metropolitana sem se preocupar com as permanências e conseqüências dessas transformações.

Por outro lado, a segunda forma é propor instalações e infra-estruturas de acordo com as necessidades e prioridades de um programa de atuação urbanística, tentando superar algumas deficiências ou acelerar transformações já discutidas em áreas degradadas da cidade. (SALES, 1999, p78). Como exemplos destacam-se a Expo de Lisboa, o projeto para a península de Greenwich e Londres, as duas exposições universais de Barcelona e o projeto dos jogos olímpicos de 1992, também em Barcelona, que propuseram a renovação de setores obsoletos da cidade, modificando a imagem e o uso dessas áreas.

Quase sempre esses projetos trazem benefícios econômicos, sociais e ambientais para o local de implantação, estendendo, em muitos casos, para toda a cidade.

\subsubsection{Expo Sevilha}

\section{Dados técnicos:}

Projeto: Expo Sevilha

Localização: Sevilha, Espanha - Latitude: $37^{\circ} 22^{\prime} \mathrm{N}$

Arquiteto Projeto Urbano: Julio Cano Laso

Cliente: Comissão de Exposições Internacionais, Prefeitura de Sevilha

Área: 215 hectares

Uso: lazer

Fase: finalizado em 1992

\section{Descrição do Projeto:}

A Exposição de 1992 foi realizada na cidade de Sevilha, Espanha. Ela foi implantada em uma área 215 hectares, desocupada e periférica da cidade, conhecida como Ilha da Cartuja.

O objetivo e pretexto fundamental era a celebração de 500 anos do descobrimento da América. Porém, devido a críticas neocolonialistas, redefiniram o tema central como a era dos descobrimentos. A ênfase da expo passou a ser novas fronteiras da ciência e da tecnologia, caminhando para um projeto mais inovador. 
Assim como todo projeto urbano, é importante entender o contexto político e econômico da época, quando a Espanha depois de anos de ditadura estava querendo aparecer para o continente Europeu.

Em 1986, convocou-se um concurso para o projeto urbano da exposição. Dos vinte projetos apresentados, dois foram vencedores: o da equipe do arquiteto José Antonio Fernandez Ordoñez e outro idealizado pela equipe do arquiteto Emílio Ambasz.

José Antonio Fernandez Ordoñez desenhou um conjunto de pavilhões sobre uma malha ortogonal, com um parque linear em um lado do rio Guadalquivir e uma esfera gigante de $100 \mathrm{~m}$ de diâmetro como modelo planetário. O projeto de Emílio Ambasz era mais paisagístico, com o protagonismo dos cursos d'água. Apesar de distintas, ambas as propostas apresentaram-se desvinculadas da zona urbana, assim como também do rio ali presente.

O projeto executado foi desenvolvido por uma nova equipe, coordenado pelo arquiteto Julio Cano Laso, que mesclou as idéias dos dois projetos premiados no concurso e manteve uma autonomia em relação ao rio e à cidade histórica.

O Projeto consiste em uma área construída de 60 hectares, com 95 pavilhões em 170hectares de espaços abertos, cinco avenidas de 300x80m e uma grande via de 2 quilômetros (Camino de los Descubrimientos), onde se situam diferentes pavilhões temáticos.

Terminada a exposição, verificou-se que como evento o projeto foi um sucesso, recebendo cerca de 41 milhões de visitantes. Porém, a cidade de Sevilha se beneficiou muito mais com o marketing urbano do que com o projeto para a cidade. Isso se deve basicamente à localização escolhida para a implantação do evento.

A opção por implantar a exposição em uma área afastada do centro foi imposta pela comissão geral do evento. A escolha da área gerou diversas discussões, já que muitos arquitetos e urbanistas defendiam a idéia de implantar a exposição na zona urbana, com o objetivo de impulsionar o desenvolvimento da cidade consolidada.

A cidade não tinha interesse em expandir sua malha urbana e sim em resolver seus problemas de infra-estrutura e equipamentos na zona urbana existente.

Fuão (1992) explica: 
"A reavaliação do plano gerou um debate entre duas posições bem claras e definidas com relação à implantação da sede da Expo Por um lado, os partidários de implantar a sede nos terrenos da Cartuja, desvinculando-a da cidade, como exigiu o protocolo firmado por Sevilha ante o BIE. Por outro, os que mantêm a idéia de fracionar a área prevista para a exposição em pequenas áreas unitárias, menores e dispostas estrategicamente ao longo do rio Guadalquivir.Ou seja, contextualizando e inserindo os recintos da exposição dentro da cidade. (...)mais uma vez a força do conservadorismo da comissão e dos organismos internacionais se impôs a todas as propostas dos arquitetos sevilhanos, consolidando-se definitivamente a implantação da Expo na ilha da Cartuja, com o modelo "imposto".pela comissão."

Como conseqüência, atualmente, apesar de ter um uso, a área do evento continua desvinculada da região central da cidade. Poucos pavilhões permaneceram e os edifícios sede se transformaram em edifícios administrativos e de uso da universidade. A área ainda conta com um parque temático, Ilha mágica, que foi criado para a cidade e é utilizado pela comunidade.

O parque científico e tecnológico ocupa 25 hectares e conta com 245 empresas dedicadas a atividades específicas, que geram cerca de 10.000 empregos e faturam o equivalente a $8 \%$ do PIB da cidade de Sevilha.

Apesar desses dados ainda é duvidoso o benefício dessa intervenção para a cidade. 0 distanciamento dessa área em relação à zona urbana faz com que os órgãos implantados ali se sintam prejudicados por terem que instalar parte de suas atividades na ilha de Cartuja.

Com o intuito de facilitar o desenho urbano, os espaços externos foram separados em três zonas: zonas de passeio, zonas de estância (espaços de descanso e contemplação dos espetáculos) e zonas adjacentes (espaços de conexão).

As zonas de passeio e as zonas adjacentes foram trabalhadas com sistemas de proteção solar e, nas zonas de estância, além da proteção solar, foram adotados sistemas de resfriamento do ar e de superfícies.

\section{Categoria 01 - Compacidade}

Durante o evento o projeto foi visitado por cerca de 41 milhões de pessoas. Porém, atualmente, a densidade é muito baixa, decorrente do distanciamento da área urbana 
consolidada e da ausência de habitações. A compacidade também é baixa, os poucos edifícios presentes apresentam uma altura mediana e são relativamente distantes uns dos outros.

\section{Categoria 02 - Mobilidade}

O projeto foi implantado em uma área afastada e ainda hoje continua desvinculada da região central da cidade, mesmo tendo um uso. Apesar do projeto estar desvinculado da zona urbana e do rio Guadalquivir ali presente, foram projetados novos passeios e pontes sobre o rio, além de reforçar a rede ferroviária, permitindo a chegada de trem de alta velocidade.

A área é servida de transporte público eficiente e assim como em toda a cidade de Sevilha há um incentivo ao uso de bicicletas.

Durante o evento houve uma grande preocupação com o pedestre e, por isso, os espaços de transição foram trabalhados de forma a torná-los habitáveis, apesar do clima rigoroso no verão. Porém, atualmente não se vê muitas pessoas circulando na área onde se situam os prédios administrativos e a universidade, talvez por essas não terem outros usos que incentivem a isso.

\section{Categoria 03 - Espaço Público e Área Verde}

A cidade de Sevilha apresenta um verão bastante rigoroso, com temperaturas do ar bastante elevadas, umidade relativa do ar baixa e altos valores de radiação solar. Diante disso, com o objetivo de amenizar as condições climáticas e tornar os espaços externos habitáveis, definiu-se duas estratégias bioclimáticas principais: sombreamento e resfriamento evaporativo direto (ar) e indireto (cobertura).

Paralelamente ao desenvolvimento do projeto, foram realizadas pesquisas científicas que tornaram possíveis modelar, testar e aplicar elementos e sistemas capazes de modificar e controlar as condições climáticas dos espaços abertos.

A vegetação e água eram recursos usados em todos os espaços externos, tanto nos espaços de lazer quanto nos espaços de transição. O sombreamento foi feito através do uso de vegetação, árvores e pérgula vegetal e coberturas simples e duplas, de formas abertas, permitindo a ventilação e o uso cores claras reduzindo o ganho de carga térmica.

Os sistemas de resfriamento de superfícies verticais eram realizados com lâminas de água, cascatas e cortinas de água e em superfícies horizontais, através do sistema de rego ou do uso de películas d'água contínua. 
Os sistemas de resfriamento do ar eram: micronizadores instalados nas torres frias e nas árvores, unidades de tratamento de ar (UTA) alimentadas por água esfriada com técnicas naturais e com dutos enterrados.

A água está presente nos espaços abertos através de um lago artificial de15 hectares, Lago de Espanha, e de 100 fontes ornamentais e numerosas cascatas.

De uma maneira geral, os espaços externos estão deteriorados, se compararmos com o projeto desenvolvido para a exposição, que tem o seu ponto alto na qualidade dos espaços livres em todo o complexo.

\section{Categoria 04 - Eficiência no uso dos Recursos Naturais água e energia}

Durante o projeto da expo houve uma grande preocupação em adotar estratégias passivas, buscando amenizar as condições climáticas desfavoráveis, sem que para isso fosse necessário o consumo de energia elétrica.

Com relação ao consumo de água, não se tem muita informação para fazer uma avaliação, porém sabe-se que a água foi um elemento marcante no projeto e no tratamento dos espaços externos.

\section{Categoria 05 - Diversidade Urbana e Expressão Arquitetônica}

Esse projeto foi pensado mais para o evento do que como uma intervenção urbana capaz criar ou consolidar um bairro de uso misto que possa abrigar parte da população. Sendo assim, não foi previsto para a área habitações ou serviços básicos capazes de dar vida à região 24 horas.

As enormes torres frias tornaram-se um elemento arquitetônico marcante da Expo, nas quais a água era micronizada no seu interior, provocando uma coluna de ar frio na sua parte inferior. O ar era movimentado no sentido descendente com o auxílio dos ventiladores internos. 


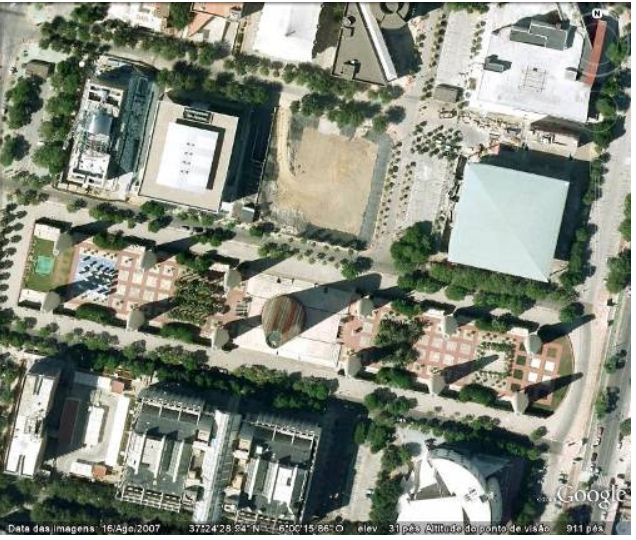

Figura 58: I magem aérea projeto Expo Sevilha

Fonte: Google

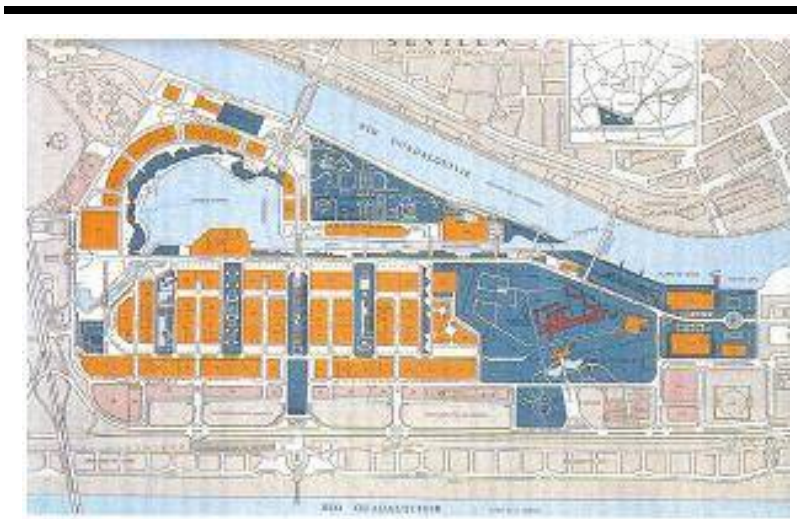

Figura 60: Planta da Expo Sevilha

Fonte: foto da autora

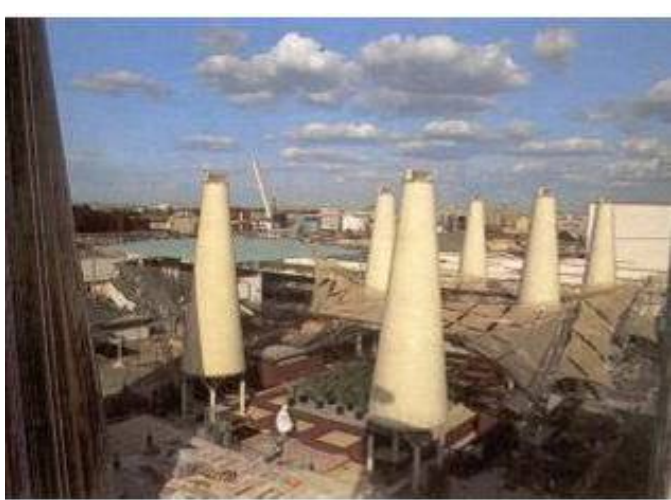

Figura 62: Torres para resfriamento do ar Fonte: site Expo

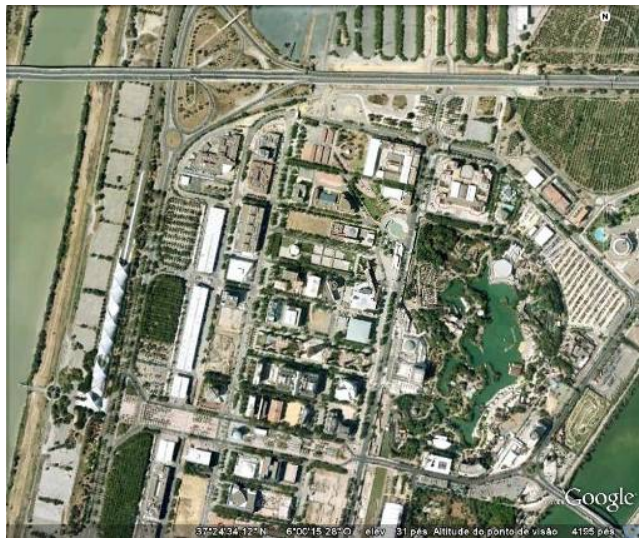

Figura 59: I magem aérea da área da Expo Sevilha

Fonte: Google

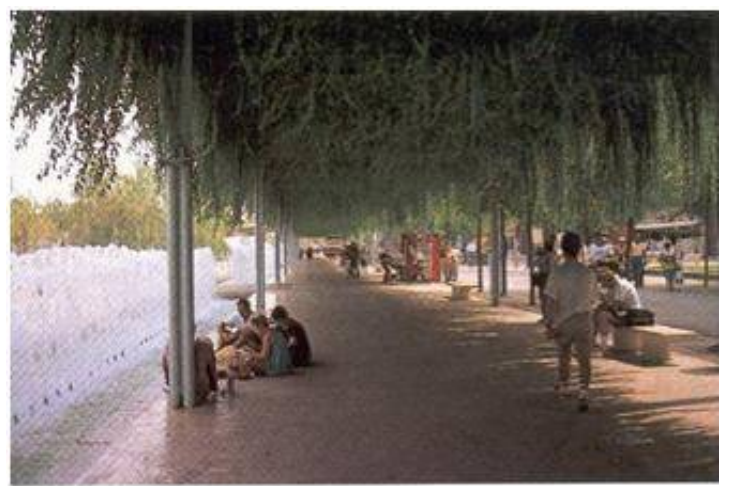

Figura 61: Espaço de transição Expo

Fonte: foto da autora

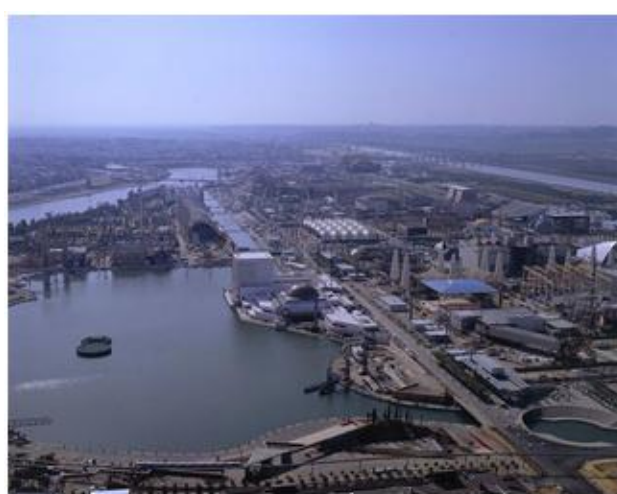

Figura 63: I magem projeto Expo Sevilha

Fonte: site Expo 
3.1.2 Expo Lisboa

\section{Dados técnicos:}

Projeto: Expo Lisboa

Localização: Lisboa, Portugal - Latitude: $38^{\circ} 46^{\prime} \mathrm{N}$

Arquiteto Projeto Urbano:

Cliente: Comissão de Exposições Internacionais, Prefeitura de Lisboa

Área: 60 hectares até 1998 e 330 hectares até 2010

Uso: lazer, residencial e comercial

Fase: finalizado em 1998 uma parte e outra prevista para 2010

\section{Descrição:}

A exposição internacional de 1998, realizada na cidade de Lisboa, Portugal, titulada "Os Oceanos, uma herança para o futuro", comemorava os 500 anos da viagem de Vasco da Gama para a Índia, que possibilitou a Lisboa se tornar um dos grandes portos mundiais.

Um ponto positivo para o sucesso da intervenção é que em nenhum momento o projeto da Expo de Lisboa foi pensado desvinculando a área de exposição do seu entorno urbano. Pelo contrário, desde o princípio o projeto foi concebido como um instrumento para impulsionar uma operação urbana de caráter estratégico e que trouxe um grande benefício para a cidade.

O plano objetivava revitalizar e reintegrar uma antiga área portuária e industrial situada ao noroeste do centro histórico, às margens do Rio Tejo. Como aconteceu em diversas cidades do mundo, antigas áreas portuárias e industriais foram se tornando áreas degradadas e em desuso, caracterizando-se pela presença de enormes galpões vazios e obsoletos.

Após conseguir a nominação por parte da comissão organizadora das exposições internacionais, Bureau International des Expositions BIE, formou-se a sociedade estatal Parque Expo 98 AS, que se responsabilizava pelas operações tanto da área da expo como também de toda a zona de intervenção. 
A área da expo abrangia 60 hectares e foi concluída em 1998, junto ao início do evento, enquanto que a zona total de intervenção contemplava 330 hectares e tem seu prazo de conclusão para 2010.

O projeto de intervenção define os parâmetros de transformação da frente ribeirinha do rio Tejo de 5 quilômetros de comprimento por $800 \mathrm{~m}$ de largura, delimitada pelo Tejo e pelas infra-estruturas viárias e ferroviárias.

O fato desta intervenção estar integrada a outros projetos urbanos e ao contexto local, e ainda ter sido projetada não só para a Expo, mas também com uma finalidade após a realização do evento, fez com que esse projeto fosse um sucesso no que diz respeito a revitalização da área.

Outros dois aspectos que contribuíram para a utilização e vitalidade da área são a diversidade de uso e a integração das edificações através dos espaços públicos de qualidade. Todo o complexo, atualmente denominado Parque das Nações, é composto por áreas residenciais, áreas de comércio e áreas lazer, além de todos os serviços necessários para o cidadão não ter que se deslocar da região no seu cotidiano, como escolas, infra-estruturas esportivas, hospital etc. Do total da área bruta de construção, 1 $240000 \mathrm{~m}^{2}$ corresponde à habitação, $610000 \mathrm{~m}^{2}$ a escritórios, $170000 \mathrm{~m}^{2}$ a comércio e $300000 \mathrm{~m}^{2}$ a outros fins.

A população residente prevista no termino do projeto é da ordem das 21.000 pessoas, enquanto o número de trabalhadores será em torno de 22.500 pessoas.

Essa intervenção urbana trouxe benefícios ambientais, sociais e econômicos, não só para a área revitalizada, mas para toda a cidade.

A presença de espaços públicos de qualidade entre as edificações favorece o uso do ambiente construído, propicia a convivência, melhora a paisagem urbana e auxilia a integração e revitalização do entorno degradado.

O projeto é destinado na sua maior parte para o lazer, com presença de museus, pavilhões de feira e diversos espaços livres constituídos por parques, jardins e espaço para o pedestre em frente ao rio Tejo.

Após a realização do evento, foi mantido o plano de monitorização ambiental da área, de modo a garantir a continuidade da qualidade ambiental no Parque das Nações. As seguintes variáveis ambientais são monitoradas: 
- Acústica urbana, tendo como principal objetivo a caracterização dos níveis de ruído, em determinados locais do Parque das Nações, visando um nível de ruído adequado ao uso residencial e comercial do espaço;

- Qualidade da Água;

- Qualidade do Ar;

- Qualidade da Água de Descarga da Rede de Coletores Pluviais, visando garantir o bom funcionamento na tarefa de encaminhamento de águas residuais, domésticas e industriais, até a ETAR de Beirolas e de águas pluviais até o rio Tejo ou Trancão;

- Dados meteorológicos;

- Acompanhamento Ambiental das Frentes de Obra, objetivando verificar o funcionamento dos estaleiros, visando minimizar os impactos nas zonas envolventes.

\section{Categoria 01 - Compacidade}

Durante o evento o projeto foi visitado por cerca de milhões de pessoas. Está previsto para que, no término do projeto, a população residente seja da ordem de 21.000 pessoas e a população total (residentes e trabalhadores), 43.500 pessoas. Como a área total é de 350 hectares, a densidade da população residente será em torno de 60hab/ha e a densidade da população residente e trabalhadores será cerca de 124hab/ha. Conclui-se assim que a densidade é baixa.

O projeto apresenta uma compacidade média, verificada com base na altura das edificações e na distância entre elas, que conta com a existência de muita área livre e de dois parques.

\section{Categoria 02 - Mobilidade}

A área revitalizada estava localizada em um ponto importante e estratégico da cidade, além de ter o seu acesso facilitado decorrente da execução de dois projetos na mesma época: a construção de uma nova estação intermodal na área da expo, finalizada em 1995 e a construção da ponte Vasco da Gama, de 17 quilômetros de comprimento, que conecta a área da intervenção urbana com a outra margem do rio Tejo e com o Sul do País.

O projeto foi implantado em uma área de fácil acesso, servida de transporte público eficiente e demais infra-estruturas. Um dos objetivos do projeto era acessibilidade central 
à rede intermodal de transportes a fim de incentivar a utilização do transporte público e viabilizar a utilização a pé da área central do Parque das Nações, onde se realizou a Exposição Mundial.

O projeto incentiva o transporte a pé e de bicicleta dentro da área revitalizada, principalmente para lazer. Os automóveis têm acesso restrito em algumas partes do complexo, como em frente ao rio Tejo, mas isso não inibe seu uso para acessar a área.

\section{Categoria 03 - Espaço Público e Área Verde}

Os espaços livres foram projetados, principalmente, para o lazer e transição de pedestres e, por esta razão, estão localizados mais afastados das vias principais de veículos motorizados, com presença de árvores e demais elementos arquitetônicos que fazem sombra. Vale destacar que o complexo também apresenta áreas livres de sombra, para que o pedestre possa receber radiação solar direta nos dias frios de inverno.

A vegetação está presente em grande parte do projeto, distribuída em: 110 hectares que são compostos por 20.000 árvores, 70.000 arbustos e 1.500 .000 herbáceos; o parque do Tejo, com 92 hectares; o Parque do Cabeço das Rolas com 7 hectares e os jardins Garcia de Orta com 1 hectare.

Ao libertar a área global do Parque das Nações de todas as atividades que ali existiam, foram recuperados 110 hectares de espaços verdes.

\section{Categoria 04 - Eficiência no uso dos Recursos Naturais água e energia}

Com relação às questões ambientais o projeto do Parque das Nações apresenta algumas iniciativas de projeto que merecem destaque: coleta seletiva e eficiente de resíduos sólidos; tratamento de águas residenciais; sistema centralizado de distribuição de frio e de calor, com objetivo de reduzir o consumo de energia, e a presença de vegetação em todo o complexo.

Com relação ao recurso água, a Estação de Tratamento de Águas Residuais (ETAR), localizada na parte norte do Parque das Nações, trata esgotos domésticos e industriais provenientes de Lisboa e Loures. Encontra-se em funcionamento desde o final de 1989, produzindo um efluente final de qualidade (água tratada). A ETAR vai manter-se no Parque das Nações e irá receber a maior parte dos efluentes gerados nessa zona. Essa estação de tratamento detém uma pequena unidade de cloragem, que permite desinfetar parte da água tratada para que possa ser reutilizada. 
Com relação à energia, o projeto conta com a presença de um sistema centralizado de distribuição de frio e de calor, visando reduzir o consumo de energia.

\section{Categoria 05 - Diversidade Urbana e Expressão Arquitetônica}

Um dos objetivos do projeto era a criação de um espaço urbano de elevada qualidade, integrando as mais diversas funções urbanas, para obter uma vivência equilibrada. 0 projeto apresenta uma diversidade de usos, residencial, comercial e lazer.

Os residentes do Parque das Nações dispõem dos mais diversos serviços de apoio: comércio e restauração, escolas, espaços de lazer ou infra-estruturas desportivas, hospital e outros serviços complementares.

O Parque das Nações tornou-se um local de eleição para a instalação das mais prestigiadas empresas nacionais e multinacionais.

Conta também com a presença de equipamentos de lazer e serviços que originam procuras concentradas e diversificadas da população, ao longo do ano, como: o Oceanógrafo de Lisboa, o Centro Vasco da Gama, a Feira Internacional de Lisboa e o Pavilhão Atlântico.

O complexo é constituído por edifícios de grande qualidade arquitetônica, de autoria de arquitetos de referência internacional, formando um pólo moderno para a cidade de Lisboa. Alguns edifícios que merecem ser destacados: o Pavilhão de Portugal, o Teatro Luís de Camões, a Torre Vasco da Gama e a Estação do Oriente.

A qualidade arquitetônica dos edifícios contribui para a valorização e consolidação de uma nova imagem urbana e uma nova relação com a frente ribeirinha. 


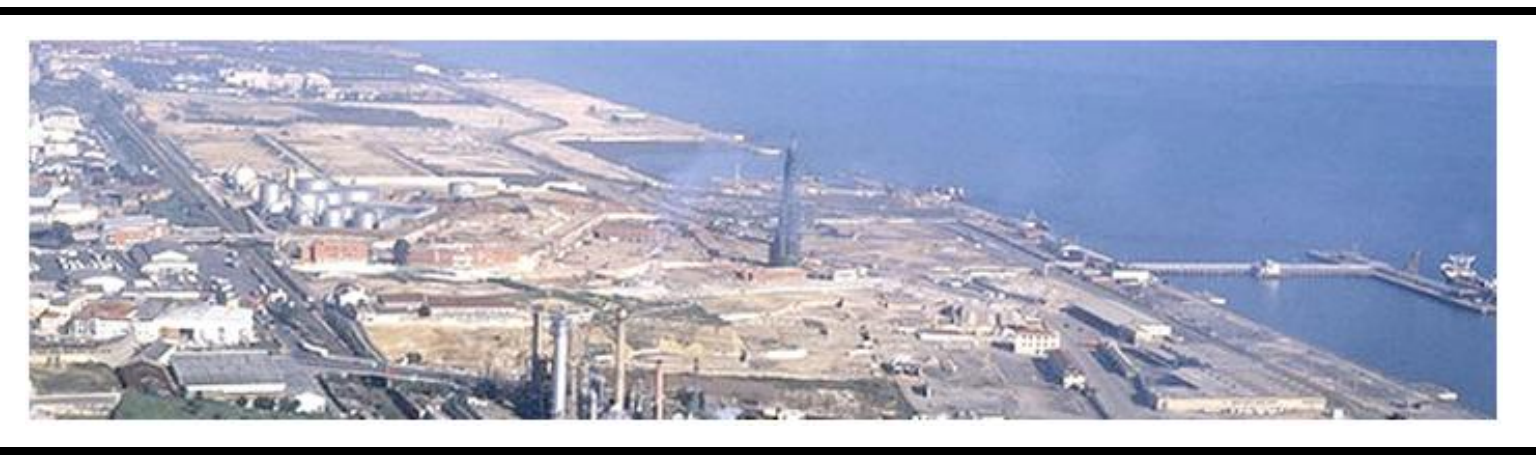

Figura 64: Área antes da intervenção urbana, Lisboa

Fonte: http://www.parqueexpo.pt/vPT/ParqueNacoes/Projecto/ODesafio/Pages/Odesafio.aspx

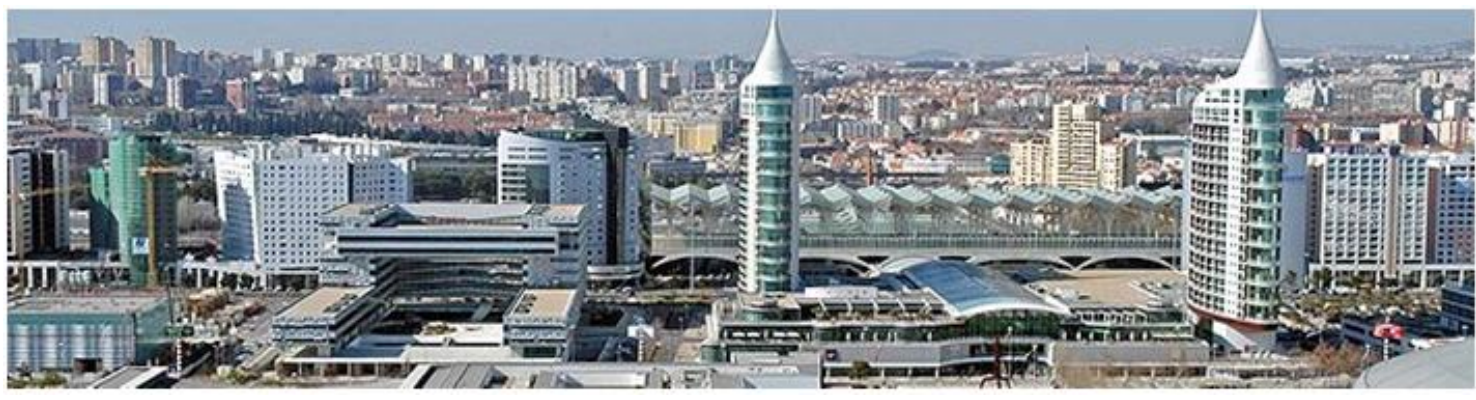

Figura 65: Área após a intervenção urbana, Lisboa

Fonte: http://www.parqueexpo.pt/vPT/ParqueNacoes/Projecto/ODesafio/Pages/Odesafio.aspx
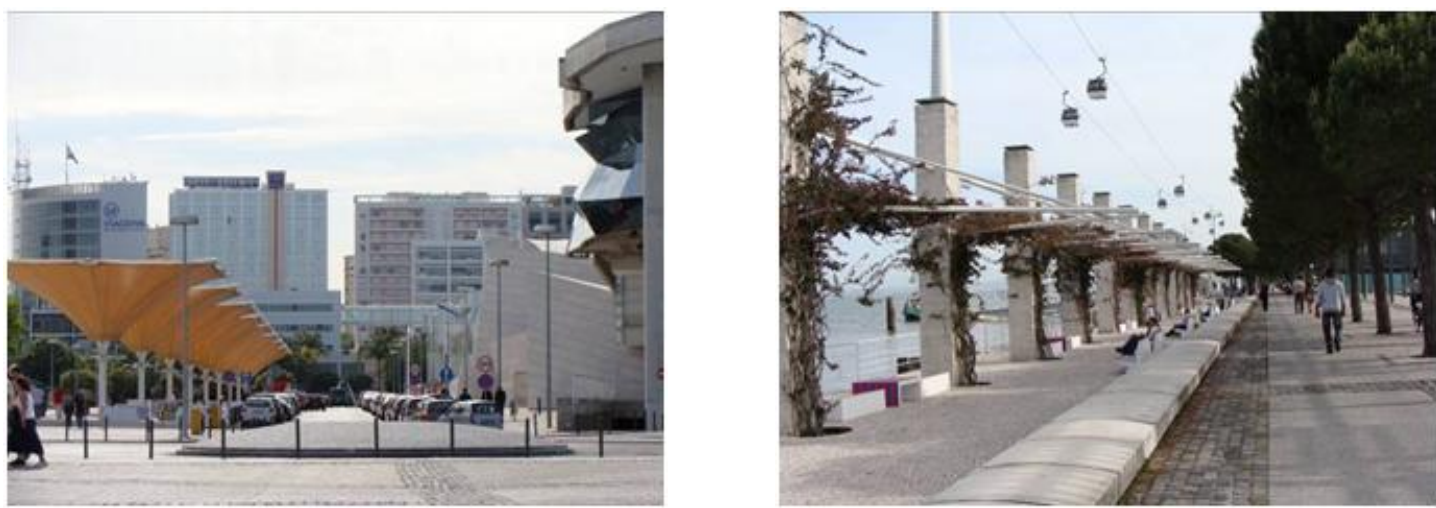

Figura 66: I magem da área da Expo Lisboa, atualmente

Figura 67: Imagem da área da Expo

Fonte: fotos da autora, maio de 2008 Lisboa, atualmente

Fonte: fotos da autora, maio de 2008 


\subsubsection{Kronsberg, Hannover - Alemanha ${ }^{65}$}

\section{Dados técnicos:}

\section{Projeto: Kronsberg}

Localização: Hannover, Alemanha - Latitude: $52^{\circ} 22^{\prime} \mathrm{N}$

Arquiteto: Reinhard Martisen

Cliente: Comissão de Exposições Internacionais, Prefeitura de Hanover

Área: 160 hectates/ 3000 habitações (fase 01) e 6000 habitações (fase 02)

Uso: misto (residencial, serviço e comercio e EXPO)

Fase: finalizada primeira fase

\section{Descrição:}

Após a Conferência das Nações Unidas no Rio de Janeiro, em 1992, quando chefes de estado firmaram a Agenda 21, a cidade de Hannover baseou todas as suas atividades urbanísticas e de desenvolvimento no enfoque de desenvolvimento sustentável.

Em 1980, Hannover venceu o concurso para receber a Exposição Mundial de 2000 e iniciou-se um planejamento para o desenvolvimento de um novo bairro em Kronsberg, de 160 hectares, com aproximadamente 6000 habitações, para 15000 pessoas e que seria exemplo de preocupação ecológica.

A Exposição Universal Expo 2000 contemplava o tema "Humanidade, Natureza $e$ tecnologia", conceitos esses que foram trabalhados em todo o projeto.

A EXPO 2000 foi uma oportunidade para aplicar projetos de melhoria para a área de Kronsberg. Baseado nos dois concursos realizados e nos planos existentes, o projeto foi realizado para a área da expo, para o novo assentamento urbano e para a parte rural.

O primeiro concurso foi realizado para definir o plano urbano da Expo e do novo assentamento com 3000 habitações para 6600 pessoas, gerando 3000 novos empregos. Prizewinner Arnaboldi, Cavadini e Hager foram autores do projeto vencedor. O júri recomendou que o empreendimento fosse desenvolvido com base no projeto vencedor,

\footnotetext{
${ }^{65}$ Este projeto também é um ecobairro.
} 
porém que incorporasse alguns elementos dos demais projetos vencedores, como o projeto paisagístico do segundo colocado, de autoria de San Remo.

O novo bairro, projetado em cima de uma área verde, "greenfield", ocupa o lado oeste do declive de Kronsberg, ao lado da nova linha de trem que conecta a região de Bemerode com a área da expo.

Implantado no sentido norte e sul, o projeto é marcado por blocos residenciais, retangulares, de 4 a 5 andares. Apesar da rigidez da forma, o projeto conta com uma variedade de estilos projetada pelos quase 40 arquitetos.

No decorrer da linha do trem e do acesso principal foram implantados lojas e escritórios. No meio do empreendimento foi implantado um shopping center, o centro de arte Krokus, um centro de saúde e uma igreja.

Hannover Kronsberg é um dos primeiros exemplos no qual o enfoque de desenvolvimento sustentável deveria aplicar-se dentro de uma estrutura de projeto urbano, rigorosamente orientada.

Para tratar os assuntos relacionados ao meio ambiente, um grupo dentro do Departamento de Meio Ambiente da prefeitura foi encarregado de fixar níveis de qualidade relacionados à energia, água, arquitetura paisagística e proteção ao entorno. 0 objetivo era controlar e guiar as atividades relacionadas ao desenvolvimento sustentável, durante todas as fases do empreendimento. Para isso, o próprio departamento implementou uma avaliação de impacto ambiental para as fases de projeto e construção.

Já na primeira fase do planejamento urbano, identificaram o espaço e a energia como os fatores chaves para o desenvolvimento sustentável a nível local.

Visando isso, o novo bairro de Kronsberg apresenta um desenho urbano compacto, uso misto e um layout que permite o uso eficiente dos recursos naturais.

A idéia é otimizar o uso do solo para que não tenha que ocupar muita área verde, minimizando o impacto ao meio ambiente, e reduzir os deslocamentos, com o objetivo de economizar energia com transporte, entre outros benefícios. 
O conceito ecológico desse novo bairro pode ser dividido em dez iniciativas importantes. São elas: ${ }^{66}$

- Métodos de construção de casas de baixa energia, apoiados em inspeção de controle de qualidade, na capacitação e em medidas de qualificação.

- Programa de capacitação e qualificação para supervisionar o projeto de construção em todas as fases, com o objetivo de economizar energia elétrica;

- Uma legislação que garantisse que todos os edifícios de Kronsberg estariam conectados ao sistema de calefação centralizado, baseado em gás natural;

- Um programa de economia de energia idealizado para o bairro;

- Instalação de componentes energéticos renováveis dentro da zona residencial.

- Reuso da água da chuva;

- Um bom projeto para as áreas verdes e paisagem, garantindo um acesso livre e direto dos residentes a uma variedade de zonas verdes;

- Utilização de materiais de construção de menor impacto ambiental, incluindo materiais recicláveis, redução e gestão de resíduos de construção e de utilização;

- Gestão ecológica do solo, reutilizando toda a terra escavada e preocupação com a contaminação do solo, causada pela substituição do solo natural pelo solo edificado;

- Fundação da KUKA, kronsberg Environmental Liaison Agency, que assumiu muitas das tarefas de acessória ambiental, aconselhando, informando e formando arquitetos, ofícios e novos residentes para que esses aplicassem as tecnologias mais modernas nas habitações de baixa energia, no projeto, construção e prática. KUKA também organizava visitas guiadas antes e durante a EXPO, tendo recebido até 2001 mais de 7200 visitantes;

O projeto teve repercussão internacional, sendo considerado um exemplo positivo da aplicação de medidas relacionadas ao desenvolvimento sustentável no projeto urbano e arquitetônico.

\footnotetext{
${ }^{66}$ Empresa Municipal de Vivienda y Suelo (EMVS).Ayuntamiento de Madrid, 2005, p120.
} 
A experiência adquirida durante o projeto do bairro Kronsberg levou a prefeitura de Hannover a aplicar as normas desenvolvidas em toda a cidade. No ano de 2000, essas normas foram reunidas em um informe da prefeitura, "Normas ecológicas dentro da esfera de influencia do municípid".

\section{Categoria 01 - Compacidade}

O novo bairro em Kronsberg, de 160 hectares de área construída, apresenta 3000 habitações na primeira fase e prevê aproximadamente 6000 habitações para a segunda fase. Sendo assim, em Kronsberg a densidade edificada é de 19 hab/ha na primeira fase do projeto e de 37,5 hab/ha na segunda fase do projeto.

O plano de indicadores de sustentabilidade ambiental elaborado para a atividade urbanística de Sevilha estabelece uma densidade edificada mínima de 45 habitações por hectare e recomenda 60 habitações por hectare. Diante disso, verifica-se que mesmo com a segunda fase do projeto finalizada, a densidade edificada do novo bairro é baixa. Vale ressaltar que a densidade ideal depende da realidade e demanda de cada localidade.

O novo bairro de Kronsberg apresenta um desenho urbano com compacidade moderada, uma utilização multifuncional do terreno e um layout favorecendo o uso eficiente dos recursos naturais.

\section{Categoria 02 - Mobilidade}

A prioridade é a locomoção a pé e através de bicicletas. Para distâncias maiores, o bairro de Kronsberg é servido de transporte público que o liga ao centro de Hannover em 15 minutos. Pontos de acesso ao trem são espalhados pela área, de modo que o usuário não tenha que caminhar mais que 300 metros.

O projeto apresenta um tráfego restrito de veículos motorizados, com áreas de estacionamento limitadas. Por essa e outra razões, parte dos residentes não utiliza automóvel, sendo 0,8 o número de carros por habitação.

\section{Categoria 03 - Espaço Público e Área Verde}

O viário público destinado ao um tráfego de veículos motorizados e as áreas de estacionamento é limitado, permitindo que as áreas públicas sejam destinadas ao lazer e a vegetação. 
O projeto das áreas livres garante um acesso direto dos cidadãos a uma variedade de zonas verdes, com jardins privados e públicos, pátios semi-públicos, corredores verdes, etc.

\section{Categoria 04 - Eficiência no uso dos Recursos Naturais água e energia}

Durante elaboração do projeto urbano foi colocado em prática um programa de economia de energia para todo ecobairro, que estabelecia, entre outras metas, que cada edificação deveria ter um índice energético de $55 \mathrm{kwh} / \mathrm{m}^{2}$. Esse valor se situa entre 30 e 50\% abaixo dos requisitos atuais para a nova construção e $20 \%$ abaixo das exigências mínimas do novo regulamento de economia de energia.

Para atingir essa meta, as edificações foram projetadas de maneira que necessitem de um menor consumo de energia para sua construção, manutenção e seu funcionamento, apoiadas em um programa de capacitação e qualificação para supervisionar o projeto de construção em todas as fases.

O programa também garante que todos os edifícios de Kronsberg estejam conectados ao sistema de calefação centralizado, baseado em gás natural. Além disso, o bairro conta com a produção de energias renováveis, eólica e solar.

Com relação ao recurso natural água, o projeto prevê o reuso das águas pluviais que são retidas em um lugar e liberadas lentamente dentro do sistema, a fim de conservar o equilíbrio natural dos recursos aquáticos. Somado a isso, o projeto apresenta uma preocupação em minimizar a construção de áreas pavimentas, promover telhados com vegetação, construção de canais e fossos permeáveis.

\section{Categoria 05 - Diversidade Urbana e Expressão Arquitetônica}

O projeto destaca a importância de integração e inclusão social, como uma das metas mais importantes do desenvolvimento urbano sustentável. ${ }^{67}$

Com a finalidade de promover uma coesão social, foram implantadas habitações de diferentes tamanhos ${ }^{68}$, para casais, famílias e pessoas sozinhas, de um, dois, três, quatro e cinco dormitórios.

\footnotetext{
${ }^{67}$ EMVS, 2006, p119.
} 
Com o mesmo objetivo, o projeto apresenta formas de financiamento diversificadas.

Com respeito à diversidade de usos, destaca-se que, apesar de ser um bairro grande, não foram planejadas atividades econômicas de importância.

Apesar da variedade de estilos arquitetônicos, cabe aqui uma critica a rigidez do desenho urbano que poderia ter tirado mais partido da implantação do conjunto e da forma para atingir os mesmos objetivos.

Em um estudo desenvolvido por Higueras, comparando cinco ecobairros sob o enfoque dos quatros eixos estabelecidos por Rueda $(2006)^{69}$, Kronsberg apresenta: Compacidade 4/5; Complexidade 3/5; Eficiência 3/5 e; Estabilidade social 3/5. (HIGUERAS et. al. , 2009, p.27).

${ }^{68}$ Das aproximadas 3000 habitações, 200 são casas unifamiliares e 2678 são apartamentos (249 unidades são de 1 dormitório; 142 unidades são de 1 e 1/2 dormitório; 762 unidades são de 2 dormitórios; 48 unidades são de 2 e 1/2 dormitórios; 1045 unidades são de 3 dormitórios; 6 unidades são de 3 e 1/2 dormitórios; 388 unidades são de 4 dormitórios; 11 unidades são de 4 e $1 \frac{1}{2}$ dormitórios e 27 unidades são de 5 ou mais dormitórios).

${ }^{69}$ Abordados no capítulo anterior. 


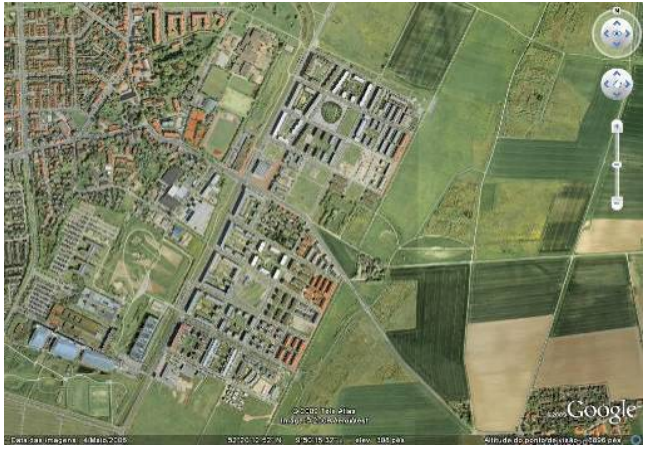

Figura 68: I magem aérea projeto Expo Fonte: Google

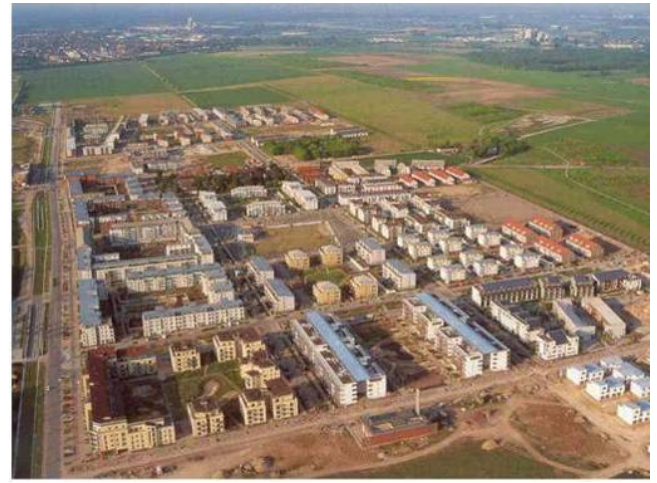

\section{Figura 70: I magem projeto ecobairro}

Kronsberg

Fonte: EMVS, 2005

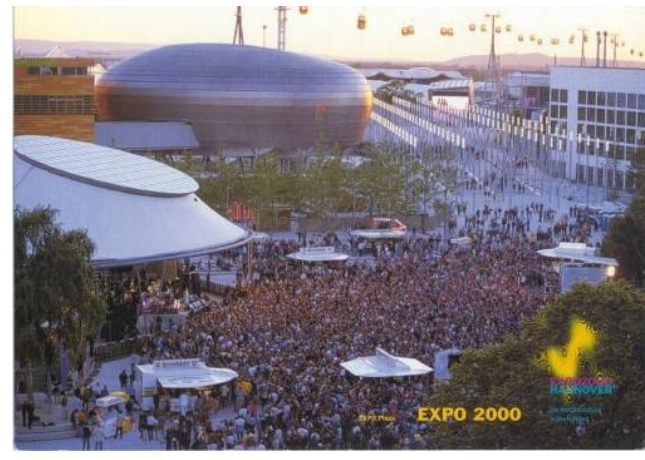

Figura 69: I magem da Expo Kronsberg

Fonte: site Expo

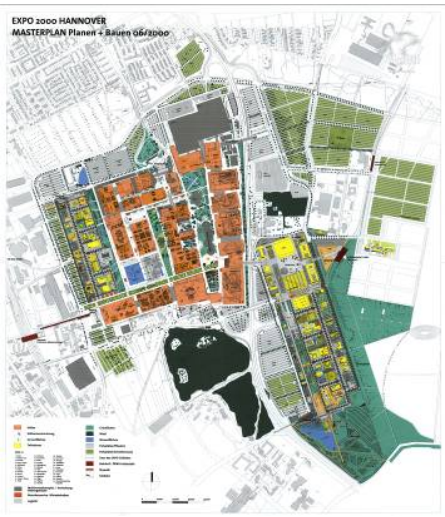

\section{Figura 71: Expo Planta Projeto} Kronsberg

Fonte: Site da expo
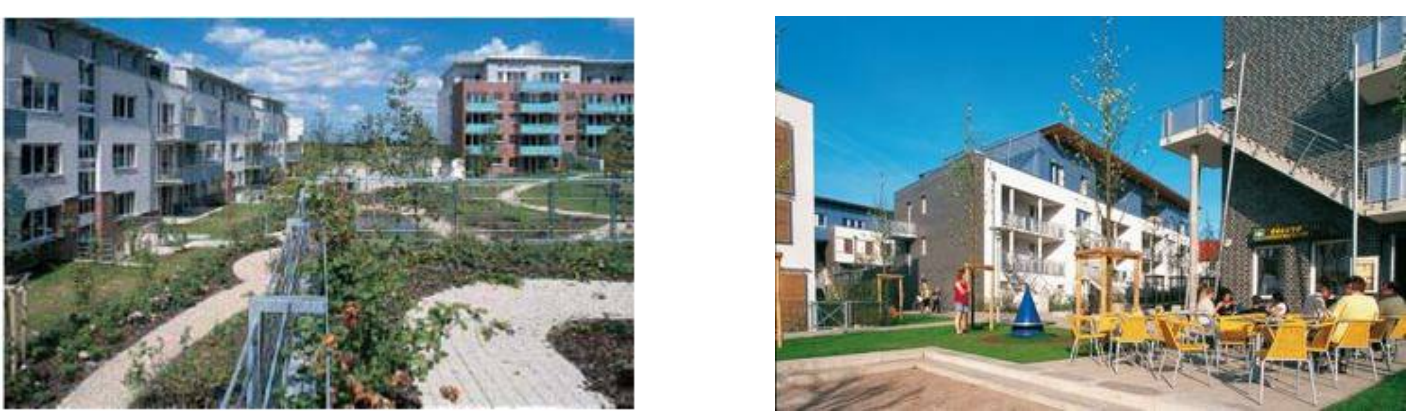

Figura 72: Imagem projeto ecobairro Kronsberg

Figura 73: I magem projeto ecobairro Kronsberg

Fonte: EMVS, 2005

Fonte: EMVS, 2005 


\subsubsection{Vila olímpica em Barcelona}

\section{Dados técnicos:}

Projeto: Vila Olímpica

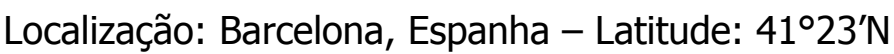

Arquiteto Projeto Urbano: Bohigas, Martorell, Mackay e Puigdomenech (MBM Architectes)

Consultoria técnica:

Cliente: Município de Barcelona e Comitê Olímpico

Área: 130 hectares

Uso: misto

Fase: finalizado em 1992

\section{Descrição:}

A partir de 1980, com a incorporação do arquiteto Oriol Bohigas à frente da equipe de urbanismo municipal de Barcelona, inicia-se um período de concretização de projetos urbanos. Fazendo parte dos projetos de requalificação urbana, o programa "Áreas de nova centralidade", potencializado pelo programa olímpico de 1992, tem os seguintes objetivos: (1) a articulação entre as partes da cidade segregada historicamente pelas infra-estruturas pesadas (linhas férreas, complexos industriais, etc), desníveis topográficos, cursos d’água, etc.; e (2) induzir a criação de sub-pólos de atividades terciárias com a participação público-privado, a fim de reduzir a pressão do terciário sobre o Ensanche ${ }^{70}$ e converter-se em uma alternativa aos velhos projetos de grandes centros direcionais nos arredores da cidade. (SALES, 1999, p50)

Dentro desse programa, a Vila olímpica é uma das áreas propostas, em decorrência da sua importante localidade como porta de saída leste da cidade, território de fronteira

\footnotetext{
70 Sales (X, p38) define Ensanche de Cerdá como o plano de expansão oitocentista da cidade de Barcelona. Representa a proposta de cidade burguesa, entendida a partir de uma nova organização morfológica trazendo a definição de um novo tipo arquitetônico e respondendo às novas exigências de residência e distribuição de seus serviços de apoio. A idéia é definida enquanto forma que relaciona o sistema viário, infra-estrutura e tipologias edilícias.
} 
entre o Ensanche e os polígonos industriais e residenciais, quanto pelas transformações graduais da zona. (SALES, 1999, p50)

O local do projeto da vila olímpica está situado a leste da cidade velha, ao longo da Avenida Icária, em uma área de 130 hectares, limitada pelo Parque da Ciudadela, a oeste, Barceloneta, a sudoeste, o Mar Mediterrâneo ao sul, o centro de Poblenou a leste e noroeste e o Ensanche ao norte. (SALES, 1999, p.95)

Além disso, a recuperação e revitalização para essa área industrial deteriorada e separada do mar pela linha férrea era assunto que a prefeitura e arquitetos urbanistas já vinham discutindo. A construção de uma vila olímpica foi então o incentivo encontrado para a realização desse projeto.

Diante disso, Narcis Serra propõe o novo bairro marítimo como Vila Olímpica, solicitando que Barcelona fosse sede dos jogos olímpicos de 1992. O prefeito Pasqual Maragall, sucessor de Serra, foi o grande impulsor do projeto.

O evento olímpico de 1992 atuou como catalisador dessa e de outras operações urbanísticas que haviam ficado paradas durante décadas por falta de vontade política e carência de recursos.

O projeto se insere no âmbito de outras intervenções urbanas, contempladas pela revisão do planejamento de Barcelona a partir de 1980, incluindo iniciativas que cobrem praticamente todas as zonas da cidade. Esse fato contribui para a realização e sucesso do projeto. (SOMEKH \& CAMPOS, 2005)

As propostas para a renovação de Barcelona tiveram como uma das principais preocupações o resgate de sua frente marítima, transformando o uso do bairro (misto), sua forma, sua acessibilidade, seus equipamentos, e seu caráter representativo, visando uma concentração urbana característica de Barcelona. Tudo isso por trás do slogan publicitário de "Abrir Barcelona ao Mar".

O projeto foi iniciado antes mesmo da nomeação de Barcelona como sede olímpica. Coordenado pelos arquitetos Martorell, Bohigas, Mackay e Puigdomenech, o projeto buscava compatibilizar a transformação a ser realizada com as carências do setor, além de conciliar as ações com as necessidades de implantações esportivas dentro da estrutura urbana como um todo. (SALES, 1999, p.79) 
Poucos foram as edificações mantidas e por isso o projeto pôde ser pensado com mais liberdade, sem muitas referências arquitetônicas. Ao mesmo tempo, o projeto adota um princípio de implantação que referencia a história da cidade, caracterizando-se pela integração que tenta estabelecer com a cidade existente.

A recuperação da praia, do porto e do passeio marítimo foram decisões de projeto exigidas pela comissão olímpica. O projeto também previu uma área para a implantação de edifícios altos, de maneira que esses não prejudicassem a visibilidade e nem as condições ambientais do entorno.

Sales (1999, p101) descreve a organização espacial do projeto:

"O arranjo espacial proposto pelo plano especial foi articulado em quatro setores paralelos ao litoral, caracterizados diversamente por funções, tipos edificatórios, tratamentos dos espaços abertos.

O setor residencial é proposto a partir da recuperação e reinterpretação das características do ensanche-Cerdá.

- A avenida do litoral é pensada como via parque, e acolhe equipamentos esportivos, de lazer, e áreas verdes. O traçado do Cinturão litoral, ao longo da Vila Olímpica vem enterrado;

- Uma área destinada a funções de atração metropolitana comercial e recreativa, desenvolve-se a partir do eixo de chegada ao mar da av. Carlos I e ao longo do Passeio Marítimo de pedestres, que margeia as praias;

- Previsão de uma linha de costa, com praias requalificadas e dotação de equipamentos necessários à ancoragem de navegação."

- Com relação às tipologias, o projeto pôde ser dividido em duas áreas: o território urbano, de uso predominantemente residencial, e o território marítimo, de uso misto, formado na maior parte por hotéis, lojas, restaurantes e escritórios.

O território urbano contém aproximadamente 2.000 habitações distribuídas em blocos perimetrais às quadras, apoiados na malha ortogonal do Ensanche Cerdá. Existia um impasse de manter a tipologia tradicional, que apresenta alguns problemas de habitabilidade ou modificá-las. Optou-se então por manter as habitações no perímetro da quadra, alinhadas no limite do lote e com gabaritos uniformizados, de cinco pavimentos. 
Porém, algumas alterações foram propostas, visando uma melhoria na qualidade ambiental como, por exemplo: uma densidade menor de 1.700 habitantes/ha; uma ampliação de escala, com módulos duas ou três vezes maior que o original; edificações mais estreitas com 12 a 14 metros de profundidade, possibilitando a ventilação cruzada e a iluminação natural; liberação e aproveitando da parte interior para jardins e equipamentos públicos e, em alguns casos, comunicação entre os pátios internos, com acesso público.

Sobre estas adaptações, Sales (1999, p112) comenta:

Assim, pertencendo a um outro tempo que não aquele do Ensanche, o projeto estabelece, ao mesmo tempo, uma idéia de habitar diversa daquela, e mais complexa. As tipologias edilícias então, ao adaptar-se, à malha urbana da cidade do século XIX, demonstram algumas mudanças formais e funcionais requeridas pela sociedade contemporânea. O projeto exprime esta intenção, de um lado liberando-se e ampliando-se os espaços no interior das quadras (proposta inicial do plano de Cerdá), para uso não mais privado e sim coletivo, conformando uma rede de espaços semipúblicos conectados entre si, e de outro, com um tipo de densidade controlada, viabilizando melhores condições de habitabilidade e conforto do espaço residencial, que se traduz também na previsão de conjuntos heterogêneos, de tipos edilícios e de formas de habitar.

Diferente do território urbano, o território marítimo está livre dos conceitos e da malha tradicional, caracterizando-se pela presença de novos edifícios, com tipologias edificatórias comuns nas principais cidades européias, resultantes das intervenções dos anos 80 .

Após os jogos de 1992, o projeto custou a deslanchar tendo em vista o perfil elitista definido pela ocupação habitacional e de serviços. Porém, a atratividade ligada à recreação ao ar livre acabou prevalecendo, configurando um pólo de referência para a população em geral. (SOMEKH \& CAMPOS, 2005)

Atualmente o impacto positivo da Vila Olímpica atingiu a cidade como um todo, sendo considerada uma intervenção urbana de referência internacional e visitada por pessoas de todo o mundo. 
Segundo Rogers (2001), Barcelona transformou-se em uma cidade privilegiada, onde as pessoas têm vontade de trabalhar, morar ou visitar, e comenta: "The Olympic Village, planned by MBM Architects is a model of successful regeneration of a large brownfield site." (ROGERS, 2001, p72)

\section{Categoria 01 - Compacidade}

O projeto Vila Olímpica apresenta alta densidade e alta compacidade. A densidade populacional é de aproximadamente 1.700 habitantes/ha. Apesar de alta, essa densidade é ainda menor que a de outros bairros de Barcelona, sendo essa uma estratégia projetual para garantir uma melhoria na qualidade ambiental do bairro, ou seja, nesse caso as variáveis ambientais definem os limites do adensamento urbano.

Segundo Rogers (2001, p72), a Vila Olímpica foi desenhada para uma densidade de 200 habitações/ha, que é considerada a menor densidade aceitável para conseguir sustentar uma econômica local diversificada, com lojas e demais facilidades. $O$ projeto apresenta um uso misto, com a construção de residências, edifícios de escritório, comércio e lazer.

\section{Categoria 02 - Mobilidade}

A Vila Olímpica foi implantada em um local importante da cidade, limitada pelo Ensanche, a cidade velha, o Parque da Ciudadela, Barceloneta, o Mar Mediterrâneo e o centro de Poblenou.

O projeto incentiva o transporte sustentável, através da construção de um novo passeio marítimo para a circulação de pedestres e bicicletas, interligando os equipamentos e usos especiais propostos no bairro.

Além disso, obras de infra-estrutura de pequena e média escala foram realizadas, garantindo o acesso a um sistema de transporte público eficiente.

\section{Categoria 03 - Espaço Público e Área Verde}

Vale destacar a qualidade dos espaços livres, constituídos de parques, jardins, passeio marítimo e a praia, que foi totalmente recuperada.

Os espaços abertos e públicos assumiram um papel determinante na configuração do bairro que, integrados à rede viária, foram considerados o eixo estruturador da composição urbana. (SALES, 1999, p103). O projeto conta com a presença de seis edifícios-pontes, permitindo o acesso de cidadãos ao interior das quadras, onde foram 
construídos jardins e/ou equipamentos públicos. Além de um grande boulevard, formando um eixo urbano interno.

\section{Categoria 04 - Eficiência no uso dos Recursos Naturais água e energia}

Algumas transformações no modelo de habitação tradicional foram realizadas, visando o maior conforto ambiental e um menor consumo de energia elétrica.

\section{Categoria 05 - Diversidade Urbana e Expressão Arquitetônica}

O projeto apresenta uma complexidade de usos, que the dá dinâmica, com residências, hotéis, escritórios, comércios e equipamentos de lazer.

Com relação à expressão arquitetônica, vale destacar os edifícios pontes, considerados marcos urbanos, que foram encomendados a seis arquitetos internacionais, sem muitas limitações normativas. Com esse mesmo critério, foram projetados monumentos escultóricos que configuram outra série de marcos ao longo dos espaços públicos. (SALES, 1999, p.100).

Apesar da garantia da qualidade arquitetônica dos edifícios, em termos sociais o projeto contradiz os objetivos iniciais porque é conivente com uma lógica de mercado, esquecendo a proposta de criar um bairro socialmente diversificado. (SALES, 1999). Porém, algumas quadras foram exceção, separando uma terça parte das unidades habitacionais para o setor de pessoas de baixa renda. 


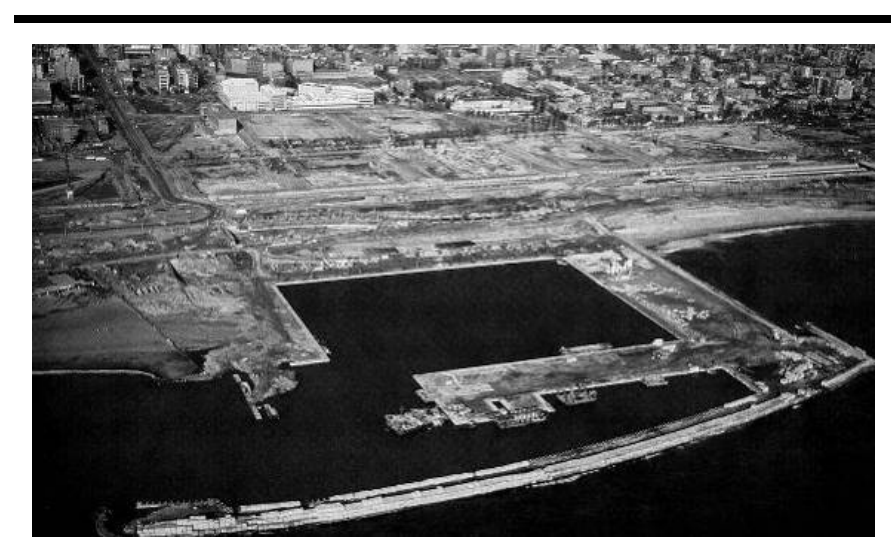

\section{Figura 74: Maquete do projeto}

Fonte: Google

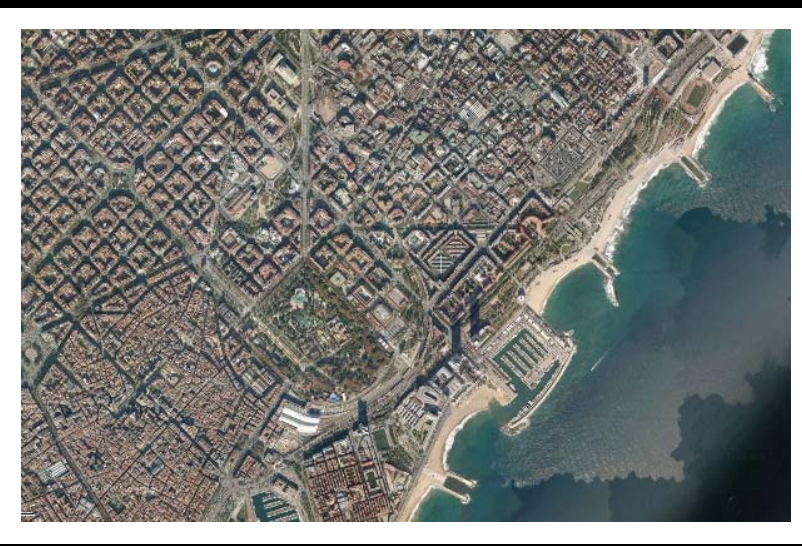

Figura 75: I magem área do projeto

Fonte: Google

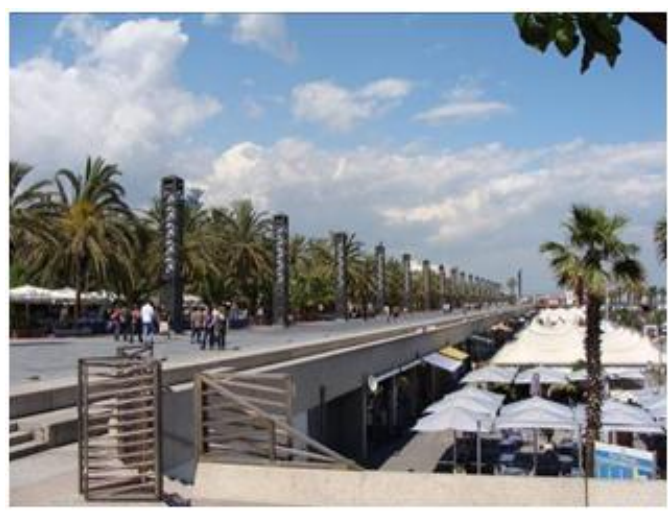

Figura 76: Área do porto

Fonte: Foto da autora, junho 2008

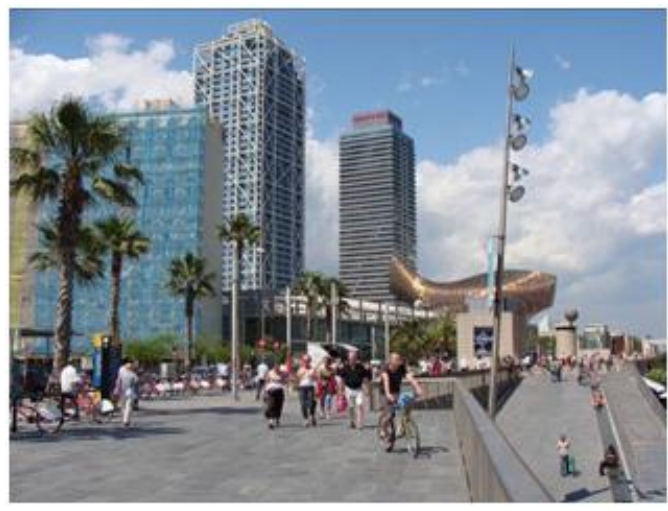

Figura 78: Orla marítima com edifícios altos

Fonte: Foto da autora, junho 2008

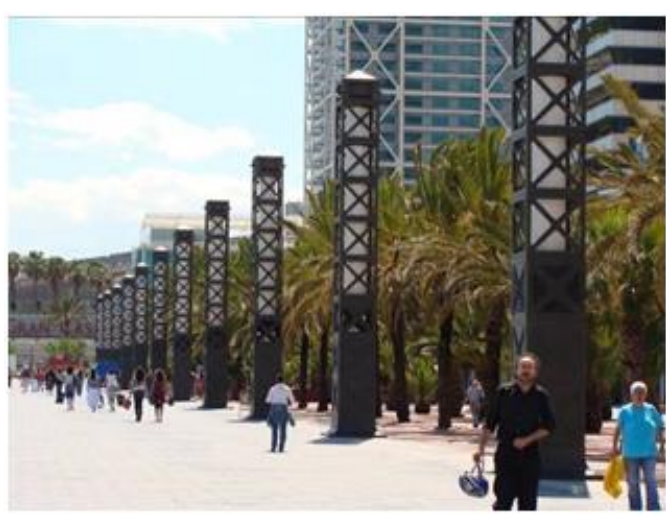

Figura 77: Orla marítima

Fonte: Foto da autora, junho 2008

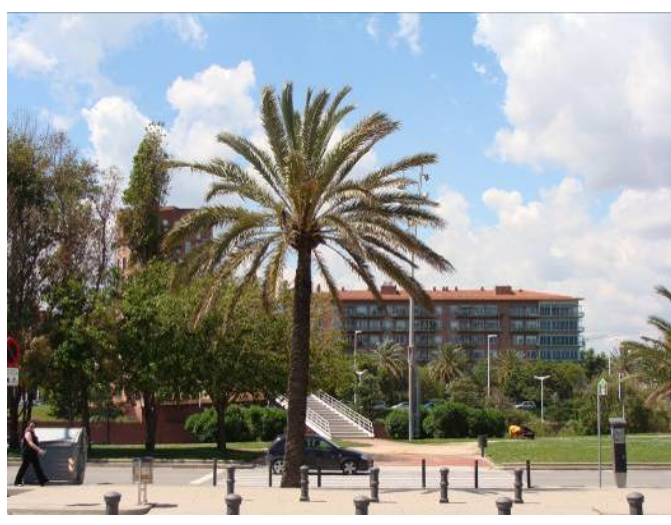

Figura 79: Área residencial - Vila Olímpica

Fonte: Foto da autora, junho 2008 


\section{EXPOSI ÇÕES I NTERNACI ONAIS E EVENTOS ESPORTI VOS}

\begin{tabular}{|c|c|c|c|c|c|c|c|}
\hline PROJ ETO & DIM. & LOCAL & CONST. & $\begin{array}{l}\text { I MPACTO } \\
\text { URBANO }\end{array}$ & $\begin{array}{l}\text { SI TUAÇÃO } \\
\text { ATUAL }\end{array}$ & ASPECTOS FAVORÁVEIS & $\begin{array}{c}\text { ASPECTOS } \\
\text { DESFAVORÁVEIS }\end{array}$ \\
\hline $\begin{array}{c}\text { SEVI LHA } \\
1992\end{array}$ & 215ha & $\begin{array}{l}\text { Ilha de } \\
\text { Cartuja } \\
\text { Guadalquivir }\end{array}$ & equipamentos & $\begin{array}{l}\text { Infra estrutura e } \\
\text { parque } \\
\text { tecnológico }\end{array}$ & $\begin{array}{l}\text { ocupada por } \\
\text { universidade e } \\
\text { edifícios } \\
\text { administrativos }\end{array}$ & $\begin{array}{l}\text { Tratamento dos espaços } \\
\text { externos visando o conforto } \\
\text { ambiental }\end{array}$ & $\begin{array}{l}\text { Escolha da área de } \\
\text { implantação do evento } \\
\text { desvinculada da região } \\
\text { central da cidade }\end{array}$ \\
\hline $\begin{array}{c}\text { 니 SBOA } \\
1998\end{array}$ & $\begin{array}{l}\text { 61ha e } \\
\text { 350ha }\end{array}$ & $\begin{array}{l}\text { Região } \\
\text { ribeirinha do } \\
\text { Rio Tejo }\end{array}$ & $\begin{array}{l}\text { Oceonário, } \\
\text { escritórios e } \\
\text { equipamentos }\end{array}$ & $\begin{array}{l}\text { Revitalização da } \\
\text { frente fluvial, } \\
\text { nova área } \\
\text { residencial }\end{array}$ & $\begin{array}{l}\text { Parque das } \\
\text { Nações, ocupado } \\
\text { por habitação, } \\
\text { comércio e } \\
\text { equipamentos de } \\
\text { lazer }\end{array}$ & $\begin{array}{l}\text { Projeto pensado para uso } \\
\text { posterior. } \\
\text { Diversidade de usos }\end{array}$ & Nada a destacar \\
\hline $\begin{array}{c}\text { KRONSBERG } \\
\text { HANNOVER } \\
2000\end{array}$ & 160ha & $\begin{array}{l}\text { "greenfield", } \\
\text { lado oeste do } \\
\text { declive de } \\
\text { Kronsberg }\end{array}$ & $\begin{array}{l}\text { Habitações e } \\
\text { equipamentos } \\
\text { básicos }\end{array}$ & $\begin{array}{l}\text { Novo bairro em } \\
\text { Kronsberg }\end{array}$ & $\begin{array}{l}\text { Primeira fase } \\
\text { finalizada e } \\
\text { segunda em } \\
\text { construção }\end{array}$ & $\begin{array}{l}\text { Repercussão internacional } \\
\text { considerado exemplo } \\
\text { positivo levou a prefeitura } \\
\text { de Hanover a aplicar as } \\
\text { normas desenvolvidas a } \\
\text { toda a cidade. }\end{array}$ & $\begin{array}{l}\text { Pouca expressão } \\
\text { arquitetônica }\end{array}$ \\
\hline $\begin{array}{c}\text { VI LA OLÍ MPI CA } \\
\text { BARCELONA } \\
1992\end{array}$ & 130 ha & $\begin{array}{l}\text { Frente } \\
\text { Marítima }\end{array}$ & $\begin{array}{l}\text { Equipamentos, } \\
\text { habitações, } \\
\text { edifícios de } \\
\text { escritórios, } \\
\text { comercio e } \\
\text { hotéis }\end{array}$ & $\begin{array}{l}\text { Revitalização da } \\
\text { orla marítima } \\
\text { Abertura de } \\
\text { Barcelona ao } \\
\text { Mar } \\
\text { Mediterrâneo }\end{array}$ & $\begin{array}{l}\text { Área de lazer e } \\
\text { habitação. } \\
\text { Construção. da } \\
\text { orla marítima e } \\
\text { recuperação da } \\
\text { praia }\end{array}$ & $\begin{array}{l}\text { Construção de habitações de } \\
\text { alta densidade adotando } \\
\text { uma tipologia edificatória } \\
\text { característica } \\
\text { Construção de uma área de } \\
\text { lazer para todos os cidadãos }\end{array}$ & $\begin{array}{l}\text { Habitações e serviços } \\
\text { direcionados para a } \\
\text { burguesia, contradizendo o } \\
\text { caráter social do projeto } \\
\text { inicial. }\end{array}$ \\
\hline
\end{tabular}




\begin{tabular}{|c|c|c|c|c|}
\hline \multicolumn{5}{|c|}{ EXPOSI ÇÕES I NTERNACI ONAIS E EVENTOS ESPORTIVOS } \\
\hline $\begin{array}{c}\text { I NDI CADORES } \\
\text { SUSTENTABI LI DADE }\end{array}$ & $\begin{array}{c}\text { EXPO SEV LHA } \\
1992\end{array}$ & $\begin{array}{c}\text { EXPO LISBOA } \\
1998\end{array}$ & $\begin{array}{c}\text { EXPO HANNOVER } \\
2000\end{array}$ & $\begin{array}{c}\text { BARCELONA } \\
\text { OLI MPÍ ADAS } 1992\end{array}$ \\
\hline COMPACI DADE & $\mathbf{X}$ & & & \\
\hline MOBI LI DADE & & & & \\
\hline $\begin{array}{l}\text { ESPAÇO PÚBLICO E } \\
\text { ÁREA VERDE }\end{array}$ & & & & \\
\hline $\begin{array}{l}\text { EFICIÊNCIA NO USO DOS } \\
\text { RECURSOS NATURAIS }\end{array}$ & & & & \\
\hline $\begin{array}{c}\text { DI VERSI DADE URBANA } \\
\text { EXPRESSÃO } \\
\text { ARQUITETONICA }\end{array}$ & & & & \\
\hline
\end{tabular}




\subsection{Projetos de Recuperação de Bairros Degradado}

O conceito de sustentabilidade também pode e deve ser aplicado a projetos de renovação urbana e recuperação de áreas degradadas.

Nos anos de 1945 a 1975, a maioria das metrópoles sofreu uma reestruturação na sua base econômica em virtude do paradigma de desenvolvimento Fordista-Keynesiano, resultante de transformações no processo de produção industrial e da flexibilização do mercado de trabalho urbano.

Durante a década de 70, o modelo fordista entra em decadência, ocasionado um processo de esvaziamento das zonas industriais, que culminou em áreas de degradação ambiental e baixa qualidade de ocupação espacial urbana. Essas grandes áreas abandonadas, denominadas "vazios urbanos"71, geralmente localizavam-se ao longo das principais vias de transporte, ao longo dos rios, canais e junto ao mar.

Algumas zonas portuárias e áreas históricas devastadas pela guerra também se tornaram grandes "vazios urbanos", sendo esses objetos de discussão entre urbanistas e profissionais da área.

Segundo Rosa:

"os vazios urbanos se destacam como elementos morfológicos estruturais das cidades, apresentando-se como essenciais para entendê-las em sua gênese e em suas transformações. Os vazios como parte da morfologia urbana, são áreas passíveis de intervenção, que podem desempenhar importante papel nas mudanças da organização, desenho e qualificação da cidade, em suas diferentes escalas. " ${ }^{~}$

\footnotetext{
${ }^{71}$ Para Solà-Morales a definição de vazios se dá através da expressão francesa terrain vague, em virtude da sua multiplicidade de significados: "vague no sentido de vacante, vazio, livre de atividades, improdutivo, e em muitos casos obsoleto, mas também vague no sentido impreciso, indefinido, vago, sem limites determinados, sem um horizonte de futuro." (ROSA, 2008, p.36)

Durante o XIX Congreso de la Unión Internacional de Arquitectos, realizada em Barcelona, em 1996, utilizouse a expressão francesa terrain vague, como uma das cinco categorias para discutir traços da nova realidade da cidade.

72 ROSA, 2008, p.120.
} 
Em 2007, os vazios urbanos também foram o tema central da Trienal de Arquitetura, realizada em Lisboa:

"Para estes 'Vazios Urbanos', em muitas cidades do mundo, equacionam-se, debatemse e concretizam-se novos conceitos e estratégias de intervenção, modelos de sustentabilidade e gestão, bem como plataformas de interação público/privado. (...) 0 futuro das principais cidades e territórios urbanos do planeta depende, em muito, do destino destes Vazios Urbanos. ${ }^{73}$

Não restam dúvidas dos benefícios ambientais, sociais e econômicos que a reabilitação e ocupação desses vazios urbanos podem trazer para a cidade. A recuperação dessas áreas pode representar uma importante oportunidade para melhorar o grau se sustentabilidade das cidades.

\subsubsection{Potsdamer Platz, Berlin}

\section{Ficha técnica:}

Projeto: Potsdamer Platz

Localização: Berlim - Latitude: 52०31"N

Arquiteto Urbanista: Coordenador - Renzo Piano - Equipe: Richard Rogers Patnership, Hans Kollhof, Arata Isozaki, Lauber und Wohr e Rafael Moneo e Christoph Kohlbecker Consultoria técnica: Ove Arup \& Partners (engineering); Möhrle \& Kruger (landscaping) Cliente: Daimler Benz AG, Sony AG, Hertie, ABB, Haus Vaterland Área: 60 hectares

Uso: misto

Fase: finalizado em 2000

\section{Descrição:}

Nos anos 30, Potsdamer Platz era uma importante área cultural e comercial para a cidade de Berlim e que foi bombardeada e destruída durante a Segunda Guerra Mundial. Finalizada a guerra, a região se tornou um grande vazio abandonado por onde, durante muitos anos, passava o muro de Berlim.

\footnotetext{
${ }^{73}$ APRESENTAÇÃO DA TRIENAL DE ARQUITETURA DE LISBOA, 2007.
} 
Em 1993, após a queda do Muro, o grupo Daimler Chrysler, um dos cinco investidores do projeto, promove um concurso do "masterplan" para a reconstrução da área e, posteriormente, outro concurso para a definição da arquitetura das novas edificações.

A área a ser projetada abrange cerca de 60 hectares, com 10 ruas, duas praças e 19 edificações.

O objeto do concurso era a reunificação dos dois lados de Berlim, ocidental e oriental, sendo muito bem trabalhada pela proposta de Renzo Piano, vencedor do concurso. A equipe de arquitetos era composta por Arata Isozaki (Tokyo), Christoph Kohlbecker (Gaggenau), Hans Kollhoff (Berlin), Ulrike Lauber and Wolfram Wöhr (Munich), José Rafael Moneo (Madrid) e Richard Rogers (London).

Como elementos chaves do projeto destacam-se: o tratamento dos espaços com curtas distâncias, vida cultural urbana, a diversidade e as diferentes possibilidades de usos da área.

Em 1998 o projeto é inaugurado, com 50\% de edifícios de escritórios, 20\% apartamentos e $30 \%$ demais serviços. Posteriormente são construídos teatros, hotéis, restaurantes, cafés, etc.

Segundo Tavares (2006), o projeto para a reconstrução da Potsdamer Platz foi um ponto fundamental de interesse na dinâmica urbana da cidade reunificada, pois era um dos lugares que marcou, não só fisicamente, mas de maneira significativa, a reunificação entre o lado ocidental e oriental de Berlim. Potsdamer Platz foi um dos pontos mais importantes de um amplo projeto de reestruturação urbana para a nova capital alemã, que contou com diferentes propostas submetidas a uma série de concursos.

Tavares comenta:

"A medida que este "vazio", que é um espaço físico pronto a receber as mais novas propostas urbanas, mas também uma tabula rasa conceitual capaz de colocar em debate as mais díspares e atuais teorias sobre a cidade, é preenchido, visualiza-se a forma do "discurso urbano" por completo e em toda sua complexidade, como prática e teoria." (TAVARES, 2006)

O projeto para Potsdamer Platz estava inserido em uma operação urbana que contava com mais de trezentos projetos e que movimentou cerca de duzentos milhões de dólares fornecidos pelas mais poderosas corporações. Ao lado da reurbanização da Alexanderplatz 
e da revitalização da Frieddrichstrasse, a recuperação da Potsdamer Platz era a parte mais significativa do processo de transformação urbana na cidade que previa a reconstrução das áreas centrais esvaziadas, a reurbanização das periferias e novos projetos de expansão da cidade, com o objetivo de transformar Berlim em uma metrópole do terciário avançado.

Nesse empreendimento, o governo concedeu incentivos fiscais às empresas e construtoras que se transferissem para Berlim.

Esse projeto, a princípio, foi muito criticado por não ter raízes naquele meio e o usuário nunca ser a população local, que na maioria dos casos são populações de baixo poder aquisitivo. O objetivo era sempre atrair novos investimentos, criando espaços de alta qualidade para populações de alto poder aquisitivo. ${ }^{74}$

Por essa razão, além de excluir a população residente, a área ficou tão valorizada que as habitações construídas se tornaram caras e, atualmente, várias delas estão vazias.

Outro problema foi o excesso de oferta de áreas para escritórios e, em conseqüência, uma crise imobiliária.

Com relação aos aspectos ambientais, duas estratégias buscando construir um projeto mais sustentável merecem ser destacadas: minimizar o consumo de energia elétricas das edificações e reaproveitar as águas pluviais para irrigação e lavatórios.

\section{Categoria 01 - Compacidade}

Se considerarmos somente os residentes, o bairro apresenta baixa densidade, agravada pelo alto preço das habitações. Porém, $50 \%$ das edificações são de escritórios e $30 \%$ serviços e lazer. Todos os dias, entre 70.000 e 100.000 pessoas usam os serviços e facilidades oferecidos na área.

Com relação à morfologia, o projeto é compacto, com presença de edifícios altos e próximos uns dos outros.

\section{Categoria 02 - Mobilidade}

\footnotetext{
74 Notas de aula da disciplina AUP 5869, Avaliação dos Grandes Projetos Urbanos: Crítica da Prática Recente da pós graduação da Faculdade de Arquitetura e Urbanismo da Universidade de São Paulo, FAU USP.
} 
Potsdamer Platz é servida por um sistema de transporte público eficiente e diversificado. Além disso, assim como em toda a cidade de Berlim, a locomoção a pé ou de bicicleta é possível.

\section{Categoria 03 - Espaço Público e Área Verde}

Foi construído um lago artificial de 1,2 hectares, localizado na Marlene-Dietrich-Platz, que armazena as águas pluviais quando as cisternas estão cheias, contribui para a biodiversidade e para a qualidade ambiental dos espaços livres.

Os espaços públicos representam um ponto importante no projeto, sendo todos esses muito bem trabalhados. Vale destacar que todas as ruas foram tratadas como espaços públicos para o pedestre.

\section{Categoria 04 - Eficiência no uso de Recursos Naturais água e energia}

O arquiteto Renzo Piano preocupou-se mais em conseguir uma eficiência energética junto ao projeto da edificação do que com o projeto urbano, masterplan. Para reduzir o consumo de energia elétrica foram feitos investimentos em tecnologia de materiais e de equipamento de aquecimento e resfriamento, além de uma combinação do sistema de resfriamento com ventilação mecânica individual controlada em todos os escritórios, reduzindo $50 \%$ do consumo se comparado com edifícios que adotam sistemas convencionais. Além disso, os edifícios foram projetados de maneira a aproveitar ao máximo a luz natural e reduzir o consumo de energia com resfriamento e aquecimento artificial, adotando tecnologias passivas.

Com relação à água, foi adotado um sistema de aproveitamento de águas da chuva para os espaços públicos desenvolvido por Herbert Dreiseitl. A proposta de Piano considera a "água em movimento", uma metáfora do processo de cura entre o leste e o oeste, como uma ponte que se deita sobre uma brecha, além de estreitar a relação de Berlim com a natureza, conectando o verde de Tiergarten ao Norte com a água de Landwehrkanal.

Segundo Andrade (2003), o sistema de manejo de água contém cinco cisternas subterrâneas que funcionam como tanque de controle. No total, podem armazenar 2.600 $\mathrm{m}^{3}$ de água dos quais 900 ficam disponíveis caso haja chuvas torrenciais. Ao passar pelas cisternas, a água é encaminhada até as zonas de purificação que contêm plantadas com raízes de juncos para depuração dos fosfatos e camadas de cascalhos e feltros para a filtragem da água. Na praça Marlene-Dietrich-Platz, a água entra em um 
grande tanque, chamado de Hauptgewasser, com uma superfície total de 1 hectare, com $12.000 \mathrm{~m}^{3}$ e um perímetro de 1,6 quilômetros, com a água sendo levada até o canal Landwehrkanal.

O sistema de manejo integrado de Potsdamer Platz tem como funções: armazenar a água com o objetivo de proteção contra inundações, reduzir os poluentes no canal circunvizinho, regular a temperatura e, ao mesmo tempo, funcionar como uma fonte de deleite urbano. $\mathrm{O}$ acesso livre a água é um dos princípios fundamentais do projeto.

Como resultado dessa estratégia são economizados aproximadamente 20 milhões de litros de água por ano

\section{Categoria 05 - Diversidade Urbana e Expressão Arquitetônica}

Potsdamer Platz apresenta uma diversidade de uso, apesar de serem predominantemente, escritórios e demais serviços.

O projeto não apresenta coesão social, sendo considerado exclusivista. O projeto foi pensado buscando atrair populações de alto poder aquisitivo, excluindo a população local de pouco recursos financeiros. Além disso, após a revitalização a área ficou muito valorizada e as habitações construídas se tornaram bastante caras.

O projeto apresenta grande expressão arquitetônica, símbolo de modernidade e tecnologia. Sob a coordenação de Renzo Piano, seis nomeados arquitetos internacionais foram selecionados para desenvolver os projetos das edificações, entre eles: Arata Isozaki (Tokyo), Christoph Kohlbecker (Gaggenau), Hans Kollhoff (Berlin), Ulrike Lauber and Wolfram Wöhr (Munich), José Rafael Moneo (Madrid) e Richard Rogers (London). 

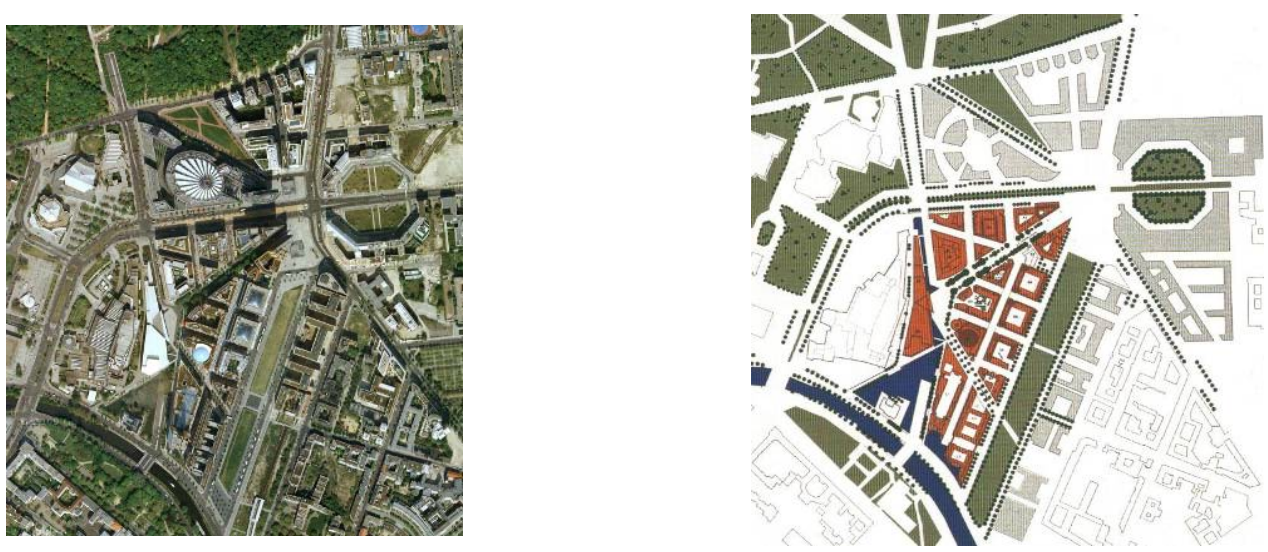

Figura 80: I magem aérea Potzdamer Platz Fonte: Google

Figura 81: Planta projeto Potzdamer Platz Fonte: RUANO, 1998
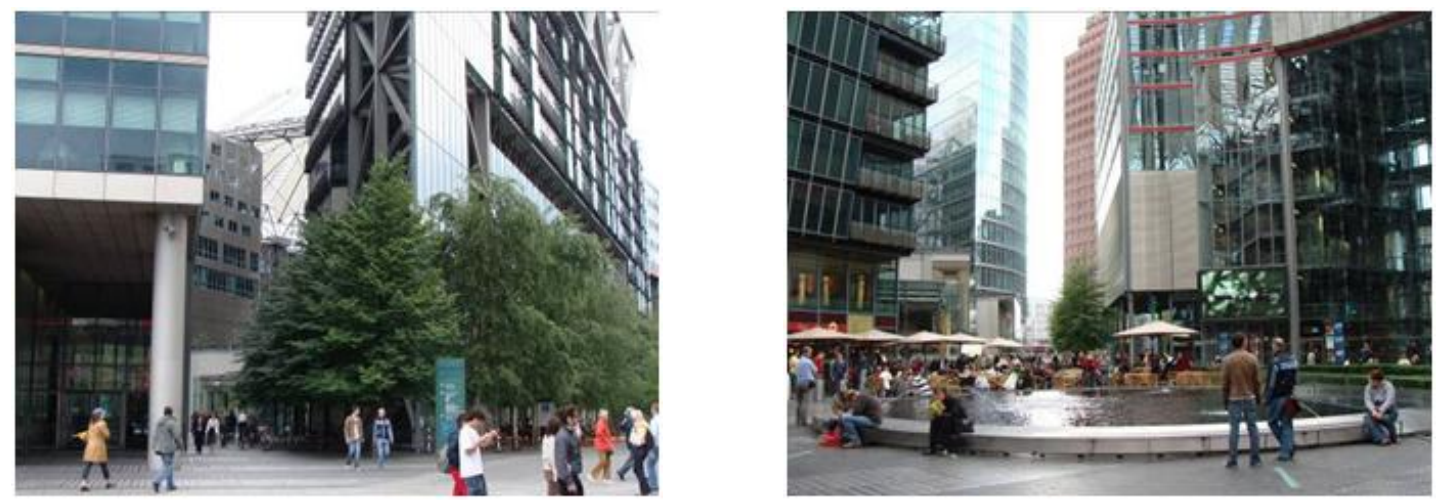

\section{Figura 82: Foto Potzdamer Platz}

Fonte: imagem da autora, junho 2008

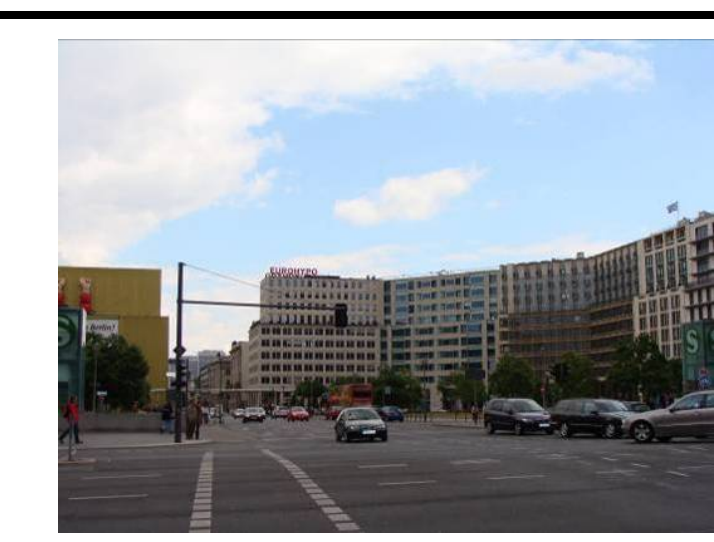

Figura 84:Foto Potzdamer Platz

Fonte: imagem da autora, junho 2008
Figura 83: Foto Potzdamer Platz

Fonte: imagem da autora, junho 2008

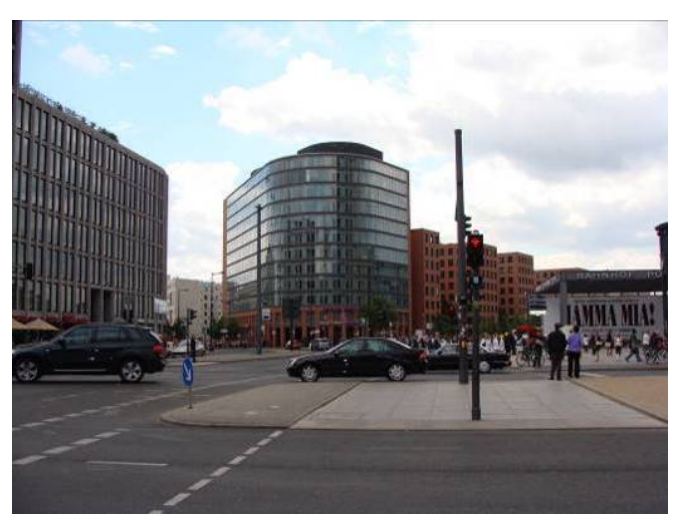

Figura 85: Foto Potzdamer Platz

Fonte: imagem da autora, junho 2008 


\subsubsection{Greenwich Península, Londres}

\section{Dados técnicos:}

Projeto: Greenwich Península

Localização: Londres, Reino Unido - Latitude: $51^{\circ} 28^{\prime} \mathrm{N}$

Arquiteto Projeto Urbano: Terry Farrell \& Partners, Richard Rogers \& Partners

Consultoria técnica: Battle Mc Carthy

Cliente: Meridian Delta Ltd. e English Partnerships

Área: 190 acres

Uso: misto

Fase: em construção

\section{Descrição:}

O projeto urbano para Greenwich consiste em um projeto de recuperação a longo prazo, da península de Greenwich, área que anteriormente funcionava uma usina de gás e que por isso parte do solo encontrava-se contaminado.

A recuperação da península de Greenwich foi e está sendo realizada em três projetos: o Projeto Millennium Dome, que atualmente é denominado de $\mathrm{O}_{2}$, o Projeto Greenwich Millennium Village, ambos finalizados e o Projeto Greenwich Península, que está em fase de construção.

No contexto de mudança para o novo milênio, várias cidades aproveitaram a ocasião para construir projetos de grandes equipamentos, como por exemplo, o Millennium Dome, construído como parte do Millennium de Londres, para a Exposição, Millenium Experience Exhibition.

Desde o princípio o projeto estava associado às estratégias gerais de renovação e revitalização de antigas áreas industriais abandonadas, às margens do rio Thames a leste de Londres. A idéia era transformar a área da península de Greenwich em um novo bairro urbano sustentável e de uso misto.

Como evento o projeto foi um fracasso, porém como projeto de intervenção urbana podese dizer que o Millennium Dome, projetado arquiteto Richard Rogers, com consultoria de conforto ambiental do escritório Battle McCarthy, permitiu a regeneração de toda a área da península de Greenwich. 
Na primeira fase da intervenção urbana foram construídos espaços públicos, espaços que permitiam a mobilidade dentro da área e um sistema de transporte com o objetivo de facilitar a realização do evento de comemoração do milênio, e ainda iniciar a construção das bases do novo bairro.

Esse é um aspecto muito importante do projeto, ou seja, a infra-estrutura local foi apropriada para a intervenção, antes que ela acontecesse. Infelizmente a maioria das intervenções, nem sempre planejada, são realizadas sem que haja uma infra-estrutura adequada que justifique o adensamento da área, como, por exemplo, o caso de ocupação de áreas periféricas da cidade, onde essas são ocupadas e somente em um momento posterior o governo é obrigado a levar a infra-estrutura básica, para evitar um problema maior.

O projeto inclui: a construção de uma estação de metrô que permite chegar ao complexo em 15 minutos a partir de Westminster, 20 hectares de parque, praças, escolas e serviços locais, 2 quilômetros de área para caminhadas ao longo do Rio, ciclovias, vias e serviços urbanos. (ROGERS, 1997)

Atualmente o Millenium Dome foi reestruturado e é denominado $\mathrm{O}_{2}$.

Com relação às habitações de Greenwich Millenium Village, implantadas na mesma área, elas foram projetadas visando a eficiência energética, a redução de resíduos sólidos e da demanda de água. Além das preocupações com a qualidade ambiental, o projeto se destaca pela diferenciada composição e expressão arquitetônica.

Durante algum tempo a área contava com o projeto de Millenium Dome, as habitações de Greenwich Village e uma enorme área verde pública, apoiados por um sistema de transporte eficiente e diversificado.

O projeto Greenwich península, que está em fase de construção, transformará toda a área, completando os dois projetos anteriores.

O projeto de recuperação da península de Greenwich está se desenvolvendo em 15 anos. O projeto consiste em quatro distritos, três residenciais e um de escritórios. A Península central é predominantemente comercial e se situa adjacente ao $\mathrm{O} 2$, incluindo a Península Square. A Península Quays, a Península Riverside e a Península Parkside são os distritos residenciais. 
O projeto também é formado por espaços públicos e verdes que consistem em um parque central, com ciclovias e espaços para pedestres, além de escolas, área de saúde, etc.

A Península será um dos locais sede dos jogos olímpicos de 2012.

O sucesso desses projetos demonstra a importância da integração das intervenções e de um planejamento a longo prazo, visto que podem levar alguns anos para se consolidarem, além das transformações da própria cidade.

O projeto alcançou a pontuação mais alta nos aspectos ambientais para as novas edificações, nível excelente no BREEAM para edifícios comerciais e quatro estrelas no Sustainable Homes.

\section{Categoria 01 - Compacidade}

O projeto apresenta densidade e compacidade absoluta média. O projeto prevê: 3,5 milhões de escritórios; 9,2 milhões de metros quadrados de residências; $194.000 \mathrm{~m}^{2}$ de indústria; $645.000 \mathrm{~m}^{2}$ de hotel e $363.000 \mathrm{~m}^{2}$ de lazer. Com relação à população está previsto um aumento de 29.000 residentes e 24.000 empregos $^{75}$.

\section{Categoria 02 - Mobilidade}

Já na primeira fase do projeto foram realizadas melhorias no transporte público, facilitando o acesso à área por meio do transporte em massa.

Além disso, o projeto adota medidas que inibem o uso de automóveis, como a construção de uma zona de baixa emissão de poluentes, na qual será cobrada uma taxa para os proprietários de automóveis particulares.

O projeto também prioriza os modos de transporte sustentáveis, através da construção de ciclovias e de caminhos para pedestres.

\section{Categoria 03 - Espaço Público e Área Verde}

O projeto prevê a construção de um parque central, espaços livres, jardins e bulevares, em um total de 48 acres de área verde, distribuídos pelo bairro.

Com o acesso restrito de veículos privados, os espaços livres ficam mais protegidos do ruído e da poluição do ar.

\footnotetext{
${ }^{75}$ Disponível em: www.greenwichpeninsula.co.uk, acesso em: agosto de 2009.
} 
A porcentagem de superfície de viário público destinado ao transporte motorizado é baixa, destinando esta ao espaço livre para lazer, circulação de pedestres e área verde.

\section{Categoria 04 - Eficiência no uso de Recursos Naturais água e energia}

Como o objetivo é reduzir a pegada ecológica do carbono, o projeto adota um desenho visando a eficiência energética, a descentralização da geração de energia e o uso de energias renováveis.

Informações sobre o projeto revelam uma preocupação em adotar medidas para minimizar a demanda de água e reuso das águas pluviais, porém essas não foram especificadas.

\section{Categoria 05 - Diversidade Urbana e Expressão Arquitetônica}

O projeto apresenta diversidade social e de usos. Das 10.000 novas habitações previstas, 3.800 são affordable homes ${ }^{76}$, ou seja, mais acessíveis a parcelas da população menos favorecidas.(ROGERS, 1997)

Projeto de grande expressão arquitetônica, com destaque para as habitações Greenwich Millenium já construídas.

\footnotetext{
76 Affordable Housing: "A range of both subsidised and non-subsidised housing designe for those whose incomes generally deny them the opportunity to purchase or rente housing on the open market." (The Regeneration of the Greenwich Peninsula: A Progress Report)
} 

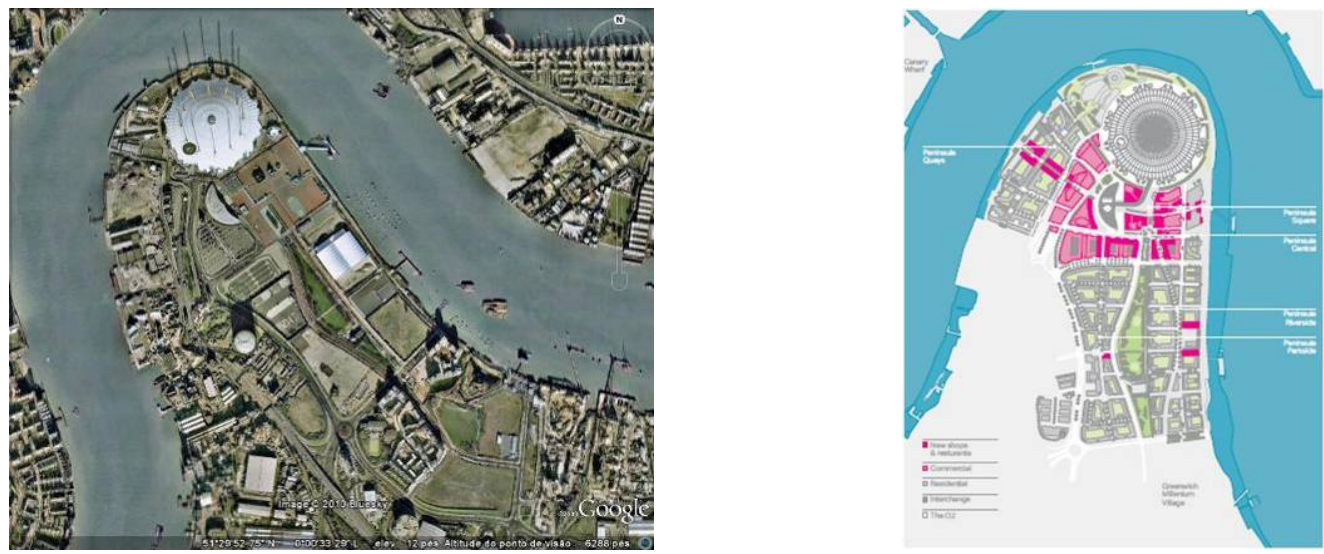

\section{Figura 86: Foto aérea Greenwich península}

Fonte: Google

Fonte: http://www.greenwichpeninsula.co.uk
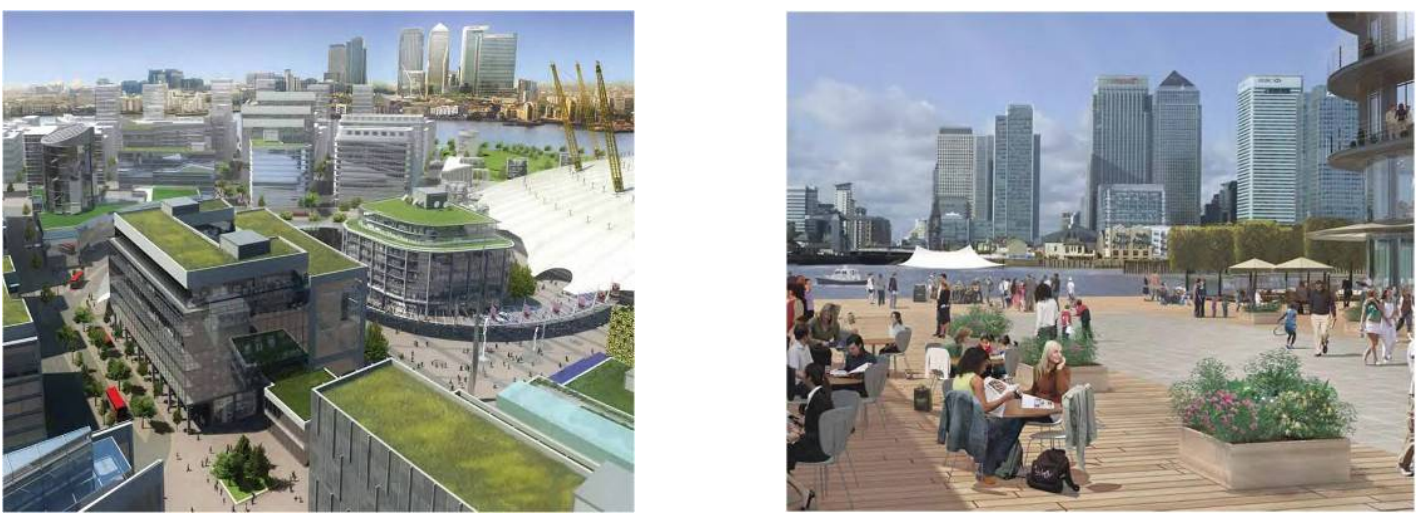

Figura 88: Projeto Greenwich península

Fonte: http://www.greenwichpeninsula.co.uk
Figura 89: Projeto Greenwich península

Fonte: http://www.greenwichpeninsula.co.uk

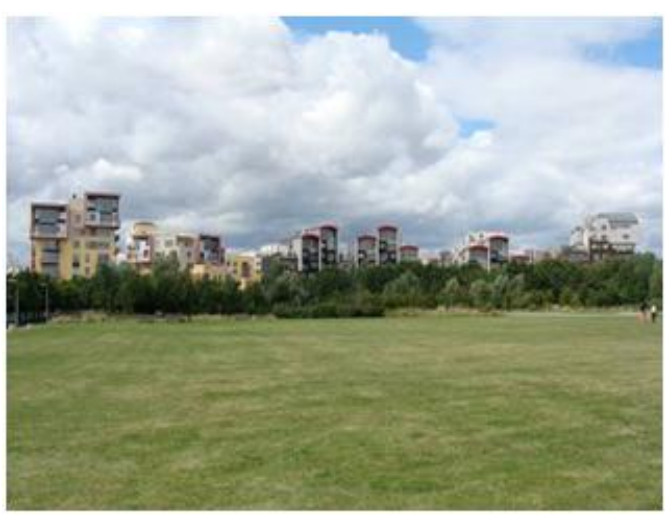

Figura 90: Greenwich Village

Fonte: imagem da autora, junho 2008

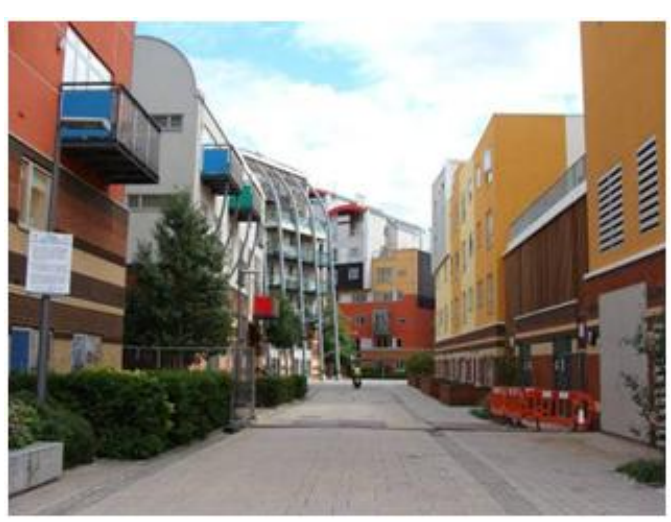

Figura 91: Greenwich Village

Fonte: imagem da autora, junho 2008 


\subsubsection{Elephant and Castle, Londres}

\section{Dados técnicos:}

Projeto: Elephant and Castle

Localização: Londres, Reino Unido - Latitude: $51^{\circ} 30^{\prime} \mathrm{N}$

Arquiteto Projeto Urbano: Foster \& Partner

Consultoria técnica: Battle Mc Carthy, GEHL Architects, Brian Dunlop Consuting Enginner, Steer Davies Gleave, JMP Consultants Limited

Cliente: Elephant \& Castle Regeneration Partnership

Área: 170 hectares

Uso: misto

Fase: projeto

\section{Descrição:}

O bairro Elephant \& Castle começou seu declínio com um extensivo bombardeio durante a Segunda Guerra Mundial. Após esse acontecimento, durante anos o bairro ficou degradado, com edificações e ruas deterioradas, estando sujeito ao desuso e à violência urbana. No decorrer dos anos, alguns investimentos para a recuperação do bairro foram realizados e, atualmente, apesar desse projeto não ter sido construído, algumas áreas de Elephant \& Castle sofreram melhorias bastante significativas. ${ }^{77}$

Esse projeto foi proposto quando o bairro Elephant \& Castle foi identificando como uma das áreas de oportunidade, dentro da região central de Londres. 0 bairro Elephant \& Castle apresenta um grande potencial devido ao transporte público e a proximidade com áreas atrativas da cidade, tais como o centro econômico, cultural e comercial.

Em 2002, o conselho Southwark decide que a única maneira de promover a região era removendo as barreiras físicas e refazendo o design e layout do bairro. As barreiras físicas

${ }^{77}$ Constatado durante visita técnica em julho de 2008. 
consideradas eram os edifícios deteriorados e ultrapassados, o volume de tráfego pesado e 0 alto índice de poluição. ${ }^{78}$

Os desafios do empreendimento eram construir em uma área de 170 hectare novos edifícios residenciais e de escritórios, espaços de comércio e serviço, além de novos espaços públicos, atraindo investimentos para recuperação da área.

O projeto urbano para o bairro Elephant and Castle proposto por Foster \& Partner foi o vencedor do concurso, que contou com a consultoria técnica de diversos outros escritórios, como por exemplo: Battle Mc Carthy, para estudos de desempenho ambiental, GEHL Architects (Urban quality consultants) para tratamento dos espaços externos, Brian Dunlop para questões relacionadas ao consumo dos recursos naturais, água e energia, JMP Consultants Limited, para transporte, etc.

Desde o princípio o projeto teve uma atenção especial com a mobilidade e com a qualidade ambiental dos espaços livres. Sendo assim, foram propostas melhorias no transporte público e incentivo a outros meios de locomoção, reduzindo o uso de automóveis e, conseqüentemente, o nível de poluição do ar e o ruído urbano.

O projeto prevê a construção de no mínimo 4.200 novas habitações, mais 1.100 novas residências substituindo as existentes na rua Heygate. As novas residências apresentam, na sua maioria, o térreo permeável destinado ao uso público, promovendo o interior da área e os dois primeiros pavimentos destinados ao comércio e demais serviços.

Com o objetivo de garantir melhorias e novas oportunidades para moradores e trabalhadores locais e ainda atrair pessoas de outras regiões e novos investimentos para área, estão previstas a construção de novas lojas, restaurantes, cafés, hotéis e espaços focados na cultura, junto da Walworth High Street, Market Square e Town Park, como também um novo centro comercial constituído de altos edifícios de escritórios (cluster).

O projeto preocupa com a preservação das comunidades locais e das atividades existentes na área, ao mesmo tempo em que propõe com a criação de novos edifícios educacionais, novas escolas, centro de saúde, biblioteca e uma central de energia para distribuição.

${ }^{78}$ Elephant and Castle Development Framework, 2004. 
Para o desenvolvido do projeto a área foi dividida em seis partes, com base nas suas características: Walworth High Street extension; the Civic Square; the Market Square; the Town Park, Heygate Boulevard e St. Mary' Churchyard.

Para a Walworth High Street o projeto propõe um novo centro de atividades, transformando toda esta rua em um local de referência para o bairro Elephant and Castle, similar a Regents Street. Na parte norte da rua está previsto uma área mais densa, com edifícios de escritórios altos e livre acesso ao pedestre. A princípio foram projetadas duas dessas torres de escritórios, marcando o início da formação de um cluster.

Sobre a implantação dos edifícios altos, esses devem ser agrupados próximos ao fluxo de pedestre, acessível ao público e em locais que os impactos ambientais gerados pela sua instalação sejam minimizados. Os edifícios altos devem promover a integração da rua com seus térreos, estabelecer boas relações com os outros edifícios do contexto e ser um elemento de atração na cidade.

Após o viaduto, railway viaduct, a densidade é menor, sendo propostos edifícios mais baixos, de uso misto, predominantemente residencial, com o térreo e o primeiro pavimento destinados a cafés, restaurantes, lojas e demais serviços comerciais. O térreo é permeável em grande parte, possibilitando uma integração da área.

Essa rua começa em uma praça, Civic Square, ponto de referência do transporte público, localizada na parte histórica do bairro.

Um ponto importante do projeto é a criação de espaços públicos para o lazer e cultura. Além da Praça Cívica (Civic Square) e da nova High Street, extensão da Rua Walworth o projeto também propõe uma nova Praça do Mercado (Market Square), ao lado do viaduto, um Parque Central (Town Park), uma nova quadra na Rua Walworth Road, Faraday Square, além das melhorias da área ao redor da Igreja Sta. Mary e dos demais espaços públicos existentes.

Ao redor do parque central, as edificações são escalonadas, tendo seu ponto mais baixo próximo do parque. Essa forma traz alguns benefícios ambientais, entre eles a penetração de sol no parque e nas edificações que o cercam.

Preocupados com os impactos no micro-clima urbano gerados pela construção das novas edificações, foram realizados uma série de estudos de insolação e ventilação, através de aplicativos computacionais, objetivando a criação de espaços que produzam um micro- 
clima diferenciado e agradável e, principalmente, um melhor desempenho para as edificações.

\section{Categoria 01 - Compacidade}

O projeto propõe densidades médias em quase todo o bairro. Porém, em algumas áreas, como a parte norte da Walworth High Street, são propostas densidades maiores.

Apesar de ter bastantes áreas livres, o projeto apresenta uma compacidade média.

\section{Categoria 02 - Mobilidade}

O bairro Elephant \& Castle está localizado próximo a importantes áreas da cidade, tais como o centro econômico, cultural e comercial.

As estações de transporte público ganham papel de destaque no projeto, fazendo conexão do transporte local com a infra-estrutura maior da cidade, além de organizar a acessibilidade dentro do complexo.

O bairro é servido de um sistema de transporte público eficiente e integrado, mas mesmo assim, foram previstas algumas melhorias, tais como: a construção de uma nova estação (Northern); melhorias no acesso para estação Bakerloo e na rail station; construção de acomodações junto ao rio e aos trens; novos ônibus e tratamento das áreas de espera, melhoria nas ligações entre as modalidades de transporte público.

Foram realizados estudos dos acessos e dos fluxos separados em: pedestres, ciclistas; veículos de abastecimento e serviços; veículos particulares. A estrutura de transporte foi pensada de maneira a hierarquizar vias e fluxos, facilitando os acessos e privilegiando o pedestre.

Incentivo à utilização de outras modalidades de locomoção, como a pé e de bicicleta, através da construção de ciclovias e caminhos para o pedestre, remoção das barreiras de acesso entre moradia e trabalho além da melhoria na qualidade das vias e calçadas.

Foram propostos locais de trabalho em áreas estratégicas, sendo o acesso do pedestre e dos ciclistas facilitado com a construção de ciclovias e de caminhos que atravessam as quadras e cruzam os lotes pelo térreo.

O projeto incentiva a redução do uso do automóvel particular, através da restrição em algumas vias e da extinção de estacionamentos nas ruas principais. O projeto prevê a localização dos estacionamentos apenas em locais necessários e em ruas secundárias. 


\section{Categoria 03 - Espaço Público e Área Verde}

Foram propostos seis novos espaços públicos e melhoria dos existentes. Os espaços públicos são importantes para a área em termos de conexão e relação com a cidade. Por essa razão tiveram uma atenção especial, tendo a participação do escritório de arquitetura dinamarquês especializados em espaços públicos, GEHL Architects - urban quality consultants, de Copenhagen, no desenvolvimento do projeto.

Visando a qualidade dos espaços públicos, o projeto prevê a redução dos níveis de poluição do ar e poluição sonora, decorrente do tráfego de veículos nas ruas e avenidas. Para decisões relacionadas a estas duas variáveis foram realizados estudos com aplicativos computacionais.

Destaca-se que foram realizados uma série de estudos de insolação e ventilação, através de simulações computacionais e em modelos reduzidos no túnel de vento, visando verificar e minimizar os impactos gerados pela construção de novas edificações. Um dos objetivos desses estudos era garantir horas de sol nos espaços externos e projetar sombra nas áreas necessárias, além de verificar possíveis modificações micro-clima urbano

Áreas de uso público e comercial de pequeno porte são tratadas com relevância e estão estrategicamente amarradas ao conjunto.

As novas habitações possuem o térreo liberado aumentando os espaços públicos destinados a lazer e à circulação, além de permitir a ventilação natural

Os espaços verdes estão presentes em todo o bairro, nas ruas, na avenida principal Walworth High Street, no Heygate Boulevard e no Town Park, contribuindo para o conforto dos pedestres e o aumento das diversidades ecológicas. O projeto também tem coberturas verdes em algumas edificações.

\section{Categoria 04 - Eficiência no uso dos Recursos Naturais água e energia}

O projeto propõe uma redução do consumo de recursos, água e energia e geração de resíduos sólidos.

Com relação à energia elétrica, a proposta para o bairro Elephant \& Castle apresenta metas inovadoras, sendo necessário o desenvolvido de um plano de consumo e geração de energia, baseado em energias renováveis e no conceito de distrito energético, no qual 
as áreas comerciais e de serviços estão associadas às residências no sentido de repassar o excedente de energia gerado em suas atividades diárias.

Com relação à água foram identificados os problemas ligados ao custo e escassez futura, sendo propostas alternativas para redução do consumo e reuso, além da inserção de novas tecnologias.

\section{Categoria 05 - Diversidade Urbana e Expressão Arquitetônica}

O projeto apresenta uma diversidade de tipologias edificatórias, de atividades e de classes sociais, através da construção de habitações diferenciadas de alta qualidade ambiental e diferentes tipologias e padrões econômicos, favorecendo assim, a coesão social e a complexidade $^{79}$.

Com relação às atividades urbanas, o projeto tem como princípios criar um faixa de alta qualidade de recreação, entretenimento e comércio, encorajar investimentos em cultura e promover novos empregos.

A proposta de revitalização do bairro Elephant and Castle contou com a participação da comunidade local, desenvolvendo e propondo espaços de qualidade, dos quais eles serão usuários.

Apesar de ser claramente embasado nos princípios da sustentabilidade, o projeto apresenta pouca expressão arquitetônica.

\footnotetext{
${ }^{79}$ Segundo Rueda (2006) dois dos eixos fundamentais da sustentabilidade ambiental urbana.
} 


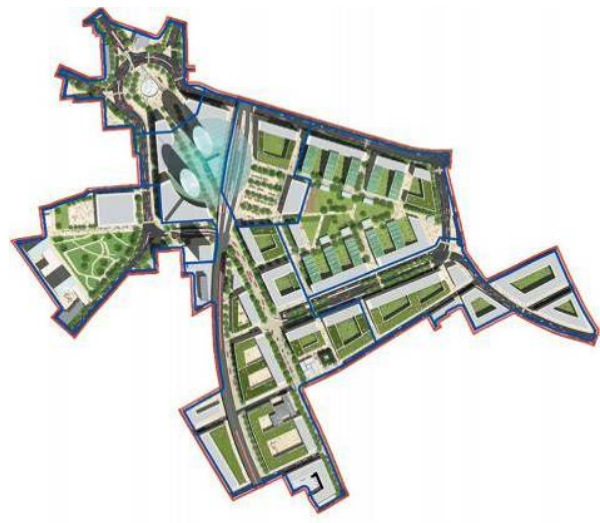

Figura 92: Projeto Elephant and Castle

Fonte: Google

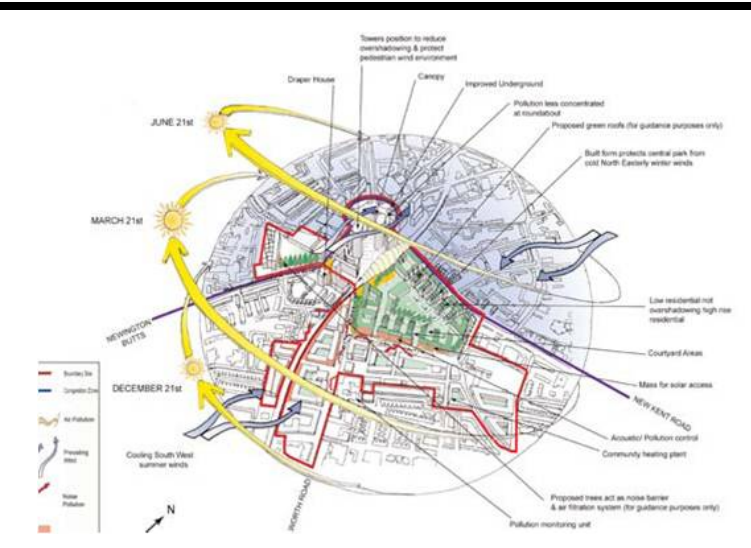

Figura 94: Estudo de insolação

Fonte: Southwark Council, 2004

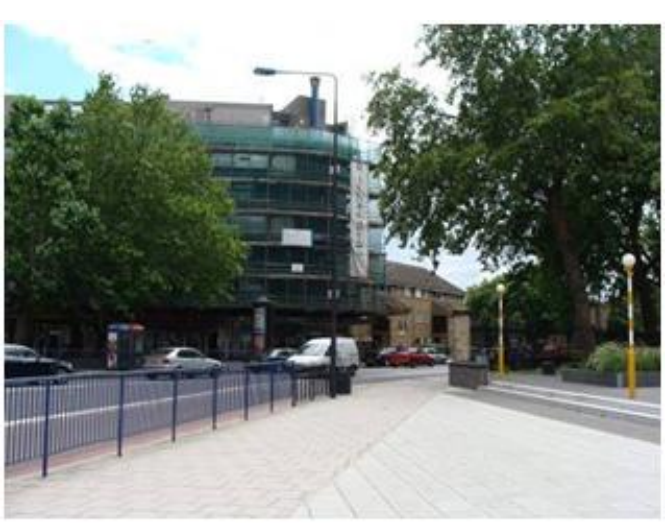

Figura 96: Foto do bairro Elephant \& Castle

Fonte: imagem da autora, julho 2008

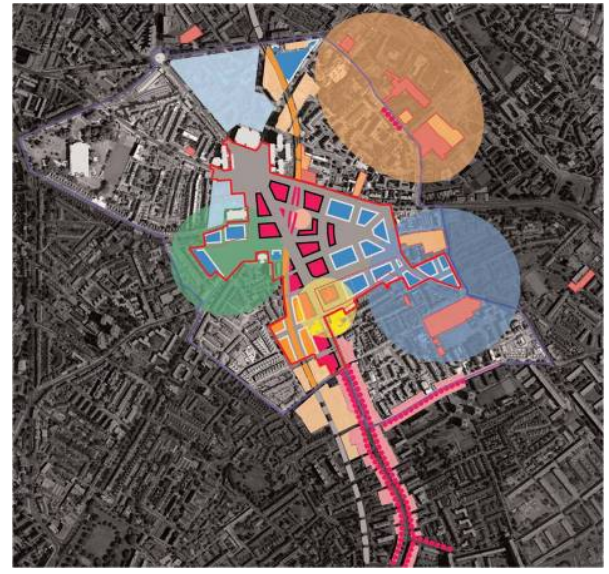

Figura 93: Projeto Elephant and Castle

Fonte: Southwark Council, 2004

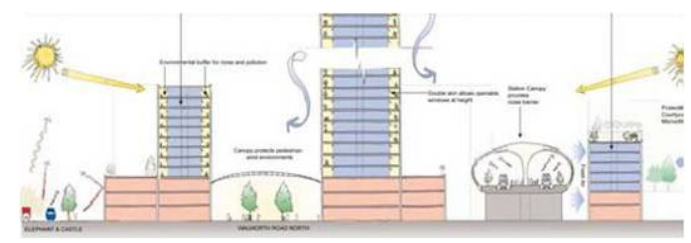

Figura 95: Estudo conforto ambiental

Fonte: Southwark Council, 2004

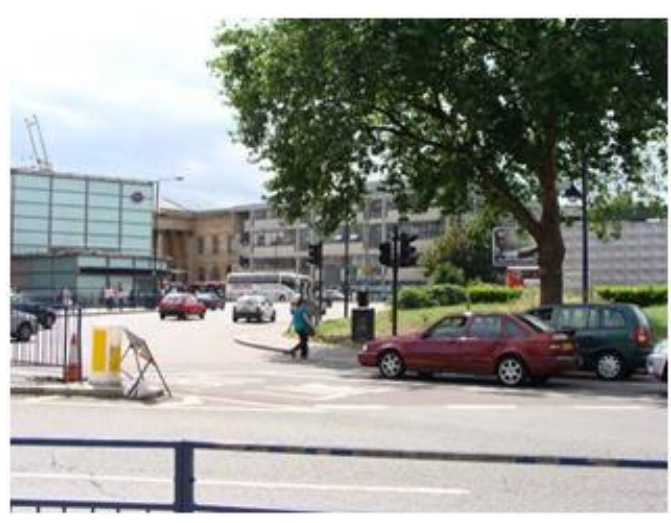

Figura 97: Foto do bairro Elephant \& Castle

Fonte: imagem da autora, julho 2008 


\subsubsection{Distrito de Lu Zia Sui, Shangai,}

\section{Dados técnicos:}

Projeto: Distrito de Lu Zia Sui

Localização: Shangai, China - Latitude: $31^{\circ} 13^{\prime} \mathrm{N}$

Arquiteto Projeto Urbano: Richard Rogers

Consultoria técnica: Ove Arup \& Partners

Cliente: Prefeitura de Shangai

Área: 150 hectares

Uso: misto

Fase: projeto finalizado em 1991, não foi construído

\section{Descrição:}

Em 1991, o prefeito de Shangai convidou o escritório Rogers \& Partners para desenvolver uma estrutura estratégica para um novo distrito de sua cidade, a reconstrução do centro de Pudong. Era uma nova oportunidade ao experimento e a pesquisa do tema da cidade compacta sustentável.

A China tem uma população de 1,5 bilhões de habitantes, representando um quarto da população mundial. Sua nação está sofrendo o maior êxodo rural da história, no qual pelo menos 80 milhões de chineses ocuparam favelas em torno das principais cidades do país, em menos de uma geração. (ROGERS, 2001, p.41)

Das dez cidades com pior poluição em todo o mundo, cinco estão na China. Quatro dos seus sete sistemas fluviais estão contaminados e a chuva ácida afeta quase um terço de seu território. (ROGERS, 2001, p.41)

Em Pudong está o novo distrito Lu Zia Sui, uma área em forma de gota de 150 hectares que conecta Pudong a Shangai por duas pontes e uma rede de túneis.

Segundo Rogers (2001, p.45), o esquema proposto pelas autoridades locais negava a diversidade cultural e comercial da velha cidade. O novo projeto deveria servir a usuários de escritórios internacionais e seria projetado, sobretudo, para ser comunicado por automóveis. O resultado seria um distrito de torres e blocos isolados, circundados por veículos motorizados.

Ao contrário disso, Rogers propõe: 
"a idéia de Lu Zia Sui como um setor comercial e residencial diversificado, realçado por uma rede de parques e espaços públicos e cujo acesso seria feito, sobretudo, por transportes de massa, constituindo uma área capaz de atuar como foco cultural para toda a área do Pudong."(ROGERS, 2001, p.45)

A proposta é constituída de seis bairros grandes e compactos, com a capacidade para 80 mil pessoas cada um, implantados ao redor de um parque central de onde partem grandes bulevares ligados as três avenidas concêntricas. A avenida mais externa destinase a pedestres e ciclista, a intermediária a bondes e ônibus e a mais interna, parcialmente afundada, às principais vias para automóveis.

Uma integração entre um sistema de transporte hierarquizado e espaços públicos segundo uma circunferência define a forma e organização espacial do projeto compacto e policêntrico. O raio da circunferência foi dimensionado para que todos os residentes estejam a uma distância máxima de dez minutos a pé do parque, do rio e das demais comunidades vizinhas ao redor do parque. ${ }^{80}$

O projeto propõe edificações de alturas variadas, sendo que os edifícios de escritórios, comércio, edifícios culturais e institucionais são localizados próximos as estações do metrô metropolitano de Shangai, enquanto as residências são agrupadas ao redor do parque e ao longo do rio, juntamente com hospitais, escolas e outros edifícios vinculados à comunidade. (ROGERS, 2001, p.49)

No modelo de Richard Rogers o tema da sustentabilidade urbana é abordado de maneira ampla, incluindo questões de estrutura sócio-econômica do espaço, transporte, clima urbano, eficiência energética das edificações, e interação social nos espaços comuns. ${ }^{81}$

Rogers (2001) comenta:

"O projeto Lu Zia Sui, não é um modelo a ser imposto, pelo contrário é uma ilustração local de uma primeira abordagem de planejamento em busca de um desenvolvimento urbano sustentável."(ROGERS, 2001, p.53)

\footnotetext{
${ }^{80}$ GONÇALVES, 2003.

${ }^{81}$ Idem.
} 
Esse plano de desenvolvimento urbano não foi executado como tal, tendo sido substituído por um conjunto arbitrário de edifícios altos. Pressões políticas e comerciais venderam os lotes isolados, sendo necessária a construção de novas vias para a comunicação desses, resultando segundo Rogers (2001, p.53) na forma clássica de criar, de acordo com as leis do mercado, empreendimentos não sustentáveis. E ainda completa:

"A menos que o governo da China mostre uma solução real e se comprometa a planejar em busca dessa sustentabilidade, a área logo será confrontada com enormes congestionamentos, poluição e insatisfação social, em uma escala ainda maior do que aquela endêmica às cidades consideradas modelos pelo governo." (ROGERS, 2001, p.53)

\section{Categoria 01 - Compacidade}

O projeto apresenta alta densidade, alta compacidade absoluta e uma proximidade de usos e funções urbana.

\section{Categoria 02 - Mobilidade}

Todos os bairros estão localizados próximos aos principais pontos nodais de transporte e ligados à rede principal de espaços públicos, sendo que as áreas comerciais e de serviços, lojas e instituições culturais são implantadas próximas as estações de metro.

O projeto apresenta um sistema de transporte hierarquizado, que engloba múltiplos meios, de calçadas a vias expressas, garantindo mobilidade para todos os cidadãos.

O escritório de consultoria Ove Arup \& Partners calculou que a diversificação de atividades e a maior ênfase no transporte público poderiam diminuir a necessidade de deslocamentos por automóveis, reduzindo assim as estradas em cerca de 60\%. (ROGERS, 2001, p.45)

Mesmo com a restrição do acesso de veículos motorizados em muitos locais, uma das principais críticas ao projeto é que a redução do uso do automóvel implica uma mudança de comportamento do usuário em prol do bem-estar coletivo.

\section{Categoria 03 - Espaço Público e Área Verde}

Como foi reduzido o espaço público destinado a transportes motorizados, aumentou-se a rede de ruas para pedestres, ciclovias, espaços para lazer e um parque. A rede de espaços públicos para atividades multifuncionais é integrada ao sistema de transporte de 
massa, facilitando assim o seu acesso. Além disso, os residentes estão a uma distância máxima de dez minutos a pé do parque e do rio.

O projeto propõe edificações de alturas variadas, como objetivo de minimizar o impacto das construções sobre o espaço aberto, garantindo insolação e ventilação para todos os espaços do conjunto, mesmo com a presença de edifícios altos e alta densidade. (ROGERS, 2001, p.49)

Shangai sofre com a poluição causada pelo excesso de veículos motorizados, e o controle do transporte é fundamental para que se possa melhorar a qualidade do ar e utilizar a ventilação natural para maior conforto térmico.

\section{Categoria 04 - Eficiência no uso de Recursos Naturais água e energia}

Segundo Rogers (2001, p.53), o enfoque circular significaria uma economia de $70 \%$ do uso global de energia. Nos modelos de cidade compactos, como o proposto, é possível a adoção de estações combinadas de energia e calor, ou seja, usinas que podem ser usadas tanto para distribuir eletricidade quanto para levar água quente, subproduto, diretamente às residências.

O projeto propõe medidas de reuso das águas resultantes das atividades domésticas e reciclagem e reuso dos resíduos sólidos. Segundo Rogers (2001), o lixo urbano poderia ser reciclado para produzir gás metano e fertilizantes. O lixo poderia ser queimado pelas usinas combinadas e fornecer até $30 \%$ das necessidades de energia de uma comunidade.

\section{Categoria 05 - Diversidade Urbana e Expressão Arquitetônica}

Com relação à coesão social e complexidade, o projeto propõe uma diversidade de usos e a criação de espaços públicos para a convivência social.

Sob o enfoque da expressão arquitetônica, faltam informações de detalhamento do projeto para poder fazer uma avaliação. Porém, destaca-se que a variedade de alturas e a forma urbana proposta propiciam um impacto positivo não só sob os aspectos de sustentabilidade abordados, mas também pode gerar um resultado interessante do ponto de vista da estética e da paisagem urbana. 


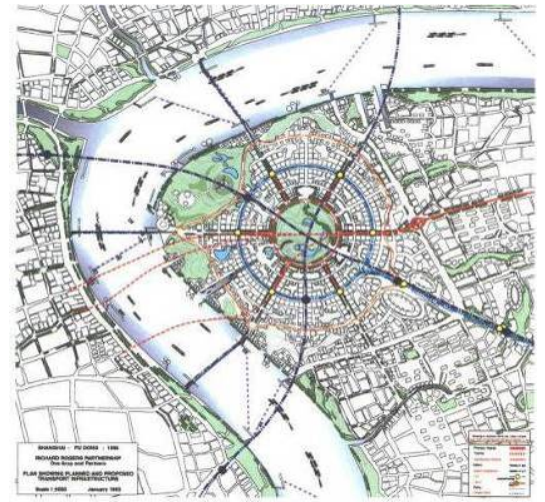

Figura 98: Planta projeto Shangai

Fonte: ROGERS, 2001.

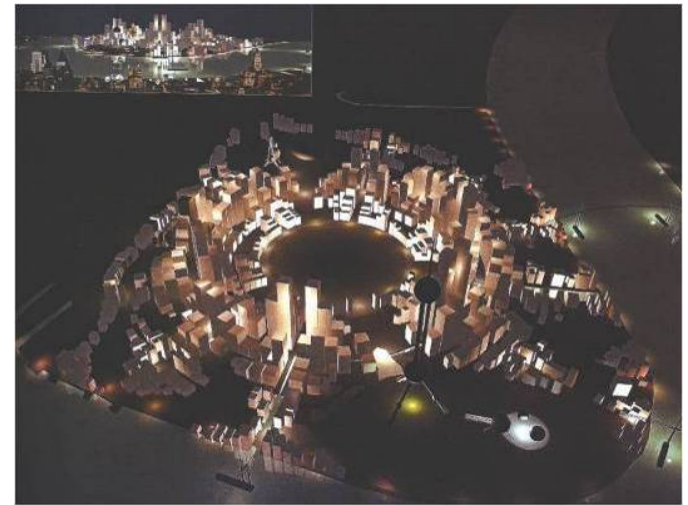

Figura 99: Maquete Projeto Shangai

Fonte: ROGERS, 2001.

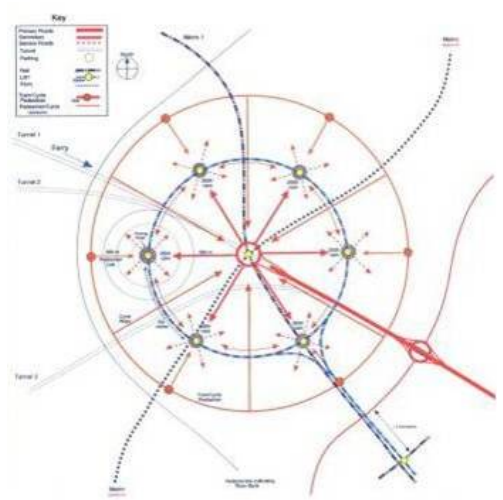

Figura 100: Estudo dos fluxos, projeto Shangai Fonte: ROGERS, 2001.

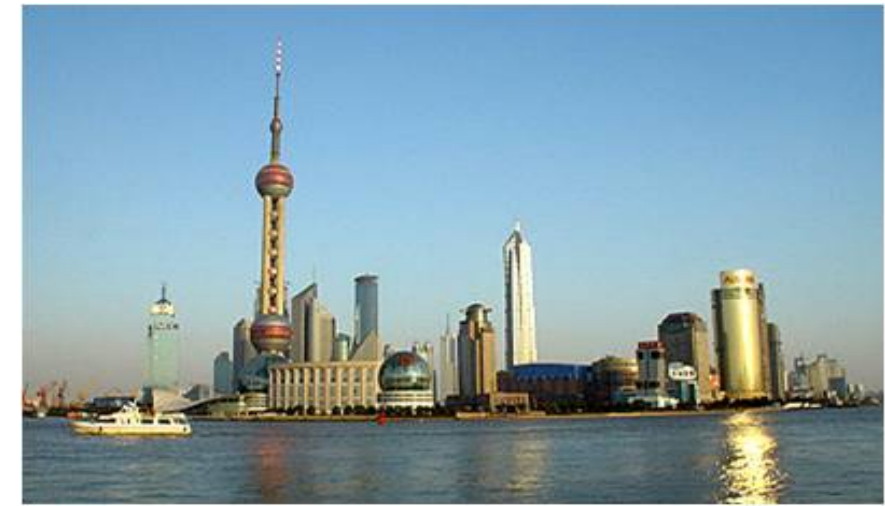

Figura 102: I magen Shangai

Fonte: Foto Shinzato, cedido para autora
Figura 101: Mistura de usos projeto Shangai

Fonte: ROGERS, 2001.

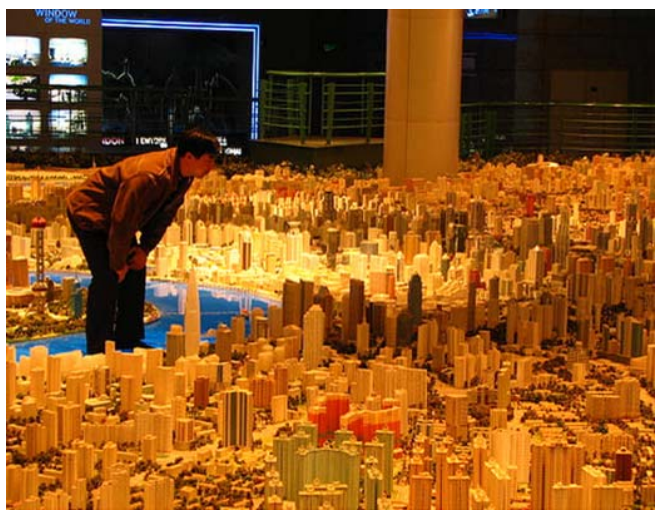

Figura 103: Maquete Shangai

Fonte: Foto Shinzato, cedido para autora 


\begin{tabular}{|c|c|c|c|c|c|c|}
\hline \multicolumn{7}{|c|}{ PROJ ETOS DE RECUPERAÇÃO DE BAI RROS DEGRADADOS } \\
\hline PROJ ETO & DIM. & LOCAL & CONST. & I MPACTO URBANO & ASPECTOS FAVORÁVEIS & ASPECTOS DESFAV. \\
\hline $\begin{array}{l}\text { POTSDAMER } \\
\text { PLATZ } \\
\text { (BERLI M) }\end{array}$ & 60ha & $\begin{array}{l}\text { um vazio, } \\
\text { por onde, } \\
\text { passava o } \\
\text { muro de } \\
\text { Berlim }\end{array}$ & $\begin{array}{l}\text { Novo bairro, } \\
\text { com edifícios } \\
\text { de } \\
\text { escritórios, } \\
\text { residenciais, } \\
\text { serviços e } \\
\text { lazer }\end{array}$ & $\begin{array}{l}\text { Reunificação dos dois } \\
\text { lados de Berlim } \\
\text { construção de um novo } \\
\text { bairro em cima de uma } \\
\text { área destruída pela } \\
\text { guerra, por onde passava } \\
\text { o muro de Berlim }\end{array}$ & $\begin{array}{l}\text { Sistema de coleta e reuso das águas pluviais } \\
\text { Eficiência energética das edificações } \\
\text { Projeto de grande expressão arquitetônica } \\
\text { Projeto de grande simbolismo para a cidade } \\
\text { Diversidade de usos }\end{array}$ & $\begin{array}{l}\text { Projeto foi pensado, } \\
\text { buscando atrair populações } \\
\text { de alto poder aquisitivo, } \\
\text { excluindo a população local } \\
\text { Habitações muito caras e } \\
\text { por isto parte delas não foi } \\
\text { ocupada. } \\
\text { Oferta de escritórios maior } \\
\text { que a demanda }\end{array}$ \\
\hline $\begin{array}{l}\text { GREENWICH } \\
\text { (LONDRES) }\end{array}$ & 190 acre & $\begin{array}{l}\text { Península } \\
\text { de } \\
\text { Greenwich }\end{array}$ & $\begin{array}{l}\text { Millen. } \\
\text { Dome, } \\
\text { Conjunto } \\
\text { residencial e } \\
\text { centro } \\
\text { comercial } \\
\end{array}$ & $\begin{array}{l}\text { Recuperação de uma } \\
\text { área de solo } \\
\text { contaminado } \\
\text { Novas residências e de } \\
\text { um novo distrito } \\
\text { comercial para Londres }\end{array}$ & $\begin{array}{l}\text { Criação de espaços públicos com qualidade } \\
\text { ambiental } \\
\text { Projeto de grande expressão arquitetônica } \\
\text { Diversidade de usos e Diversidade social } \\
\text { Sistema de transporte público eficiente }\end{array}$ & Nada a destacar \\
\hline $\begin{array}{c}\text { ELEPHANT } \\
\text { AND CASTLE } \\
\text { (LONDRES) }\end{array}$ & 170 ha & $\begin{array}{l}\text { Elephant } \\
\text { and castle }\end{array}$ & $\begin{array}{l}\text { Projeto não } \\
\text { foi construído }\end{array}$ & $\begin{array}{l}\text { Revitalização do Bairro } \\
\text { Elephant and castle } \\
\text { Construção de novas } \\
\text { habitações, edifícios de } \\
\text { escritórios e espaços } \\
\text { públicos }\end{array}$ & $\begin{array}{l}\text { Criação de espaços públicos de qualidade } \\
\text { Redução do uso de automóvel e incentivo a } \\
\text { outras modalidades } \\
\text { Sistema de transporte público diversificado e } \\
\text { integrado } \\
\text { Redução do consumo de recursos, água e } \\
\text { energia. Diversidade de usos, de tipologias } \\
\text { edificatórias e de classes sociais }\end{array}$ & $\begin{array}{l}\text { Pouca expressão } \\
\text { arquitetônica }\end{array}$ \\
\hline $\begin{array}{l}\text { LU ZIA SUI } \\
\text { (SHANGAI) }\end{array}$ & 150ha & $\begin{array}{l}\text { Pudong, } \\
\text { Shangai }\end{array}$ & $\begin{array}{l}\text { Projeto não } \\
\text { foi construído }\end{array}$ & $\begin{array}{l}\text { Revitalização do centro } \\
\text { de Pudong }\end{array}$ & $\begin{array}{l}\text { Projeto de bairros compactos e diversificados } \\
\text { Redução do uso de automóvel e incentivo a } \\
\text { outras modalidades } \\
\text { Acesso dos cidadãos ao transporte público e } \\
\text { aos espaços públicos } \\
\text { Edificações de alturas variadas, visando o } \\
\text { conforto nos espaços abertos }\end{array}$ & Nada a destacar \\
\hline
\end{tabular}




\begin{tabular}{|c|c|c|c|c|}
\hline \multicolumn{5}{|c|}{ PROJ ETOS DE RECUPERAÇÃO DE BAI RROS DEGRADADOS } \\
\hline $\begin{array}{c}\text { I NDI CADORES } \\
\text { SUSTENTABILI DADE }\end{array}$ & POTSDAMER PLATZ & GREENWICH & ELEPHANT AND CASTLE & LU ZIA SUI, SHANGAI \\
\hline COMPACI DADE & & & & \\
\hline MOBI LIDADE & & & & \\
\hline $\begin{array}{l}\text { ESPAÇO PÚBLI CO E } \\
\text { ÁREA VERDE }\end{array}$ & & & & \\
\hline $\begin{array}{l}\text { EFICIÊNCI A NO USO DO } \\
\text { RECURSOS NATURAIS }\end{array}$ & & & & \\
\hline $\begin{array}{c}\text { DI VERSI DADE URBANA } \\
\text { EXPRESSÃO } \\
\text { ARQUITETONI CA }\end{array}$ & & & & \\
\hline
\end{tabular}




\subsection{Ecobairros}

A partir da década de 70, após a Conferência das Nações Unidas sobre meio ambiente, em Estocolmo, começaram a surgir alguns bairros com preocupações ecológicas, motivados, principalmente, pelo movimento ambientalista (ANDRADE, 2005)

Grande parte desses exemplos se inspirou nas idéias de Howard, de Cidade Jardim ${ }^{82}$, as quais eram pensadas visando à auto-suficiência, na tentativa de resolver os problemas urbanos locais por meio do desenho de novas cidades que tivessem uma estreita relação com o campo, assegurando os benefícios de uma vida urbana, cheia de oportunidades e entretenimento, juntamente à produtividade e demais vantagens do campo.

Alguns idéais da cidade-jardim podem ser identificados nos projetos dos ecobairros, tais como: tamanho controlado com acessibilidade aos espaços verdes e aos pedestres, transporte público adequado, uso misto, diversidade social e reaproveitamento de resíduos sólidos em terras agrícolas (ANDRADE, 2005).

O ecobairro é um conceito que foi construído na medida em que se desenvolveram as novas práticas de urbanismo embasadas em critérios de sustentabilidade. Rueda (2005) o define como "o desenho, a construção ou a remodelação, segundo seja o caso, de bairros com o desenvolvimento de quatro eixos fundamentais: a compacidade, a complexidade, a eficiência e a estabilidade social." (EMVS, 2006, tradução da autora).

Segundo Higueras (2009, p.63), o ecobairro é um fragmento urbano que se projeta com requerimentos de eficiência energética e que deve, entre outros: fechar melhor os ciclos e matéria e energia; estabelecer uma adequada relação com seu território e paisagem; reduzir a contaminação e as emissões no ar, água e solo e melhorar as relações sociais de seus residentes.

Os ecobairros são uma realidade urbana que perseguem os princípios de eficiência, igualdade e variedade, que estão se configurando como uma referência para outros assentamentos urbanos (EMVS, 2006)

\footnotetext{
${ }^{82}$ Abordada no capítulo 01 da Tese.
} 
Enfim, os ecobairros se caracterizam por incorporar os princípios da ecologia urbana ao projeto, o que os torna uma alternativa para a construção de cidades habitáveis e sustentáveis.

Os ecobairros trabalham os aspectos sociais, econômicos e ambientais de forma integrada, devendo destacar que os resultados são obtidos a longo prazo, dentro de uma visão de impactos de longo alcance e da economia de consumo de recursos.

Dos cinco ecobairros avaliados, quatros são europeus, sendo dois desses holandeses. Para alguns estudiosos, a Holanda é um dos países que se destaca em matéria de desenvolvimento sustentável, talvez pelo risco de inundações caso o nível do mar seja elevado devido ao aquecimento global.

Apesar da maioria dos exemplos de ecobairros estarem situados na Europa, uma das primeiras Ecovilas, a Village Homes, foi implantada nos Estados Unidos.

Segundo East e Leonardos (2001)

"As Ecovilas são assentamentos de escala humana, multifuncionais, nos quais as atividades humanas são integradas sem danificar o mundo natural, contribuindo com o desenvolvimento humano saudável e assim podendo continuar no futuro indefinido". (apud ANDRADE, 2005, p.54)

A construção de Village Homes foi iniciada em 1973, em terras agrícolas próximas à Universidade da Califórnia, em Davis, com o objetivo de atender os futuros professores da instituição. O projeto idealizado por Michael Corbett e Judy Corbett consiste em um condomínio de 28 hectares, com 240 habitações, grandes cinturões verdes repletos de árvores frutíferas, zonas agrícolas em meio às casas, drenagem natural da superfície, uma rede de caminhos para pedestres e ciclovias interligadas na rede da cidade. Além de habitações, o condomínio apresenta outros usos como comércio e empresas de pequeno porte.

O objetivo era a criação de uma comunidade modelo com relação às questões ambientais, evidenciando o sentido de vizinhança. Objetivo esse que foi alcançado, pois atualmente o condomínio de Village Homes é considerado um bom exemplo de ecobairro. 


\subsubsection{Ecolonia, Alphen, Holanda}

\section{Dados técnicos:}

Projeto: Ecolonia

Localização: Alphen-aan-den-Rijn, Holanda-Latitude:

Arquiteto Projeto Urbano: Lucien Kroll - Diretor do Atellier d'Urbanisme d'Arquitecture ET d'Informatique, Bruxelas

Arquitetos edificações: BEAR Architects and Renovation Consultants; Albert \& Van Hut Architects and Engineers; Hopman bv; J.P Moehrlein; Bakker Boots, Van Haaren, Van der Donk Architects; Peter van Gerwen; Archi Service e Vakgroep FAGO (Faculty of building technology).

Cliente: Bouwfonds Woningbouw Housing Association; Netherlands Agency for Energy and Environment (NOVEM), Ministry of Housing, Physical Planning and Environment (VROM), Ministry of Economic Affairs (EZ), local energy supplier (EWR)

Área: aproximadamente 5 hectare/ 101 habitações

Uso: residencial

Fase: finalizado em 1992

\section{Descrição:}

A escolha do município de Alphen para a implantação do ecobarrio Ecolonia se deve para tentar corrigir o erro de um projeto urbano que levou a contaminação do seu subsolo.

Ecolonia foi promovida pela Bouwfonds Woningbouw Housing Association junto a Agência de energia holandesa (NOVEM). O projeto urbano foi solicitado ao arquiteto Lucien Kroll, que se tornou responsável pela seleção e coordenação de nove arquitetos, autores dos projetos de 101 habitações.

Kroll descreve o projeto como contemporâneo e orgânico e completa: Não obriguei os arquitetos de Ecolonia a adotarem a uniformidade ou o cosmético do urbanismo oficial: os situei a condições de liberdade e de paralelismo de intenções que fazem que esta desordem seja aparentemente e esta ordem oculta. (EMVS, 2006, p.40, tradução nossa).

O projeto foi realizado em cima de uma tábua rasa, sendo as principais preocupações do autor, o habitante e o equilíbrio cidade-natureza. Pode-se dizer que a forma com que Kroll 
tratou essa relação torna esse projeto mais atrativo, na medida em que coloca o habitante em contato direto com alguns aspectos da natureza.

O projeto consiste em edifícios predominantemente residenciais, de um, dois ou três pavimentos, apresentando uma variedade de tipologias. Essa diversidade tipológica se deve, em parte, ao grande número de escritórios de arquitetura responsáveis pelos projetos das habitações.

O projeto apresenta residências ao redor de uma lagoa que funciona como espaço de convívio da comunidade, além de ser um reservatório natural no período de chuva.

As habitações com terraço são predominantemente orientadas no sentindo leste-oeste, tendo seu telhado e a fachada principal voltada para o sul.

Segundo publicação do Riba sobre comunidades sustentáveis, o governo holandês foi o primeiro da Europa a adotar os princípios estabelecidos em 1987, pela Brundtland Report, sendo o projeto Ecolonia a primeira demonstração disso, em 1990. ${ }^{83}$

Apesar de algumas críticas, o projeto tem sua importância por tentar sintetizar alguns princípios da sustentabilidade, em uma época que o tema não estava tão em evidência quanto nos dias de hoje. E que muitas decisões de projeto ainda estavam em fase de experiência.

Sobre o projeto Andrade (2005) comenta:

"Entre os exemplos bem sucedidos de desenho urbano sustentável na Europa, foi destacado o condomínio de Ecolônia, implantado na Holanda na década de 90, que serviu de referência para outros empreendimentos no país, nos quais os aspectos sociais, urbanos, arquitetônicos, comunitários e ambientais foram tratados de forma integrada, juntamente com as tecnologias sustentáveis. Percebe-se claramente a aplicação de princípios de sustentabilidade refletidos no desenho urbano, especialmente a drenagem urbana, a política dos $3 R$ 's, a gestão integrada da água, a mobilidade sustentável e o sentido de vizinhança, expressos no desenho das ruas estreitas para carros e pedestres e para maximizar o acesso solar nas moradias, minimizando, por outro lado, a exposição aos ventos. "(ANDRADE, 2005, p.187)

\footnotetext{
83 The Royal Institute of British Architects, 2009, p39.
} 
Todo o desenho é baseado em pesquisas de especialistas das universidades e demais instituições, que auxiliaram no tratamento das questões ambientais.

As pesquisas ecológicas se centram em três eixos: energia, reciclagem e qualidade, cada um dos quais se declina em três direções. Cada arquiteto tinha que aprofundar em uma destas solicitações e depois integrar as demais.

As pesquisas sobre energia se dividiam em: hiper-isolamento, energia solar e economia de energia para a construção de habitação. O tema reciclagem abordava: economia de água e materiais, materiais duradouros, sem manutenção, visando uma arquitetura orgânica e flexibilidade e adaptação. Com relação à qualidade, a pesquisa se dividia em: isolamento acústico, saúde e segurança e pesquisa bio-ecológica.

Pode-se dizer que as estratégias baseadas nos princípios de sustentabilidade foram direcionadas e aplicadas mais nos projetos das habitações do que no próprio projeto urbano

Junto às habitações foi possível verificar os resultados positivos da aplicação de algumas estratégias. Em 1993, foi realizado um programa de medições das habitações, apresentando o seguinte resultado: $40 \%$ de economia no consumo de gás; $20 \%$ de economia no consumo de água e $10 \%$ no consumo de energia elétrica. Porém deve-se destacar que não ficou claro com relação à que se refere esta comparação.

Com relação ao projeto urbano, percebe-se a ausência de regras. Kroll compara seu projeto à espontaneidade e liberdade de algumas cidades antigas, que se formavam sem muitas regras, sem uma disposição calculada, e critica a repetição de modelos com pequenas variações.

Apesar disso, é importante refletir uma questão que foi apontada durante o evento Urban Age, realizado em dezembro de 2008, em São Paulo: será que para construir as cidades que estamos almejando, baseada nos princípios da sustentabilidade, é necessária a definição de algumas regras?

\section{Categoria 01 - Compacidade}

O ecobairro Ecolonia apresenta uma baixa densidade construtiva, de aproximadamente 30 habitações/ha e uma baixa compacidade, com edificações de no máximo três pavimentos.

\section{Categoria 02 - Mobilidade}


As circulações de pedestres, de bicicletas e automóveis são tratadas com igual importância. Além disso, não foi reservada nenhuma área especial para estacionamento, com o autor optando por dispersar as vagas por todo o terreno.

Diferente de muitos projetos urbanos, o sistema viário não impõe a sua forma. As vias principais e secundárias não são diferenciadas, sendo assim, as formas ou imagens não facilitam uma circulação cômoda dos automóveis, obrigando esses a circular com velocidade reduzida. Essa decisão projetual interfere positivamente na qualidade do ar e no ruído urbano, uma vez que diminui o trânsito e a velocidade de veículos nas ruas.

\section{Categoria 03 - Espaço Público e Área Verde}

O projeto apresenta uma preocupação com a relação cidade e meio ambiente, colocando os residentes em contato direto com a natureza. O espaço de convívio é localizado junto às residências, ao redor de uma lagoa que funciona também como reservatório natural.

A preocupação com a habitabilidade dos espaços externos é verificada através da presença de vegetação e da inibição do uso de automóveis dentro do bairro, resultando em um impacto positivo na qualidade do ar e no ruído urbano.

\section{Categoria 04 - Eficiência no uso de Recursos Naturais água e energia}

Sobre o aproveitamento do sol para aquecimento das habitações, o autor do projeto urbano Kroll comenta:

"não pretendemos expressar em um traçado urbano regras comuns de orientação solar, de implantação, etc.(...) as casa não estão todas orientadas para a máxima eficácia solar (...). Estas pequenas imperfeições fazem com que a paisagem não seja a de um parque de demonstração e sem um bairro comum e repetível." (EMVS, 2006, p.44, tradução nossa).

Apesar disso, a maioria das habitações é orientada no sentindo leste-oeste, tendo seu telhado e a fachada principal voltada para o Sul, que nesse caso, representa uma ótima orientação para o aquecimento solar, economizando energia elétrica necessária para calefação.

Dois dos princípios da sustentabilidade associados eficiência no uso dos recursos naturais tiveram relevância na orientação o desenho urbano, como o tratamento da água da chuva por meio da drenagem natural e o uso da energia solar visando uma maior eficiência energética e a geração de energia limpa. 
Presença de coletores solares nas coberturas das habitações para geração de energia elétrica, através dos painéis fotovoltaicos e para aquecimento de água. Das 101 habitações, 80 delas têm coletores solares no telhado da fachada sul.

O projeto apresenta uma drenagem natural, através da qual a água da chuva é retida o maior tempo possível na superfície, em vez de ser encaminhada diretamente para as tubulações. A água é conduzida para uma lagoa através de drenos, onde é retida por algum tempo e purificada por uma variedade de espécies. Esses filtros de vegetação ajudam a quebrar os poluentes transportados pelas superfícies das ruas, bem como os resíduos químicos de alguns jardins.

Andrade (2005) explica:

"as lagoas de retenção são utilizadas primeiramente para contribuir contra a pressão exercida nos sistemas de drenagem tradicional durante as chuvas torrenciais. Essas lagoas retêm a água ao longo do ano, coletando durante a tempestade e liberando-a vagarosamente. O processo, que acontece num período de dias (ao invés de horas ou minutos), diminui a necessidade de sistemas de drenagem dimensionados para fluxos de picos máximos, reduzindo, conseqüentemente, o custo de infra-estrutura." (ANDRADE, 2005, pX)

\section{Categoria 05 - Diversidade Urbana e Expressão Arquitetônica}

As habitações foram projetadas para atrair uma grande parcela da população, sendo muitas delas com preço acessível. Porém, devido à tipologia residencial adotada o projeto atrai um tipo determinado de residentes com rendas similares, o que não resulta em uma integração urbana.

Além disso, o projeto foi criticado por apresentar um uso exclusivamente residencial e por estar "ilhado".

Com relação à expressão arquitetônica, Ecolonia apresenta uma variedade de tipologias edificatórias, resultante do trabalho de nove escritórios de arquitetura, responsáveis pelos projetos das habitações. 
De acordo com a avaliação de Higueras, com base nos critérios estabelecidos como determinantes por Rueda ${ }^{84}$, Ecolonia apresenta os seguintes resultados: Compacidade 1/5; Complexidade 1/5; Eficiência 3/5 e; Estabilidade social 3/5. (AYUNTAMIENTO DE MADRID, 2009, p.27).

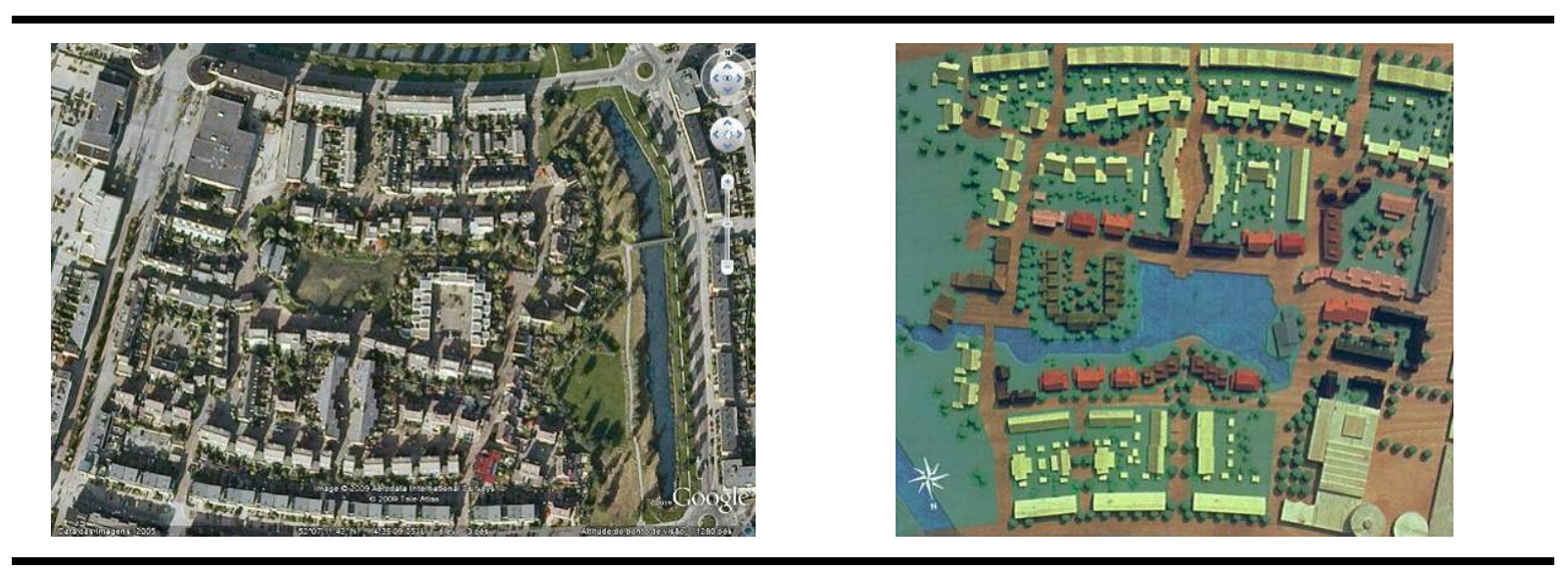

Figura 104: Foto aérea Ecolonia

Fonte: Google

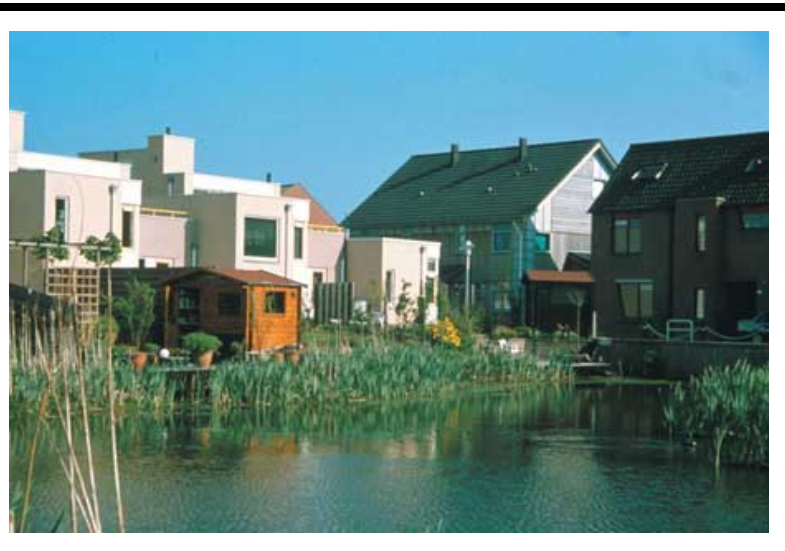

Figura 106: Foto Ecolonia

Fonte: EMVS, 2006
Figura 105: Planta do ecobairro ecolonia

Fonte: EMVS, 2006

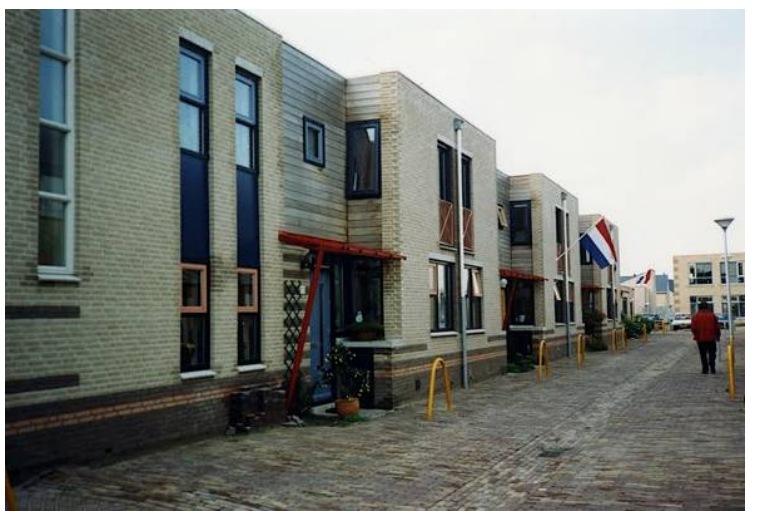

Figura 107: Foto Ecolonia

Fonte: EMVS, 2006

${ }^{84}$ RUEDA, 2006. 


\subsubsection{GWL, Amsterdam, Holanda}

\section{Dados técnicos:}

Projeto: Ecobairro GWL

Localização: Amsterdam, Holanda - Latitude: $52^{\circ} 22^{\prime} \mathrm{N}$

Arquiteto Urbanista: Kees Christiaanse (KCAP)

Arquitetos edificações: Atelier Zeinstra van de Pol, Neutelings Riedijk, DKV, Meyer \& Van Schooten e KCAP

Consultoria Técnica: Paisagismo - West 8 Landscape Architects

Cliente: Município de Amsterdam (City Council) e Fundação Eco-plan Amsterdam

Área: 6 hectares/ 600 habitações

Uso: misto

Fase: finalizada em 1998

\section{Descrição:}

O projeto GWL está englobado no programa de renovação baseado nos princípios sociais e ecológicos do desenvolvimento sustentável, colocado em prática na Holanda desde no final da década de oitenta. O projeto consiste na revitalização de uma zona industrial obsoleta, na qual estava instalada a antiga companhia municipal de água potável de Amsterdam (GWL).

Cinco associados de habitações se uniram para formar a fundação Eco-plan Amsterdam, que finalmente atuou como cliente. Esse consórcio de promotores, associado ao município, queria conciliar alta densidade construtiva com as demandas formuladas pela vizinhança da área a favor de um bairro ecológico, livre de automóveis.

O município aprovou a idéia e em 1992 elaborou um programa específico para a criação de um bairro ecológico que considerava as exigências meio ambientais, a superfície disponível e os desejos dos futuros usuário. Esse programa serviu de base para o concurso realizado para a seleção do projeto urbano, no qual o desenvolvido por Kees Christiaanse foi o vencedor.

Antes da revitalização do bairro GWL, Amsterdam já iniciava medidas a favor do desenvolvimento sustentável. Gauzin-Muller (2002) aponta estas medidas: inserção de uma lista de materiais alternativos ou ecológicos nas obrigações e recomendações para 
novas edificações, colocado em prática desde 1992; política restrita com relação aos deslocamentos em automóveis e de estacionamento no centro da cidade; grandes obras de infra-estrutura para o transporte coletivo e para bicicletas e reestruturação de zonas degradadas e criação de novos bairros respeitando os princípios do desenvolvimento sustentável. ${ }^{85}$

GWL era um projeto modelo para o Ministério de Habitação, Planejamento Espacial e Meio Ambiental (VROM).

O ecobairro GWL ocupa uma área de 6 hectares, localizada na região de Van Hallstraat, Westerpark, Western Amsterdam. O projeto conta com 600 habitações, apresentando uma densidade média de 100 habitações por hectare.

O projeto manteve quatro edifícios históricos e um depósito de água que agora constitui uma área de comércios, serviços e lazer e que contribui para o caráter do bairro, atraindo também os moradores de áreas vizinhas.

Fisicamente, a implantação desse ecobairro marca uma fronteira entre os blocos residenciais tradicionais do bairro de Staatsliedene e os blocos industriais.

A separação da área residencial proposta da zona industrial ali presente é realizada pela construção de dois grandes blocos de apartamentos de nove andares, delimitado dois lados do terreno, norte e oeste. Ao norte, esses blocos atuam também como barreira ao ruído da avenida principal de Haarlemmerweg e a oeste, eles protegem o interior do bairro dos ventos dominantes.

Nas outras direções o bairro se abre mais ao entorno e os edifícios são implantados livremente no meio da zona verde projetada.

Esses blocos residenciais contêm aproximadamente 57\% das habitações do bairro. Sua alta densidade possibilita uma construção mais dispersa no interior do conjunto, caracterizada pela implantação de 14 edifícios lâminas de quatro e cinco pavimentos e da criação de espaços públicos e privados interligados.

${ }^{85}$ Gauzin-Muller, 2002, p76. 
Ao norte do conjunto se encontra a zona residencial mais densa, que se agrupa ao redor de uma praça urbanizada rodeada de comércios e, ao sul está implantada uma zona residencial mais dispensa, privilegiando a relação de habitação com a vegetação.

Higueras comenta: "uma proposta interessante por múltiplos motivos e que responde satisfatoriamente as metas da sustentabilidade." (AYUNTAMIENTO DE MADRID, 2009, p.22).

\section{Categoria 01 - Compacidade}

O ecobairro GWL apresenta uma densidade média de 100 habitações/ hectare, porém considerada alta para os padrões locais.

GWL apresenta uma alta compacidade, que é ilustrada nesse caso, não só pela sua densidade, mas também por reunir em um espaço possível de recorrer-lo a pé, demais funções e usos além da residencial.

\section{Categoria 02 - Mobilidade}

Com relação à mobilidade, o projeto se destaca pela eliminação de veículos motorizados. Porém, a região é muito bem servida pelo transporte público, além de apresentar ruas de pedestres e ciclovias, aumentando a facilidade de deslocamento para o residente.

O ecobairro GWL foi a primeira experiência de reduzir o uso de automóveis fora do centro histórico. A eliminação dos veículos motorizados constitui uma medida a favor do meio ambiente que marca a identidade do bairro, "Car-free community".

O projeto conta apenas com 135 vagas de estacionamento, sendo 110 vagas para residentes e 25 para visitantes. Esse número cobre menos de $20 \%$ das habitações, ou seja, uma média de 0,3 veículos por habitação.

A decisão de reduzir o uso do automóvel incentivou muitos moradores a desfazerem de seus veículos, sendo que $57 \%$ dos morados não possuem automóveis e o restante faz uso moderado desses, em torno de 10 viagens semanais. ${ }^{86}$

\footnotetext{
${ }^{86}$ Gauzin-Muller, 2002, p78.
} 
O bairro conta com um sistema de automóvel compartido, usado por $10 \%$ dos residentes. ${ }^{87}$

De acordo com Gauzin-Muller, aproximadamente $73 \%$ dos trajetos se realizam sem recorrer ao transporte motorizado. Além do transporte público disponível, os usuários buscam alternativas como o deslocamento a pé e o uso de bicicletas, muito comum na Holanda.

\section{Categoria 03 - Espaço Público e Área Verde}

A estrutura verde forma parte integral da urbanização como área de lazer e reduz a impermeabilidade do terreno.

Os projetos de edificação apresentam corredores externos, distribuições flexíveis e um acesso direto aos jardins.

A medida de reduzir o uso dos veículos motorizados favorece a qualidade ambiental, principalmente dos espaços externos do bairro. Entre os benefícios destaca-se a redução do ruído urbano, a melhoria da qualidade ar e o aumento de área destinada para a vegetação e o espaço público.

Também, visando a habitabilidade dos espaços públicos, os dois grandes blocos de apartamentos de nove andares formam uma barreira ao ruído da avenida principal a norte e aos ventos dominantes a oeste.

\section{Categoria 04 - Eficiência no uso de Recursos Naturais água e energia}

A dimensão ecológica de GWL reside em grande parte na preocupação com insolação e ventilação nas edificações e nos espaços externos, no uso e tratamento da vegetação, no aproveitamento das águas pluviais, no tratamento dos resíduos, na utilização de materiais mais sustentáveis e no bom isolamento dos edifícios.

As habitações foram orientadas para o sul sempre que possível, com o objetivo de aproveitar o máximo à radiação solar.

Visando a eficiência energética, o projeto conta com sua própria planta de produção combinada de calor e eletricidade, muito adequada para a escala do bairro.

87 idem 
O bairro apresenta um sistema de gestão de águas de ciclo fechado que garante o seu abastecimento. Parte da água da chuva é absorvida pela área verde, parte é reutilizada nos jardins e sanitários e, parte é encaminhada por uma rede a um canal, que funciona com reserva natural. Além disso, os edifícios foram construídos incorporando algumas medidas que permitiam o reuso de água.

\section{Categoria 05 - Diversidade Urbana e Expressão Arquitetônica}

O ecobairro apresenta uma diversidade de tipologias edificatórias, de usos e de rendas.

O bairro buscou atrair residentes de uma zona considerada como uma das mais pobres de Amsterdam. O projeto conta com 600 habitações, sendo 300 habitações social, "social rented", 150 com preço abaixo do mercado, "subsidised sale" e 150 com preço de mercado, facilitando a mistura de distintos estratos da sociedade e populações com diferentes idades.

Somado a todos os aspectos positivos relacionados à sustentabilidade ambiental, o ecobairro GWL destaca pela qualidade tanto nos projetos dos espaços externos quanto no projeto das edificações, apresentando uma identidade arquitetônica.

De acordo com a avaliação de Higueras, sob o enfoque nos critérios estabelecidos como determinantes por Rueda, GWL apresenta os seguintes resultados: Compacidade 5/5; Complexidade 4/5; Eficiência 3/5 e; Estabilidade social 5/5. (AYUNTAMIENTO DE MADRID, 2009, p.27).

Nesta avaliação comparativa, Higueras conclui que GWL é o ecobairro que reúne melhor os requisitos estabelecidos como exemplo de boa prática de ecobairro por Rueda (AYUNTAMIENTO DE MADRID, 2009). 


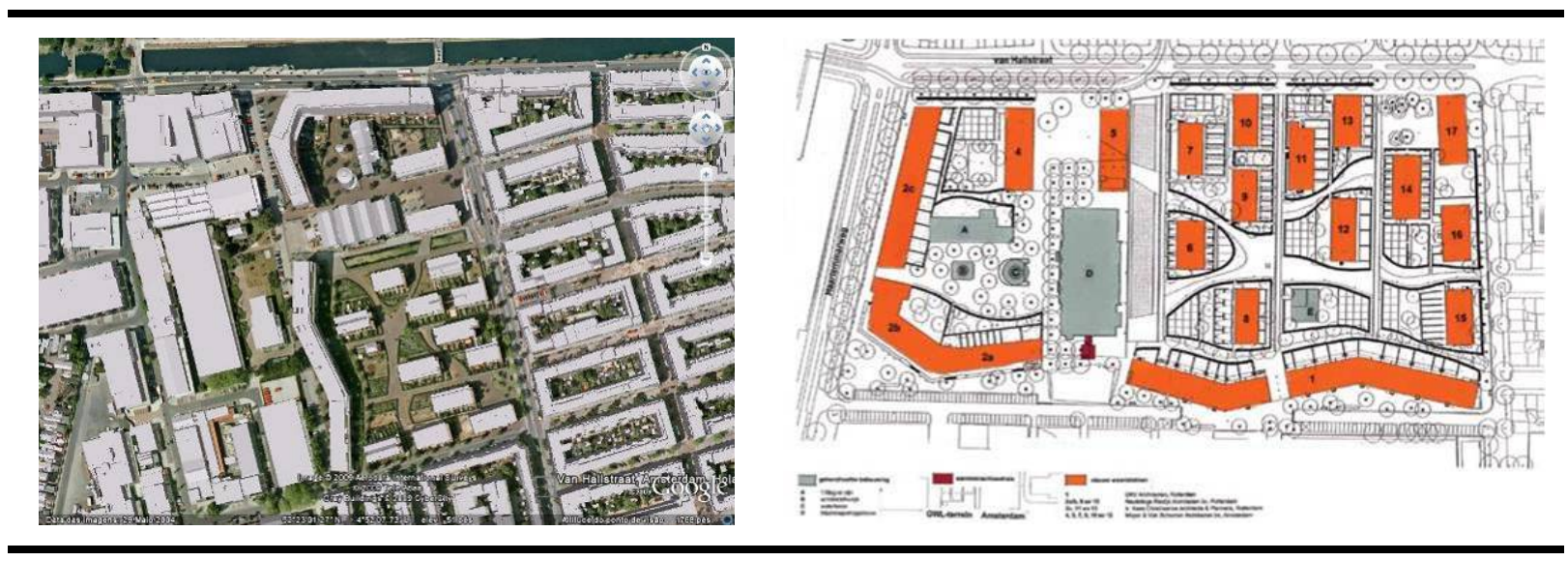

Figura 108: Foto aérea projeto GWL

Fonte: Google
Figura 109: Planta ecobairro GWL

Fonte: EMVS, 2006

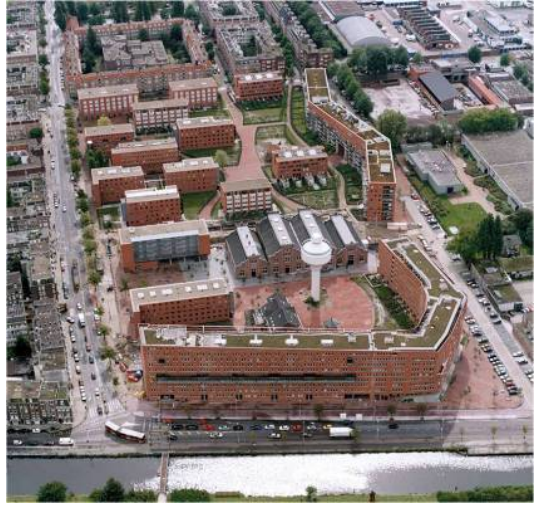

Figura 110: Projeto ecobairro GWL

Fonte: EMVS, 2006

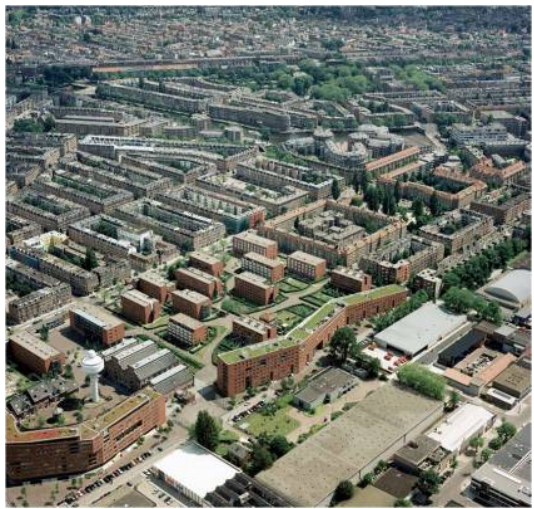

Figura 111: Inserção do ecobairro no entorno

Fonte: EMVS, 2006

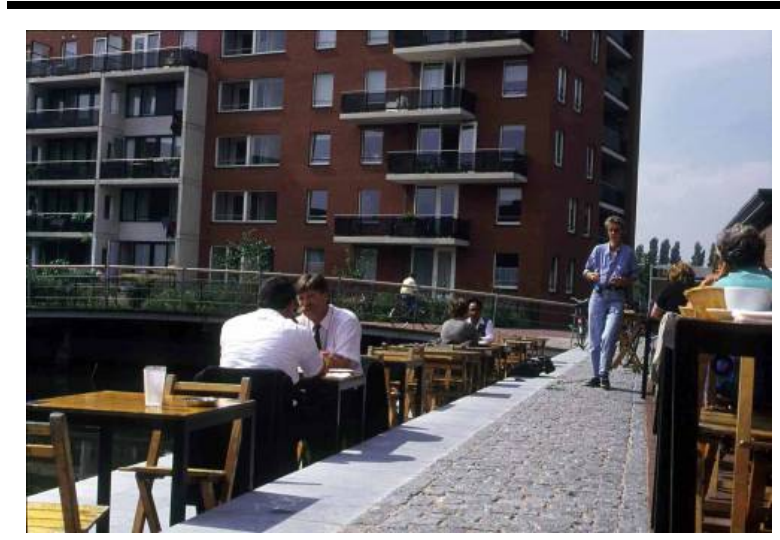

Figura 112: Foto da área de convivência

Fonte: EMVS, 2006

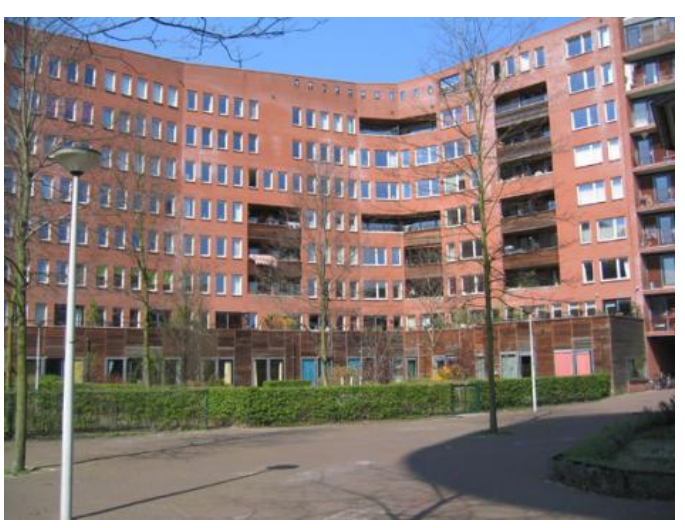

Figura 113: interior do ecobairro GWL

Fonte: EMVS, 2006 


\subsubsection{Viikie, Helsinki, Finlândia}

\section{Dados técnicos:}

Projeto: Bairro Viikki e a Eco-comunidade Viikki

Localização: Helsinki, Finlândia - Latitude: $61^{\circ} 55^{\prime} \mathrm{N}$

Arquiteto Urbanista: Petri Laaksinen

Cliente: Departamento de Uso do solo - Ministério do Meio Ambiente da Finlândia Governo Finlandês

Área: Bairro Viikki1100 hectares

Ecobairro 23 hectares/ 1700 residentes

Uso: Misto

Fase: finalizada

\section{Descrição:}

Viikki está implantado a oito quilômetros do centro da cidade de Helsinki, ocupando uma área de 1100 hectares. Está previsto para 2010, quando finalizam as obras, 13 mil residentes de 6 mil lugares de trabalho.

Segundo Gauzin-Muller, o urbanismo finlandês se distingue pela qualidade e a escala humana de suas atuações paisagísticas e de seus espaços públicos. ${ }^{88}$

O projeto foi realizado em parceria da cidade de Helsinki, sua universidade, o Estado e as empresas privadas.

O projeto abrange um parque universitário e tecnológico, uma reserva natural e alguns bairros residenciais, entre eles o ecobairro Viikki.

O objetivo do projeto era controlar a densidade junto à reserva natural e, ao mesmo tempo, explorar as infra-estruturas existentes. Os serviços técnicos da Agência Municipal de Urbanismo realizaram estudos a fim de otimizar a diversidade social e favorecer a proximidade e o equilíbrio entre moradia e local de trabalho no interior do bairro, reduzindo, dessa forma, os deslocamentos.

\footnotetext{
${ }^{88}$ Gauzin-Muller, 2002.
} 
Latokartano é a principal zona residencial de Viikki, para a qual foi previsto entre 8.000 e 9.000 residentes, com habitações para aluguel, venda e para o setor privado. Na parte sul de Latokartano foi implantado o bairro experimental, que foi incluído no programa Ecocomunidade, projeto em parceria entre a Associação dos Arquitetos finlandeses (Safa), do Ministério do Meio Ambiente e o Centro de desenvolvimento tecnológico (Tekes).

O ecobairro construído dentro de Viikki ocupa uma área de 23 hectares, sendo formado por habitações para 1700 residentes e espaço para serviços públicos, comerciais, sociais e assistenciais.

Para encontrar o modelo de bairro ecológico proposto foi realizado um concurso que recebeu 91 projetos. O plano urbano de Viikki se baseia na proposta vencedora de autoria do arquiteto Petri Laaksonen. O projeto vencedor reproduz o planejamento urbano de Helsinki, com corredores verdes penetrando entre as alinhadas quadras (manzanas).

O plano apresenta uma estrutura compacta e baseada em eixos, na qual os edifícios, orientados na maioria para o sul, agrupam-se em zonas residenciais, interceptadas por corredores verdes.

O contato com a natureza virgem e sua proximidade com o centro da cidade fazem Viikki um lugar atrativo para se viver.

Para o projeto das edificações foi promovido um segundo concurso. A idéia era atrair empresas dispostas a desenvolver inovações, produtos e soluções ecológicas. Porém, as propostas recebidas eram tradicionais, tanto com relação ao desenho arquitetônico quanto às técnicas construtivas.

Antes da realização do projeto do bairro de Viikki, Helsinki já iniciava medidas a favor do desenvolvimento sustentável. Gauzin-Muller (2002) aponta estas medidas: programa de controle de gastos energéticos para o parque imobiliário da cidade; $91 \%$ das habitações e 95\% dos edifícios de escritórios são abastecidos pela rede pública de aquecimento, sendo esta $52 \%$ co-geração de gás natural, $46 \%$ de carbono e $1 \%$ de petróleo; programa de adensamento urbano em curso; programa de proteção da natureza e gestão ecológica dos bosques; definição de $10 \mathrm{~m}^{2}$ de jardins municipais por habitante; desenvolvimento do transporte público e incentivo ao deslocamento em bicicleta; e realização de bairros experimentais segundo os princípios de desenvolvimento sustentável. 
Higueras comenta: "Viikki tem ambiciosos critérios e aspectos muito inovadores, começando desde o planejamento que estuda a viabilidade da transformação do solo em urbano com uma avaliação detalhada de critérios ecológicos." (AYUNTAMIENTO DE MADRID, 2009, p.21, tradução da autora)

O concurso teve grande importância educacional, já que em seu edital eram definidos níveis ecológicos, algumas metas, ficando a cargo do arquiteto como alcançá-los.

Para avaliar o nível ecológico das propostas foram definidos critérios separados em cinco aspectos relacionados ao meio ambiente, que deveriam ser levados em consideração: a contaminação $\left(\mathrm{CO}_{2}\right.$, águas residuais, resíduos, etc); os recursos naturais (combustíveis fósseis, energia, uso do solo, etc); a salubridade (clima, ruído, etc); a biodiversidade e a vegetação e nutrientes do solo.

Apesar da existência de critérios, foi verificada uma dificuldade em medir o quão ecológico era o projeto, principalmente no caso dos planos urbanos.

Com relação aos edifícios, esses tinham que cumprir os requisitos mínimos dos critérios ecológicos para ter a permissão para construção, sendo que este nível mínimo significa um melhor desempenho em relação aos edifícios convencionais.

É importante ressaltar que não basta ter planos urbanos mais sustentáveis se os projetos das edificações não têm a mesma premissa. Assim como menor é a eficiência de projetos de edificações sustentáveis se o contexto urbano não é pensado para garantir o desempenho destas.

Vale destacar que todos os planos de Eco-Viikki tinham que incluir a construção experimental ecológica. O novo bairro e seus aspectos inovadores constituíram um objeto de estudo para os institutos universitários ali instalados.

Apesar de tantos aspectos positivos o projeto foi criticado pela sua pouca expressão arquitetônica. A revista Finnish Architectural Review (número 1/2005) comenta:

"a zona carece de um núcleo que revele sua alma, um edifício o um espaço com um ambiente relacionado com a nova filosofia (...) a zona carece de encanto e graça, é confusa e semiacabada."

Korpivaara concorda com a crítica, e ainda completa: 
"a falta de excelência arquitetônica dos edifícios de Eco-Viikki é de lamentar em vista dos ambiciosos objetivos globais. Resultaria mais fácil promover a sustentabilidade com uma boa arquitetura. (...) Sigo crescendo que é possível integrar uma boa arquitetura, as inovações, a tecnologia e a ecologia."

\section{Categoria 01 - Compacidade}

A densidade construtiva de Viikki é relativamente baixa, porém é maior que a densidade média de Helsinki.

Viikki apresenta uma compacidade absoluta média, mas que também supõe um grande avanço ao modelo de ocupação do solo finlandês. (AYUNTAMIENTO DE MADRID, 2009, p.21).

Viikki é um bairro que aproveita da proximidade que o conecta com o centro da cidade e que combina diferentes tipos de atividades. A vantagem disso é que reunindo em um espaço próximo habitações coletivas, unifamiliares, serviços públicos, zonas verdes, etc.

\section{Categoria 02 - Mobilidade}

A proximidade com o centro também é uma característica positiva do ponto de vista da mobilidade urbana. O projeto conta com a criação de dois centros urbanos, reduzindo as distâncias a serem deslocadas.

O bairro como um todo apresenta medidas limitando o uso de automóveis. Apesar disso, muitas famílias utilizam dois automóveis para se locomover. Mesmo assim, o projeto apresenta metade da necessidade de estacionamento, comparado com a necessidade das zonas suburbanas.

O bairro apresenta uma rede eficiente e diversificada de transporte público interno e externo com ônibus, trem e uma linha de transvia rápida.

O projeto apresenta circulações de pedestres e automóveis separadas.

\section{Categoria 03 - Espaço Público e Área Verde}

Os edifícios estão conectados diretamente às zonas de vegetação. A presença de zonas verdes entre as edificações é uma característica importante de Helsinki, favorecendo o microclima e aumentando a biodiversidade. A biodiversidade dos espaços naturais é preservada e reforçada mediante a construção de variados ecossistemas. 
Os problemas de ruído urbano gerados pelo tráfego de automóveis foi resolvido com a implantação dos equipamentos terciários e universitários mais próxima da autopista, criando uma barreira para as zonas residenciais.

Com o objetivo de proteger dos ventos, principalmente no inverno, a proposta trabalha com as alturas diferenciadas das edificações. Além disso, o autor trabalha também com uma barreira de vegetação para reduzir a exposição aos ventos dominantes, assim como para limitar a área edificada.

O projeto conta com a presença de corredores verdes e jardins individuais, que constituem uma superfície importante para a infiltração das águas pluviais.

\section{Categoria 04 - Eficiência no uso de Recursos Naturais água e energia}

O projeto levou em consideração aspectos de insolação e ventilação desde a fase de implantação. A maioria dos edifícios foi orientada para o sul para que recebessem sol durante o dia todo, localizando nesta fachada as salas ou varandas envidraçadas, visando o aquecimento solar passivo. Além disso, foi realizados estudos de sombra para a definição das distâncias entre os edifícios, evitando sombras prejudiciais de um edifício no outro.

Algumas residências utilizam energia solar para aquecimento de água e geração de energia. Os painéis solares da casa de energia solar Salvia (39 habitações) se integram na varanda e produz $24 \mathrm{Kw}$ de energia elétrica, a qual representa $20 \%$ das necessidades energéticas da edificação. Durante o verão o excesso de energia solar é transferido para a rede elétrica e no inverno esta é aproveitada.

O autor do projeto Viikki apresenta uma grande preocupação com relação à água da chuva, já que uma parcela muito pequena desta consegue ser absorvida pelo terreno, em decorrência do solo argiloso. Sendo assim, foi realocado um canal (la zanja Viikinoja) para a zona do parque nos limites dos blocos residenciais, para atuar como uma reserva natural. Parcela da água da chuva segue pelas tubulações de esgoto e pelas depressões até as zonas verdes, de onde escoam até o canal La Zanja Viikinoja. Esse canal e os eixos verdes desaceleram o escoamento das águas superficiais e melhoram a qualidade da água antes que esta chegue aos reservatórios naturais.

O sistema também conta com um grande número de poços que acumulam parte da água da chuva para ser reutilizada nos jardins do bairro. 
A água procedente da chuva e da neve derretida devem se tornar mais lenta na medida do possível, para que penetre no solo. O objetivo é de manter mais limpo o escorrimento das águas superficiais que fluem em direção a zona de conservação natural, melhorando o habitat para a flora. Além disso, cruzando por numerosas passarelas o arroio urbano constitui um elemento paisagístico muito importante.

Durante os primeiros anos de funcionamento, foi verificado que a meta de energia não foi alcançada, mas que os edifícios economizam $25 \%$ de energia para a calefação, se comparado com os convencionais.

Com relação ao consumo de água, a economia está em torno de $22 \%$, sendo que em média os residentes consomem 126 litros por dia.

\section{Categoria 05 - Diversidade Urbana e Expressão Arquitetônica}

O projeto apresenta diversidade de usos e de tipologias residenciais, propiciando a complexidade e a coesão social.

Apesar das características positivas o projeto apresenta pouca expressão arquitetônica.

Segundo a análise dos ecobairro realizada por Higueras, com base nos critérios estabelecidos como determinantes por Rueda (2006), Viikki apresenta os seguintes resultados: Compacidade 3/5; Complexidade 3/5; Eficiência 4/5 e; Estabilidade social 4/5. (AYUNTAMIENTO DE MADRID, 2009, p.27). 


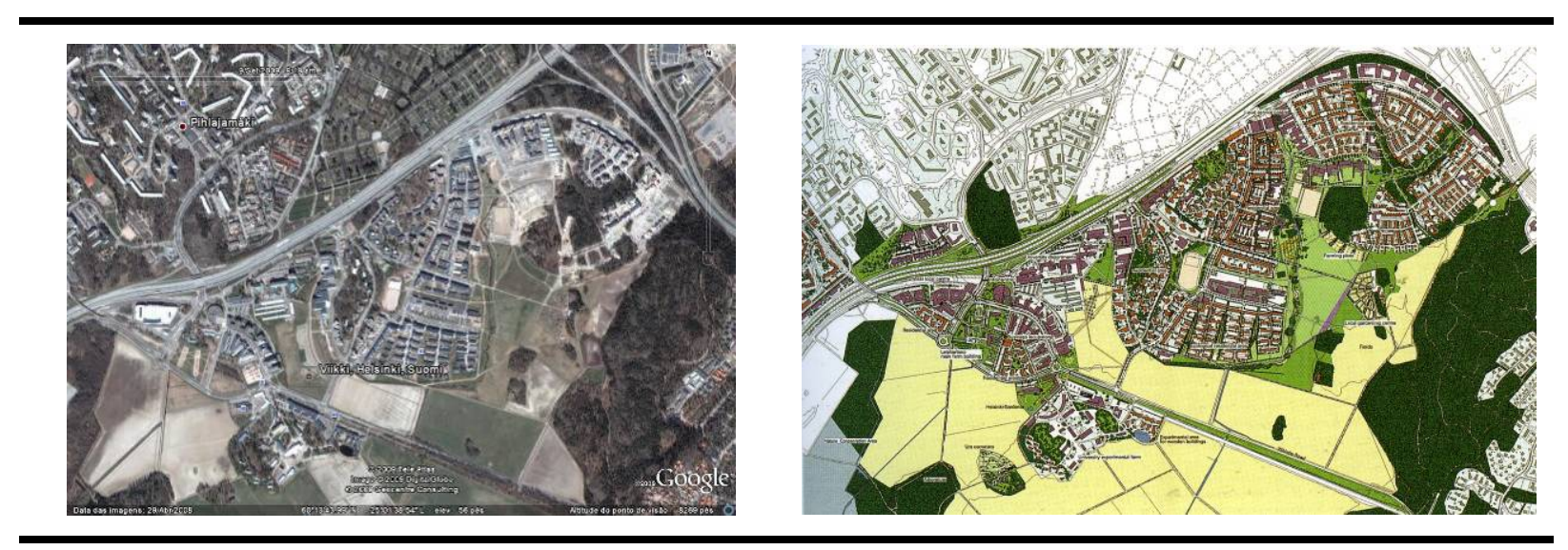

Figura 114: I magem aérea Ecobairro Viikki Figura 115: Planta Ecobairro Viikki

Fonte: Google

Fonte: Gauzin-Muller, 2002.
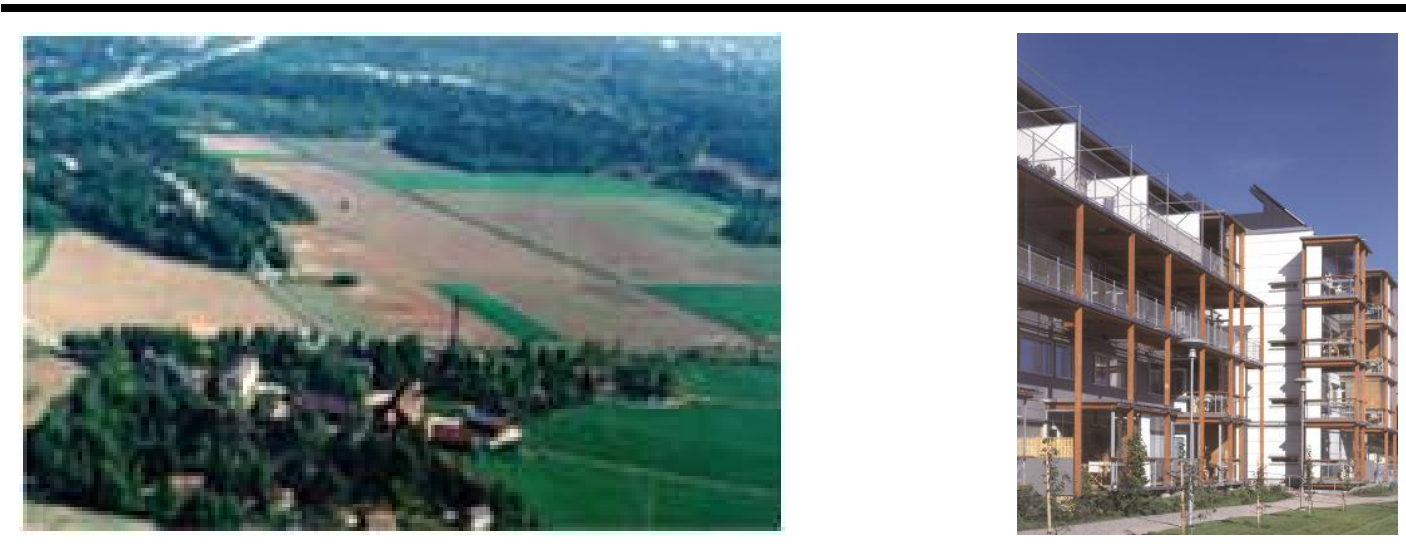

Figura 116: Foto a área do projeto ecobairro Viikki

Figura 117: Foto do ecobairro Viikki

Fonte: EMVS, 2006

Fonte: EMVS, 2006 


\subsubsection{Solar City ${ }^{89}$, Austria}

\section{Dados técnicos:}

Projeto: SolarCity Pichiling

Localização: Linz, Austria - Latitude: $48^{\circ} 15^{\prime} \mathrm{N}$

Arquiteto Urbanista: Rowland Rainer

Consultoria técnica: Renzo Piano

Projeto de Arquitetura e Sustentabilidade - Richard Rogers, Thomas Herzog e Norman Foster (Fase 01); e Martin Treberspurg (Fase 02)

Projeto de paisagismo - Latz and Partner

Environmental engineer - Norbert Kaiser

Cliente: Município de Linz, ESG, SBL,

Área: 32 hectares/ 1317 habitações

Uso: misto, predominantemente residencial

Fase: finalizada em 2005

\section{Descrição:}

A cidade solar consiste em uma vila de 1300 habitações, para 6000 residentes, construída em Pichling, lado sul da cidade de Linz, Áustria. O projeto finalizado em 2005 inclui, além de habitações, lojas, escola, parque esportivo e outros serviços básicos necessários.

A idéia de construir um novo assentamento urbano com base nos princípios ecológicos iniciou-se em 1990, quando Linz introduziu uma política de habitação social de baixo consumo de energia. Nessa época 12.000 pessoas procuravam habitações na área de Linz. Além da demanda por habitações, o consumo de energia elétrica estava aumentando e, como conseqüência, as emissões de $\mathrm{CO}_{2}$ também.

Sendo assim, em 1992 o município de Linz solicitou ao urbanista Rowland Raines um projeto de um bairro residencial de baixo consumo energético, com 630 habitações, em uma área já servida de infra-estrutura básica, às margens do Danube.

\footnotetext{
${ }^{89}$ Apesar da denominação solar city, cidade solar, o projeto apresenta uma escala de bairro.
} 
Um ano depois o conselho do município consegue fundos com a Comunidade européia para as pesquisas necessárias para que a construção desse bairro seja uma referência no novo milênio.

Em 1994 quatro firmas de construção confirmam a intenção de fundar o novo bairro de baixo consumo energético no distrito de Pichling. No ano seguinte, outras oito firmas juntam ao grupo e a escala do projeto aumenta para 1.317 habitações em uma área de 32 hectares. $^{90}$

Para a primeira fase, líderes do município convidaram os arquitetos Norman Foster, Richard Rogers e Thomas Herzog para o projeto de 630 habitações, com a consultoria do engenheiro Norbert Kaiser, coordenador do grupo READ, Renewable Energy in Architecture and Desing e do arquiteto Renzo Piano.

Para a segunda fase do projeto, foi realizado um concurso, em 1996, para o projeto das demais habitações. O vencedor do concurso foi o arquiteto Vienense Martin Treberspurg.

Demais arquitetos também fizeram parte da equipe, nos projetos de edifícios públicos e residenciais $^{91}$.

O plano diretor se organiza em uma série de bairros compactos de uso misto, articulados a distâncias facilmente caminháveis, em torno a uma praça central dotada de serviços de transporte público a fim de reduzir o uso do automóvel. ${ }^{92}$

O projeto é formado por edifícios de dois a quatro pavimentos, orientados, quando possíveis, no sentido norte e sul, com sua fachada principal para sul.

Além desses, o projeto apresenta mais quatro tipologias de blocos residenciais: blocos lineares de três andares, com 16 metros de profundidade, 2 e 4 dormitórios, orientados para leste e oeste; blocos lineares de três pavimentos, com 15 metros de profundidade, 3

\footnotetext{
${ }^{90}$ Architeken Loudon + Habeler, arch-schimek.at, archsolar, Auer + weber + Architekten, Jordan architektur \& energie, Pointner Architeken e Reinhard Stummer.

91 Architektur weismann, Future Systems, Herzog and Partner, Herbert Karrer, Franz Kneidinger, Heiz Stogmuller, Architekturburo Gellner, Kaufnamm Partner, Lassy Architektur + Raumplanung, Helmuth Schweiger e Reinhard Stummer.

92 Mais informações sobre o projeto na publicação: TREBERSPURG, Martin. Solarcity Linz-Pichling Sustainable Urban Development. Springer Vienna New York.
} 
dormitórios, orientados para nordeste e sudoeste; blocos quadrados de quatro pavimentos, com suas fachadas principais orientadas para sudeste e sudoeste; eblocos delgados de mini apartamentos, com a fachada principal orientada para sudoeste (RUANO, 2000).

Todas as edificações foram construídas de acordo com o padrão de eficiência energética, sendo o aproveitamento do sol a sua principal estratégia. As edificações são compactas e orientadas, na sua maioria, para o sul, aproveitando o máximo de radiação solar para aquecimento no inverno, através do uso de vidros na fachada e controlando o ganho excessivo de calor no verão, por meio da aplicação de proteções solares.

É importante destacar que apesar dos edifícios não estarem todos implantados na orientação mais favorável para insolação, os autores do projeto souberam adaptar, trabalhando com a forma, a envoltória e o layout, sem perder o foco principal de aproveitar ao máximo os recursos naturais como sol e vento.

Os edifícios apresentam alturas limitadas, sendo implantados a uma distância que garanta radiação solar nos ambientes internos durante o inverno, ou seja, sem que um edifício faça sombra no outro.

Um aspecto que merece destacar do projeto é que ele incorpora no desenho urbano e na arquitetura dos edifícios a inserção e integração com o meio ambiente e o aproveitamento dos recursos naturais.

O projeto SolarCity foi premiado diversas vezes. Em 1998, as Nações Unidas o concedeu o prêmio "the Best Practice" na categoria de Progresso Ambiental, Enhancement of the Environment. Em1999, solarCity recebe o prêmio "Environmental Award 2001" da "Earth Society Foundation", da NGO group (non-governmental organization), um grupo nãogovernamental de Nova York. Em 2000, o projeto se encontra entre os cinco melhores em concepções inovadoras "innovative building concepts" na competição Casa do Futuro, "Haus der Zukunft". (MAGISTRAT LINZ, 2004 apud JÜRGEN H. BREUSTE, JÜRGEN RIEPEL).

Após 15 anos de uso, Solarcity contém 2.942 residentes e 1.293 habitações construídas em 36 hectares. O consumo energético não ultrapassa a $40 \mathrm{kwh} / \mathrm{m}^{2} /$ ano (JÜRGEN H. BREUSTE, JÜRGEN RIEPEL). 


\section{Categoria 01 - Compacidade}

O projeto apresenta uma densidade construtiva de aproximadamente 40 habitações/ha e uma densidade populacional de 187,5 pessoas/ha.

A compacidade absoluta é média, com blocos de três e quatro pavimentos, a uma distância mínima um do outro, de acordo com o estudo de insolação.

Solarcity também apresenta uma proximidade de diferentes usos e funções urbana.

\section{Categoria 02 - Mobilidade}

Com relação a mobilidade, parte considerável dos residentes trabalha em Linz, tendo a opção de se deslocar ao centro da cidade através do trem ou de ônibus. A cidade solar é abastecida de transporte público eficiente e diversificado (trem e ônibus), com estações a 300 metros das residências.

Para distâncias menores, o projeto favorece o transporte de pedestres e de bicicleta e restringe o uso de veículos privados dentro da área. As áreas de estacionamento de veículos são subterrâneas, separadas das áreas de convivência.

\section{Categoria 03 - Espaço Público e Área Verde}

Projeto integrado com a natureza, através de jardins na cobertura, junto às margens do Danúbio e um parque. A vegetação é adotada também para amenizar as condições climáticas e proteger a biodiversidade.

A porcentagem da superfície de viário público destinada ao transporte motorizada é pequena, já que dentro do bairro o uso de automóveis é restrito. Essa decisão interfere positivamente o conforto acústico e a qualidade do ar nos espaços externos.

Com base no estudo de sombras, o projeto foi desenvolvido buscando atingir uma densidade máxima, com o máximo de insolação possível no período de inverno, reduzindo a área de sombra dos espaços externos.

\section{Categoria 04 - Eficiência no uso de Recursos Naturais água e energia}

Como diz o próprio nome "solarcity" todo o projeto está fundamentado nas variáveis ambientais relacionadas ao sol. Com isto, foram adotados os seguintes princípios: desenho do bairro e das habitações desenvolvidos com base nos fundamentos da "arquitetura solar", utilização de energia solar passiva; aproveitamento da radiação solar 
direta para a permanência de pessoas nos espaços externos durante o período de frio; geração de energia renovável e etc.

O aquecimento de água e a geração de energia limpa foram feitos por meio de coletores solares e painéis fotovoltaicos, respectivamente, implantados na cobertura das edificações. Além da energia solar, o projeto também adotou o uso de biomassa para geração de energia renovável.

A iluminação natural e ventilação natural foram estratégias adotadas nas habitações, visando à economia de energia elétrica e o conforto do usuário.

Os edifícios residenciais da cidade solar consomem $37 \mathrm{kwh} / \mathrm{m}^{2} /$ ano para aquecimento, sendo que uma construção de baixo consumo de energia na Áustria gasta $44 \mathrm{kwh} / \mathrm{m}^{2} / \mathrm{ano}$ e a média é de $65 \mathrm{kwh} / \mathrm{m}^{2} / \mathrm{ano}^{93}$

O projeto adotou estratégias para coleta e reuso das águas da chuva. As margens do rio Danube é um canal natural, para drenagem e tratamento das águas. O projeto conta com a presença de pântanos, wetlands, para tratamento das águas pluviais.

Além disso, o projeto também prevê a filtragem das águas cinza em estação de tratamento através das plantas, para depois conduzir ao rio mais próximo.

\section{Categoria 05 - Diversidade Urbana e Expressão Arquitetônica}

A cidade solar apresenta habitações de tamanhos distintos e uso misto, duas características cruciais para promover a diversidade e as vantagens que a acompanham.

Projeto compacto, encorajando a proximidade social.

O projeto apresenta uma diversidade tipológica, além de grande expressão arquitetônica.

\footnotetext{
${ }^{93}$ http://www.martinot.info/solarcities/linz.htm
} 


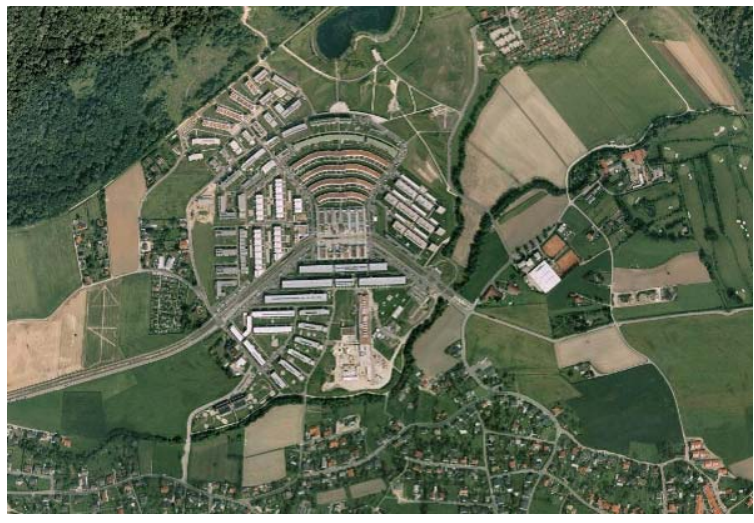

Figura 118: I magem aérea ecobairro Solarcity Fonte: Google

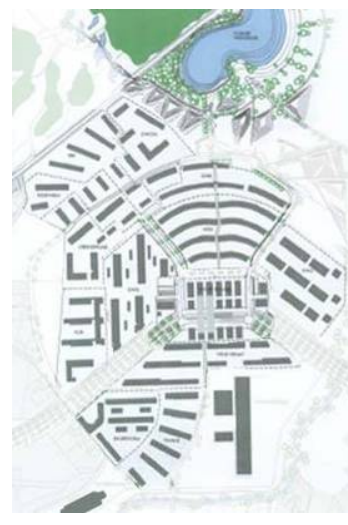

Figura 119: Planta projeto solarcity

Fonte: RUANO, 1998

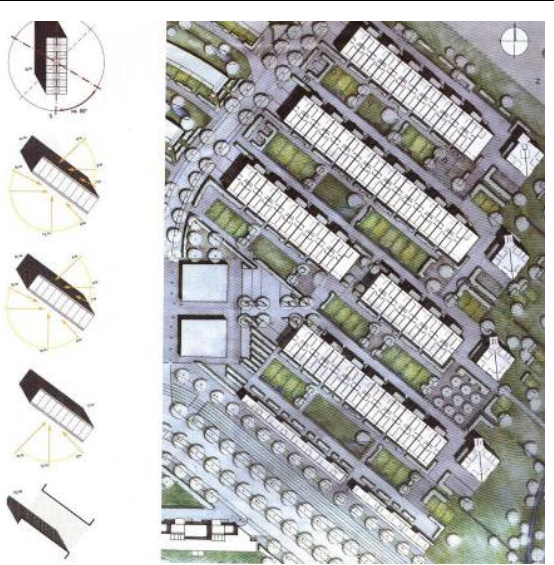

Figura 120: Estudo de insolação dos edifícios do ecobairro solarcity

Fonte: RUANO, 1998

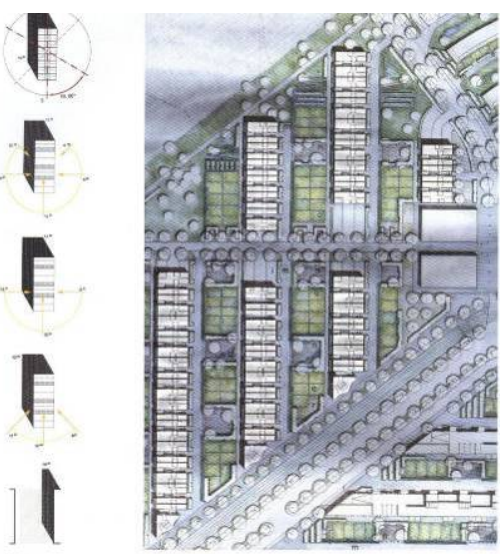

Figura 121: Estudo de insolação dos edifícios do ecobairro solarcity

Fonte: RUANO, 1998
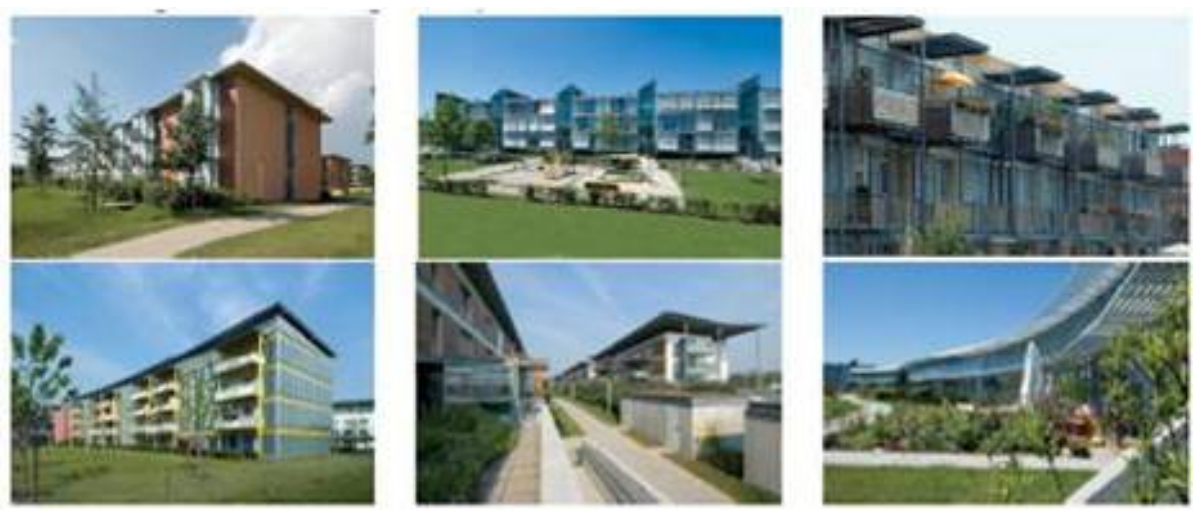

Figura 122: I magens do ecobairro Solarcity

Fonte: http://www.linz.at/english/solarcity/frameset.html 


\section{Bedzed, Londres, Reino Unido}

\section{Dados técnicos:}

Projeto: Bedzed, Beddington Zero Fossil Energy Development

Localização: London Borough of Sutton - Latitude: $51^{\circ} 30^{\prime} \mathrm{N}$

Arquiteto Urbanista: Bill Dunster Architects/ ZEDfactory Itd

Consultoria técnica: Sustainability advisors - BioRegional Development group; Building physics - Over Arup \& Partnes; Estrutural - Ellis and Moore; Paisagismo - Andrew Grant Associates

Cliente: The Peabody Trust - Housing Association

Área: 1,7 hectares/ 82 habitações

Uso: Misto (residencial e comercial)

Fase: finalizada em 2002

\section{Descrição:}

O ecobairro BedZED, construído no final dos anos 90, visava criar uma comunidade cujos parâmetros de vida são regidos pelos requisitos do desenvolvimento sustentável.

O BedZED, the Beddington Zero-Energy Development, constitui um bairro predominantemente residencial, com 82 habitações e uma área comercial e de serviço de $1695 m^{2}$.

O projeto parte do objetivo de não emitir dióxido de carbono $\left(\mathrm{CO}_{2}\right)$ com o seu consumo energético, tendo como principais metas: conciliar alta densidade com qualidade de vida e baixo consumo de energia e água, proteger a área verde do desenvolvimento urbano; reduzir o impacto ambiental global do processo de urbanização no Reino Unido; desenvolver a economia local; adotar bons materiais locais e consumir energia produzida na região.

O projeto do conjunto foi desenvolvido pelo arquiteto Bill Dunster em parceria com o escritório Bio Regional Development Group. O projeto consiste em blocos lineares e compactos de edifícios habitacionais, seguindo a arquitetura residencial inglesa tradicional. 
As habitações, orientadas para o sul, foram projetadas de maneira a aproveitar o máximo a energia solar para aquecimento e para geração de energia elétrica através de painéis fotovoltaicos, usados também como proteções solares.

Já os espaços de trabalho foram localizados em áreas de sombra e nos jardins privados nas coberturas.

É possível dizer que a aplicação dos aspectos relacionados à sustentabilidade nos projetos das edificações está muito clara, até mais que no projeto urbano. Mas o resultado como um todo é bastante positivo, pois o projeto conseguiu alcançar seus objetivos de reduzir o consumo dos recursos naturais e de geração de resíduos sólidos.

Além disso, o projeto é uma referência internacional, sendo um exemplo de aplicação de estratégias passivas e de bom desempenho, somado a uma estética interessante e atraente.

Por essas razões o projeto é visitado por pessoas do mundo todo, que através de uma exposição permanente e da visita guiada ao condomínio e ao apartamento modelo podem saber detalhes do projeto e aprender mais sobre as estratégias adotadas. O projeto também está exposto no Museu Victoria \& Albert, em Londres.

Outra maneira de divulgação do Bedzed é através dos informes, reports, produzidos pelo BioRegional Development Group, também responsável pelo projeto. O mesmo grupo monitora o desempenho do bairro e suas habitações, realizando algumas avaliações com relação ao transporte, a qualidade de vida dos seus habitantes e as questões ligadas à água, energia e resíduos sólidos. ${ }^{94}$

Em um desses reports foi apresentado um estudo comparando um modelo de bairro convencional projetado no mesmo sítio do Bedzed e o ecobairro atual, com algumas estratégias relacionadas à sustentabilidade aplicadas. No modelo convencional, as áreas

${ }^{94}$ BIO REGIONAL, Case study Report: Bedzed. Março, 2002.

BIO REGIONAL, Bedzed: toolkit part I. Best practical Report. Dezembro, 2002.

BIO REGIONAL, Bedzed: toolkit part II. A practical guide to producing affordable carbon neutral developments. Outubro, 2003.

BIO REGIONAL, Bedzed: seven years on. The impact of UK's best Known eco-village and its residents. Julho, 2009. 
destinadas à habitação, estacionamento, vias para veículos motorizados e área verde são, $1.938 \mathrm{~m}^{2}, 1.568 \mathrm{~m}^{2}, 2.454 \mathrm{~m}^{2}$ e $5.105 \mathrm{~m}^{2}$, respectivamente. Com relação ao bairro atual, verificou-se que a área de habitações aumentou para $2.378 \mathrm{~m}^{2}$, a área de estacionamento e vias destinadas ao transporte motorizado reduziu para $980 \mathrm{~m}^{2}$ e $540 \mathrm{~m}^{2}$, respectivamente e a área verde aumentou para $5.803 \mathrm{~m}^{2}$, e ainda foi introduzida uma área de trabalho de $1.216 \mathrm{~m}^{2}$ (Figura 123).

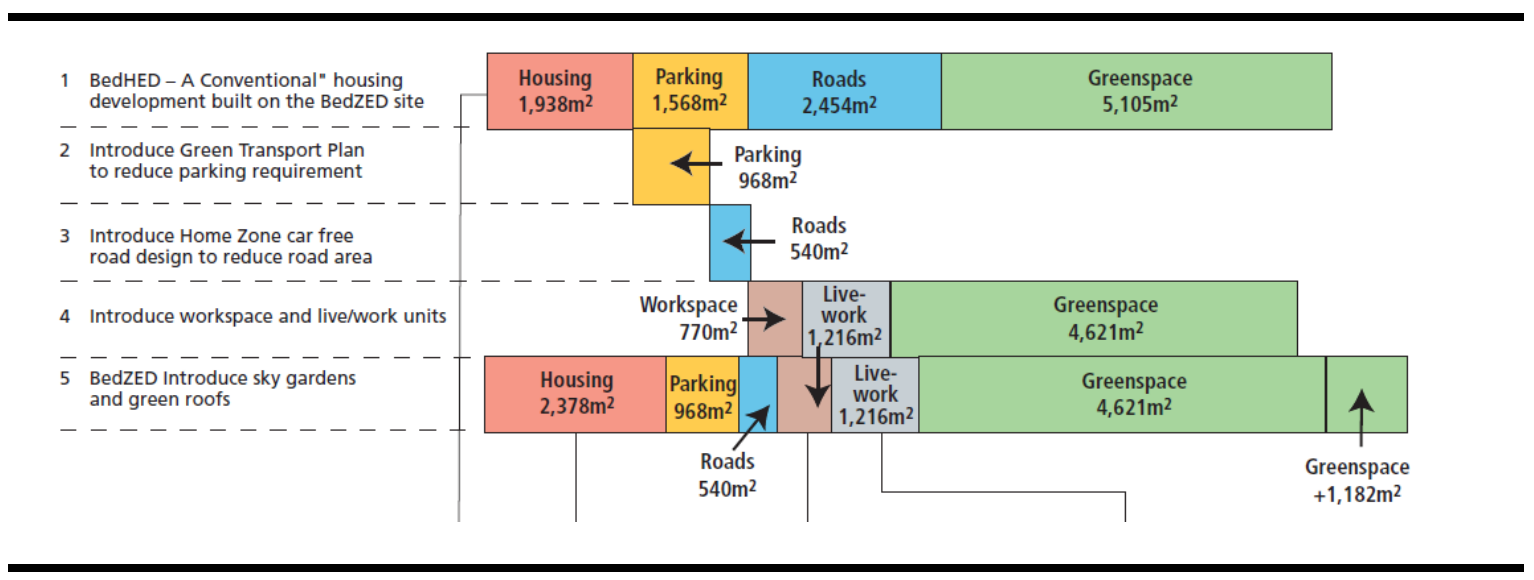

Figura 123: Esquema comparando Bedzed a um modelo de bairro convencional

Isso demonstra que algumas decisões projetuais visando uma maior sustentabilidade ambiental urbana podem trazer benefícios diretos ao bairro e a seus residentes.

Dunster explica que não há nada de inovador nas idéias aplicada individualmente. O que há de novo é agregá-las e aplicar o conceito em grandes cidades. ${ }^{95}$

Após um ano e, posteriormente, sete anos de uso foram realizadas algumas avaliações para verificar o desempenho das habitações do ecobairro Bedzed

A média do consumo de energia utilizado para aquecimento de água nas habitações do ecobairro Bedzed é aproximadamente $40 \%$ menos que a média das habitações de mesmo tamanho em Londres.

Com relação ao consumo de energia destinado a iluminação e demais atividades da rotina de uma habitação é $58 \%$ a menos.

O consumo de água é $55 \%$ a menos que a média das habitações de mesmo tamanho em Londres.

\footnotetext{
95 http://www.arq.ufsc.br/arq5661/trabalhos_2007-1/sustentabilidade/hh.htm 02/10/2009
} 
Vale destacar que o sucesso do empreendimento também se deve a mudança de postura de seus residentes em relação ao desperdício de recursos naturais e os impactos que a urbanização causa diariamente ao meio ambiente.

\section{Categoria 01 - Compacidade}

Densidade construtiva média, de aproximadamente 47 habitações/ha e 120 espaços de trabalho/ha. A densidade populacional é de 267 pessoas/ha, entre residentes e trabalhadores, sendo 148 residentes/ha. ${ }^{96}$

Analisando somente o núcleo central do bairro, o core, a densidade chega a aproximadamente 500 pessoas por hectare incluindo residentes (309 residentes/ha) e trabalhadores. Com relação à densidade construtiva, essa atinge o valor de 100habitações/ha.

O desenho das edificações do núcleo central do bairro foi realizado junto ao estudo de insolação, de maneira a compatibilizar alta densidade com aproveitamento da radiação solar para aquecimento nas habitações e espaços de trabalho. Como ilustrado na Fig X.

Compacidade média. Os edifícios apresentam uma altura de três pavimentos e uma pequena distância entre as edificações. Se considerar o núcleo central, core, a compacidade é maior, pois essa área apresenta menos espaço livre.

\section{Categoria 02 - Mobilidade}

O local para a implantação do eco-bairro, London Borough of Sutton, foi selecionado em decorrência, entre outros motivos, do acesso ao transporte público, através de ônibus que chegam ao local e a proximidade de estações de trem e trem, a sete e dez minutos a pé respectivamente.

Foi estabelecido um plano, "Green Travel Plan", que engloba todas as questões relacionadas à mobilidade. Fazia parte desse plano, negociar com as autoridades locais a redução de $50 \%$ da área de estacionamento padrão, limitando esta para 84 vagas.

O projeto restringe o uso do automóvel e privilegia o pedestre e o uso de bicicletas. Além disso, o ecobairro desenvolveu um programa de aluguel de carro por algumas horas, do

\footnotetext{
${ }^{96}$ Government's Energy Efficiency Best Practice programme. General information report 89. Beddington zero energy development, p.30.
} 
próprio condomínio, "car clubs, Zedcars", que é uma possibilidade para aqueles residentes que não possuem veículos privados.

Bedzed foi projetado de forma a reduzir a necessidade de deslocamento, através de oportunidades de emprego e facilidades locais proporcionadas pelo uso misto. Para isto, o bairro também conta com o serviço de entrega de alimentos orgânicos e supermercado.

Em uma avaliação após um ano de funcionamento do bairro, foi verificado que Bedzed apresenta 0,61 de automóveis privados por habitação. Isso mostra a redução de 32-50\% comparado com Londres e Surrey, respectivamente, alcançando as metas estabelecidas pelo plano verde de transporte, Green Transport Plan. (BIO REGIONAL, 2003).

\section{Categoria 03 - Espaço Público e Área Verde}

Em estudo comparando o Bedzed atual a um modelo de bairro convencional no mesmo lugar, verificou-se que o Bedzed utiliza $2500 \mathrm{~m}^{2}$ a menos de área de estacionamento e vias públicas destinada ao transporte motorizado. Esse valor equivale a 22,5\% da área do bairro que pode ser destinada à área verde ou qualquer outro uso. Com isso, o projeto conta com uma área de $3000 \mathrm{~m}^{2}$ por ha de espaço livre.

O projeto inclui medidas favorecendo a biodiversidade, através da presença de vegetação, com $4000 \mathrm{~m}^{2}$. A vegetação está diretamente conectada ao usuário, nas ruas arborizadas e nos sky gardens, que são jardins na cobertura das residências.

Aproximadamente $95 \%$ das árvores existentes foram mantidas.

Além das áreas verdes, para reduzir a impermeabilidade do solo, o projeto adotou pavimentos porosos em algumas áreas do condomínio.

\section{Categoria 04 - Eficiência no uso de Recursos Naturais água e energia}

O ecobairro Bedzed apresenta algumas medidas para reduzir o consumo de energia, água e resíduos sólidos. Suas principais metas com relação à eficiência no uso dos recursos naturais são: (BIO REGIONAL, 2003).

- Reduzir em 33\% o consumo de água com relação à média do Reino Unido.

- Reduzir em 33\% o consumo de energia elétrica com relação à média do Reino Unido.

- Reduzir em 90\% o consumo de energia elétrica para calefação, com relação à média do Reino Unido. 
- Reduzir em 50\% o combustível gasto pelos veículos privados.

- Eliminar as emissões de $\mathrm{CO}_{2}$ derivadas do consumo de energia elétrica

Para reduzir o consumo de energia elétrica as edificações foram desenhadas e implantadas para obter a melhor insolação de acordo com o clima local, ou seja, aproveitar a radiação solar para aquecimento no inverno e uso de proteções solares no verão, ou em horários ou locais que o sol não é desejável. Além disso, as edificações dispõem de um sistema de isolamento que dificulta a perda de calor no inverno, reduzindo o uso de energia elétrica para calefação.

Além disso, foram adotadas medidas para geração de energia renovável, incluindo biomassa (CHP) e através de painéis fotovoltaicos (PV) implantados nas coberturas. A energia solar também é usada para aquecimento de água.

Com relação ao recurso natural água, o projeto conta com sistemas reuso das águas pluviais que são coletadas através de dutos que ligam as coberturas das edificações às cisternas no subsolo. Lá elas são filtradas e armazenadas, para serem reutilizadas para a irrigação, em máquinas de lavar em bacias sanitárias.

O ecobairro também adotou um sistema de tratamento e reuso das águas cinza, que são purificadas (na estação de tratamento) através de tanques com plantas e reutilizadas na irrigação e bacias sanitárias.

\section{Categoria 05 - Diversidade Urbana e Expressão Arquitetônica}

O projeto inclui uma mistura de usos e de rendas. Com relação ao uso, BedZed conta com 82 habitações, com 271 cômodos habitáveis e, $2.500 \mathrm{~m}^{2}$ de espaços de trabalho, estúdios, e facilidades da comunidade. Sendo que dois terços das habitações são sociais, "affordable housing".

Além de todas essas características positivas, o projeto apresenta grande expressão arquitetônica e um caráter inovador, integrando tecnologia a uma estética diferenciada.

"BedZED represented state-of-the-art for sustainable housing in the UK." (BIO REGIONAL, 2003). O projeto ganhou o prêmio por excelência na RIBA's Housing Design Awards em julho de 2000, dois meses depois do início da construção. 


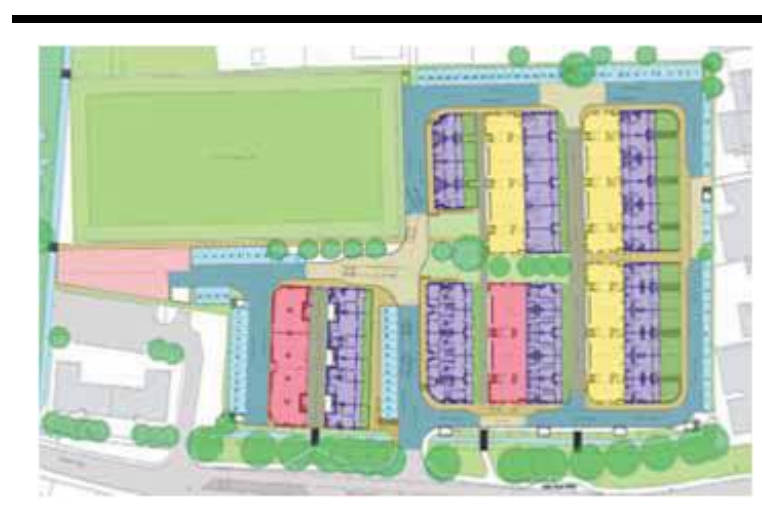

Figura 124: Planta ecobairro Bedzed

Fonte: BIO REGIONAL, 2002

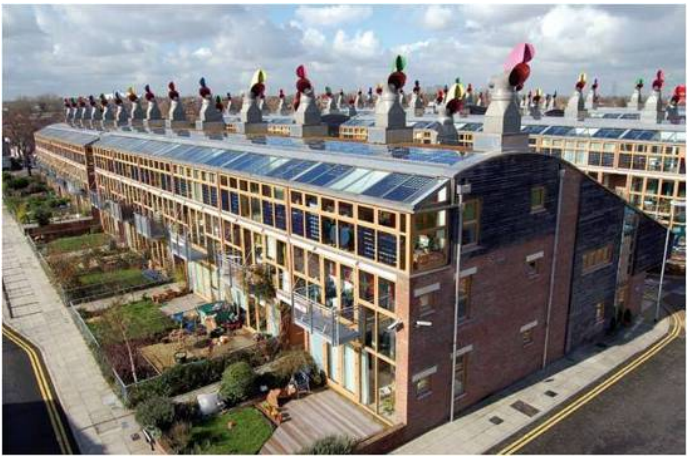

Figura 125: Foto ecobairro Bedzed

Fonte: BIO REGIONAL, 2002
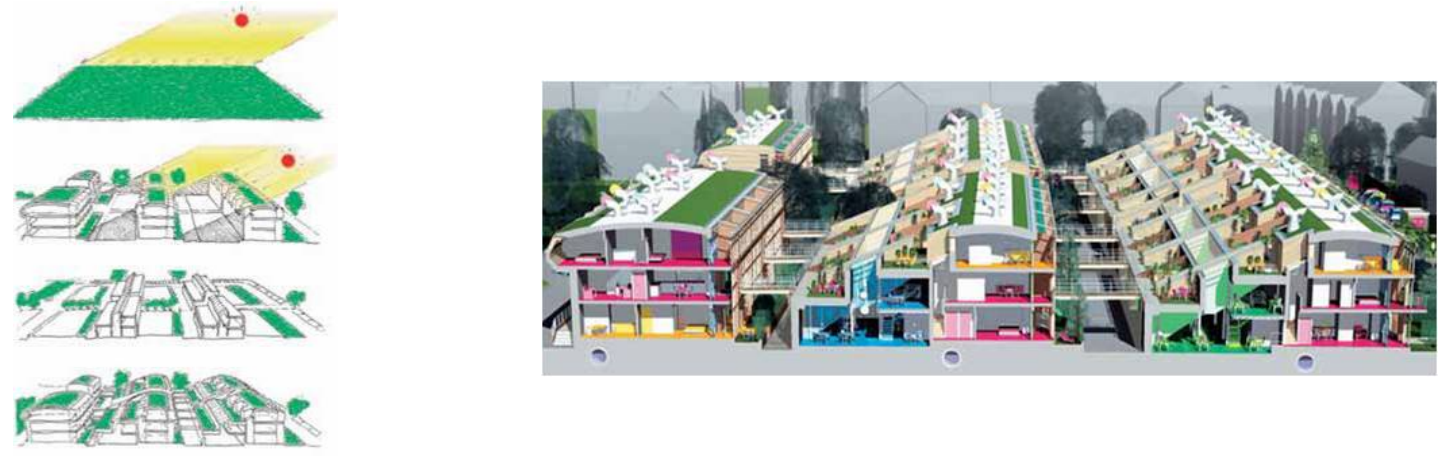

Figura 126: Estudo de insolação para definir forma e distâncias entre edificações

Figura 127: Corte dos edifícios Bedzed

Fonte: BIO REGIONAL, 2002

Fonte: BIO REGIONAL, 2002
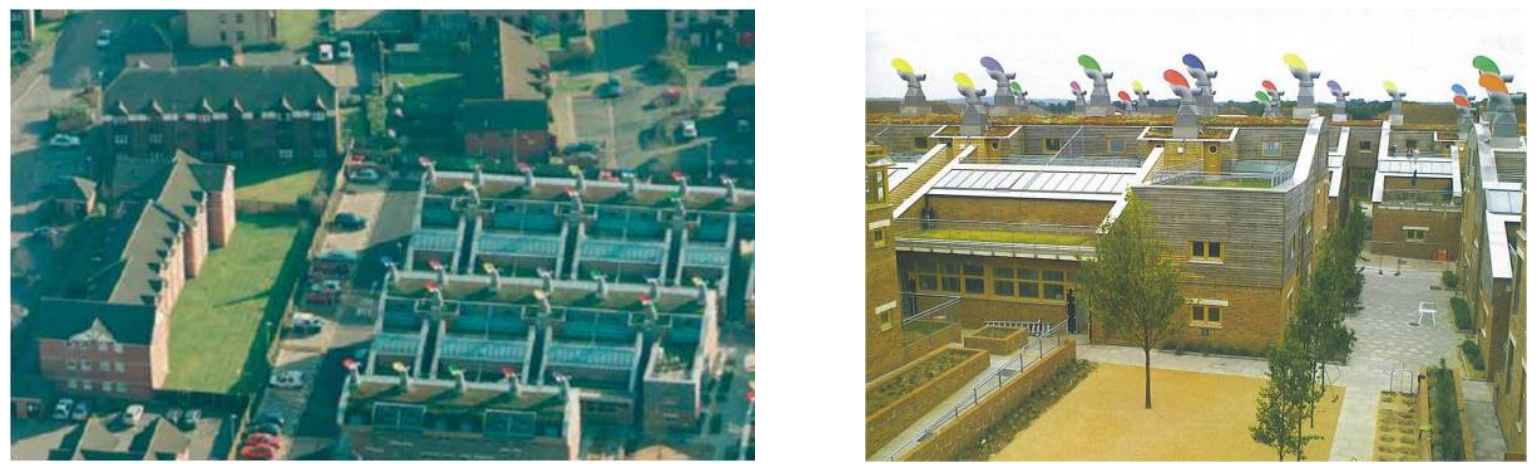

Figura 128: I magem ecobairro Bedzed

Fonte: BIO REGIONAL, 2002
Figura 129: I magem ecobairro Bedzed

Fonte: BIO REGIONAL, 2002 
ECOBAI RROS

\begin{tabular}{|c|c|c|c|c|c|c|}
\hline PROJ ETO & DIM. & LOCAL & CONST. & I MPACTO URBANO & ASPECTOS FAVORÁVEIS & ASPECTOS DESFAV. \\
\hline ECOLONIA & 5ha & $\begin{array}{l}\text { Município de } \\
\text { Alphen }\end{array}$ & Habitações & $\begin{array}{l}\text { Novo bairro em uma } \\
\text { área que tinha seu } \\
\text { subsolo contaminado }\end{array}$ & $\begin{array}{l}\text { Drenagem natural } \\
\text { Uso da energia solar para geração de } \\
\text { energia elétrica e aquecimento de água } \\
\text { Contato direto com a natureza }\end{array}$ & $\begin{array}{l}\text { Uso somente residencial } \\
\text { Localização } \\
\text { Ausência de regras }\end{array}$ \\
\hline GWL & 6 ha & $\begin{array}{l}\text { Região de } \\
\text { Van } \\
\text { Hallstraat, } \\
\text { Amsterdam }\end{array}$ & $\begin{array}{l}\text { Habitações, área } \\
\text { de comércio, } \\
\text { serviços e lazer }\end{array}$ & $\begin{array}{l}\text { Revitalização de uma } \\
\text { zona industrial obsoleta }\end{array}$ & $\begin{array}{l}\text { Eliminação de veículos motorizados } \\
\text { Projeto considerou as variáveis climáticas } \\
\text { desde a implantação } \\
\text { Drenagem natural } \\
\text { Acesso dos cidadãos as áreas verdes }\end{array}$ & Nada da destacar \\
\hline VI IKI & $\begin{array}{l}\text { 1100ha } \\
\text { conjunto } \\
\text { e 23ha } \\
\text { ecobairro }\end{array}$ & $\begin{array}{l}8 \mathrm{~km} \text { do } \\
\text { centro de } \\
\text { Helsinki }\end{array}$ & $\begin{array}{l}\text { Habitações, } \\
\text { espaço para } \\
\text { serviços sociais e } \\
\text { comerciais, Parque } \\
\text { universitário } \\
\text { Reserva natural }\end{array}$ & $\begin{array}{l}\text { Novos bairros } \\
\text { residenciais, incluindo o } \\
\text { ecobairro com caráter } \\
\text { experimental e } \\
\text { inovador }\end{array}$ & $\begin{array}{l}\text { Concurso com importância educacional } \\
\text { Projeto considerou as variáveis climáticas } \\
\text { desde a implantação } \\
\text { Drenagem natural } \\
\text { Uso da energia solar para geração de } \\
\text { energia elétrica e aquecimento de água } \\
\text { Contato direto com a natureza }\end{array}$ & $\begin{array}{l}\text { Pouca expressão } \\
\text { arquitetônica }\end{array}$ \\
\hline $\begin{array}{l}\text { SOLAR } \\
\text { CITY }\end{array}$ & 32ha & $\begin{array}{l}\text { arredores da } \\
\text { cidade de } \\
\text { Linz, Austria }\end{array}$ & $\begin{array}{l}\text { Habitações, } \\
\text { escola, parque } \\
\text { esportivo e outros } \\
\text { serviços básicos }\end{array}$ & Novo bairro residencial & $\begin{array}{l}\text { O projeto restringe o uso do automóvel e } \\
\text { privilegia o pedestre e o uso de bicicletas } \\
\text { Projeto considerou as variáveis climáticas } \\
\text { desde a implantação } \\
\text { Uso da energia solar para geração de } \\
\text { energia elétrica e aquecimento de água }\end{array}$ & $\begin{array}{l}\text { Construído em uma área } \\
\text { verde, greenfield }\end{array}$ \\
\hline BEDZED & 1,7 ha & $\begin{array}{l}\text { Wallington, } \\
\text { Surrey, } \\
\text { Londres }\end{array}$ & $\begin{array}{l}\text { Habitações, } \\
\text { Espaços de } \\
\text { trabalho, área de } \\
\text { comércio, serviços } \\
\text { e lazer }\end{array}$ & $\begin{array}{l}\text { Novo bairro residencial } \\
\text { exemplo de eco-village }\end{array}$ & $\begin{array}{l}\text { Uso do automóvel restrito } \\
\text { Incentivo a outros modos de locomoção } \\
\text { Redução do consumo de energia, água } \\
\text { Geração de energia renovável } \\
\text { Aplicação de estratégias passivas, somado } \\
\text { a uma estética interessante }\end{array}$ & $\begin{array}{l}\text { Alguns residentes } \\
\text { consideram a localização } \\
\text { um aspecto negativo, } \\
\text { porém apesar da distância } \\
\text { o bairro é servido de } \\
\text { transporte público eficiente }\end{array}$ \\
\hline
\end{tabular}




\begin{tabular}{|c|c|c|c|c|c|}
\hline \multicolumn{6}{|c|}{ ECOBAI RROS } \\
\hline $\begin{array}{c}\text { I NDI CADORES } \\
\text { SUSTENTABI LIDADE }\end{array}$ & ECOLONIA & GWL & VI IKKI & SOLAR CITY & BEDZED \\
\hline COMPACI DADE & $\mathbf{X}$ & & & & \\
\hline MOBI LIDADE & & & & & \\
\hline $\begin{array}{l}\text { ESPAÇO PÚBLICO E } \\
\text { ÁREA VERDE }\end{array}$ & & & & & \\
\hline $\begin{array}{l}\text { EFICIÊNCIA NO USO } \\
\text { DOS RECURSOS } \\
\text { NATURAIS }\end{array}$ & & & & & \\
\hline $\begin{array}{c}\text { DIVERSI DADE URBANA } \\
\text { E EXPRESSÃO } \\
\text { ARQUITETONI CA }\end{array}$ & & & & & \\
\hline
\end{tabular}




\subsection{Outras referências}

\subsubsection{Projetos escala de bairro}

Além dos projetos já apresentados e avaliados, vale citar outras intervenções urbanas que trouxeram benefícios para a cidade e que das quais pode ser extraído algum aprendizado. Para seleção desses projetos, foram adotados os mesmo critérios de busca, baseados nos seguintes fatores: localização; contexto urbano; contexto climático; escala urbana; finalidade; caráter e repercussão.

Com base nisso, foram selecionados os seguintes projetos: o projeto do Boulevar Vallecas em Madrid, Espanha (latitude $40^{\circ} \mathrm{N}$ ); o projeto da Canalização do Rio Túria em Valencia, Espanha (latitude $39^{\circ} 28^{\prime} \mathrm{N}$ ) os projetos habitacionais da I/ha de Java em Amsterdam, Holanda (latitude $52^{\circ} 22^{\prime} \mathrm{N}$ ) e de Barbican em Londres, Reino Unido (latitude $51^{\circ} 30^{\prime} \mathrm{N}$ ); o projeto de recuperação de Docklands, também em Londres (latitude $51^{\circ} 30^{\prime} \mathrm{N}$ ) e o Centro Experimental de Tecnologias Habitacionais Sustentáveis (CETHS), no Rio Grande do Sul, Brasil (latitude 29³4'S).

A configuração de espaços públicos de acordo com critérios de sustentabilidade constitui um eixo estruturador da cidade. Sendo assim selecionaram-se dois projetos de espaços públicos: o projeto do Boulevar Vallecas e a canalização do Rio Turia. O primeiro destaca-se pela experiência, pelas idéias produzidas no concurso e pela sua escala. Em escalas menores o controle dos aspectos ambientais é mais fácil, podendo criar exemplos diretos de qualidade que possam transformar em soluções de grande escala. O segundo projeto destaca-se pelo seu impacto positivo sobre a cidade, em uma área maior do que a de intervenção, apesar desse projeto ter uma escala metropolitana.

Os conjuntos residenciais Barbican e I lha de Java apresentam qualidades comuns, como: a qualidade dos espaços públicos criados entre as edificações, que possibilita a circulação de pedestres e favorece a convivência dos seus moradores; a localização em pontos estratégicos da cidade, com acesso facilitado pelo transporte público que liga ao restante da cidade e; a qualidade e expressão arquitetônica, cada um dentro do seu contexto temporal.

Com relação ao projeto de docklands, esse se destaca por não considerar alguns princípios básicos da sustentabilidade, como, por exemplo, a diversidade e a presença de 
infra-estrutura, e que por isso precisou de anos e de muitos investimentos para ser considerado um sucesso.

Por fim, o Centro Experimental de Tecnologias Habitacionais Sustentáveis é aqui abordado por ilustrar que, apesar da sua baixa densidade populacional, ele é um projeto sustentável, ou seja, a sustentabilidade urbana não está relacionada somente a modelos de ocupação compactos e densos, mas a uma série de fatores combinados.

\section{Projeto Boulevar Vallecas, Madrid}

A Comissão Européia, através do Programa Life, desenvolve algumas iniciativas pontuais, porém que apresentam resultados importantes tanto para cidade, quando para a atual discussão sobre cidades mais sustentáveis. Um exemplo disso é o concurso para um projeto de um bulevar bioclimático para o Bairro de Vallecas em Madrid.

Foi detectado que a habitabilidade nas cidades européias, sobre tudo nos bairros criados nas últimas décadas, apresenta condições generalizadas de degradação do espaço público. As causas fundamentais desta situação se concentram nos defeitos do desenho, as carências de integração nos bairros, os processos de construção da cidade sem cooperação de vizinhança e a crescente instrução dos veículos motorizados. As zonas mais problemáticas são as periferias urbanas, onde o espaço de comunicação não é mais a rua. (AYUTAMINETO DE MADRID, 2005)

Por esta razão é convocado esse concurso, tendo como tema a regeneração dos ambientes urbanos através da transformação da rede de espaços públicos da cidade em uma estrutura de conexão qualificada. (AYUTAMINETO DE MADRID, 2005)

O objetivo é levar a cabo um projeto real de espaços abertos que constitua uma experiência demonstrativa e inovadora de desenho urbano sustentável, que melhore o conforto ambiental e a qualidade da paisagem urbana, promova o intercâmbio social, o aumento da complexidade e da diversidade urbana, favoreça a circulação de pedestres e iniba o uso de automóveis, princípios fundamentais para o futuro das cidades.

A configuração de espaços públicos de acordo com critérios de sustentabilidade constitui um eixo de atuação de algumas prefeituras na Espanha. Em Madrid, o concurso não se trata de uma iniciativa isolada, a inserção de um bulevar bioclimático em um planejamento estratégico, "Eco Valle", pretende abordar dentro da região de Vallecas a questão da sustentabilidade urbana a distintos níveis, junto com outras ações 
demonstrativas, como a quadra bioclimática, "Sunrise". (AYUTAMINETO DE MADRID, 2005)

Para esse concurso foram convidados oito escritórios de arquitetura, sendo a proposta apresentada pelo escritório Ecosistema Urbano a vencedora.

Segundo o arquiteto José M. Torres Nadal, ao convocar o concurso e reunir um grupo de arquitetos para trabalhar em cima de uma mesma área, a prefeitura cria a possibilidade de desenvolver projetos para uma parte da cidade. Além disso, um novo espaço é um laboratório.

O traçado de vias urbanas em bulevar é uma boa solução, pois une o traçado de uma grande seção viária a incorporação de uma vegetação significativa, a instalação de atividades diversificadas e passeios para o trânsito de pedestres.

A maioria dos projetos utilizou materiais reciclados, energias alternativas e climatização por sistemas passivos, otimizando o uso dos recursos naturais para criar um espaço de convivência e valor social para a cidade.

As realizações de projeto piloto de caráter inovador podem servir como modelo para outras cidades. Pequenas intervenções podem ser mais fáceis de controlar os aspectos ambientais, mas ao mesmo tempo criar exemplos diretos de qualidade que possam transformar em soluções de grande escala, discutindo fórmulas de polarização desde pequenas dimensões que possam gerar uma experiência reaplicável.

\section{Canalização do Rio Túria, Valencia}

Outro projeto que merece ser destacados pelos benefícios ambientais e sociais que trouxe para a cidade de Valencia, foi a canalização do rio Túria e a criação de um parque urbano linear que atravessa a cidade de oeste a leste, ligando o centro histórico ao mar Mediterrâneo, passando pela contemporânea e monumental Cidade das Artes.

Após as enchentes sofridas em Valencia no ano de 1957, foi planejada uma maneira de acabar definitivamente com as inundações do rio Túria. Para isso foi adotado uma solução de desviar o rio pelo sul da cidade através de um novo leito.

O antigo leito foi requalificado com zona verde e se transformado em um dos elementos estruturantes de maior presença na cidade de Valencia. 
O Projeto foi inaugurado em 1986 e abrange uma área de 110 hectares. A recuperação do rio Túria combina o traçado público e privado, com parque e zonas de usos recreativos, com interessantes soluções formais e funcionais.

No projeto estão presentes características dos espaços livres e das zonas verdes que contribuem para a sustentabilidade da cidade, tais como: hierarquia dos espaços livres com diversidade de ambientes e funções; estratégias necessárias para conseguir o conforto nos espaços abertos, no caso, por exemplo, o sombreamento, a presença de água e o uso de muita vegetação, para amenizar as altas temperaturas e as baixas umidades do ar durante as estações de verão; contribuição para o aumento da biodiversidade; otimização das necessidades hídricas das zonas verdes; elemento estruturante da cidade e fácil acesso aos cidadãos.

A canalização do rio Túria é um exemplo claro de como uma intervenção visando aspectos ambientais pode trazer benefícios sociais e econômicos diretos para as áreas próximas ao parque construído.

\section{Ilha de Java, Amsterdam}

Ilha de Java, situada em Amsterdam é uma península construída em 1900, onde chegavam os navios. Antiga área industrial que foi revitalizada e transformada em uma área residencial, com cerca de 1300 habitações.

O projeto urbano, "masterplan", realizado de 1991 a 2000, foi desenvolvido pelo arquiteto holandês Sjoerd Soeters que implantou as residências dos dois lados da ilha (perímetro) e no seu interior foi construído áreas verdes, formando espaços públicos para seus residentes.

Além disso, o projeto tirou partido dos quatro canais que atravessam a ilha, com a construção de pontes e residência dos dois lados do canal.

O programa é constituído de 1300 residências, 1300 vagas de estacionamento, $2.400 \mathrm{~m} 2$ de área comercial. Existem áreas específicas para estacionar o automóvel, no cinturão externo ao conjunto, não necessitando percorrer com ele dentro do perímetro residencial.

As unidades habitacionais possuem programas independentes e foram projetadas por diferentes arquitetos, resultado em uma diversidade arquitetônica que se repete em módulos pelo complexo. 
Vale destacar três aspectos positivos do projeto. O primeiro em relação a sua alta densidade habitacional, resolvida de maneira que não compromete a qualidade ambiental, criando um conjunto de grande expressão arquitetônica

O segundo ponto positivo é a proximidade da ilha em relação ao centro urbano e o seu fácil acesso, que permite que mesmo sendo uma área predominantemente residencial, não cause tantos problemas de deslocamento de pessoas.

E por fim, é importante mencionar a qualidade dos espaços públicos criados entre as edificações, que possibilita a circulação de pedestres e favorece a convivência dos seus moradores.

\section{Barbican, Londres}

Conjunto predominantemente residencial projetado por Chamberlin, Powell e Bon no final da década de 50, e construído nos anos de 1964 a 1982. Mesmo não sendo um projeto contemporâneo o conjunto Barbican pode ser considerado com referência se for observado os seguintes pontos: localização e acesso, diversidade de uso e de tipologias, qualidade arquitetônica das edificações e dos espaços de lazer.

O conjunto Barbican está localizado em uma área privilegiada de Londres, próximo aos centros de comércio e empresarial da cidade. Além disso, existe uma estação de metro junto a uma das saídas do conjunto, que permite o acesso rápido a quase toda cidade.

A densidade habitacional do conjunto é de 230 pessoas/ha e para cada 1000 habitantes foi criado 1,5 hectares de espaço livre. Sendo assim, é possível verificar que apesar de bastante denso, o conjunto dispõe de bastante área de lazer para seus residentes, assim como para seus visitantes.

O complexo é constituído uma área habitacional, com diferentes tipologias, desde edifícios altos de três a quatro dormitórios, a edifícios baixos de dois pavimentos, para estudantes. Além disso, o conjunto dispõe de edifícios comerciais e equipamentos de lazer, como museu, teatro e restaurante. Parte significativa dos equipamentos de lazer está voltada a arte e cultura, além da faculdade de arte ali instalada.

Figueroa (2006) classifica o projeto como uma mega-estrutura, um experimento embasado na revisão dos princípios da cultura moderna, aliada as distintas tendências 
arquitetônicas surgidas nos paises industrializados e a um otimismo perante as novas possibilidades tecnológicas. O autor ainda comenta:

"Através de uma descomunal exaltação estrutural e tecnológica que se sobrepunha ao ambiente urbano existente as mega-estruturas geravam uma topografia artificial que comportariam as mais distintas atividades necessárias para uma metrópole. Esta paisagem artificial deveria ser de múltiplos níveis gerando um sólido tridimensional. Esta nova escala dimensional acreditava-se poder recuperar uma maior liberdade $e$ oferecer utopias alternativas ao caos urbano." (FIGUEROA, 2006, p. 4).

Apesar de todas essas preocupações ambientais, é questionável a distribuição da vegetação pelo conjunto, assim como o conforto nos espaços e no interior das habitações.

Segundo informações do site do conjunto ${ }^{97}$, em 1963, quando estavam sendo construídas as edificações, verificou-se que muitas cozinhas e banhos das residências não dispunham de janela e nem de ventilação.

Além disso, foi verificada a criação de corredores de vento no conjunto que, em decorrência da ausência de barreiras, podem causar um desconforto durante os meses de clima frio.

Mesmo assim, Barbican continua sendo uma referência de conjunto habitacional que contribui para resolver alguns dos problemas das cidades contemporâneas. Resultado de outra época, o conjunto Barbican que está resistindo a mudanças urbanas e continuam sendo um sucesso sócio econômico.

\section{London Docklands, Londres}

A região das docas de Londres começou a se desenvolver a partir do século XVIII e chegou a ser o maior porto do mundo no século XIX. A partir de 1960 o Porto foi perdendo a sua importância e em 1980 acabou fechando, em decorrência do processo de continerização dos portos, de legislação ambiental restritiva e da construção do porto de Tilbury a 40 quilômetros dali. Isto implicou na perda de 100 mil empregos e de 10 a $20 \%$ da população local. (NOBRE, 2006)

\footnotetext{
${ }^{97}$ http://www.barbicanliving.co.uk/h6g.html
} 
Em julho de 1981 se estabeleceu a London Docklands Developmet Corporation (L.D.D.C.) com caráter de órgão diretor das Docklands Urban Development área. E no ano seguinte foi estipulada a $\mathrm{EZ}^{98}$ (Zonas de Empreendimento) dentro dos seus limites.

Durante os anos 80 e 90 as Docklands se contemplaram como uma área de máxima oportunidade, que segundo Enguita (2008, p149) existia um quase completo vazio econômico, que deveria ocupar-se por áreas de atividades com potencial de crescimento para o futuro.

Segundo uma avaliação estatística, realizada na metade do ano de 1985, a superfície total de solo afetada pelo projeto de regeneração atendia a 561,6 hectares e a superfície de água, 170 hectares. (ENGUITA, 2008, p150)

A área apresentava uma decadência física e a necessidade urgente de uma regeneração. A área do projeto localiza-se a leste da City, centro financeiro de Londres, estendendo-se por 15 quilômetros do rio Thames, podendo ser dividida em três regiões: a oeste, Surrey Docks, Wapping \& Limehouse; ao cento, Isle of Dogs (Ilha dos Cães) e a leste, Royal Docks.

Consciente da escala e importância dos Royals, a L.D.D.C. requisitou a colaboração dos arquitetos e urbanistas Richard Rogers \& Partners e William Gillespie \& Partners, que propuseram um grande complexo multiuso high-tech, com centro empresarial, conjuntos residenciais, galeria de arte, marinas, etc. Tudo ao redor do novo Aeroporto de Londres, London City Airport, um projeto impulsor para a zona.

Essa zona pretendia ser um dos maiores centros de comunicação do mundo e tecnologicamente mais avançado, contando com uma ampla variedade de equipamentos, serviços e infra-estrutura que atendem a seus usuários no século XXI.

\footnotetext{
98 Durante o governo Thatcher a política urbana inglesa sofreu algumas reformulações. Em uma dessas foi criada a EZs, Zonas de Empreendimento, que significa: "áreas urbanas decadentes nas quais existem incentivos para a instalação de determinados tipos de empreendimentos através da isenção de impostos e da não necessidade de alvará de construção." (NOBRE, 2006). Na mesma época criou-se as "Corporações de Desenvolvimento Urbano que são companhias criadas para desapropriar áreas decadentes, destruir construções existentes, instalar infra-estruturas e vender as terras a privados." (NOBRE, 2006)
} 
Em Limehouse foi realizada a reutilização do edifício Free Trade Warf, construído pelas Companhias das índias orientais em 1795, para comércio, escritórios, bares, restaurantes e habitações. E Wapping foi a área elegida para o primeiro translado as Docklands das grandes empresas de jornais.

A ilha dos Cães é onde se encontra a maior parte da Zona de Empreendimento. No apogeu do porto, a ilha concentrava as Companhias das Índias Ocidentais e Orientais. Atualmente, os incentivos atraem a implantação de importantes atividades econômicas, distribuídas nos edifícios altos.

Durante os anos 80 era muito comum as empresas que investiam em novos projetos, buscarem recuperar seus investimentos em apenas quatro anos. Sendo assim, para atender uma demanda comercial imediata e direcionada ao mercado, as intervenções urbanas geraram complexos urbanos monofuncionais.

No caso de Docklands, o projeto não era totalmente monofuncional, mas o grande objetivo era transformar a área em um novo pólo comercial de Londres. Os usos previstos se dividem do seguinte modo: residencial 155,6 ha, indústria e comércio 317,6 ha e espaços ambientais e comunitários 88,4 ha. (ENGUITA, 2008, p150)

O resultado foi uma abundância de edifícios comerciais e de escritórios que durante 20 anos, ficou mais de $50 \%$ vazio. Isto se deve, em parte, ao esfriamento do mercado imobiliário de escritórios, decorrente da quebra da bolsa de Nova Iorque em 1987, reduzindo os empregos no setor financeiro e a falta de infra-estrutura da área.

Segundo Nobre (2006) o tamanho dos empreendimentos que ocorreram na Ilha dos Cães foi maior que o previsto, e o transporte público entrou em colapso, pois a região já apresentava problemas de acessibilidade a priori.

O dinheiro que governo gastou indiretamente para encorajar esse empreendimento, com isenções de impostos e ainda os custos com infra-estrutura, transformou esta intervenção em um fracasso durante muitos anos.

Esta experiência foi muito criticada também por ser um exemplo da sujeição do planejamento ao ideário neoliberal, criando "ilhas" de privilégio que tiram proveito das novas localizações valorizadas, ignorando a provisão de serviços sociais e habitação popular. (SOMEKH, \& CAMPOS, 2005). 
Sem dúvida, a regeneração das Docklands, somada a revitalização das zonas circundantes, impulsionada pelas melhorias no transporte público, produziram uma conseqüente elevação dos preços das habitações da região. As intervenções realizadas na região das docas agravaram os problemas sociais da população local, aumentando o desemprego e "expulsando" a população local, devido ao processo de especulação imobiliária (NOBRE, 2006).

Por essas razões, a intervenção nas docas da ilha dos cães é um projeto polêmico. Porém, atualmente o empreendimento se tornou um sucesso, na hora em que foi investido em infra-estrutura e o transporte público chegou até a área com a construção de duas estações de metro.

Durante os últimos 20 anos, a população das Docklands mais que dobrou, e a área se converteu em um centro de negócios de grande importância, da mesma forma, que se tornou uma zona para viver com qualidade crescente.

Canary Warf se tornou um dos maiores pólos de concentração de edifícios altos a escala européia.

Analisando esse projeto verifica-se a importância da diversidade de usos e, principalmente, da preocupação com a questão habitacional. Além disso, a presença de infra-estrutura já existente e consolidada é fundamental para o sucesso e justificativa da intervenção.

Outro ponto que merece destacar é que muitas intervenções necessitam de um tempo para acontecerem. Analisando esta intervenção a curto prazo, ela merece todas as críticas que recebeu, porém a longo prazo, esse projeto transformou uma área deteriorada em um novo pólo comercial, provida de espaços públicos de qualidade, que permitem a circulação de pedestres e a convivência de seus usuários.

CETHS (Centro Experimental de Tecnologias Habitacionais Sustentáveis), Rio Grande do Sul

Desde a crise ao petróleo, em 1970 o Brasil já vem tendo consciência das conseqüências geradas pela construção de uma arquitetura desvinculada com o meio ambiente. Atualmente já existem iniciativas, mesmo que poucas, em inserir os princípios da sustentabilidade em projetos de edificações e em projetos urbanos, principalmente por 
parte de instituições acadêmicas e organizações de assentamentos sustentáveis no âmbito rural.

Como exemplo vale destacar a proposta do Centro Experimental de Tecnologias Habitacionais Sustentáveis (CETHS), inserido no Núcleo Orientado para Inovação da Edificação (NORIE) da UFRGS (Universidade Federal do Rio Grande do Sul), coordenado pelo Prof. Sattler. ${ }^{99}$

O centro desenvolve pesquisa na área da sustentabilidade relacionada às habitações para populações de baixa renda.

A idéia é construir um espaço de demonstração e divulgação de tecnologias sustentáveis. Para isso, em 2000, foi desenvolvido um projeto para prefeitura de Nova Hartz, região metropolitana de Porto Alegre.

O projeto consta na implantação de um assentamento popular de baixo impacto ambiental, aplicando alguns princípios e tecnologias sustentáveis como: adequação ao clima; o uso de energias alternativas, energia eólica e biogás; o uso de materiais de baixo impacto ambiental; gestão da água e de resíduos sólidos; e tratamento das águas negras. Além dessas, o projeto apresentava características específicas das ecovilas como: preocupação com as questões sociais e educacionais; produção local de alimentos; e o uso de paisagismo produtivo (ANDRADE, 2005 e SATTLER, 2007).

Andrade descreve o projeto:

"O desenho urbano da área de demonstração procurou modificar a relação entre os elementos que compõem a paisagem urbana na gleba, transformando a rua em um lugar de convívio comunitário integrado. As vias estreitas sinuosas em um só sentido não possibilitam o tráfego rápido, valorizando os pedestres por meio de bolsões com vegetação e mobiliário urbano que configurem lugar de estar.

\footnotetext{
${ }^{99}$ Informações detalhadas sobre esse projeto de outras pesquisas do grupo NORIE: Sattler, Miguel Aloysio. Habitações de baixo custo mais sustentáveis: a casa Alvorada e o Centro Experimental de tecnologias habitacionais sustentáveis. Porto Alegre: ANTAC, 2007. Coleção Habitare, 8. Disponível em <www.habitare.com.br> Acesso em: junho de 2010.
} 
O protótipo da habitação teve como diretrizes gerais a funcionalidade, o uso de matérias sustentáveis, a adoção de princípios bioclimáticos, a habitabilidade adequada, a auto-construção por meio de tecnologias adequadas, os espaços para atividades geradoras de renda e as possibilidades para futuras ampliações $e$ remanejamento de espaços. "(ANDRADE, 2005, p. 52)

É importante destacar que esse projeto é muito mais sustentável pelo seu caráter "/ow ted", já que ele pensado para uma baixa densidade populacional, decorrente principalmente da sua localização em regiões periféricas. Nesse caso, esta seria uma solução para essas áreas, que devem apresentar uma densidade mais baixa devida a deficiência ou ausência de infra-estrutura, além de buscar a auto-sustentabilidade dessas comunidades.
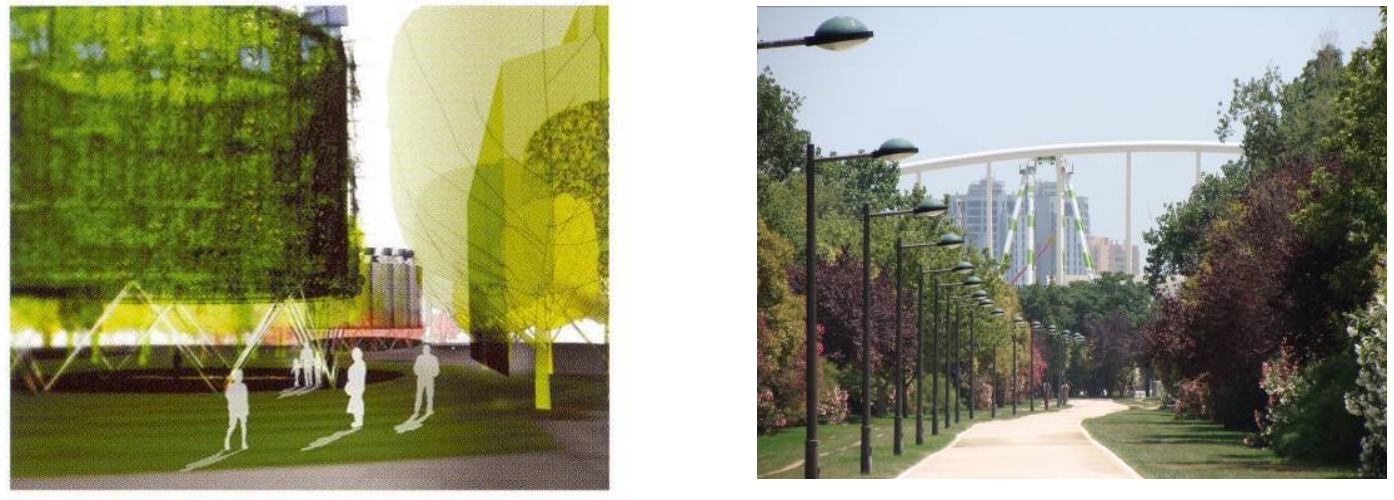

\section{Figura 130: I magem projeto Bulevar Figura 131: I magem projeto canalização Vallecas do rio Túria}

Fonte: Google

Fonte: Foto da autora

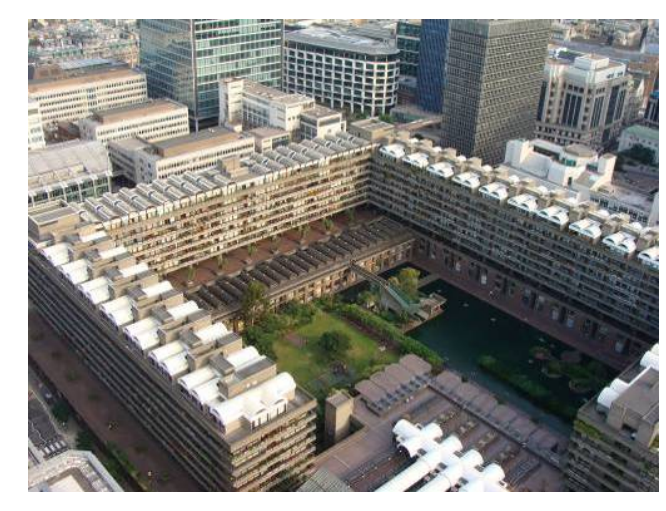

Figura 132: I magem projeto Barbican Fonte: Foto da autora

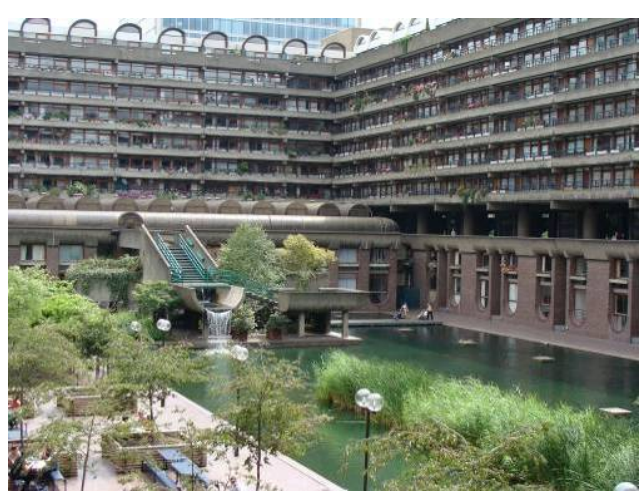

Figura 133: I magem projeto Barbican

Fonte: Foto da autora 


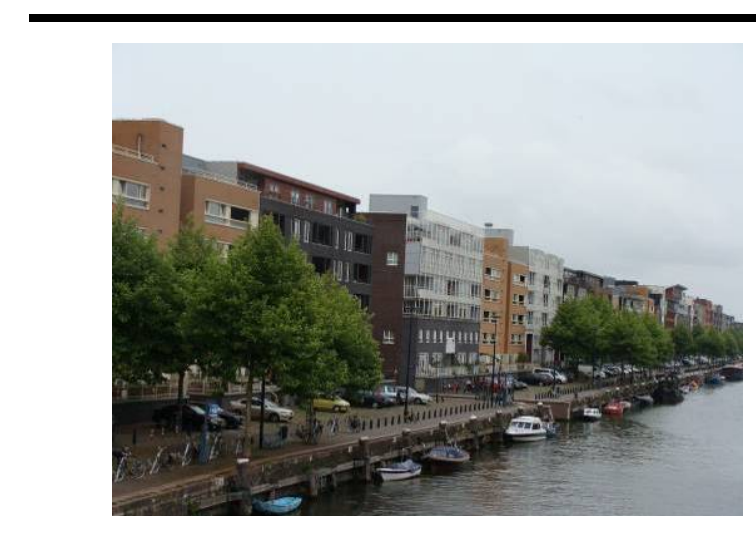

Figura 134: I magem I lha de J ava

Fonte: Foto da autora

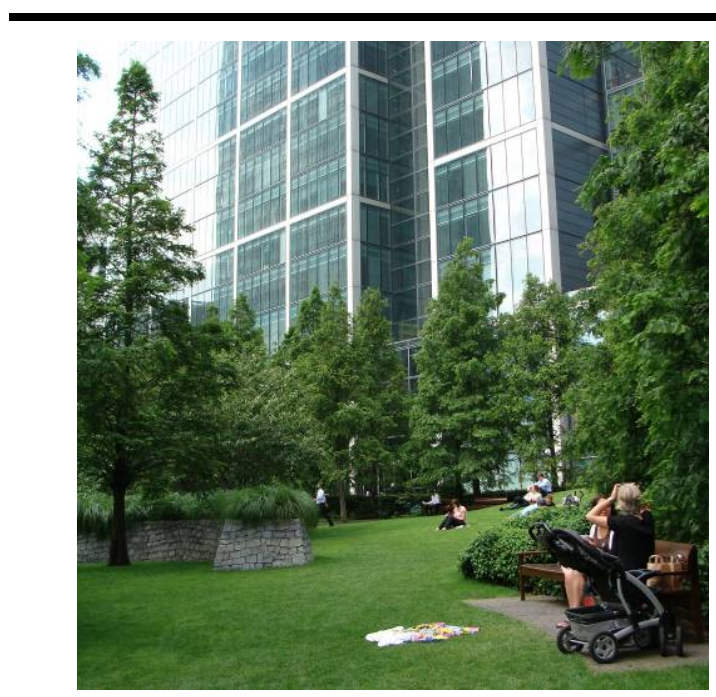

Figura 136: I magem Docklands

Fonte: Foto da autora

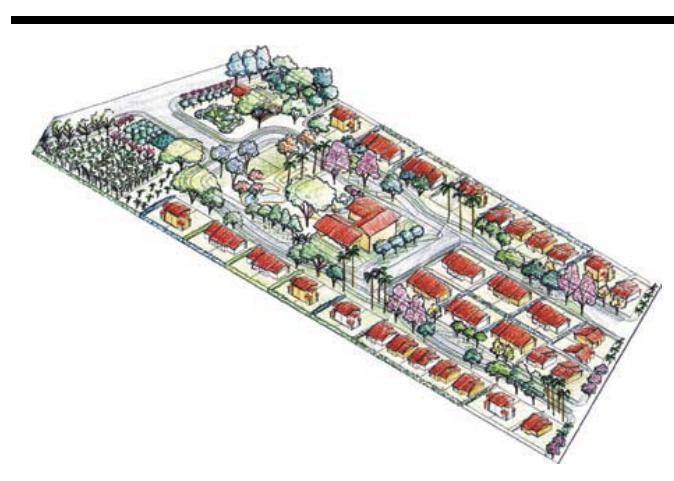

Figura 138: I magem CETHS

Fonte: SATTLER, 2007

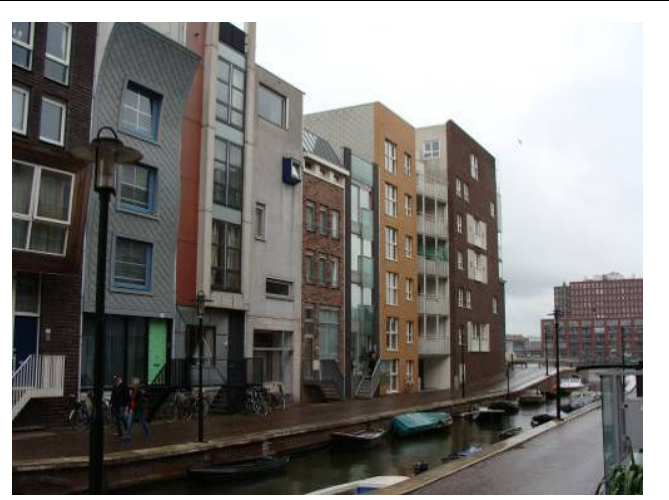

Figura 135: I magem I Iha de J ava

Fonte: Foto da autora

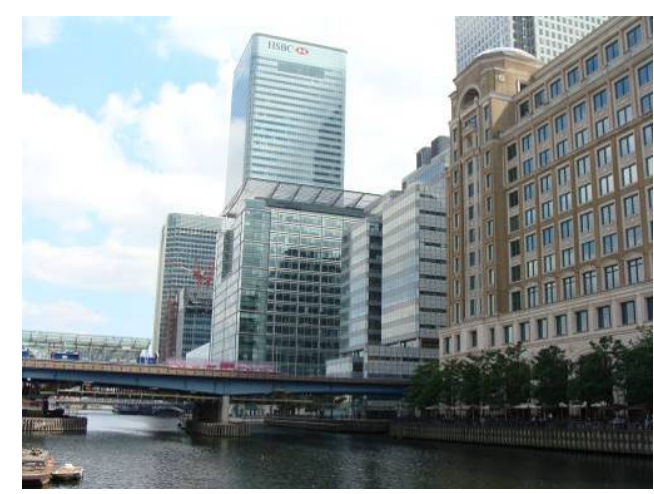

Figura 137: I magem Docklands

Fonte: Foto da autora

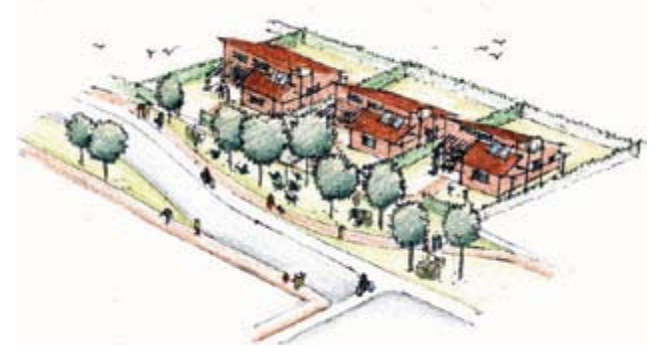

Figura 139: I magem CETHS

Fonte: SATTLER, 2007 


\subsubsection{Projetos Escala de Cidades: Ecotowns???}

Além dos ecobairros, atualmente surgiram projetos de novas cidades com base, principalmente, nos princípios da eficiência energética. Para avaliar melhor o funcionamento e desempenho ambiental dessas cidades, seria necessário um estudo mais detalhado com simulações ou estudos em maquetes, já que nenhuma delas está totalmente construída e algumas nem serão. Porém vale comentar sobre suas principais teorias e apresentar algumas imagens, já que atualmente esses projetos estão sendo consideradas referências de "ecotowns". Entre estas se destacam: Sociópolis em Valencia, latitude $39^{\circ} 28^{\prime} \mathrm{N}$; Dongtan, próximo de Shangai, China, latitude $31^{\circ} 31^{\prime} \mathrm{N}$ e; Masdar nos Emirados Árabes, latitude $24^{\circ} 26^{\prime} \mathrm{N}$.

A importância em abordar sobre o projeto Sociópolis está na sua preocupação em atender a uma demanda habitacional e mais que isso, pelo caráter inovador do projeto, gerando um resultado teórico muito criativo e positivo, servindo de inspiração e referência para experiências futuras.

Com relação às cidades de Dongtan e Masdar, dois aspectos foram fundamentais para sua seleção: a localização, em greenfields e no meio do deserto, respectivamente e por esses serem projetos polêmicos que vêm mobilizando renomeados escritórios internacionais de arquitetura e de engenharia.

\section{Sociópolis, Valencia, Espanha}

Esse é um projeto recente para uma área do Município de Valência, Espanha, que apresenta como objetivo principal conectar comunidades sociais e arquitetura experimental.

O projeto consiste em 2.800 habitações sociais impulsionadas pela Generalitat Valenciana e a Prefeitura de Valencia, localizadas ao sul da cidade de Valencia, entorno do novo leiro do rio Túria, em uma área de 35 hectares. 0 projeto apresenta a importante contribuição de um grande espaço verde central pensado como uma horta, espaço de relação, de ócio e produtivo (HIGUERAS, 2009).

O projeto apresenta uma densidade de 75 habitações/hectares, de uso predominantemente residencial, disposta em edifícios torre e lâminas, em blocos abertos. Os edifícios propostos estão orientados para a zona verde central que tem uma superfície 
de 12 hectares sendo acessíveis desde um circuito de tráfico perimetral que rodeia 0 complexo.

A idéia era promover um novo conceito de habitação baseado não somente na funcionalidade, mas também na mudança.

Sociópolis envolveu vários arquitetos internacionais, de maneira que o plano urbanístico foi desenvolvido pelo coordenador do projeto Vicente Guallart que dividiu a área em 13 partes, entregando cada uma delas a um grupo de arquitetos. Cada grupo tinha a liberdade de criar em cima de um programa definido, respondendo aos aspectos de integração social, aspectos tecnológicos e ligação com a natureza.

O resultado teórico desse projeto foi sem dúvida muito criativo e inovador, o que é positivo para arquitetura e o desenho urbano, porém percebe-se uma ausência de critérios, que na prática pode comprometer a qualidade ambiental urbana e o desempenho das edificações.

O agravante é que esse projeto sem critérios definidos está se tornando referência internacional, causado talvez, pela carência de exemplos concretos em um momento em que as cidades de uma maneira global necessitam visivelmente de soluções de planejamento, desenho urbano e arquitetura para a sua sustentabilidade.

\section{Dongtan, China}

O projeto da cidade de Dongtan foi desenvolvido pelo escritório Over Arup, tendo como cliente a Shanghai Industrial Investment Corporate (SIIC). Dongtan está localizada na ilha de Chongming, rodeada pelo rio Yangtze. A ilha de Chongming é a terceira maior ilha da china, com uma área de aproximadamente 8.600 hectares. O projeto prevê a utilização de um terço dessa área para o desenvolvimento de Dongtan, sendo o restante utilizado para agricultura.

O projeto consiste em uma cidade com crescimento populacional controlado, sendo previsto até 2010, 10 mil habitantes e para 2040, 500 mil habitantes. Douglas McGray comenta em seu artigo sobre Dongtan da necessidade de adensar a cidade e completa:

"Dongtan needed more people. Way more. But how many more people? Double? Triple? The team found research on energy consumption in cities around the world, plotted on a curve according to population density. Up to about 50 residents per acre, roughly equivalent to Stockholm or Copenhagen, per capita energy use falls fast. 
People walk and bike more, public transit makes economic sense, and there are ways to make heating and cooling more efficient. But then the curve flattens out. Pack in 120 people per acre, like Singapore, or 300 people, like Hong Kong, and the energy savings are negligible. Dongtan, the team decided, should try to hit that sweet spot around Stockholm."(DOUGLAS, 2007).

Apesar disso, Dongtan está sendo construída para uma densidade e uma compacidade relativamente baixa, sendo constituída por residências unifamiliares de três pavimentos.

O plano diretor divide Dongtan em cinco principais zonas:

(1) Zona Norte, reservada para desenvolvimento de agricultura ecológica e para a construção de parques e estádios;

(2) Zona Central, onde está situado o Chong Ming National Forest Park com $3.55 \mathrm{~km}^{2}$, o maior parque existente em Shangai, com centros de visita e recreação. Expansão da área de vegetação de $16 \%$ para 55\% até 2020 ;

(3) Zona Oeste, onde está situado o Lago Ecológico Mingzhu, na qual prevê um Centro Internacional de Exposições;

(4) Zona Sul, será implantada a área industrial e a residencial, com os demais serviços necessários. Essa zona está separada em três vilas, conectadas por ciclovias, e caminhos de pedestres.

(5) Zona Leste, destinada ao turismo ecológico, Dongtan wetlands;

O objetivo principal é criar uma cidade de baixo consumo energético e que não emita $\mathrm{CO}_{2}$, se possível. Para isso, o projeto conta com a produção de energias renováveis, como a energia eólica e a energia solar, além a energia elétrica gerada a partir dos dejetos agrícolas (casca de arroz).

Além do baixo consumo de energia e, conseqüente redução de emissão de $\mathrm{CO}_{2}$, o projeto apresenta outros princípios da sustentabilidade ambiental urbana como: uso de meios de locomoção mais sustentáveis, com a adoção de veículos de hidrogênio e mini-automóveis compartidos e a possibilidade do deslocamento a pé ou de bicicleta; diversidade de usos; eficiência no uso do recurso natural água, através do reuso; reciclagem de $90 \%$ do seu lixo; desenho bioclimático do conjunto, presença de vegetação em todo o conjunto, por 
meio de pequenos parques e corredores verdes na área urbana, e um parque principal na área central, além da adoção de coberturas, verdes.

Apesar de todas essas características positivas para a sustentabilidade da cidade, o projeto apresenta uma densidade e uma compacidade baixa, tendo seu projeto dirigido a usuários com alto poder aquisitivo.

Sobre a sustentabilidade de Dongtan Rogers (2001) ainda comenta:

"Cidades como Shenzhen, Dongguan e Zhuhai estão destruindo grandes extensões de área rural, seja para o fornecimento de materiais de construção, seja para pavimentar o caminho do desenvolvimento futuro.

A urbanização é a primeira fase na transformação de uma sociedade rural comunal para uma sociedade de consumo. As novas cidades chinesas estão sendo planejadas em torno de estradas, e não de sistemas de transporte de massa." (ROGERS, 2001, P.41).

\section{Madsar, Emirados Árabe}

Projeto de uma nova cidade para 50.000 mil habitantes, localizada a 17 quilômetros de Abu Dhabi, encomendado pela Masdar-Abu Dhabi Future Energy Company, Mubadala Development Company ao escritório Norman Fostes and Partners.

O principal objetivo é ser um dos mais sustentáveis assentamentos urbanos, apoiado na energia renovável como a energia solar, eólica e a gerada por usina de hidrogênio.

Segundo o marketing urbano a cidade foi projetada para emissão zero de carbono e resíduos. Além disso, o projeto tem como meta:

- Ausência de automóveis;

- $100 \%$ da energia fornecida deve vir de fontes renováveis;

- Sem emissão de carbono, o transporte da cidade será inteiramente público;

- Utilização de materiais recicláveis e/ou materiais certificados;

- Os esforços sobre a conservação de água na cidade envolvem os planos de reuso de pelo menos $80 \%$ da água utilizada. Por meio desses processos, os planejadores da cidade esperam reduzir o consumo de água em $60 \%$.

- Investimentos na qualidade de vida e eventos para todos os tipos de habitantes.Desenho de uma cidade murada medieval que cresce em densidade e 
concentra distâncias de maneira que nenhum ponto fica a mais de 200 metros de alguma conexão de transporte público, em caminhos sombreados.

As edificações foram projetadas de forma a reduzir a necessidade do consumo de energia elétrica com luz artificial e condicionamento artificial. Os edifícios estão implantados com uma proximidade tal que permitam criar sombras uns sobre os outros como forma de diminuir o ganho de calor por radiação solar, que somado às altas temperaturas do deserto pode causar grande desconforto e a necessidade do uso de equipamentos de ar condicionado.

Além disso, a cidade foi implantada no sentido nordeste-sudoestes, de forma a aproveitar a brisa noturna e se proteger dos ventos quentes diurnos.

Inspirado na arquitetura e no planejamento urbano da tradicional cidade Arab, Masdar incorpora ruas corredores, proteções solares inércia térmica elevada, presença de jardins internos, torres de vento e uso da vegetação para sombreamento e para direcionar o vento. O projeto de Masdar sem dúvida alguma se destaca pela sua adequação ao clima local, classificado como desértico.

Com relação à mobilidade, um trem elétrico com trilhos elevados garantirá o transporte fácil entre Masdar City e Abu Dhabi. Sendo a cidade de Masdar uma cidade livre de carros, localizam-se os estacionamentos na periferia da cidade, o que faz com que as pessoas desloquem-se à pé ou através de veículos que funcionam sobre trilhos magnéticos utilizando energia elétrica, equipados por eficientes sistemas de buscas.

Profissionais atuantes na área de projeto reconhecem ser mais fácil construir esses novos tipos de empreendimentos, ditos sustentáveis, em cidades que ainda possuem grandes terrenos vazios e que se submetem a governos não democráticos, nos quais os projetos são impostos e, portanto, rapidamente construídos. Ao contrário, em cidades como Londres e Frankfurt, um empreendimento como o Masdar levaria muito tempo para ser discutido e dificilmente seria implantado (UMAKOSHI, 2008).

Esse projeto ganhou alguns prêmios, entre eles: "The first World Clean Energy Award" em 2007 da Transatlantic 21 Association, em Basel, Suiça e; foi eleito "Sustainable Region / City of the Year" pela Euromoney and Ernst \& Young's Global Renewable Energy Awards.

Mesmo com todas essas metas e preocupações ambientais que orientaram o projeto, é questionável a sustentabilidade da construção de Masdar, visto que ela foi implantada no 
meio de um deserto, em uma área desprovida de qualquer infra-estrutura, gerando alto custo econômico e ambiental. Além disso, não está clara a real necessidade da construção desta cidade, assim como a parcela da população a qual ela visa atrair.

Enfim, deve-se ter muita atenção e visão crítica ao considerar qualquer um desses três projetos como referências de ecotowns, pois apesar de todos incorporarem princípios da sustentabilidade ambiental urbana, principalmente com relação à eficiência no uso dos recursos naturais, água e energia, elas parecem mais utópicas que reais. Ou seja, no caso de Dongtan e Masdar, principalmente teve-se uma preocupação maior em criar um ícone através do uso de tecnologias, a qualquer custo, do que abordar problemas de crescimento, espalhamento, adensamento e impacto ambiental de aglomerados urbanos existentes e em processos dinâmicos de transformação. 


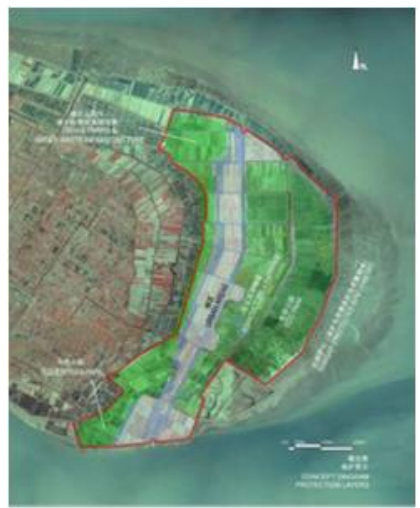

Figura 140: Projeto Dongtan

Fonte: Google

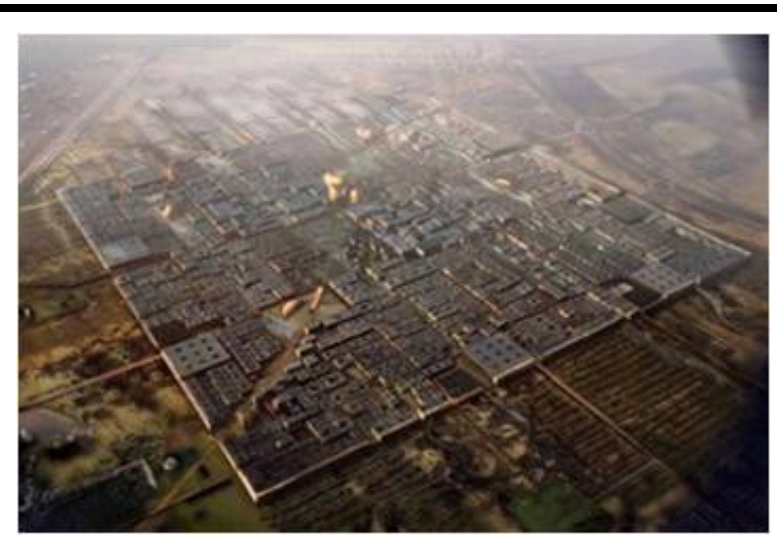

Figura 142: Projeto Masdar

Fonte: Google

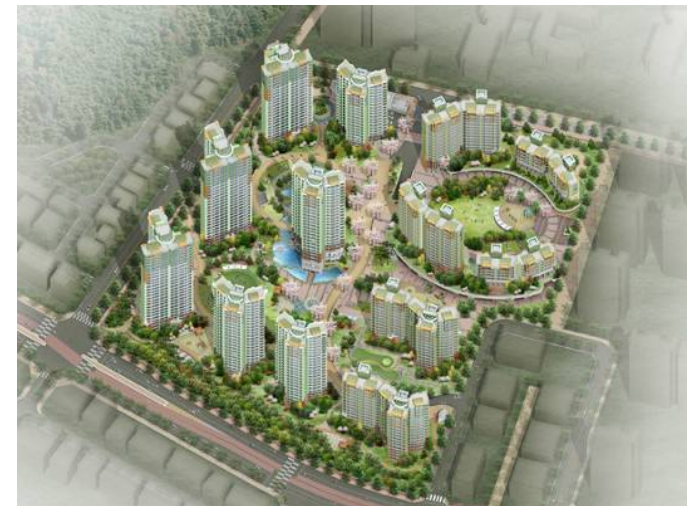

Figura 141: Projeto Dongtan

Fonte: Google

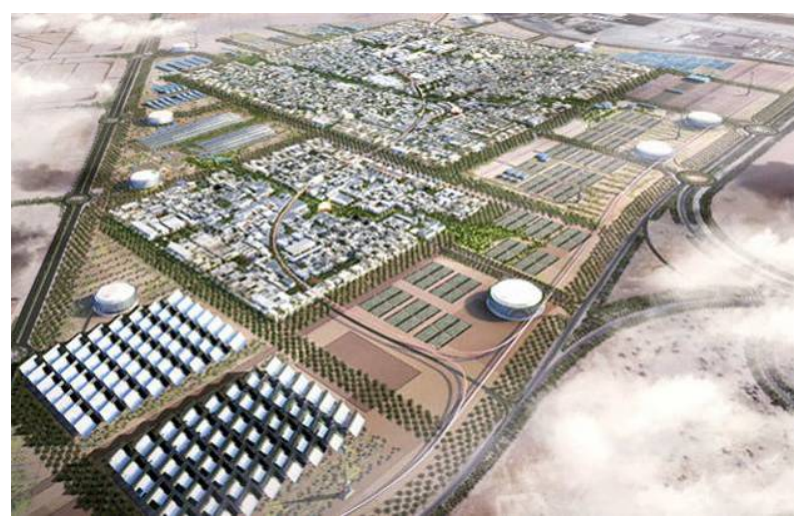

Figura 143: Projeto Masdar

Fonte: Google

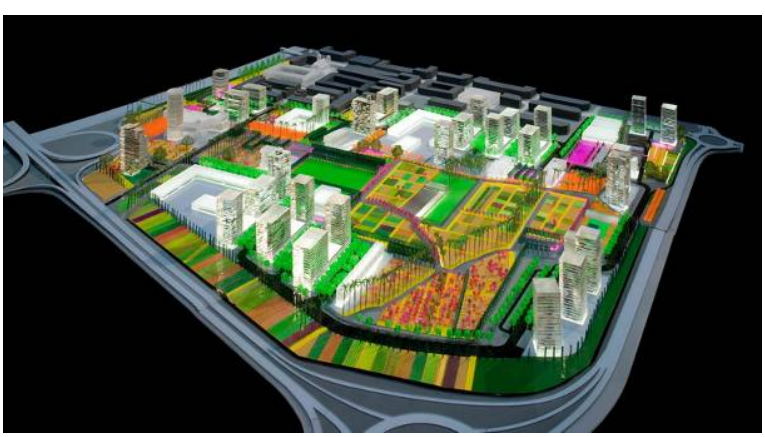

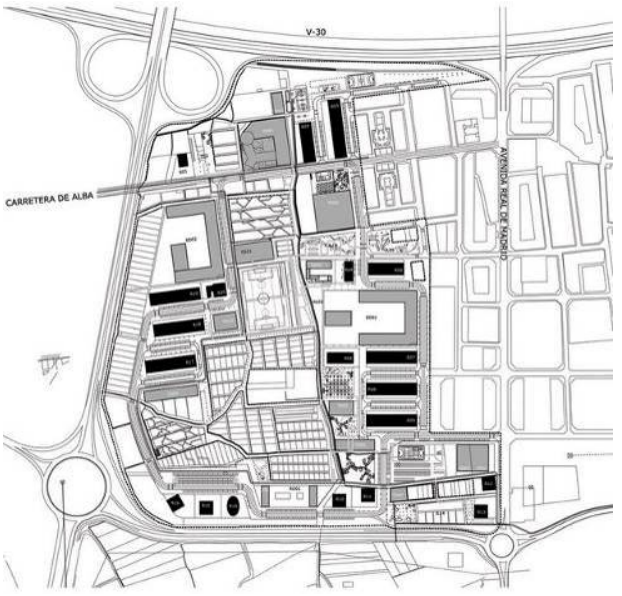

Figura 144: Planta projeto Sociópolis

Fonte: Site do projeto
Figura 145: Projeto Sociópolis

Fonte: Site do projeto 
"Han sido muchos los cambios que se han producido en la forma de planificar ciudades desde la revolución Industrial. Sin duda, uno de los ejes claves ha sido el reto medioambiental, que desde una situación de alarma inicial ha conducido a considerar las cuestiones ambientales y la gestión adecuada de recursos desde una visión completamente nueva introduciendo los objetivos de sostenibilidad en la planificación territorial y urbana. Sin embargo, todavía queda un largo camino por recorrer, ya que las metas son altas y se experimenta un continuo proceso de mejora de los resultados."(HIGUERAS, 2009). 


\section{CAPÍTULO 4 - PROPOSTA DE INSERÇÃO DE PARÂMETROS AMBIENTAIS NO PROCESSO DO

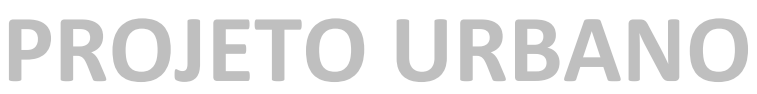

Este capítulo está estruturado em três partes. A primeira parte é a contextualização do método proposto, na qual são abordados três métodos de projeto urbano e os trabalhos desenvolvidos pelos pesquisadores do Laboratório de Conforto Ambiental e Eficiência Energética da Faculdade de Arquitetura e Urbanismo da Universidade de São Paulo (LABAUT FAUUSP), que contribuíram para a elaboração do método de inserção de fatores ambientais no processo de projeto.

$\mathrm{Na}$ segunda parte do capítulo é apresentado o estudo de caso que consiste em uma descrição e análise do exercício de projeto "Desenho Urbano para o Desempenho Ambiental com Benefícios Sócio-Econômicos", desenvolvido pelo grupo de pesquisadores do LABAUT FAUUSP, no qual a autora está inserida. A análise dessa aplicação prática, com base na estrutura proposta, foi fundamental para a definição das variáveis ambientais a serem consideradas e como essas deveriam ser trabalhadas no método.

A terceira parte do capítulo consiste na descrição da proposta de método, baseado nos trabalhos abordados nas duas primeiras partes.

\subsection{Contextualização do método proposto}

Para elaboração do método de inserção de fatores ambientais no processo de projeto foi realizada uma revisão bibliográfica dos métodos de projeto urbano existentes que consideram, de alguma forma, os aspectos relacionados à sustentabilidade ambiental. 
Com base nessa revisão verifica-se que, no contexto científico, poucas pesquisas abordam essa temática de uma forma ampla, integrando as variáveis ambientais e demais aspectos da sustentabilidade ambiental entre si e à prática do projeto urbano.

Já na prática profissional, percebe-se que em alguns casos existe uma preocupação com as questões ambientais e que, embora os exemplos não sejam muitos, há uma maior aplicação desses conceitos no projeto. Para isso são usadas ferramentas computacionais e estudos em modelos reduzidos. Porém, na maioria das vezes, os critérios quantitativos que possibilitam a inserção e avaliação das variáveis ambientais no projeto urbano não estão claros ou não foram definidos.

Apesar disso, as pesquisas na área apresentam uma contribuição de grande importância para o processo de projeto urbano e que, de certa forma, elas se complementam.

Na década de 60, McHarg (1969) escreveu "Design with Nature", que até os dias de hoje continua sendo um dos mais reconhecidos textos em arquitetura paisagística e planejamento do uso do solo. Nessa época, o planejamento tratava apenas das questões sócio-econômicas, não havendo aplicação do conhecimento do ambiente nem integração entre as ciências ambientais que se preocupassem em avaliar e planejar o espaço urbano. Sendo assim, McHarg (1969), buscando relacionar ecologia e planejamento, propõe um método chamado Método de Planejamento Ecológico (NUCCI, 2008).

O método consiste na incorporação de parâmetros do meio físico no planejamento com o mapeamento dos fatores intrínsecos do meio ambiente (clima, hidrologia, geologia, solo e habitat da vida selvagem), combinando-os dentro de uma simples composição que indica (por cores e tons usados por vários fatores) a susceptibilidade da terra por vários usos (como residencial, comercial, industrial, conservação e recreação ativa ou passiva). Esse método teve como pretensão apresentar um caráter mais abrangente no planejamento, incluindo áreas onde havia dominância humana, diferentemente do que ocorria com a pesquisa ecológica tradicional que selecionava ambientes com o mínimo de influência humana (NUCCI, 2008).

Destaca-se que McHarg (1969) estabelece conceitos básicos que depois foram adotados e mais desenvolvidos para o Geographic Information Systems (GIS). Hoje o GIS provê as ferramentas necessárias para viabilizar com mais agilidade a visão de McHarg. Diversos tipos de dados (físicos, biológicos ou culturais) podem ser incorporados na representação 
da paisagem, usando uma topologia que mantém as suas relações espaciais. Isso mudou a forma de trabalhar com dados espaciais e a forma de pensar sobre o mapeamento propriamente dito.

Com relação às referências mais recentes destacam-se as pesquisas acadêmicas que contribuíram para a elaboração do método proposto neste trabalho. São elas: o método do grupo de pesquisa DIMPO (1994) $)^{100}$, o método Andrade (2005), o método Higueras (2006) e os trabalhos desenvolvidos pelo grupo de pesquisadores do Laboratório de Conforto Ambiental e Eficiência Energética da Faculdade de Arquitetura e Urbanismo da Universidade de São Paulo (LABAUT FAUUSP), no qual a autora está inserida.

\subsubsection{Metodologia Dimensões morfológicas do Processo de Urbanização}

O grupo de pesquisa DIMPU (Dimensões Morfológicas do Processo de Urbanização), da Faculdade de Arquitetura e Urbanismo da Universidade de Brasília (FAUUnB), desenvolveu uma pesquisa que instituiu o nome ao grupo, por iniciativa da Professora Benamy Turkienicz, com a participação dos professores Gunter Kohlsdorf, Márcio Villas Boas, Maria Elaine Kohlsdorf, Mário Júlio Kruger e Paulo Marcos P. de Oliveira. ${ }^{101}$

O objetivo da pesquisa era investigar como a forma da cidade afeta a vida das pessoas em todos os aspectos e desenvolver uma metodologia a facultar o confronto do desempenho da forma urbana nos vários aspectos. ${ }^{102}$

Para Holanda e Kohlsdorf (1994), um espaço deve ser avaliado em relação as expectativas sociais correlatas a dimensões espaciais com várias descrições de um mesmo lugar, segundo diferentes atributos (categorias e elementos analíticos). Sendo assim, a avaliação global é uma ponderação entre essas avaliações parciais.

Segundo os autores da metodologia, as dimensões dos espaços arquitetônicos são ${ }^{103}$ :

\footnotetext{
100 Dimensões morfológicas do Processo de Urbanização: Holanda, F.; Kohlsdorf, G.; Kohlsdorf, M.E. e Villas Boas, M., Brasília: FAU-UnB / FINEP / CNPq, 1985 - 1994 . Disponível em:<http://www.unb.br/fau/cidade_arquitetura/>. Acesso em: 18 nov. 2008.

${ }^{101}$ Disponível em: <http://www.unb.br/fau/dimpu/index.html/> Acesso em: 18 nov. 2008.

102 Disponível em: http://www.unb.br/fau/dimpu/index.html/ acesso em: 18 nov. 2008.

103 idem
} 
- Funcional: observa as características morfológicas dos lugares, com relação à eficiência e adequação à realização de atividades pragmáticas neles desenvolvidas pelos indivíduos.

- Bioclimática: abrange as características morfológicas do espaço que estão relacionadas, ao conforto higrotérmico, acústico e luminoso do indivíduo e a qualidade do ar.

- Co-presencial: observa as características morfológicas do espaço, que propiciam ou restringem encontros sociais não programados em espaços externos púbicos.

- Topoceptiva: aborda as características configurativas dos espaços que interferem na noção de localização e identificação dos lugares.

- Econômica: observa as características morfológicas dos espaços com relação a seus custos de construção e utilização.

- Expressiva e simbólica: aborda as características configurativas da área estudada incidentes na criação de relações afetivas entre sujeitos e lugares por meio da fruição visual ou da evocação de conteúdo significativo.

Além dessas seis dimensões do espaço arquitetônico, Andrade et al. (2007) considera mais três macro-dimensões. Além do vínculo entre pessoas e espaços, existem as relações entre pessoas, pessoas e meio ambiente e pessoas com o mundo simbólico. Isso gera três macro-dimensões morfológicas para tratar de cada uma dessas macro-relações: a ética; a ecologia e a estética.

Andrade et al. (2007) comenta que uma macro-dimensão pode cruzar várias funções da arquitetura (dimensões), por exemplo: na dimensão estética encontra-se a beleza que pode ser obtida através do estudo da luz, com os efeitos de "luz e sombra", relacionado aos aspectos bioclimáticos, encontra certas identidades de lugares relacionadas aos aspectos topoceptivos, e ainda os afetos, relacionados aos aspectos emocionais.

Todas essas dimensões e macro dimensões são áreas de pesquisas separadas, mas que se interagem no projeto e que, segundo Holanda e Kohlsdorf (1994), deve ser entendido como proposta desenvolvida em processo seqüencial e iterativo de momentos de criação e de avaliação. De acordo com a metodologia de Kolsdorf, o projeto é realizado em três etapas focadas nos atributos morfológicos de cada dimensão do espaço arquitetônico: a 
análise, que consiste no levantamento do existente (descrições por categorias e elementos incidentes em cada dimensão); a avaliação da situação arquitetônica quanto a seu desempenho funcional, bioclimático, de co-presença, topoceptivo, econômico, expressivo e afetivo e proposição de uma nova situação arquitetônica, que supere os problemas detectados na avaliação. ${ }^{104}$

Essa metodologia pode ser utilizada tanto no processo de desenvolvimento do projeto quanto para avaliar uma intervenção urbana.

Apesar de apresentar alguns aspectos questionáveis, com relação à integração dos dados e aos resultados obtidos, essa metodologia contribui para uma visualização e compreensão do projeto como um todo, com suas dimensões apontando os atributos (elementos) que devem ser confrontados com a morfologia urbana.

Além disso, a metodologia define as três fases de elaboração do projeto, o levantamento, o diagnóstico e a proposição, destacando a importância de interagir a etapa de proposição com a etapa de avaliação.

\subsubsection{Método Andrade}

Segundo Andrade (2005), os sistemas urbanos não podem ser reduzidos ao pensamento linear ou a uma análise particularizada dos elementos que os integram. É necessária uma nova ciência guiada por uma visão sistêmica da estrutura da cidade e interdependência essencial de todos os fenômenos físicos, biológicos, culturais e sociais que ali ocorrem.

Com base nessa visão, dentro da macro dimensão ecológica, Andrade (2005) desenvolve um método para implantação e a recuperação de espaços urbanos baseado nos princípios de sustentabilidade ambiental associado à morfologia urbana, estabelecido por Dauncey e Peck (2002, apud ANDRADE, 2005).

O método consiste em traduzir os princípios em estratégias e técnicas para o processo de desenho, visando produzir assentamentos humanos em equilíbrio com o meio ambiente e economicamente viáveis.

${ }^{104}$ KOLSDORF, 2006. 
A primeira etapa da metodologia consiste em um diagnóstico socioambiental, para estabelecer os problemas e os recursos do local. Na aplicação do método, Andrade (2005) realizou o diagnóstico socioambiental por meio de EIAs-RIMAs.

A partir de então, são definidas as estratégias necessárias (concepção urbana) para alcançar os princípios de sustentabilidade ambiental desenvolvidos por Dauncey e Peck, que são: proteção ecológica (biodiversidade), adensamento urbano, revitalização urbana, implantação de centros de bairro e desenvolvimento da economia local, implementação de transporte sustentável e moradias economicamente viáveis, comunidades com sentido de vizinhança, tratamento de esgoto alternativo, drenagem natural, gestão integrada da água, energias alternativas e, finalmente, as políticas baseadas nos 3R's (reduzir, reusar e reciclar).

A partir do estabelecimento das estratégias são definidas as técnicas de desenho ou recomendações específicas.

Segundo Andrade (2005, p189):

"os princípios devem considerar a teoria ou o conceito. As estratégias compreendem a arte de traçar os planos - o planejamento estratégico propriamente dito - e as recomendações específicas basicamente se traduzem em técnicas que serão utilizadas para se alcançar o objetivo final: atender os princípios de sustentabilidade ambiental."

Os princípios de sustentabilidade ambiental e as estratégias se aplicam no ambiente urbano como um todo, independente da escala. Porém, as técnicas urbanas são apresentadas em diferentes níveis: a escala das grandes estruturas urbanas, que envolve o bairro e seu entorno, ou seja, a capacidade de suporte do meio no qual o assentamento está inserido; a escala do setor ou bairro; e a escala específica do edifício.

O método sintetiza as principais questões relacionadas à sustentabilidade ambiental, que devem ser incorporadas ao processo de desenho urbano, através de uma visão sistêmica e integrada que possibilita o entendimento dos impactos e das potencialidades para produzir espaços em equilíbrio com o meio ambiente. 
Além disso, a grande contribuição desse método é apontar diretrizes para projeto urbano baseadas em princípios de sustentabilidade ambiental para assentamentos humanos. ${ }^{105}$

\subsubsection{Método Higueras: Urbanismo bioclimático}

Segundo Higueras (2007), o urbanismo bioclimático deve adequar os traçados urbanos às condições singulares do clima e território, entendendo que cada situação geográfica deve gerar um desenho urbano característico e diferenciado com relação a outros lugares.

Para conseguir que o projeto urbano esteja adequado ao meio natural no qual ele está inserido, Higueras (2007) propõe a seguinte metodologia:

Etapa 01 - Estabelecer uma síntese das condicionantes do meio físico e ambiental, através de um diagnóstico local, verificando as seguintes variáveis: geomorfologia, água, solo, vegetação, insolação e vento;

Etapa 02 - Estabelecer as determinantes que condicionam o microclima local, sobretudo as de vento e sol, com objetivo de quantificar as necessidades locais para inverno e verão, através da carta bioclimática, possibilitado a definição das principais estratégias (diagnóstico climático);

Etapa 03 - Por fim, as estratégias gerais são detalhadas nos documentos de planejamento territorial ou planejamento urbano, articulados aos sistemas gerais urbanos, rede viária, equipamentos e zonas verdes e espaços livres.

A ilustração 8, apresenta um esquema da seqüência da metodologia.

Detalhando essa metodologia, na primeira etapa, são estudadas uma série de variáveis ambientais e sua relação com a capacidade e estrutura do meio urbano, para constatar o modo que essas variáveis podem modificar os planejamentos gerais de um assentamento urbano com critérios ambientais.

Com relação às variáveis ambientais sol e vento, essas são fundamentais para o urbanismo bioclimático, sendo que, para compreendê-las, é necessária a obtenção de

105 Andrade (2005, p. 195) apresenta um quadro síntese de como os princípios de sustentabilidade ambiental, as estratégias e a técnicas urbanas podem ser incorporados ao processo de desenho urbano. 
algumas informações como: direção e velocidade do vento dominante e quantidade de radiação solar direta e difusa, para todos os meses do ano. Para o estudo de insolação e de sombras, são adotadas as cartas solares de acordo com a latitude do local. ${ }^{106}$

O estudo da vegetação abrange desde o estudo dos usos agrícolas, exploração de recursos florestais e espécies, à localização e distribuição de áreas verdes e análise da paisagem visual.

Com relação à variável ambiental água, o estudo do seu ciclo é muito importante para a definição do desenho urbano e para a gestão deste recurso, para que esses interfiram o menos possível no seu ciclo natural.

Devem ser verificadas questões relacionadas à qualidade da água e a sua capacidade de auto-depuração, através do conhecimento do seu limite de oxigênio.

Ainda nessa etapa, devem ser verificadas as áreas de possíveis inundações, para que sejam evitadas. Para esse estudo, Higueras recomenda Dunee e Leopold. ${ }^{107}$

Com relação à geomorfologia, para a análise das formas do terreno são estabelecidos dois estudos mínimos: o estudo topográfico, com a inclinação do terreno e as cotas altimétricas (desde o nível do mar) e o estudo de insolação, para definir áreas de sombra e exposição das ladeiras.

Após o estudo de cada uma dessas variáveis, era necessário um mecanismo para sintetizar o diagnóstico ambiental. Com isso, Higueras (2007) desenvolveu uma matriz que resume a relação entre o meio ambiente e o meio urbano, tornando possível determinar as estratégias para, a partir delas, estabelecer os critérios necessários para conseguir um desenvolvimento urbano adequado ao meio ambiente.

A Tabela 14 apresenta uma matriz de interação entre o meio natural e o meio urbano.

\footnotetext{
106 As cartas solares para todas as latitudes podem ser encontradas em: impressas - FROTA, 2004 e em arquivo eletrônico - Disponível em <http://www.usp.br/fau/pesquisas/laboratorios/labaut/conforto/index.html $>$ Acesso em jan de 2009.

107 DUNNE, Thomas and LEOPOLD, Luna. Water in environmenral planning, W.H. Freman, New York, 1998.
} 
Tabela 14: Matriz de interação entre o meio natural e o meio urbano

Fonte: HIGUERAS, 2007, p97, traduzida pela autora

\begin{tabular}{|c|c|c|c|c|c|}
\hline \multicolumn{6}{|c|}{ VARI ÁVEIS DO MEI O NATURAL X VARIÁVEI S DO MEIO URBANO } \\
\hline $\begin{array}{l}\text { Critérios } \\
\text { de } \\
\text { otimização } \\
\text { do meio } \\
\text { ambiente }\end{array}$ & sol & vegetação & vento & água & geomorfologia \\
\hline $\begin{array}{l}\text { Rede } \\
\text { viária }\end{array}$ & $\begin{array}{l}\text { Orientação } \\
\text { Forma }\end{array}$ & localização & $\begin{array}{l}\text { Orientação } \\
\text { Forma }\end{array}$ & $\begin{array}{l}\text { Microclima } \\
\text { externo }\end{array}$ & $\begin{array}{l}\text { Condição de suporte } \\
\text { aptidão do solo } \\
\text { Adaptação topográfica }\end{array}$ \\
\hline $\begin{array}{l}\text { Espaços } \\
\text { livres }\end{array}$ & $\begin{array}{l}\text { Orientação } \\
\text { Forma }\end{array}$ & $\begin{array}{l}\text { Espécies } \\
\text { Densidade } \\
\text { localização }\end{array}$ & $\begin{array}{l}\text { Orientação } \\
\text { Forma }\end{array}$ & $\begin{array}{l}\text { Microclima } \\
\text { externo }\end{array}$ & $\begin{array}{l}\text { Condição de suporte } \\
\text { aptidão do solo }\end{array}$ \\
\hline $\begin{array}{l}\text { Condições } \\
\text { quadra }\end{array}$ & $\begin{array}{l}\text { Orientação } \\
\text { Geometria } \\
\text { Densidade }\end{array}$ & & $\begin{array}{l}\text { Orientação } \\
\text { Geometria } \\
\text { Densidade }\end{array}$ & & \\
\hline $\begin{array}{l}\text { Condições } \\
\text { lote }\end{array}$ & $\begin{array}{l}\text { Geometria } \\
\text { Alturas } \\
\text { Ocupação } \\
\text { potencial } \\
\text { construtivo }\end{array}$ & & $\begin{array}{l}\text { Geometria } \\
\text { Alturas } \\
\text { potencial } \\
\text { construtivo. }\end{array}$ & & \\
\hline $\begin{array}{l}\text { Condições } \\
\text { edificação }\end{array}$ & $\begin{array}{l}\text { Controle } \\
\text { solar } \\
\text { Acondic. } \\
\text { passivo }\end{array}$ & & $\begin{array}{l}\text { Ventilação } \\
\text { interna } \\
\text { Localização } \\
\text { aberturas }\end{array}$ & $\begin{array}{l}\text { Microclima } \\
\text { interno }\end{array}$ & \\
\hline
\end{tabular}

Em Anexo são apresentados cinco quadros, sintetizando as influências das variáveis ambientais (sol, vegetação, vento, água e geomorfologia) em um assentamento urbano, mostrando quais os fatores relacionados a elas que devem ser analisados.

Higueras (2007) destaca a importância de sintetizar e integrar todas essas informações, através de representações gráficas e a redação de um diagnóstico ambiental. Para isso, Higueras recomenda os Sistemas de Informação Geográfica (SIG), que são ferramentas muito usadas por profissionais e muito úteis para conseguir este objetivo.

Higueras (2007) também recomenda a metodologia de Ian L McHarg (2000) para analisar a capacidade ambiental de um território, por meio de um diagnóstico de superposições de diversos planos de análises setoriais, das diferentes variáveis que se integram no território.

A segunda etapa da metodologia consiste no conhecimento do clima e definição das estratégias gerais, através de um diagnóstico climático. Por meio do cruzamento de dados 
climáticos, interpolados na carta bioclimática, é possível definir as principais estratégias a serem adotadas, para adequar o projeto às condições do clima local. ${ }^{108}$

A última etapa da metodologia é desenvolver o planejamento ambiental, que consiste em um documento que considera todo o processo de planejamento, as particularidades próprias de cada entorno, sociedade e clima, para que as diretrizes urbanas estejam em equilíbrio com seu entorno e, assim, avançar em direção ao desenvolvimento sustentável em qualquer tipo de projeto urbano.

Uma importante contribuição do método de Higueras (2007) é a síntese das variáveis ambientais que devem ser consideradas no projeto urbano, com seus fatores de análise, parâmetros de projeto e a influência delas em um assentamento humano.

Assim, o método auxilia o desenvolvimento do diagnóstico do meio ambiente e diagnóstico climático e direciona a elaboração de estratégias gerais de projeto a serem incorporadas na legislação urbana, através dos planos diretores e outros instrumentos de planejamento.

\subsubsection{Pesquisas LABAUT FAUUSP}

A revisão bibliográfica também contempla pesquisas sobre os temas específicos abordados no método tais como: ventilação natural nos espaços urbanos; acesso ao sol e disponibilidade de luz natural; conforto térmico e conforto acústico nos espaços externos; eficiência energética e vegetação no meio urbano.

Sobre todos os temas específicos buscou-se considerar: a relevância do tema para a qualidade ambiental urbana; a relação do tema com as condicionantes de projeto, ou melhor, a sua influência na forma urbana e vice-versa; os fatores relacionados a esses que devem ser analisados; a existência ou não de parâmetros de avaliação; e os métodos existentes para avaliação do tema no processo de projeto.

Destacam-se aqui alguns trabalhos realizados por pesquisadores do LABAUT FAUUSP nessa área, com ênfase ao conforto ambiental urbano.

\footnotetext{
${ }^{108}$ Esta metodologia, conhecida como diagnóstico climático é adotada por diversos pesquisadores da área do conforto ambiental.
} 
Duarte (2000) buscou estabelecer uma correlação entre as formas urbanas e as condições térmicas resultantes, propondo uma correlação entre o aquecimento urbano com variáveis próprias do planejamento urbano, tais como taxa de ocupação, coeficiente de aproveitamento e a existência de massas de água e vegetação.

Prata (2005) desenvolveu um trabalho a respeito de simulações de ventilação natural em espaços urbanos, através de aplicativos computacionais e em túnel de vento, validando estes estudos com medidas em campo. No trabalho é tratado principalmente o campo de velocidades causado pela obstrução de edifícios. Finalizado este trabalho, Prata (2008) desenvolveu uma pesquisa sobre os valores de rugosidade $\left(z_{0}\right)$, perfis de velocidades médias e de intensidade de turbulência, a partir de tipologias de ocupação urbana da cidade de São Paulo.

Monteiro (2008) estudou os índices de conforto aplicáveis a espaços externos, fornecendo material para a determinação das necessidades ambientais de conforto térmico dos usuários.

Ramos (2007) estudou as formas de avaliação do ruído urbano, contribuindo com informações para aplicação no planejamento urbano.

Brandão (2004) desenvolveu uma ferramenta que permite avaliar o efeito de novas edificações no desempenho térmico, luminoso e energético dos vizinhos, servindo como parâmetro para a determinação de recuos, gabaritos e densidade urbana. Posteriormente, Brandão (2009) abordou a relação das edificações com outros aspectos do clima urbano, avaliando principalmente as alterações de temperatura e a intensidade e distribuição da ventilação. Como resultado Brandão (2009) propôs equações de regressão que relacionam a ocupação urbana com variáveis meteorológicas locais. O autor comenta que apesar da aplicabilidade limitada, tais equações podem ser utilizadas para gerar recomendações gerais de planejamento e que o processo desenvolvido para obter as equações pode ser utilizado na avaliação comparativa de áreas urbanas.

Relacionando o edifício no espaço urbano que ele se insere, Gonçalves (2003.), na tese " $A$ sustentabilidade de edifícios altos: uma nova geração de edifícios altos e sua inserção urbana", abordou as implicações e impactos, nem sempre negativos, do edifício alto como objeto do planejamento e desenho urbano antes mesmo de ser um objeto da arquitetura. 
Continuando essa pesquisa, Umakoshi (2008) elaborou uma visão crítica sobre os edifícios altos apresentados nas últimas duas décadas, como sustentáveis, destacando características do projeto arquitetônico em relação ao desempenho ambiental.

De uma maneira mais ampla, Kronka Mülfarth (2003) aborda os conceitos de sustentabilidade e sua aplicação na arquitetura, desenvolvendo uma sistematização do assunto.

Com relação às ferramentas de projeto, Alucci vem desenvolvendo diversos softwares que auxiliam tanto o processo de projeto quanto a avaliação do desempenho das edificações. Alguns desses aplicativos computacionais são específicos para edificações como, por exemplo, o Climaticus (ALUCCI, 2005), o TAO (ALUCCI, 2007), o Acústico (2002), porém que apresentam algumas avaliações que auxiliam o diagnóstico e a implantação de assentamentos humanos. Outros como o Urbano (ALUCCI e MONTEIRO, 2004) já são específicos para espaços externos e podem ser usados como ferramentas para o desenvolvimento do projeto desses espaços. ${ }^{109}$

Em geral, essas pesquisas abordam questões específicas de fundamental importância, porém tratadas de forma isolada no projeto urbano. Sendo assim, visando preencher essa lacuna, o próprio grupo de pesquisa vem realizando exercícios de projetos urbanos, colocando em prática os conhecimentos adquiridos e as ferramentas desenvolvidas nesses trabalhos.

O primeiro deles foi o projeto desenvolvido para o concurso Bairro Novo promovido pela prefeitura do Município de São Paulo, através da Empresa Municipal de Urbanização EMURB, com o objetivo de impulsionar a discussão ampla da produção e do desenho da cidade e sua relação com as centralidades urbanas, com melhoria ambiental e dos espaços públicos e com o próprio exercício da cidadania. O projeto foi apresentado em nível de Estudo Preliminar a ser implantado na área de Intervenção, localizada na Região da Água Branca, município de São Paulo. ${ }^{110}$

\footnotetext{
${ }^{109}$ Disponível em<http://www.usp.br/fau/pesquisas/laboratorios/labaut/conforto/index.html> Acesso em jan. de 2008.

${ }^{110}$ Equipe do LABAUT FAUUSP que desenvolveu o projeto do Concurso Bairro Novo: Professores: Joana Carla Gonçalves e Denise Duarte. Pesquisadores do curso de pós-graduação: Anna Chistina Miana e Cecília Mueller.
} 
Não existia um método específico, sendo o projeto desenvolvido de uma maneira bem tradicional. Porém, as questões de conforto ambiental no espaço urbano e nos edifícios foram tratadas desde a concepção inicial da proposta conjuntamente com outras áreas de projeto como macro e micro-drenagem, mobilidade urbana, densidade de ocupação, critérios para a implantação de edifícios altos e o desenho dos espaços externos. Os resultados de projeto demonstraram o potencial dessa interação em propostas de requalificação urbana que integram qualidade ambiental e diversidade espacial, abordando e compatibilizando questões do edifício e do espaço aberto.

Após a realização deste projeto verificou-se ainda mais a necessidade de trabalhos que apliquem os aspectos ambientais no processo de projeto urbano, dando suporte científico para as decisões adotadas durante o desenvolvimento do projeto. Diante disso, o grupo de pesquisa do LABAUT FAUUSP se reuniu para realizar dois exercícios de projeto urbano coordenado pela co-orientadora dessa pesquisa de doutorado, Prof. Dra. Joana Carla Soares Gonçalves, que possibilitaram a discussão e aplicação de aspectos ambientais no processo de projeto.

O primeiro exercício de projeto, intitulado "Sustainable urban spaces: a case study in São Paulo, Brazil', foi realizado durante os anos de 2005 e 2006, em parceria com o Profs. Dr. Koen Steemers da University of Cambridge e a Prof. Dra. Susannah Hagan da University of East London. ${ }^{111} \mathrm{O}$ segundo, intitulado "Desenho Urbano para o Desempenho Ambiental com Benefícios Sócio-Econômicos", foi desenvolvido durante o ano de 2009 com a cooperação internacional London School of Economics, Urban Age. ${ }^{112}$

Alunos do curso de graduação FAUUSP (hoje já graduados): Marcos Rosa (coordenador do projeto), Daniela Weintraub, Fabio Faria, Lene Nettelbeck, Tatiana Souza, Vanessa Grossman. Consultoria: Prof. Dr. Ricardo Toledo, Prof. Dr. Khaled Ghoubar, Dra. Alessandra Prata Shimomura.

111 Equipe pesquisa "Sustainable urban spaces: a case study in São Paulo, Brazil": Coordenadoras: Professoras Joana Gonçalves e Dra. Denise Duarte. Pesquisadores do curso de pós-graduação FAUUSP: Norberto Moura, Alessandra Prata Shimomura, Rafael Brandão, Anna Christina Miana e Mônica Marcondes, Anarrita Buoro, Andrea Bazarian, Carolina Gaspar Leite, Erica Umakoshi, Paula Shinzato e Luciana Ferreira. Consultoria: Prof. Dra. Marcia Alucci

112 Este projeto foi apresentado pela primeira vez, na Conferência Internacional Urban Age, realizada em São Paulo, em dezembro de 2008. O projeto foi desenvolvido pela seguinte equipe de pesquisadores: Professores: Joana Carla Soares Gonçalves e Roberta Kronka Mulfarth (coordenadoras do projeto), Norberto Moura, José 
De uma maneira geral, o segundo exercício é uma continuação do primeiro. A diferença é que no segundo exercício o grupo de pesquisa já tinha consciência das deficiências metodológicas e da ausência de critérios ambientais, além de uma experiência maior no uso das ferramentas de avaliação de aspectos ambientais específicos.

O primeiro exercício foi aplicado em duas áreas degradadas da cidade de São Paulo, os bairros da Luz a da Barra Funda. Já no segundo exercício, o projeto foi desenvolvido para uma das áreas, a área do PRI no Bairro da Luz, e, por essa razão, o projeto pôde ser mais aprofundado, incluindo o retrofit de dois edifícios degradados.

Durante o desenvolvimento desses trabalhos, principalmente o último mencionado, foi possível estabelecer um método de inserção dos fatores ambientais, discutindo requisitos e critérios de desempenho e testando ferramentas de avaliação. Sendo assim, apresentase esse como o estudo de caso, apontando como ele foi desenvolvido e os resultados obtidos. Destaca-se que, como o método proposto é fruto também desse exercício de projeto, verificou-se a importância em descrevê-lo e analisá-lo antes de sintetizar o método.

Além disso, visando entender onde as questões ambientais se inserem, o estudo de caso é abordado seguindo as etapas do método proposto, com base na idéia do que seria o projeto urbano no momento atual com suas camadas e os enfoques com que essas e suas interrelações devem ser analisadas.

Retomando essa idéia, o projeto urbano apresenta diversas camadas: usos, estoque construído, redes de infra-estrutura e meio ambiente. A camada meio ambiente engloba as seguintes variáveis ambientais: relevo, vegetação, água, energia e clima. Todas as

Fernando Cremonesi, Marcelo Giacaglia, Maria Ruth Amaral de Sampaio, Marcia Peinado Alucci, Anésia Barros Frota e Denise Helena Silva Duarte.

Pesquisadores do curso de pós-graduação: Alessandra Rodrigues Prata, Anna Christina Miana, José Ovídio Ramos, Leonardo Marques Monteiro, Luciana Schwandner Ferreira, Paula Shinzato, Rafael Silva Brandão, Rodrigo Cavalcante, Kátia Moreira.

Alunos do curso de graduação FAUUSP (hoje já graduados): Alex Uzueli, Bruno Henrique Emanuel Mendes, Clara Pássaro, Daniele Queiroz dos Santos, Joanna Conceição, Katheleen Chiang, Mariane M. Klettenhofer, Melissa Benito, Renata Sandoli, Sabrina Harris, Patrícia Sanches, Virginia X. 
camadas do projeto e suas inter-relações devem ser analisadas sob os seguintes enfoques: ambiental, econômico, social, estético e cultural. ${ }^{113}$

\subsection{Estudo de Caso: Exercícios de projeto LABAUT FAUUSP}

O objetivo do trabalho era desenvolver um modelo de intervenção urbana sustentável para São Paulo, que trata da requalificação do ambiente construído, do uso eficiente da infra-estrutura e da inserção de edifícios novos. Visando minimizar os impactos ambientais causados pelo crescimento urbano e aumento da densidade, foram definidos aspectos ambientais e de eficiência energética que, junto com o diagnóstico socioambiental da área, formaram a base para a elaboração do projeto.

Selecionada a área de estudo, um conjunto de aproximadamente 27 quadras, na área do PRIH, no bairro da Luz, o projeto foi desenvolvido seguindo as etapas:

\section{ETAPA 01 - CARACTERI ZAÇÃO DA ÁREA E DI AGNÓSTI CO}

A área do PRIH da Luz, Perímetro de Reabilitação Integrada do Habitat da Luz, foi selecionada para desenvolvimento do exercício de projeto por um conjunto de fatores: baixa densidade populacional em contradição a uma elevada taxa de ocupação do solo; localização estratégica de centralidade no território urbano; proximidade com algumas das principais estações de transporte publico da cidade; presença marcante na acomodação de atividades econômicas, onde a questão da regeneração urbana esta atrelada a recuperação do ambiente construído e de sua qualidade ambiental, somada a um conjunto de estratégias para lidar com os problemas de ordem social (GONÇALVES e KRONKA MÜLFARTH, 2008).

Segundo a classificação do IBGE (2000), a área do PRIH Luz insere-se no bairro de Santa Ifigênia, englobando dois distritos: Bom Retiro e República.

\footnotetext{
${ }^{113}$ Os enfoques econômico, social, estético e cultural não fazem parte do escopo dessa pesquisa.
} 

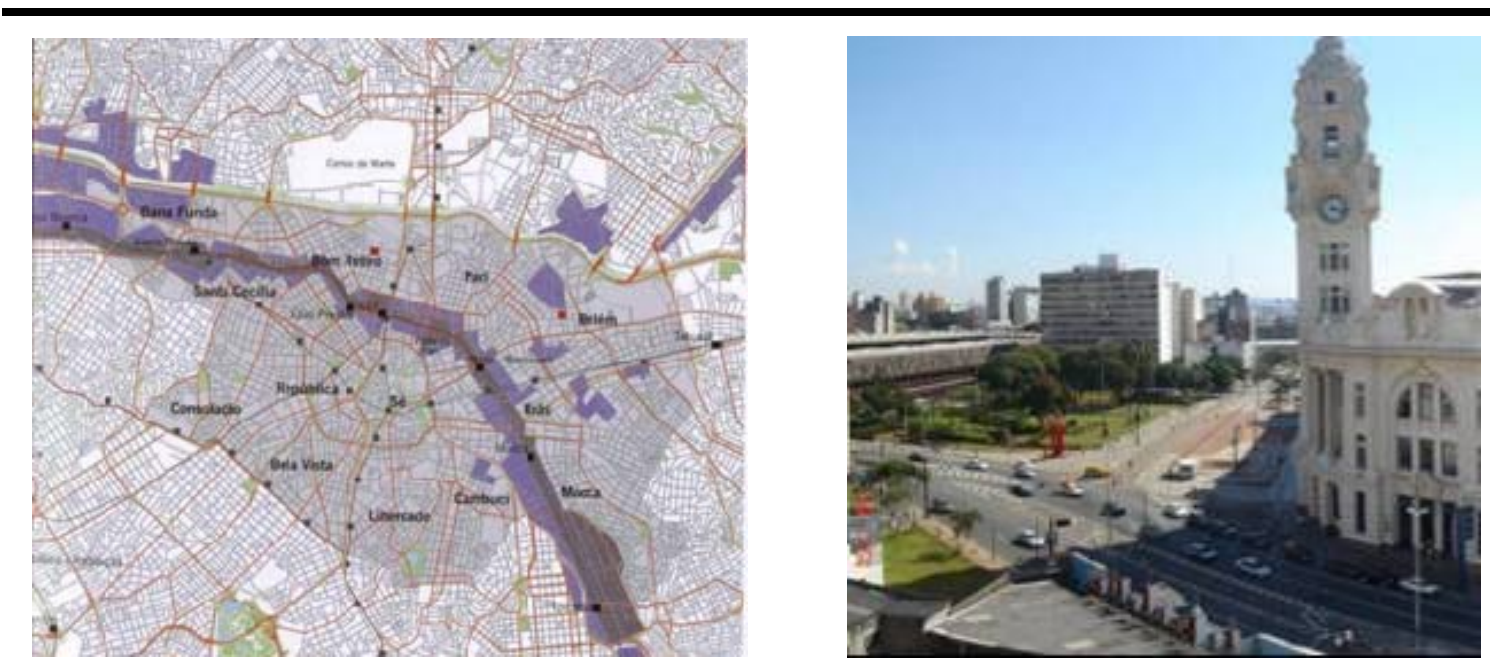

Figura 146: Mapa da área de interesse PRI H do Bairro da Luz , São Paulo

Fonte: Material produzido pela equipe do projeto
Figura 147: Foto da área de interesse PRI H do Bairro da Luz , São Paulo

Fonte: Material produzido pela equipe do projeto

\section{Sobre a população local:}

\section{- Densidade populacional}

Segundo Bonduki (2003), entre 1980 e 2000 a subprefeitura da Sé perdeu cerca de 230.000 habitantes. Entre 1991 e 1996, o bairro do Pari perdeu aproximadamente 25\% da sua população, o Bom Retiro $20 \%$, o bairro da Sé $18 \%$ e o Brás $17 \%$.

Atualmente o bairro da Luz abriga aproximadamente 26.600 habitantes e tem uma densidade populacional em torno de 60habitantes/ha.

Na cidade de São Paulo observa-se uma forte concentração da densidade construtiva na área central, expandindo-se para o setor sudoeste, que não corresponde à maior densidade habitacional (Figura 148).

A degradação do centro da cidade levou a um paradoxo de densidades. Ou seja, enquanto os bairros centrais, que constituem uma das áreas de maior adensamento construtivo da cidade servido de infra-estrutura urbana, têm cerca de $30 \%$ do seu estoque construído vazio, a periferia da cidade concentra o adensamento populacional, mal servido de todos os tipos de infra-estrutura e distante das oportunidades de trabalho e demais serviços oferecidos pela estrutura urbana consolidada do centro da cidade (CUSINATO, 2004). 

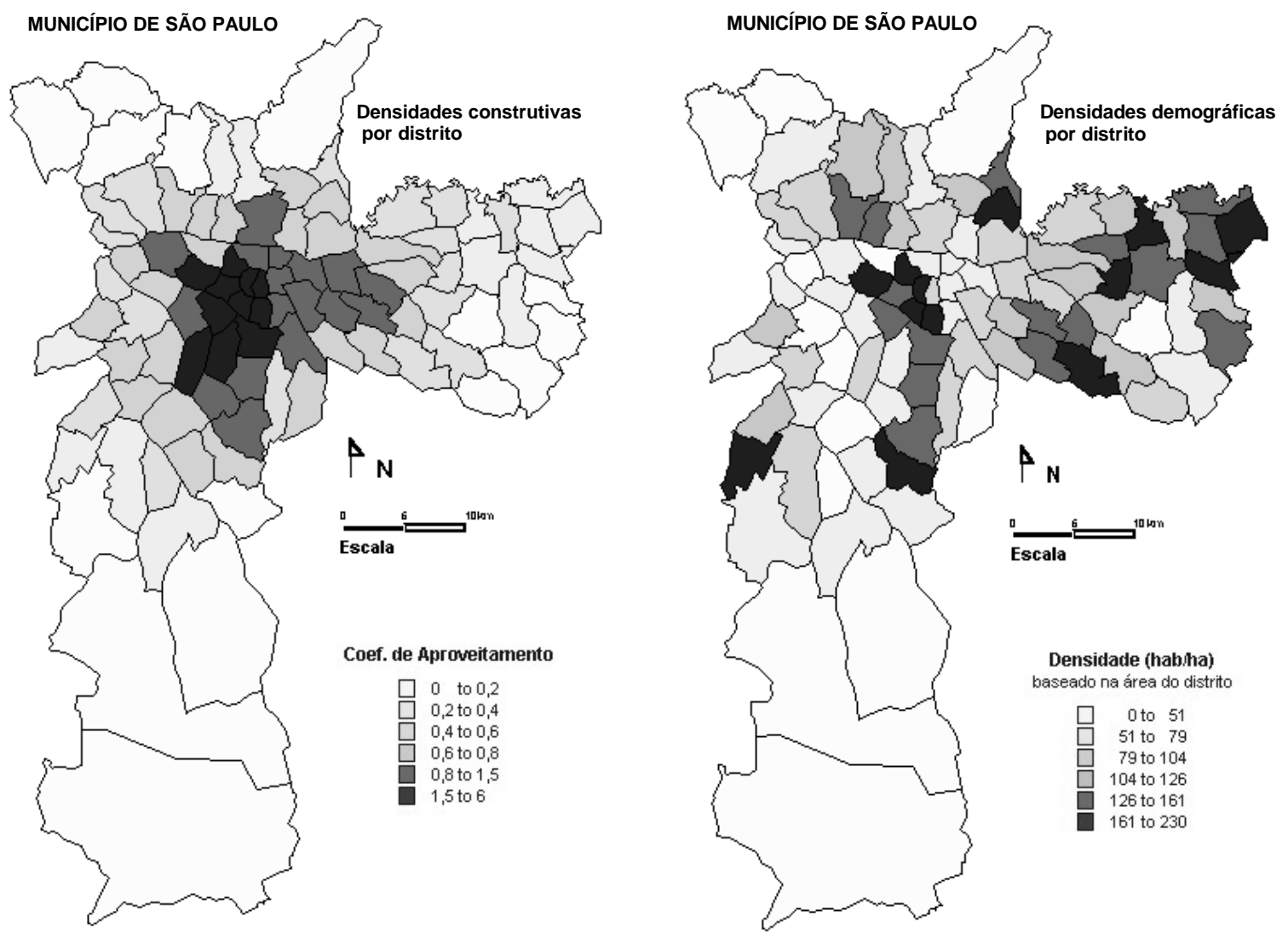

Figura 148: Mapas Densidades de ocupação para São Paulo - Densidade construtiva por distrito de São Paulo e Densidade Populacional por distrito de São Paulo

Fonte: Elaborado por Brandão (2009) a partir de dados da SEMPLA (Mapeamento dos coeficientes de aproveitamento por quadra, arquivo eletrônico tipo MID) e do Instituto Brasileiro de Geografia e Estatística, IBGE, Sumário de Dados 2004. Base cartográfica: CESAD/FAUUSP

Em resumo, a área de estudo apresenta um grande potencial de adensamento, com base na sua baixa densidade populacional e na presença de infra-estrutura instalada. Para isso é necessário, entre outras medidas, uma análise do estoque construído, identificando os edifícios que devem ser retrofitados e os que devem ser demolidos, liberando espaço livre para vegetação ou para novas edificações e o incentivo a diversidade de usos, de rendas e de tipologias arquitetônicas.

\section{Sobre as camadas do projeto urbano}

- Usos (residencial, comercial, escritórios, institucional, estacionamento e vazios urbanos) 
Como pode ser verificada no mapa de usos resultado do levantamento das 27 quadras selecionadas, a área apresenta um uso predominantemente comercial, com a presença de alguns lotes vazios, alguns galpões destinados a estacionamentos e alguns edifícios residenciais, sendo que a maioria deles apresenta o térreo comercial.

Sob o enfoque ambiental: ressalta-se a necessidade de estimular o uso misto, que nesse caso, está ligado ao incentivo da construção de habitações. Dessa forma torna-se possível aumentar a densidade populacional, otimizar a infra-estrutura existente e reduzir a necessidade de deslocamentos e todas as conseqüências dessa estratégia, visto que o centro oferece oferta de atividades culturais e de empregos.

\section{- I nfra-estrutura urbana:}

São Paulo vem sofrendo com os problemas gerados pelo excesso de veículos, agravados, entre outros fatores, pela ocupação em áreas periféricas. Malta (2008) salienta sobre número crescente de veículos e a falta de espaço nas ruas e avenidas para circulação desses.

Sob o enfoque ambiental: verifica-se a urgente necessidade de reduzir o número de veículos particulares nas ruas, que pode ser conseguido com a redução da necessidade de deslocamentos e o uso do transporte público e meio de locomoção sustentáveis.

Com esses objetivos, a reabilitação das áreas centrais das cidades é essencial, visto que elas apresentam um sistema de transporte público eficiente e diversificado, somado a possibilidade de implantação de medidas que incentivam o uso misto.

Na visão do ex-secretário de planejamento de São Paulo, Jorge Wilheim esse abandono dos bairros centrais constitui um problema de crescimento da cidade, de maneira a subaproveitar a infra-estrutura presente nas áreas centrais consolidadas. O centro de São Paulo é uma das regiões da cidade mais bem servida de transporte e espaços públicos. Segundo Bonduki (2003), a região central de São Paulo é um nó de articulação, de onde partem mais de 250 linhas de ônibus, metrô e trem urbano que conecta os moradores com todos os quadrantes da metrópole, sendo esses atrativos para tornar as áreas centrais interessante para moradores de várias faixas etárias. 


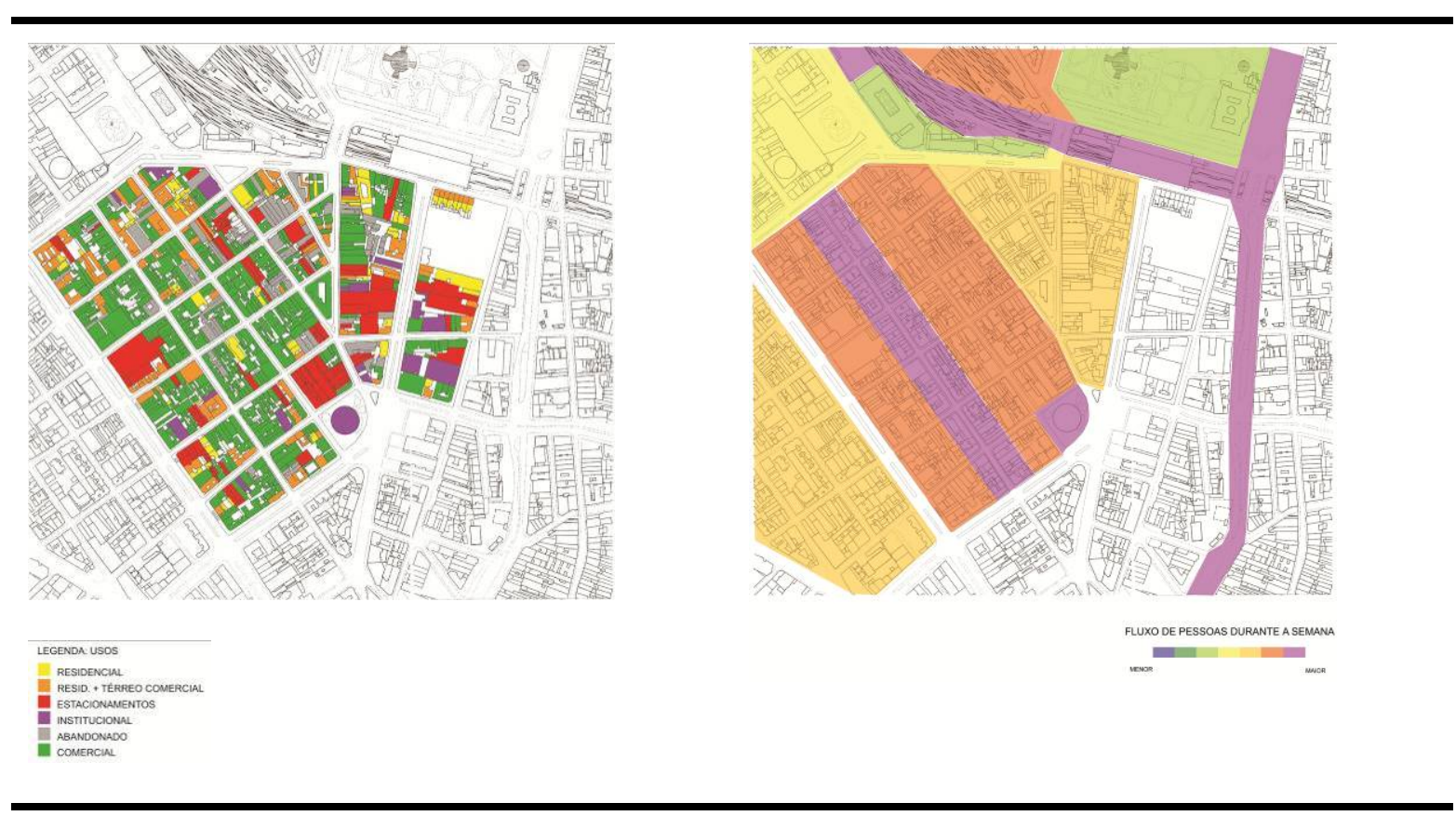

Figura 149: Mapa de uso do solo da área de estudo PRIH no bairro da Luz, São Paulo.

Fonte: Material produzido pela equipe do projeto

\section{Figura 150: Mapa de fluxos}

Fonte: Material produzido pela equipe do projeto

\section{- $\quad$ Estoque construído}

Com relação ao estoque construído foi verificado edificações de diferentes tamanhos e alturas, seguindo o padrão da morfologia de grande parte dos bairros centrais de São Paulo. Um número significativo de edifícios altos destaca na forma urbana, tanto pela sua altura quando pelo estado de degradação física, apresentando uma necessidade urgente de recuperação construtiva e espacial (Figura 151).

No Bom Retiro predominam edifícios de três a cinco andares e residências unifamiliares de 1 pavimento. Destaca-se a presença de cortiços (domicílios improvisados e coletivos), localizados em casa e edifícios. Na área da República predominam domicílios em edifícios multifamiliares, significativamente mais altos, existindo também habitações encortiçadas.

Edifícios altos e de pequeno porte, somados a lotes vazios e galpões destinados ao uso de estacionamentos, construídos sobre uma malha de traçado ortogonal inicialmente criam um ambiente construído compacto com uma elevada taxa de ocupação e coeficiente de aproveitamento, onde a área livre é praticamente inexistente. 
Sob o enfoque ambiental: verifica-se que o núcleo das quadras, resultado da forma urbana existente, é caracterizado por espaços abertos delimitados pelos fundos das construções, com restrita visão do céu prejudicando o acesso ao sol e a disponibilidade de luz natural.

Somado a isso, a forma urbana compacta do conjunto pode prejudicar a ventilação natural o que somada à concentração do calor proveniente do aquecimento das superfícies edificadas, associada à falta de vegetação, eleva a temperatura do ar, criando um micro-clima mais desconfortável do que o natural da região.

A pouca permeabilidade ao vento interfere, nesse caso negativamente, no conforto dos pedestres nos espaços urbanos e no desempenho térmico das edificações. Além disso, a forma urbana pouco permeável à ventilação natural prejudica também a dispersão de poluentes e, conseqüentemente, compromete a qualidade do ar, tanto no nível das ruas como nas alturas dos pavimentos dos edifícios altos. Esse problema se agrava nos dias frios do ano, quando são registrados fenômenos de inversão térmica, em que uma camada elevada de ar frio impede à dissipação da poluição gerada no nível do pedestre, trazendo risco a saúde publica.

Soma-se a essas condições ambientais o ruído urbano gerado pelo intenso fluxo de veículos e atividades socioeconômicas concentradas no nível das ruas, é contido pela forma urbana compacta, criando situações de extremo desconforto no período diurno.

Com relação aos espaços livres, esses se restringem ao ambiente das calçadas e ruas estreitas, já que os núcleos das quadras, formados pela parte residual dos lotes edificados, são espaços privados, sem acesso direto ao público. Além de limitados, os espaços públicos apresentam baixa qualidade ambiental causada pelo ruído urbano, poluição e demais condições microclimáticas desfavoráveis ao conforto ambiental do pedestre. 


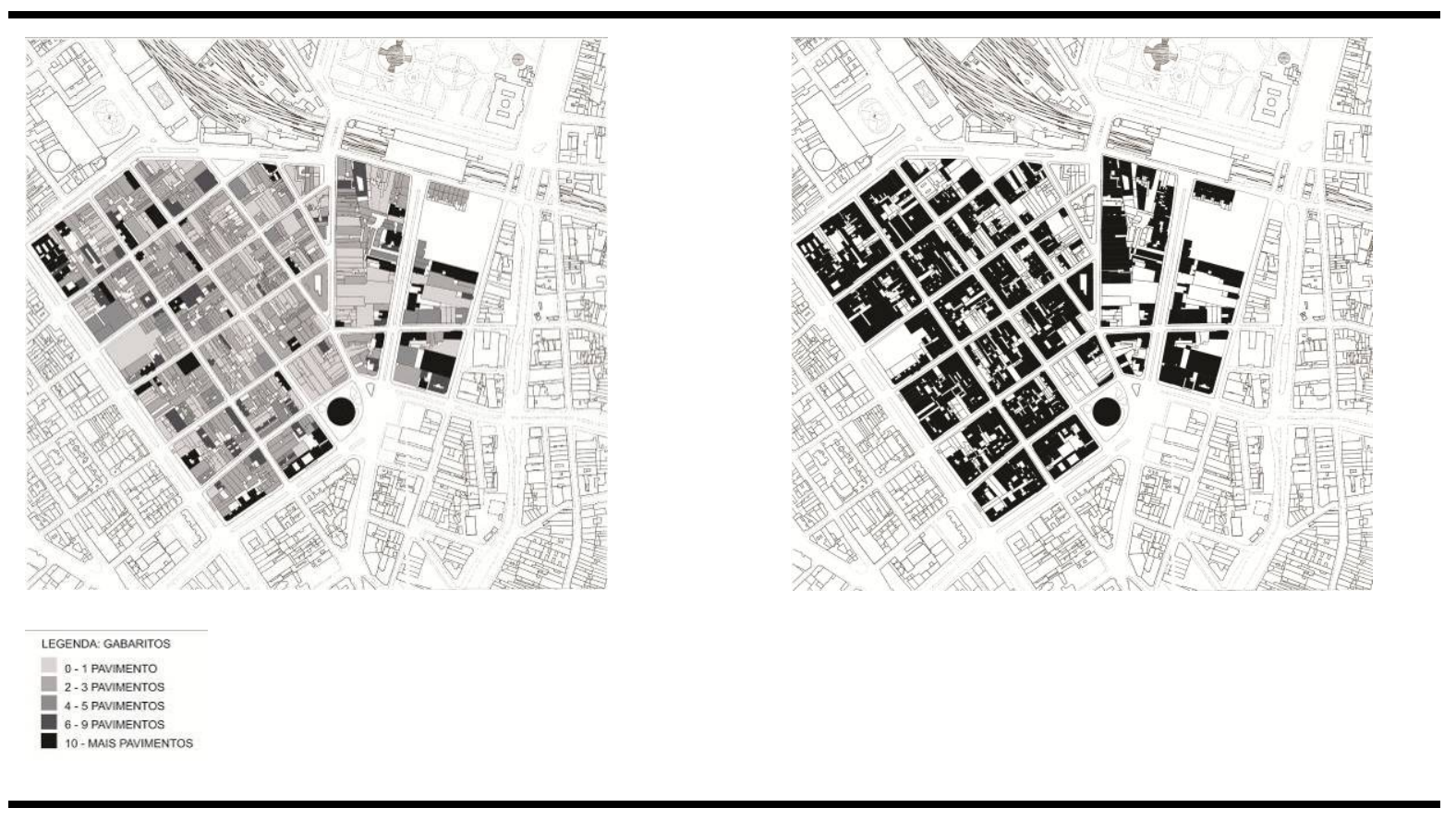

Figura 151: Mapa de gabarito dos Figura 152: Mapa de cheios e vazios da edifícios da área de estudo, PRIH do área de estudo, PRIH do bairro da Luz, bairro da Luz, São Paulo. São Paulo.

Fonte: Material produzido pela equipe do Fonte: Material produzido pela equipe do projeto projeto

- Meio ambiente

\section{Relevo (solo urbano) ${ }^{114}$}

A avaliação das condições gerais do solo na cidade de São Paulo remete especialmente à presença de áreas de risco devido às inundações e escorregamento, de áreas de erosão e assoreamento e de áreas contaminadas.

\section{Energia}

Segundo Goldemberg (2001), no Brasil o parque edificado é responsável por $46 \%$ do consumo energético nacional, sendo que o setor residencial $(22,6 \%)$ e o comercial $(14,2 \%)$ são os principais responsáveis pelos altos índices de crescimento do consumo.

\footnotetext{
114 Apesar da importância da variável ambiental solo urbano, o método proposto não aborda as questões relacionadas a ela, devido à necessidade de reduzir o número de variáveis para conclusão do trabalho. Porém destaca-se que a inclusão dessa variável no método é uma das perspectivas de continuação da pesquisa.
} 
Diante disso verifica-se a real necessidade de reduzir o consumo energético, através da eficiência energética das edificações, dos modelos de ocupação urbana e da geração de energia renovável.

Segundo dados de 2005 (BRASIL, 2005), sobre o consumo desagregado de energia elétrica do setor residencial no Brasil, observa-se que o chuveiro elétrico é responsável por $26 \%$. Diante desse cenário, a captação da energia solar para aquecimento de água para uso doméstico tem um papel determinante nas diretrizes do desenho urbano com base em critérios ambientais.

Além disso, a iluminação é responsável por $24 \%$ do consumo de energia do setor residencial no Brasil (BRASIL, 2005), mostrando mais uma vez a necessidade de aproveitar a radiação solar para tecnologias passivas, nesse caso, para otimizar aproveitamento da iluminação natural no interior das habitações, reduzindo a o uso da iluminação artificial e, conseqüentemente, a demanda de energia elétrica.

A geração de energia elétrica com o uso da radiação solar, também é uma estratégia interessante a ser adotada nesse contexto. De acordo com os dados de radiação solar na latitude de São Paulo (FROTA, 2004), verifica-se a real potencialidade de utilizar essa para geração de energia através de painéis fotovoltaicos e para aquecimento de água por meio de coletores solares instalados nas coberturas das edificações.

\section{Vegetação}

Com relação à área do PRIH da Luz, devido à ocupação compacta, com uma elevada taxa de ocupação e coeficiente de aproveitamento, o verde é praticamente inexistente e o solo urbano é altamente impermeável ás águas de chuva.

Isso tem conseqüências negativas diretas sobre o micro-clima urbano, na qualidade do ar e no ciclo natural da água. Somado a isso, a impermeabilidade do solo aumenta o risco de inundações durante os períodos de chuvas intensas.

Além dos aspectos ambientais, a ausência de vegetação tem impacto na estética urbana e efeitos psicológicos nos seus habitantes.

\section{Clima}

O município de São Paulo está localizado a $23^{\circ} 37^{\prime}$ de latitude sul e $46^{\circ} 39^{\prime}$ de longitude oeste. Segundo a classificação climática de Koppen-Geiger (2009), a cidade de São Paulo 
se configura como clima tropical de altitude, que apresenta condições amenas em termos de temperatura e umidade do ar por $70 \%$ do ano, estando sob o efeito de radiação solar elevada. Essa categoria climática incorpora regiões onde os verões são quentes e as temperaturas médias do mês mais frio encontram-se com médias superiores a $10^{\circ} \mathrm{C}$.

O diagnóstico climático para a cidade de São Paulo foi realizado a partir do aplicativo Climaticus (ALUCCI, 2003), com base nas normais climatológicas ${ }^{115}$ do Instituto Nacional de Meteorologia, INMET (baseado em dados obtidos pela estação meteorológica Mirante Santana - A701 - São Paulo, SP).

O Climaticus apresenta as principais estratégias de projeto visando à adequação climática, baseada na carta bioclimática de Givoni (1976). Além disso, o software oferece uma análise do clima em relação aos períodos noturnos e diurnos de calor, frio ou conforto, a partir das tabelas de Mahoney (KOENIGSBERGER et al, 1977).

\section{Tabela 15: Normais climatológicas para a cidade de São Paulo}

Fonte: Alucci, 2006

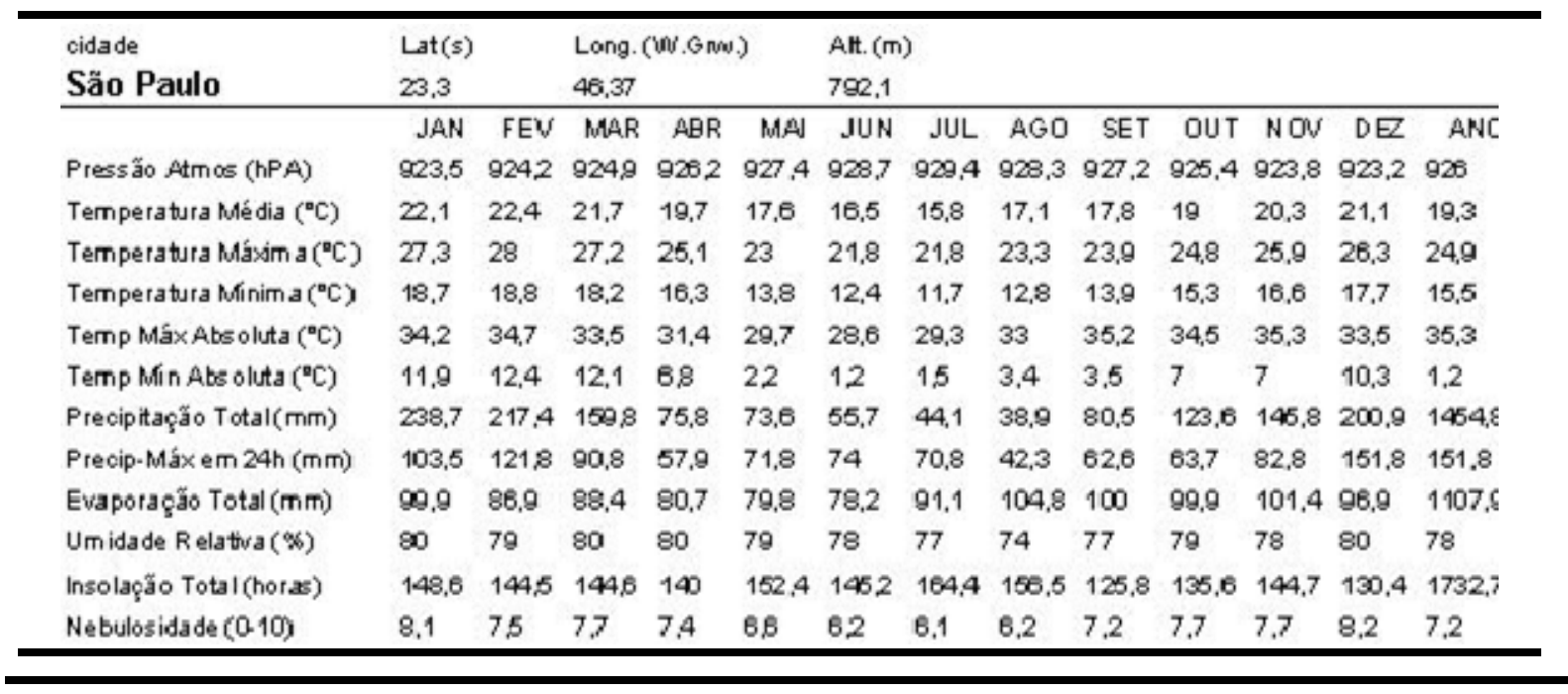

Figura 153 - Avaliação bioclimática da Figura 154 - Avaliação bioclimática da cidade de São Paulo pelos métodos de cidade de São Paulo pelos métodos de Mahoney e Givoni. Mahoney e Givoni.

Fonte: Climaticus 2006.

Fonte: Climaticus 2006.

\footnotetext{
${ }^{115}$ As normais são médias dos dados obtidos em uma determinada estação em um período de 30 anos, sendo que a mais recente compreende o período entre 1960 e 1990.
} 


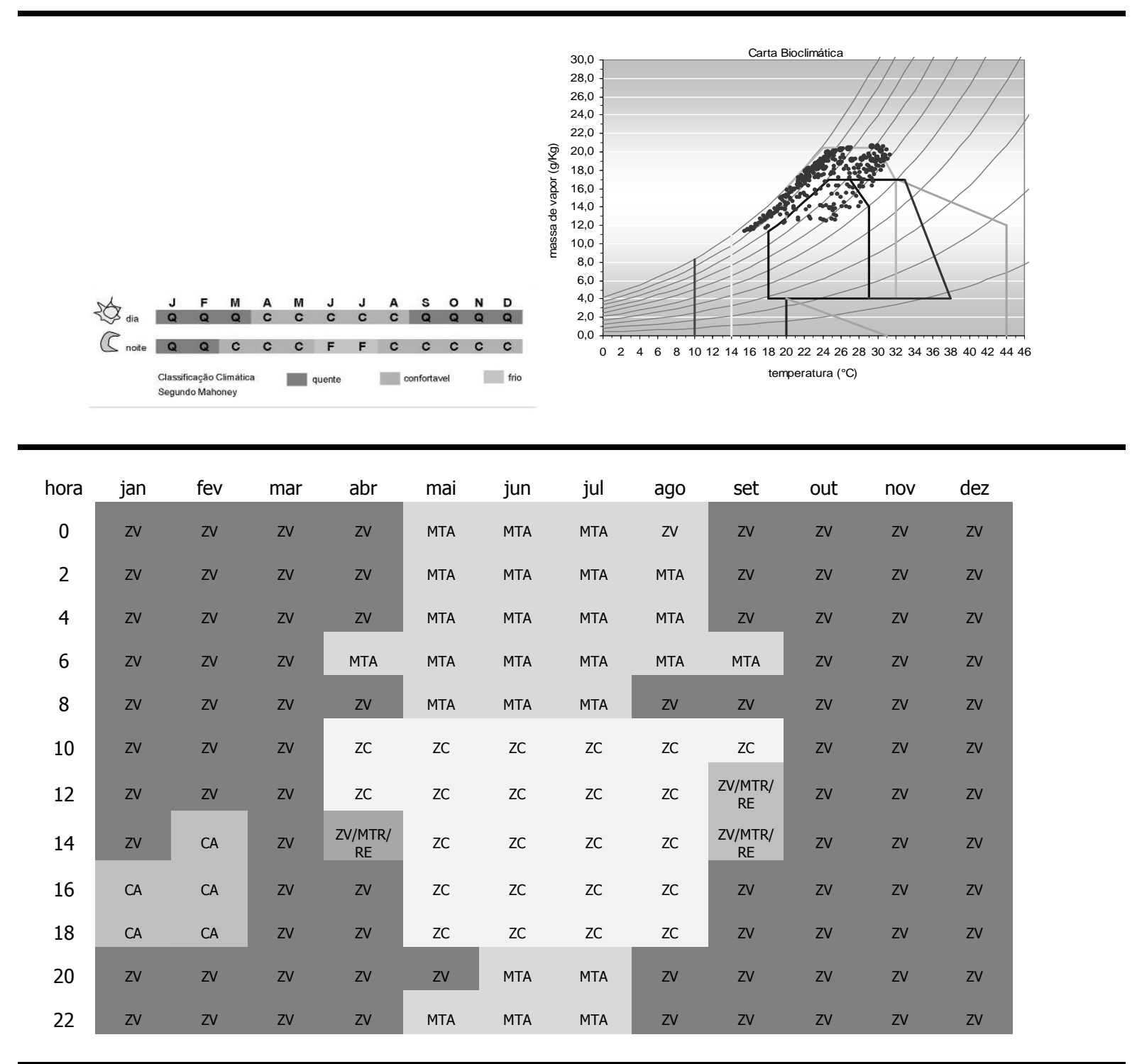

$17,0 \%$ Conforto (ZC)

63,5 \% Ventilação (ZV)

$17,4 \%$ Massa Térmica/ Aquecimento (MTA)

2,4 \% Resfriamento Evaporativo (RE)

$3,1 \%$ Condicionamento Artificial (CA)

Figura 155: Diagnóstico Climático da cidade de São Paulo, baseado em dados de temperatura e umidade do ar plotados sobre a carta psicrométrica, com a delimitação das zonas bioclimáticas.

Fonte: Climaticus 2006.

De acordo com o diagnóstico climático, adaptado a partir das propostas de Givoni (1998), no clima da cidade de São Paulo $17,0 \%$ das horas do ano oferecem condições de 
conforto térmico (Climaticus, 2005) (116 $^{11}$ O clima local favorece o projeto de edifícios residenciais de satisfatória qualidade ambiental sem a necessidade de sistemas artificiais de climatização que, de acordo com o diagnóstico, indica 3,1 \% das horas do ano.

No entanto, vale destacar que nos meses quentes do ano, o conforto térmico nos espaços internos e externos vai depender do bloqueio da radiação solar e da eficiência da ventilação natural. Durante $63,5 \%$ do ano o uso da ventilação natural é a estratégia mais indicada para se alcançar condições de conforto, principalmente nos períodos mais quentes, entre os meses de outubro a maio.

Em 2,4\% das horas do ano a combinação de temperaturas elevadas e baixa taxa de umidade relativa do ar sugerem o emprego de resfriamento evaporativo para obtenção das condições desejáveis de conforto.

Já no inverno, o isolamento térmico e a captação da radiação solar, juntamente com a ventilação controlada, constituem as principais estratégias de projeto para o conforto térmico nos espaços internos. A significativa amplitude média (entre $9^{\circ} \mathrm{C}$ e $10^{\circ} \mathrm{C}$ ) indica a possibilidade de se beneficiar da utilização de massa térmica para aquecimento, armazenando o calor durante o dia quente. Essa estratégia é recomendada para 17,4\% das horas do ano, concentrado nas primeiras e últimas horas dos dias de inverno, prioritariamente.

Essa interpretação do clima é válida como indicação das principais estratégias de projeto, com a finalidade de orientar e/ou verificar as definições do partido arquitetônico, apontando as potencialidades e as dificuldades para se alcançar conforto ambiental e eficiência energética.

Outra variável favorável é a disponibilidade de luz natural. O gráfico apresentado na Figura 156 relaciona o nível mínimo de iluminâncias em klux com a freqüência de ocorrência das mesmas durante o período anual em valores percentuais. Essa relação é inversamente proporcional, pois quando o nível exterior aumenta, diminui a freqüência de ocorrência e vice-versa. Na leitura do gráfico verifica-se que o céu de São Paulo oferece grandes quantidades de luz, em $80 \%$ das horas de sol do ano, por exemplo, a

\footnotetext{
${ }^{116}$ Cabe ressaltar que os dados de temperatura utilizados nessa análise foram registrados à sombra, seguindo padrões internacionais de medição.
} 
disponibilidade de luz natural é de, no mínimo, 11.000 lux. Certamente, esse é um fator positivo para o bom desempenho luminoso do edifício.

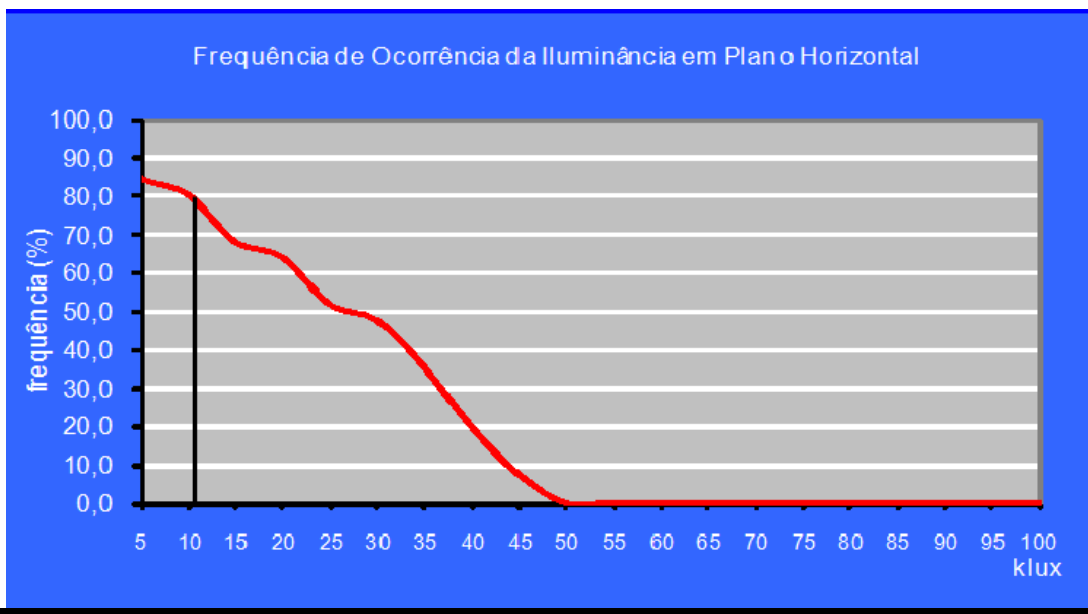

Figura 156: Frequência de ocorrência da iluminância no plano horizontal para São Paulo Fonte: Climaticus, 2006.

Por outro lado, a cidade apresenta uma grande variedade de microclimas urbanos marcados por problemas de qualidade do ar, aquecimento do ambiente construído, nos períodos quentes, ventilação urbana insuficiente, ruído urbano e também ilhas de calor. Problemas esses que estão associados aos aspectos da forma urbana e a falta de vegetação (Prefeitura de São Paulo, 2002).

\section{ETAPA 02 - DEFINIÇÃO DOS REQUISITOS E CRITÉRIOS AMBIENTAIS RELACIONADOS AO ADENSAMENTO E A FORMA URBANA}

Os centros urbanos ainda podem acomodar um número bem maior de pessoas com qualidade e dignidade, sem que isso cause impactos negativos sobre o meio ambiente, ao contrário, que possa ser positivo em diferentes aspectos, as propostas urbanas foram definidas com base em sete temas do domínio ambiental das cidades: acesso ao sol para edifícios e espaços abertos; qualidade do ar; conforto térmico nos espaços abertos; conforto acústico nos espaços abertos e nos edifícios; potencial de geração de energia solar nas cobertura de edifícios; acessibilidade no espaço publico e mobilidade do pedestre e drenagem e coleta da água de chuva. ${ }^{117118}$

\footnotetext{
${ }^{117}$ No método proposto esses temas são separados em: exigências, requisitos e critérios.
} 
Quanto à escala de prioridades, tendo em vista as questões problemáticas do contexto ambiental local, desse conjunto quatro foram identificados como parâmetros principais do desempenho ambiental da forma urbana: qualidade do ar; conforto acústico nos espaços abertos e nos edifícios, acessibilidade no espaço publico e drenagem e coleta da água de chuva. As questões de conforto térmico nos espaços abertos, acesso ao sol para edifícios e espaços abertos, disponibilidade de luz natural para edifícios e potencial de geração de energia pela a partir da radiação solar vieram agregar qualidade e valor ao projeto pela melhoria das condições ambientais em edifícios e espaços abertos, além de minimizar a demanda energética a ser respondida pela infra-estrutura urbana (GONÇALVES \& KRONKA, 2008).

Apesar de terem sido considerados prioridade nesse estudo de caso, os fatores relacionados à drenagem e coleta de águas pluviais e à acessibilidade no espaço público e mobilidade do pedestre ainda não foram inseridos no método proposto e por essa razão não serão aqui contemplados.

\section{ETAPA 03 - PROPOSTA DE DESENHO URBANO: DEFI NI ÇÃO DOS CENÁRI OS}

Antes de descrever a proposta de adensamento com qualidade ambiental da área do PRIH da Luz, em São Paulo, é importante destacar que alguns valores adotados, principalmente em relação à densidade inicial, porcentagem de habitações de interesse social e habitações de médio padrão e alguns critérios como o de demolição, divisão de usos, etc. são sujeitos a discussões, apesar de todos estarem embasados em levantamento de dados sócio-econômicos e sobre o estoque construído e informações fornecidas por profissionais da área.

A hipótese inicial de densidade líquida para a formulação das propostas urbanas foi de 2.500 pessoas por hectare, baseada na capacidade instalada do sistema existente de transporte publico (trem e metro) que dá suporte aos bairros centrais (Metro, 2008 apud, GONÇALVES e KRONKA MÜLFARTH, 2008).

118 Esses temas serão abordados com mais detalhes a seguir na etapa de avaliação do desempenho das edificações e do conjunto, para facilitar a compreensão dos critérios e das ferramentas de avaliação. 
Com base em metas do poder público local, $40 \%$ da nova população faz parte do programa de financiamento HIS (Habitação de Interesse Social), para o qual foi estabelecida, nesse exercício, a unidade residencial padrão de $50 \mathrm{~m}^{2}$ para famílias de quatro integrantes, enquanto que os $60 \%$ restantes devem ser incluídos no programa HMP (Habitação Médio Padrão), para o qual foi definido o tamanho padrão de $70 \mathrm{~m}^{2}$ também para famílias de quatro integrantes. Com os tamanhos padrões das unidades residenciais e as porcentagens de cada grupo de financiamento foi calculada a área total necessária para abrigar a nova densidade (tabela $\mathrm{x}$ ).

Para alcançar a meta de densidade era necessária a inserção de novos edifícios, levando a uma proposta criteriosa de demolição de parte do estoque construído. A abertura de espaço livre teve o propósito duplo de criar espaço para novas edificações e também para a ampliação do espaço publico quase inexistente, tendo em vista a elevada taxa de ocupação da área.

Tabela 16: Áreas relacionadas ao projeto de desenho urbano e adensamento, contemplando a situação atual, a proposta de demolição e a proposta de adensamento urbano.

Fonte: GONÇALVES e KRONKA MÜLFARTH, 2008.

\begin{tabular}{ll}
\hline Situação atual & \\
área das quadras & $268.217,00 \mathrm{~m}^{2}$ \\
área construída total & $692.551,00 \mathrm{~m}^{2}$ \\
Proposta de demolição & \\
área construída que permanece & $541.131,00 \mathrm{~m}^{2}$ \\
área construída a demolir & $151.420,00 \mathrm{~m}^{2}$ \\
Proposta de adensamento urbano & \\
área residencial a construir (40\% HIS + 60\% HMP) & $1.424 .420,00 \mathrm{~m}^{2}$ \\
área comercial a construir & $284.000,00 \mathrm{~m}^{2}$ \\
área total a construir & $1.708 .420,00 \mathrm{~m}^{2}$ \\
\hline
\end{tabular}

De forma resumida adotou-se como premissas do projeto:

- Demolição de edifícios não tombados e sem valor arquitetônico, em estado de conservação ruim ou péssimo e até cinco pavimentos. 
- Redução do o número de veículos particulares, assim como restrição dos espaços para estacionamentos na área de interesse.

- Os níveis térreos e primeiro pavimento de todos os novos edifícios foram reservados para o uso de comércio e serviços e a área para acomodar a nova densidade populacional foi prevista a partir do segundo pavimento.

Para alcançar a meta de densidade populacional estabelecida foram adotadas três tipologias de adensamento: edifícios torre, edifícios lâminas e edifícios perimetrais. Porém, durante o processo de projeto, as tipologias de torre e lâmina formaram um único cenário a ser estudado.

Assim, definidas as tipologias edificatórias a serem adotadas e calculada a área a ser construída foram desenvolvidas duas propostas de adensamento inseridas no contexto existente, após a demolição de algumas edificações.

A primeira proposta consiste na implantação de novos edifícios com alturas variando de 15 a 35 pavimentos ao lado dos existentes, formando a quadra perimetral. No caso a área de intervenção é delimitada pelas edificações, criando no seu interior espaços públicos protegidos do ambiente das calçadas e ruas. Esse espaço aberto no centro das quadras é conectado ao espaço público das calçadas por acessos de pedestres.

A segunda proposta é formada com edifícios mais altos, incluindo tipologias de edifícios de base quadrada, torres e também de base retangular, lâminas, dependendo da área de possível ocupação do novo edifício. Nessa solução, os novos edifícios com altura variando de 15 a 55 pavimentos, foram implantados em quadras abertas, soltos dos existentes. Essa proposta traz o conceito de extensão do espaço público das calçadas, criando pequenas praças no espaço das quadras, e edifícios novos separados dos existentes e recuados do limite das calçadas.

A tipologia do edifício lâmina aparece nas duas propostas, porém com um gabarito maior na segunda proposta.

Nas duas propostas, a altura dos edifícios novos foi estabelecida com base no gabarito do entorno imediato, mantendo o objetivo de inserir edifícios mais altos, porém com uma relação de proporção com o contexto, ou seja, os edifícios novos e existentes foram agrupados de acordo com a sua altura (GONÇALVES e KRONKA MÜLFARTH, 2008). 
Junto ao processo de implantação das edificações, foram projetadas as áreas verdes, com relação à quantidade e localização, além da definição da distribuição de usos e tipos de habitação nas quadras e nos edifícios. As propostas também consideraram o uso do espaço público, incluindo áreas de passagem e permanência curta e prolongada (projeto de adequação urbana).

Além dessas, no exercício de projeto foram tratadas algumas questões específicas, que no método proposto elas ainda não foram inseridas, tais como: coleta e reuso de águas, acessibilidade e conforto ergonômico do espaço público (incluindo percursos de pedestres) e tratamento das superfícies do espaço público (para o conforto térmico, a acústica urbana, a absorção das águas de chuva e o conforto ergonômico).

\section{ETAPA 04 - AVALI AÇÃO DE DESEMPENHO}

Projetados os cenários, cenário 01 , constituído de bloco perímetro e, cenário 02 , constituído de edifícios lâminas e torres, foram realizadas avaliações da qualidade ambiental e ao conforto do usuário nos espaços abertos e nos edifícios, com base nos temas já mencionados na etapa 02.

Segundo Gonçalves e Kronka (2008), o processo de avaliação de desempenho ambiental das soluções de ocupação incluiu um conjunto de etapas e técnicas, reunindo medições de variáveis climáticas (temperatura do ar, umidade e vento) e ruído urbano no local do projeto, simulações computacionais com ferramentas de avançada complexidade metodológica (como no caso dos cálculos de captação de energia solar para o aquecimento de água e da ventilação urbana), métodos analíticos (como feito no caso das previsões de ruído urbano) e exercícios de projeto com base em referências e normas nacionais e internacionais (como nos da drenagem urbana).

Os critérios e requisitos foram avaliados somente em uma quadra, devido ao limite de tempo para a realização da pesquisa. Porém destaca-se a importância de avaliar todas as quadras, já que o desempenho ambiental das edificações e dos conjuntos está ligada diretamente a forma urbana da quadra e do entorno imediato.

Para avaliação do acesso ao sol nas unidades residenciais, foi estabelecido o critério de uma hora de sol a partir dos segundo piso, em todas as fachadas possíveis, no solstício de inverno. 
Esse foi definido com base nos critérios de insolação propostos por Assis, Valadares \& Souza (1995) que, segundo Brandão (2004), mostraram-se adequados para uma avaliação simplificada da questão. Por essa razão, Brandão (2004) adotou o mesmo critério para na elaboração do seu código de obras da cidade de Mogi das Cruzes, em São Paulo.

O estudo foi feito utilizando a carta solar para a latitude da cidade de São Paulo, marcando-se os ângulos de obstrução máximos que permitissem a incidência de sol no período desejado. Sendo assim, verificou-se que para atender ao critério estabelecido, os ângulos de obstrução para as fachadas Noroeste, Oeste e Sudoeste, são de $70^{\circ}, 65^{\circ} \mathrm{e}$ $63^{\circ}$, respectivamente (Figura 157 ).

Devido à simetria da trajetória solar com relação ao eixo norte-sul, os ângulos máximos de obstrução para as fachadas Noroeste, Oeste e Sudoeste são os mesmos das fachadas Nordeste, Leste e Sudeste, respectivamente.

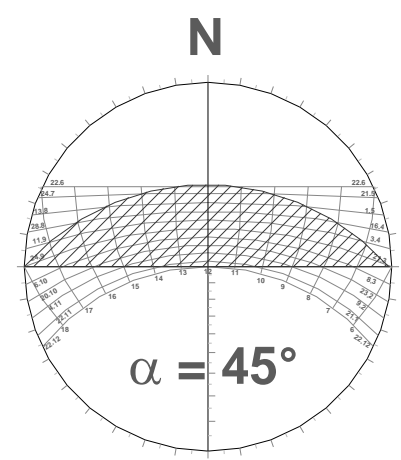

Fachada Norte

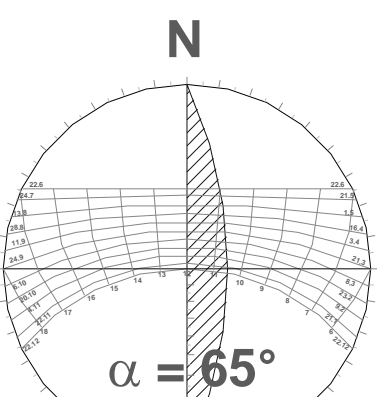

Fachada Leste

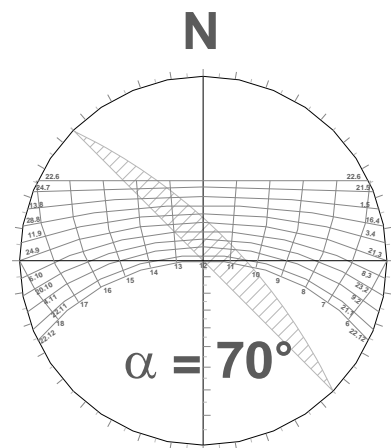

Fachada Nordeste

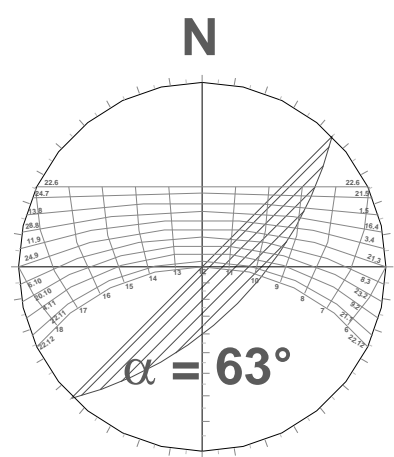

Fachada Sudeste

Figura 157: Análise das obstruções máximas que permitissem uma hora de sol nas fachadas Norte, Nordeste, Leste e Sudeste

Fonte: Brandão 2004. 
Destaca-se que como o objetivo é proteger o sol do vizinho e não o seu próprio, ângulo de obstrução deve ser aplicado na fachada de orientação oposta. Desse modo, cada edifício tem o seu acesso ao sol garantido porque a construção vizinha segue os ângulos propostos. Assim, o recuo com ângulo de $45^{\circ}$ deve ser aplicado na fachada sul do edifício, o de $70^{\circ}$ nas fachadas sudeste e sudoeste, o de $63^{\circ}$ nas fachadas nordeste e noroeste e o de $65^{\circ}$ nas fachadas leste e oeste.

Dessa forma foi possível evitar que os edifícios novos sombreassem totalmente (quesito tempo) os edifícios do entorno, da mesma maneira que orientava a implantação desses em relação aos edifícios existentes.

Brandão (2004) ressalva que a grande inovação dessa proposta é sugerir recuos diferenciados para cada orientação, observando-se que caso se tomasse o ângulo mais restritivo como critério, a densidade construtiva seria reduzida excessivamente sem necessidade.

Após a implantação dos novos edifícios foi realizada uma avaliação de uma quadra específica na qual foi verificado através de um estudo detalhado o impacto das novas edificações no mascaramento do entorno imediato. Para isso foram definidos pontos de interesse nas fachadas dos edifícios e geradas as máscaras do sombreamento com o auxílio da ferramenta computacional Ecotect ${ }^{119}$.

Segundo Gonçalves e Kronka (2008), com a hibridade geométrica do tecido urbano, acentuada nas duas opções de ocupação urbana (marcado pela mistura de edifícios existentes e novos), combinada às alturas favoráveis ao acesso sol nas orientações nordeste e noroeste em que estão estabelecidas as quadras urbanas, foi possível atender ao critério mínimo de acesso ao sol em todo o conjunto.

\footnotetext{
${ }^{119}$ Disponível em:<http://www.squ1.com> Acesso em: jan 2007.
} 

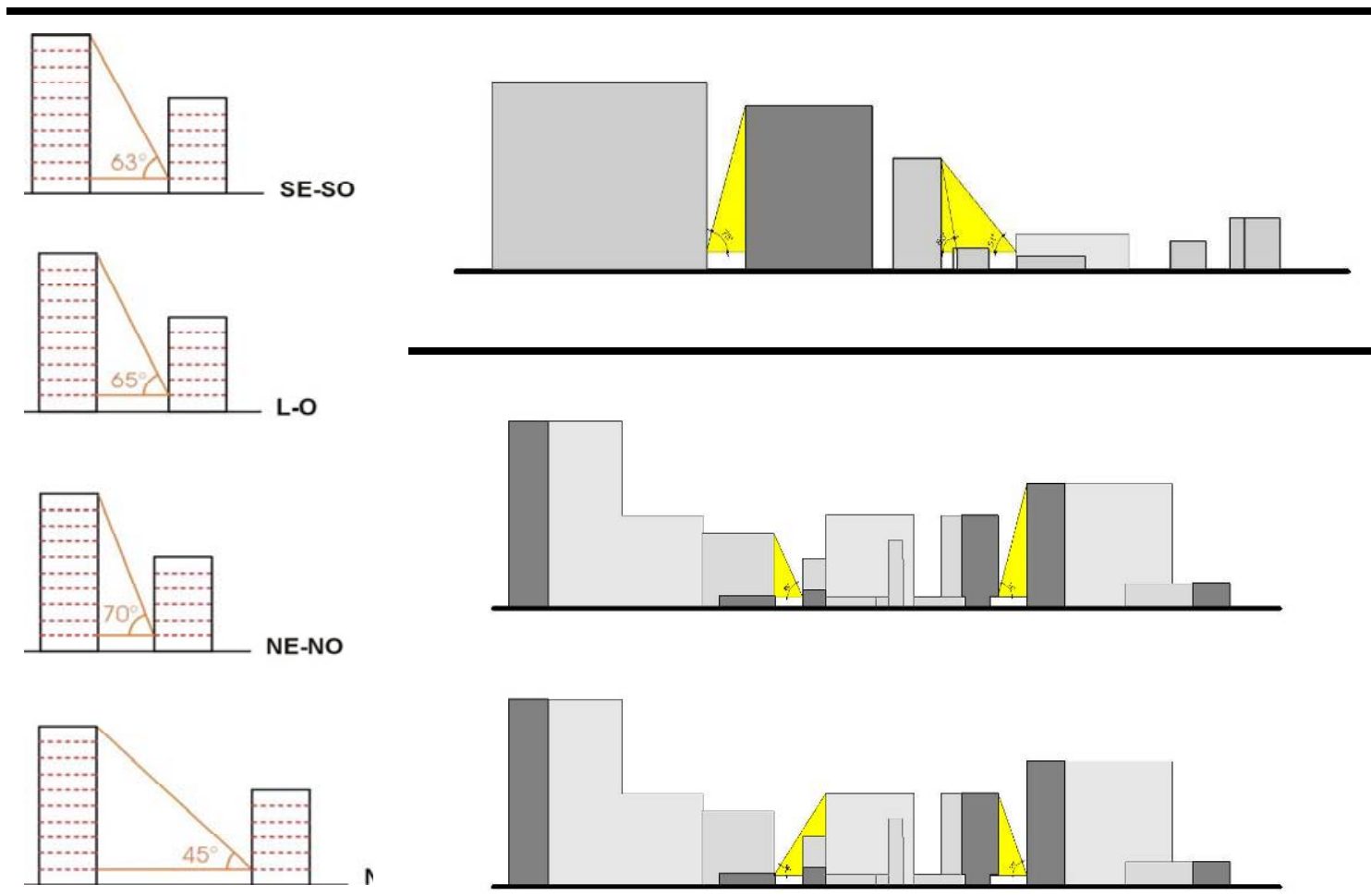

\section{Figura 158: Ângulos Figura 159: Aplicação e verificação dos ângulos de de obstrução obstrução da quadra adotada para estudo, visando a (máximo) para cada garantia do acesso ao sol. orientação para latitude $\mathbf{2 4}^{\circ}$}

Fonte: MIANA, Anna; MOURA, Norberto e KLETTENHOFER, Mariane. Relatório Técnico de Insolação. Projeto "Desenho Urbano para o Desempenho Ambiental com Benefícios SócioEconômicos". LABAUT FAUUSP, 2008. Acesso restrito.

Para avaliar o conforto térmico nos espaços externos e nas edificações, o acesso ao sol é apenas uma das variáveis. Destaca-se que a necessidade de sol ou sombra esta relacionada ao clima, época do ano e o período do dia, sendo que essa informação pode ser extraída do diagnóstico climático. Sendo assim, para avaliar a sombra gerada pela forma urbana nos espaços externos e nas edificações foi realizado um estudo de sombra dos dois cenários propostos através de simulações computacionais com o aplicativo computacional Ecotect. As simulações foram realizadas para todos os horários, nos solstícios de inverno, verão e equinócios. 


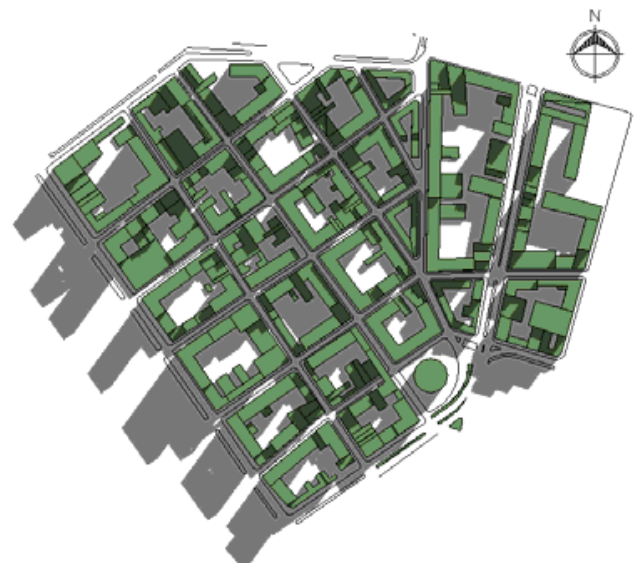

Figura 160: Estudo de sombra as 10hs no solstício de inverno - Cenário 01 quadras perimetrais

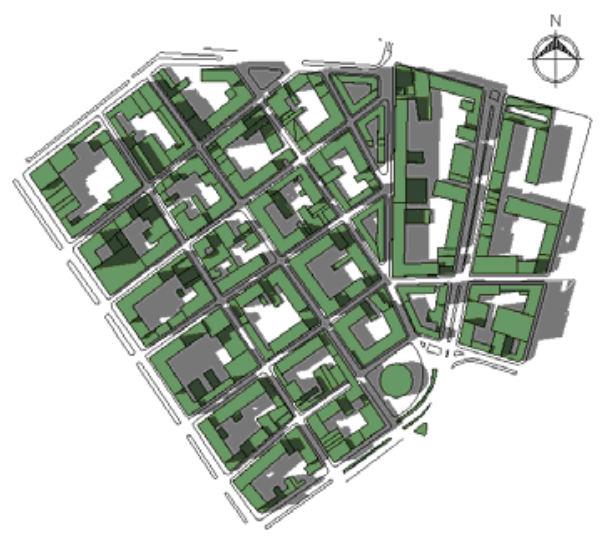

Figura 161: Estudo de sombra as 10hs no solstício de verão - Cenário 01 quadras perimetrais

Fonte: MIANA, Anna; MOURA, Norberto e KLETTENHOFER, Mariane. Relatório Técnico de Insolação. Projeto "Desenho Urbano para o Desempenho Ambiental com Benefícios SócioEconômicos". LABAUT FAUUSP, 2008. Acesso restrito.

Para a avaliação da qualidade do ar foram considerados três parâmetros: quantidade de veículos por hora, largura da via e velocidade do vento, utilizando o método proposto por Road World Association (SILVA, 2001). O método considera a emissão de poluentes e propõe uma vazão de ar fresco de diluição, que faz com que o nível de poluente se encontre abaixo de um dado valor. De acordo com o método, o indicador do nível de toxicidade é o $\mathrm{CO}$ e a base desse critério foi extraída dos Padrões Nacionais de Qualidade do Ar. $^{120121}$

Para avaliação da ventilação natural foram realizadas simulações computacionais utilizando o software CFX $5.7^{122}$, nas quais foram analisadas a velocidade e o percurso do vento.

\footnotetext{
120 PRATA SHIMOMURA, A. e BRANDÃO, Rafael. Relatório Técnico de Ventilação Natural e Qualidade do ar. Projeto "Desenho Urbano para o Desempenho Ambiental com Benefícios Sócio-Econômicos". LABAUT FAUUSP, 2008. Acesso restrito.

${ }^{121}$ CETEB - Companhia de Tecnologia de Saneamento Ambiental. Resolução CONAMA nº 03 de 28/06/90

122 Disponível em < http://www.esss.com.br/> Acesso em jan. 2007.
} 
Esse estudo foi realizado em duas fases: uma primeira fase de simulações das opções de ocupação, verificando as condições gerais de ventilação, identificando problemas e potencialidades de cada solução, gerando critérios para o projeto dos pavimentos térreos; e uma segunda fase de simulação detalhada de uma quadra padrão, considerando-se o projeto de térreo, verificando as melhorias obtidas no detalhamento.

As simulações de ventilação natural foram realizadas para duas direções, considerando o vento nos dias mais quentes, quando a ventilação é importante para o conforto térmico no ambiente construído e nos espaços externos e nos dias mais frios, quando se aumentam os riscos de ocorrência do fenômeno de inversão térmica, que concentra a poluição no nível do pedestre.

Com relação aos resultados observou-se que a proximidade entre os edifícios e o aumento do tamanho dos mesmos mostrou deficiências significativas para a ventilação urbana, principalmente no nível do pedestre. Essa situação é mais grave no cenário 01, formado por quadras perimetrais, onde o afastamento entre os edifícios é menor. Sendo assim, de maneira geral, os blocos perimetrais tiveram um desempenho mais desfavorável, de início, do que o visto no cenário 02 , constituído por quadras abertas com edifícios altos tipo torre e lâmina. No entanto, apesar do efeito da altura e da localização dos edifícios na distribuição e velocidade dos ventos, a permeabilidade dos primeiros pavimentos apresentou um efeito determinante, alcançando resultados corretivos, quando necessário (GONÇALVES e KRONKA, 2010) (ver Figura 162 e Figura 163).

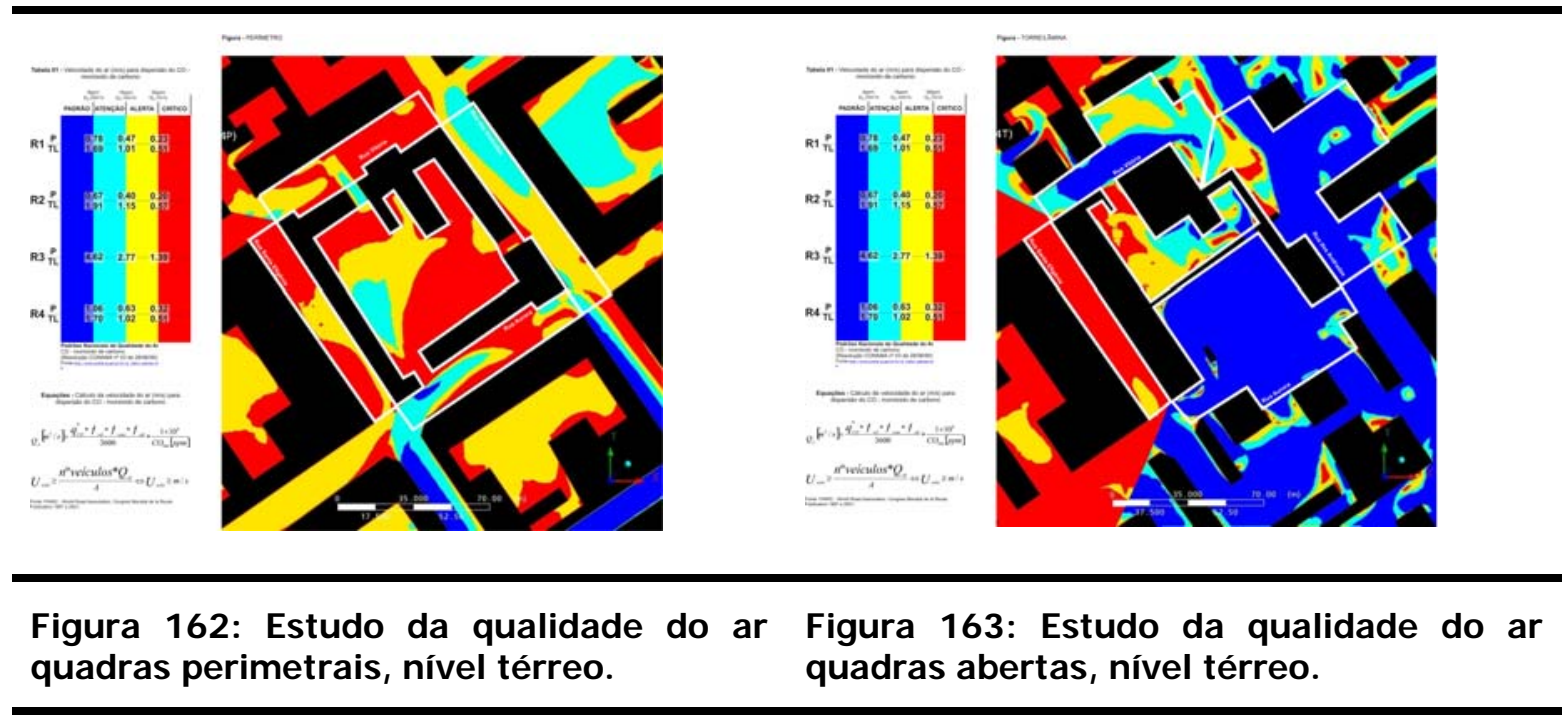

Fonte: PRATA SHIMOMURA, A. e BRANDÃO, Rafael. Relatório Técnico de Ventilação Natural e Qualidade do ar. LABAUT FAUUSP, 2008. Acesso restrito. 
Para avaliação do conforto térmico nos espaços abertos foram consideradas variáveis climáticas (temperatura do ar, umidade, velocidade do ar e radiação), atividades previstas para o uso dos espaços e o padrão de vestimenta das pessoas. Essas variáveis foram reunidas no índice Temperatura Equivalentes Percebida (TEP) de conforto térmico em espaços abertos desenvolvido por MONTEIRO (2008). ${ }^{123}$

Para cálculo da Temperatura Equivalente Percebida foram utilizados os resultados dos estudos de sombra e os estudos de ventilação natural, somados às condições de clima local, a avaliação da dimensão e localização de novas áreas verdes e avaliação do fator de visão de céu (Figura 164).

Segundo Monteiro, para efeito de cálculo foi considerada uma malha de pontos em cada uma das soluções de ocupação, marcando três configurações urbanas características do espaço aberto local: calçadas, centros das quadras e esquinas. ${ }^{124}$

Como resultado dessa avaliação, apresenta-se um mapeamento das condições de conforto térmico das áreas que se encontram nas zonas de: neutralidade, pouco calor, calor e muito calor.

Ambas as soluções apresentaram-se satisfatórias, tendo em vista as condições impostas pelo clima local. Em áreas de permanência para a tipologia das quadras perimetrais e em áreas de passagem para a tipologia das quadras abertas, os resultados apresentaram ligeiramente mais significativos (ver Figura 165 e Figura 166).

Observa-se que as quadras perimetrais apresentam maiores sombreamentos, devido tanto a forma urbana quanto a proposição de áreas verdes, porém condições de ventilação mais desfavorável. Por outro lado, no cenário 02 com edifícios tipo torre e lâmina, o espaço público aberto ao ambiente das calçadas apresenta menos áreas sombreadas, mas uma ventilação mais satisfatória. (GONÇALVES \& KRONKA, 2008).

\footnotetext{
123 MONTEIRO, Leonardo. Relatório Técnico de Conforto Térmico nos espaços abertos. Projeto "Desenho Urbano para o Desempenho Ambiental com Benefícios Sócio-Econômicos". LABAUT FAUUSP, 2008. Acesso restrito.

124 MONTEIRO, Leonardo. Relatório Técnico de Conforto Térmico nos espaços abertos. Projeto "Desenho Urbano para o Desempenho Ambiental com Benefícios Sócio-Econômicos". LABAUT FAUUSP, 2008. Acesso restrito.
} 


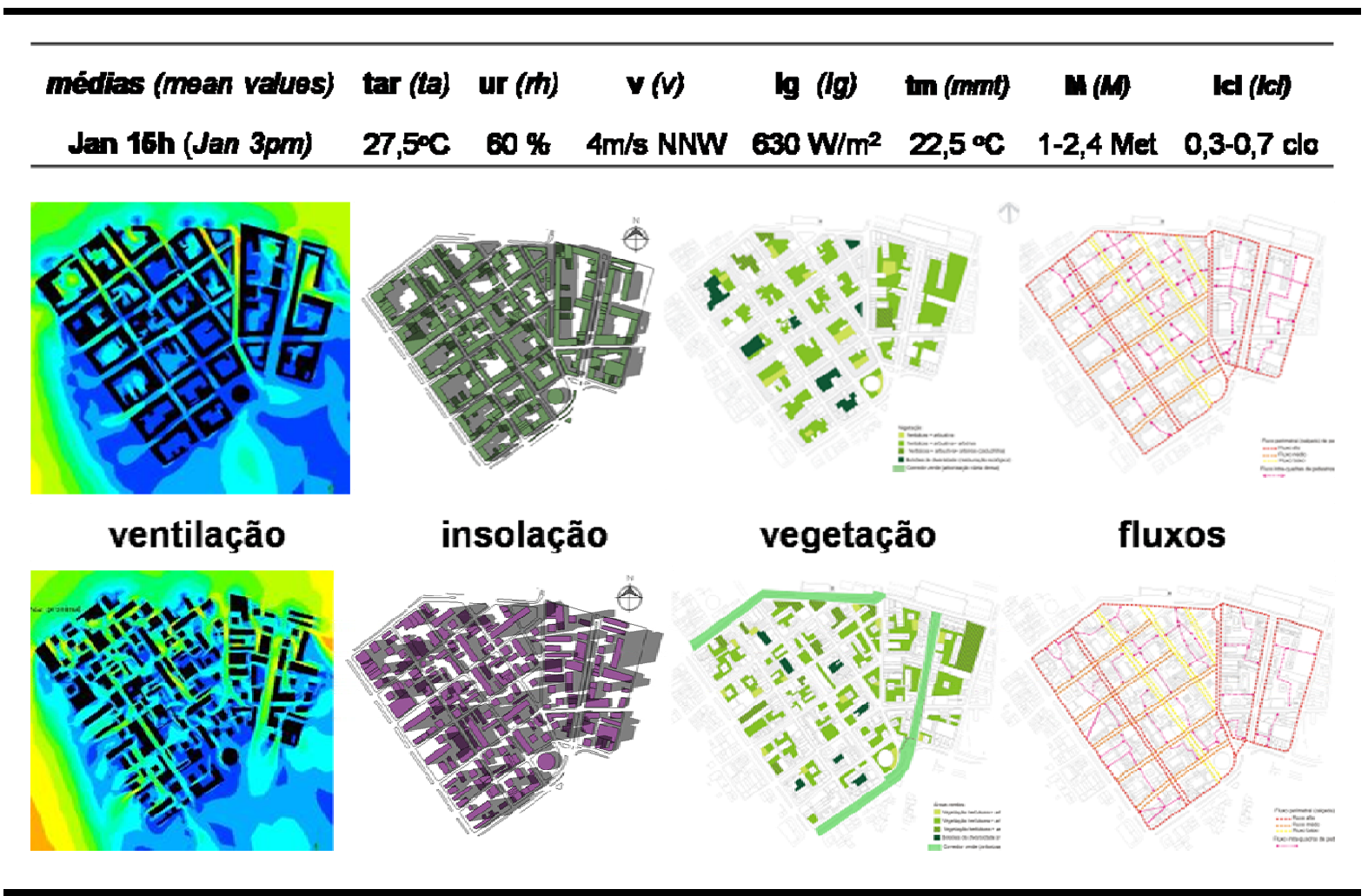

Figura 164: Variáveis e estudos técnicos para avaliação do conforto térmico nos espaços abertos

Fonte: Material produzido pela equipe do projeto
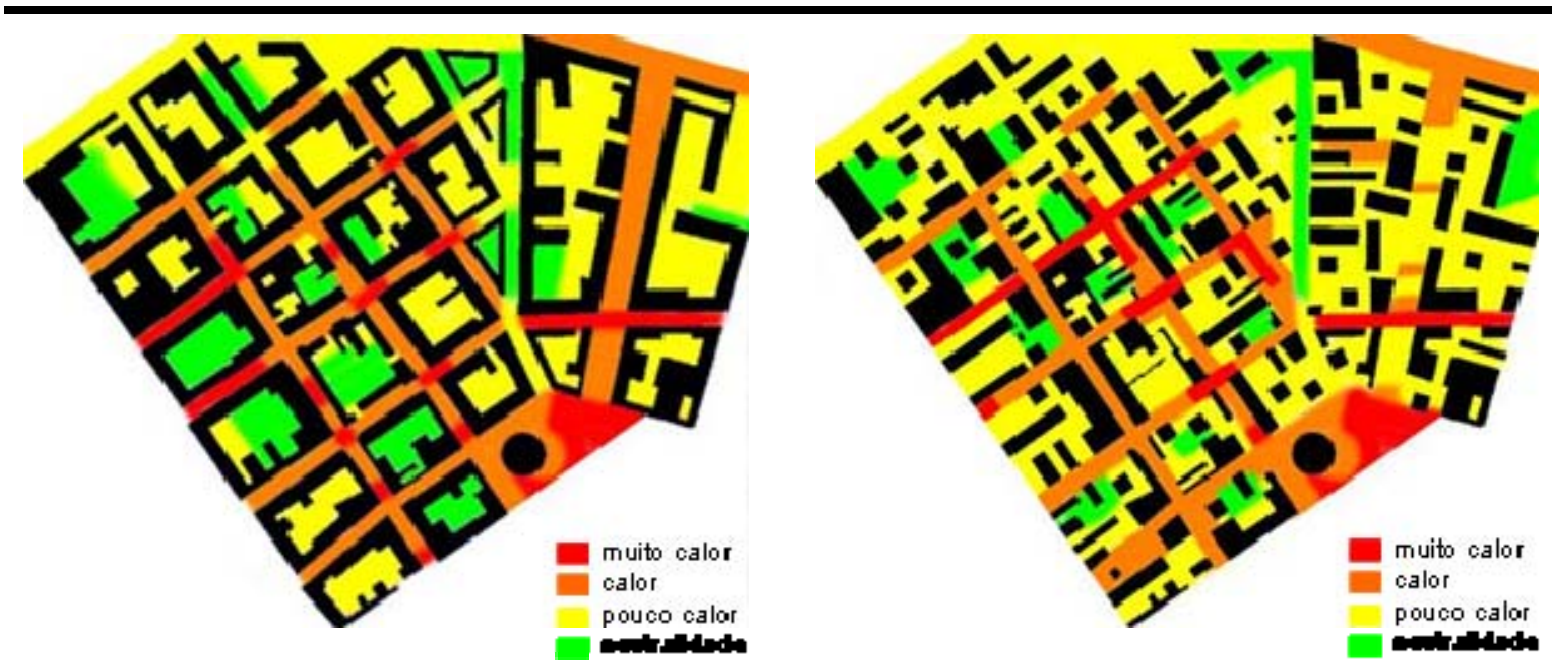

Figura 165: Desempenho do conforto térmico nos espaços abertos - Cenário 01 quadras perimetrais.

Figura 166: Desempenho do conforto térmico nos espaços abertos - Cenário 02 quadras abertas.

Fonte: MONTEIRO, Leonardo. Relatório Técnico de Conforto Térmico nos espaços abertos. Projeto "Desenho Urbano para o Desempenho Ambiental com Benefícios Sócio-Econômicos". LABAUT FAUUSP, 2008. Acesso restrito. 
Visando a redução do consumo de energia elétrica das unidades residenciais, foi definida como estratégia energética a captação de energia solar para o aquecimento de água com a instalação de coletores solares nas coberturas das edificações. Além disso, foi proposta a geração de energia solar através de painéis fotovoltáicos, também instalados nas coberturas das edificações.

Para avaliar o potencial de geração de energia renovável e captação de energia solar para aquecimento de água utilizou-se como método de avaliação as diretrizes de cálculo do Decreto Municipal 49.148 (PREFEITURA DO MUNICÍPIO DE SÃO PAULO, 2008), para a instalação de sistema de aquecimento de água por energia solar nas novas edificações do Município de São Paulo. ${ }^{125}$ O potencial de geração de energia solar por meio de painéis fotovoltaicos teve seu desempenho comparado ao dos coletores solares para aquecimento de água.

O Decreto (PREFEITURA DO MUNICÍPIO DE SÃO PAULO, 2008) recomenda o estudo do sombreamento da área de colocação dos coletores solares no dia 6 de abril às 9h; $12 \mathrm{~h}$ e 15h. Esse estudo foi realizado com o aplicativo computacional Ecotect ${ }^{26}$.

Como critério de desempenho é estabelecido que, áreas sombreadas por mais de $60 \%$ em um desses horários não são favoráveis adoção do sistema de aquecimento solar. Dessa forma calculou-se a área total apropriada para os coletores e painéis em função das áreas disponíveis (PREFEITURA DO MUNICÍPIO DE SÃO PAULO, 2008).

Sendo assim, com os resultados das simulações foram mapeadas as áreas conforme a porcentagem de sombreamento: acima de 60\%; entre 30 e 60\% e; abaixo de $30 \%$ (ver ilustrações 31 e 32). Segundo Moura (2008) as áreas com mais de 60\% sombreada eram descartadas, as áreas entre 30 e $60 \%$ sombreadas eram multiplicadas pelo fator de

125 Decreto Estadual No. 49.148, De 21.01.2008: Regulamenta a Lei n 14.459, de 03.07.2007, que acrescenta o item 9.3.5 à Seção 9.3 - Instalações Prediais do Anexo I da Lei no. 11.228, de 25.06.1992 (Código de Obras e Edificações), e dispõe sobre a instalação de sistema de aquecimento de água por energia solar nas novas edificações do Município de São Paulo.

${ }^{126}$ Disponível em< http://www.squ1.com> Acesso em jan de 2007. 
insolação 0,55 e as áreas com menos de 30\% sombreadas eram multiplicadas pelo fator de insolação $1 .^{127}$
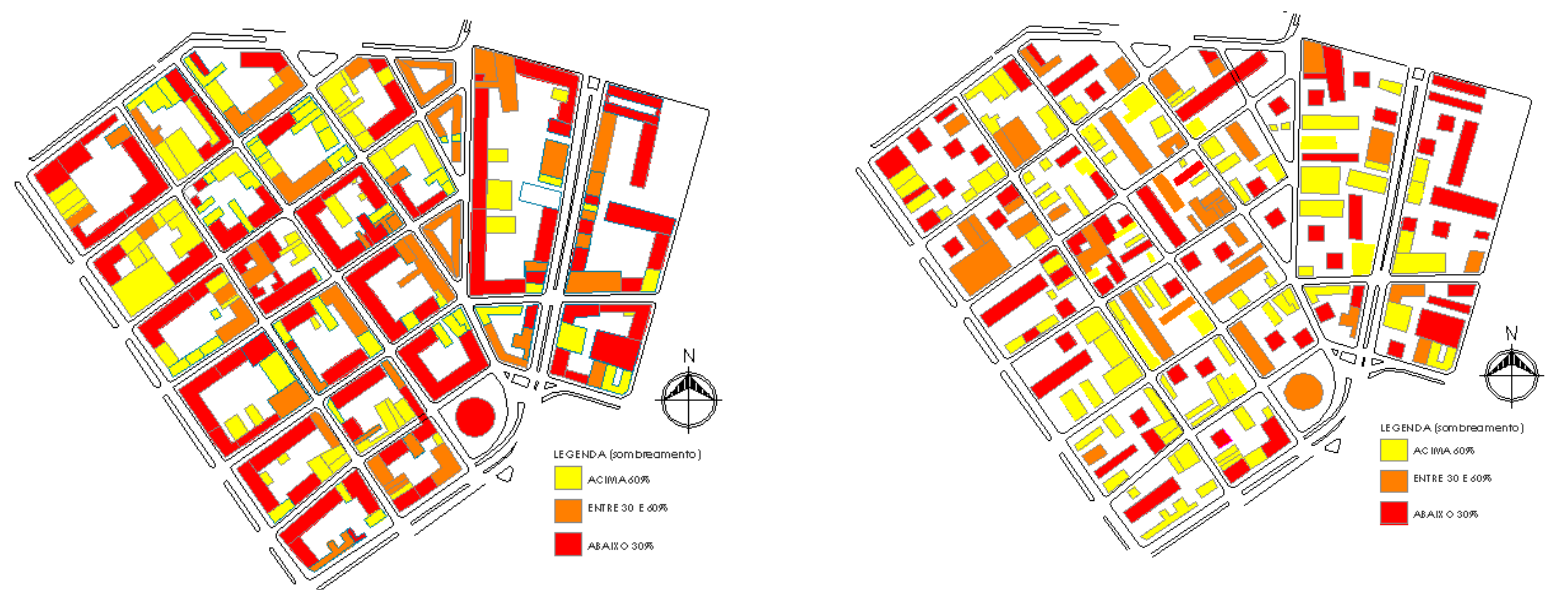

Figura 167 - I magem da área de estudo

Figura 168 - I magem da área de estudo

Fonte: Material produzido pela equipe do projeto

Para cálculo da demanda mensal de energia foi adotada a seguinte equação:

$E=\frac{V \times C p \times\left(t_{2}-t_{1}\right) \times 30}{3600}[\mathrm{kWh} / \mathrm{mês}] \quad($ eq.01)

E Demanda de energia mensal

V Volume diário de água quente a ser aquecida em litros

(Considerar para banho 80 litros por pessoa)

Cp Calor específico da água: $4,18 \mathrm{~kJ} / \mathrm{kg}{ }^{\circ} \mathrm{C}$

$t_{2} \quad$ Temperatura da água quente (adotar $45^{\circ} \mathrm{C}$ )

$\mathrm{t}_{1} \quad$ Temperatura da água fria: $20,2^{\circ} \mathrm{C}$ (São Paulo)

127 MOURA, Norberto. Relatório Técnico de avaliação do potencial de geração de energia solar. Projeto "Desenho Urbano para o Desempenho Ambiental com Benefícios Sócio-Econômicos". LABAUT FAUUSP, 2008. Acesso restrito. 
Com o valor da demanda e com o potencial de captação de energia solar para aquecimento e geração de energia renovável, foi possível comparar os dois cenários, através da porcentagem da população atendida.

TABELA 17: Potencial de aquecimento de água por meio de coletores solares instalados nas coberturas das edificações.

Fonte: MOURA, Norberto. Relatório Técnico de avaliação do potencial de geração de energia solar. Projeto "Desenho Urbano para o Desempenho Ambiental com Benefícios Sócio-Econômicos". LABAUT FAUUSP, 2008. Acesso restrito.

\begin{tabular}{l|r|r|r}
\hline Aquecimento de água & \multicolumn{2}{|c|}{ População } & \multicolumn{2}{c}{65000} \\
\hline Tipologia & Usuários Atendidos & \multicolumn{1}{c}{$\%$} & Contribuição Solar \\
\hline Lâmina + Torre & 62830 & $96,66 \%$ & 0,6 \\
Perímetro & 73451 & $113,00 \%$ & 0,8 \\
& & & \\
Tudo Lâmina & 67486 & $103,83 \%$ & 0,6 \\
Tudo Torre & 45104 & $69,39 \%$ & 0,4 \\
Tudo Perímetro & 109948 & $169,15 \%$ & 0,8 \\
\hline
\end{tabular}

TABELA 18: Potencial de geração de energia elétrica por meio de células fotovoltaicas instaladas nas coberturas das edificações.

Fonte: MOURA, Norberto. Relatório Técnico de avaliação do potencial de geração de energia solar. Projeto "Desenho Urbano para o Desempenho Ambiental com Benefícios Sócio-Econômicos". LABAUT FAUUSP, 2008. Acesso restrito.

\begin{tabular}{|c|c|c|c|}
\hline \multicolumn{2}{|c|}{ Painéis Fotovoltaicos } & \multirow{2}{*}{$\begin{array}{c}\text { População } \\
\%\end{array}$} & \multirow[t]{2}{*}{65000} \\
\hline Tipologia & Usuários Atendidos & & \\
\hline Lâmina + Torre & 4853 & $7,47 \%$ & \\
\hline Perímetro & 8096 & $12,46 \%$ & \\
\hline Tudo Lâmina & 5806 & $8,93 \%$ & \\
\hline Tudo Torre & 2587 & $3,98 \%$ & \\
\hline Tudo Perímetro & 12218 & $18,80 \%$ & \\
\hline
\end{tabular}

A proposta de quadras perimetrais teve um desempenho superior à proposta de quadras abertas com edifícios altos, tipo torre e lâminas. No entanto, em ambos os casos o sistema de aquecimento solar provou ser economicamente eficiente. Mesmo na pior situação, com os edifícios novos mais altos e separados dos edifícios existentes, mostrou responder para aproximadamente $70 \%$ da demanda por água quente.

Com relação aos painéis fotovoltáicos, a pior opção chega a pouco mais de $12 \%$ da demanda de energia elétrica, contra pouco mais de $20 \%$, comparada a proposta de ocupação com quadras perimetrais (ver tabela 2). Nesse caso a justificativa para o investimento inicial está muito mais na conscientização em proteger o meio ambiente, 
minimizando os impactos causados pela produção de energia elétrica através de matrizes poluidoras, do que pelas vantagens econômicas.

Para avaliar o conforto acústico nos espaços abertos e nos edifícios, foi realizado um diagnóstico por meio de dados medidos in loco e um estudo analítico simplificados, com base no método de Josse $(1967)^{128}$ e Bistafa $(2006)^{129}$.

O diagnóstico partiu de medições do nível de ruído e número de veículos no entorno imediato da área estudada e nas suas principais vias. Como o projeto parte da premissa de restrição do aumento do número de veículos de passagem na área de interesse, as medições realizadas no local serviram de base para o cálculo do nível de ruído nas duas novas propostas de ocupação.

Assim como as demais avaliações de desempenho, o estudo foi realizado em duas fases: uma primeira fase de avaliação das condições gerais da acústica urbana do conjunto; e uma segunda fase de estudo detalhado de uma quadra padrão, calculando o nível de ruído em pontos específico como nas calçadas, no interior da quadra e nas fachadas das edificações.

Para avaliar se o nível do ruído urbano estava adequado ou não ao uso da área adotou-se como parâmetros quantitativos os valores recomendados nas normas brasileiras.

Com relação aos resultados, a proposta de quadras com fechamento perimetral apresenta uma área maior de espaços abertos mais protegidos do ruído urbano. No entanto, as quatro fachadas do bloco perimetral ficam mais expostas aos ruídos das vias. Segundo Cavalcanti (2008), o fato das lâminas dos edifícios apresentarem alturas diferentes e o térreo ser, em boa parte do conjunto, recuado, contribuíram para a diminuição das múltiplas reflexões entre os edifícios, o que poderia elevar o nível sonoro em até $4 \mathrm{~dB}(\mathrm{~A})$, como apresentado para os estudos paramétricos ${ }^{130} .131$

\footnotetext{
${ }^{128}$ STEPHENSON e VULKAN, Urban planning against noise. Official Architecture Planning, 1967.

${ }^{129}$ BISTAFA, Acústica aplicada ao controle do ruído, São Paulo: Blucher, 2006.

${ }^{130}$ Os estudos paramétricos foram realizados visando comparar as três tipologias edificatórias: edifícios tipo perímetro, edifício tipo torre e edifício tipo lâmina. Os resultados desse estudo é apresentado no item 4.3 da Tese.
} 
Em contrapartida, a proposta de quadras abertas com edifícios altos tipo torre e tipo lâmina apresentou um melhor desempenho acústico por parte dos edifícios, visto que grande área das fachadas principais ficam mais afastadas e, conseqüentemente, mais protegidas do alto nível de ruído das ruas. Por outro lado, essa proposta de ocupação prejudica o desempenho acústico dos espaços públicos, que ficam mais expostos ao ruído urbano. Porém, segundo Cavalcanti (2008) esses excessos podem ser mitigados com o projeto de superfícies absorventes e presença de vegetação arbórea para difusão sonora no nível térreo.

\section{ETAPA 05 - ADEQUAÇÃO DO PROJ ETO}

Com base nas avaliações realizadas na etapa anterior e no resultado do espaço produzido, foram revistas e adequadas as propostas de projeto urbano. Destaca-se que em muitos momentos as avaliações de desempenho foram desenvolvidas em paralelo com o desenvolvimento e adequação das propostas de ocupação urbana.

Com respeito aos resultados apresentados no projeto, foi observado que para o clima subtropical de São Paulo, a diversidade edificatória cria condições favoráveis ao conforto ambiental nos espaços abertos e edifícios, criando sombreamento da forma urbana e dos espaços abertos, assim como turbulências de ventilação. Contudo, essa qualidade é limitada e pode ser comprometida pela proximidade dos edifícios (GONÇALVES e KRONKA MÜLFARTH, 2008).

A tabela 19 traz uma avaliação qualitativa do desempenho ambiental das duas propostas com base nos resultados obtidos nos estudos técnicos da etapa 04.

131 CAVALCANTI, Rodrigo, RAMOS, José Ovídio e CREMONESI, Fernando. Relatório Técnico de conforto acústico. Projeto "Desenho Urbano para o Desempenho Ambiental com Benefícios Sócio-Econômicos". LABAUT FAUUSP, 2008. Acesso restrito 
Tabela 19: Avaliação qualitativa do desempenho ambiental das soluções de ocupação urbana.

Fonte: GONÇALVES e KRONKA MÜLFARTH, 2008.

\section{Soluções de ocupação urbana}

Qualidade
do ar

Solução 1:

Quadras perimetrais

$\sqrt{ } \sqrt{ }$

Solução 2:

Quadras abertas com edifícios altos

lâmina e torre

Critério de qualificação

\section{FATORES AMBIENTAIS}

Acesso

Conforto

Ruido

Geração

termico urbano de energia

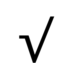

$\sqrt{ }$ $\sqrt{ } \sqrt{ }$ $\sqrt{ } \sqrt{ }$

\begin{tabular}{ll}
\hline & $\checkmark$ - resultado nao satisfatorio (ou satisfatorio em areas restritas da proposta), \\
& porem com potencial de melhora a ser explorado e expectativas de \\
& conformidade com o criterio em grande parte da area de projeto. \\
Critério de & $\sqrt{ }$ - resultado satisfatorio, porem com potencial de melhora de forma a \\
qualificação & responder aproximadamente $100 \%$ para o criterio de desempenho e toda a \\
& area de projeto. \\
& $\sqrt{ } \sqrt{ }$ - resultado praticamente $100 \%$ satisfatorio, sem a necessidade de \\
& correções ou alterações na proposta de ocupação. \\
\hline
\end{tabular}

\subsection{Descrição da proposta}

A proposta para inserção dos fatores ambientais no processo de projeto engloba as seguintes atividades: levantamento dos dados e diagnóstico do perfil sócio-econômico e das condições físicas e ambientais da área de interesse, com base no enfoque ambiental; definição das tipologias de adensamento; definição dos requisitos e critérios de desempenho ambiental necessários para atender as exigências humanas; análise crítica da forma urbana e tipologia arquitetônica e avaliação técnica de desempenho ambiental incluindo análises comparativas dos resultados; e adequação do projeto urbano com base nos resultados obtidos na etapa anterior.

As etapas da proposta são descritas a seguir.

\section{ETAPA 01 - CARACTERI ZAÇÃO DA ÁREA E DI AGNÓSTI CO}

Para realizar a inserção de aspectos ambientais no processo de projeto, visando o desenho urbano em equilíbrio com o meio natural, é necessário conhecer os recursos e potencialidades do território, assim como suas deficiências. 
Para conhecer a área de intervenção e o seu entorno imediato, deve ser realizado um levantamento de dados quantitativos sobre o contexto urbano sócio-econômico e ambiental e um mapeamento da situação atual. Com essas informações elabora-se um diagnóstico da área, apontando seus principais problemas e suas potencialidades, e ainda definir a densidade inicial proposta com base na capacidade de suporte da infra-estrutura existente.

O levantamento de dados quantitativos sobre o contexto urbano, ambiental e socioeconômico, deve conter as seguintes informações das camadas:

\section{Sobre a população local:}

- $\quad$ Densidade populacional

A partir dos dados de densidade populacional, é possível avaliar se esta é baixa, média ou alta e o potencial de adensamento da área, junto com outras variáveis de projeto.

- $\quad$ Renda familiar e per capta

Os dados com relação à renda familiar é importante primeiro para verificar a possibilidade da população ser atendida pelos programas de financiamento Habitação de Interesse Social, HIS, e Habitação de Médio Padrão, HMP. Segundo que, um dos princípios da sustentabilidade é a diversidade de classes sociais, sendo assim, com base no levantamento sobre a renda da população define-se as tipologias de habitação a serem adotadas.

\section{Sobre as camadas do projeto urbano}

- Usos (residencial, comercial, escritórios, institucional, estacionamento e vazios urbanos)

O levantamento desses dados é fundamental para definir os usos das edificações a serem projetadas, visando aumentar a complexidade, a diversidade urbana.

- Infra-estrutura urbana:

Com base na capacidade de infra-estrutura é possível definir a hipótese de densidade inicial a ser adotada. Além disso, é importante observar, entre outros aspectos, os fluxos existentes, de pedestres, de veículos particulares, de transportes públicos e demais meios de mobilidade urbana. 
Devem ser levantados também, dados sobre as principais ruas e avenidas com seu fluxo de veículos ${ }^{132}$ para avaliação da dispersão de poluentes ${ }^{133}$ e para cálculo do nível de ruído urbano, visando o atendimento às exigências humanas de qualidade do ar e conforto acústico, respectivamente.

Para diagnóstico do ruído urbano existem duas opções: realização de medidas in loco do nível de ruído urbano em $\mathrm{dB}(\mathrm{A})$, de acordo com a Norma Brasileira, ou cálculo do nível sonoro (LC) que atinge o objeto de estudo, adotando a equação de Josse (1975). Alucci (2007) comenta que essa equação foi desenvolvida com base em ensaios realizados na década de 70, o que poderia gerar a dúvida quanto às características atuais dos veículos, com certeza distintas dos veículos de trinta anos atrás. Porém Calixto (2003) também comparou os resultados obtidos com a aplicação da equação a dados obtidos por rodovias brasileiras, verificando que esta é ainda adequada (ALUCCI, 2007). Del Carlo e Ovídio (2006) também confirmam a aplicabilidade da equação de Josse através dos resultados de medidas realizadas na área urbana de São Paulo.

Cremonesi (2007) e Alucci (2007, p. 111) descrevem esse método, que pode ser aplicado com o auxílio do software Acústico (ALUCCI, 2002) $)^{134}$ ou TAO (ALUCCI, 2007) ${ }^{135}$.

- $\quad$ Estoque construído

Com relação ao estoque construído é importante levantar os seguintes dados: área construída, localização e geometria (largura, altura e profundidade) das edificações existentes, distância entre as edificações, estado de conservação, valor cultural e

\footnotetext{
132 Dado que pode ser obtido no CET, no caso de São Paulo ou órgão responsável pelo controle do tráfego, ou através de levantamento na área.

133 Neste método a avaliação de dispersão de poluentes será baseada apenas na permeabilidade ao vento, porém pretende-se, posteriormente, considerar as demais variáveis, como por exemplo, o quantidade de veículos de passeio, emissores de $\mathrm{CO}_{2}$.

134 ALUCCI, Marcia Peinado. Software Acústico 2.0. Departamento de Tecnologia da Arquitetura, FAU USP, 2002. Disponível em: <http://www.usp.br/fau/pesquisas/laboratorios/labaut/conforto/index.html>. Acesso em: jan 2009.

135 ALUCCI, Marcia Peinado. Software TAO. Departamento de Tecnologia da Arquitetura, FAU USP, 2007. Disponível em: <http://www.usp.br/fau/pesquisas/laboratorios/labaut/conforto/index.html>. Acesso em: jan 2009.
} 
arquitetônico, presença de edifícios tombados, de vazios urbanos, de áreas de estacionamento e de áreas livres, etc.

Devem ser levantadas informações sobre o entorno das quadras, que também se caracteriza pela localização e dimensão das calçadas e vias de tráfego.

Com essas informações são produzidos mapas para facilitar o diagnóstico e a proposta de intervenção.

\section{- $\quad$ Meio ambiente}

Para inserção da camada meio ambiente no processo de projeto devem ser levantados dados referentes a: o solo urbano ${ }^{136}$, a energia, a água ${ }^{137}$, a vegetação e o clima.

A forma do relevo é sempre o primeiro elemento de estudo, já que condiciona os demais e determina totalmente o desenvolvimento ou implantação de novas atividades ou infraestrutura sobre o território.

Sendo assim, com relação ao solo urbano, devem ser observadas: a topografia e altitude do terreno, a exposição das ladeiras e demais zonas ao sol e a presença de áreas de risco devido às inundações e escorregamento, de áreas de erosão e assoreamento e de áreas contaminadas.

Devem ser levantados dados referentes ao consumo desagregado de energia elétrica nos edifícios de acordo com o seu uso, para definir as principais estratégias devem ser adotadas visando uma maior eficiência energética. Além disso, deve ser considerado a disponibilidade deste recurso e o potencial de geração de energia limpa.

Com relação ao recurso água é importante observar: a disponibilidade de água (superficial e subterrânea), considerando o que chove e as características do solo; o balanço hídrico que estabelece a quantidade de água verdadeiramente disponível,

\footnotetext{
136 Apesar da importância da variável ambiental solo urbano, não faz parte do escopo do método proposto abordar a fundo as questões relacionadas a ela, devido sua complexidade e à necessidade de reduzir o número de variáveis para conclusão do trabalho. Porém são aqui mencionados os aspectos relacionados a essa variável que devem ser considerados e que futuramente podem ser inseridos no método.

137 Com relação ao recurso natural água, será abordada a questão da necessidade de área permeável para reduzir os riscos de inundações. Como essa questão está relacionada também ao solo urbano e à presença de vegetação, nesse método ela será tratada junto a variável vegetação.
} 
considerando o que evapora e a que é filtrada para o solo cada mês; o consumo de água urbano para todos os usos e relacionando com a qualidade da água necessária e específica para cada atividade de modo que se possa conhecer suas formas de obtenção mais sustentáveis e; a existência de pontos de alagamento.

Para estudo do potencial de inundação da área, Higueras (2007) recomenda Dunne \& Leopold $(1998)^{138}$ que resume as informação necessárias para tal análise: as correntes superficiais alteradas pelas zonas urbanizadas e desflorestadas, e a sua direção; o volume de chuva; a altura da inundação considerando a topografia do lugar; e o hidrograma temporal deste aumento e a velocidade da água.

Devem ser levantadas as zonas verdes na região a ser realizada a intervenção urbana, com sua área e localização, para que sejam avaliadas a porcentagem de área permeável e a distribuição da vegetação, importante para o atendimento dos requisitos qualidade do ar e conforto térmico nos espaços externos.

Diante da diversidade climática fica claro a necessidade do conhecimento do contexto climático e realização de um diagnóstico para desenvolvimento de projetos. 0 conhecimento do clima local e a correta avaliação de um diagnóstico climático permitem tomadas decisões importantes em prol do conforto ambiental dos usuários e da eficiência energética do conjunto e das edificações.

O diagnóstico climático consiste em uma análise do clima e definição das principais estratégias de projeto para adequação climática, com base nos dados de temperaturas e umidades relativas do ar máximas e mínimas para todos os meses do ano ${ }^{139}$.

No caso das principais cidades brasileiras, o diagnóstico climático pode ser realizado a partir do aplicativo Climaticus (ALUCCI, 2005), que utiliza a carta bioclimática ${ }^{140}$ de Givoni

\footnotetext{
138 DUNNE, Thomas \& LEOPOLD, Luna. Water in environmental planning, W. H. Freeman, New York, 1998.

${ }^{139}$ Fontes de dados climáticos: INMET, disponível em: www.inmet.gov.br; INPE, disponível em: www.inpe.br; Aeroportos; Instituto Astronômico e Geofísico da Universidade de São Paulo (IAG USP).

140 Olgyay (1963) desenvolveu o primeiro diagrama bioclimático que propõe estratégias de adaptação ao clima, visando o conforto nos espaços externos. Anos mais tarde Givoni (1976) concebeu uma carta bioclimática para edifícios, que corrigia algumas limitações desse diagrama. Posterior à isso, a carta foi adaptada para países de climas quentes, fundamentada no Index of Thermal Stress (Índice de estresse
} 
(1992) com base nas normais climatológicas ${ }^{141}$ do Instituto Nacional de Meteorologia, INMET. Para cidades que não estão contidas no programa, existe a possibilidade de inserí-la desde que os dados sobre o clima estejam completos. ${ }^{142}$

Além das recomendações arquitetônicas baseada nas zonas bioclimáticas de Givoni, o Climaticus também oferece uma análise do clima em relação aos períodos noturnos e diurnos de calor, frio ou conforto, a partir das tabelas de Mahoney ${ }^{143}$ (KOENIGSBERGER et al, 1977). ${ }^{144}$

A carta bioclmática proporciona três estratégias para remediar as situações desfavoráveis: radiação solar para situações de frio; umidade para situações de alta temperatura e baixa umidade ambiental; e vento para situações de temperatura e umidade elevadas (HIGUERAS, 2007).

Diante disso, definidas as estratégias, são necessários os dados de radiação solar ${ }^{145}$ e dos ventos dominantes ${ }^{146}$ para aplicar essas ao projeto. Esses dados também são fundamentais para a avaliação do potencial de geração de energia renovável, solar ou eólica, respectivamente.

térmico). Givoni (1992) explica que o clima interno em edifícios não climatizados reage mais largamente à variação do clima externo, ou seja, pressupõem uma maior tolerância do usuário às variações ambientais do espaço interno, devido às variações do clima externo, estendendo a zona de conforto.

${ }^{141}$ As normais são médias dos dados obtidos em uma determinada estação em um período de 30 anos, sendo que a mais recente compreende o período entre 1960 e 1990.

142 O Diagnóstico também pode ser realizado com o auxílio do software Analysis Bio 2.1.1, que utiliza o mesmo método do Climaticus. LAMBERTS, Roberto et al. Analysis Bio. Versão 2.1.1. Florianópolis: UFSC, 1994. Disponível em: <http://www.labeee.ufsc.br/software/analysisBIO.html>. Acesso em: dez. 2007.

${ }^{143}$ As tabelas de Mahoney são ferramentas pioneiras nesta questão porque relacionam dados climáticos locais aos limites do conforto, de acordo com os períodos do dia e da noite, para a identificação de estratégias específicas de projeto.

${ }^{144}$ ALUCCI, Marcia Peinado. Software Climaticus 4.1. Departamento de Tecnologia da Arquitetura, FAU USP, 2005. Disponível em: <http://www.usp.br/fau/pesquisas/laboratorios/labaut/conforto/index.html>. Acesso em: jan. 2009.

${ }^{145}$ FROTA, A. B. \& SCHIFFER, S. Manual de conforto térmico. São Paulo, Editora Nobel, 1987. e FROTA, A. B. Geometria da insolação. São Paulo, Geros, 2004.

${ }^{146}$ Estações metrológicas ou para algumas cidades brasileiras climaticus (ALUCCI, 2005). 
Além desses, é necessário o levantamento de dados sobre a disponibilidade de luz natural ${ }^{147}$, que serão utilizados para avaliação do critério do ângulo de obstrução do céu para atendimento do conforto luminoso no interior das edificações.

Destaca-se que, dependendo da localização e do projeto, pode ser relevante a realização de medidas de campo, já que em determinadas situações as condições do microclima local podem ser bastante diversas.

\section{ETAPA 02 - DEFINIÇÃO DOS REQUISITOS E CRITÉRIOS AMBI ENTAIS RELACI ONADOS AO ADENSAMENTO E A FORMA URBANA}

Segundo Alucci (2007), a metodologia clássica de avaliação de desempenho pressupõe a definição de exigências humanas, requisitos, critérios e métodos de avaliação. Com base nisso, estendendo os conceitos de avaliação de desempenho do edifício para um conjunto de edificações, no caso, assentamentos humanos, essa etapa do método consiste na definição das variáveis a serem consideradas no processo de projeto, as exigências humanas relacionadas a elas e os requisitos e critérios necessários para verificação do atendimento dessas exigências.

No que se refere ao método proposto no presente trabalho, foram selecionadas as seguintes variáveis ambientais a serem inseridas e avaliadas no processo de projeto urbano: sol; vento; vegetação; energia; água e ruído urbano.

Com base nas variáveis ambientais a serem consideradas no processo de projeto urbano e na lista de exigências humanas apresentada nas normas ISO $6241^{148}$ e na NBR $15575^{149}$, são definidas as principais exigências humanas adotadas no método proposto. São elas: salubridade; conforto térmico nos espaços externos e edifício $^{150 ;}$ conforto luminoso nos edifícios; qualidade do ar; eficiência energética; conforto acústico nos espaços externos e edifício.

\footnotetext{
147 Também pode ser obtido através do Climaticus (ALUCCI, 2005) (para as 57 cidades inseridas) ou FROTA (2004).

148 INTERNATIONAL ORGANIZATION FOR STANDARDIZATION. Performance standards in buildings: principles for their preparation and factors to be considered, ISO 6241. London, 1984.

${ }^{149}$ ABNT NBR 15.575-1. Edifícios habitacionais de até cinco pavimentos - Desempenho - Parte 1: Requisitos gerais.

${ }^{150}$ No caso na edificação, nesta pesquisa refere-se a ao estudo até a fachada.
} 
Por meio do levantamento de dados e caracterização da área e diagnóstico das condicionantes locais são extraídos os principais problemas ambientais e as potencialidades. Com base nisso é estabelecida a hierarquia com que as exigências humanas devem ser trabalhadas, dependendo principalmente do seu uso e de sua localidade.

Para avaliar se essas exigências humanas estão sendo atendidas, são estabelecidos parâmetros qualitativos, os requisitos e, os parâmetros quantitativos, os critérios.

Sendo assim, com base no exercício de projeto desenvolvido pelo grupo de pesquisadores LABAUT FAUUSP e nas referências existentes sobre cada tema, foram definidos os requisitos e critérios que têm relação direta com o adensamento e a forma urbana, visando o atendimento das exigências humanas.

Requisitos: permeabilidade ao vento; insolação adequada nos espaços externos e nos edifícios; visão do céu adequada; acesso dos cidadãos à vegetação; porcentagem adequada de área permeável; potencial de geração de energia solar pela instalação de painéis fotovoltaicos nas coberturas; nível adequado de ruído.

Critérios: velocidade do ar entre $3 \mathrm{~m} / \mathrm{s}$ e $5 \mathrm{~m} / \mathrm{s}$; 2 horas de sol no Solstício de inverno em todas as fachadas possíveis; ângulo de obstrução de acordo com gráfico recomendado, distância entre cidadãos e vegetação relacionada ao tamanho da área verde; área permeável entre 30 e 50\%; potencial de geração de energia solar em $50 \%$ das coberturas; nível de ruído urbano $60 \mathrm{~dB}$.

A seguir uma apresentação das variáveis, exigências humanas, requisitos e critérios a serem inseridos no método proposto. Para cada conjunto desses são destacados os principais parâmetros de projeto a serem considerados.

\section{ETAPA 03 - PROPOSTA DE DESENHO URBANO: DEFI NI ÇÃO DOS CENÁRI OS}

Nesta etapa são estabelecidos os cenários teóricos para a quadra urbana, com base nos requisitos e critérios ambientais a serem atendidos, visando alcançar a densidade inicial estabelecida. Para isso, três tipologias edificatórias de adensamento são adotadas para a composição da morfologia urbana: o edifício lâmina, característico da arquitetura moderna brasileira, o bloco perimetral, morfologia de quadra presente em várias cidades européias; 
e o edifício torre, ícone da arquitetura contemporânea, presente em todas as megacidades. ${ }^{151}$

Destaca-se que nenhuma tipologia arquitetônica é por si só melhor que as demais. Cada uma apresenta vantagens e desvantagens particulares dependendo do clima e da função. Para proposta de adensamento urbano são apresentadas três tipologias que a princípio podem ser estudadas separadamente, mas que no desenvolvimento do projeto podem e devem ser combinadas.

Mesmo porque a diversidade edificatória é um atributo de sustentabilidade, implicando uma variedade de formas arquitetônicas que ajuda a estruturar o espaço, uma variedade de tipologias habitacionais, uma variedade de pessoas e uma melhor adequação das condições locais (HIGUERAS et al, 2009).

\section{ETAPA 04 - AVALI AÇÃO DE DESEMPENHO}

A palavra "desempenho" está relacionada ao comportamento de um produto durante a sua utilização, caracterizando-se o fato de que este deve apresentar certas propriedades para cumprir a função proposta quando sujeito a determinadas influências ou ações durante a sua vida útil. Essas ações que atuam sobre o edifício, ou um conjunto de edificações são chamadas condições de exposição (GOLÇALVES et al, 2004).

Assim, avaliar o desempenho de um produto implica definir qualitativa e/ou quantitativamente quais as condições que devem ser atendidas por ele quando submetido às condições normais de uso (GOLÇALVES et al, 2004).

Em resumo, a avaliação de desempenho de uma edificação ou de um conjunto de edificações consiste em prever seu comportamento potencial quando submetidos a condições normais de exposição e avaliar se tal comportamento satisfaz às exigências do usuário por meio dos requisitos e critérios de desempenho.

A metodologia básica utilizada para a avaliação do desempenho é composta pelas seguintes etapas:

1. Identificação das exigências do usuário;

\footnotetext{
${ }^{151} \mathrm{O}$ item 1.4 desta tese apresenta uma descrição das tipologias de adensamento apontando seus aspectos favoráveis e os desfavoráveis.
} 
2. Identificação das condições de exposição a que está submetido o edifício;

3. Definição dos requisitos e critérios de desempenho a serem atendidos;

4. Definição dos métodos de avaliação.

Enfim, para cada requisito ou critério é apresentada uma ferramenta de avaliação do desempenho do projeto com relação a eles. No método proposto, as ferramentas de avaliação consistem em: estudos com modelos reduzidos; estudos gráficos, por meio de mapas e desenhos do projeto em escala adequada; e aplicativos computacionais ${ }^{152}$.

Apesar dessas evidências, para se chegar aos indicadores de qualidade ambiental, por mais que se procure utilizar métodos científicos, as decisões serão, muitas vezes, baseadas em julgamentos subjetivos, envolvendo valores, sensibilidade, convicções e preconceitos, bem como, naturalmente, verdades científicas (Matthews, 1975 apud NUCCI, 2008).

\section{Variável 01: Sol}

O estudo da geometria da insolação representa um importante instrumento de projeto e de sua aplicação depende o desempenho térmico das edificações e o conforto dos usuários nos espaços externos (FROTA, 2004).

Nesta pesquisa, consideram-se os seguintes benefícios da energia solar incidente na edificação e nos espaços externos: efeito bactericida, visando atender à exigência humana de salubridade nas habitações; conforto térmico nos espaços externos e no interior nas edificações, conforto luminoso também nos espaços internos das edificações, aquecimento de água e geração de energia renovável, através dos coletores solares e painéis fotovoltaicos, respectivamente, instalados nas coberturas.

\section{Exigência humana: Salubridade}

A radiação solar pode ser utilizada como fator bactericida, contribuindo para a salubridade da edificação. Ambientes sem incidência de sol, especialmente residências e áreas molhadas, podem acumular fungos e outros microorganismos nocivos à saúde (Obolenksy e Korzin, 1982, apud BRANDÃO, 2004).

\footnotetext{
152 O LABAUT FAUUSP tem licença educacional para utilizar os softwares pagos.
} 
Requisito: horas mínimas de insolação nas habitações em todas as fachadas possíveis

Critério: Duas horas de sol no solstício de inverno (período crítico com relação ao acesso ao sol) na fachada.

\section{Exigência humana: Conforto térmico nos espaços externos e nas edificações}

Requisito: horas mínimas de sol ou sombra nos espaços externos e nas edificações, dependendo do clima local e do uso.

Critério: a necessidade de sol ou sombra depende, entre outros fatores, das condições climáticas locais, não podendo adotar um valor único. Para avaliação do conforto nos espaços externos será adotado o índice de conforto definido por Monteiro (2008), o TEP, no qual insolação é apenas um dos fatores (inclui vento e vegetação, entre outros).

O IES (1998) apresenta estudos a respeito dos efeitos da radiação sobre microorganismos, mostrando a irradiância necessária para se evitar a formação de colônias de micro organismos. O mais resistente resiste a uma exposição de até $0,36 \mathrm{~W} / \mathrm{m}^{2}$ durante um período de uma hora (BRANDÃO, 2004).

De acordo com o cálculo de Duffie e Beckman (1980, p.6), na radiação emitida pelo sol tem-se incidindo normalmente no topo da atmosfera $49 \mathrm{~W} / \mathrm{m}^{2}$ na faixa do ultravioleta, entre 220 e 300 nm, ou seja, 3,59\% do total. Diante desse valor, Brandão (2004) aborda que se essa proporção fosse reduzida à metade pela passagem pela atmosfera ${ }^{153}$, superfícies que recebessem acima de $20 \mathrm{~W} / \mathrm{m}^{2}$ por uma hora estariam devidamente descontaminadas. E completa que: "o valor baixo indica que a principal preocupação na verdade deve ser garantir que todas as superfícies recebam radiação solar, pois a radiação direta do sol apresenta normalmente valores superiores a esse." (BRANDÃO, 2004, p.82)

Outras referências brasileiras utilizaram critérios semelhantes (uma hora de sol no quadrante norte), como os trabalhos de Assis, Valadares \& Souza (1995) que se basearam em recomendações feitas por Moretti (1997) e Alucci, Carneiro e Baring (1996).

\footnotetext{
153 Na verdade a distribuição espectral da radiação incidente na Terra dificilmente é medida. A proporção entre o ultra-violeta depende da composição da atmosfera e da espessura da camada de ar atravessada pelo raio. A redução de $50 \%$ nessa proporção é apenas um exercício teórico, devendo ser complementada por estudos posteriores.
} 
Deve-se ter em mente que esse critério atende à exigência humana de salubridade, porém com relação a outras exigências, como a de conforto térmico nos espaços externos e edificações ou conforto luminoso nas edificações, esse deve ser revisto considerando as condições climáticas locais e as principais necessidades para adequação ao clima.

Nesses casos, considerar como válido um mínimo de horas de sol nos solstício de inverno pode ser insuficiente. Apesar disso, vários autores adotam esta necessidade de duas horas no inverno.

A necessidade de sol depende do clima de cada local. Lugares relativamente frios necessitam de pelo menos quatro horas de sol durante as horas centrais do dia, na situação mais desfavorável. Às 12 horas é quando se tem a máxima altura solar e a maior radiação, já que o percurso através da atmosfera é o mínimo.

Higueras et al. (2009), por exemplo, recomenda para Madrid, Espanha, garantir uma insolação nas horas centrais do dia no solstício de inverno, entre as 10 horas da manhã e às 14 horas da tarde. A autora se baseia nos cálculos de Neila (1999), que mostram que, com essas quatro horas no meio do dia, garante-se $75 \%$ da radiação solar possível. Porém, destaca-se que para conseguir liberar de obstruções a trajetória do sol entre as 10 horas e as 14 horas, é necessário condições entre largura da rua e altura das edificações bastante exigente. Em outras situações climáticas esse requerimento pode variar.

Em resumo, para cada local a recomendação é estabelecer a necessidade de sol ou de sombra nos espaços externos e edificações de acordo com as estratégias do diagnóstico climático do lugar, considerando a trajetória do sol e a intensidade da radiação solar (direta e difusa).

No que tange ao projeto urbano, a presença ou não de obstrução causada por edificações e pela vegetação, no caso de espaços externos, é o principal parâmetro de desempenho.

\section{Exigência: conforto luminoso nos interior das edificações}

A iluminação deve proporcionar qualidade visual e, portanto, relaciona-se com a sensação de bem-estar da visão. Outros fatores podem influenciar nesta sensação, mas a luz como elemento revelador do espaço cumpre função determinante (BRANDÃO, 2004).

A luz difusa (proveniente do céu) é a mais adequada por sua intensidade e maior uniformidade. Por ser um fenômeno dinâmico, sua penetração no interior dos ambientes 
necessita ser avaliada, em função da localização geográfica (latitude e longitude), data e hora. No que tange ao projeto urbano, a presença ou não de obstrução causada por novas edificações é o principal parâmetro de desempenho.

Requisito: garantir a visão de uma parte do céu, possibilitando a disponibilidade de luz natural na fachada, para que o profissional que irá detalhar o projeto da edificação possa definir o dimensionamento adequado da janela, atendendo à exigência do usuário.

Critério: ângulo de obstrução encontrado no ábaco (Figura 171) que relaciona a distância entre as edificações, as características da abóbada celeste da região, a altura das edificações e a dimensão das aberturas. (ALUCCI, 1986, p.19).

Segundo Brandão (2004), um dos mais tradicionais mecanismos de proteção do acesso ao sol e à luz natural são os ângulos de obstrução. O autor define obstruções como sendo elementos que se interponham entre o sol e o céu (ou parte dele) e o ponto analisado, podendo ser naturais ou não. É importante observar que a obstrução depende do ponto que está sendo estudado. (BRANDÃO, 2004, p.60). ${ }^{154}$

Um dos poucos estudos encontrados para a determinação dos ângulos de obstrução para iluminação foi desenvolvido por Alucci, Carneiro e Baring (1986), para o espaçamento de edificações em conjuntos habitacionais.

Brandão (2004) alerta sobre a generalização dos ângulos, já que estes foram desenvolvidos para conjuntos habitacionais que possuem características bem específicas e que não se aplicam às demais edificações da cidade. O resultado também depende da razão entre área de janela e área de piso, que é determinada na maior parte das cidades brasileiras pelo código de obras, normalmente com valor na faixa de 0,16 (1/6).

Uma adaptação do modelo de ângulos de obstrução, os recuos progressivos, é apresentada por Assis (2000). Nesse modelo o ângulo de obstrução é convertido em

\footnotetext{
154 Para estudo mais detalhado sobre a obstrução causada por edificações, recomenda-se Brandão (2004) e Frota (2004).
} 
recuos que aumentam de acordo com a altura do prédio, sendo uma das ferramentas de mais fácil aplicação. ${ }^{155}$
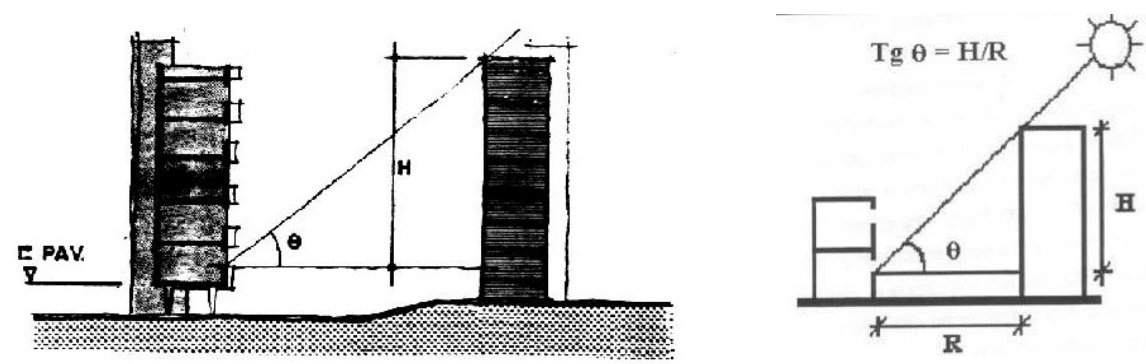

Envelope solar sohne um lote

$\operatorname{so\theta } \theta \frac{H}{\mathrm{O}}$

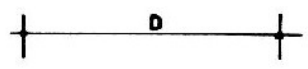

H= ALTURA ENTRE O TOPO DA DBSTRUGío E O

BORDO NFERIOR OA JANELA DO PRIMEIRO PAVIMENTO

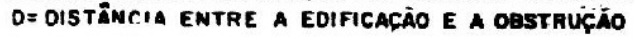

Figura 169: Ábaco para a determinação da distância mínima entre edificações

Fonte: Alucci, Carneiro \& Baring (1986)
Figura 170: Modelo de envelope com recuos progressivos

Fonte: Assis (2000)

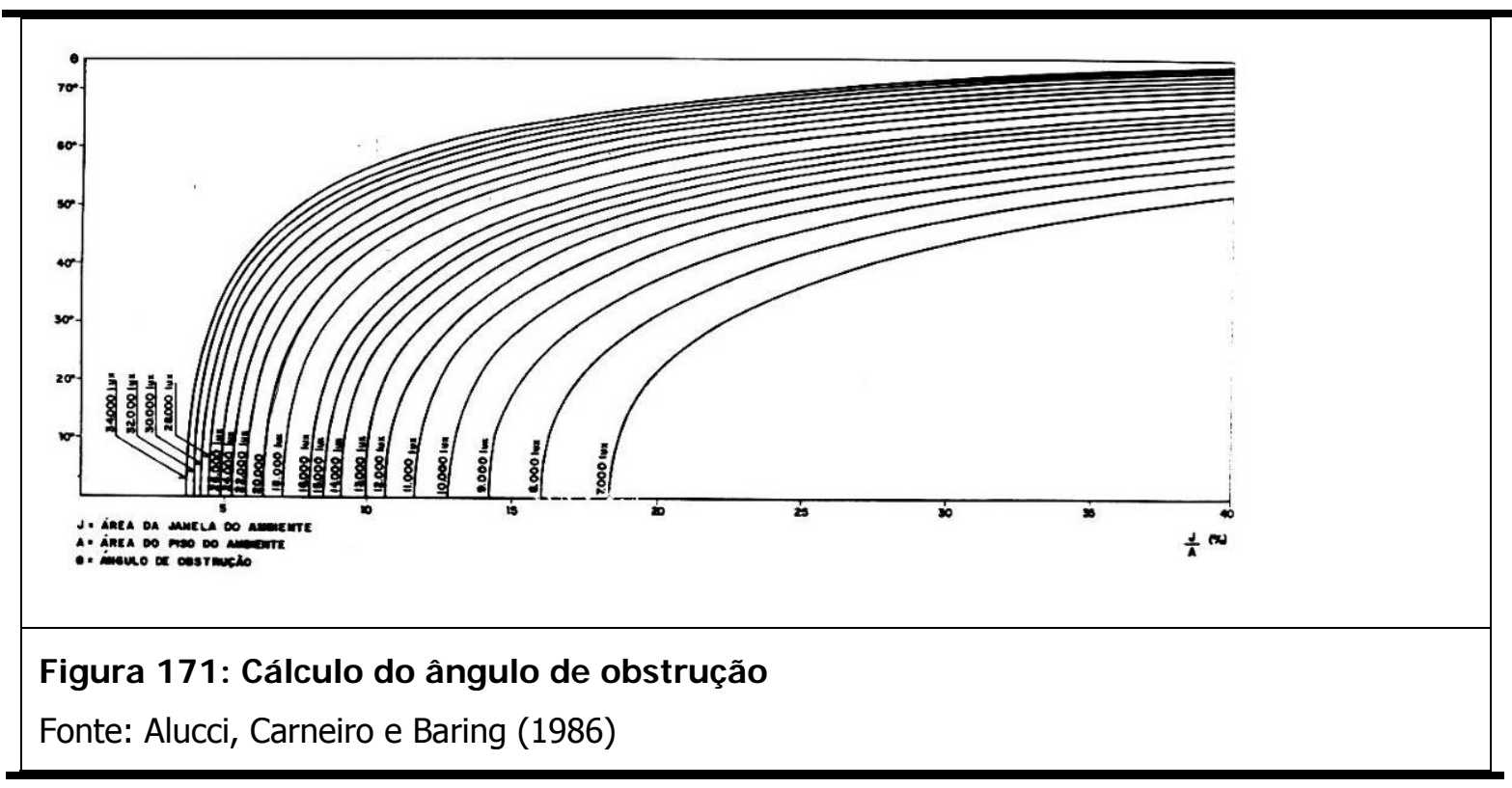

155 Este modelo acabou sendo incorporado na revisão da legislação urbanística de Belo Horizonte, ainda que de forma parcial. Assis, Valladares e Souza (1995) desenvolveram um estudo para a cidade aplicando o modelo de Alucci, Carneiro e Baring (1986) e o critério de uma hora de sol em cada fachada. 
Destaca-se que o ângulo de obstrução é válido para garantir horas de sol, mas o contrário ele não se aplica, ou seja, caso seja necessário o sombreamento, é necessário um ângulo referente tanto à altura da edificação quanto a largura. Mesmo assim este cálculo é muito simplificado já que normalmente o forma das edificações não são tão homogêneas.

Ferramentas: método gráfico; método de simulação com modelos físicos reduzidos e; método de simulação com o aplicativo computacional Ecotect e TAO.

\section{Método Gráfico}

O método do Traçado de Máscara ${ }^{156}$ consiste na construção de máscaras de sombreamento e na sobreposição à carta solar do local, mostrando os períodos de sombra e sol durante todo o ano, para determinado ponto específico. O método utiliza instrumentos gráficos como as Cartas Solares, Figura 172, os Transferidores de Coordenadas Solares e o Gráfico Auxiliar, Figura 173.

Através da geometria eqüidistante, transforma-se qualquer elemento sombreador numa mancha gráfica (máscara), que sobreposta à carta solar indica os horários do ano em que haverá sombra ou sol em um determinado ponto. (DUTRA, 1994, p.22).

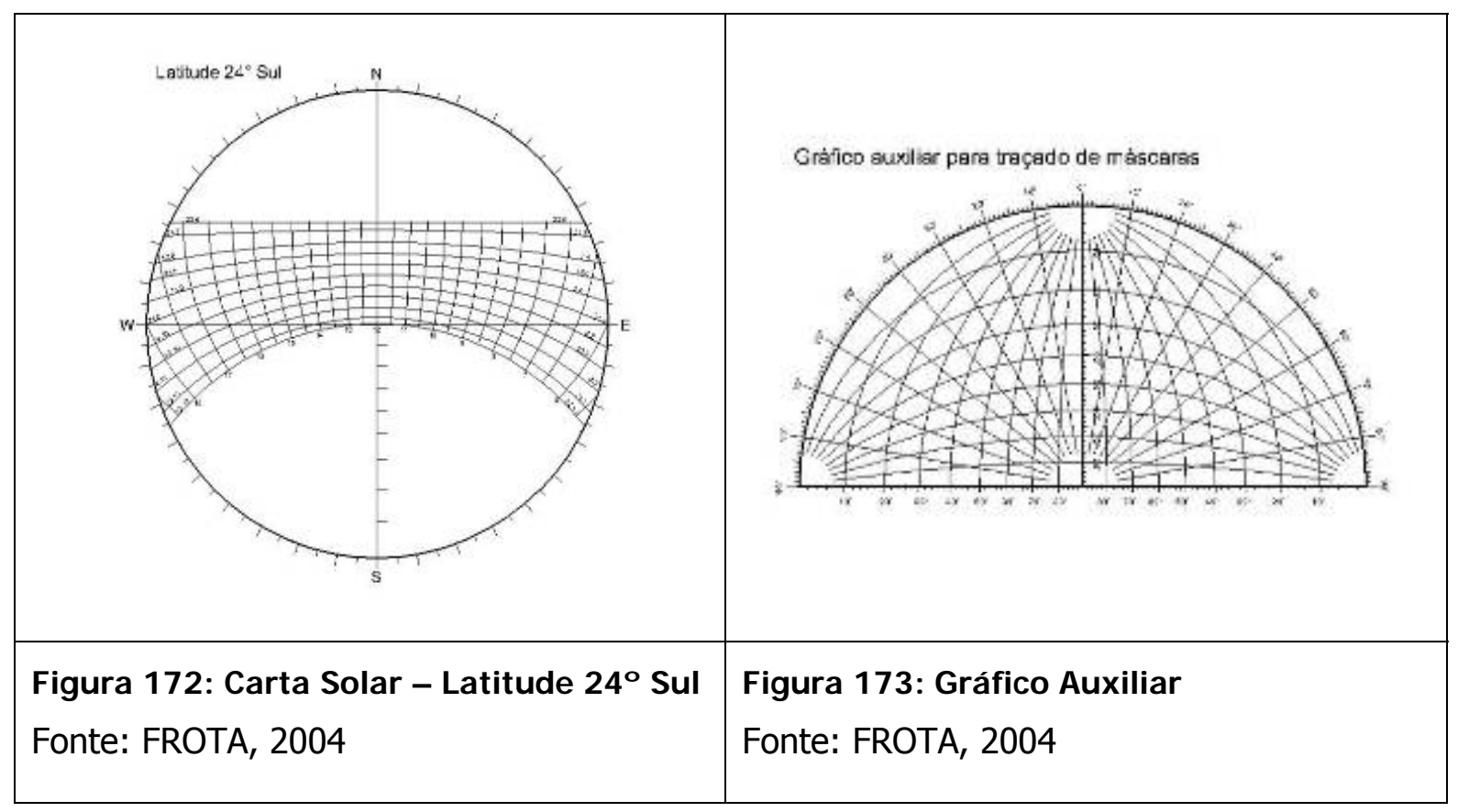

${ }^{156}$ A descrição desse método pode ser encontrada nas seguintes referências: Olgyay (1957); Frota (2004). 


\section{Método de simulação com modelos físicos reduzidos}

Para estudos de insolação e penetração da luz natural em modelos reduzidos destaca-se o quadrante solar, também conhecido como relógio de sol, desenvolvido por Pleijel. (SILVA \& MALATO, 1969; RIVERO, 1986). São conhecidos dois tipos de quadrantes solares: os universais que podem ser regulados e utilizados para qualquer latitude, e os locais, adequados à latitude para a qual foram construídos (Figura 174).

Para estudos com modelos reduzidos em laboratórios, utilizam-se um projetor de luz representando o sol e uma prancheta representando o plano do horizonte. Estes instrumentos são denominados de acordo com o método de operação tais como: heliodon de régua, heliodon de haste, heliodon de arco, termoeliodon, etc (Figura 176).

Esses simuladores possuem a vantagem de serem de fácil visualização, porém a desvantagem é que o tamanho do modelo é limitado, os resultados, na grande maioria, são apenas qualitativos e a construção desses instrumentos acarreta custos e necessita de espaço para a instalação (MIANA, 2005).

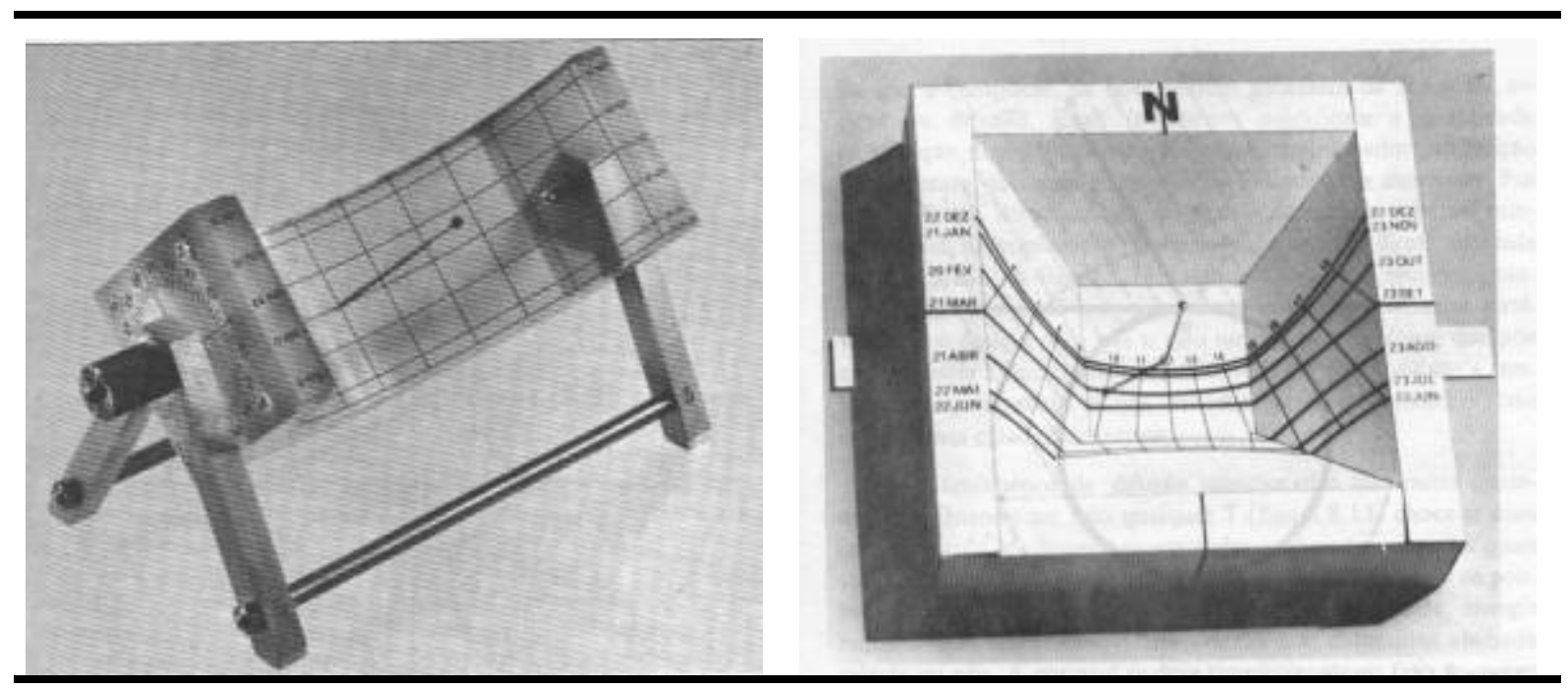

Figura 174: Quadrante solar universal Fonte - SILVA \& MALATO, 1969 apud MIANA, 2005
Figura 175: Relógio de sol montado com as lâminas do livro do Rivero

Fonte - RIVERO, 1986 

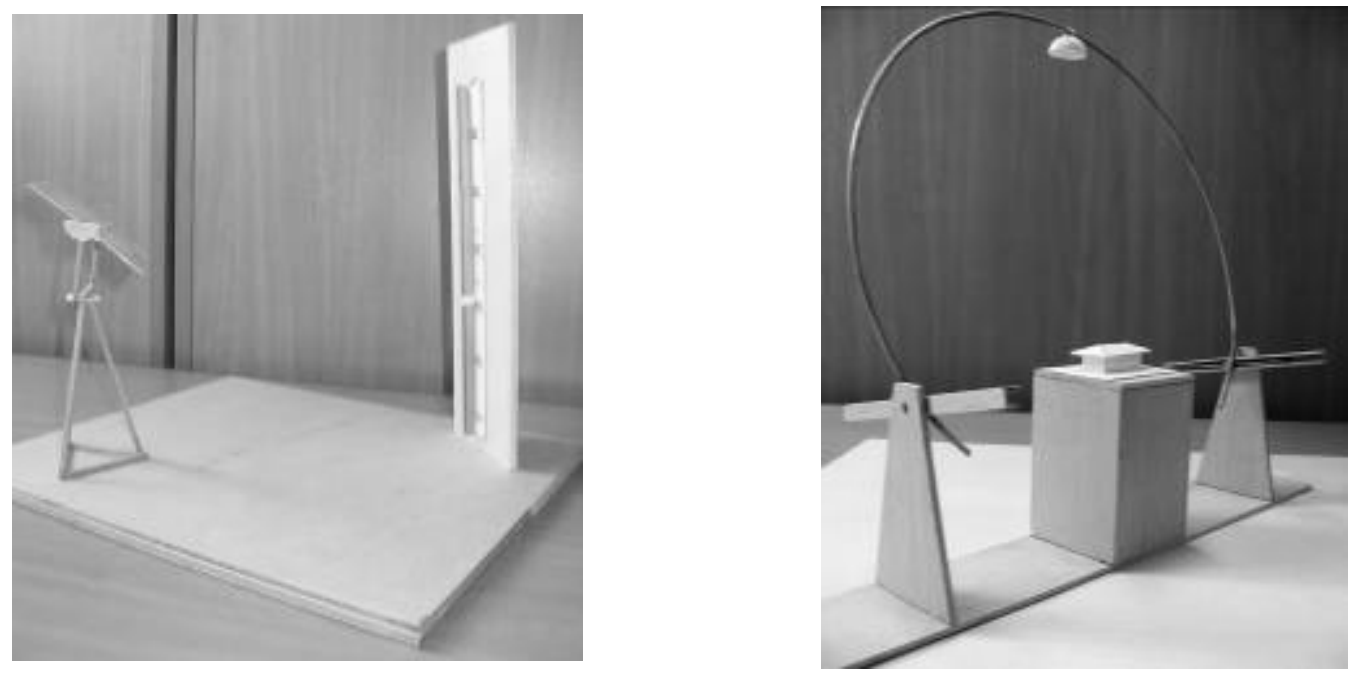

Figura 176: Maquete do Heliodon de régua Fonte - SOUZA, 2004

Figura 177: Maquete do Heliodon com um arco

Fonte - SOUZA, 2004

\section{Método de simulações com aplicativos computacionais}

Recomenda-se o aplicativo computacional Ecotect $5.2{ }^{157}$ para realização de simulações da sombra de edifícios no espaço urbano e em outras edificações, além disso, com o auxílio do aplicativo é possível gerar máscaras de sombra em pontos específicos a serem analisados, como o método gráfico. Com base em estudos utilizando o software verificouse que este aplicativo é bastante útil para estudos de isolação e de sombras, pois apresenta um resultado gráfico de fácil visualização e bastante coerente. Além disso, grande vantagem do aplicativo computacional é que mesmo apresentando formas complexas, após finalizado o desenho do modelo em 3D é possível realizar simulações para todo o ano, de forma rápida e eficiente.

Recomenda-se o aplicativo computacional tao ${ }^{158}$ para estudo da iluminação natural no interior das edificações.

Considerações: A trajetória do sol deve ser parte das estratégias para o desenho urbano, onde as relações entre largura das ruas, altura das edificações e orientação das

\footnotetext{
157 MARSH e RAINES, 2004. Disponível em< http://www.squ1.com> Acesso em jan de 2007.

158 ALUCCI, 2007.
} 
fachadas e da malha urbana podem impossibilitar o acesso da radiação solar no inverno, período que o sol apresenta uma altura mais baixa.

São muitos os fatores que devem ser considerados para melhorar a insolação. Higueras et al. (2009) aponta quatro estratégias possíveis em zonas urbanas de novo planejamento, por ordem de prioridade: variar a orientação das ruas, aumentarem a largura das ruas, diminuir a altura das edificações e alterar a tipologia edificatória.

No caso de localidades do hemisfério sul, por exemplo, a fachada sul é a que recebe o máximo número de noras de sol, sem considerar é claro, as obstruções. Uma variação de $15^{\circ}$ a $30^{\circ}$, desta orientação pode derivar outras situações favoráveis.

É preciso considerar a orientação de cada fachada para análise da insolação. Para o hemisfério sul, de uma maneira geral, sem considerar qualquer obstrução a fachada que mais recebe radiação é a norte e a que menos recebe é a sul. A fachada leste recebe sol pela manhã e a oeste pela tarde. É importante destacar que a radiação solar é desejável em alguns climas e em algumas épocas do ano, do contrário, o excesso de radiação solar pode gerar um ganho de carga térmica muito elevada, causando desconforto, principalmente em períodos e clima quente, e na fachada oeste.

Com relação aos espaços externos, estes devem ter acesso a radiação solar, nos períodos frios e serem protegidos com a sombra das árvores, nos períodos quentes.

A importância da radiação solar direta no meio urbano se centra principalmente na intensidade que as superfícies horizontais a recebem. Para determinar a quantidade de sol que incide sobre um espaço livre ou edificado, é fundamental o conhecimento sobre a irradiância solar $\mathrm{W} / \mathrm{m}^{2}$ e sua distribuição horária.

\section{Variável 02: Vento}

\section{Exigências: Qualidade do ar e Conforto térmico nos espaços externos}

Para a qualidade do ar o vento é um fator de fundamental importância para a dispersão de poluentes. Sendo assim, deve-se pensar na localização de equipamentos urbanos e/ou locais de concentração de partículas poluidoras, assim como as formas urbanas que favoreçam a permeabilidade ao vento. Vale destacar que nas cidades a concentração de emissões de poluentes está localizada na altura dos pedestres e que é gerada, principalmente, pelos veículos automotores. 
O conforto humano associado ao vento pode influenciar no bem estar das pessoas quanto ao conforto ou desconforto (fatores térmicos) causado pelo vento. O efeito do vento no corpo humano afeta a troca de calor entre o corpo e o ar proporcionalmente à velocidade do ar, através de convecção e aumenta a evaporação de suor e, por conseguinte, o resfriamento da pele (PRATA, 2005).

Requisito: Permeabilidade ao vento

Critério: velocidade do vento entre 3,5 e 5m/s e distribuição mais homogênea

Segundo Prata (2005), basicamente dois critérios podem ser verificados com relação ao vento em espaços urbanos: a velocidade efetiva, que combina o efeito da velocidade média do vento e das rajadas, e a segurança dos pedestres (BLANPAIN, 1995; GANDEMER, 1976; SARAIVA et al, 1997; SILVA, 1999).

Através dos estudos pode-se definir critérios de conforto para pessoas que trabalhavam no campo (velocidades medidas em 10 minutos a 2,00m do chão): $\mathrm{V}=5 \mathrm{~m} / \mathrm{s}$ início de desconforto; $V=10 \mathrm{~m} / \mathrm{s}$ claramente desconfortável; $\mathrm{V}=20 \mathrm{~m} / \mathrm{s}$ perigoso (PRATA, 2005, p.35).

Na definição de critérios de conforto e segurança, Prata (2005) utilizou a escala de Beaufort devido ao fato de se tratar de uma escala de força e por descrever os efeitos do vento. 
Tabela 20: Escala de Beaufort

Fonte: SARAIVA, 1994 apud PRATA, 2004

\begin{tabular}{l|l|l|l}
\hline \multicolumn{2}{c|}{ Escala de Beaufort } & $\begin{array}{l}\text { Velocidade } \\
(\mathrm{m} / \mathrm{s})\end{array}$ & \multicolumn{1}{c}{ Efeito } \\
\hline Calmaria & $0-1$ & $0-1.5$ & Calmo, sem vento perceptivel \\
\hline Brisa leve & 2 & $1.6-3.3$ & $\begin{array}{l}\text { Vento perceptível na face/movem-se as } \\
\text { folhas das árvores }\end{array}$ \\
\hline Brisa fraca & 3 & $3.4-5.4$ & $\begin{array}{l}\text { Vento desfralda bandeira leve/cabelo } \\
\text { mexe/roupas balançam/folhas das árvores } \\
\text { se agitam }\end{array}$ \\
\hline Brisa moderada & 4 & $5.5-7.9$ & $\begin{array}{l}\text { Levanta poeira, solo seco e papéis/ cabelo } \\
\text { é desarrumado/movem-se os galhos das } \\
\text { árvores }\end{array}$ \\
\hline Brisa fresca & 5 & $8.0-10.7$ & $\begin{array}{l}\text { Força do vento sentida no corpo/movem- } \\
\text { se as pequenas árvores }\end{array}$ \\
\hline Brisa forte & 6 & $10.8-13.8$ & $\begin{array}{l}\text { Dificuldade em usar guarda-chuvas/cabelo } \\
\text { é levantado/dificuldade em andar } \\
\text { direito/barulho de vento sentido nos } \\
\text { ouvidos/movem-se os maiores galhos das } \\
\text { árvores }\end{array}$ \\
\hline Vento fraco & 7 & $13.9-17.1$ & $\begin{array}{l}\text { Dificuldade para caminhar/movem-se as } \\
\text { grandes árvores }\end{array}$ \\
\hline Vento moderado & 8 & $17.2-20.7$ & $\begin{array}{l}\text { Impedimento para caminhar/grande } \\
\text { dificuldade de manter o equilibrio durante } \\
\text { rajada/quebram-se os galhos das árvores }\end{array}$ \\
\hline Vento forte & 9 & $20.8-24.4$ & $\begin{array}{l}\text { Impossivel caminhar contra o vento/danos } \\
\text { nas partes salientes das árvores }\end{array}$ \\
\hline
\end{tabular}

Com base nessas referências, adotou-se como critério de ventilação a velocidade do vento entre 3,5 e 5m/s, classificado como brisa fraca na escala de Beaufort e abaixo da velocidade inicial de desconforto, segundo Prata (2005).

Destaca-se que a questão da ventilação no meio urbano é bastante complexa e, por essa razão, um critério simplificado é bastante questionável, sendo assim não é descartada a necessidade de um estudo mais aprofundado dessa variável e do critério a ser adotado para atender as exigências humanas, relacionadas a ela. 
Ferramenta de avaliação: método de simulação com modelos físicos reduzidos em túnel de vento e método de simulação com o aplicativo CFD ${ }^{159}$.

\section{Método de simulação com modelos físicos reduzidos}

Os ensaios em túnel de vento são utilizados para a verificação dos efeitos do vento nos espaços urbanos, sendo de fácil visualização, porém a construção do modelo, assim como todo o ensaio deve ser bastante criterioso.

Em túneis mais complexos é possível ter uma avaliação quantitativa, com valores de velocidade. Por outro lado, em túneis simplificados, a análise é qualitativa e referente à distribuição do fluxo de ar.

Os trabalhos de Prata (2005 e 2008) apresentam ensaios em túnel de vento, detalhando sobre os aspectos e variáveis a serem considerados.

\section{Método de simulações com o aplicativo computacional CFD (CFX)}

Segundo Brandão (2009), o CFX permite a simulação virtualmente de qualquer situação envolvendo a mecânica dos fluidos, em qualquer escala e com qualquer tipo de condição de contorno, desde que se tenha capacidade computacional para tanto.

Os seguintes trabalhos adotaram esse software para estudo da ventilação natural em espaços urbanos: Prata (2005), Leite (2008) e Bradão (2009), sendo que esses dois últimos apresentaram um roteiro para o uso deste aplicativo.

\section{Considerações:}

É necessário conhecer os dados de vento para empregar fatores de correção para conseguir o conforto térmico nos espaços livres, protegendo-se dos ventos dominantes no período de inverno e buscando a máxima ventilação nos meses de verão.

Segundo Prata (2005), o campo do escoamento do vento atmosférico em torno de um edifício é determinado pelas características do vento imediatamente a barlavento, pela direção que se apresenta e pelas características geométricas do próprio edifício. A localização, forma de dimensão dos edifícios (comprimento, largura, altura) e sua

${ }^{159}$ ANSYS, 2005. Disponível em < http://www.esss.com.br/> Acesso em jan. 2007. 
orientação em relação ao vento, são de fundamental importância para a eficiência da ventilação natural do meio externo. (PRATA, 1998).

No nível do pedestre, a permeabilidade ao vento é estabelecida pela complexa interação entre as condicionantes climáticas e o meio construído. Diferentes formas urbanas apresentam diferentes efeitos, podendo ser negativos ou positivos relacionados com a questão da ventilação natural, ou seja, as dimensões, formas e justaposições dos elementos que compõem a cidade definem zonas de baixas e altas pressões ao redor dos edifícios, que podem gerar ou não aceleração do vento e contribuir para a sua distribuição.

Assis et al. (1995) apresenta um quadro com os efeitos aerodinâmicos de vento sobre conjuntos de edificações, importante para decisões com relação à implantação e forma das edificações em espaços urbanos.

Alucci, Carneiro e Baring (1986) apresentam algumas recomendações para implantação de conjuntos habitacionais considerando aspectos da ventilação natural.

\section{Variável 03: Vegetação}

No item 2.3.2 da Tese foram abordados os benefícios gerados pela presença de vegetação no meio urbano, tais como: melhoria do microclima urbano e da qualidade do ar no seu entorno, geração de sombra em áreas livres e nas fachadas das edificações, formação de uma barreira aos ventos frios; aumento das áreas permeáveis da cidade, efeitos psicológicos nos seus habitantes, benefícios estéticos, etc.

Esses benefícios estão ligados à quantidade, distribuição e qualidade das áreas verdes.

No método aqui proposto são considerados aspectos referentes à quantidade de área verde, através do índice de permeabilidade e o acesso dos cidadãos à vegetação, visando atender às exigências humanas de evitar inundações, de conforto térmico e de qualidade do ar nos espaços externos.

Exigências: Evitar inundações e Conforto térmico nos espaços externos

Requisito: Índice de permeabilização do solo urbano

Critério: Índice de permeabilização do solo urbano de 30\% da área total 
A produção da cidade implica, normalmente, na impermeabilização de boa parte do território que se urbaniza. Isso supõe restringir de maneira drástica a possibilidade de vida vegetal, o que pode gerar alterações no microclima e conforto urbano, no ciclo da água e na qualidade do ar.

Sendo assim, segundo os indicadores estabelecidos por Rueda (2006) é necessário garantir que pelo menos $30 \%$ do solo do espaço urbano seja permeável.

\section{Exigências: Qualidade do ar e Conforto térmico nos espaços externos}

Requisito: Acesso dos cidadãos à área verde

Critério: como critério adotou-se os valores definidos por Rueda (2006) para

- espaço verde $>1000 \mathrm{~m}^{2}$ a uma distância < de $200 \mathrm{~m}$ (deslocamento a pé de caráter cotidiano)

- espaço verde $>5000 \mathrm{~m}^{2}$ a uma distância < de $750 \mathrm{~m}$ (deslocamento a pé de caráter cotidiano)

- espaço verde $>1$ ha a uma distância $<$ de $2 \mathrm{~km}$ (deslocamento em bicicleta)

- espaço verde > 10ha a uma distância < de 4km (deslocamento em transporte público)

A proximidade da população aos espaços verdes é um parâmetro que avalia sua qualidade, já que esta depende de que a população possa desfrutar cotidianamente ou com regularidade destes espaços. O objetivo é que todo cidadão disponha de acesso a uma zona verde a uma distância que possa ser percorrida em menos de cinco minutos a pé.

Ferramenta de avaliação: método gráfico através de mapas e desenhos do projeto em planta em escala adequada.

\section{Método Gráfico}

Para avaliação do índice de permeabilidade são necessárias as seguintes informações:

- Classificação do solo segundo as seguintes categorias:

solo com superfícies permeáveis: aqueles que se encontram em estado natural sem compactar e que mantém suas funções naturais. São por tanto, superfícies que dispõem 
de vegetação ou oferecem condições para que esta possa se desenvolver e, espaços com pavimentos permeáveis brandos.

solo com superfícies semipermeáveis: solos que se encontram em estado natural mantendo parcialmente as suas funções. São, em geral, superfícies que foram cobertas com pavimentos permeáveis e que permitem infiltrações de água até o lençol freático e que facilitam o intercâmbio de gases entre a terra e a atmosfera.

solos impermeáveis não edificados: superfícies pavimentadas onde os solos já não tem sua função natural.

solos com superfícies impermeáveis edificadas: superfícies não susceptíveis de renaturalização do solo. Englobam medidas compensadoras tais como o reverdecimento de fachadas ou coberturas.

- Malha de referência. Rueda (2006) recomenda uma malha de 200 x 200m de largura da célula.

Com base nessas informações seguem as seguintes etapas:

1 - Digitação (geração de informação gráfica) dos espaços segundo seu grau de permeabilidade;

2 Soma total das áreas segundo sua categoria;

3 Relação do índice de permeabilidade para cada célula da malha.

Exemplo de um estudo gráfico comparando o índice de permeabilidade de dois casos: 


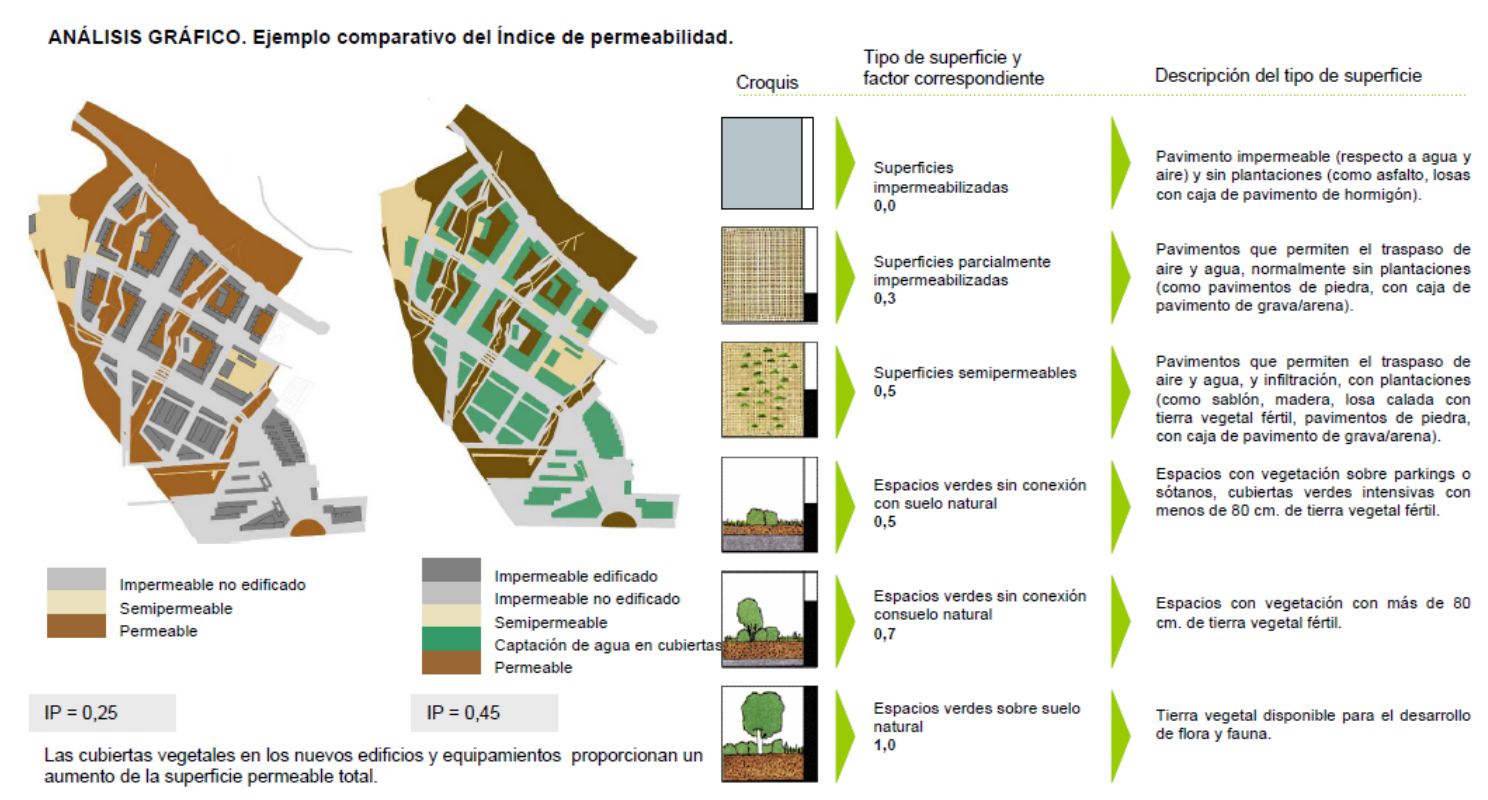

Figura 178: Avaliação do índice de permeabilidade do solo

Fonte: RUEDA, 2006

Para avaliação do acesso de cidadãos às áreas verdes são necessárias as seguintes informações:

- Espaços verdes segundo sua tipologia. De acordo com Rueda (2006), a superfície mínima que se considera como espaço verde é de $1000 \mathrm{~m}^{2}$, com mais de $50 \%$ de área permeável e/ou verde;

- Localização física da população ou de população em potencial;

- Tramas de ruas de pedestres, de transporte público e de bicicleta.

Com base nessas informações seguem as seguintes etapas:

1 - Digitação (geração de informação gráfica) dos espaços verdes, associando esses a tipologia e área de superfície;

2 Localização espacial das habitações e da população real ou em potencial;

3 Análise de proximidade segundo distância e superfície do espaço verde.

\section{Consideração:}

Além de todos os aspectos aqui mencionados, destaca-se a importância da implantação de um sistema de zonas verdes e espaços livres integrado. 
Variáveis 04: Sol, vento e vegetação

Exigência: Conforto térmico nos espaços abertos

Requisitos: Condições climáticas que proporcionem conforto nos espaços abertos, incluindo os seguintes parâmetros de desempenho relacionados à morfologia urbana: permeabilidade ao vento, períodos de sol e sombra (o que for necessário) e porcentagem de superfície vegetal.

Critério: como critério para avaliar o conforto térmico nos espaços abertos adotou-se o Índice Temperatura Equivalentes Percebida (TEP), desenvolvido por Monteiro (2008).

Para o atendimento do critério a sensação térmica deve estar compreendida entre pouco frio e pouco calor, sendo o ideal a neutralidade.

Tabela 21: Faixas interpretativas para a temperatura equivalente percebida (TEP) Fonte: MONTEIRO, 2008

Faixas interpretativas para a temperatura equivalente percebida

(TEP)

\begin{tabular}{|c|c|}
\hline TEP & Sensação \\
\hline$>42,4$ & muito calor \\
\hline $34,9 \sim 42,4$ & calor \\
\hline $27,3 \sim 34,8$ & pouco calor \\
\hline $19,6 \sim 27,2$ & neutralidade \\
\hline $12,0 \sim 19,5$ & pouco frio \\
\hline $4,4 \sim 11,9$ & frio \\
\hline$<4,4$ & muito frio \\
\hline
\end{tabular}

\section{Método Analítico}

Para avaliação do conforto térmico nos espaços abertos são necessárias as seguintes informações:

- condições de clima local, incluindo temperatura do ar, umidade relativa do ar velocidade do ar e radiação solar;

- atividades previstas para o uso dos espaços;

- padrão de vestimenta das pessoas. 
Essas variáveis são reunidas no Í ndice Temperatura Equivalentes Percebida (TEP) de conforto térmico em espaços abertos desenvolvido por MONTEIRO (2008).

Para cálculo da Temperatura Equivalente Percebida são necessárias as seguintes avaliações técnicas:

- estudos de sombra;

- estudos de ventilação natural;

- avaliação da dimensão e localização de áreas verdes;

- avaliação do fator de visão de céu

Para efeito de cálculo, Monteiro (2008) recomenda a adoção de uma malha de pontos marcando as diferentes configurações urbanas apresentadas.

Como resultado dessa avaliação apresenta-se um mapeamento das condições de conforto térmico das áreas que se encontram nas zonas de: neutralidade, pouco calor, calor e muito calor, de acordo com a Tabela 21.

\section{Variável 05: Energia}

Exigência: Redução do consumo de energia e geração de energia limpa

Requisito: Eficiência energética das edificações e potencial de aquecimento de água e geração de energia solar através da instalação de coletores solares e painéis fotovoltaicos nas coberturas

Critério: redução de $15 \%$ do consumo de energia das edificações

Como comentado anteriormente, aproximadamente $25 \%$ do consumo de energia elétrica no setor residencial no Brasil é referente ao uso do chuveiro elétrico (ALMEIDA et al., 2001). Diante disso, através da substituição do uso de chuveiro elétrico pelo uso de coletores solares para aquecimento das águas domiciliares é possível uma redução significativa desse valor.

Sendo assim, como proposta inicial adotou-se uma economia de $60 \%$ do consumo destinado ao uso do chuveiro elétrico, que significa $15 \%$ do total da energia consumida no setor residencial no Brasil.

Além da economia energética através do uso de coletores solares para aquecimento de água, o método proposto também considera e avalia o potencial de geração de energia 
limpa através da instalação de painéis fotovoltaicos nas coberturas. Para avaliação desse requisito, adota-se o mesmo método do potencial de instalação de coletores solares para aquecimento de água nas coberturas das edificações.

Ferramenta de avaliação: para avaliar o potencial de geração de energia renovável e captação de energia solar para aquecimento de água utiliza-se o método apresentado no Decreto Municipal 49.148 (PREFEITURA DO MUNICÍPIO DE SÃO PAULO, 2008), mesmo adotado no exercício de projeto apresentado no item anterior.

\section{Método Analítico conjunto com método de simulação com aplicativos computacionais}

Para essa avaliação é necessário um estudo do sombreamento da área de colocação dos coletores solares no dia 6 de abril às $9 \mathrm{~h} ; 12 \mathrm{~h}$ e $15 \mathrm{~h}$. Para isso recomenda-se o aplicativo computacional Ecotect.

Como critério de desempenho é estabelecido que, áreas sombreadas por mais de $60 \%$ em um desses horários não são favoráveis para a adoção do sistema de aquecimento solar. Dessa forma, calculou-se a área total apropriada para os coletores e painéis em função das áreas disponíveis (PREFEITURA DO MUNICÍPIO DE SÃO PAULO, 2008).

Sendo assim, com os resultados das simulações devem ser mapeadas as áreas conforme a porcentagem de sombreamento e adotado o seguinte fator de correção (MOURA, 2008):

- acima de $60 \%$ área sombrada - área descartada

- entre 30 e $60 \%$ área sombreada - multiplicado pelo fator de correção 0,55

- com menos de $30 \%$ da área sombreada - multiplicada pelo fator de correção 1

Para cálculo da demanda mensal de energia foi adotada a seguinte equação:

$$
E=\frac{V \times C p \times\left(t_{2}-t_{1}\right) \times 30}{3600}[\mathrm{kWh} / \mathrm{mês}] \quad(\text { eq.01) }
$$

E Demanda de energia mensal

V Volume diário de água quente a ser aquecida em litros

(Considerar para banho 80 litros por pessoa)

Cp Calor específico da água: $4,18 \mathrm{~kJ} / \mathrm{kg}^{\circ} \mathrm{C}$ 
$t_{2} \quad$ Temperatura da água quente (adotar $45^{\circ} \mathrm{C}$ )

$\mathrm{t}_{1} \quad$ Temperatura da água fria: $20,2^{\circ} \mathrm{C}$ (São Paulo)

Com o valor da demanda e com o potencial de captação de energia solar para aquecimento de água e geração de energia solar verifica-se a porcentagem da população atendida e com isso a economia de energia atingida.

\section{Considerações:}

Entre outras medidas para proporcionar uma redução no consumo energético destacamse: o correto desenho urbano e arquitetônico adequado as condições climáticas e ambientais de cada território; adoção de modelos de ocupação eficientes, visando à redução de deslocamentos, mediante diversificação de usos, fomento de transporte coletivo eficiente e mobilidade a pé ou de bicicleta e; avaliação do potencial de geração de energia limpa (energia eólica, energia geotérmica, utilização de biomassa ou resíduos; plantas de ciclo combinado, etc).

\section{Variável 06: Ruído urbano}

Exigências: Conforto acústico nos espaços externos e nas unidades habitacionais

Requisito: nível sonoro adequado para a atividade estabelecida

Critério: nível de ruído máximo de $55 \mathrm{~dB}(\mathrm{~A})$ para espaços externos e na fachada das edificações (NBR 10151, 2000).

O desempenho acústico de um ambiente é caracterizado pelo nível sonoro ao qual os usuários são submetidos. Em função do tipo de atividade, o nível sonoro para garantir as condições de conforto acústico dos usuários é estabelecido pela NBR 10152 (1987).

Para a Norma Brasileira 10151 (2000), o valor limite do nível sonoro em área de uso misto com vocação comercial e administrativa é de $60 \mathrm{~dB}(\mathrm{~A})$ para o período diurno e 55 $\mathrm{dB}(\mathrm{A})$ para período noturno. Nessa mesma Norma, em área de uso misto com predominância residencial os valores são de $55 \mathrm{~dB}(\mathrm{~A})$ (diurno) e $50 \mathrm{~dB}(\mathrm{~A})$ (noturno).

Já a Norma Técnica L11.032 (1992) da CETESB para áreas externas, também estabelece o valor de $60 \mathrm{~dB}(\mathrm{~A})$ para áreas denominadas diversificadas (residência, comércio e industria), no período de $7 \mathrm{~h}$ às $19 \mathrm{~h}$, e de $55 \mathrm{~dB}(\mathrm{~A})$ para o período de $19 \mathrm{~h}$ às $22 \mathrm{~h}$ e 50 $\mathrm{dB}(\mathrm{A})$ para o período das $22 \mathrm{~h}$ às $7 \mathrm{~h}$. 
A Organização Mundial da Saúde (OMS) concluiu que o conforto auditivo termina acima de 50dBA e o estresse começa acima de 55dBA (WHO, 1980; Berglund \& Lindvall, 1995 apud ALUCCI, 2007).

No método aqui proposto são adotados os valores da NBR 10151 (2000), considerando o valor limite estabelecido para áreas de uso misto com predominância residencial de 55 $d B(A)$.

Ferramenta de avaliação: aplicativos computacionais $\mathrm{TAO}^{160}$ ou acústico

\section{Considerações:}

O valor do nível sonoro em um dado ponto da fachada de uma edificação é função: da posição do ponto na fachada; dos trechos de pistas que podem ser vistos por esse ponto; do número de veículos por hora que circulam nas pistas; da velocidade dos veículos; da porcentagem de veículos leves e pesados; da inclinação das pistas; da existência de obstruções no entorno da edificação; da presença de barreiras; da posição relativa das obstruções (em relação ao ponto da fachada) (ALUCCI, 2007).

No âmbito urbano, visando o conforto acústico nos espaços urbanos, recomenda-se: reduzir a geração de ruído e implantar esses mais distantes das vias ou de outras fontes de ruído. Para as novas edificações, recomenda-se a implantação no terreno que evite a exposição das aberturas às fontes sonoras importantes.

Alucci, Carneiro e Baring (1986) apresentam algumas recomendações para implantação de conjuntos habitacionais considerando aspectos referentes à acústica urbana.

\section{Avaliação geral quali-quantitativa:}

Por fim, destaca-se que, para a avaliação do conforto acústico e luminoso no interior das edificações, adotou-se como parâmetro de desempenho o nível de ruído e a disponibilidade de luz natural na fachada, respectivamente.

Outro aspecto que merece ser mencionado é que todos os fatores devem ser avaliados por quadra, pois qualquer mudança na sua forma e nas características do entorno

${ }^{160}$ ALUCCI, 2007. Disponível em: <http://www.usp.br/fau/pesquisas/laboratorios/labaut/conforto/index.html> Acesso em jan de 2009. 
imediato pode ocasionar alteração no desempenho das edificações, do conjunto da quadra estudada e das edificações que a circundam.

Além disso, alguns requisitos como o acesso ao sol, a disponibilidade de luz natural e o nível de ruído, deve, ser analisado em diferentes pontos (altura) da fachada e em todas as fachadas da edificação.

Finalizados as avaliações técnicas

A Tabela 22 apresenta a legenda usada na etapa de avaliação quali-quantitativas dos projetos urbanos em desenvolvimento.

Tabela 22: Legenda da avaliação quali-quantitativa de projetos urbanos

Avaliação quali-quantitativa dos critérios ambientais por quadra

$\mathbf{X}$ não atende ao critério em nenhuma quadra do projeto urbano

atende a ao critério em até $1 / 3$ das quadras do projeto urbano

atende a ao critério em $1 / 3$ a $2 / 3$ das quadras do projeto urbano

atende a ao critério em todas as quadras do projeto urbano

\section{ETAPA 05 - ADEQUAÇÃO DO PROJ ETO}

Com base nas avaliações é definido o cenário que melhor atende às exigências humanas e verificado onde essa proposta deve ser aprimorada. Além disso, é analisada a qualidade dos espaços produzidos, do ponto de vista da paisagem urbana e integração do espaço urbano com o restante da cidade.

Deve-se destacar que nesse momento do método, as etapas 03, 04 e 05 são realizadas simultaneamente.

\subsection{Resumo do método proposto}

A Figura 179 apresenta um esquema da estrutura do método de inserção dos parâmetros ambientais no processo de projeto urbano e a Tabela 23um quadro síntese do método, com as variáveis, exigências humanas, requisitos, critérios e ferramentas de avaliação.

Figura 179: Esquema da estrutura do método de inserção de parâmetros ambientais no processo de projeto 


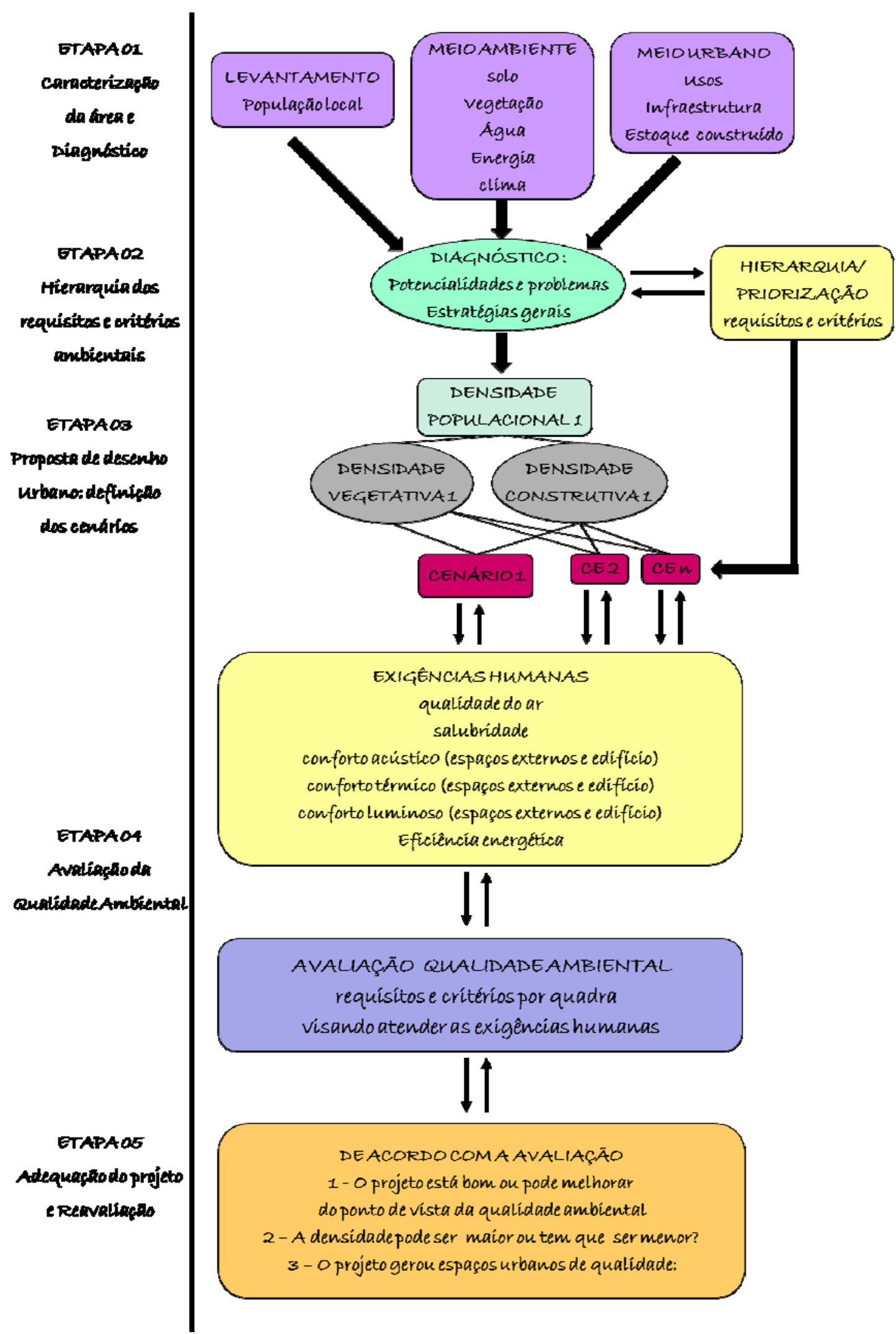





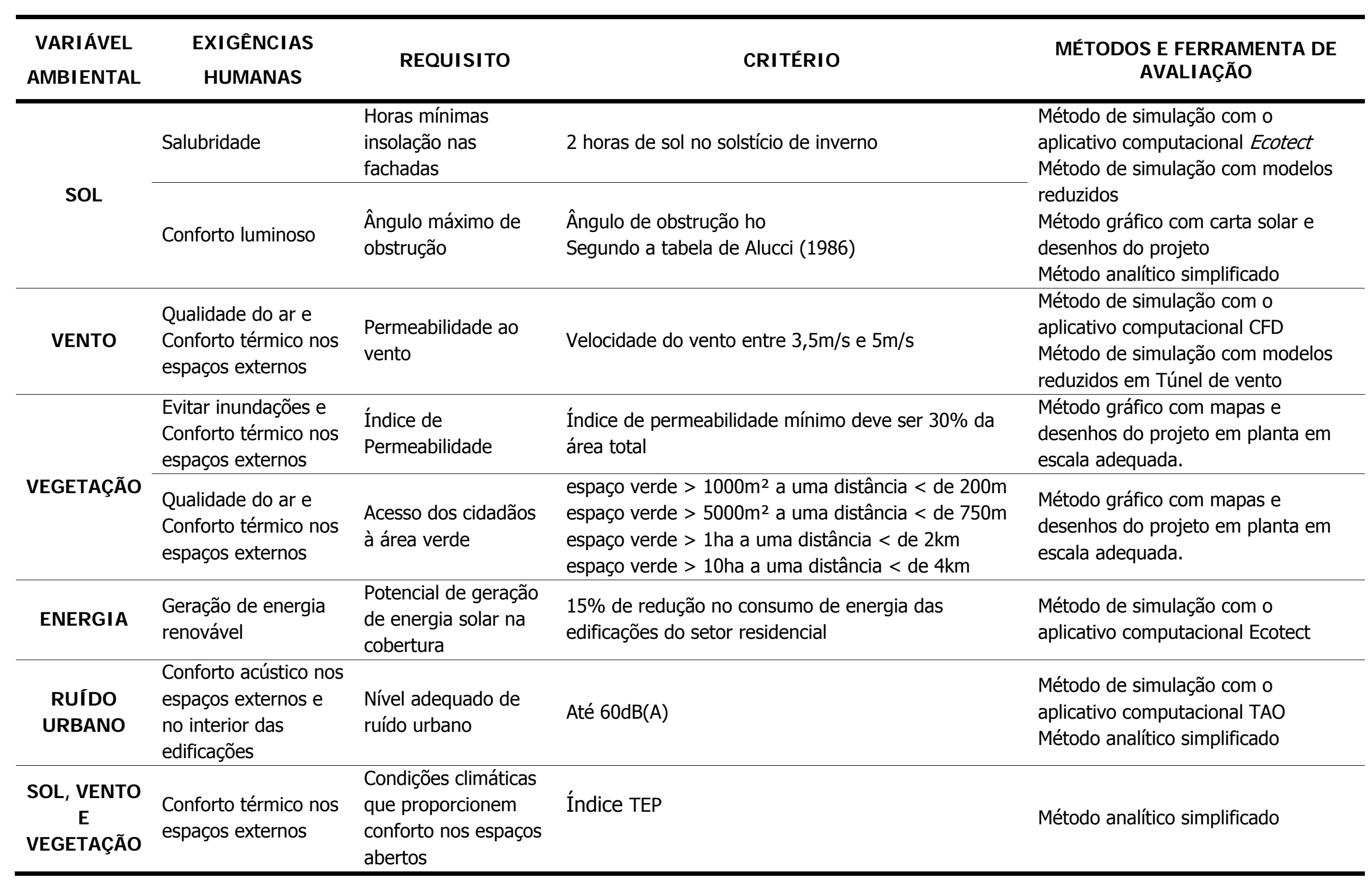




\section{CONSIDERAÇÕES FINAIS}

\section{Síntese das principais conclusões}

Com base no estudo histórico, na fundamentação teórica, na análise das experiências de projetos urbanos contemporâneos, no estudo dos métodos de projeto urbanos mais sustentáveis, no estudo de caso e na proposição do método de inserção de paramentos ambientais no processo de projeto apresentam-se as conclusões do trabalho.

Através do estudo das questões ambientais na história do desenho urbano e das principais utopias urbanísticas, verificou-se que o crescimento acelerado das cidades vinha acompanhado de problemas ambientais e sociais. Nos séculos XVIII e XIX, as condições ambientais das cidades começaram a se deteriorar, apresentando um quadro de poluição, densidade excessiva e desigualdade social. Essa situação gerou diversas reações e debates sobre as direções que deveriam tomar o crescimento das cidades.

Entre as utopias apresentadas no capítulo 01 destacam-se a cidade-jardim, de Howard e as propostas de Le Corbusier para o urbanismo moderno.

A cidade-jardim apresenta princípios que hoje são resgatados na busca de modelos de cidade mais sustentáveis, como: densidade controlada, acesso dos cidadãos aos espaços verdes, priorização dos pedestres, transporte público adequado, uso misto, etc.

Porém muitas vezes esse modelo foi aplicado em áreas afastadas, gerando subúrbios jardim, presentes nos EUA e em diversas cidades latino-americanas. Apesar disso deve-se considerar que um caminho para o desenvolvimento urbano sustentável é tentar completar as partes deficientes nos ideais de Howard.

Com relação às utopias de Le Corbusier, essas se destacam por apresentar uma preocupação com a insolação e ventilação das habitações, em abrigar uma grande densidade sem comprometer o solo urbano, adotando uma tipologia edificatória mais verticalizada, liberando o solo para as áreas verdes e livres. Apesar dessas preocupações, os bairros funcionalistas, em geral, se projetavam com uma absoluta ausência de referência da natureza e do entorno. Outro aspecto que comprometeu a sustentabilidade ambiental desses modelos foi que esses foram desenvolvidos com base na segregação de atividades e no uso do automóvel. Isso resultou em modelos de ocupação urbana 
dispersos, com graves conseqüências para o meio natural e com mudanças nem sempre positivas na qualidade de vida da população.

Enquanto Le Corbusier se baseava em princípios que incentivavam a expansão horizontal dos subúrbios, propostas mais recentes para as cidades se apoiavam nas vantagens oferecidas por modelos mais compactos

Cidades compactas apresentam um menor consumo de solo urbano, uma versatilidade de morfologias urbanas possíveis, otimização do uso de transporte público, a existência de áreas multifuncionais as quais o acesso é possível andando ou de bicicleta, a redução dos tráfegos de veículos privados; a sociabilidade e os intercâmbios pessoais.

A forma de cidade compacta é considerada bastante sustentável frente a outras opções. Apesar disso, modelos urbanos compactos apresentam as seguintes desvantagens: congestão, pouco espaço para área verde e área livre, produção de segregação da população devido à carência de solo urbano e grande possibilidade de comprometimento do desempenho térmico, luminoso, acústico e energético das edificações, principalmente, se essas questões não forem consideradas no projeto.

Sendo assim, a conclusão é que modelos urbanos mais compactos podem ser a solução para o crescimento das cidades, porém, necessitam ser revistos de acordo com os tempos atuais, não só considerando a cidade propriamente dita, mas também seu território e área de influência, adotando para cada escala o modelo adequado com base nas suas particularidades e recursos disponíveis.

Alguns autores propõem como ideal uma mescla entre formas compactas e difusas segundo a escala urbana, ou seja, dispor de estruturas formais compactas na escala urbana local, organizadas mediante estruturas de formas difusa na escala regional ou metropolitanas unidas por meios de transporte eficiente e não contaminante. Esta solução permite uma boa acessibilidade equilibrada com amplos espaços abertos entre as diferentes cidades compactas e, por outro lado um adequado controle sobre o uso e eficiência do transporte, preservando as zonas verdes de interesse.

Com base na fundamentação teórica foi concluído que a Cidade sustentável é aquela que busca uma maior qualidade ambiental dos espaços externos e das edificações, sem que isso gere um impacto no meio natural. Ou seja, a cidade sustentável apresenta uma preservação e liberação de áreas naturais através das vantagens da compacidade urbana. 
É aquela eficiente no consumo dos recursos naturais em geral, de prática mobilidade, com sistemas de transportes eficientes e diversificados, preparada para o deslocamento do pedestre e de outros modos sustentáveis, servida de espaços públicos habitáveis e de qualidade, constituída de edifícios adequados as condições climáticas locais, e que apresenta complexidade e uma coesão social, ou seja, diversidade de usos, de tipologias edificatórias e diversidade social.

Muitos autores, principalmente ecólogos e geógrafos, consideram a cidade um ecossistema, na medida em que essa também é um sistema complexo de fatores e condicionantes inter-relacionados. Sendo assim, os sistemas urbanos devem ter um planejamento ecossistêmico, o que implica em uma concepção global e não somente uma análise particularizada das partes que o integram.

Sob essa visão, verifica-se que para uma maior sustentabilidade das cidades os atuais processos lineares de produção, causadores de poluição e de consumo devem ser substituídos por aqueles que objetivem um sistema circular de uso e reuso. Esses processos aumentam a eficiência global do núcleo urbano e reduzem o impacto ao meio ambiente. Sendo assim, todos os assentamentos humanos e ocupações urbanas devem considerar o ciclo da água, do ar e da energia, visando reduzir a necessidade de consumo de recursos naturais e a geração de resíduos e contaminantes.

Ainda com relação ao capítulo 02 foi concluído que o adensamento urbano pode ser positivo, desde que os impactos negativos gerados por esse sejam considerados no processo de projeto, visando a sua minimização. Além disso, verificou-se que, com mesmas densidades podem apresentar diferentes formas urbanas que apresentam diferentes desempenhos ambientais, com diferentes impactos ao meio natural.

Concluiu-se também, que os indicadores de sustentabilidade são um mecanismo efetivo para o projeto e construção de cidades mais sustentáveis. Porém verificou-se que é difícil e complexo selecionar um conjunto de indicadores capazes de representar a interdependência entre sistema urbano e recursos naturais globais e concluir daí a sua sustentabilidade.

Além disso, só os indicadores por si não são capazes de promover melhorias, metas e parâmetros são também necessários para embasar os indicadores e permitir a avaliação do progresso. Os indicadores podem auxiliar no desenvolvimento de diretrizes para projetos de intervenções urbanas e edificações, sendo ferramentas importantes de 
tomada de decisão no que tange às conquistas e aos desafios da organização em alcançar suas metas.

Entre os indicadores de sustentabilidade urbana destacam-se o indicador desenvolvido por William Rees e Mathis Wackernagel (1996), que consiste no conceito de pegada ecológica (ecological footprint), com o objetivo de visualizar as conseqüências diretas do desenvolvimento urbano sobre o planeta, ou seja, quantificar o impacto ambiental das cidades. E os indicadores de sustentabilidade ambiental urbana, desenvolvidos para Sevilha (RUEDA, 2006).

Com relação aos projetos contemporâneos avaliados no capítulo 03, concluiu-se que, de fato, os projetos que apresentaram uma preocupação explícita com as questões ambientais, por parte dos projetistas, obtiveram melhores resultados na avaliação com relação à sustentabilidade urbana como, por exemplo, os ecobairros presentes na Europa. Os ecobairros destacaram-se por apresentar de maneira clara o comprometimento com o meio natural, através da incorporação dos princípios da sustentabilidade ambiental urbana ao projeto. Sendo assim, em geral os ecobairros apresentam como tema estruturante: um cuidado com a conservação e integração com o meio ambiente, fechamento dos ciclos urbanos; uma adequada relação com seu território e paisagem; a redução da contaminação do ar, água e solo e melhores relações sociais de seus residentes. Enfim, os ecobairros são uma alternativa para a construção de cidades habitáveis e sustentáveis.

Com relação aos projetos de exposições internacionais e os eventos esportivos, na maioria das vezes, esses funcionaram como catalisadores para a realização de grandes intervenções urbanas. Em muitos casos, o projeto do evento foi o incentivo necessário para a resolução de problemas da cidade com relação, principalmente, à infra-estrutura e às áreas degradadas, resultando na transformação nos locais onde foram implantados, benefícios que ultrapassaram esses limites.

Os projetos de recuperação de áreas degradadas representam uma grande oportunidade de melhorar o grau de sustentabilidade das cidades. A implantação de projetos nos chamados vazios urbanos é importante para melhorar a dinâmica da cidade, atender a uma demanda de adensamento e transformar essas áreas urbanas já consolidadas, trazendo, na maioria das vezes, benefícios sociais, econômicos e ambientais para toda a cidade. Além disso, a criação de bairros novos em vazios urbanos traz a oportunidade de 
exploração de diferentes configurações morfológicas e o estabelecimento de outras metas de adensamento restritas pelas condicionantes ambientais.

Com base nas avaliações concluiu-se que quase todas as intervenções urbanas de qualidade têm como fator principal a preocupação com o meio natural circundante (relevo, cursos de água, características do solo e do local, etc.), partindo dessas a morfologia urbana.

Concluiu-se ainda que através de uma intervenção pontual, todos os projetos analisados trouxeram, de alguma maneira, benefícios para a cidade e seus residentes, uns mais outros menos. Além disso, eles apresentaram estratégias de projeto que podem ser reaplicadas em outros casos, desde que sejam considerados o contexto local e as condições climáticas da área. Não existem soluções únicas, cada sitio e cada projeto necessita de medidas específicas relacionadas às suas características próprias.

Da mesma maneira que não existe um método de projeto universal, já que esse é definido diante dos problemas e potencialidades apresentados. Porém são necessárias a definição e adoção de parâmetros e regras que orientem o processo de projeto que visa à sustentabilidade ambiental, o atendimento às exigências humanas e a produção de espaços urbanos de qualidade com o mínimo impacto ao meio natural.

O apoio de ferramentas de simulação computacional para a avaliação do desempenho ambiental, incluindo microclimas e energia, por exemplo, significa uma inovação com um papel importante na elaboração de projetos urbanos voltados para uma melhor qualidade ambiental. Os resultados de tais avaliações dão suporte às decisões com relação à forma urbana e também à inserção de tecnologias em prol de uma maior eficiência energética dos edifícios. Com o auxílio das simulações, é possível identificar o efeito da forma, da orientação, das tipologias arquitetônicas e das massas de vegetação no comportamento do vento, na incidência da radiação solar, na disponibilidade de luz natural, na umidade e na temperatura do ar, na eficiência energética e na propagação do ruído nos espaços abertos, conseqüentemente, no conforto do pedestre e na qualidade ambiental do espaço público.

Através do estudo de caso, verificou-se, mais uma vez, que alta densidade urbana e qualidade ambiental são compatíveis desde que as questões ambientais sejam consideradas no processo de projeto. Concluiu-se ainda que o adensamento urbano pode ser positivo para a sustentabilidade da cidade, através de um maior aproveitamento da 
infraestrutura da cidade, da redução de deslocamentos, do uso mais eficiente do espaço publico e da potencialização da vitalidade urbana.

Com a aplicação criteriosa de estratégias de desenho urbano fundamentadas em princípios de desempenho ambiental, alcança-se melhor qualidade urbana (não somente ambiental) com espaços abertos convidativos $e$ apropriados as dinâmicas socioeconômicas do ambiente urbano, cercados por edifícios também de melhor qualidade ambiental e, ainda, menor consumo de energia.

Em resumo conclui-se que novos assentamentos urbanos devem: ser diversos, com relação às tipologias edificatórias, as classes sociais e aos usos do solo urbano; construir a cidade para o pedestre, para tanto, deve-se investir no sistema de transporte público, diminuindo o uso de veículos particulares; valorizar a integração, ampliação e desenho da rede de espaços verdes e livres; planejar ocupações para conseguir densidades moderadas ou altas, evitando as baixas densidades e áreas com casas unifamiliares, para que os custos de infra-estrutura e energéticos não sejam tão elevados; aproveitar os recursos naturais (sol, vento, água de chuva) para a adoção de tecnologias passivas e como fontes de energia renováveis em escala urbana.

Destaca-se que nenhuma tipologia arquitetônica é por si só melhor que as outras, cada uma apresenta vantagens e desvantagens particulares dependendo do clima e da função. Destaca-se ainda que a diversidade edificatória é um atributo de sustentabilidade, implicando uma variedade de formas arquitetônicas e de tipologias habitacionais, além de uma melhor adequação às condições locais.

\section{Perspectivas futuras}

Durante o desenvolvimento do trabalho verificou-se a necessidade da realização de mais pesquisas relacionadas ao tema. Sendo assim, apresentam-se aqui as possibilidades de trabalhos futuros.

Dando continuidade ao estudo de caso, é importante que a avaliação de desempenho seja realizada para todas as quadras, aplicando depois a avaliação proposta no método de inserção de parâmetros ambientais no processo de projeto.

O método de inserção de parâmetros ambientais no processo de projeto deve ser aplicado em outras áreas, podendo, por exemplo, ser utilizado para a realização de um 
projeto para a área da Barra Funda em São Paulo, já que esta apresenta vazios urbanos, possibilitando um adensamento, justificado pela infra-estrutura já consolidada.

Com base nestas aplicações, o método deve ser revisto sob todos os aspectos: requisitos, critérios, necessidade de inserção de outras variáveis, ferramentas de avaliação, etc.

Outra pesquisa de grande contribuição seria analisar o que está sendo construído em São Paulo pelo poder público e pelo poder privado, sob o ponto de vista da sustentabilidade ambiental. Para isso poderiam ser adotados os mesmos indicadores e a mesma qualificação utilizados nas avaliações dos projetos urbanos contemporâneos, apresentadas no capítulo 03 da Tese. Os resultados dessas avaliações dariam suporte para a definição de melhorias para esses projetos, apontando os aspectos que devem ser considerados no processo de projeto.

Com base nessas aplicações do método e na avaliação do que está sendo construído em São Paulo, devem ser desenvolvidas diretrizes de projeto urbano, visando a produção de espaços urbanos com qualidade ambiental.

Por fim, é importante avaliar as políticas urbanas, verificando medidas para viabilizar estas intervenções. 
A.A.V.V. Libro verde del médio ambiente. 1990. Disponível em: <http://www.bcnecologia.net>.Acesso em: 10 jun. 2008.

A.A.V.V.A green vitruvius. Principles and practice of sustainable architectural design. London: James \& James, 1999.

ABBAGNANO, N. Dicionário de Filosofia. São Paulo: Ed. Mestre Jou, 1982, p260.

ACIOLY, C.; DAVIDSON, F. Densidade urbana: um instrumento de planejamento e gestão urbana. Rio de Janeiro: Ed. Mauad, 1998.

ACSELRAD, Henri. A duração das cidades: sustentabilidade e risco nas políticas urbanas. Rio de Janeiro: DPPA, 2001.

ACSELRAD, Henri. Discursos da sustentabilidade urbana. Revista Brasileira de Estudos Urbanos e Regionais. São Paulo: ANPUR. n.1, p. 79-90, maio 1999.

ADRIAANSE, A. In search of Balance: A conceptual Framework for sustainable development Indicators, Network Seminar on Sustainable Development I ndicator. London, 1994.

ALBERTI, M. SOLERA, G. e TSETSI, V. La città sosttenibile. Angeli, Roma, 1994.

ALUCCI, M. P. (Coord), CARNEIRO, C. DE M., BARING, J. G. A. I mplantação de Conjuntos Habitacionais: Recomendações para Adequação Climática e Acústica. São Paulo: IPT, 1986.

ALUCCI, M. P. (Coord.). Coberturas têxteis; determinação das características termo-luminosas. (Relatório de pesquisa) São Paulo: LABAUT, CNPq, 2005.

ALUCCI, M. P. Software Climaticus 4.2. Departamento de Tecnologia da Arquitetura, FAU USP, 2006. Disponível: em: <http://www.usp.br/fau/pesquisas /laboratorios/labaut/conforto/index.html>. Acesso em: jan. 2006. 
ALUCCI, M. P. Software TAO. Departamento de Tecnologia da Arquitetura, FAU USP, 2007. Disponível em: <http://www.usp.br/fau/pesquisas /laboratorios/labaut/conforto/index.html>. Acesso em: jan. 2009.

ALUCCI, M. P. TAO: uma metodologia para implantação de edificação. Ênfase no desempenho térmico, acústico, luminoso e energético. Tese (Livre Docência em Arquitetura e Urbanismo) Faculdade de Arquitetura e Urbanismo, Universidade de São Paulo, São Paulo, São Paulo, 2007.

ALUCCI, M. P.. Software Urbano. Departamento de Tecnologia da Arquitetura, FAU USP, 2005. Disponível em: <http://www.usp.br/fau/pesquisas /laboratorios/labaut/conforto/index.html>. Acesso em: jan. 2008.

ALUCCI, M. P.; MONTEIRO, Leonardo Marques. Climate and Thermal Stress in.Outdoor Spaces In: PASSIVE AND LOW ENERGY ARCHITECTURE, 21, Eindhoven, 2004. Built environments and environmental buildings. Eindhoven: PLEA, 2004 (CD-ROM).

ALUCCI, Márcia Peinado. Conforto térmico, conforto luminoso e conservação de energia elétrica: procedimentos para desenvolvimento e avaliação de projetos de edificações. Tese (Doutorado em Arquitetura e Urbanismo, Estruturas Ambientais Urbanas) Faculdade de Arquitetura e Urbanismo, Universidade de São Paulo, São Paulo, 1992.

ALUCCI, Marcia Peinado. Software Acústico 2.0. Departamento de Tecnologia da Arquitetura, FAU USP, 2002. Disponível em: <http://www.usp.br/fau/pesquisas /laboratorios/labaut/conforto/index.html>. Acesso em: jan. 2008.

ANDRADE, Liza e ROMERO, Marta Adriana Bustos. Desenho de assentamentos urbanos sustentáveis: proposta metodológica. In: I Conferência Latinoamericana de Construção Sustentável e 10o. Encontro Brasileiro de Tecnologia do Ambiente Construído. Anais. São Paulo: [s.n.], 2004.

ANDRADE, Liza e ROMERO, Marta. Construção de indicadores de eficiência hídrica. In: Seminário A Questão Ambiental Urbana: Experiências e Perspectivas. Anais. Brasília: Núcleo de Estudos Urbanos e Regionais - NEUR/UnB, 2004. 
ANDRADE, Liza e ROMERO, Marta. Estudos para a elaboração do projeto corporativo para a Reabilitação Ambiental e Construção Sustentável das Unidades da ECT. Documento interno LaSUS/FAU/UnB.Brasília, 2006.

ANDRADE, Liza e VIANNA, Rejane. Desenho para um condomínio sustentável. Trabalho de Mestrado apresentado na disciplina de ateliê de Desenho Urbano (PPGFAU/UnB) ministrado pela professora Marta Adriana Bustos Romero. Brasília: UnB, 2003.

ANDRADE, Liza M. S. Agenda verde x Agenda marrom: Inexistência de princípios ecológicos para o desenho de assentamentos urbanos. Dissertação (Mestrado em Arquitetura e Urbanismo) a Faculdade de Arquitetura e Urbanismo da Universidade de Brasília, Brasília, 2005.

ANDRADE, Liza M. S. e ROMERO, Marta A. B.. Construção de indicadores de eficiência hídrica urbana: desafios para a gestão ambiental urbana. In Paranoá. Caderno de Arquitetura e Urbanismo, Indicadores de sustentabilidade urbana, n4, p63-80, 2007.

ANDRADE, Liza M. S. O conceito de Cidades-Jardins: uma adaptação para as cidades sustentáveis. Portal Vitruvius. Arquitextos 042. Nov de 2003. Disponível em: <http://www.vitruvius.com.br/arquitextos/arq042/arq042_02.asp>. Acesso em: out 2008.

ANDRADE, Liza M. S.; Kohlsdorf, Maria Elaine; Garrocho, Juliana Saiter; Kéti, Nelton. Módulo de Sobrevivência: exercício-tema de projeto para a aplicação da dimensão ecológica ao ensino de arquitetura. IV Encontro Nacional e II Encontro latino-americano sobre Edificações e Comunidades Sustentáveis. ELECS 2007.

ANTOINE, Pierre. Príncipes d'urbanisme. Paris: B. Ballière et Fils, 1946, p.5-15.

ASSIS, Eleonora Sad de. I mpactos da forma urbana na mudança climática; método para previsão do comportamento térmico e melhoria de desempenho do ambiente urbano. Tese (Doutorado em Arquitetura e Urbanismo, Estruturas Ambientais Urbanas) Faculdade de Arquitetura e Urbanismo, Universidade de São Paulo, São Paulo, 2000. 
ASSOCIAÇÃO BRASILEIRA DE NORMAS TÉCNICAS. ABNT: 10151 - Avaliação do Ruído em Áreas Habitadas Visando o Conforto da Comunidade. Rio de Janeiro, 2001. ASSOCIAÇÃO BRASILEIRA DE NORMAS TÉCNICAS. ABNT: NBR 10152 - Níveis de Ruído para Conforto Acústico. Rio de Janeiro, 2001.

AYOMONINO, C. Origenes y desarrollo de la ciudad moderna. Barcelona: Gustavo Gili, 1971.

AZEVEDO NETTO, Domingos Theodoro de. Aplicação dos instrumentos de planejamento e gestão do uso do solo, bem como normas e procedimentos. I n: I PEA. Diretoria de Política Regional e Urbana. Coordenação Geral de Política Urbana. Estudo, gestão do uso do solo e disfunções do crescimento urbano. Relatório n. 4 (consultoria), Brasília: IPEA, 1996, p. 29-66.

B. N. Winther and A. G. Hestnes "Solar Versus Green: The Analysis of a Norwegian Row House". Solar Energy vol. 66 nº 6 pp. 387-393, 1999.

BAKER, Nick, STEEMERS, Koen. Energy and Environment in Architecture: A Technical Design Guide. 1 ed. Londres: Routledge mot E F \& N Spon, 2000.

BAKER, Nick. Sustainable refurbishment of buildings. Department of Architecture. University of Cambridge. Cambridge, 2009.

BATTLE, Guy, McCARTHY, Christopher. Sustainable Ecosystems and the built environment. London: Wiley-Academy, 2001.

BEATLEY, Timothy. Green Urbanism: Learning from European Cities. Island Press, 1999.

BECKER, Bertha K. Amazônia pós ECO 92. Para pensar o Desenvolvimento Sustentável, 1994.

BENEVOLO, Leonardo. Arquitetura no novo milênio. São Paulo: Estação Liberdade, 2007

BENEVOLO, Leonardo. História da Cidade. São Paulo: Perspectiva, 1983.

BETTINI, Virginio. Elementos de ecologia urbana. Madrid: Editorial Trotta, serie médio ambiente, 1998. 
BEZERRA, Benilton. Vazio a palavra da moda. Rio de Janeiro: Jornal do Brasil, 2002.

BIO REGIONAL Bedzed: seven years on. The impact of UK's best Known eco-village and its residents. Julho, 2009.

BIO REGIONAL Bedzed: toolkit part I. Best practical Report. Dezembro, 2002.

BIO REGIONAL Bedzed: toolkit part II. A practical guide to producing affordable carbon neutral developments. Outubro, 2003.

BIO REGIONAL Case study Report: Bedzed. Março, 2002.

BIO REGIONAL. Government's Energy Efficiency Best Practice programme. General information report 89. Beddington zero energy development, p.30.

BISTAFA, S. R. Acústica aplicada ao controle do ruído. São Paulo: Blucher, 2006.

BLUMENSCHEIN, Raquel Naves. A sustentabilidade na cadeia produtiva da indústria da construção. Tese (Doutorado em Desenvolvimento Sustentável) Universidade de Brasília. Centro de Desenvolvimento Sustentável. Brasília: UnB/CDS, 2004.

BONDUKI, Nabil. Fórum de debates. $5^{a}$ Bienal Internacional de Arquitetura e Design de São Paulo Metrópole. São Paulo, 13-20 de setembro de 2003.

BORDE, Andréa. Vazios urbanos, A forma urbana em movimento. In Simpósio a cidade nas Américas. Perspectivas da forma urbanística no século XXI . Estudos urbanos. Florianópolis: Caderno de resumos, PAT-7, 2003.

BRANDÃO, Carlos Antônio Leite Brandão. As Cidades da Cidade. Belo Horizontes: Coleção IEAT, UFMG, 2006

BRANDÃO, Rafael Silva. Acesso ao sol e à luz natural: avaliação do impacto de novas edificações no desempenho térmico, luminoso e energético no seu entorno. Dissertação (Mestrado em Arquitetura e Urbanismo, Tecnologia da Arquitetura) Faculdade de Arquitetura e Urbanismo, Universidade de São Paulo, São Paulo, 2004.

BRANDÃO, Rafael Silva. As I nterações Espaciais Urbanas e o Clima: incorporação das análises térmicas e energéticas no planejamento urbano. Tese (Doutorado em Arquitetura e Urbanismo, Tecnologia da Arquitetura) Faculdade de Arquitetura e Urbanismo, Universidade de São Paulo, São Paulo, 2009. 
BRANDÃO, Rafael Silva. Apresentação seminário UEMG. São João, 2009.

BRUNDTLAND, Gro Harlem. Our Common Future. The World Commission on Environment and Development. Oxford: Oxford University Press, 1987. (versão em português, Nosso Futuro Comum. São Paulo: FGV, 2001).

BRUSE, M.. Updated ovenview over ENVI-met 3.0, 2004. Disponível em: <http://www.geographie.ruhr-uni-bochum.de/agklima/envimet/scidocs.htm>. Acesso em: 18 jun. 2005.

BUCCHERI FILHO, Alexandre T.. Qualidade ambiental no Bairro Alto da Xv, Curitiba/ Pr. Dissertação (Mestrado), Universidade Federal do Paraná. Curitiba, 2006.

BUCKMINSTER FULLER INSTITUTE (BFI). Fuller's Global Research. New York: BFI <http://www.bfi.org/fullers_global_research.htm>. Acesso em: 06 jul. 2005.

BURJATO, Ana Lúcia Pinto de Faria. Parques acessíveis - um direito de cidadania. Aplicação de procedimentos de avaliação do projeto implantado: o caso do Parque Villa-lobos. São Paulo, 2004. Dissertação (Mestrado) - Faculdade de Arquitetura e Urbanismo Universidade de São Paulo.

CABE. Creating successful masterplans: a guide for clients. Londres, 2004

CABE. Disponivel em: <http://www.cabe.org.uk/publications>. Acesso em: ago 2008.

CALIXTO, A.; DINIZ, B.; ZANNIN, P. H. T. The Statistical Modeling of Road

CAPRA, Fritjof. As conexões ocultas, ciência para um vida sustentável. São Paulo: Pensamento/Cultrix, 2002.

CAPRA, Fritjof. Uma ciência para a vida sustentável. ECO 21, jun. de 2003. Disponível em: <http://www.eco21.com.br >. Acesso em: 15 nov. 2003.

CARO, C.M. \& RIVAS, J.L. Arquitectura urbana: elementos de teoria y diseño. Madrid: Lib. Ed. Bellisco, 1990.

CETEB - Companhia de Tecnologia de Saneamento Ambiental. Resolução CONAMA no 03 de 28/06/90. Disponível em: <http://www.cetesb.sp.gov.br/Ar/ar_indice_padroes.asp.> Acesso em: nov. 2008. 
CFX. Installing and introduction to CFX-5. Diddcot Oxfordshire: CFX, 2003.

CHOAY, François. O urbanismo, utopias e realidades. São Paulo: Perspectivas, 1998.

COMISION de las COMUNIDADES EUROPEAS (1990). Libro Verde sobre el Medio Ambiente Urbano. Bruselas: Edit. Comisión Europea. 1990.

Comissión Europea, Programa Life, Mediterranean verandahways, ENV/E/000198. Hacia un Nuevo espacio público: ocho propuestas para el Bulevar Bioclimático de Vallecas en Madrid. Empresa Municipal de la vivienda y suelo. Madrid, 2005.

COMPANHIA DE TECNOLOGIA DE SANEAMENTO AMBIENTAL CETESB. Norma Técnica L11.032: Ruído. Determinação do Nível de Ruído em Ambientes Internos e Externos de Áreas Habitadas; Métodos de Ensaio. São Paulo 1992.

CORBETT, M. Designing Sustainable Communities. Learning from Village Homes. Island Press, 2000.

CORRÊA, Roberto Lobato. O espaço urbano. 4. ed.. São Paulo: Ática, 2005.

CORSINI, J. M. O.. Diseño urbano y pensamiento contemporáneo. Barcelona, 1995.

COSTA, Heloisa Soares de Moura. Desenvolvimento urbano sustentável: uma contradição em termos? Revista Brasileira de Estudos Urbanos e Regionais, n.2, p. 5571, março de 2000. ANPUR.

COSTA, Lúcio. Registro de uma vivência. São Paulo, Empresa das Artes, 1995

CREMONESI, Fernando. Roteiro de cálculo para acústica. Notas de aula disciplina AUT 268 - Conforto Ambiental - integração interdisciplinar, da graduação da Faculdade de Arquitetura e Urbanismo da Universidade de São Paulo (FAU USP), 2007.

CUSINATO, Váleria Bonfim. Os espaços edificados vazios na área central da cidade de São Paulo e dinâmica urbana. Dissertação (Mestrado em engenharia) Escola politécnica da Universidade de São Paulo, Poli-USP, 2004, p. 69-76.

DAUNCEY, Guy e PECK, Steven. 12 features of sustainable community development: social, economic and environmental benefits and two case studies in sustainable community development in Canada. Disponível em: <http://www.peck.ca/nua/>. Acesso em: nov. 2002. 
DEGW. High Rise Rotterdam, A Strategy for I ntensification and I nnovation. London: Report October 1998.

DEL RIO, Vicente. I ntrodução ao desenho urbano no processo de planejamento. São Paulo: Pini, 1990.

DEL RIO, Vicente. Voltando às origens. A revitalização de áreas portuárias nos centros urbanos. Arquitextos, Texto Especial no 091. São Paulo, Portal Vitruvius, agosto 2001. Disponível em: <http://www.vitruvius.com.br/arquitextos/arq000/esp091.asp> Acesso em: mar. 2008

DELLA MANNA, Eduardo. Broadacre City: meio ambiente, desenvolvimento sustentável e ecologia social. Disponível em: <www.vitruvius.com.br>. Acesso em: abr. 2008

DETR - Department of the Environment, Transport and the Regions of London. Towards an Urban Renaissance. Final Report of the Urban Task Force, chaired by Lord Rogers of Riverside. London: E. and FN SPON, 1999.

DOMINGUES, Servando Alvarez et al. Control Climático en Espacios Abiertos. Proyecto EXPO 92. Sevilha: CIEMAT, 1994.

DOUGLAS, I. - The urban environment. Londres, Edward Arnold (Publishers) Ltda, DUARTE, Denise Helena. Padrões de ocupação do solo e microclimas urbanos na região de clima tropical continental; método para previsão do comportamento térmico e melhoria de desempenho do ambiente urbano. Tese (Doutorado em Arquitetura e Urbanismo, Estruturas Ambientais Urbanas) Faculdade de Arquitetura e Urbanismo, Universidade de São Paulo, São Paulo, 2000.

DUARTE, Denise, MÜLFARTH, Roberta Consentino Kronka, GONÇALVES, Joana. Sustentabilidade Ambiental urbana no ensino de graduação: proposta do Departamento de Tecnologia. In: ENCAC ELACAC 2007 - IX Encontro nacional e V Encontro latino-Americano de Conforto no Ambiente Construído, 2007, Ouro Preto. ENCAC ELACAC 2007 - IX Encontro nacional e V Encontro latino-Americano de Conforto no Ambiente Construído, 2007. 
EBNER, Iris de Almeida Rezende. Vazios urbanos: uma abordagem do ambiente construído. Dissertação (Mestrado em Arquitetura e Urbanismo) Faculdade de Arquitetura e Urbanismo da Universidade de São Paulo, 1997.

ECHENIQUE, Marcial, SAINT, Andrew. Cities for the New Millennium. London: Routledge E F \& N Spon, 2001.

EDWARDS, Brian Guia Básica de La Sostentabilidade. Barcelona: Editorial Gustavo Gili SA, 2004.

EDWARDS, Brian, HYETT, Paul (colab.). Rough Guide to Sustainability. London: RIBA, 2002.

EDWARDS, Brian. Green Architecture. AD, v.71, n.4, July 2001.

Empresa Municipal de Vivienda y Suelo (EMVS). Ecobairros en Europa. Ayuntamiento de Madrid, 2006.

Empresa Municipal de Vivienda y Suelo (EMVS). Hacia un nuevo espacio público: ocho propuestas para el bulevar bioclimático de Vallecas en Madrid. Ayuntamiento de Madrid, 2006.

EMURB (EMPRESA MUNICIPAL DE URBANIZAÇÃO). Ação para o Centro de São Paulo. São Paulo, 2004.

EUROPEAN COMMISSION. Hannover Kronsberg Handbook. Planning and Realisation. Updated, based on the EU Project, SIBART (Seeing Is Believing As a Replication Tool). Supported by the European Commission, DG TREN ALTENER programme, Leipzig, 2004.

EUROPEAN COMMISSION. Living in Kronsberg. Hannover Kronsberg Handbook. Energy Framework Programme DG.TREN SIBART (Seeing is Believing As a Replication Tool) Karin Rumming City of Hannover Environmental Protection, 2003.

EUROSTAT. EUROPEAN UNION STATISTICAL OFFICE. Energy and environment indicators - 1985 - 2000. Eurostat, Luxembourg, 2002. EUROSTAT. EUROPEAN UNION STATISTICAL OFFICE. Environmental pressure indicators for the EU - 1985 - 1998. 2. ed. EUROSTAT, Luxembourg, 2001. 
EUROSTAT. EUROPEAN UNION STATISTICAL OFFICE. Towards Environmental Pressure I ndicators. Luxembourg: Eurostat, 1999.

FARIÑA, José. La ciudad y el medio natural. Madrid: Akal, 1998.

FARNSTEIN, Susan F.. Planning theory and the city. Journal of Planning Education and Research, v. 25, 2005, p.121-130.

FARNSTEIN, Susan F.. New directions in planning theory. Urban Affairs Review, v. 34, n. 4,2000, p.451-478.

FAUSTO, Adriana; RABAGO, Jesus. ¿Vacíos urbanos o vacío de poder metropolitano? México: Puebla. Disponível em: <http://www.habitat.aq.upm.es/boletim/n21/aafau.htm>. Acesso em: 10 dez. 2008.

FAUSTO, Adriana; RABAGO, Jesus. ¿Vacíos urbanos o vacío de poder metropolitano? Puebla, México. Disponível em: <http://www.habitat.aq.upm.es/boletim/n21/aafau.htm>. Acesso em: dez. 2008.

FERREIRA, Luciana Schwandner. Projeto urbano com base em critérios ambientais: Barra Funda. Trabalho Final de Graduação da Faculdade de Arquitetura e Urbanismo da Universidade de São Paulo, 2007.

FERREIRA, Luciana Schwandner. Projeto urbano com base em critérios ambientais: Barra Funda. Trabalho Final de Graduação da Faculdade de Arquitetura e Urbanismo da Universidade de São Paulo, 2007.

FIGUEROA, Mário. Habitação coletiva e a evolução da quadra. Arquitextos, Texto Especial no 357. São Paulo, Portal Vitruvius, fevereiro 2008. Disponível em: <http://www.vitruvius.com.br/arquitextos/arq000/esp357.asp.> Acesso em: mar. 2008.

FISHMAN, Robert. Urban Utopias in the twentieth Century. New York: Basic Book, Inc.,1977.

FOLHA DE SÃO PAULO. Em três meses, ar só ficou bom em 17 dias. 24 de Abril de 2010.

Fonte: Mihraratne, Vale \& Vale (2005) 
FOSTER \& PARTNERS. Elephant \& Castle; development framework. London: Southwark Concil, 2004, 96 p.

FRAMPTON, Kenneth. História crítica da arquitetura moderna. São Paulo: Martins Fontes, 1997.

Frankl P, Fullana P, Kreissig J (2007). Communication of Life Cycle Assessment in the Building and Energy Sectors. Report on the International Expert Workshop: Sector-Specific Approaches for Communication of Life Cycle Information to different Stakeholders, Barcelona, September 8th, 2005.

FREY, Hildebrand. Designing the City: Towards a More Sustainable Urban Form. London: E \& FN Spon, 1999.

FROTA, A. B.; SCHIFFER, S. R. Manual de Conforto Térmico. 4.ed. São Paulo: Nobel, 2000.

FROTA, Anésia B.. Geometria da I nsolação. São Paulo: Geros, 2004.

FROTA, Anésia B.. Clima local e micro-clima na cidade universitária: estudos de microclima no Edifício da FAU. Tese (Doutorado em Arquitetura e Urbanismo, Estruturas Ambientais Urbanas) Faculdade de Arquitetura e Urbanismo, Universidade de São Paulo, São Paulo, 1982.

FUÃO, Fernando Freitas. Sevilha e a Expo 92: duas realidades contrapostas. Texto publicado na Revista Projeto, n.138. São Paulo, 1992.

GAUZIN-MÜLLER, Dominique. Arquitetura ecológica, 29 ejemplos europeos. Barcelona: GG, 2001.

GEDDES, Patrick. Cidades em Evolução. tradução Maria José Ferreira de Castilho. Campinas: Papirus, 1994.

GIRADET, Herbert. Creating Sustainable Cities. Schumacher Briefings n.2. Bristol: Green Books, 2003 GIRARDET, Herbert, (1997): "Sustainable Cities. A Contradiction in Terms?" in AD Architectural Design The Architecture of Ecology, London.

GIRARDET, Herbert. Cities People Planet: Livable Cities for a Sustainable World. Wiley-Academy, 2004 
GIRARDET, Herbet. The city metabolism: to make global urbanisation sustainable, we must first understand how own cities function. Disponível em: < http://www.oneworld.org/guides/ thecity/superorganism/metabolism.html > Acesso em: 15 nov 2003.

GIVONI, Baruch. Climate considerations in building and urban design. New York: John Wiley \& Sons, 1998.

GIVONI, Baruch. Man, Climate and Archictecture. $2^{\mathrm{a}}$ ed. London: Applied Science Publishers LTD., 1976. 307-339.

GOLDEMBERG, José. Energia, meio ambiente e desenvolvimento. São Paulo: USP, 2001.

GONÇALVES, Joana C. S. e KRONKA MÜLFARTH, Roberta C.. Relatório de pesquisa: Projeto “Desenho Urbano para o Desempenho Ambiental com Benefícios SócioEconômicos". LABAUT FAUUSP, 2008. Acesso restrito.

GONÇALVES, Joana C. S., DUARTE, Denise H. e KRONKA MÜLFARTH, Roberta C.. 0 Projeto Urbano e as Questões Ambientais. Revista URBS n44 - out/nov/dez, 2008.

GONÇALVES, Joana C. S., DUARTE, Denise H. e KRONKA MÜLFARTH, Roberta C.. Sustentabilidade Ambiental urbana no ensino de graduação: proposta do Departamento de Tecnologia. In: ENCAC ELACAC 2007 - IX Encontro nacional e V Encontro latino-Americano de Conforto no Ambiente Construído, 2007, Ouro Preto. ENCAC ELACAC 2007 - IX Encontro nacional e V Encontro latino-Americano de Conforto no Ambiente Construído, 2007.

GONÇALVES, Joana C. S., DUARTE, Denise H. e KRONKA MÜLFARTH, Roberta C.. Sustentabilidade Ambiental urbana no ensino de graduação: proposta do Departamento de Tecnologia. In: ENCAC ELACAC 2007 - IX Encontro nacional e V Encontro latino-Americano de Conforto no Ambiente Construído, 2007, Ouro Preto. ENCAC ELACAC 2007 - IX Encontro nacional e V Encontro latino-Americano de Conforto no Ambiente Construído, 2007. 
GONÇALVES, Joana C. S., DUARTE, Denise H.. Arquitetura Sustentável. Uma integração entre Ambiente, Projeto e Tecnologia em Experiências de Pesquisa, Prática e Ensino. Ambiente Construído, v. 6, p. 51-81, 2006.

GONÇALVES, Joana C. S.. A sustentabilidade de edifícios altos: uma nova geração de edifícios altos e sua inserção urbana. Tese (Doutorado em Arquitetura e Urbanismo, Estruturas Ambientais Urbanas) Faculdade de Arquitetura e Urbanismo, Universidade de São Paulo, São Paulo, 2003.

GONÇALVES, Joana C. S.. Um olhar crítico sobre as cidades globais. Revista URBS n44 - out/nov/dez, 2008.

Goulart, Solange V. G., Lamberts, Roberto, Firmino, Samanta. Dados climáticos para projeto e avaliação energética de edificações para 14 cidades brasileiras. Florianópolis: Núcleo de Pesquisa em Construção/UFSC,1998.

GUALLART, Vicente, et.al. Sociopolis: Project for a City of the Future. Espanha, 2004. GUITON, Jacques. The I deas of Le Corbusier. Translation by Margaret Guiton. New York: George Braziller, 1981.

GUNN, Philip, CORREIA, Telma. 0 urbanismo, a medicina e a biologia nas palavras e imagens da cidade. Pós, São Paulo, n.10, dez. , p.34-61, 2001.

HAGAN, Susana, HEWITT, Mark. City Fights: debates on sustainable cities. London: James and James, 2000.

HAGAN, Susannah. Taking Shape: A new contract between architecture and nature. Oxford: Architectural Press, 2001.

HALL, Peter. Cidades do amanhã. São Paulo: Perspectiva, 1995.

HARVEY, David. The New Urbanism and the communitarian trap. Harvard Design Magazine. n.1. Boston: Harvard College, MIT Press, Winter/Spring 1997.

HERZOG, Thomas. Solar energy in architecture and urban planning. Munich: Prestel, 1998. 
HIGUERAS GARCÍA, Ester. Agendas 21: objetivos, método y oportunidad desde el urbanismo. Madrid: Edita Mairea, 2002.

HIGUERAS GARCÍA, Ester. Urbanismo Bioclimático. Barcelona: Gustavo Gili, 2006.

HIGUERAS García, Esther. Buenas prácticas en arquitectura y urbanismo para Madrid criterios bioclimáticos y de eficiencia energética. Madrid: Área de Gobierno de Urbanismo y Vivienda del Ayuntamiento de Madrid, 2009.

Higueras García, Esther. El reto de la ciudad habitable y sostenible. Pamplona: DAPP Publicaciones Jurídicas, 2009.

HIGUERAS, Ester; ENGUITA, Abel; DOMOUSO, Francisco e DÍAZ, Juan. La ciudad contemporánea: Análisis de su estructura y desarrollo. Madrid: CEIM, Confederación Empresarial de Madrid CEOE, 2008.

HOLANDA, F.; KOHLSDORF, G. ; KOHLSDORF, M.E. e VILLAS BOAS, M. Dimensões morfológicas do Processo de Urbanização. Brasília: FAU-UnB / FINEP / CNPq, 1985 1994. Disponível em: <http://www.unb.br/fau/cidade_arquitetura/>. Acesso em: 18 nov. 2008.

HOLANDA, Frederico e KOHLSDORF, Gunter. Arquitetura como situação relacional. Grupo de Pesquisa Dimensões morfológicas do processo de Urbanização PPG-FAU/UnB. Brasília, 1994.

HOLDEMBERG, J., BASS, S., TIMBERLAKE, L. Defending the Future. A Guide to Sustainable Development. London: IIED/Earthscan, 1991.

HOUGH, Michael. Naturaleza y ciudad. Barcelona: Gustavo Gili, 1998.

HOWARD, Ebenezer. Cidades-Jardins de amanhã. Tradução: Marco Aurélio Lagonego, Introdução: Dácio Araújo Benedito Otoni. São Paulo, Estudos Urbanos, Série Arte e Vida Urbana, Hucitec, 1996.

HOWARD, Ebenezer. Garden cities of to-morrow. London: Faber and Faber, 1946.

IBGE, CENSO (2000), Ed. no. 10, Brasília (2000). 
IEA - International Energy Agency. World Energy Outlook 2002 Sees Abundant Energy Till 2030, But Projects Challenges on Security, Investment, Environment and Poverty. Press release. Osaka, Japan, 21 September 2002.

IEA - International Energy Agency. Dados energéticos de 2009.

JACOBS, Jane. Muerte y vida de las grandes ciudades. Madrid: Península, 2000. ( $1^{\text {a }}$ ed. 1973)

Japan Green Build Council, JaGBC (2008). Comprehensive Assessment System for Building Environmental Efficiency - CASBE 2008.

Javier Mozas, Aurora Fernandez. Densidad. Nueva vivienda colectiva. Victoria-Gastiez, 2006.

JENKS, M; DEMPSEY, N. Future Forms and Design for Sustainable Cities. Oxford: Architectural Press, 2005.

JONH, V.M.; AGOPYAN, V; ABIKO, A.K.; PRADO, R.T.A.; GONÇALVES, O.M.; SOUZA, U.E. Agenda 21 for the brazilian construction industry - a proposal. In: Construction and environment: from theory into practice. 23-24 november 2000. Proceedings. São Paulo, CIB/PCC.USP, 2000.

JONH, V.M.; AGOPYAN, V; SILVA,V.G. Agenda 21: uma proposta de discussão para o construbusiness brasileiro. In: II Encontro Nacional e I Encontro Latino-americano sobre edificações e comunidades sustentáveis. Anais. ANTAC/ UFRGS, Canela - RS, 24-27 de abril de 2001, p.91-98.

JURGEN H. BREUSTE, JURGEN RIEPEL. Paris-Lodron-University of Salzburg Division of Physical and Applied Geography

KATZSCHNER, LutZ. Urban climate studies as tools for urban planning and architecture. In: ENCONTRO NACIONAL DE CONFORTO NO AMBIENTE CONSTRUÍDO, 4, 1997, Salvador. Anais... Salvador: FAUFBA / LACAM; ANTAC, 1997, p. 49-58.

KELBAUGH, Doug. Three paradigms: new urbanism, everyday urbanism, post urbanism. [s.I]: University of Washington Press, 2000. 
KNOWLES, Ralph; BERRY, Richard. Solar envelope concepts; moderate density building applications. Los Angeles: University of Southern California. 1980.135 p.

KOENIGSBERGER, O.H. et al. Viviendas y edifcios em zonas cálidas y tropicales. Madrid: Paraninfo, 1977.

KOHLSDORF, G. A avaliação de desempenho morfológico no desenho urbano. ANPUR: Anais do VII ENANPUR. Brasília: Ed. ANPUR, 1995.

KÖPPEN-GEIGER. Classificação climática de Köppen-Geiger. Disponível em: <http://pt.wikipedia.org/wiki/Classifica\%C3\%A7\%C3\%A3o_clim\%C3\%A1tica_de_K\%C3 \%B6ppen-Geiger>. Acesso em: jun. 2009.

KRONKA MÜLFARTH, Roberta C.. A Sustentabilidade e a Arquitetura. São Paulo, AU, n.147, jun.2006, p. 70-73.

KRONKA MÜLFARTH, Roberta C.. Arquitetura de baixo impacto humano e ambiental. Tese (Doutorado em Arquitetura e Urbanismo, Estruturas Ambientais Urbanas) Faculdade de Arquitetura e Urbanismo, Universidade de São Paulo, São Paulo, 2003.

KRONSBERG, Modell. Sustainable building for the future. Hannover, 2000.

LAMAS, José Manuel R. G.. Morfologia Urbana e Desenho da Cidade. Lisboa: Fundação para a ciência e a tecnologia, 2004.

LAMBERTS, Roberto et al. Analysis Bio. Versão 2.1.1. Florianópolis: UFSC, 1994. Disponível em: < http://www.labeee.ufsc.br/software/analysisBIO.html>. Acesso em: 04 jun. 2004.

LAMBERTS, Roberto; DUTRA, Luciano, PEREIRA, Fernando O. R.. Eficiência energética na arquitetura. São Paulo: PW, 1997.

LAMPARD, E. Aspectos históricos da urbanização in HAUSER \& SCHNORE, org. Estudos de Urbanização. São Paulo, Pioneira, 1975. 
LAUSTSEN, J. (2008) Energy Efficiency Requirements in Building Codes, Energy

Efficiency Policies for New Buildings: IEA Information Paper. Paris: OECD/IEA (International Energy Agency).

LE CORBUSIER. A Carta de Atenas. São Paulo: HUCITEC:EDUSP, 1993.

LE CORBUSIER. Les plans Le Corbusier de Paris 1922-1953. Editions de Minuit, 1956

LE CORBUSIER. Planejamento Urbano. Perspectiva, São Paulo, 2004.

LE CORBUSIER. Planejamento Urbano. Perspectiva, São Paulo, 2004.

LE CORBUSIER. Por uma arquitetura. Perspectiva, São Paulo, 2002.

LE CORBUSIER. The City of To-Morrow and I ts Planning. 1987.

LE CORBUSIER. Urbanismo. Martins Fontes, São Paulo, 2000.

LE GOFF, Jaques. Por amor às cidades. Tradução Reginaldo Carmello Corrêa Moraes. São Paulo: Unesp, 1998.

LEED FOR NEIGHBORHOOD DEVELOPMENT. Disponível em: <http://www.usgbc.org> Acesso em: set 2009.

LEVINE M. et al. Residential and Commercial Buildings in Climate Change. Mitigation, Contribution of Working Group III to the Fourth Assessment Report of the IPCC - Cambridge University Press, Unites Kingdom and New York NY, USA, 2007.

LOPEZ DE LUCIO Ramón (1993). Ciudad y Urbanismo a finales del siglo XXI. Valencia: Universidad de Valencia, 1993.

LUCEY, Norman. The effect of Sir Ebenezer Howard and the garden city movement of twentieth century town planning. Rickmansworth, Hertfordshire, 1973. Disponível em<: http://rickmansworthhertts.freeserve.co.uk> Acesso em: jan 2009.

LYNCH, Kevin. A theory of good city form. Cambridge: MIT Press, 1981.

LYNCH, Kevin. La buena forma de La ciudad: MIT Press, 1981.

LYNCH, Kevin. Planificación del sitio. Ed GG, 1975 
MACEDO, S.S. Paisagem e habitação verticalizada. São Paulo, FAUUSP;

MARSH, A.; RAINES, C..Ecotect v.5.20. Square One; Joondalup: Austrália, 2004.

MARTIN, L. et al. La estructura del espacio urbano. Barcelona: Gustavo Gili, 1975. 235-249.

MARTIN. Leslie. La estructura del espacio urbano. Barcelona: Gustavo Gili, 1975 MASCARÓ, Lúcia. Ambiência Urbana. Porto Alegre: Sagra - Luzzatto, 1996.

MASCARÓ, Lúcia. Densidades, ambiência e infra-estrutura urbana. Arquitextos, Texto Especial no 102. São Paulo, Portal Vitruvius, outubro 2001. Disponível em: <http://www.vitruvius.com.br/arquitextos/arq000/esp102.asp> Acesso em: mar. de 2008.

MASCARÓ, Lúcia; MASCARÓ, Juan Luis. Código de obras; aspectos ambientais. Porto Alegre: UFRGS, 1994.

Mc HARG, Ian L. Design with nature. New York: American Museum of Natural History, 1969. Reeditado 2000.

MC HARG, Ian. Proyectar con la Naturaleza. Gustavo Gili. Barcelona, 2000.

MCKINSEY \& COMPANY. Pathways to a Low-Carbon Economy: Version 2 of the Global Greenhouse Gas Abatement Cost Curve. Disponível em: <http://globalghgcostcurve.bymckinsey.com > Acesso em: jan 2009

MENNEH, Márcia Halluli. Morfologia da paisagem verticalizada: conflitos e padrões urbanísticos. Dissertação (Mestrado em Arquitetura e Urbanismo, Estruturas Ambientais Urbanas) Faculdade de Arquitetura e Urbanismo, Universidade de São Paulo, São Paulo, 1997.

Metrô. Indicadores. 2008a. Disponivel em: <http://www.metro.sp.gov.br/empresa/numeros/indicadores/indicadores03.shtml> Acesso em: ago. 2008.

Metrô. Por dentro da operação 2007. Metrô, Gerência de Operações, Departamento de Operação Centralizada e Tráfego, 2008b. 
MEYER, Regina, GROSTEIN, Marta Dora; BIDERMAN, Ciro. Os desafios contemporâneos da metrópole: $\mathbf{O}$ caso de São Paulo. Palestra no Seminário Internacional Cidades Sustentáveis: Do projeto urbano às edificações. FAUUSP, 20 e 21 de junho de 2007. São Paulo, 2007.

MEYER, Regina, GROSTEIN, Marta Dora; BIDERMAN, Ciro. São Paulo metrópole. São Paulo: Eduusp, 2004.

MINISTÉRIO DE MEDIO AMBIENTE. Dirección general de calidad y evaluación ambiental. Sistema Español de Indicadores Ambientales. Madrid: Area Gobierno de medio ambiente, 2000.

MONTEIRO, Carlos Augusto, MENDONÇA, Francisco. Clima Urbano. São Paulo: Contexto, 2003.

MONTEIRO, Leonardo Marques. Modelos preditivos de conforto térmico: quantificação de relações entre variáveis microclimáticas e de sensação térmica para avaliação e projeto de espaços abertos. Tese (Doutorado - Área de Concentração: Tecnologia da Arquitetura) - FAUUSP. São Paulo, 2008.

MOREIRA, Antônio Cláudio M.L. Megaprojetos \& ambiente urbano: parâmetros para elaboração do Relatório de I mpacto de Vizinhança. Pós - Revista do Programa de Pós-Graduação em Arquitetura e Urbanismo da FAUUSP, São Paulo, FAUUSP, n. 7, p. 107118, 1999.

MOREIRA, Antônio Cláudio M.L. Megaprojetos \& ambiente urbano: parâmetros para elaboração do Relatório de I mpacto de Vizinhança. Tese (Doutorado e, Arquitetura e Urbanismo) FAU-USP, 1997.

MORRIS, Antony E. J.. Historia de la forma urbana desde sus orígenes hasta revolución industrial. Gustavo Gili, Barcelona, 1979.

MOUGHTIN, Cliff; Shirley, Peter. Urban design: green dimensions. 2. ed. Amsterdam: Elsevier Architectural Press, 2005.

MOURA, Norberto. Segurança, eficiência energética e conforto visual em emboques de túneis rodoviários: soluções arquitetônicas. Tese (Doutorado - Área 
de Concentração: Tecnologia da Arquitetura) Faculdade de Arquitetura e Urbanismo, Universidade de São Paulo, São Paulo, 2007.

MUMFORD, Lewis. A cidade na história. São Paulo: Martins Fontes, 1998. (1 ${ }^{\text {a }}$ ed.1960).

NAES, Peter. Urban form and energy use to transport, a Nordic experience. 1996.

NAREDO, J. M.. Sobre el origen, el Uso y el Contenido del Término Sostenible. In: Ciudades para un futuro más sostenible. Ministerio de Obras Públicas, Trasnsportes y Medio Ambiente. Madrid, 1996.

NATIONAL STRATEGIES FOR SUSTAINABLE DEVELOPMENT - NSSD. Sustainable Development: Concepts and approaches, 2003. Disponível em:<http://www.nssd.net/references/SustDev.htm> Acesso em: jan 2007.

NEWTON, Norman T. Design on the land. The development of landscape architecture. The Belknap Press of Harvard University, Press Cambridge, Massachusets, 1971.

NOBRE, Eduardo A.C.. As transformações do Capitalismo. notas de aula da disciplina AUP5869 de pós graduação da Faculdade de Arquitetura e Urbanismo da Universidade de São Paulo, 2006.

NOBRE, Eduardo A.C.. O pós-fordismo na cidade. notas de aula da disciplina AUP5869 de pós graduação da Faculdade de Arquitetura e Urbanismo da Universidade de São Paulo, 2006.

NUCCI, João Carlos. Qualidade ambiental e adensamento urbano: um estudo de ecologia e planejamento da paisagem aplicado ao distrito de Santa Cecília (MSP). $\quad 2^{\mathrm{a}}$ ed. Curitiba, 2008. Disponível no endereço: <http://www.geografia.ufpr.br/laboratorios/labs> Acesso em: dez 2009.

ODUM, E. P. Ecology., New York: Holt, Rinehart and Winston, 1963.

OECD. ORGANIZATION FOR ECONOMIC COOPERATION AND DEVELOPMENT. Council Recommendation on Environmental Indicators and Information. 1991. 
OECD. ORGANIZATION FOR ECONOMIC COOPERATION AND DEVELOPMENT. Developing OECD Agri-Environmental I ndicators. Paris, 1996.

OKE, T.R. The energetic base of urban heat island. Quartely Journal of the Royal Meteorological Society. London, Elsevier Science, 108, p. 1-24, 1982.

OKE, T.R. City size and the urban heat island. Atmospheric Environment. London, Pergamon, 7, p. 769-779, 1973.

OKE, T.R. City size and the urban heat island. Atmospheric Environment. London, Pergamon, 7, p. 769-779, 1973.

OKE, T.R. The energetic base of urban heat island. Quartely Journal of the Royal Meteorological Society. London, Elsevier Science, 108, p. 1-24, 1982.

OLGYAY, V. Design with Climate. New Jersey: Princeton University, 1963.

OLGYAY. Arquitectura y Clima. Manual de diseño para arquitectos y urbanistas. Barcelona: CC, 1998.

OPSCHOOR, J. B. e COSTANZA, R. Toward Environmental Performance Indicators Based on Preserving Ecosystems Health, Wuppertal Institute, Wuppertal, 1994.

GONÇALVES, Orestes M, JOHN, Vanderley M., PICCHI, Flávio Augusto e SATO, Neide M. N. Normalização e Certificação na Construção Habitacional. Coletânea Habitare, vol. 3 $-42-53$.

ORGANIZAÇÃO DAS NAÇÕES UNIDAS. Comissão Mundial sobre o Meio Ambiente e Desenvolvimento. Nosso Futuro Comum. Rio de Janeiro: Editora da Fundação Getúlio Vargas, 1998.

ORGANIZAÇÃO DAS NAÇÕES UNIDAS. Comissão Mundial sobre o Meio Ambiente e Desenvolvimento. Nosso Futuro Comum. Rio de Janeiro: Editora da Fundação Getúlio Vargas, 1998.

PALOMO, Pedro Salvador. La planificación verde en las ciudades.Barcelona: Gustavo Gili, 2003. 
PESSOA, Denise Falcão. Utopia e cidades: proposições. São Paulo: Annablume, Fapesp, 2006.

PIERCE, Margaret. Letchworth Garden City (1903-2003). Letchworth Garden City, Yesterdays World Publications, 2003. Disponível em: <http://letcworthgardencity.net >

PRATA SHIMOMURA, Alessandra Rodrigues. Densificação Urbana: valores de rugosidade para verticalização. Relatório (Pós - Doutorado em Arquitetura e Urbanismo) Faculdade de Arquitetura e Urbanismo, Universidade de São Paulo, São Paulo, 2008.

PRATA SHIMOMURA, Alessandra Rodrigues. Dimensionamento do impacto da altura de edifícios nas condições de ventilação natural do meio urbano simulado em túnel de vento: o caso de Santos. Tese (Doutorado em Arquitetura e Urbanismo) Faculdade de Arquitetura e Urbanismo, Universidade de São Paulo, São Paulo, 2005.

PREFEITURA DO MUNICÍPIO DE SÃO PAULO. Decreto Estadual NNo. 49.148, De 21.01.2008: Regulamenta a Lei $n^{\circ} 14.459$, de 03.07.2007, que acrescenta o item 9.3.5 à Seção 9.3 - Instalações Prediais do Anexo I da Lei no. 11.228, de 25.06.1992 (Código de Obras e Edificações), e dispõe sobre a instalação de sistema de aquecimento de água por energia solar nas novas edificações do Município de São Paulo.

RAMOS. José Ovídio. Dinâmica Urbana na cidade de São Paulo. Dissertação (Mestrado em Arquitetura e Urbanismo, Tecnologia da Arquitetura) Faculdade de Arquitetura e Urbanismo, Universidade de São Paulo, São Paulo, 2007.

REGISTER, Richard. Ecocities, building cities in balance with nature. Berkeley: Berkeley Hills Book, 2002.

RODRIGUES. Desenho urbano, cabeça, campo e prancheta. Projeto 1986 116p.

ROGERS, Richard (chairman). Towards an Urban Renaissance. Final Report of the Urban Task Force. DETR - Department of the Environment, Transport and the Regions of London. London: E \& FN SPON, 1999.

ROGERS, Richard, GUMUCHDJIAN, Philip (ed.). Cidades para um Pequeno Planeta. Barcelona: GUSTAVO GILI GG, 2001. 
ROGERS, Richard. Cities for a Small Planet. London: Faber and Faber, 1997.

ROMERO, Marta A. B. Arquitetura Bioclimática dos Espaços Públicos. Brasília: Editora UnB, 2001.

ROMERO, Marta A. B.. Frentes do urbano a construção de indicadores de sustentabilidade intra urbano. In Paranoá. Caderno de Arquitetura e Urbanismo, Indicadores de sustentabilidade urbana, n4, p47-62, 2007.

ROSA, Iná. A Cidade sendo redesenhada pelos vazios: Franco da Rocha nas terras de Juquery. Tese de doutorado apresentada à Faculdade de Arquitetura e Urbanismo da Universidade de São Paulo - FAUUSP, em 2006.

ROSA, Iná. Vazios urbanos como vazios de preservação: Franco da Rocha nas terras de Juquery. Revista Pós - do programa de Pós-graduação em arquitetura e urbanismo da FAU USP, n 23, jun, 2008.

RUANO, Miguel. Ecourbanismo, entornos humanos sostenibles : 60 proyectos. Barcelona: Gustavo Gili, 1998.

RUEDA, Salvador. Modelos de ciudad: indicadores básicos y las escalas de la sostenibilidade. Barcelona: [s.n.]. 2000. Quaderns - D'arquitetura e urbanismo Collegio D' Arquitetos de Catalunya.

RUEDA, Salvador. Modelos e indicadores para ciudades más sostenibles. Barcelona: Departament de Medi Ambient de la Generalitat de la Catalunya/Fundació Forum Ambiental, 1999.

RUEDA, Salvador. Plan especial de indicadores de Sostenibilidad de la Actividad Urbanística de Sevilla. Barcelona, 2006. Disponível em: <http://www.bcnecologia.net> Acesso em: mar de 2008.

SALES, Marta Lagreca de. Projeto urbano: opção metodológica e algumas práticas. Dissertação (Mestrado em Arquitetura e Urbanismo, Historia e Fundamentos da Arquitetura e do Urbanismo) Faculdade de Arquitetura e Urbanismo, Universidade de São Paulo, São Paulo, 2008. 
SALES, Marta Lagreca de. Territórios de intermediação: uma hipótese para a análise e o projeto da cidade contemporânea. Tese (Doutorado em Arquitetura e Urbanismo, Historia e Fundamentos da Arquitetura e do Urbanismo) Faculdade de Arquitetura e Urbanismo, Universidade de São Paulo, São Paulo, 2008.

SALES, Pedro M. R. Operações Urbanas em São Paulo: crítica, plano e projeto. Arquitextos, Texto Especial $n^{\circ}$ 295. São Paulo, Portal Vitruvius, 2005. Disponível em: <www.vitruvius.com.br/arquitextos/arq000/esp295.asp> Acesso em: nov 2008.

SANDOLI, Renata. Arquitetura urbana: Repensando a Cidade através de uma proposta de ocupação, requalificação tecnológica e ambiental na Barra Funda. Trabalho Final de Graduação, Faculdade de Arquitetura e Urbanismo da Universidade de São Paulo. São Paulo, 2008.

SANTAMOURIS, M. (Ed.). Energy and climate in the urban built environment. London: James \& James, 2001.

Sattler, Miguel Aloysio Habitações de baixo custo mais sustentáveis: a casa Alvorada e o Centro Experimental de tecnologias habitacionais sustentáveis. Porto Alegre : ANTAC, 2007. - (Coleção Habitare, 8)

Sattler, Miguel Aloysio. Habitações de baixo custo mais sustentáveis: a casa Alvorada e o Centro Experimental de tecnologias habitacionais sustentáveis. Porto Alegre: ANTAC, 2007. Coleção Habitare, 8. Disponível em <www.habitare.com.br> Acesso em: junho de 2010.

SATTLER, Miguel e SCUSSEL, Maria C. B.. (Des)Construindo índices de qualidade de vida: uma abordagem crítico-analítica à formulação de indicadores de sustentabilidade para Porto Alegre. In Paranoá. Caderno de Arquitetura e Urbanismo, Indicadores de sustentabilidade urbana, n4, p31-46, 2007.

SCHILLER, Silvia. Parâmetros de sustentabilidade. Centro de investigación Habitat y energia. Faculdade de Arquitetura, desenho e urbanismo de Buenos Aires, Argentina. Disponível em: <http://www.geaes.org/bioconstruccion/arqclima_biocons.html>. 
SILVA, Marcos Virgilio da. Naturalismo e biologização das cidades na constituição da idéia do meio ambiente urbano. Dissertação (Mestrado em Arquitetura). Faculdade de Arquitetura e Urbanismo, Universidade de São Paulo, São Paulo, 2005.

SILVA, Miguel Torres Ribeiro Marques da. A I nfluência da densificação urbana na ventilação das cidades. Projecto de Termodinâmica Aplicada. Departamento de Engenharia Mecânica, Instituto Superior Técnico, Lisboa, Portugal, 2001.

SILVA, Nelson Eduardo Xavier da. O Urbanismo moderno de Le Corbusier: princípios e projetos que transformaram o modo de fazer cidade. Dissertação (Mestrado em Arquitetura e Urbanismo, Historia e Fundamentos da Arquitetura e do Urbanismo) Faculdade de Arquitetura e Urbanismo, Universidade de São Paulo, São Paulo, 2006.

SILVA, Sandra Regina Mota. Indicadores de sustentabilidade urbana: as perspectivas e as limitações da operacionalização de um referencial sustentável. Dissertação (Mestrado em Engenharia Urbana). São Carlos, UFSCar, 2000.

SILVA, Vanessa Gomes da. Avaliação da sustentabilidade de edifícios de escritórios brasileiros: diretrizes e base metodológica. Tese (Doutorado em Engenharia Civil). São Paulo: POLI/USP, 2003.

SILVA, Vanessa Gomes da. Indicadores de sustentabilidade de edifícios: estado da arte e desafios para desenvolvimento no Brasil. In Ambiente Construído. v.7, n.1, p.47-66, jan./mar. 2007.

SIMMONS, Matthew. Revisiting The Limits of Growth; could the Club of Rome have been correct, after all?, 2000 disponível em <http://www.greatchange.org/ovsimmons, club_of_rome_revisted.pdf> Acesso em: jun 2005.

SÒLA-MORALES, Ignasi de. Presente y futuro. In: XIX Congreso de la Unión Internacional de Arquitectos, 1996, Barcelona. Anales...Barcelona: Collegi d'Arquitectes de Catalunya/ centre de Cultura contemporània de Barcelona, 1996.

SOLARCITY LINZ/AUSTRIA - A EUROPEAN EXAMPLE FOR URBAN ECOLOGICAL SETTLEMENTS AND ITS ECOLOGICAL EVALUATION 632-643 - site 
SOMEKH, Nadia \& CAMPOS, Candido Malta. Desenvolvimento local e projetos urbanos. Arquitextos Vitruvius, 059.01, 2005. Disponível em:<www.arquitextos.com.br>. Acesso em: set 2005.

STEEMERS, Koen (ed). Architecture City Environment. Proceedings of PLEA 2000, Cambridge, UK, July 2000. PLEA - Passive and Low Energy Architecture.

STEEMERS, Koen, STEANE, Mary Ann. Environmental Diversity in Architecture. Spon Press, 2004.

STITT, Fred (ed.). Ecological Design Handbook. McGraw-Hill, 1999.

SUSTAINABLE SEATTLE. I ndicators of sustainable community, Sustainable Seattle. Seattle, 1993.

SZOKOLAY, S.V. Thermal design of buildings. Australia: Raia Education Division, 1987.

SZOKOLAY, Steven. PLEA Notes: Design Tools and Techniques - Solar Geometry. Queensland: University of Queensland, PLEA 1996.

TAVARES, Paulo. Arquitetura e esquizofrenia ou "não encontro Potsdamer Platz" Texto Especial 365 - abril 2006. Arquitextos - Periódico mensal de textos de arquitetura. Disponível em: <http://www.vitruvius.com.br/arquitextos/arq000/esp365.asp> Acesso em: set 2009.

The Regeneration of the Greenwich Peninsula: A Progress Report. Report by the comptroller and auditor general HC 338 session 2007-2008, july 2008.

The Royal Institute of British Architects. Sustainable Communities. Disponível em:<http://74.125.47.132/search?q=cache:bb7OGC0Etkw]:www.architecture.com/Files/R IBAHoldings/PolicyAndInternationaIRelations/Policy/PublicAffairs/responseToEganReviewOf Skills.pdf+ecolonia+netherlands\&cd=22\&hl=pt-BR\&ct=clnk\&gl=br> Acesso em set 2009.

UK. Southwork Council. Elephant and Castle. London Borough of Southwark. Development Framework, $2004 . \quad$ Disponível em:<http://www.elephantandcastle.org.uk>. Acesso em: março 2004. UMAKOSHI, Erica. Uma visão crítica do Edifício Alto Sob a ótica da sustentabilidade. Dissertação (Mestrado - Área de Concentração: Tecnologia da 
Arquitetura) Faculdade de Arquitetura e Urbanismo da Universidade de São Paulo. São Paulo, 2008.

UNITED STATES. Department of Energy. Office of Energy Efficiency and Renewable Energy. Utility-scale flat-plate thin film photovoltaics. Washington: DOE. 2004. Disponível em: <http://www.eere.energy.gov/consumerinfo/pdfs/thinfilm_pv.pdf>. Acesso em: jun 2004.

UNITED STATES. Department of Energy. Solar Energy Research I nstitute. Solar envelope zoning; Application to the city planning process. Los Angeles case study. Los Angeles: Technical Information Office, 1982.

UNSTAT. UNITED NATIONS STATISTICAL DIVISION. Activities of the Environment Statistics Section of the United Nations Statistics Division. 2002b. Disponível em:<http://unstats.un.org/UNSTAT/ENVIRONMENT/activities.htm>. Acesso em: 2 mar. 2002.

VALASKI, Simone. Avaliação da qualidade ambiental em condomínios residenciais horizontais com base nos princípios do planejamento da paisagem estudo de caso: bairro santa felicidade. Curitiba/Pr. Dissertação (Mestrado) Departamento de Geografia, Setor de Ciências da Terra, Universidade Federal do Paraná. Curitiba, 2008.

VILAÇA, Flavio. Espaço intra-urbano no Brasil. São Paulo: Studio Nobel/Fapesp/Lincoln Institute, 1998.

VIOLA, Eduardo J. A problemática ambiental do Brasil (1971-1991): da proteção ambiental ao desenvolvimento sustentável. São Paulo: Polis, n. 3, p. 4-14, 1991.

VOSGHERITCHIAN, Andrea Bazarian. A abordagem de sistemas de avaliação de sustentabilidade da arquitetura nos quesitos de energia, materiais e água, e suas associações às novas tecnologias. Dissertação (Mestrado em Arquitetura). São Paulo: FAUUSP, 2006.

WACKERNAGEL, M.; REES, W. Our ecological footprint: reducing human impact on the Earth. The new catalyst Bioregional Series, v. 9. Canada: New Society Publishers, Gabriola Island, B.C., 1995. 
WATSON, D. , LABS, K.. Climatic design: energy-efficiente building principles and practices. New York: Mcgraw-hill, 1983.

WBG - The World Bank Grupo. Disponível em: <http//:wbg.org>. Acesso em: 17 dez 2002.

World Business Council Sustainable Development Energy. Efficiency in Buildings. Transforming the Market 2009.

World Business Council Sustainable Development. Energy Efficiency in Buildings. Business realities and opportunities - FACTS Summary Report, October 2007.

DUTRA, Luciano. Uma metodologia para a determinação do fator desejável em aberturas. Florianópolis. 1994. Dissertação (Mestrado) - Universidade Federal de Santa Catarina.

MARAGNO, Gogliardo V.. Eficiência e forma do Brise-soleil na arquitetura de Campo Grande- MS. (2001). In: IV Encontro Nacional/ III Encontro Latino Americano sobre Conforto no Ambiente Construído. - São Pedro, 2001.

MARAGNO, Gogliardo V.. Eficiência e forma do brise-soleil na arquitetura de Campo Grande - MS. Porto Alegre, 2000. Dissertação (Mestrado)

OLGYAY, V. \& OLGYAY, A. Design with Climates: bioclimatic approach to architectural regionalism. Princeton: Princeton University Press, 1963.

OLGYAY, Vitor. Arquitectura y clima: manual de diseño bioclimático para arquitectos y urbanistas. Princeton University, 1963.

OLGYAY, Vitor. Solar control and shading devices. Princeton University, 1957, RIVERO, Roberto. Eficacia de algunos sistemas de parasoles ante la radiacion solar. Montevideo, Servicio de climatologia aplicada a la arquitectura/Faculdade de arquitetura, 1987.

SILVA, Armando Cavaleiro e; MALATO, João José. Geometria da Insolação de edifícios. Lisboa: Laboratório Nacional de Engenharia Civil, Informação técnica Edifícios 5, 1969. 
SOUZA, Marisa B.. Pesquisa, Projeto e Construção de ferramentas de ensaio para modelos físicos em conforto ambiental - heliodon. São Paulo, 2004. Relatório Final de Iniciação Científica - PIBIC - Faculdade de Arquitetura e Urbanismo, Universidade de São Paulo. 


\section{Tabela 24: I mpacto Adensamento populacional}

Fonte: NUCCI, 1996, apud NUCCI, 2008.

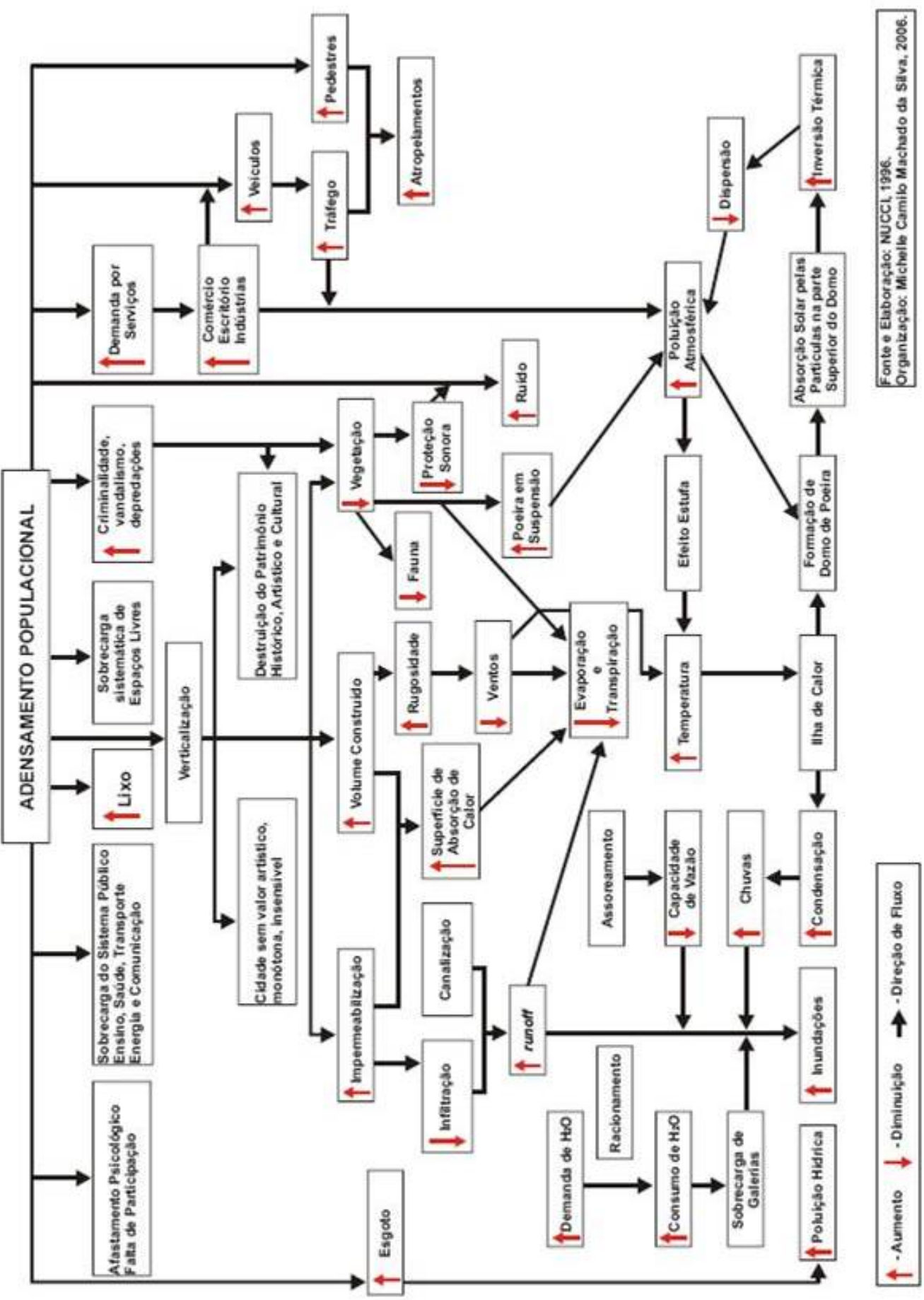




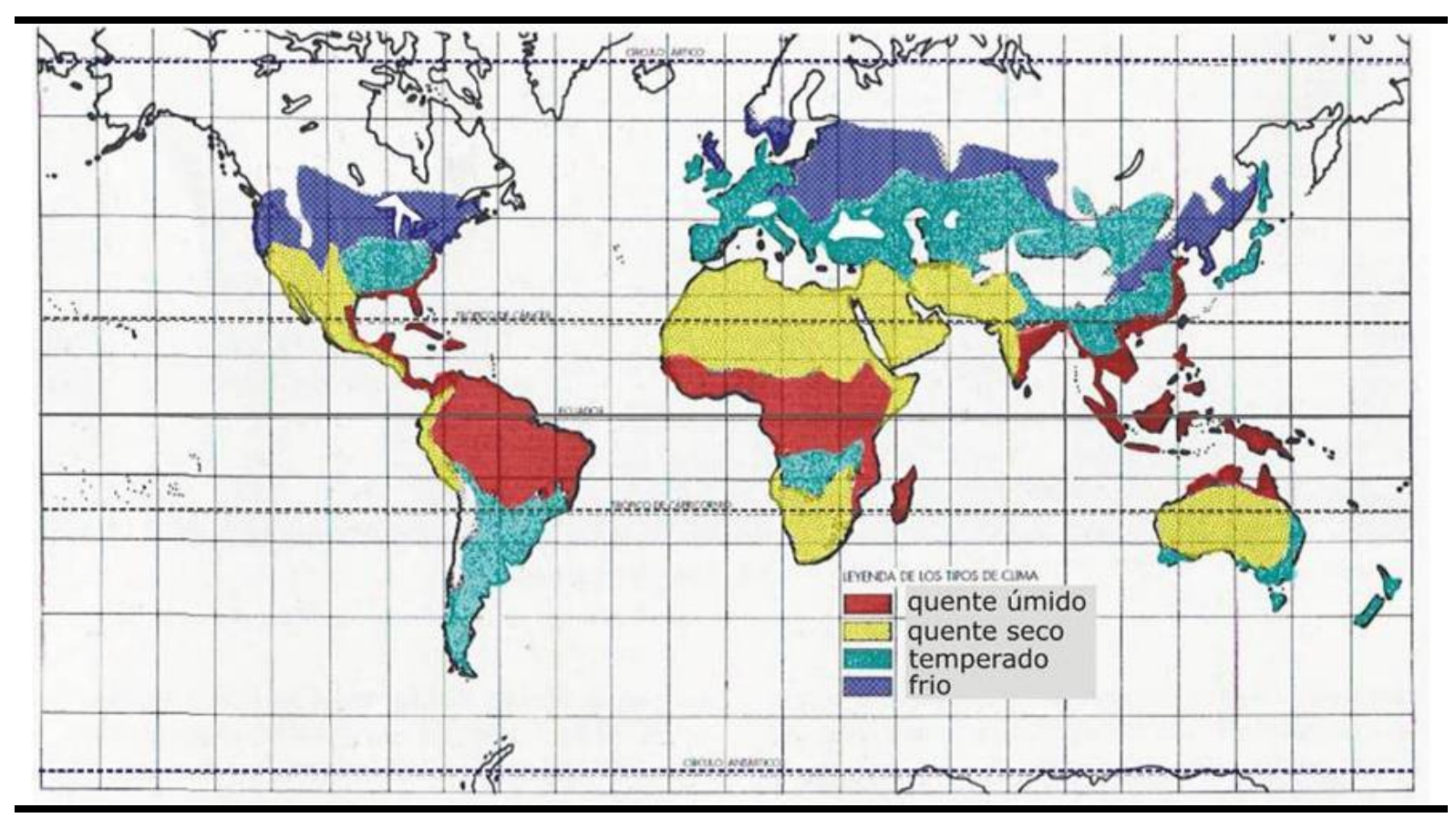

Figura 180: Classificação climática Anstrahler

Fonte: Google.

World map of Köppen-Geiger climate classification
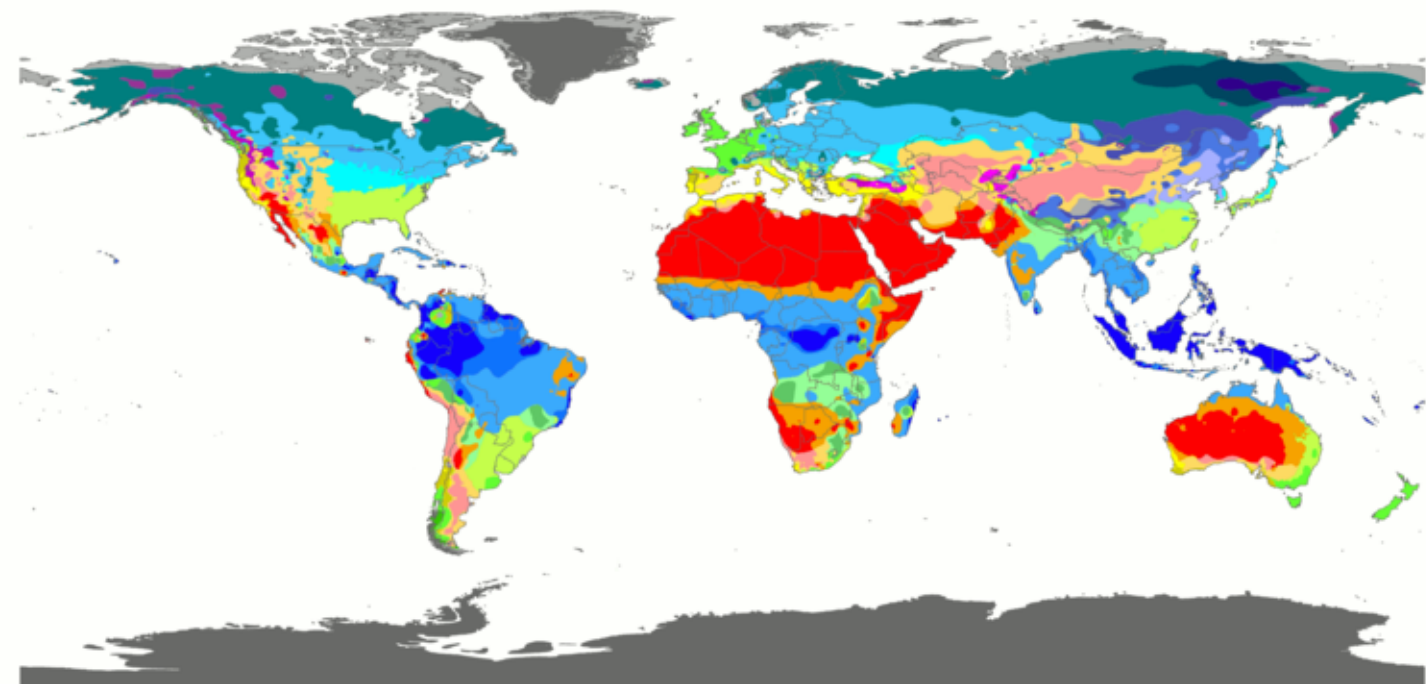

\begin{tabular}{|c|c|c|c|c|c|c|c|c|c|c|}
\hline & Af & BWh & Csa & Cwa & Cla & Dsa & Dwa & Dfa & ET & Temperature $(\mathrm{N}=4,844)$ and \\
\hline & Am & BWk & Csb & Cwb & $\mathrm{Cfb}$ & Dsb & Dwb & $\mathrm{Dfb}$ & EF & Precipitation $(\mathrm{N}=12,396)$ \\
\hline 8 & Aw & BSh & & Cwe & $\mathrm{Clc}$ & Dsc & Dwc & Dfc & & PERIOD OF RECORD : All available \\
\hline THE UNIVERSITY OF & & BSk & & & & Dsd & Dwd & Dfd & & MIN LENGTH : $\geq 30$ for each month. \\
\hline MELBOURNE & & Cont: & Iurray & el (mpe & imelt: & iu) for & infor: & & & RESOLUTION : 0.1 degree lat/long \\
\hline
\end{tabular}

Figura 181: Classificação climática Koppen Geiger

Fonte: Disponível em: < http://pt.wikipedia.org.> Acesso em: jun 2009 
